

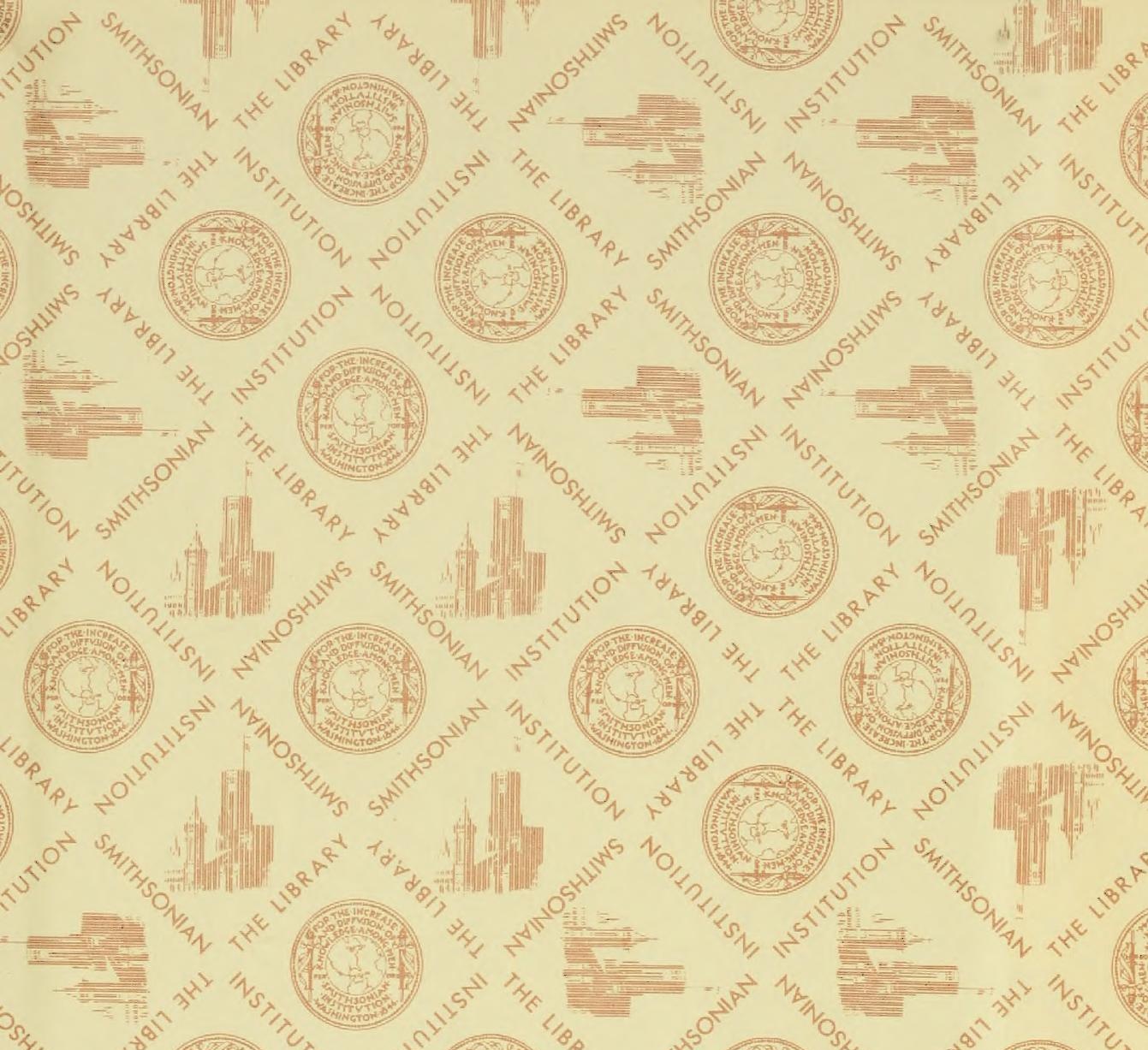







\section{ФАУНА РОССIII}

II COIIPEय

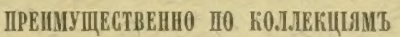

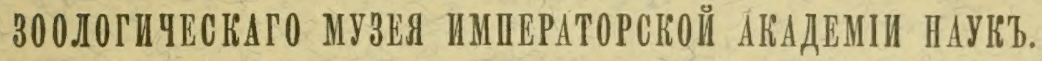

\section{НАСБКОМЫЯ ПОЛУЖЕСТКОКРЫЛЫЯ}

(Insecta Hemiptera).

Томъ II.

Выпуекъ 1.

А. Н. Кирнченко.

\section{PAINE DE LA RIISSIE}

ET DES PAYS IIMITROPIIES FONDÉE PRINCIPALENENT SUR LES COLLECTIONS

DU MUSÉE ZOOLOGIQUE DE L'ACADÉMIE IMPÉRIALE DES SCIENGES DE ST.-PÉTERSBOURG.

INSECTES HÉMIPTĖRES $\left\{\begin{array}{c}\text { Disodid } \\ + \\ \text { Aradidae }\end{array}\right\}$
(Insecta Hemiptera).

Volume VI.

Livraison 1.

Par A. N. Kiritshenko (Kiriěenko).

C.-ПЕТЕРБУРГЪ. 1913. Sт.-PÉTERSBOURG. 



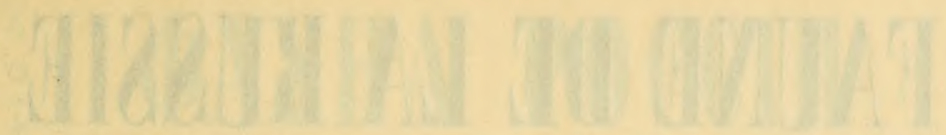

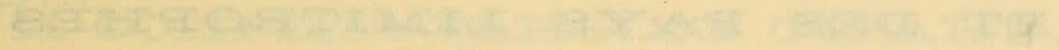

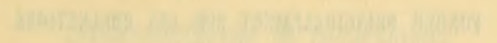

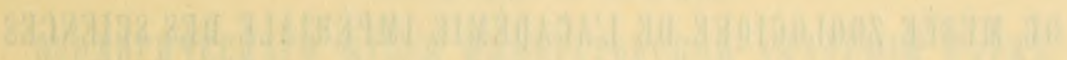

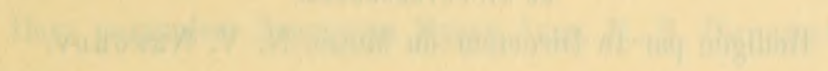

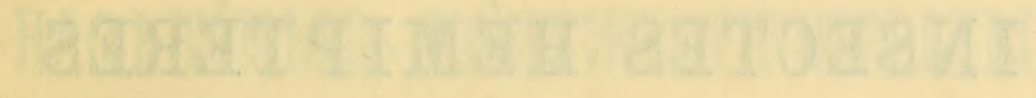

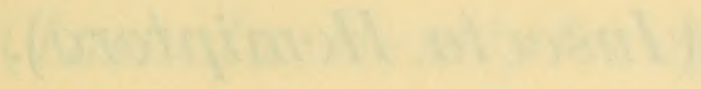

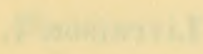

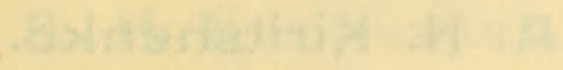

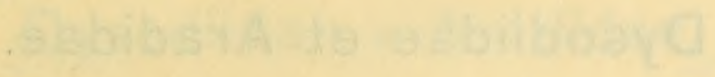




\section{FAINE ILE LA RIISSIE}

ET DES PAYS IIMITROPEIES FONDÉE PRINGipaleneNT SUR LES COLLECTIONS

DU MUSÉE Z00LOGIQUE DE LAGADÉMIE IMPÉRIALE DES SCIENCES DE ST.PÉTERSBOURG.

Redigée par le Directeur du Musée N. V. Nasonov.

\section{INSECTES HÉMIPTËRES}

(Insecta Hemiptera).

Volume VI.

Livraison 1.

A. N. Kiritshenko.

Dysodiidae et Aradidae.

(Avec 2 planches et 90 figures dans le texte). 


\title{
ФAУIIA POCCIII
}

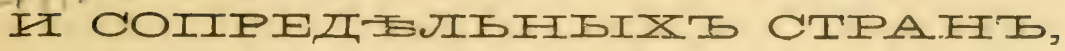

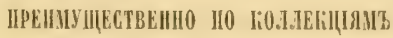

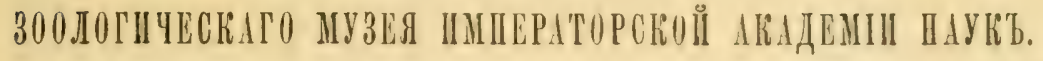

Подъ редакціего Директора Музея Акад. Н. В. ПІасонова.

\section{НАСТКОМЫЯ ПОЛУЖЕССТКОКРЫЛЫЯ}

\author{
(Insecta Hemiptera). \\ TОМт VI. \\ Випуско 1. \\ А. Н. Қирнченко. \\ Dysodiidae и Aradidae.
}

( Ст 2 таблпцами и 90 рпсунтамй вт, тетстҢ).

С.-ПЕТЕРБУРГЪ. 1913. 
Напечатано по распорнженію Императорс кой Акадевіи Наукъ. Сентло́рь 1913 г. Непремкнный Секретарь, Академикъ С. Ольденбуиъ. -

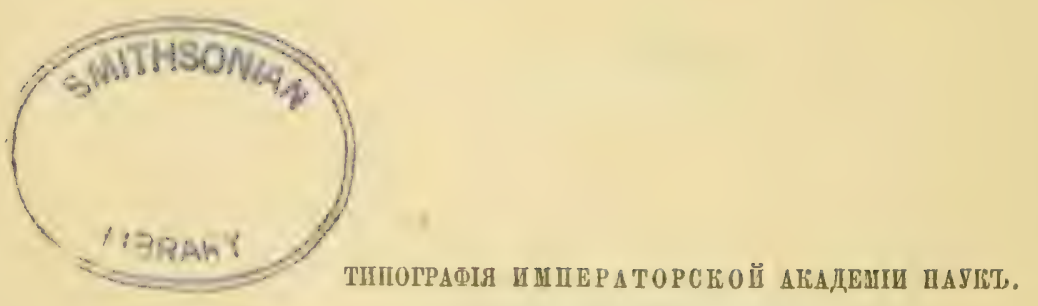

Вас. Остр., 9 лин., 끄 12. 


\section{ОГЛАВЛЕНІЕ.}

CTP.

Предисловіе.................... I

Подотрядъ HETEROPTERA LAтR.

Cepis Phloeobiotica ............... 1

Cerr. Dysodiidae ........... . . . .

Родт Calisius StА̊̆. . . . . . . . . ti

Calisius ghiliani (Costa) .................... 6

Родт Mezira Ам. SErv. . . . . . . .

Mezira tremulae (GerM.) . . . . . . . . . . . 11

Mezira setosa JАk. . . . . . . . . . . . 15

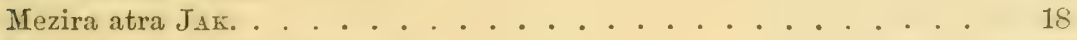

Mezira verrucigera $($ BerGr.) . . . . . . . . . . . 21

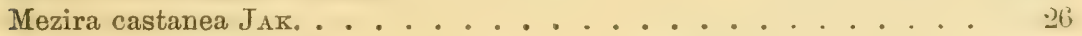

Mezira brevicornis REUT. . . . . . . . . . . . . 30

Mezira scabrosa Scorт. ...................... 32

Mezira basalis (Freв.) . . . . . . . . . . . . . 33

Родт Aneurus Curt. . . . . . . . . . . . ;3

Aneurus laevis (FABr.) . . . . . . . . . . . . . 36

Aneurus tuberculatus Млӧв. . . . . . . . . . . . 40

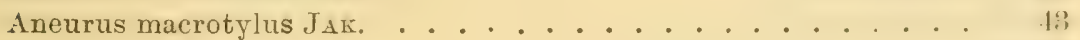

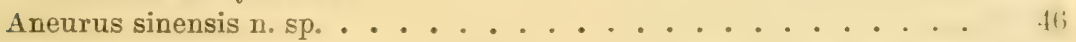

Cenr. Aradidae........... . . 4 . .

Родъ Aradus FABr. . . . . . . . . . . . . 52

Подродъ Aradus (s. str.) SтА̊L. . . . . . . . . . . .

Aradus versicolor H.S. . . . . . . . . . . . . 6s

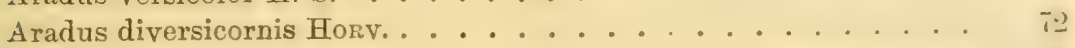

Aradus spinicollis JAK. . . . . . . . . . . . .

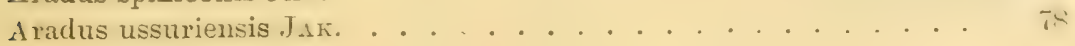


CTP.

Aradus tauricus $J_{\text {An. }}$. . . . . . . . . . . . . 82

Aradus cinnamomeus PAsz. ............ 85

A radus depressus (FABr.) . . . . . . . . . . . . . . . . 90

Aradus depressus leptocertus Horv. . . . . . . . . . 95

Aradus dissimilis Costa . . . . . . . . . . . . . . . . . . 96

Aradus consentaneus Horr. . . . . . . . . . . . . . 9 97

Aradus somcheticus n. sp. ............... 100

Aradus erosus Fall. . . . . . . . . . . . . 102

Aradus truncatus Fieb. . . . . . . . . . . 106

Aradus reuterianus Pбт. . . . . . . . . . . . . 109

Aradus pallescens H.-S. . . . . . . . . . . 111

Aradus pallescens frigidus nov. . . . . . . . . . . 114

Aradus eversmanni $J_{A}$. . . . . . . . . . . . 116

Aradus distinctus Freb. . . . . . . . . . . . . . . . . 118

Aradus brevicollis FALL. . . . . . . . . . . . 121

Aradus bergrothianus nom. nov. .............. 124

Aradus compar n. sp. . . . . . . . . . . . . . . . 128

Aradus transiens n. sp. . . . . . . . . . . . . . . 131

Aradus crenatus SAI. ............... 13 . . . . .

Aradus betulinus FALL. ................. 138

Aradus planus Fabr. . . . . . . . . . . . . 141

Aradus corticalis (Lrsr.) . . . . . . . . . . . . 144

Aradus corticalis amuulicornis $\mathrm{F}_{\triangle \mathrm{BR}} \ldots$. . . . . . . . . 149

Aradus melas JAK. . . . . . . . . . . . . . . 150

Aradus megerlei Reut. . . . . . . . . . . . . . 153

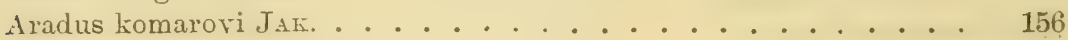

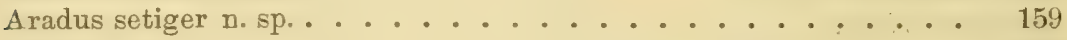

Aradus unicolor n. sp. . . . . . . . . . . . . 162

Aradus pictus BaEr. . . . . . . . . . . . . 165

Aradus hieroglyphicus J. SAнLв. . . . . . . . . . . 168

Aradus krueperi Retr. . . . . . . . . . . . . . 172

Aradus caucasicus Kol. . . . . . . . . . . . . 175

A radus turkestanicus $J_{A \mathrm{~K}}$. . . . . . . . . . . . 179

Aradus margianus n. sp. . . . . . . . . . . . 182

Aradus betulae (Lrs.) . . . . . . . . . . . . 185

Aradus brenskei Reut. . . . . . . . . . . . . . . . . 194

Aradus anisotomus Pcr. . . . . . . . . . . . . . 197

Aradus signaticornis R. F. SАнLB. . . . . . . . . . . 200

Aradus pulchellus T. SArre. . . . . . . . . . . . 204

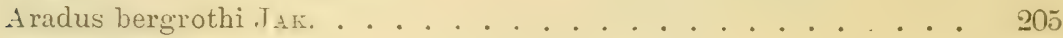

Aradus lugubris FALL. . . . . . . . . . . . . 209

Aradus flavicornis Datsr. . . . . . . . . . . . . 217

Aradus angularis J. Strils. . . . . . . . . . . 221

Aradus laeviusculus Reut. . . . . . . . . . . . . . 224

Aradus laeviusculus f. simillimus ReUt. . . . . . . . . . . . . 2.2T

Aradus dissors n. sp. . . . . . . . . . . . . . . 20

Aradu- hinalen iatu- Relt. . . . . . . . . . . 231 
CTP.

Aradus selectus $J_{A K}$. . . . . . . . . . . . . . . 238

Aradus sareptanus $\mathrm{J}_{\mathrm{AK}}$. . . . . . . . . . . . . . 236

Aradus sordidus Horv. . . . . . . . . . . . . . . 237

Aradus vitiosus $\mathrm{J}_{\mathrm{A}}$. . . . . . . . . . . . . . . 210

Aradus semilacer n. sp. . . . . . . . . . . . . 243

Aradus morio JAK. . . . . . . . . . . . . . . 216

Aradus aterrimus Frв. . . . . . . . . . . . . 249

Aradus aterrimus f. moestus Reur. . . . . . . . . . 250

Aradus aterrimus f. diversicollis Reur. . . . . . . . . . . 251

Aradus nemtschinovae $\mathrm{J}_{\mathrm{AK}}$. . . . . . . . . . . . 2 2 I

Aradus crenaticollis R. F. SAнLB. . . . . . . . . . . 2.jt

Aradus poppiusi n. sp. . . . . . . . . . . . 25?

Подродт Quilnus SтА̊............ 262

Aradus (Quilnus) mirus Bergr. . . . . . . . . . . . . . $26 t$

Aradus (Quilnus) brevirostris Honv. . . . . . . . . . . . 267

A radus (Quilnus) discedens Horv. . . . . . . . . . . . 265

Перечисленіе не русскихъ видовъ . . . . . . . . . . . . . . 271

Дополненія и исправленія . . . . . . . . . . . . . . . 27t

Теографппесгое распространеніе серіи Phloeobiotica Reut. . . . . 27

Экологическія условія жизни серіи Phloeobiotica REuт. . . . . . 288

Алфоравнтнй угазатель . . . . . . . . . . . . 289

Обълсненіе таблиць рпсунковт . . . . . . . . . . . 301 



\section{ПРЕДИСЛОВІЕ.}

Предлагаемая работа содержить спстематическое описаніе ceм. Dysodiidae ш Aradidae главнымь образомь по матөріаламь обширнеъйеї гемптерологическої коллекців Зоол. Муз. Имп. Акад. Наукъ. Въ коллепціц Зоол. Музея по Hemiptera-Heteroptora находятся почтп всб тппы къ оппсаніямб полужесткоры-

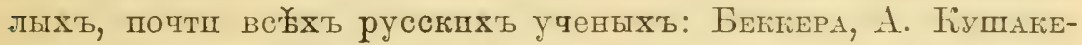

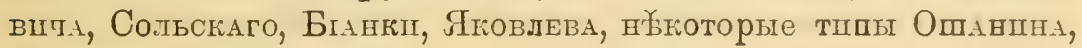
Kolenati, Kuрпченко.

Благодаря очень важної коллекціп В. Е. ЭковлевА, вопедппеї въ составь основной поллекціп Музел, а также благодаря непосредственному сотрудничеству нбкоторыхъ финляндскшх I западно-европейскшхь ученыхъ въ обработке ге матеріаловъ, Музеї располагаетъ многшмп тнпамп Reuter'a, Porpius'a, J. SAHLBerg'a, Puton'a.

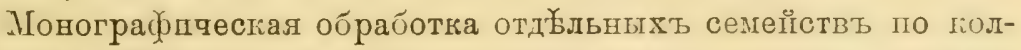
лепціямь Музея не можеть ве дать много новыхъ данвыхъ по систематнке полужесткокрылыхъ. Музейскіе матөріалы изљ окрапнъ Россіп: Туркестана, Сибирш, Уссурійскаго крал п сопредүзыныхъ странь Азіп: Персіп, Монголіп, Ћиная, заключають въ сөб各 очень больпое чпсло новыхъ еще не оппсаныхъ виговт.

Поэтому систематпческое описанів гемпптерологпческой коллекціш Зоол. Муз. Агад. Наукъ представпла бы весьла полную обработку фауны Россіп по Hemiptera-Heteroptera п гмхестет съ түмъ явплось бы необходшмымт, п важнымъ дополненіемт къ коллектиной работь Запалной Европы II Финляндіи, иыльсншвшшхъ въ свопхъ предтыльъ сравнительно подробно своп фауны.

Фауна Россіп. Насығодыя додудестоврыды. IV. 
Обработта II оппсаніе сем. Dysodiidae п Aradidae, предлагаемыя в'ъ настолщемъ выпускег, какъ указано выше, зиждутся главнымъ образомъ на коллекцілхъ Зоол. Музея Академіш Наукь, несмотря на чрезвычайно спедіальный образъ жизни втдовъ әтнхъ семействъ, рблтость некоторыхъ шпдовъ, п невниманіе къ нимь коллекторовъ, достаточно богатыхъ. Благодаря главнымъ образомь ноллекціямъ Муяея пзъ 9 вшдовъ сем.

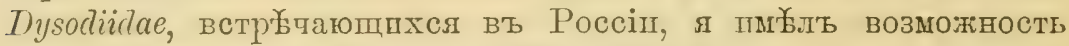
пэучпть въ натур⿱夂口 8 впдовъ (Mezira brevicornis Rешт. осталаст,

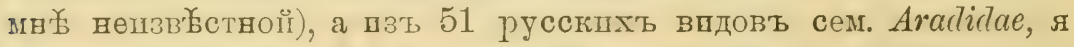
не впдйль тольғо 2: A. planus Faвr., $A$. (Quilnus) brevirostris HoRv., но относптельно пөрваго у меня шм'ются рисунип и оптеаніл, до сихъ порь еше не бывшів опубликованнымп, сдй-

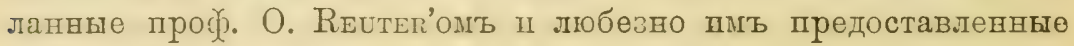
мнеге для пспольвованія.

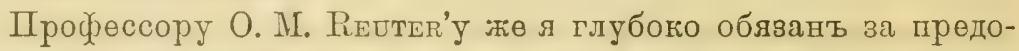
ставленіе пмъ нбкоторыхъ рпсунковъ, которые съ его любез-

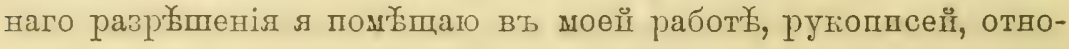
сящихся къ рлду малопзвъстныхъ вшдовъ и прөдставляющихъ описаніл видовъ, сдйланныл пмъ по тпппчнымъ экз. ВЪнскаго, Берлинстаго п др. музеевъ, п наконецъ за возможность ознако-

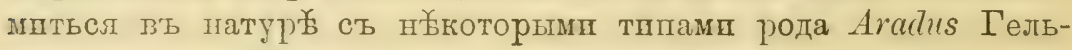
спнгфорскаго Музея. Совершенно нешзученное географипеское распространеніо полужесткокрылыхъ въ Россіп не даетъ воззожностп огранцчпть чпс.ло вводымыхъ въ „Фауну Россіп" вп-

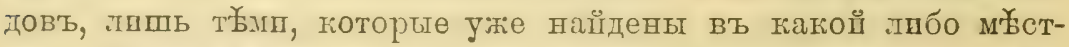
ності Россіп ІІ заставило ввести, хотя бы по лптературнымъ даннымь п многіе западно-европеїсгіе впды, въролтность нахожіденія которыхъ въ предех.тахъ Россіп не псключена, а въ

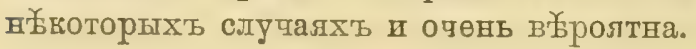

A. Н. Кіприченко. 


\section{IIодотрядь HETEROP'TERA Latr.}

\section{Cepis Phloeobiotica.}

Разсматрпваемыя въ этомь томеㅎ "Фауны Россіп" семейства полужестгокрылыхъ Aradidae п Dysodiviae, соединялпсь ойыновенно въ одно, со временъ Costa, установнвшаго это семеїство. Однако рәзккое различіе тпда строенія многихъ важныхъ органовъ: головы, глазъ, хоботка, сочлененія брютныхъ сегментовъ, строенія посльдншхъ бргшныхъ сегментовъ, дыхалецъ, вертлуговъ ногъ ш проч., дало освованіе большинству авторовъ раздышть вшды, относящіеся гъ этпмъ семеисствамъ, ва два подсемейства: Aradinae пा Brachyrhynchinae.

Зваченіө самостоятельныхъ семействъ пршдаль имғ О. M.

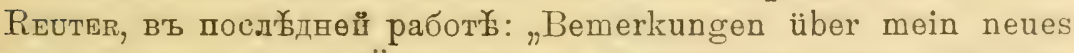
Heteropterensystem “ (Öf $\nabla$. af Finsk. Vetensk.-Soc. Förl., Bd.LIV, Afd. А., 조 6, 1911-1912), гд⿱⺊口 онъ разлпчаетъ семейства: Aradidae п Dysodiidae, образующі серію Phloeobiotica.

Серія Phloeoliotica плш сем. Aradidae auct. (sensu lato) у больпинства авторовъ сблнжалось съ сем. Tingididae (т. е. Piesmidae II Tingididae) шлп непосредственно, илп иногда перезь Neogacidae (= Hebridae) пі Macrocephalidae (= Phymatidae). Только въ нов бїпее время взглядъ на болиогенетпческое родство серіп пзмь-

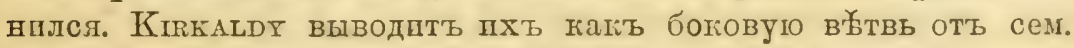
Pentatomidae, Haxdlirsch отъ Corcidae, но въ спстемахъ обопхъ этихъ авторовъ родство пхъ съ сем. Tingididae сохранено. Совершенно изолпрованное отъ этого посльдняго семециства м'сто занпмают Aradidae въ двухъ нов тйпихъ спстемахъ О. М. Reuter'a (1910 п 1912 г.). Въ первой пзъ нихъ сем. Aradidae

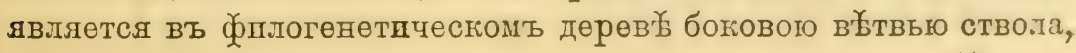


объединяющаго надсемейства серіц Anonychia ${ }^{1}$ ). Въ слтабдугщей спстем 1912 года сем. Aractidae и Dysodiiclae выд болены въ особую серію Phloeoliotica, поставленную между серіеї Polyneuria (семейства Pentatomidae II Coreidae въ старомь пониманіп) ІІ cepieĭ Onychiophora (старыя семейства Berytidae, Lygaeillae I Pyrrhocoriclae).

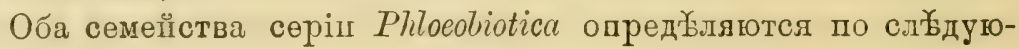
픈 таблицर्ર.

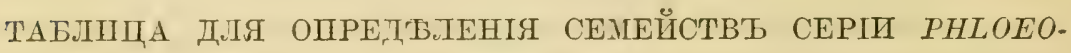 BIOTICA.}

1 (4). Задняя пасть головы дозади г:азъ шире предглазничной части. Гааза мало выдающіеся, мало нлг совсбмъ не выступающіе за послььлазничную тасть головы. Первый членикъ успковъ у основанія постепенно съужшвающійся. Вертлугі ногь ясно отгранпченные. Задніе края сегментовт прямые пли вогнутые. Дыхальца на брюшка отодвинуты отъ задняго края сегментовъ. Хоботокъ короткій, достигающій самое большее основанія головы. Грудь п брюшко безъ

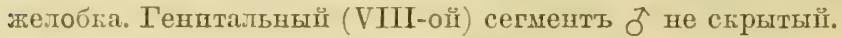

2 (3). Tylus и щекп толовн продвинуты впередт кпереди отъ мұста прпкрғпленія хоботка; VШ-ой абдоминальный сегменгъ бо очень тороткій, боковые грая его оттянуты назадъ въ вшдх короткшх пршдатковъ; VIII-ой генитальный сегментт вздутый, выстав:яющійся. . .

3 (2). Голова безъ передняго отростка, хоботогъ прикрблленъ у вершшны головы, па половнну ея тороче . . . сем. Dysodidae подс. Isoderminae.

4 (1). Задняя часть головы позади глазъ не шпре предггазничной частг. Глаза спльно выступающіе. Хоботокт длинный, достпгающій по больпей тастп основанія переднегруди пли дальше, ръдио доходяшії только до основанія головы. Г'рудь ㅍ брюшко съ желобкомъ. Первыи членикъ усшковъ короткій пи толстый, у основанія сразу

1) Cерія Anonychia Reut. 1910 зантюдаетъ въ себъ 16 семействъ. По-

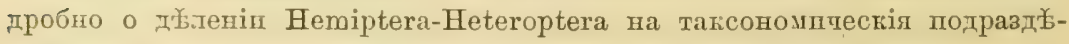
ленія высшаго чБхь семейство порядга см. литературу:

Revter. Neue Beiträge zur Phylogenie und Systematik der Miriden nebst einleitenden Bemerkungen über die Phylogenie der Heteropteren-Familien. (Acta Societatis Scientiarum Fennicae XXXVII, № 3. 1910.

Recter. Bemerkungen uiber mein neues Heteropterensystem (Öfversigt af Finska Vetenskaps-Societetens Förhandlingar. Bd. LIV. 1911-1912. Afd. A. 스 6.

Объемъ упоминаемыхъ серій см. тапже у Osнахпм. Katalog der paläarIrtischen Hemipteren. Berlin. 1912. 
съужпвающйся въ коротпую, тонкую, пскривленную ножгу. Задніе грая сегментовь сходящіеся подь угломь. Генштальный сегменть б совершенно скрыть въ чашеобразном углубленіп VII-го сег-

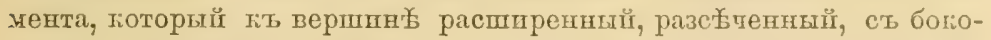
вымп лопастямп. Дыхальца оть бокового хірая брюшпа далето отодвинуты, лежать у основанія сегментовь. Вертлуги ногъ слиты съ бедрамп . . . . . . . . . . . . . ces. Aradidae.

Подсемейство Isoderminae семейства Dysodicdae въ тпсло्̆ ноһ̆скольпхъ вшдовъ, населяетъ шсплютштельно Южн. Америгу I Аветралію.

\section{Cen. Dysodiidae.}

Aradidae auct. (partim).

Brachyrhynchidae DoHrN. Catal. Hemipt. p. 43. 1859.

Aneuridae Dougt. Sсотт. Brit. Hemipt. I, p. 26. 1865.

Aradidae subf. Brachyrhynchina STAL-t-subf. Isodermina Stís. Enum. Hemipt., III, p. 135. 1873.

Aradidae subf. Brachyrhynchidae Letн. et Sev. Cat. gen. des Hém. III, p.3848. 1896.

Aradidae subf. Mezirina OsH. Verz. d. palearkt. Hemipt. I, p. 478. 1908.

Aradidae subf. Brachyr.hynchinae Снамp. Biol. Centr. Am., Hemipt.-Het. Ш, p. 66. 1898. Dist. Faun. Br. Ind. II, p. 153. 1903.

Dysodiidae Reut. Öfv. af Finsk. Vetensk. Soc. Förh., Bd. LIV, 1911-1912, Afd. A, № 6, p. 32.1912.

Діагнозъ. Caput parte postoculari parte anteoculari latiore, partem posticam oculorum tangente, saepe ultra oculos extrorsum spinoso-producta. Oculi ultra parten postocularem capitis haud vel levissime prominuli. Rostrum basin capitis rarissime superans. Antennae articulo primo basi sensim vel minus subito angustato. Trochanteres distincti. Stigmati abdominalia a nargine basali segmentorum ventralium remota. Segmento VIII genitali maris haud latente, producto.

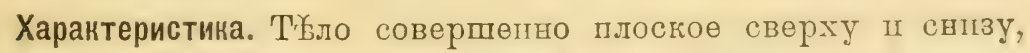
овальное пли удлиненно-овальной формы. Голова горпзонтальная, является въ передней тастп расщепленвой на три части: передній отростокь, выдаюшійся между усптамп далеко впередь п на два боловыхт отростка вт, больнпнств сы слудаевт

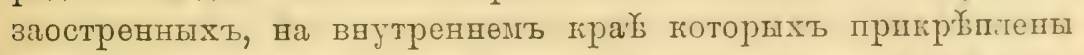
усшкш. Задняя часть головы, лежащая позадш глазь, пиро частп, лежащей впередш глазь и касаетсл заднлго края послҮднхъ

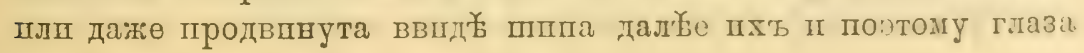




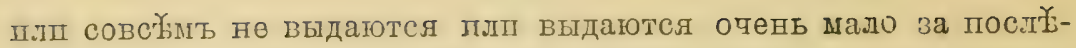

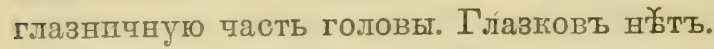

Хоботокь очень короткї̈, достигаеть по больпеї частп лишь основанія головы, четырехчленпковый, во первый членшкъ его, спрятанныц въ хоботковомъ желобк', образованномъ ротовымш пластшнками, очень маленькій, трудно различный п поэтому хоботокъ кажется трехтленшковымъ.

Успки въ больпцнств б. случаевъ длпвнбе головы п толстые, тетырехчлсншковые; первыц членпиъ у основаніл сильно, постепөнно съужшвающійся.

Составныя частп гемәлптрь: clavus, corium II membrana. Clarus никогда нө заходпть за вершину щитка, къ вершпни постепенно съужпвающійя. Membrana съ небсколькпмп неправпльнымш ш анастомозпрующшмпел жнлгамп пли однородная безъ жплок. Средвія п заднія плевры простыя. Бргшныя дыхальца отодвднуты отъ заднвхъ гіраевъ абдомшнальныхъ сегментовъ. Вертлугп ногъ явственные; тапкп двухчлениковыя, поготки лишенные пршдатіовъ (arolii). Генштальныі сегменть ठे ве скрытый, выставляющійся впередъ.

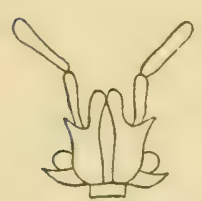

Pnc. 1. Tuтова Meziva.

Обзоръ родовъ. Въ составъ сем. Dysodiidae входитъ свыше 30 родовъ, ивъ которыхъ въ палеарктическоџ̆ областп встрб̆таются липь 3 ( $\mathrm{Ca}$ lisius Stio, Mezira Aм. Serv., I Aneurus Curt.).

Напболо्бе богаты пмп страны неотропшческаго

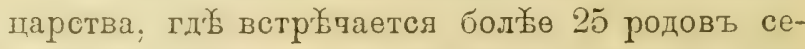
мейства, многіе пзъ которыхъ әндемичны для царства. Гораздо меньше пхъ въ оріентальномъ I австралійскомь дарствахь (болџо 9 родовъ въ каждомъ), очень мало въ әбіопсгомь (ополо 4 родовъ) п неаритппескомъ (около 5 родовъ).

Роды Mezira Aм. Serv. п Aneurus CбRт. космополитнины, такъ

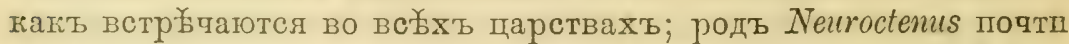
космополитпченъ, такъ какъ непзвьстно представнтелей его только пзь палеарктши, во въ неарктпческомь царств представленъ.

Роть Calisius Stíl свойствененъ австралійскоц̆ п неотропитеской фаунамь и встрђ баөтся въ средизелноморстой провинціп палеарктпческаго царства.

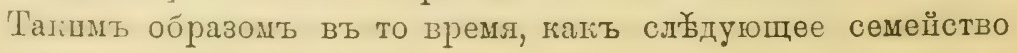


Aractidae съ едпнственнымь свонм родомь Aradus F. является пріуроченнымь главнымь образомь къ палеарктпческому п неарктическому царствамь, сем. Dysodindue, представленное въ

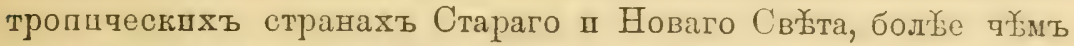

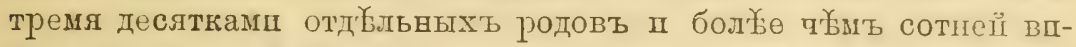
довъ, въ нашей ф্қаун官 является липь обломками и насчптываетъ лишь 13 вшдовъ, относяцихея къ тремъ родамь. Больппнство пхъ прп этомъ свойственно лишь Восточно-азіатской

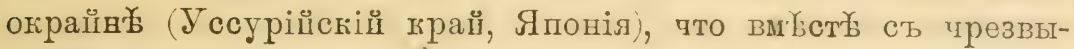
чайно прерывчатымь распространеніем другшхь представптелей семейства (Merira tremulae) явно угазываеть на рецентный характеръ всего семейства.

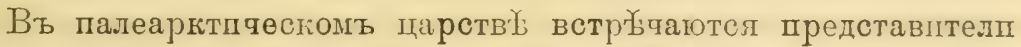
трехъ родовъ семейства: Calisius Stil., Mezira An. Sert., Aneиrus Curt.

TАБ.IIILA T.IЯ OПPEДT.IEHIG POTOBT CEM. DYSODIIDAE, ВСТРБЧАЮЩИХСЯ ВТ ПА.ІЕАРКТIЧЕСКОМТ ЦАРСТВІ.

1 (2). Щитикъ съ тупымъ пилемъ по серединет, закрываегъ всю дорзальнуг поверхность брюшиа, оставляя свободными лишь вздутые боковые края. Усики очень короткіе, два первые членика вмоғсто взятые короче передняго отростка головы. Крал хоботковаго тіелобка на всемъ протяжепіп отстоящіе другъ оть друга. Надкрылья пере-

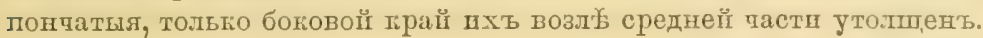

Calisius Stå. 1858.

2 (1). ШШтикъ короткіп̆, оставляющй открытымп всб кожпстыя части натврылій. У сики длинные, пхъ первый пленпь не гороче плп очень немногпм пороче передняго отростка головы, второй членињ далеко заходить за вершину его. Края хоботноваго желобга впереди сближенные, скрывающіе основаніе хоботка.

3 (4). Шптиъ треугольный, по большей тастью удлиненный. IV-цй тлендкъ усиговъ гороче третьяг, хоботковый желобокт съ прямымп краямш. Membrana сь густой с£тью неправпльно анастомозтруюпцхся жнлотьъ . . . . . . . . . . Mezira A.. Serv $18 \pm 3$.

4 (3). Щитик' пирокій, поперепный, у вершин шпроко огруглешый.

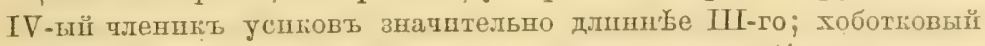
желобољь ланцетовидный; membrana, заншагщая бо́льшуг часть надкрылій, безъ жплтогь . . . . . . . Aneurus Curtis, 1825.

Для рода Calisius Sті亡 авторь его јстановиль особое полсемейство Calisiaria SтіL, пуда относятея роты Calisius ș.í, Aradacanthia Costa, Catisiopsis Снаме.

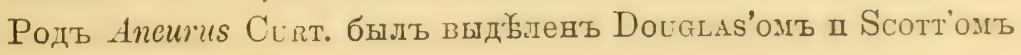


въ сел. Aneuridae. Отлпчія во्бкоторыхъ чертъ въ его органшзаціп даютъ основаніе выд宅лпть его такжіе въ особое подсемейство.

\section{Родъ 1. Calisius STr̊̊. 1860.}

Calisius Sт̊̊. B. Bidrag till Rio Janeiro Tractens Hemipter-Fauna 1, p. 67. 1860; Hemipt. afr. 3, p. 30. 1865; Enum. Hemipt, 3, p. 138. 1873. - BerGR. Ent. Tidskr., 15, p. 98. 1894,-Сhамp. Biol. Centr. Am. Hemipt.-Het. I, p. 66. 1898.

Aradosyrtis Costa. Ann. Mus. Zool. Nap., 2, p. 132. 1864.

Діагнозъ. Scutello maximo, longe ultra medium abdominis extenso, hemelytra tegente, carina obtusa longitudinali instructo; antennis brevibus, articulis duobus basalilus brevissimis, simul sumtis prolongatione antica capitis brevioribus; marginibus sulci rostralis totis distantibus; loco insertionis rostri distinguendo, hemelytris membranaceis, margine costali tantum ultra medium incrassato.

Typus generis Callisins pallipes STÅL.

Характеристика. Щптпкъ покрывающій всг дорзальнуғо поверхность брюшка за псключеніемъ сопnехірит'а, остающагося

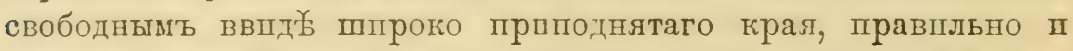
мелкозубчатаго; у основанія щитпка вздутіе треугольной формы пі съ таждой стороны по два маленькихъ бугорка; вергшна щитпка закругленная; по середине өг пго проходпть, доходяпій до вершины киль.

Перөднің отростокь головы тлпнны п толстыи, боковые отрос́ткп острые, позади впхь небольпої пипт. Успкп очень гороткіе, незначптельно заходящіе за вершпну передняго отростка, отдею.тьные тленпки усвковъ, почти равные между собой, круглые.

Переднеспнвка съ 4 сплопнымп кплямп.

Обзоръ видовъ. Родъ Calisius STÅц. насчптываетъ нөмногочпсленныхъ, елвншчныхъ представштелей в’ь фаунахъ неотроппческой, австралійскоӵ п палеарктпческой. Едпнственный претставпель палеарктпческаго царства обптатель средиземноморскаго подцарства:

1. Calisius ghiliani (Costa). 1861.

Aradosyrtis ghitiani Costa. Ann. Mus. Zool. Nap. 2, p. 133, t. 1, f. 6. 1861; Sti̊. Enum. Hemipt., 3, p. 138. 1873; - Put. Synops. Hémipt. Hét. de France, 1, p. 140. 1879. 
Aradus pygmaeus GArB. Bull. S. N. E. Ital. 1, p. 276.1869.

Calisius ghiliani Bergr. Entom. Tidskr., 15, p. 98. 1894.

Діагнозъ. Corpus orale, nigrum opacum. Caput lineis duabus longitudinalibus elevatis, albidis instructum. Pronotum marginibus lateralibus denticulatis, margine postico sinuato; angulis anterioribus spinoso-productis

Описаніе. Овальныі, черваго, матоваго цвогта, съ сәроватымъ

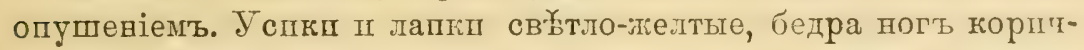
невыя. Голова съ двумя продольнымп, возвышеннымш, бұловатаго цвозта лпніямп, начшнаюпимися у основанія головы п пдущимп до основанія передняго отростка.

Переднесппнка съ боковыми краямп вубчатымп. Передніо углы вытянуты ввнда, зубцовъ; задній край съ выемгої; поверхность его съ четырьмя кплямп. Основаніе пптика сь трехугольнымъ поднятіемъ, боковые грал слабо зазубренные, оставляющіе открытыха боковые грая. Connexivum сшльно прнпод-

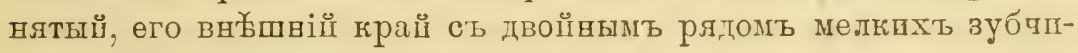
говъ. Длинна 3 мплл.

Описавіе этого вида взято у Рштом'а.

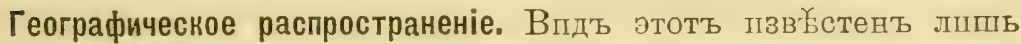
пзъ южн. Франдіп, ІІталіп п Спріг. Въ Россіп онъ до спхт порь не найденъ, но опень, возможно нахозгденіе его въ Крыму плп на Кавказй.

Геогра(бпиескоо распространеніе сородичеї C.ghitiani (Cosт.1)

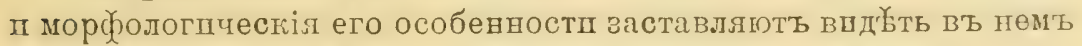
гревній третпчный вшдъ, дожившій до нашего временп.

Родъ 2. Mezira Aм. Serv. 1843.

Brachyihynchus suhg. Bruchyrhynchus LA1. Essai, p. 5t. 1S32 (non. pracocc.). Brachyrhynchus Ax. Serr. Hemipt., p. 30t. 18t3. - H'reb. Eur. Hemipt., p. 31 et 115. 1861. - Sт⿺辶̀. Hemipt. Afric. 3, p. 32. 1865. - Sтї. Enum. Hemipt. 3, p. 140. 1873.-Dist. Faun. Brit. Ind. 2, p. 159. 1903.

Mezira Ar. Serv. Hemipt., p. 30t. 1813. - Freb. Eur. Hemipt., p. 34 et 115. 1861.-Stít. Hemipt. Afric. 3, p. 31. 1S65.-Puton. Synops. des Hémipt. Hét. de Fr., 1, p. 128. 1879.-Bergr. Wien. Ent. Zeit. IV, p. 191. 1885.Bergr. Canad. Entom., 38, p. 202. 1906.

Dusius Bergr. Ent. Tidsk. V, p. 104. 1894.

Arictus SтÅ. Hemipt. Afr. III, p. 31. 1865.

Bráchyrhynchus subg. Arictus Stì. Enum. Hemipt. 3, p. 144. 1873. 
Діагнозъ. Corpus ovatum rel subparallelum. Caput pone oculos subito dilatatum, lobis tenuporalibus (spina vel dente) extrorsum vergentibus armatum, ultra latera oculorum plus minusve prominentibus; lobis lateralibus vel antenniferis in spinam prominentibis. Rostrum brevissimum. Antennae articulo primo apicem capitis attingente vel paullo superante.

Pronotum transversum, paullo ante medium sulco transverso praeditum, dimidio antico rugis duabus (rare 4) minus elevatis vel olsoletissimis, rarius disctinctis instructo; margine posteriore plerumque sinuato, marginibus lateralibus rectis, unisinuatis $v e l$ emarginatis.

Scutellun triangulare, planum.

Pedibus lurevibus, inermibus. Membrana venosa, venis anastomosantibus.

Typus generis Mezira membranacea $\mathrm{F}$.

Характеристина. Тъ.то удлиненно-овальное плІ съ почти параллельнымп Ііраямш, пногда квади слабо распшрящееся, снизу очевь слабо выпуклое. Голова послт्र глазъ расширевная; височ-

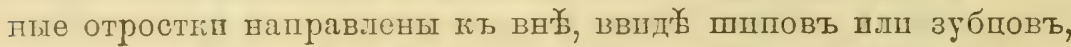
заходящіе больше шли меньше за глаза. Успки сравнптөльно ґороткіе, шхъ первы членши доходить до выппны передвяго отростка головы нлш его немного превышаетъ. Переднеспинка поперечная, ея боковые храя прямые пли съ легкой выемкой, рбакоо глубоко вырбззанные, основної край съ выемкой. По-

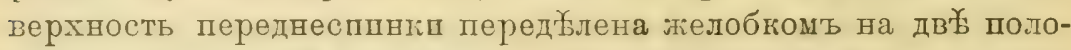

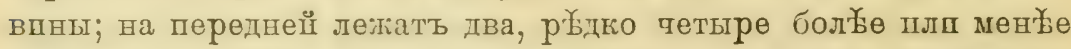
выдающхся бугра, ве переходящшхъ на заднюю половину.

Щптшъ треугольныи, ровный, тасто безъ отчөтливаго юиля

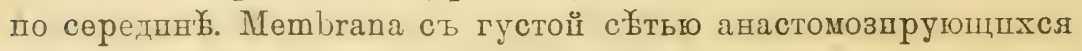
эншлокъ.

Ноги короткія, бедра ихъ не вооружены.

Ясно разлшпмыхъ брюшныхъ сегментовъ у すす п 우 우 восемь.

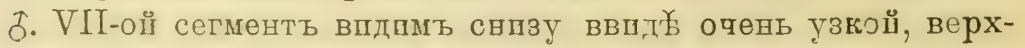
вей частп буквы T, понцы которой оттянуты назадъ въ два узтихъ, гюркообразныхъ отростка. VIII-ой сегменть-генцтальный, глубоко вдвинуть въ VII-ой сегментъ; выдающаясл

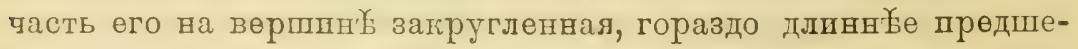
ствующаго еї участиа VII-го сегмента.

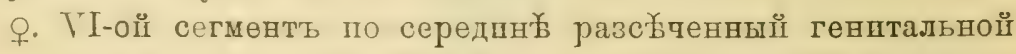
щөльг, въ него вдвндуть VII-й сегментъ, выдающійся назадъ 
ввшд двухъ боковыхъ отростковь, между которымп выходпть вершпна VIII -го сегмента.

Граншцы сегментовъ прямыл пли широко зағругленныл. Терминологія сегментовъ пргнимается нами, такпмъ образомъ, сльдующая. Для § I-VII-абдоминальные сегменты, VIII-генштальныи, оттянутые отросткц V'Il-го сегмента-мы наљдваемъ-боковыми лопастлми VII-го сегмента (lobuli), длл 우 I-VI-абдомпнальные сегменты, VII-генштальный, VIII-генитальный ${ }^{\mathrm{I}}$ ).

0бзоръ видовъ. Родъ Mezira Aм. et. Serv. являетсл напболье обппрнымъ во всемъ сөмействб, чпсленно преобладая въ та-

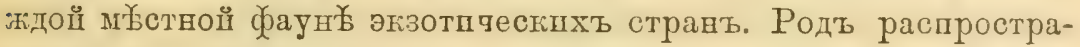
ненъ въ неарктпческомъ, неотропическоль, оріентальномь. эбіопскомь, австралійскомъ п палеарктпческомъ дарствахъ.

Въ палөарктпческомъ царствю्) насqптываөтся $S$ вшдовъ рода, пзъ которыхъ 6 әндемпчны тля Уссурійскаго края ІІ Японін, т. е. для гшмалайско-кптайско-япошской баувы (и распространевіе впдовъ рода Ilеzira Aм. S. ясно указываеть на чуждость этой ( (ауны палеарғтческой областп). Собственно палеарктппескпх впдовъ въ родт Mezira Aм. Serv.-2. Одпн'ь свойственныї средвземноморскому подцарству (Андалузія, Греція) п другої спорадпчески распространенный по Европ务 II на Кавказ'.

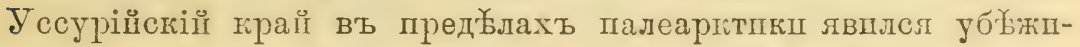
щемъ - refugium для вшдовъ этого рода, гды пхъ сохраншлось напбольшее число.

Интересно отмर्্ेтпть, что средп шестп уссуріїскшхь впдовъ

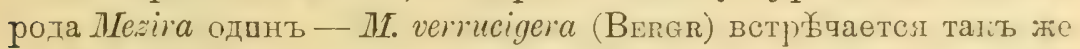
на Суматрь (вь оріентальномь царств ()). Но в'ь то же времл вт

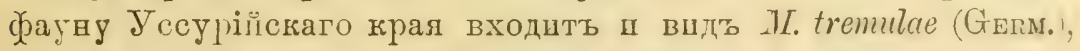

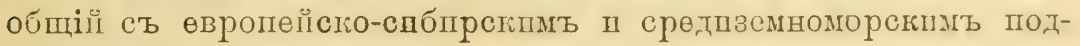
царетвомъ.

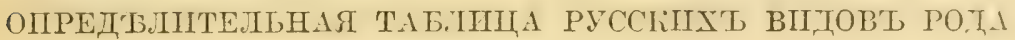
MIEZIRA AMr. SERv.

1 (8). Пыхальца не отдығыены оть бонового грая таждаго абдомиальнаго сегмента явственнымш, свбтлым, возвышеннымш лшлям, проходлщшми вдоль сегментовъ въ передней ихт трети.

1) Нумерація сегментовт принятая нами видна пзт ршс. 3 іл 7; взадмоотношенія между стернитами и гомологія ихт ст тйып же стернитамп Вт

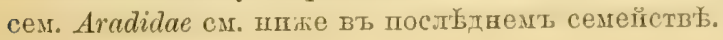


2 (3). Шнтпкъ ґороче переднеспни. Передній отростокъ широкій, короткій, прямой; висотные отросткп заходящіе за прая глазъ, задній грай пхт вт впді лезвія . . . . . . Mezira tremulae (Gerir.).

3 (2). Питикъ одпнаковой длины съ переднеспнниої. Височные отросткп

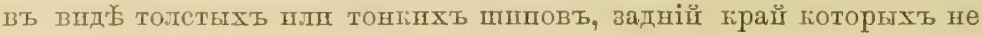
выравненъ, въ вшдо्⿱亠䒑 лезвія.

4 (7). Боковые грая переднеспни впереди съ выемкой пли глубоко вырұзаны. У спш сравнштельно тонкіе п длшнные.

5 (6). Боговыя грая переднеспингп въ передней половине흐 съ спльной выемкой, позади выемпп прлмые, параллельные. III-ій членпкъ усп-

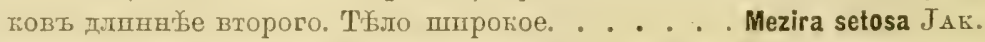

6 (5). Боковне грая переднесппни впередп съ глубокой прямоугольной выр әेзой, позадп тоторой боговой прай вытянут въ шипь, вапра-

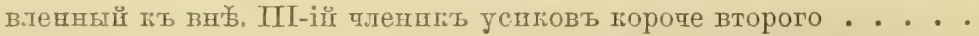

- . Mezira verrucigera (BERGR.).

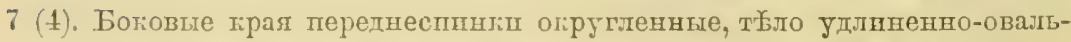

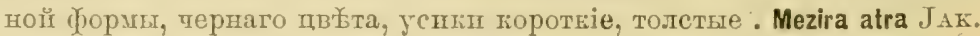

8 (1). Пыхальца отдотлены оть боговнхт траевъ абдоминальншхъ сегментовъ явственными, волншстыми, возвышенными килямп желтаго

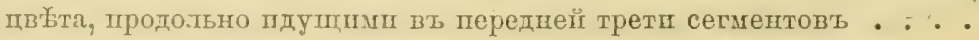

Mezira castanea JAK.

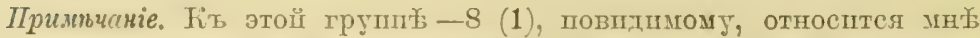

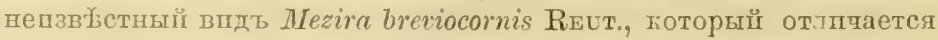

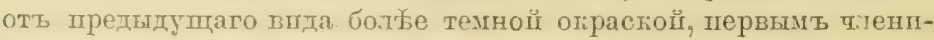
том' усиховь не заходящшмь за вершину передняго отростіа головы, отсутствіемт кпля по середшно्⿱宀 щитпка, однодв жожіштымш согіum'омъ п clavus'омь гемэлштрт.

Прпведенвая сшноптптеская таблдца русекшхъ вшдовъ рода

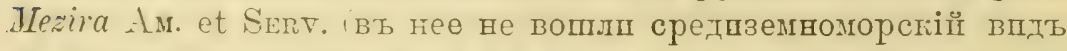

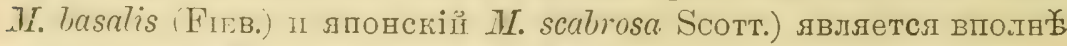
пскусственної, пршспособленної для діагностпческшх ци́блей.

Tiаного ппбо рогства впдовъ п даже шхь группшровюп таб.лцца совершенно не выражаетъ, тто совершенно непзбћжн, талі, кант громадное большинство впдовъ - экзотпческіе впды II Іъ разнымъ группамь пхь прцмыкають өдыничные препставптели рода въ палеарктическомъ царств'́б.

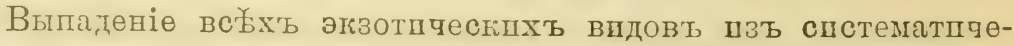
скаго обзора вндовъ этого рода даеть картину чрезвычайно

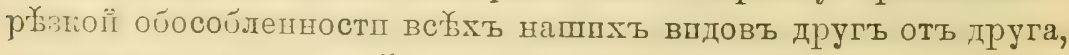
хараптерпзующпхся делымъ рядомъ прпзнаковъ.

Крог прпзнағовъ, указанныхъ въ таблдц совершенно не могуть быть смипаннымш по строенію пятаго, 


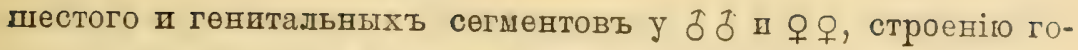
ловы, перөднеспинки, щитика, гемэлитръ и т. п.

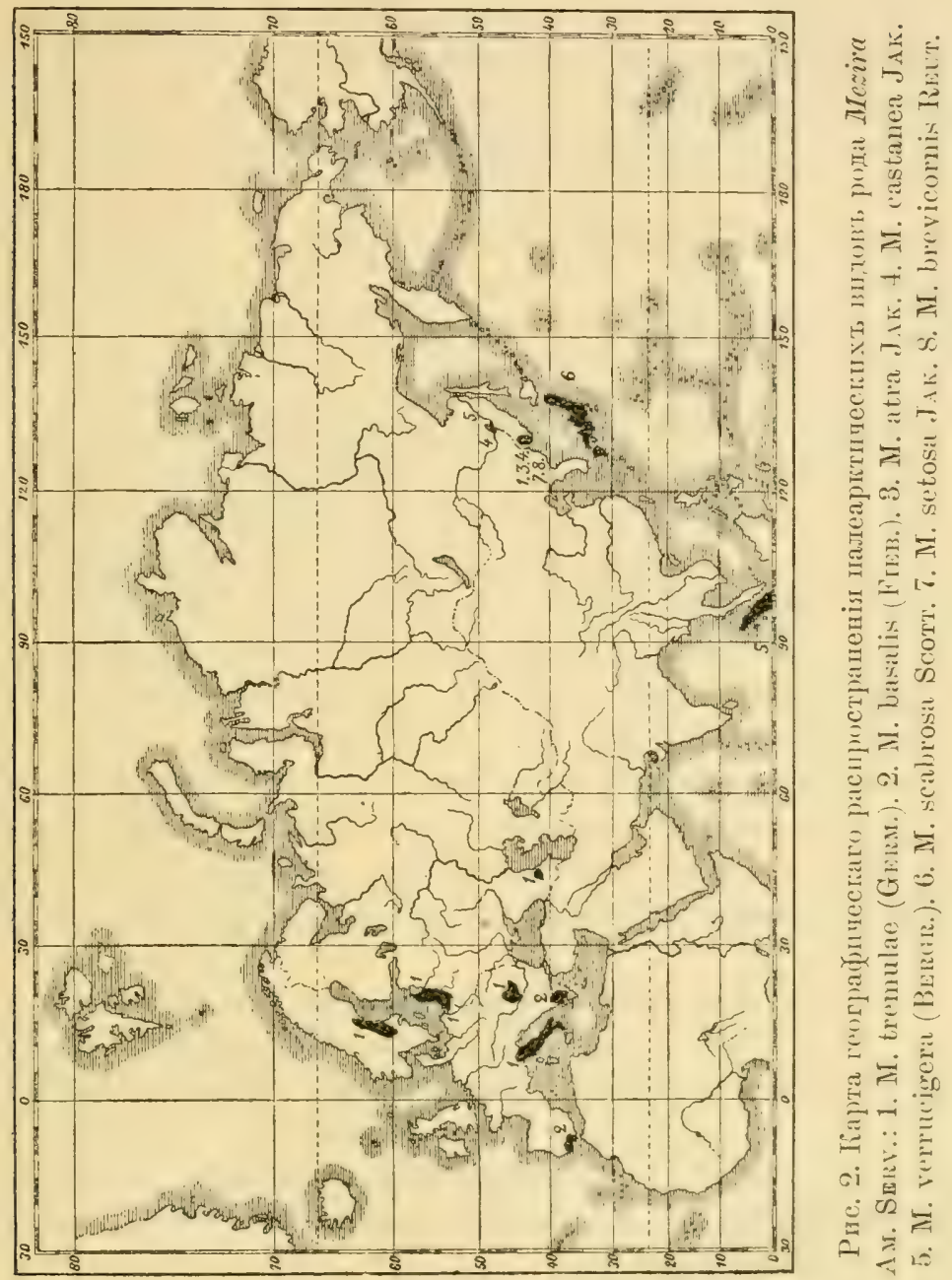

1. Mezira tremulae (Germ.). 1822.

(Табл. I, фиг. 1).

Aradus tremulae Gerar. Faun. Eur. 5, 21. 1822. - Kor. Bull. S. Nat. Mosc.

XXIX, 1856, p. 436, Melet. Entom., fasc. VI, p. 18. 1857.

Dysodius tremulae H. S. Wanz. Ins. VIII, p. 121, fig. 886. 1818. 
Mezira tremulae Freb. Eur. Hemipt., p. 115. 1861. - Jaজ. Bull. S. NAт. Mosc, p. 135. 1878, ibidem. 1880. 1, p. 171.

Brachyrhynchus ditatatus BurM. Handb. 2, p. 255.1835.

\section{Фауниспческая литература, касающаяся Россів.}

Fieb. loc. cit., p. 115 (Livland, Kurland).

Kol. loc. cit., p. 436 (Caucasus Lhesgicum).

Jak, loc. cit., p. 134. 1878 (Dagestan: Derbent; Ussuri).

\section{Экземпляры Зоологическаго Музея.}

Samara (ㅇ).

Derbent $(8$ J゙, 9 ㅇ). A. Komarov.

Ussuri. (穴). Dувоvsкi.

Діагнозъ. Obscure fusca, flaro-pilosa, corpus oblongum, retrorsum dilatatum (đ) vel lateribus fere parallelis (ㅇ).

Caput prolongatione antica antrorsum dilatata, apice jugis tylum sat multo superantibus et ante tylum emarginaturam profundam formantibus; lobis lateralibus antenniferis longis, acutis, divergentibus, lobis temporalibus acutis ultra orbitas oculorum proninentibus, margine posteriore depresso harpiformi; crista ad orbitam interiorem oculi alta.

Antennae articulo primo crasso, prolongatione antica capitis longiore, articulo secundo basin rersus sensim angustato, in $1 / \$$ breviore quam articulus tertius, articulus tertius articulo primo aequilongus, articulus quartus in $1 / 3$ brevior quam articulus tertius.

Pronotum transversum, longitudine sua fere duplo latius, lateribus reflexis, fere rectis, pone medium vix angulato-rodundatis; margine anteriore profunde sinuato, margine postico latissme sinuato; angulis anticis rotundatis, posticis fere rectis; disco superne medio profunde sulcatum; parte anteriore concava, tuberculis 4 instructa, parte posteriore magis plana, sed altiore, medio carina transversa praedita.

Scutellum pronoto brevius, aequilatero-triangulare, transversim rugosum, lateribus reflexis, carinatis.

Corio hemelytrorum basi dilatato, dein valde angustato, fere duplo scutello longiore; sutura membranae recta, angulo apicali corii acuminato. Membrana subdiluta.

Connexirum marginibus posterioribus segmentorum convexis; lateribus connexivum rugositate longitudinali, partem trientem exteriorem segmentorum occupantibus, praeditum. 
§. Segmentum quintum ventrale profundissime sinuatum; linea mediana marginibus lateralibus fere duplo breviore et segmento sexto duplo breviore; segmentum sextum magnum, convexum post basin tuberculo instructum; segnentum septimum segmento octavo genitali duplo breviore, lol,ulis lateralibus segmenti septimi longis, apicem segmenti genitalis vix attingentibus.

‥ Segmentum quintum rentrale profundissine sinuatum, margine elevatione semicirculari praedito, linea mediana duplo breviore quam nargo lateralis et magis quam duplo breviore quam segmentum sextum; segmentum sextum depressionibus duabus obliquis instructum; lobi laterales segmenti septimi genitalis magni, lati, apicem segmenti postici attingentes.

Long. 9,5 mm., lat. 3,5 $\mathrm{mm}$.

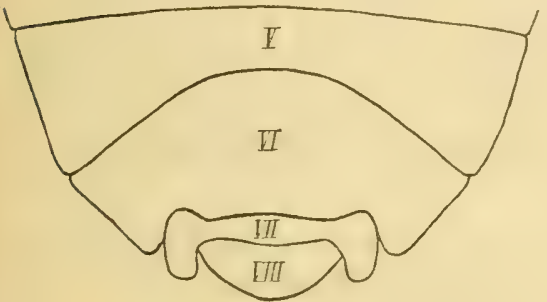

Pнс. 3. V-VIII стерниты бргшка. Ђ. Mezira tremulae (GERм.) (Пзъ Дербента).

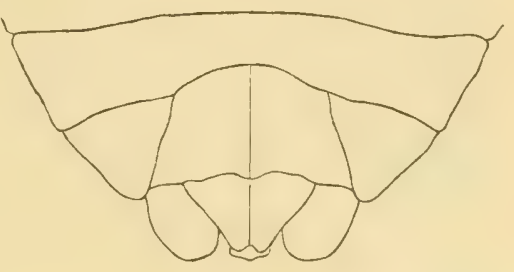

Pпс. 4. V-VIII стерниты бргоша. ․ Mezira tremulae (GEпм.) (пзъ Перо́ента).

Описаніе. Т危ло длшнное, поуті съ параллельнымш краямш, одөнь незначптельно расширяюееся кзаді ( 9 ), довольно

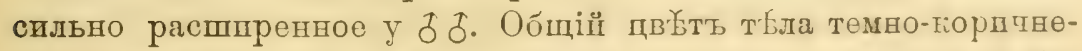
вый, кромх⿱夂口 пөредне- п ередне-грудп, которыя черныя п бо-

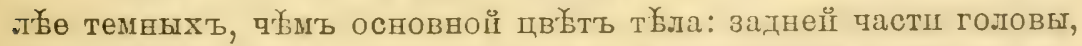
переднеіг части переднеспнни (за шсключеніемъ боговыхъ краевъ ея), щитика п надкрылічі ; түло сверху п свцзу покрыто короткими желтоватыми волосками.

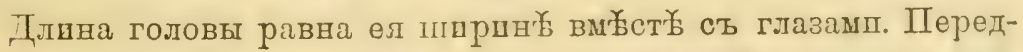
ній отростокь головы прямой, не достигающіг вөршины перваго пленпка јспюовъ, ћъ верпшн жду скуловымп пластпнкамп гіубокал, среднял qасть отростка

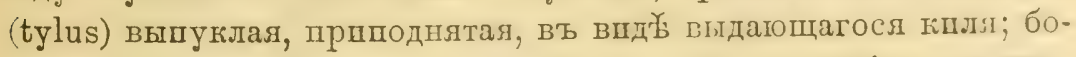
новые отросткп головы острые, спльо расходящіеся, напра- 
влены впередъ II гъ вн立; длпнныө ввсочныө отростки острыө, заходящіе за вн务пній край глаза, шмњють форму плоскаго лезвія, задній граї котораго загругленныи; гребень, вдущії оть орбшты глазъ къ основавію головы, высокій затылочнше желобкп глубокіе, довольно пирокіе, къ основанію сходящіеся.

Первый членпкъ уепковъ длинн它е передвяго отростка головы, толще остальныхъ; второй членпкъ постөпенно съуживающійся кь основанію, на ${ }_{1 / 4}^{1 /}$ короче третьяго; третій равенъ по длпнег первому, четвертый членпкь на $1 / 4$ короте третьяго, спльно булавовшдно утолщающі

Переднеспннка съ боковыми праямп почті прямымп, посл危 середшны едва выдающпмпся въ виде́ㅇ отень тупого угла, края приподнятые; передній краї съ глубокої выемкої, заднії очень пироко и полого выөмчатыі. Поверхность переднеспини глубокимъ желобкомъ передх्⿱一兀тена: на переднюю, закругленно-

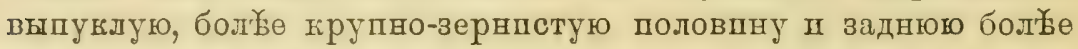
плоскую, но болъе высоко прпподнятую, по середин各 съ неявственнымъ килемъ. Передніе углы переднеспшнки закругленные, задвіе почти прлмые. Переднеспиниа почти вдвое шире своей напбольшей длшны.

Пцтигъ звачительно короче переднеспинкп, поперечно мор-

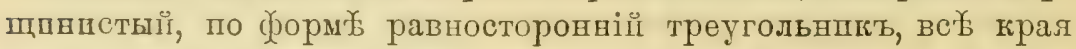
его огружены высоко прнподнятымъ килемъ.

Надкрылья однопв'бтныя, у основанія расшпренныя, съ божовымъ праемъ прямыљ, а затйын быстро съужпвающіяся. Соrium надкрыліі почти в твое длпнн神е щитпка, мембранальный повь прямої, вершпна corium'a острая. Membrana полупрозрачная съ болье св болыми жилками. Connexivum съ граншцамп отдығыьныхъ сегментовъ пплеватымп, вдоль бокового края его шдеть черноватая полоса, образованная продольнымш морщинками.

б. Пятый брюшної сегменть съ очень глубокої п пологой вырґзкой, средняя линія его почтп вдвое корочө боковыхъ краевъ п въ два раза короче шөстого сегмевта; шестоџ̆ сегментъ большой, выпуклыи, съ больпимъ бугоркомъ въ основной третп; седьмої сегменть въ два раза короче восьмого генитальнаго; отростки длшнвые, почти достпгающіе вершины генптальнаго сегмента.

오. ІІлтый брюшной сегментъ, очень глубоко вырбаззаный ло краю, съ полукруглымъ возвышеніемъ, средняя линія его въ 


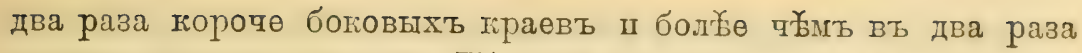
корочө шестого сегмента. ПШестої сегментъ сь двумя продольнымш желобкамп, боковня лопасти седьмого генптальнаго сегмента большія, шпрокія, доходящія до вершины восьмого-послюдняго генптальнаго сегмевта; на поверхностп пхъ недалего отъ основанія заметтно по большому бугорку.

§. Длина 7,6-8,6 милл., пирвна брюшка $3,4-4$ милл.

‥ Дллгна 8,8-9 милл., шшрнва бргошка 3,6-3,8 мплл.

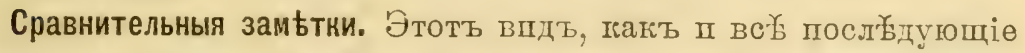
вдды рода Mezira Ax. SERv., являетея płзго отгранпченнымъ рядомь морфиологпческпхъ особенностей, ему прпсущпхъ. Оть всьиъ палеарғтпческих впдовъ рода отлшчается щшткомљ, бо-

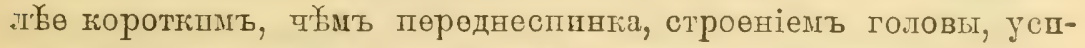
ковъ, переднеспинц, посльгыншхь стернштовъ брюпка.

Геограбцческое распространеніе Mesira tremulae (Gerм.) (cм. карту), а также рхззкая обособленность его отъ других'ь вцдовъ указываетъ на пзвъстную древность впда.

Географическое распространеніе. Впдъ спорадпчеспп встр务чающійся въ Европ年, Закавкавь немь Восток' Спбари.

Извъстенъ изъ Пивеціп, Германіп, Пталіп, Венгріп-въ Запалной Европ', пзъ съв.-зап. п вост. Россіп: Курляндіп,

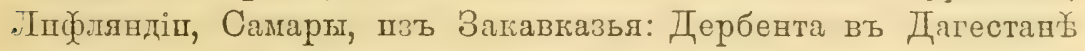
II нз' У Уссурійскаго края.

Образъ жизни. На КавказҰз тпветъ подъ торої тополеї (Ко-

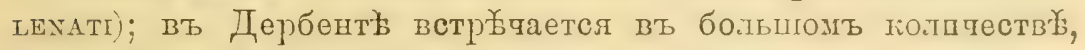
такъ, напр., А. Ћомаровъ нашель до 100 эгземпляровъ этого вшда.

\section{Mezira setosa $J_{A K}, 1880$.}

Mezira setosa JAT. Bull. Soc. Nat. Mosc. 1880. 1, p. 171.

Фаушетическая литература, гасающаяея Россін.

MIezirca setosa JAK. loc. cit., p. 171 (Vladivostok).

\section{Экземпляры Зоологичеснаго Музея.}

Ussuri (P).

Aiагнозъ. Subparallela, retrorsum vix dilatata, fusco-nigra, setis brevibus, adpressis, flavis dense vestita. 
Caput prolongatione antica medio constricta, apice valde dilatata, nutante, apicem articuli primi antennarum vix superante; lobis lateralibus antenniferis acutis, sat longis, extrorsum vergentibus; lobis temporalibus acutis, sursum reflexis, ultra latera oculorum vix prominentibus, margine exteriore loborum recto, cum basi capitis angulum obtusum formante; crista ad orbitam interiorem alta.

Antennae pilosae; articulo primo curvato, articulo secundo fere in ${ }_{3}^{1}$ quam articulus primus longiore, basin versus sensim angustato, articulo tertio sat tenui, basin versus sensim angustato et quam articulus secundus longiore, articulo quarto tertio breviore, basi angustato, apice flavo.

Rostrum tenue, basin capitis vix superans.

Pronotum transversum, longitudine sua duplo latius, granulosum; margine anteriore late et profunde sinuato; margine postico sinuato; marginibus lateralibus post medium rectis, parallelis, antice profunde obtuse angulato-emarginatis; marginibus incisurae indistincte crenulatis, reflexis, fuscis. Pronotum medio sulco transverso instructum, in dimidio pronoti antico tuberculis 4intermediis magnis et lateralibus minoribus armatum; dimidium posticum valde convexum.

Scutellum pronoto longitudine aequale, apice angustatum, tuberculis basalibus et carina mediana instructum.

Corium hemelytrorum scutello multo longius, basi dilatatum, apicem versus angustatum, sinuatum; angulo apicali rotundato; sutura membranae late sinuata. Membrana brunnea, prope angulum apicalem corii albida.

Connexivum marginibus basalilus segmentorum late flavis; inter marginem exteriorem et spiraculos impressionibus nigris instructum.

Inferme rufescenti-brunnea; connexivo angulis basalibus maculis flavis, magnis ornato.

․ Linea media segmenti quinti ventralis margine laterali duplo breviore et quan segmentum sextum duplo breviore; segmentum sextum basi sinuatum, lobis lateralibus triangularilus. Lobi laterales segmenti septimi genitalis magni, lati, apicem segmenti octari attingentes.

오. Long. $9 \mathrm{~mm}$, lat. $4 \mathrm{~mm}$.

Описаніе. ТҐло съ почтп параллельвымп краямш, кзади слегка 
распиряющеест, темно-бураго, почтп төрнаго цвб̆та съ матовоі, грубо-зернпстої поверхностыо, покрытой коротюпми, едва замехтными, щетинпстымп волоскаму.

Голова почти одинаково раявнтая, какь въ длпну, такь

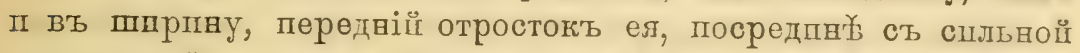
перетяжкой, впередп съ очень узкой вырґзкой; боговые отро-

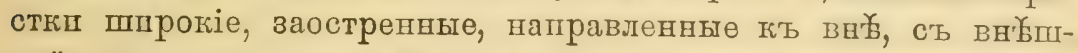
неї стороны съ легкой выемкої; впсочные отростіл прямые, острые, короткіе, едва заходящіе за вноㅎшній край глаљъ, направленные немного вверхъ, ихъ задній краї-прямої, косо сръзанныи; гребень, пдущіиі отъ орбпты глазъ къ основанію головы, высокій, почти вертпкально поставленный; затылотныл борозды къ основаніг головы расходящілся.

Јспкц въ бугоркахь, на вершшнахт которыхъ спдять волоскп, пөрвыі членшкъ нө достигаеть вершпны передвяго отростка, спльно пзогнутыц, второй членшкь длинный, по

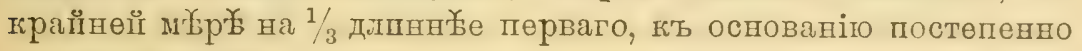
съужпвающійя, третій членикљ длпнне ве второго, постөпенно съулшвающіися къ основаніг, тоныпе второго; четвертый тлентік на вершшн вершины, короче третьяго членига.

Переднеспнка поперечнал, вгвое тороче своей пиршпы, длпна ея равна щптпку. Перегтії край глубоко II шпрогі выемчатыі; ваднії краї передъ основаніемъ щптпіа съ пологої выемтой, боковые края вт, передней половпне하 несуть г.тү-

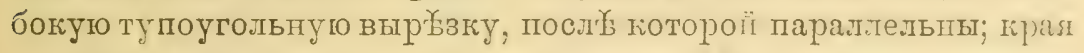
вырҺзки мелко зазубрены, прппогняты. Поверхновть передне-

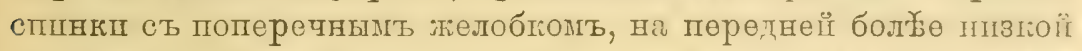
половшн

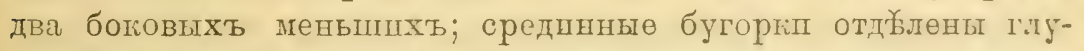
бокой бороздої; задняя половцна пөрегнеспниц прппогнятая, плечевые углы на ней вздутые.

Пптикъ треугольный, удлшневныц, т верппны слегка сту-

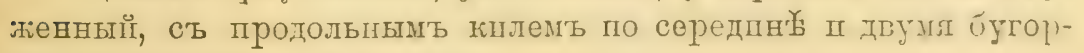
ками въ основныхъ углахъ.

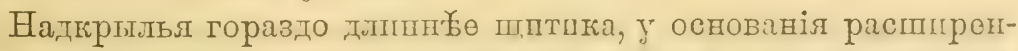

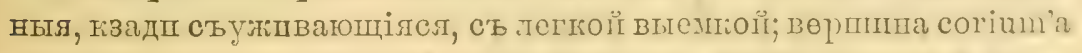
образуеть очень ппрогій остры ї уголь, мембрянальны й повт,

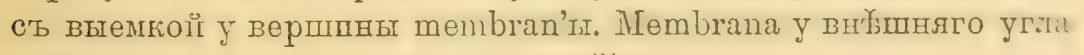
corium'a и ея вөршпна желтовато-бљлал. 
Connexivum бурый, съ ғелтоватыми, шпрокпи, поперечнымш полосами по заднему краю отдызыьныхь сегментов'; на пе-

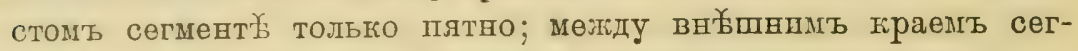
ментовт п дыхальдамп неясныя вдавленія чөрнаго цвы̆та.

Снпзу төмно-бурая, въ основныхъ углахъ connexivum'a желтыя пятна.

\section{Ногп черныя.}

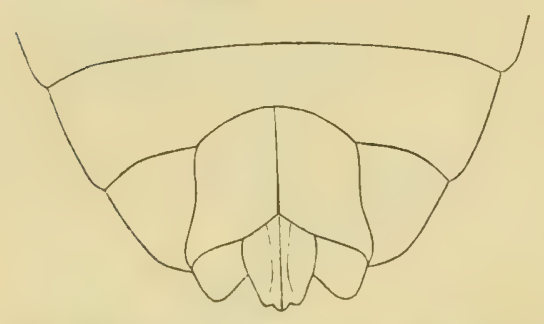

PII. 5. V-VIII стернпть б́рюnia. ㅇ. Mezira setosa JАK. (匹зъ Уссурi⿱䒑стаго гірал).

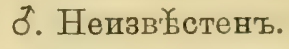

ㅇ. Пятый брюшної сөг* ментъ глубоко вырьванный, срединная линія его почти равна длпни्্́ пятаго сегмента; боковыя лопасти седьмого генптальнаго сегмента треугольныя, выпуклыя, достигающія вершшны восьмого сегмента.

Длшна 9 милл., пшрина 4 мшлл.

Сравнительныя замьтки. Этоть впдъ, какъ п всґ прочіө палеарктпескіе виды рода Mеzira Ам. SERv., рłзко отлшчается отъ другшхъ рлдомь морфологпческпхъ прпзнаковъ іл нц съ

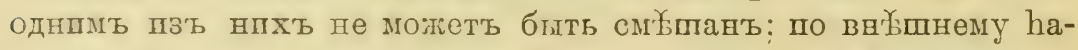
bitus'y небскольно походить на Mrezira tremulae (Gerм.), но гораздо тороче п шпре ея, особенно ея переднеспшнка; вшсочные отростнш ея ввшды пшповъ, ботовые гірая переднеспшнк впереди

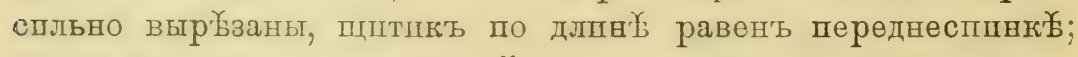

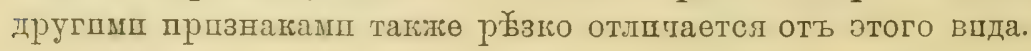

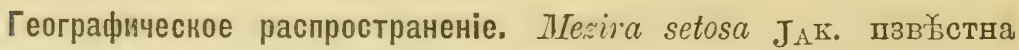
только пзъ 10 жно-У ссурійскаго края (Владпвостокъ).

\section{Mezira atra JAK. 1878.}

(Табл. I, фиг. 2).

Mezira atra $\mathrm{J}_{\mathrm{AE}}$. Bull. Soc. Nat. Mosc. 1878. 1, p. 135 et 136; ibid. 1880. 1. p. 171.

Фаунпетпческая литература, касающаяся Россіп.

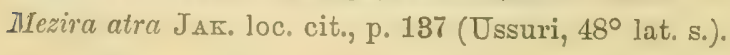




\section{Энземплары Зоологичеснаго Музея.}

Ussuri (2 of). Dувоуsкi.

Діагно3ъ. Sub-parallela, oblonga, nigra, retrorsum leviter dilatata, glabra.

Caput latitudine sua longius, prolongatione antica medio constricta, paulo deorsum recurvata, apicem articuli primi antennarum vix superante; lobis lateralibus antenniferis brevibus, antrorsum et extrorsum vergentibus; lobis temporalibus dentiformibus marginem oculorum haud superantibus, margine exteriore loborum recto; crista ad orbitam interiorem oculorum alta, sulcis verticis profundis.

Antennae crassae, breves; articulo primo prolongatione antica capitis vix breviore, margine interiore tuberculo obtuso instructo; articulo secundo primo tenuiore, articulo tertio longitudine aequali; articulo tertio basin versus in pedunculum brevem angustato; articulo quarto fusiformi, albido-piloso, quam articulus tertius in $1 / 4$ breviore.

Pronotum longitudine sua duplo et dimidio latius, antrorsum angustatum, medio convexum; sulco instructum; in dimidio apicali tuberculis quatuor: duobus lateralibus distinctis et duobus intermediis obsoletis; anguli humerales convexi; marginibus anteriore posterioreque leviter late sinuatis, marginibus lateralibus rotundatis.

Scutellum triangulare, pronoto aequilongum; lateribus, apice imo excepto, carinato-elevatis, medio indistincte carinato.

Margine exteriore corii hemelytrorum basi recto; corio api- . cem versus gradatim angustato, sutura membranae recta, vix undata. Membrana nitida, nigra.

б. Segmentum quintum ventrale marginibus lateralihus fere aequilongis, quam segmentum sextum sosqui hrevius; margine posteriore sensim et haud profunde sinuato. Segmentum sextum basi rugis linearibus indistinctis praeditum. Segnentum septimum angustum quam segmentum octarum genitale quater brevius, lobulis lateralibus brevibus, dimidium segmenti octavi haud attingentibus.

ㅇ. Segmentum quintum rentrale latum, trisinuatum: haud profunde et late ante medium lateribusque anto lobos laterales segmenti septimi; linea mediana sesqui breviore quam segmentum sextum et fere totidem margine laterali segmenti quinti; 
lobi laterales segmenti septimi genitalis apicem segmenti octavi haud attingentes.

§. Long. $9 \mathrm{~mm}$., latit. $3,5 \mathrm{~mm}$.

ㅇ. Long. 9,5-10 mm., latit. 3,8-4 mm.

Описаніе. Совершенно чернаго цвҺัбта, только ляшкп, вертлугп, вершпны голеней п лапи бурыя; удлшненная съ почтп

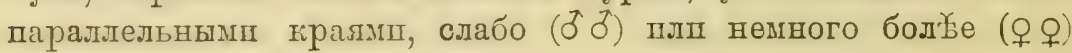
расшпряющаяся кзади.

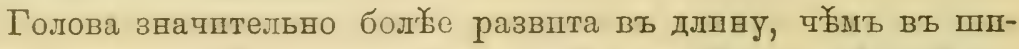

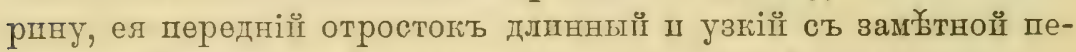
ретяжкой посредшна্ব, клювооиразно загнутый внизъ, равенъ длина б перваго членпка усшковъ; боковые отросткп короткіе,

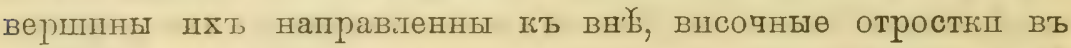
впдеу жюроткшхъ, толстыхъ пвповъ, нө заходящпхъ за край глаза, задвіө грая шхъ прямые; гребень, вдущії оть орбдты глаза цъ основанію головы, высокій; затылочные желобнш глубокіе.

Успкп толстые, лороткіе; пхъ первый пленпкъ короче перегняго отростка головы съ тунымъ выростомъ на внутреннеіі сторон角, второї чшенпкъ тоньше перваго, по велпчние равенъ третьему, третій члению тоньше второго, постепенно утончающійсл, отанчпвающійся пожкой, четвертый членикъ бобовидный, пріостревныц у основанія іл вершіны, покрытый бӗловатыми волоскамп.

- Переднеспнка вдвое тороче своеї напбольшей ппрпны, равномгорно слабо выпүклая, съ неглуботой бороздої по сре-

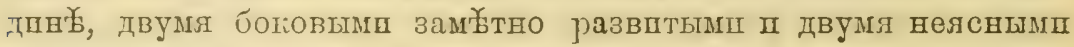
сретшннып бугоркамш: плечевые углы переднеспинки выпті-

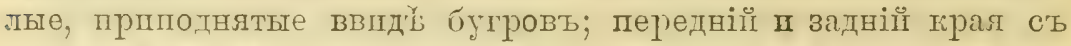
замfтної выемкої; боговые края закругленные, ппереди съужшвающіеся.

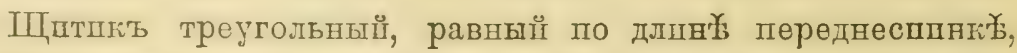
съ боковнми граямш, псключал самой вершпны, кплевато прпподнятыми; на поверхностш у основанія ел неявственный пшль.

Надхрылья съ боковнмъ граемъ прямымъ, у основанія не расшпреннымь, постепенно съужшвающіяся къ вершшнб, мембранальный повъ прлмоі, чуть волншстый, безъ выемкп. Мемbrana темно-бурая, блестящая. 
3. Средняя линія пятаго брюпнаго сегмента въ 11/2 раза гіроче шестого сегмента, почтп равна боковому праю: задній трац сегмента полого пі неглубого выр ъзань. Пестої брюшной сегментъ съ бугорномъ п неяснымъ лшнейнымъ возвыпевіель йлпзъ

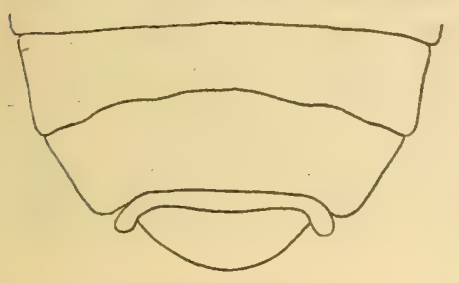

Pшс. 6. V-VIII брюшные стернитьі.

Mezira atra $\mathrm{J}_{\mathrm{AK}}$ ठั.

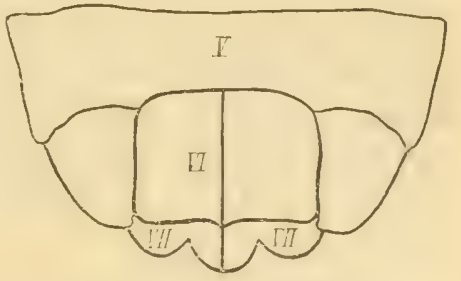

Pис. 7. V-VIII брюшные стерншты. IIezira atra $\mathrm{J}_{\mathrm{AE}}$. 우.

основанія. Седьмой сегменть узтій, въ четыре раза уже восьмого генитальнаго сегмента. Отростіг седьмого сегмента короткіе, не доходящіе до половины восьмого генптальнаго сегмента.

ф. Пятый брюпной сегменть ппрокій, трпжды вырқзанныі: неглубоко п полого передт пестымь сегментоль пі передъ боковымп лопастямп его. Средпнная лпнія въ $1_{2}^{1 / 2}$ раза короче шестого сегмента п почти тағже бокового жрая; боковия топасти седьмого генптальнаго сегмента не достпгатот вершпны посльдняг (VIII) генитальнаго сегмента.

ठे. Длина 9 мплл., шшршна 3,5 мшлл.

‥ Длшна 9,5-10 мшлл., тирнна 3,8-4 мплл.

Сравнительныя замьтки. Вшдт этотт рłзко отлдчается отъ

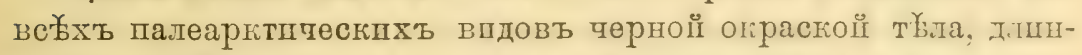
ной головой, нороткимг, толетымп успкамд, тупымт выростомь на первомъ членпкет успковъ, строеніемъ перегнеспниш, наг-

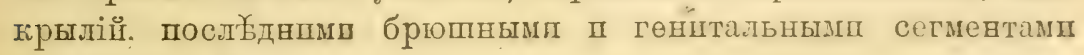
今. II 우 п др. признаками.

Географическое распространеніе. Ветрбчается Въ Южно-Јссу-

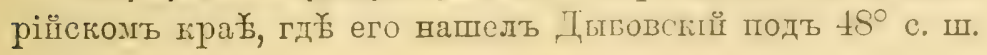

4. Mezira verrucigera (Bergr.). 1892.

Brachyrhynchus rermcigry Bergr. Rev. d'Ent., p. 261. 1892. - Ent. Tidik., p. 108. 1894. 


\section{Фаунистпеская литература, касающаяея Россіш.}

Brachyrhynchus vernuciger BERGR, loc. cit., p. 261. 1892 („Amuria“).

Дiагн03ъ. Obovata, fusca. Caput latitudine sua longius; prolongatione antica medio angustata, antrorsum dilatata, apice biloba, dimidium articuli primi antennarum superante; lobis lateralibus antenniferis acutis, extrorsum vergentibus; lobis temporalibus spiniformibus, acutis, rectis, marginem exteriorem oculi superantibus; margine posteriore loborum sinuato; superficie capitis pilis flavicanti-albidis, adpressis dense vestita; crista ad orbitam interiorem oculi alta.

Articulo primo antennarum basi tenui, flavicante, post trientem partem longitudinis suae incrassato, articulo secundo primo fere aequilongo, apicem versus sensim incrassato, articulo tertio secundo breviore, basi in pedunculum longum, pallidum, gracilem angustato, apicen versus incrassato, apice imo pallidiore, articulo quarto tertio in ${ }_{1 / 4}^{1 /}$ breviore, fusiformi, distincte longe piloso, apice imo pallidiore.

Rostrum longum, angustum, cylindricum, basin capitis attingens, flavicans, articulo secundo primo duplo longiore.

Pronotum dense flaro-pilosum, transversum, longitudine sua duplo latius; margine anteriore post caput lateribusque profunde sinuato, margine anteriore itaque trisinuato; marginibus lateralibus ante medium profundissime angulato-incisis; lobi pronoti inter angulum incisurae et sinuationem lateralem marginis anterioris sursum vergentes, laeti; marginibus horizontalibus angulorum rectorum incisurae extrorsun dentato-productis; marginibus lateralibus pronoti postice leviter sinuatis, deinde subparallelis; margine posteriore pronoti trisinuato.

Pronotum sulco transverso praeditum, quo in partes duas dirisum: dimidio antico humiliore, tuberculis intermediis magnis, conicis, sulco longitudinali discretis, tuberculisque parvis utrinque instructo: dimidio postico majore, convexo, carina bisinuata instructo.

Scutellum longitudine sua parum latius, longitudine pronoti aequilongo, dense flaro-pilosm, medio propo basin sat elevatum, carina media percurrente instructum, in angulis basalibas utrinque tuberculo pallido praeditum.

Hemelytra pilosa, apicem versus fortiter angustata, margipe laterali basi truncato, fore recto, loviter sinuato, haud dila- 
tato; corio sordide flavescente, granulis, costa externa, sutura membranae, margine extereriore obscure-fuscis; corio scutello sesqui longiore, angulo apicali rotundato; sutura membranae sinuata; membrana lorunnea, dense rugulosa, venis distinctis destituta, basi albescente.

Connexivum flavo-variegatum, marginibus apicalibus, segmenti sexti excepti, lato albido-flavis, segmento sexto in angulo basali macula aldido-flava ornato; angulis posticis segmentorum singulorum prominentibus, marginibus lateralibus rectis, segmenti sexti sinuatis.

Pedes longiusculi, fusci, trochanteribus ac tibiarum hasi et annulo medio pallide testaceis, annulo subbasali tibiarum nigricante.

๙. Segmentum quintum leviter sinuatum, linea media lateribus parum breviore; segmento sexto quinto fere aequilongo, angulis posterioribus acutis, segmentum septimum brerissimum, lolulis segmenti septimi tenuissimis, apice flavis, apicem segmenti ultimi haud attingentibus, segmentum genitale conicum.

9. Ignota.

Long. 7-7,4 mm., lat. $3,5 \mathrm{~mm}$.

Описаніе. ППпрого-овальнал, төмно-горпчневаго цв妾та. Голова

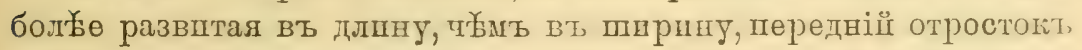

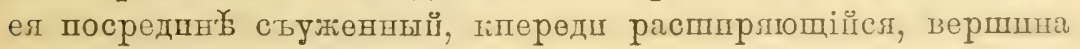

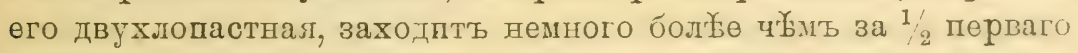
членшка успковъ, боговые отростки диннные, тонкіе, острие,

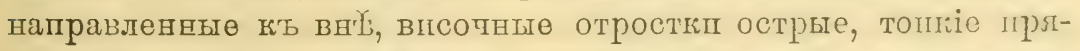
мые, заходящіе за край глаза, задніе грал пхъ выемчатые; иоверхность головы густо погрыта б́бловато-желтыми прилегацщимц волоскамп, гребень, пдущі ї оть оришты глаза пі основанію головы, высокій; возлы внжшняго грая его отт, верпннц гребня до уровня основанія боковыхт отростковт находятя

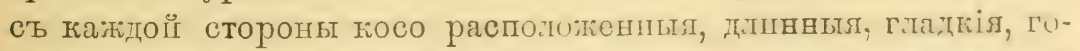
лыя плопцадкш, за которымц находятел затылочныл борозды; за-

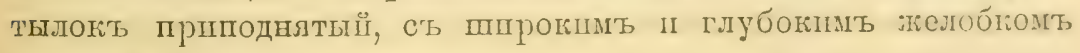
посредшнег.

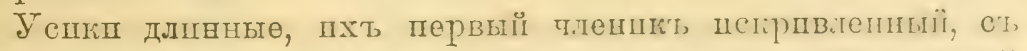

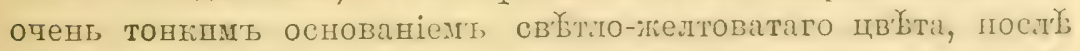

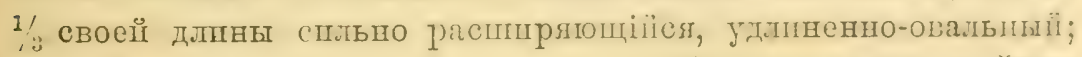

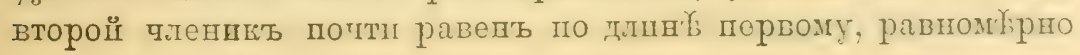


II очень незначптельно утолщатщійся отъ основанія къ вершине, гораздо тоньше перваго; третії членцкь самый тонкії,

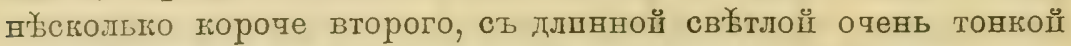
ножкой у основаніл, утопщаюшійся къ вершпнг, вөршпна его бол'е св төнообразный, ст зам Ұтно длиннымп волоскамп, на самої вер-

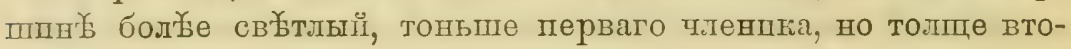
рого.

Хоботокъ длннныцั, достпгашщій основаніл головы, тонкіп,

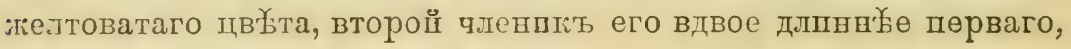
правшльно пшлиндрической формы.

Переднесппнка поперечная, вдвое шпре своеї длпны, передніiі жрай ея съ глубокой выемкой передъ голової п епе несеть дв. бо боле глубогіл выемкп по бокамъ; боковые крал въ переднеї третп очень глубого прямоугольно вырұзаны, участкп перөднесппнцп между вертпкальноі стороноі прямого угла вы-

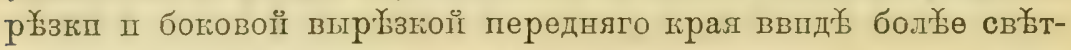
лыхъ лопастей загнуты вверхъ; горпзонтальнал сторона пря-

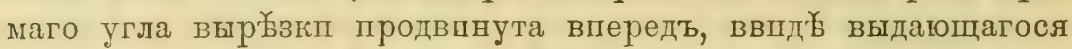
угла сь закругленной вершиной, позадш котораго боковые края съ эегхой выемкой, а ватею̆мъ потти параллельны; задвій граї переднеспшвки съ тремя выемкамп.

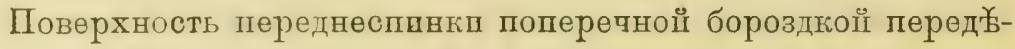
лена да дв各 долп: передняя, болькө низкая несеть два срединныхъ, высокпхъ, коншческшхь выроста, отдығленныхъ продольної бороздої, а по бокамъ пхъ два маленькшхъ бугорка; зад-

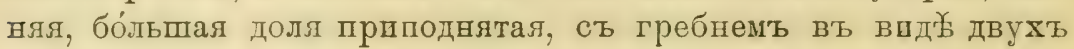
соединенныхъ свопмп концама, неправпльныхь дугљ. Вся поверхность переднесппнкп, исключая кондовъ вырұзип боковыхъ краевъ и желобка, раздйллющаго два выроста пөредней доли, густо покрыта бұлювато-желтоватыми, прплегацщпи волоскамш.

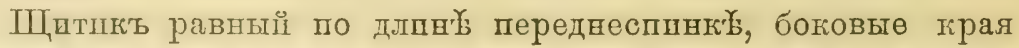
его прнподнятые; посредшнй пптнга проходшть кпль, въ основныхь углахь его по св верхность волоспстая.

Надікылья доходять до середпны шестого брюшного сегмента; согіum пхъ гораздо длшннызе щитпка, у основанія почтп прямої, те расширенный, образующій въ понци своеї гервої третп слегка выдающіися уголь, посл息 котораго съужпвается, 
ства лишь съ, тагъ называемымш, палөарптшческшмш вшдамп. Пзученіе некіоторыхъ энзотшческшхъ вшдовъ не позволяетъ п этсть впдъ выдбллть пзъ чрезвычащнн гетерогеннаго рода Meziva Ам. SERv. Подойное удшвцтельное строеніе пөрөднө-

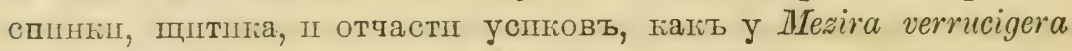
(Bergr.), шщететь, напр., впдь Mezira tenericornis (Bergr.) пзъ Бшрманіш.

Географическое распространеніе. Вгдъ этоть встрҺъчается на

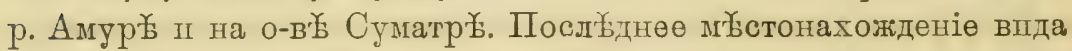
унавано авторомъ BЕRGRотн'омъ, таћъ тто врлдъ лі можеть

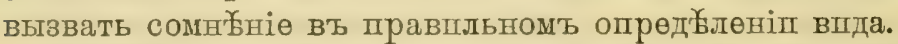

В. Ф. Ошанинь вызгазываеть сомнбніе (см. Verz. d. palaearct. Hemipt., I, p. 480) въ в „Amuria“", но я пмъль въ рукахь эквемплярь изъ Южно-Уссу-

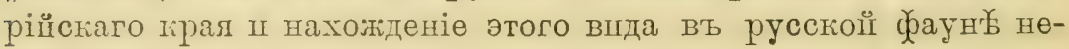
сомно्रेнно.

5. Mezira castanea JAK. 1878.

(Табл. I, фопгі. 3).

Mezira castanea JAK. Bull. Soc. Nat. Mosc. 1878. 1, p. 137; ibid. 1880. 1, p. 171. Mezira oviventris Reut. Wien. Entom. Zeit., p. 136. 1884; BerGr. Wien. Ent. Zeit., p. 181. 1885.

Фауппстиеская литература, касацаяся Россіп.

Mezira castanea JAk. loc. cit., p. 139. 1878 (Ussuri, $48^{\circ}$ lat. s.). Mezira oviventris Reur. loc. cit., p. 136 (Vladivostok).

\section{Экземпляры Зоологичеснаго Музеа.}

Ussuri, $48^{\circ}$ lat. s. (ठ゚). DrBovski.

Vladivostok. 1912. () (specimen typicum M. castaneae $J_{A \text { K. }}$ ).

Vladivostok. (Q) (specimen co-typicum M. oviventris REUT.).

Діагнозъ. Obovalis, fusco-castanea, retrorsum parum dilatata, glabra.

Caput longius, quam latum; prolongatione antica brevi, apicem articuli primi antennarum vix attingente, lobis lateralibus antenniferis brevibus, acutis, loviter divergentibus, lobis temporalibus brevibus, marginem exteriorem oculorum rix superantibus, apice sit obtusis, margine exteriore loborum obliquo; crista ad orbitam interiorem humili; sulcis verticis paulo divergentibus.

Antennae articulo primo crasso, apicem capitis vix attingente, articulo secundo quam primus longiore, tenuiore, apicem 
rersus sensim incrassato, articulo tertio quam articulus secundus fere in $1 / 4$ et quam articulus quartus duplo longiore, basi pedunculum brevissimum formante; articulo quarto apice flavo.

Rostrum subtile, flavum.

Pronotum transversum, longitudine sua magis quam duplo latius, antrorsum angustatum; margine anteriore profunde sinuato, margine posteriore late sinuato, marginibus lateralibus reflexis, ante medium vix sinuatis, angulis anterioribus obtusis. Suporficies pronoti sulco transverso, haud profundo, indistincto priedita, antice tuberculis obsoletis, pallidioribus, longitudinaliter productis instructo; angulis humeralibus convexis.

Scutellum triangulare, pronoto vix longius, medio carina distincta instructum.

Hemelytra marginibus lateralibus basi rectis, haud dilatatis, apicem rersus fortiter angustata; corio sordide testaceo, subhyitlino, costis, granulis, angulo basali margineque exteriore late fuscis; corio fere in ${ }_{1 / 3}$ quam scutellum longiore, angulo apicali acuminato; sutura membranae sinuata; mombrana funata, nitente, basi ritta obliqua undulata albida, medio interdum macula albida signata.

Connexirum marginibus basalibus segmentorum pillide flavescentibus; spiraculis a margine exteriore sogmentorum lineis longitudinalibus, elevatis, ferrugineis discretis.

Pedes castanei.

万. Segmentum quintum ventrale profunde sinuatum; linea media lateribus duplo breriore et quam segmentum sextum quoque duplo breviore; segmentum septimum sit longum quim sermentum octarum genitale fere duplo lrevius et ynam socmentum sextum duplo et dimidio brevius: lobulis segmenti septimi apicem segmenti octavi haud attingentibus.

o. Segmentum quintum rentrale margine apicali trisinuatum. linea media marginibus lateralibus duplo breviore ot quam se:mentum sextum totidem breviore; margino apicali sommenti sexti sinuato, medio anto riman gonitalem antrorsum producto, loli. lateralibus segmenti genitulis septimi sat ancustis, apice sẹmenti octavi paulo haud attingentibus.

Long. 6,5 mm., lat. $3,5 \mathrm{~mm}$.

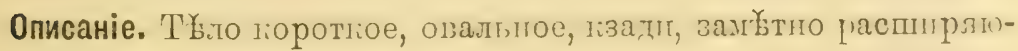
щееся, темно-ғаштановаго цвог̆бта, бөзводосое. 


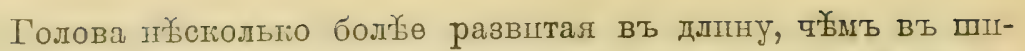
рпну, переднііі отростогъ ея поротній, горшзонтальный, съ небольшой выемпой бокового грая посредшнг্ ; пөредъ tylus'омъ

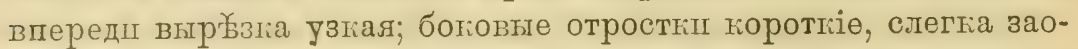
стренные І слабо направленные къ внર્א; впсочные отростіп съ притупленной верпшной, прямые, короткіе, не заходять за краі

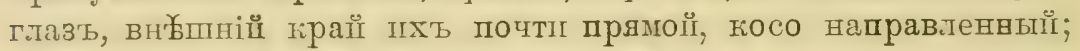
греб́ень, пдущій оть орбщты ть основанію головы, не высокій; төмянные жөлобкп мало расходящіеся.

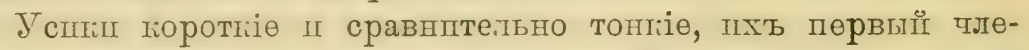
нић' доходшть до верпины передняго отростіа головы, второї гленці немного длпние перваго, шъ основанію съуӝваю-

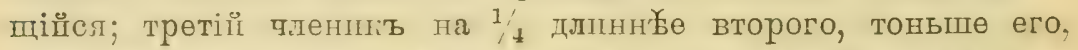
гъъ основанію спльно съуживающічося, образующій ножгу жел-

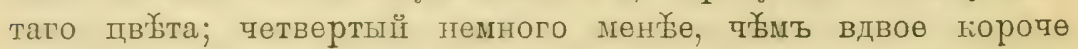
третьлг, волоспстая верпина его желтая; хоботогь буроватожелтый.

Переднеспшна поперөчнал, вдвое шпре своей длины; передній тіраї өл ст довольно глубогой выемкой, задній, очень шірого и полого выемчатыі, боловые гірая огруглены, обравугть передь серөдниої небольшую выемпу, загнуты ввөрхъ, почті безъ зазуборннъ. Поверхность переднеспнгі довольно

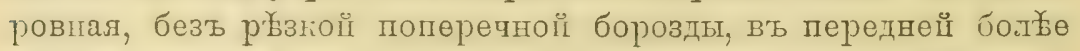
темной половпн рыхъ находлтея два госо направленныхъ торотіпхъ ребра, желтоватаго цвёта.

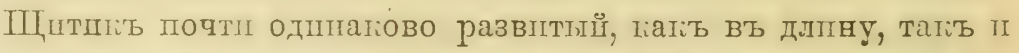

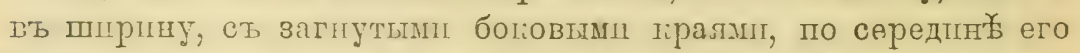
проходить лвственный дігль изъ попереqныхъ морщпногіт.

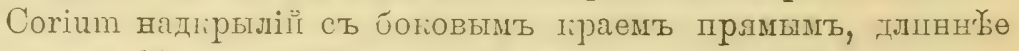

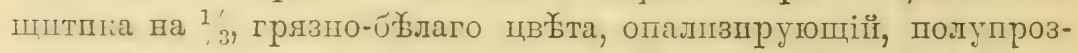

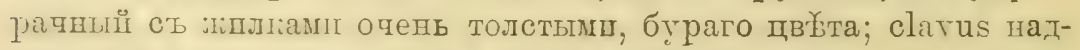

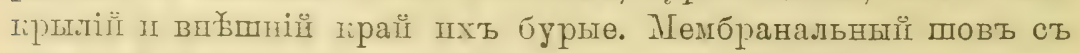
зыемпой у основалія; membrana бурая, основаніө ея грязно. бураго цветта сь небскольпмп бурымп пятнамп.

Ботіовые тірая сопnехіvит'а пзадш спльно расшпряющіесл,

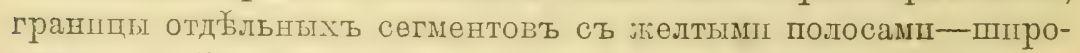

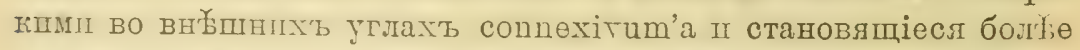
үвтпм по направленіг Іъь его внутренниль угламъ. Дыхальца

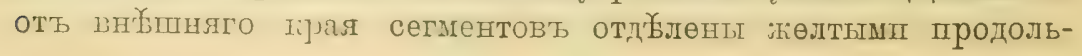


продольныя лпніп на connexivum'各, отдияляющія дыхальца оть внеишняго края, соверпенно опущенъ въ граткомъ нйыедкомъ (которымт, жонечно, только ІІ могутъ пользоваться не славянстіе авторы) діагноз в В. Е. ЯковлевА. Въ русскомъ описаніш о немъ упомннается, но совершенно неясно: „внутренніе края сегмента съ поперечнымш желтоватымп полоскамп, св Ұтлыми пятнами ил линіями".

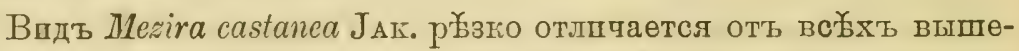

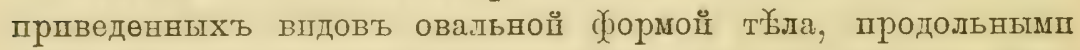

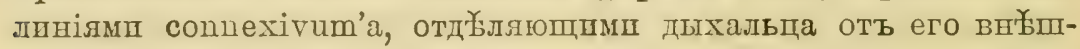
няго края и другимп прнзнаками.

Географическое распространеніе. Ввдъ этоть нац̆дөнъ вт ЮжноУссурійскомъ крағ подъ $48^{\circ}$ с. ш. п въ Владнвосток各.

\section{Mezira brevicornis Reut. 1881.}

ILezira brevicornis ReUt. Wien. Ent. Zeit., III, p. 137. 1884. - Bergr. Wien. Ent. Zeit., IV, p. 181. 1885.

\section{Фаунистпеская литература, касающаяся Россіп.}

Mezira brevicornis REUT. loc. cit., p. 137 (Vladivostok).

Діагнозъ. Sub-parallela, obscure castanea, glabra, dense granulosa, capite latitudine basali fere dimidio longiore, parte pone basin antenuarum sub-quadrato, lobis lateralilus antenniferis sat brevibus, ultra latera oculorum haud prominentibus, sulcis rerticis sat angustis leriter divergentibus, crista ad orbitam interiorem oculorum humili; oculis minutis; antennis articulo primo apicem capitis haud attingente, secundo primo nounihil ]ongiore, tertio secundo longitudine aequali, sed basi longius pedunculato, quarto tertio paulo breviore; pronoto lateribus mox pone medium obtuse rotundatis margine subintegris, basi latissime simuato: scutello aequelateraliter triangulari, pronoto rix longiore, angulis basalibus hand callosis, disco carina destituto; corio et claro coriaceis, obscure castaneis, illo scutellum solum tertia apicali parte superante; membrana fusca, angulis basalibus albidis, sutura membrana interne sinuata; abdomine pedibusque obscure castaneis, solum ipsis marginibus seginentorum, tiljiis et tarsis panto dilutioribus. Long. o $7^{1 / 2} \mathrm{~mm}$. (no Revter'y). 
Описаніе. Сь почтш параллельнылш тіраямп, темво-капгтанваго цвъта, поверхностт, тъ.ла сптьно зернпстал. безволосая.

Голова наполовпнт длиннҰе своей пирниы у основавіл: боковые отростки головы ғоротніе; голова позади гла:э, почті ғвадратная, грөбень на нөй. пгуцій къ внутреннему крап орбпты нпзкій, затылочные желобкп узиіе, слегка расходящіеся.

Первый членпкь успков'ь не доходітть до верппит голопы, второй членшкъ длшннееㅡ перваго, третій равенъ ззторому; у основанія съ дланной нолтоо̆, четвертый членикь слегка лороче третьяго.

Передвеспнка ! основанія ст очень ппрогой втемгои; боковые гірая ея почти пйльные, посль' середины тупо-закругленные.

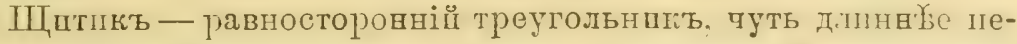
реднеспинк; основные углы его безъ возвышеніӵ, средшнныи ґпль также отсутствуетъ.

Надқрылья темно-гаштановаго дв

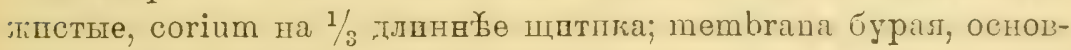
ные углы ея бъ̆ле; мембранальный шовъ съ выемкой.

Брюппо сипзу и ногп темно-каптановыя; гірая сегментовъ,

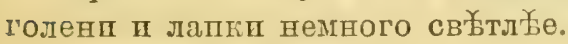

ㅇ․ Длива 7,5 мплл.

Сравнительныя замьтки. Кіь сожал年нію тппь этого впла я не мог' получить на просмотрь пзъ Гельсингфорскаго Музея, такъ какъ онъ утерянъ.

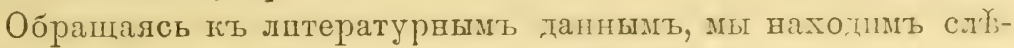
дуюшія данныя о нектоторыхъ его особенностяхъ.

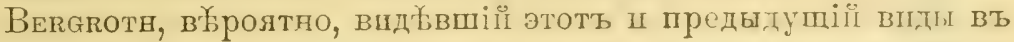
Гельспнгфорскомъ Музељ, говоритт, обт, налпчності У Мегіна brevicornis Reut. II Mesira ovicentris lin. продольныхь возвы-

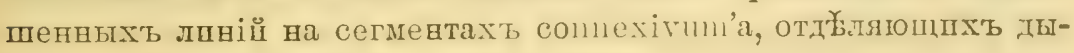
хальца оть внеютняго грал сегментовъ.

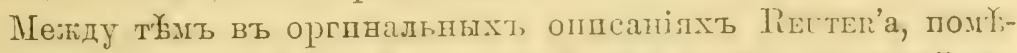

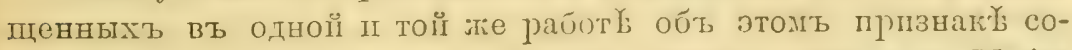

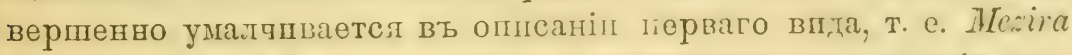

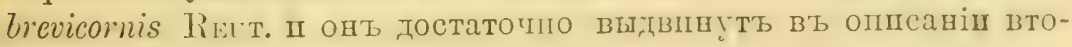
рого вшда.

Во всякомъ случағ видъ этотъ не можеть быть смишанъ ніг съ однпмь шзъ вышеоппсанных ь пщдовъ.

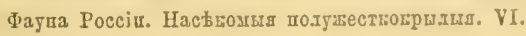




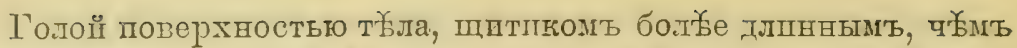

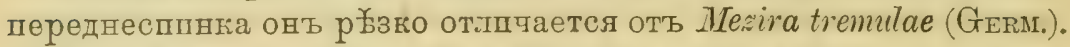

Голої поверхностыо түғыл, боковымп храямп переднеспннки

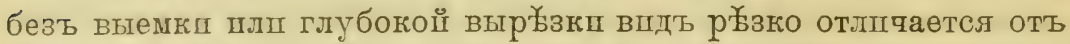

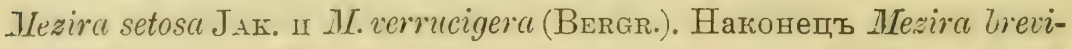

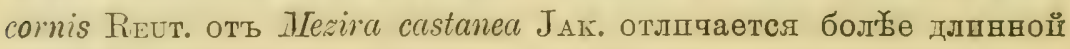
головой, строеніемъ успковъ, отсутствіемъ продольнаго кпля на пптпке́, corium'омь п clavus'омь вадкрылій - кожпстымш, одноцветтнымп и другпми прнзнакамг.

Оть Меzira atra ЈАк. отлптается темно-каштановымъ цв томъ, мембранальнымъ швомъ выемчатымъ, первымъ членикомъ успковъ безъ выдаюшагося бугра на внутренней поверхностп.

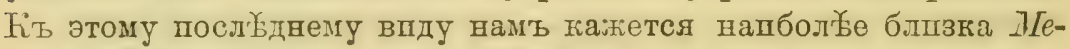
zira brevicomis Rect, еслI указаніе Bergrotн'a на присутствіе

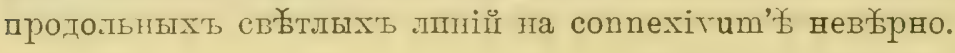

Географическое распространеніе. Мlezira brevicomį Rебт. пзвъстна только пзъ Владивостока.

\section{Mezira seabrosa Scotr. 1874.}

Mezira scabrosa Scort. Ann. M. N. Hist. (4), 14, 1874, p. 444.

Діагнозъ. Corpus piceo-nigrum vel finscum, verrucosum. Antennae articulo quarto apice sordide-flaro. Pronotum tuberculis 4 apicalibus praeditum. Scutellum carina longitudinali instructum. Connexirum marginibus apicalibus segmentorum pallide fuscis.

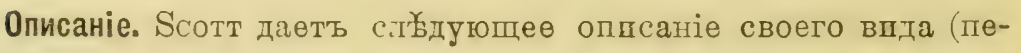
рөводъ).

Смоляно-черная плп бурая, густо поғрытая бугоркамп. У сши смоляно-черные, въ густыхъ точнахъ, четвертый ч:тенпкъ пхъ на концеот грязно-желтыт.

Глаза смоляно-черные. Хойотокъ темно-бурып̆. Переднеспннка матовая, смоляно-черная, бугоркіп густо п неправшльно расположенные. Четыре верпинныхъ бугра обыкновенно бурые въ дентрђ.

Шатпћ черный плш смоляно-черныці, въ гүсто расположен-

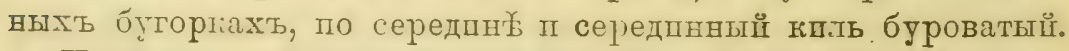

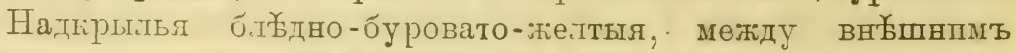

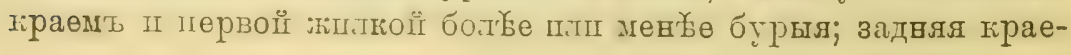




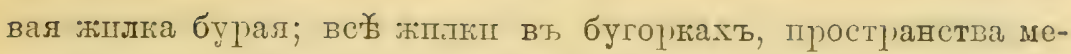
жду ними въ рүғкпхъ бугоркахъ; бугоркп бурые.

Membrana буровато-желтая, жилкі бурџля; за вершиної соrium'а лежшть желтое пятно.

Грудь черно-бурая, вокругь основанія ногъ темно-бурая.

Ногп темно-бурыя, бедра густо п् мелко-зернистыя.

Брюшко снизу темно-бурое; передніе края первыхъ четц-

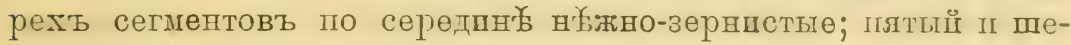
стой сөгменты спгопь зөрнпстые. Соnпехітим төмно-бууый, задніе края сегментовъ сво्бтло-бурые.

Длина 7,5-10 милл.

Сравнительныя замьтки. Впдъ совершенно нелостаточно опи-

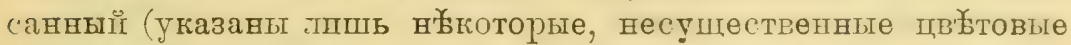
признакп), совершенно не характерпзованныи ц не сравнивается ніг съ одншмъ пзъ другихъ видовъ. Безъ пзслордованія тпповъ Sсотт'а очень түудно 1 впшть, относптся лш әтотъ вшдъ къ одному пзъ пзвйстныхъ уссурійскпхъ плп әто особый само-

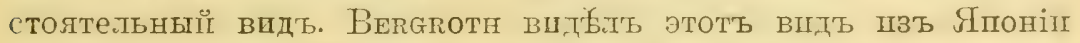

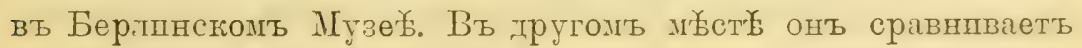
съ $\lambda$. scalrosa одшнъ пвъ свопхъ новоописываехыхъ впдовъ.

Географичесное распространеніе. Sсотт опдсаль свой впдъ ІІз Японіп. Очень возхожно, что видъ этоть заходпть п въ фұауну нашего Уесурійскаго края.

\section{Mezira basalis (Frвв.). 1861.}

Brachyrhynchus basalis FIEB. Eur. Hem., p. 115. 1861.

Этоть вшдъ, описанный пзь Андалузіп п впосльдствіп шай-

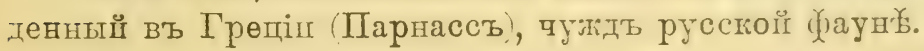

\section{Родъ 3. Aneurus Curtis. 1825.}

Aneurus Curt. Brit. Ent., 2, p. 86. 1825.-Fuor. Rhynch. Livl, 1, p. 395. 1860.Freb. Eur. Hemipt., 35 et 116. 1861.-Dougl. Scotr. Br. Hemipt, p. 267. 1865. - Srì. Hemipt. Afr., 3, p. 32. 1865. - REut. Öfv. af Kongl. Vet.Akad. Förh., № 5, p. 62. 1872.- STit. Enum. Hemipt. 3, p. 140. 1873.Pur. Synops. de Hémipt. Hétér. de Fr., 1, p. 128. 1879.- Bergr. Verh. zool.-bot. Ges. Wien, XXXVI, p. 58. 1886.-Champ. Biol. Centr. Americ., Ins., Rhynch., Hemipt-Het., II, p. 113 1897-1901.-Dist. Fn. Br. Ind. 2, p. 166. 1904 . 
Aiarн03ъ. Corpus glalurum, ollongo-oratum: laterilus retrorsum dilatatis rel fere rectis. Caput prolongatione antica apicen versus paulo ancustata: tylo lato, jugis superne angustis, fere linearibus, apice tỵlo aequilongis vel haud attingentibus: lolis: lateralibus antenniferis lrevibus. apice haud vel paulo acuminatis: lolis temporalibus orbitan oculi haud superantilus, obtusis: caput collo angusto, distincto instructum.

Rostrum prope apicem capitis insertum.

Antennae articulo primo oborato rel oroideo, pedunculo recto brevissimo instructo, brevi, apicem capitis rix superante, articulo quart, longo, articulis tertio secundoque acquilongo rel illis longiore.

Pronotum planmm, transver:mu, longitudine sua duplo latius, margine antico sinuato, postico subrecto, mirginibus lateralilus leviter crenulatis, antice magis minusve late sinuatis, postice rotundatis.

Scutellum latim, apice late rotunditum, lateribus levissine eleratis, hand carinati. Henelvtra abdomine breviora et nulto ancustioral: corio brevi. margine exteriore sulprecto. hasi hand dilatato: membrana maxinam partem hemelytrorum occupante, renis destituta, dense rugulosa.

\$. Segmento unico genitali conico, ultra apicem abdominis excedente, segmento septimo lobnlis parris utrinque praedito.

ㅇ. Segmentis duabus genitalihus lobis lateralibus privati., segmento secundo minutissimo.

'Typus generis: Aneurus laevis (FABr.).

Характеристика. ТҒ.то овальное, сверху ІІ снпз совершенно плоское, безволосое.

Передніі отростокъ головы ғпеједи немного съужпваюпіися, сверху кажется образованнымь главнымъ образомъ ппрокимъ tylus'onғ, скуловые отростки (jugi) сверху очень узкіе, почти лшнейные, достпгаюціо впередп вершпны tylus'a шли немного его короче: боковые отростип головы, несупіө усшп, короткіе, не заходлщіе вершпнами за уровень орбпты глазъ; впсочные отросткп тупые, не вығающіеся за орбшту глазъ, направленные назағъ. Голова прш самомь своемь основаніп стужена вт, узкую, хорошо видимую пею. Хои́отковый желобокъ лавдетовшдыи: хоботоґъ прпкряпленъ блпзь вершшны головы. 
Успкп тонкіе, пхъ первый членпкъ напболье толстый,

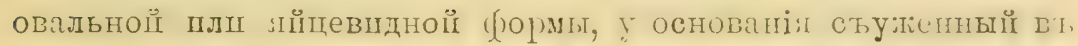
узкую, прямую ножку, короткій, едва заходящій вал вершпну

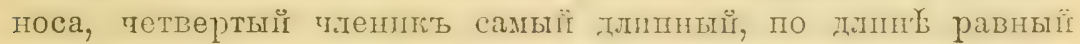
плІ превыпаюцій длпну третьяго п четвертаго членщковъ, вмбете взятыхъ.

Переднеспинка ровная, безъ пшлей, шшроко-попереднал,

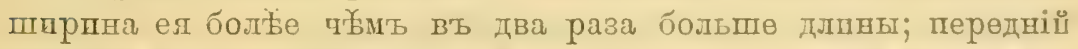
край ея съ глуобокой выемкой, заднії поптп прямої пли съ не-

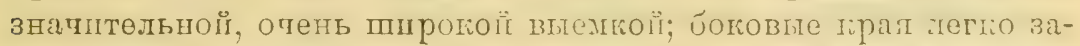

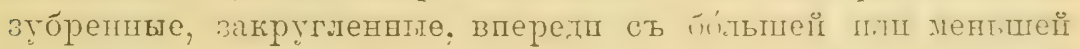
выр б̌з̆ой.

Шштикъ большой, широкічั, вершпна его шшрого закруглевная, боковые грая едва прппотнятые, поверхность поперечно морщшнистая.

Надкрылья короче п значительво у́же сппнной поверхностп брюшка, съ очень короткпмь согілт'омъ, боковой краї кото-

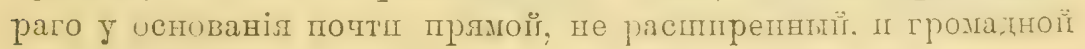
membran'oĭ. Membrana безъ экшлкованія, моршпнпетая.

Ногп булавовндно-вздутыя.

§. Генптальный сегментъ одпнъ, больтой, коншческій, далеко выставленный ва конецъ бртшка, по бокамъ его съ обюшхъ

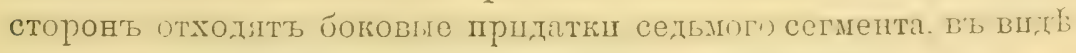
маленькпхъ, рәેдко довольно большпхъ бугорковъ.

‥ Генитальныхь сегмента два, безь боковихт лопастеі̆, второї генптальный сегменть очень маленьііг.

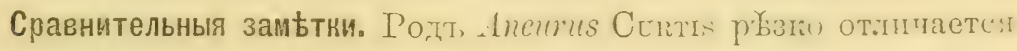
не только оть двухъ предыдущшхє, встрғчающшхя п въ па-

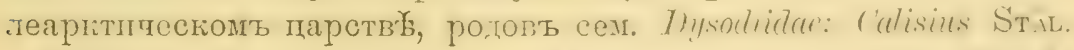

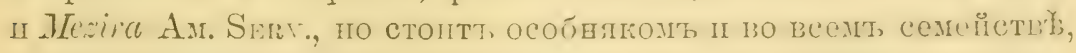
отлштаясь оть другпхъ родовъ строеніемъ пштпк, усшковъ,

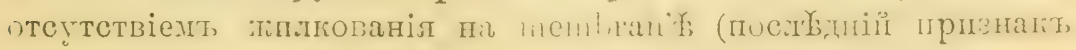
такіте у рода Pictinus StåL.).

Редукція довольно сложнаго жплованія mеmbran'ьг, прпеущшаго всему семейству, у рода Aneurus Curtrs, повидпмому, ука-

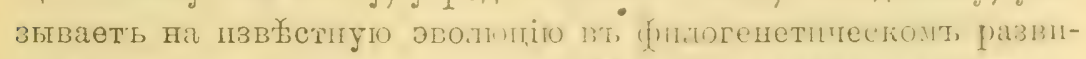

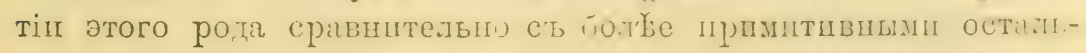
ными родамг семенства. 
На это указытаеть п современное геограбопеское распространеніе рода, космополптпческаго, широго распространеннаго п въ палеарктпческої области.

Родъ Aneurus Crktis прп созданіп спстематпческої групппровки внутрп семейства; въ́роятно, долженъ стать тппомъ особаго подсемейства.

Хајактернстика рода даетсл, напш на основаніп 4-хъ палеарктическпљ впдовъ и 1 пндійскаго.

Географичесное распространеніе. Виды рода Aneurus Cтrтis распространены въ палеарктпческомъ, неарктпческомт, неотропшесколь, австралійскомъ, әбоопскомь п оріентальномь дарствахъ. Изъ 4-хъ палеарптическхъ видовъ два впда ши-

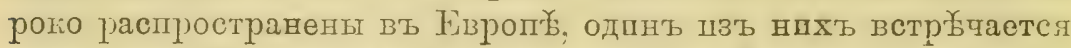

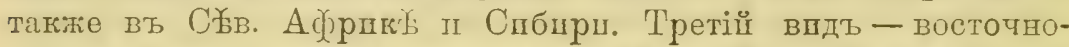

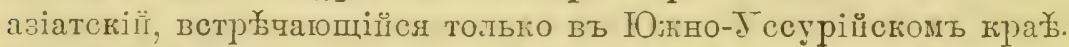

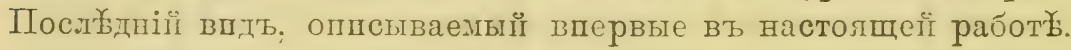
пзъ средвяго Кітая (пров. Сычуань).

OПPEIT.IITE.IЬHAЯ TABIIIA IIAIEAPKTHUECKHXT BIIIOBT POIA ANEURUS CURTIS.

1 (2). Второй тлевпћь јспиовъ короче перваго членика пі почтп вдвое короче третьяго. Боковые трая переднеспшнгі съ небольшой, по.тогой выемкой. Шейные јглы переднеспини огругленные.

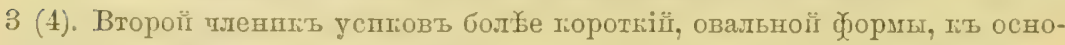
ванію спльно съуденпый.

万. IV-ый дорзальный сегментъ по серединӗ безъ бугорка. Седьмой сегменть ст больере длпннымп боговыми отросткамп.

ㅇ․ Шестой брюшной сегхенть съ заднимъ траемъ прямымъ, без̆ виступовъ. . . . . . . . . . . . A. laevis (Faвr. .

4 (3). Второй тленшт успковт болбе длпнный, къ основаніго мень̆е съуженный.

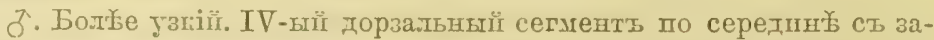

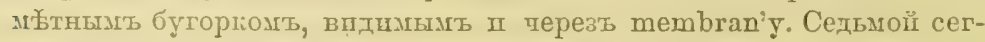
ментъ съ болье поротнпми отросткамп.

… Пестой брюшной сегментт позадп ст двумя сблпженншмп отростіами, заходящими за верппну досліо дняго генитальнаго сегменіта .

A. tuberculatus MIör.

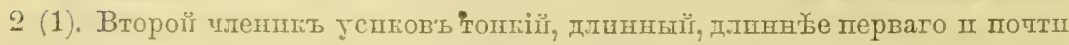
равент третьему пленпиу. Боговые грая переднеспинкі съ отчетлпвой спльной выемгой; шейные углы вытянуты впередъ въ впда yINIOB'b. 


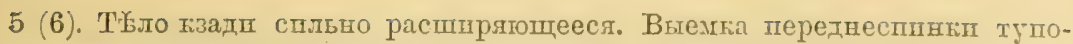
угольная. Четвертый членић усиковъ длиннеке второго п третьяго.

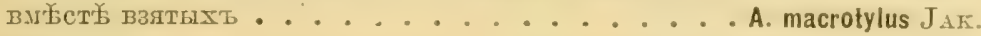

6 (5). Тйбло съ почти параллельнымп праямп, незначптельно расширяюпееся ғзади. Нырғзка переднеспншп округленная. पетвертый чле-

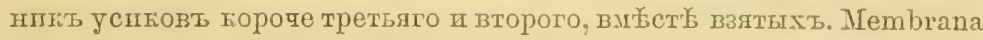
съ прупнымп п мелкпмп бұлымп пятнамп . . . . . A. sinensis n. sp.

\section{Aneurus laevis (FABr.). 1775.}

Acanthia laevis FABr. Syst. Ent., p. 695. 1775. - FABr. Ent. Syst., IV, p. 73. 1794.

Aradus laevis F.вr. Syst. Rhyng., p. 119. 1803; Fal. Hem. Svec., p. 140. 1829. Aneurus lacvis Curt. Brit. Ent. II, tab. 86. 1825. Burx. Handb. d. Ent. II, p. 253. 1835.-H. S. Wanz. Ins. IX, p. 141, f. 951. 1850. - Kor. Bull. Soc. Nat. Mosc. 고 4, 185̌6, p. 493; Melet. Ent., fasc. VI, p. 25, sp. 228. 1857.-Fror. Rhynch. Livl., 1, p. 397. 1860._Freв. Eur. Hemipt., p. 116. 1861. - DGu. Sc. Brit. Hemipt., p. 268, t. 9, f. 8. 1865. - Reut. Öfr. af Kongl. Vet.-Akad. Eörh., 1872, № 5, p. 62; Entom. Tidskr., p. 108. 1882.-Saund. Trans. Ent. Soc. 1875, IV, p. 258,-Put. Synops. Hémipt. Hét. de France, 1, p. 139. 1879.-Reut. Rev. synon. II, p. 23 (ed. sep.) № 202. 1888. - SAUND. Hemipt. Het. Br., p. 141. 1892. - МЈöв. Arkir f. Zool. 5, № 11, 1909, p. 2, fig. 1a, $2 \mathrm{a}, 2 \mathrm{a}^{1} 3 \mathrm{~b}, 3 \mathrm{~d}, 4 \mathrm{a}$.

Acanthia carpini Schrc. Fn. Boic. 2, p. 63. 1801.

Aradus aventius DuF. Rech. anat. Hémipt., p. ó4, t. 4, f. 36-37. 1833.

Ancurus levis Brolisé. Hist. Ins. 9, p. 335, t. 23, f. 3. 1835.

\section{Фауниспиеская литература, насающаяся Россін.}

Aneurus lacvis Revt., loc. cit., p. 62, 1872 (Fennia: Abo, Jockis). - J. SAHLb. Medd. Soc. Faun. Fl. fenn. Förb. VII, p. 4t. 1881 (Fennia: Vasa).J. SAнцb. Not. Sällsk. Faun. Fl. fenn. Förh. IX, p. 182.1867 (Karelia mer. or.: Räisälä). - ЈАк. Труды Русск. Энт. Оо́щ. VIII, р. 70. 1876 (St.-Petersburg). - Osh. Verz. d. palaearkt. Hemipt., I, p. 481. 1008 (gub. Novgorod: Bjelozersk).-Flor., loc. cit., p. 397 (Kurland). - PAczoskг, Зап. Kiевск. Общ. Естествопсп, X, вып. 2, стр. 417 (Volynia). - Jaroschewsis, Труды Общ, Ест. Прпр. Харык, Унпв., VIII, 1874 , p. 55 (gub. Charkor: distr. Zmiev., Konstantinovka). - JA太. Hor. Soc. Ent. Ross., IV, p. 149. 1870 (Kazan).-JАк. Труды Руссг. Энт. Оóщц., XII, 1880-1881, p. 114 (Sarepta, Caucasus: qub. Erivan: Karavan-saraj).-Evr. Bull. Soc. Nat. Mosc. 1837, vol. 10, p. 34 (inter Wolgam et montes Ural). - JAK. Hor. Soc. Ent. Ross., XXIVII, p. 237. 1905 (Tauria: Tavel). - Krr. Rev. russ. d'Ent., XII, p. 363.1912 ('Tauria: Agarmysh.).-Koz., loc. cit., p. 413 (Caucasus, Iberia).- Horv. in Schiemer. Naturwiss. Beitr. z. Kenntn. d. Kaukasusländes, p. 81. 1878 (Caucasus: Kara-usta prope Borzhom, Sarijal).-Kir. Rev. russ, d'Ent., X, p. 179. 1910 (Barnaul).-JAк. Horae Soc. Ent. Ross. XXVII.

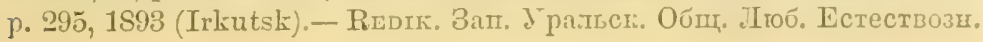


въ Енатеринб́, XXXI, 1, стр. 86. 1911 (Gub. Perm: Palkino, Kamenyja Palatki,.

\section{Экземпляры Зоологическаго Музея.}

Marocco. Vaucher. (2 $q$ ).

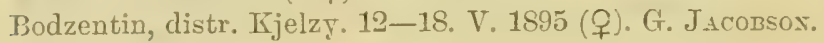

Gub. Perm: Pylaevo, distr. Kamyshlov. 18. IX. $186 \pm$ (q). Czenanowski

Tauria: mons Agarmysh, distr. Feodosia. 24. IV. 1906 (우). Krritscheskó.

Transcaucasia: Borzhom (ㅇ).

Gub. Irkutsk: Pashki (ㅇ).

Gub. Irkutsk: Padun in fl. Angara. IV. 1867 (Q)). CzekAxowskr.

Gub. Irkutsk: Padun in fl. Angara. 25. III-IV (q). Czekanowskr.

Діагнозъ. Oboralis, retrorsmu dilatitus, rifo-lırmnneus: capite, pronoto scutelloque obscurioribus. Antennae articulo secundo orali, rotundato, basi fortiter coarctato, pedunculum sat angustum formante, quan articulus prinus panlo breviore, articulo tertio secundo longiore, articulo quarto articulis duobus praecedentibus simul simptis aequilongro.

Pronot:ım marginibus lateralibus antice vix sinuatis: scutellum longius ac latum, apice late rotundato, memlrana fortiter ruguiosa.

Tergitum quartmu abdoninis apud mares medio tuberculo destitutum.

Spiraculis segmentorum al,dominalium $2,3,4,5$ medio dispositis, segmentorum 1, 6 ad marginem exterioren appropinquatis.

J. Semmentum gentale, quam in specie sequente debiliore et hroviore et quam sechnentum sextun abdominalo triplo breviore; lobulis segmenti septimi paulo majoribus.

ㅇ. Segmentum sextum apice truncatum, processibus excedentibus destitutun.

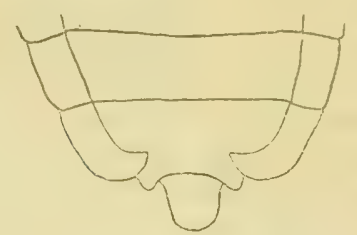

PII. 11. V-TIII брюшные стернітік. Ancurus Tereris (FABR.) $\delta^{\top}$.

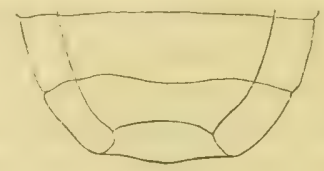

Pис. 12. V-VII бртоные тергпты. Aneurus lacris (FABR.) P.

Oписаніе. Ј тлпнено-овальный, сшльно распиряющійся кзадп, нрасповато-буриго пцията, голова, передвесппнга п цштикъ бо-

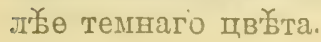




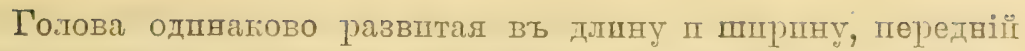
отростокь ея не достигаеть вершпны перваго членпіа усп-

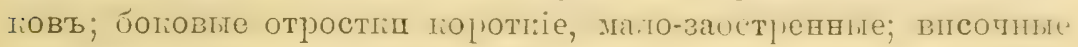
отросткп не заходятъ за прай глазъ; поверхность головы по-

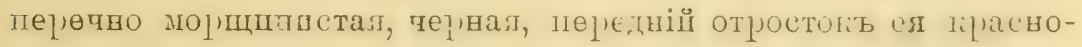
вато-бурыч.

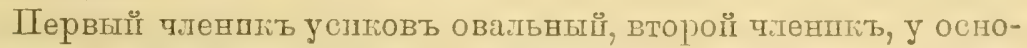
вавія съ явно выраженної ножноц, овальноі формы, сраввп-

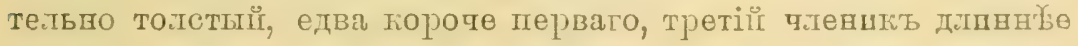

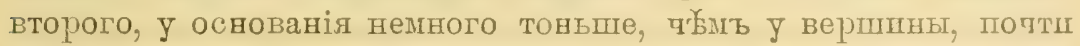

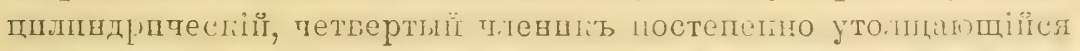

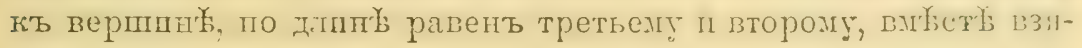
тымъ.

Переднеспшна поперечная, ппередп съужпвапаяся; передніі край ея съ небольшой выемкой, заднііг почтп прямоџ;

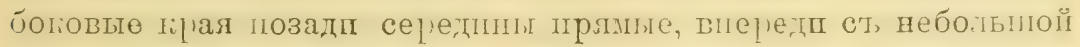
выемюой, мелпо :азуйренние; шейнпе угли тупые, совершенио не выдающіеся впередъ.

Шштпкъ почтп одинапово развштыі каль въ длпну, такъ I въ пшрлну, съ ппроко загругтенної верпшной, по длия вевъ пөреднеспнвкі.

Надкрылья у вершпны согіum'а съ бълой полосой; membrana спльно морщшнистая, connexivum съ продольнымъ жіелойкомь, раздыляюдым сегменты на, гвж равныя половны.

Дыхальца ншжней сторовы брюпка на II, IIT, IV, V сегментахъ лежать на одної линіп по середшне́ํ connexivum'а, на сег-

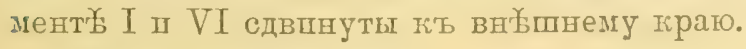

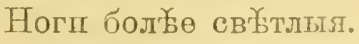

б. Генштальныі сегменть выпуклый, длина его вљ тргі раза

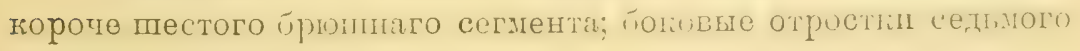
сегмента короткіе II толстые.

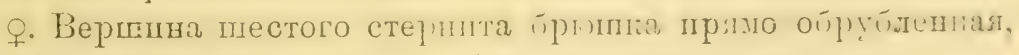
б́зљ выростовъ.

Длпна 4,5 мм., пирцна 2,4 мплл.

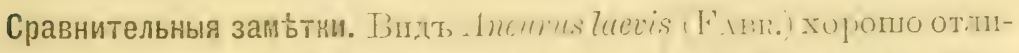

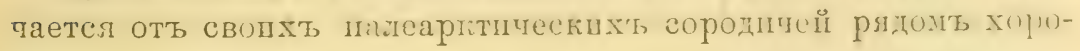
шпхъ прпзнатовъ.

Несомиянио, что до самаго недавнлго временш видљ этотт

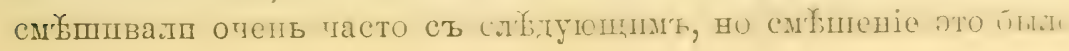


рөзультатомь пшш повөрхностнаго пзученія ои́ъектовъ п не служпть угазаніель на нерұзкость видовыхъ гранпцъ вшда.

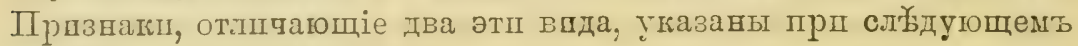
виде․‥

Географическое распространеніе. Вшдъ этоть шпрого распро-

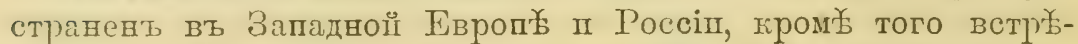

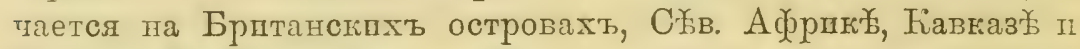
Спбпрп. Въ Россіп онъ найденъ, судя по матеріаламъ Зоолотическаго Музея, лштературнымъ даннымъ п әкземплярамъ

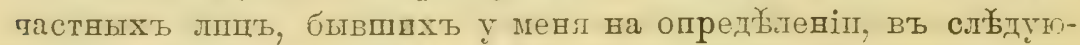
ппхъ морстностлхъ: Фпнляндін, Олонедкой, Петербургспой, Кб.тецко, Орловской (Брянскъ. 25. V. 07. Впноградовъ-Нпкитинь), Минской (Мдхановпчи. Т. 07. В. Сеславинъ), Херсон-

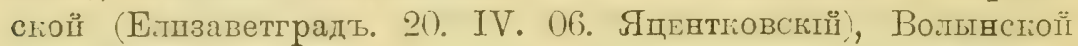
Харьковсгої, Тиазанекой губернілхъ, по ср. теч. Волги до Саpenты, между Волгої ш У раломъ, въ Крыму, на Кавказъ: Гру-

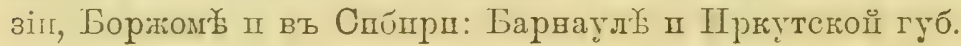

0бразъ жизни. Впдъ этоть встрҰчается подъ корой деревьевъ, въ Фпнгяндіп поль тіорой Betula allıа. O біологіп впда на пог

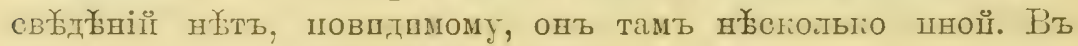
Крыму попадался въ дубовомъ лйсу.

\section{Aneurus tuberculatus Млӧв. 1903.}

Aneurus Taevis SAXD. Hemipt. Heter. Br. t. 13, f. 2. 1892.

Aneurus tuberculatus Msöв. Ent. Tidskr., p. 79. 1903; Arkiv f. Zoologi, 5, 시 11, 1909, p. 2 , fig. 1b, 2b, 2bl, 3a, 3c, 4 b.

\section{фауппетптеская литература, кіасающаяся Россіп.}

Anewnus tuberculatus Krr. Rev. russ. d'Ent. XII, p. 363.1912 (Tauria: Dzhalman, Taushan Bazar, Korbekly, Tshatyrdag, Alushta).

Aneurus Taeris Honr. Hemiptera caucasica in Museum Cancasicum. Die Sammlungen des Kaukasischen Mruseum im Vereine mit Special Gelehrten bearbeitet und geraugegeben von Dr. Gustav RADDE, Band. I. Zoologie, p. 464. 1899 (Kaukasus: Utsh-dere, montes Meskenses).

Aneurus tuberculatus Horv. Ann. Mus. Nat. Hung. IX, p. 587. 1911 (Tauria: Jalta, Caucasus: Utsh-dere, Gudaut. Svanetia, montes Meskenses. Lirik, Amurat).

Aneurus taevis JAк. Tр. Русск. Энтохг. Общ. XII, стр. 114. 1880-1881 (Cаиcasus: gub. Erivan, Karavan Saraj.); ibid. XIII, стр. 119. 1881-1882 (Caucisus: Zakitaly). 


\section{Экземпляры Зоологическаго Музея.}

Tauria (4 万, 1 む).

Tauria: Korbekly in declivitate mont. Tshatyrdag. 19. VI, 1907 (3 J, 7 q). Grigoriev.

Caucasus occ.: Utsh-dere. Koenig (2 $\delta$ ).

Caucasus occ.: Azhary prope Tshchalta in fl. Kodor. 30. VII. 1905 (Q). K.1LISCHEWSKI.

Transcaucasia: Zakataly $(15$ f, 1 \%).

Transcaucasia: Lagodechi. 1893 (§). MLokossiewricz.

Transcaucasia: gub. Erivan, Karavan-saraj (Q).

Transcaucasia: gub. Erivan, Dartshitshag (q). MaLjuzhexro.

Talysh: Lirik, distr. Lenkoran. 12. V. 1909 (4 お, 5 Q). Kiritshexio.

Діагнозъ. Species tergito quarto abdominis maris medio tuberculo distincto instructo nec non structura segmenti genitalis maris feminaeque distincta.

Antennae articulo primo crassiore, articulo secundo tenuiore. basin versus minus angustato, quam articulus primus vix longiore; scutellum transversum, apice minus late rotundatum, membrana bemelytrorum minus rugulosa.

ठ. Sat angustus, retrorsum parum dilatatus. Dorsum aldominis segmento quarto medio tuberculo distincto instructo. Segmentum genitale robustum et longius, quam segmentum sextum rentrale duplo brevius, lobulis lateralibus segmenti septimi parum minoribus.

o. Segmentum sextum ventrale margine apicali sulutus processibus duolus, appropinquatis, ultra apicem segmenti genitalis excedentibus instructum.

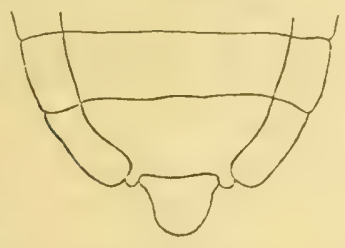

Pис. 13. V-VIII брюшные стерншты.

Aneurus tuberculatus Мјӧв. ठ․

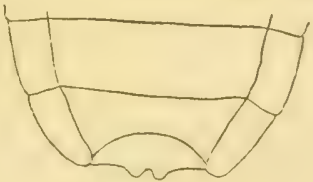

Prс. 14. V-VIII брюшные тергпты. Aneurus tuberculatus Мॅзӧв. ㅇ.

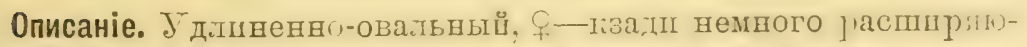

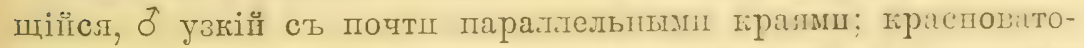

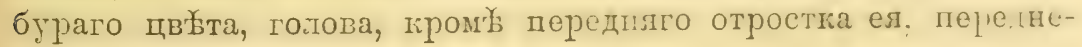
спинка ш щштпкъ бол占е темнаго цв宛а. 
Передвій отростокь годовы не достпгаеть вершыны перваго тлендка усшковт, боковые отростін коротғіе, вдсочные не заходять ва край глазъ.

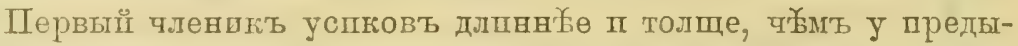
дущаго впда, второй членпкъ едва длпинеге перваго, поптш

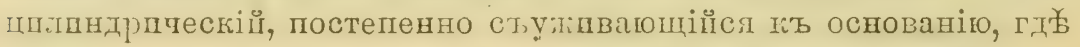

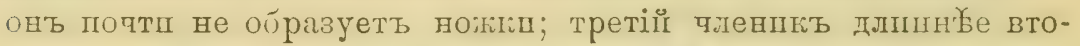
рого, опень незнатптельно съуживающійсл кљ основанію, чет-

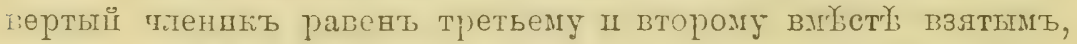

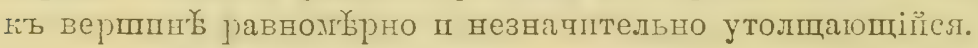

Перетнеспниа поперечная, ипереди стукивающаяся. Пе-

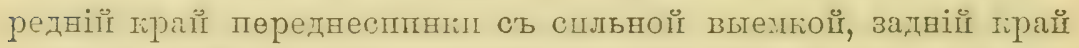
поттіг прямої, сь очень стайой выемпой; боліовые гірая въ зад-

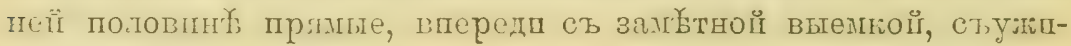
ватщіесл.

Шитпкъ поперечный, шпре своеіг длпвы, верпшна его ме-

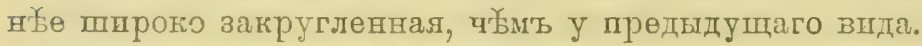

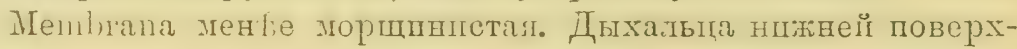
ності брюшка на сегмевтахъ I, IV, V, VI смещены къ вношнему краю, гпхальда на II II III сегментахт занпматт, догтя средшнное положеніе.

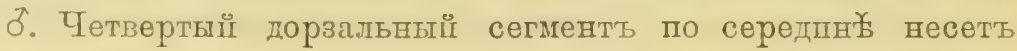
отчетлпвый, впдимый пा черевъ membran'y, бугорокъ.

Гендтальный сегменть болһе сшльнй, длига его въ два раза пороче ІІ-го брюшного; боліовые отростиі седымого сегмента боль⿻ тонкіе II пороткіе.

ㅇ․ Вершинныі граї шестого абдомпнальнаго стернита по

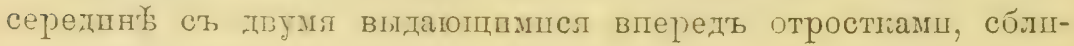

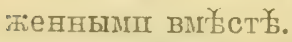

§. Длпна 4,5 мплл., шприна 2 мшлл.

ㅇ․ Далша 5,2 мплл., пшрпна 2,4 мшлл.

Сравнительныя замьтии. Видь этотт, хотя опень недавно

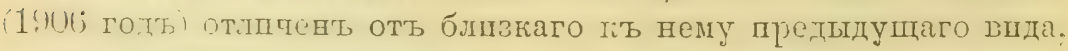

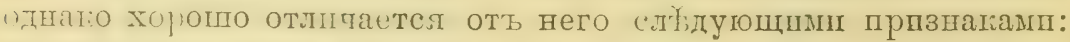

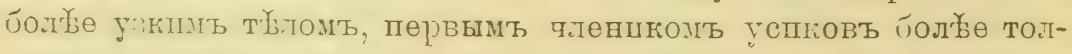

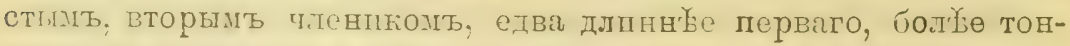

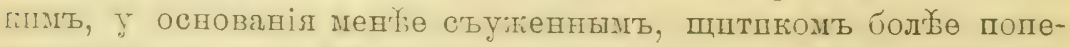

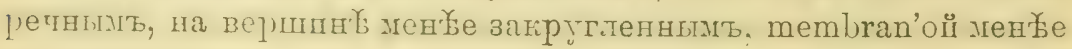
морщинпстої. 


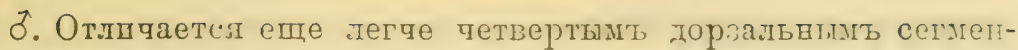
томъ, по середине котораго паходптсл отqетліво шидимй ш черезъ мембрану бугорогъ. Генштальныі сегментъ больһ спльный пі длпнный, въ два раза ліроле VI-го айдоминальнаго сег-

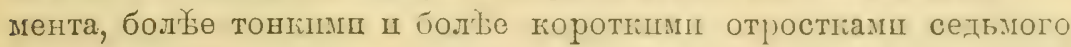
сегмента.

․ Также легко отлпчается шестым стернштом бргшіа,

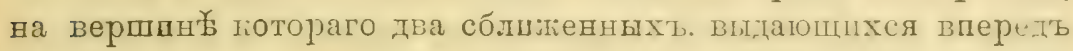
отростка.

Географическое распространеніе. Несомнбнно, что поль име-

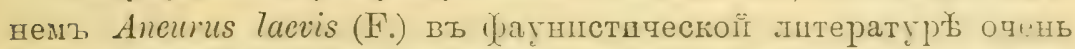

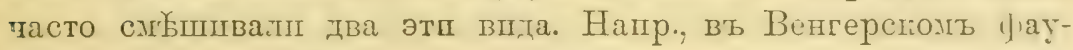
нпстическомъ сппскею до 1911 г. звачплся всегда A. laevis (F.). Теперь же огазывается, что въ Венгріш преобладающій ввдъA.tuberculatus Млӧв., шпрого распространенный по всей Венгрін.

Въ Крыму, гды Aneurиs довольно ойыновениый вщдъ лыс-

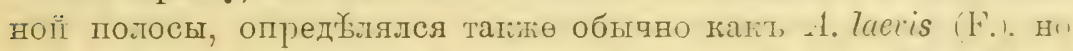
огазалось qто спльно преобладающій впдъ- 1 . twhercutatus Млӥв. Другіе случап сметшенія әтпхъ двухъ ипдовъ првведены выпе въ цштатахъ фаунпстцческихъ работъ.

По. экземплярамъ Зоологпческаго Музея, частныхъ лппъ,

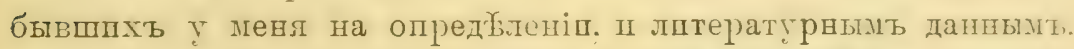
геограбпческое распространеніе А. tuberculatus Млӥв. прегсти-

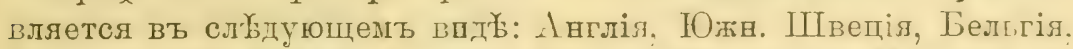
Франція, Швейдарія, Вепгріл, Боснія, Мағедонія, Малал \зіт.

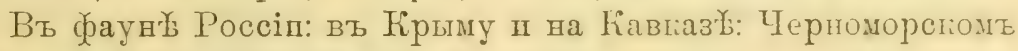
поберөжь

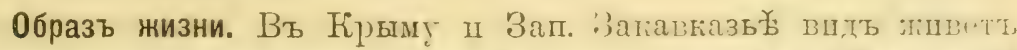
подь корою деревьевъ: главнымъ образомь б́тіа (Fаğls sp., въ Зап. Закавлазьљ (Хоста, Черноморской обл.) А. А. Сп-

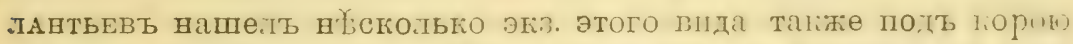
сухого дуба ((иегсus), на Талыше я пойаль 1 экз. этого вида подь корой сухого ствола куста шиповнпка (Rosa sp.).

\section{Aneurus macrotylus J.1. $18 s 0$.}

Ancurus macrotylus JAK. Bull. Soc. Nat. Mosc. I, p. 169. 1880.

Фаупистическая литература, гасающаяся Россін.

Aneurus macrotylus JAIs. loc. cit., p. 169 (Ussuri). 
Экземпляры Зоологическаго Музея.

Vladivostok (2 ð, 2 , $)$.

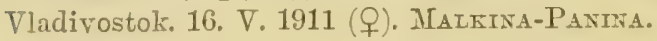

Діагно3ъ. Corpus latum, retrorsum valde dilatatum. Prolongatione antica capitis basi dilatata, apicem articuli primi antennarum vix attingente. Articulo secundo antennarum cylindrico, basin versus parum angustato, quam articulus primus in $1 / 4$ longiore et articulo tertio fere aequilongo, articulo quarto articulis tertio secundoque simul sumptis parum longiore.

Pronotum lateribus ante medium profunde obtuse angulatosinuatis; angulis anterioribus antrorsum productis.

Scutellum transversum; longitudine sua in $1 \frac{1}{2}$ latius, medio convexum, transversim rugulosum.

๙. Segmentum genitale latissimum, fere totum in incisura profunda segmenti sexti abdominalis latente; lobuli laterales segmenti septimi magni, lati, breves, apice rotundati, parti prominenti segmenti genitalis aequilongi.

‥ Segmentum genitale truncatum, lateribus tuberculis duobus obtusis, excedentibus instructum.

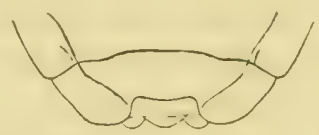

PIIc. 15. V-VIII брюшные стерниты.

Aneurus macrotylus $\mathrm{J}_{\mathrm{AK}}$. $\sigma^{\circ}$.

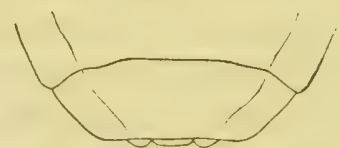

Рпс. 16. V-VIII брюшные стерниты.

Aneurus macrotylus $\mathrm{J}_{\Delta \mathrm{K}}$. 오.

Описаніе. Широкіі, квадп сшіьно расширяющійся; красноватобураго цвотта, голова, переднесппнка п пптикъ бол尔е темные.

Голсва одннагіово развнтая какъ въ діпну, такъ ІІ въ шшрпну; передній отростокт ея, достпгапіи верппны перваго

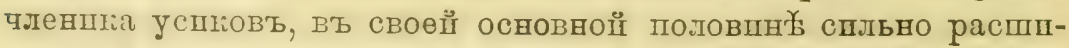
рен'ъ; боғовые отросткі толстые, вершина шхъ иногда заостреннал; поверхность головы, особөнно задняя, грубо-морщпншстая.

Первый тленшкъ јспковъ толстый, овальный; второї членпкъ дшлшндрпчестії, незначштельно съужнвающійся къ основа-

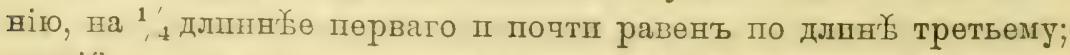
третії почти правпльно цшлиндршческій, волоспстый, у осно- 
ванія сь довольно длинной ножкой, четвертый густо-волосистый, слегка пгогнутый, немного длшннеке второго п् третьлго

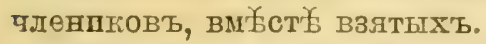

Переднесппка въ два съ небольпиь раза пире своеіі длпны; передній краї ел съ неглубокої выемгой, задніі тррай прямой; боговые края зазубренные, въ передней половпв各 несуть глубокую тупоугольную вырқзку, позадп нел прал параллельные шлп слегка закругленные; передніе углы нөзвпчцтельно выдаются впередъ. Поверхность переднеспинкш, особенно въ передней части, спльно морщинпстал, плечевые углы вздутые.

Щитпғь вь $1 \frac{1}{2}$ раза пшре своеї діпвы, поперечно-морщпнпстый, у основанія прпподнятыї.

Corium надтірылій очень маленькіц; membrana мало морппншстал, мало блестяцая. Соnпехітип спльно морщпнпетый, по сөредпнег съ явственноі̆, продольної, вдавленной бороздкой, отдызляющеї выпуклый бокової крац̆.

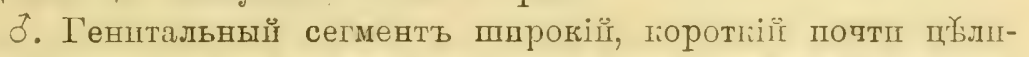
коль входить въ шшрокую вырłзку пестого абдомпнальнаго сегмента, отросткі седьмого сегмента снльные, толстые, короткіе, сзадп огругленвые, равные по длине выступаюей тасти генштальнаго сегмента.

‥ Генптальный сегменть сзадп обрубленный, по бокамь выдаютея два тупыхь бугорка.

Длпна す t,8 милл., 9 5,

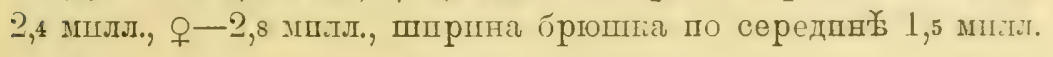

Сравнительныя замьтки. Впдт этоть хоропо отлпчается оть обопхъ европейскпхъ впдов'ь длиннымъ вторымъ членпгомъ успковъ, который длинн神 перваго членпіа II почтп равенъ третьему, значптельно болье длпнымь первцмъ членшғомъ, широкпмъ, прпподнятым по середнн䄈 у основанія щитикомт,

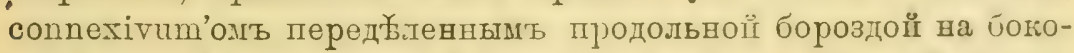
вої вздутый ІІ внутреннії плоскіії крал, своеобразвої, совершенно от:ичної отъ другихъ палеарғтпческхъ видовъ, қормой генитальныхъ сегментов' $\delta$ 프 오 ㅍ др. признакамп.

Географическое распространеніе. Ancurus macrotylus JА亡. цвв Б-

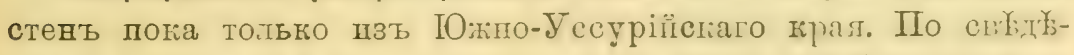

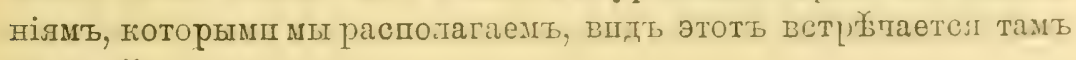
ва лип ґ́. 


\section{Aneurus sinensis n. sp.}

(Таб... I, (๖џг. 4).

\section{Экземпляры Зоологическато Музея.}

China centr.: Ta-tsien-lu, prov. Sz'tscwan, 9. VII. 1893 (ठ). Potaxis.

Дiarн03ъ. Sat magnus, rufescenti-brmmeus, corpore retrorsum vix dilatato, lateribus fere parallelis.

Caput longius, quam latum; prolongatione antica capitis basi paulo dilatata, apicem articuli primi antennarum haud attingente, lobis lateralibus antenniferis acutiusculis, extrorsum rergentibus, subtilibus; lobis temporalibus narginem exteriorem oculormm attingentibus, angulus externus illorum rotundatus; caput parte posteriore crasse rugosum.

Antennae longae, graciles; articulo primo crasso, orali, basin rersus in pedunculum longum, subtilem angustato: articulo secundo basin versus gradatim et paulo angustato, quam articulus primus longiore et articulo tertio aequilongo, apice rotundato. albido-testaceo; articulo tetio basin versus angustato; articulo quarto basi pallidiore, angustato, apice acuminato, quan articuli tertius et secundus simul simpti breviore.

Pronotum transversum, longitudine sua plus quam duplo latius; angulis anterioribus rotundatis, antrorsum proluctis: angulis posticis rectis: marginibus anteriore posterioreque fere rectis. vix sinuatis; marginibus lateralibus crenulatis, antice profunde rotundato-sinuatis, post medium parallelis.

Pronoto medio plano, in dimidio apicali duabus areis quadrangularibus, concaris, fusco-brunneis praedito; angulis humeralibus conrexis.

Scutellum transtersum, medio transtersim convexum, granulato-rugrosum, medio ad apicem late striis transrersis, linearibus ruguloso.

Hemelytra corio brunneo, venis margineque laterali medio nigris; margine laterali recto; memlorana nitida, ralde rugulosa, brunnea, apud basin maculis magnis allidis, maculisque parris in locis variis membranae, ornata.

Marginibus lateralibus connexivi fere rectis, parallelis margine exteriore segmentorum IV, T, TI abdominalium angulis 
obsoletissimis, tix prominentibus instructis: post angulum senmenti VI margine distincte sinuato; connexirum granulato rugosum.

Pedes fusci, tarsis flarescentibus.

§. Segmentum genitale sat parrum, latum quam segmentum sextum ventrale in $1 / 3$ brevius, lobuli segmenti septimi maximi, apicem segmenti fere attingentes, lati, elongato-triangulares.

‥ Ignota.

Long. $0^{\top}-5,5 \mathrm{~mm}$., lat. pronoti-1,7 mm., lat. abd.-2,3 mm.

Описаніе. Больтой, кзалц очень мало распшряющійсл, съ почтп параллельнымп краями, красновато-бураго цвйта; голова. пөреднеспинка, щитпіъ п ногш темн危е.

Голова болґе развитая въ длин, түмъ въ ширпну; перетнії отростокъ ея, незначительно расппренный у своего основанія, не достпгаетъ вершпны перваго членпка успновъ; божовые отросткп заостренные, направленвые къ вн年, товкіе; впсочные отростки не заходятъ за крал глазъ, вн年шній уголь замҮтно округленный; задняя часть головы грубо-морпшншстал.

Усикп длшныле п тонгіе, шхъ первый членшкъ толстыў. овальный, прп основаніп съуженный въ товгую, длшнную ножіу; второй членшкъ, къ основанію постепенно и незначптельно

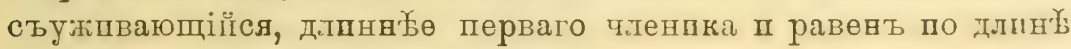

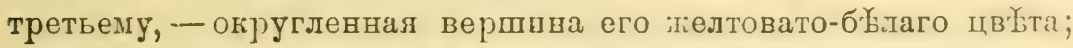
третій членпкъ волосистыи, къ основанію съужшвающійся, основаніе его св Һेтлое, четвертый членикь густо-волосистый, зао-

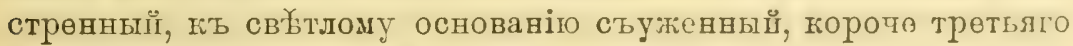

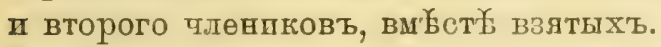

Пөреднесппнка поперечная, пирнва ея вт два съ небольппмъ раза шире своей длины, пейные углы закругіены п продвинуты впередъ, плечевые углы прямы ; передній ш задній грая оба поqти прямые, съ едва замүтными выеміами, боковые края съ глубокой полугруглой выемкой въ перетней половшн џ параллельные позади выемкп, на всемъ протяженіп зазу́ренные. - Поверхность переднеспикп по серөдин: плостіая, Вт,

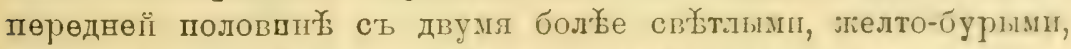

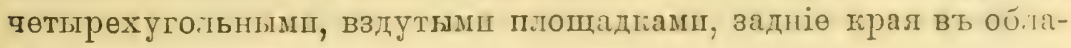
сти плечевыхъ угловъ вздутые.

Щптшкъ удлиненный, болье развптыї въ ширшну, түмъ въ Фауна Россіщ. Наськозия ведужествоврияла. VI. 


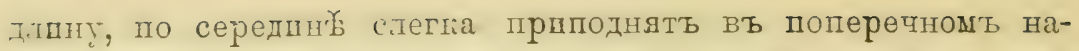
правленіш; поверхность щптпка вся зерндсто-лоршиппстая, оть основанія ғъ вершпн по передпне пдеть широкая полоса поперечныхъ, лднейныхъ, сблпженныхъ морщинокъ.

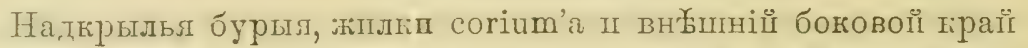
п сөредина corium'a чернаго цвотта; боковой край пхъ прлмої; membrana блестяцая, спіьно морщпнпстая, бураго цвбта, съ крупными бълымп пятнами у основанія п мелкпми неяснымш, разбросаннымп въ разлдчныхъ метстахъ ея.

Боковые грая сопnехічит'а почти прямые, параллельные внґшніӥ край тетвертаго, пятаго п пестого абдомпнальныхь сегментовь сь етва замдтнымп вшдающшися угіамп по сере-

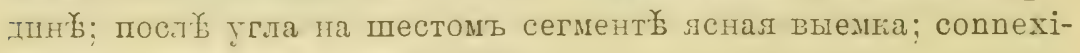
тит зерншсто-доршднпстый.

Ногш бурыя, лапкп желтоватыя.

§. Генптальный сегментъ неболь-

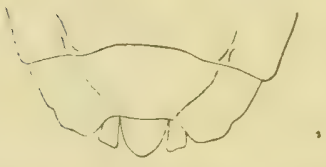

Prrc. 17. $\mathrm{V}$-VIII борюшные стерниты.

Aneurus sinensis Krr. $\sigma^{\circ}$. шоіг II mірохіпі, на $1 / 3$ выдающійся за задніiі праї пестого сегмента. Отросткп седьмого сегмента, почтп достигающіе вершины генитальнаго сегмента, ппрокіе, удлиненно-треугольные.

Длина-5,5 мплл.; шпрнна переднеспннкщ-1,7 мплл.; брюшка-2,3 мплл.

Сравнительныя замьтки. По бормге телла, съ прямымп, почтп

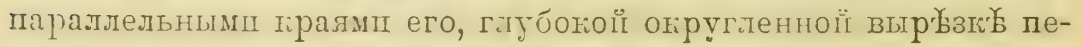
редпеспинг, продольой полосъ линейнхъ попереqныхъ мор-

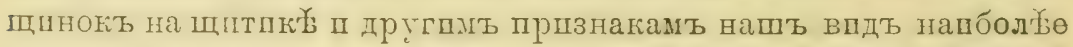
близко подходпть къ индійскому впду Aneurus inclicus Bergr., оть котораго однако хорошо отлпчается: больпей велпчиной,

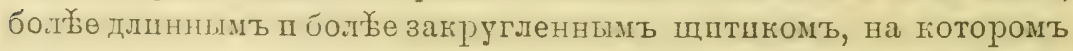
отсутствуеть поперечное возвыненіе, бълым пятнамп на mөм-

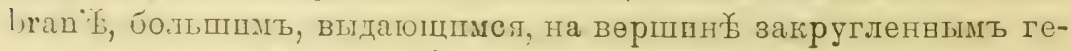

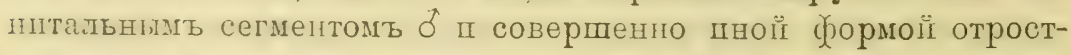
повь седьмого сегмента, не достигающшм вершины генштальнаго сегмента:

Aneurus macrotylus JАг, на котораго новый впдъ походить по строенію второго членпка успіовъ, отличаетсл спльно рас-

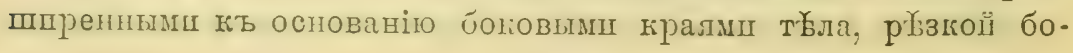




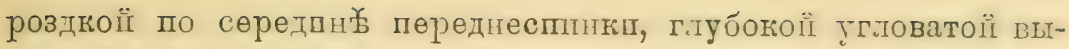

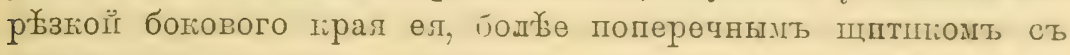

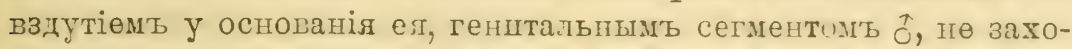
дящпмъ за краї брюшиа, Һормой отросткогъ сельмого сегмента, вершины которшхъ выдвшнты за вершшиу генитальнаго сегмента.

Географическое распространеніе. Incurus sinensis и. пайдень

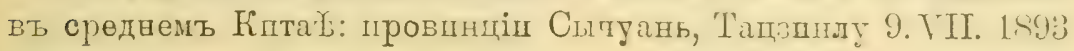
(ПотАнинъ).

\section{Cerr. Aradidae.}

Aradini Costa Cim. Neap., II, p. 15. 1813.

Ductirostri trib. Corticicolae Aar. Serv. Hist. des Ins. Hém., p. 303. 1813.

Araditae Sprs. Tav, sinott. Ins. Artroid., p. 27. 1850.

Aradoidea Fię̧. Gen. Hydrocorid., p. 9. 1851.-Fror Rhynch. Livl., 1, p. 375. 1860.

Aradidae Costa Cim. Neap., III, p. 67. 1852.-Frem. Eur. Hemipt., p. 2t. 1861.Pur. Synops. de Hém.-Hétér. de Fr., 1, pp. $t$ et 128. 1879. - Dist. Fn. Br. Ind., 2, p. 153. 1903. - Krrk. Canad. Entom., p. 360. 1908, - Оін. Verz. d. palaearkt. Hemipt., I, p. 463. 1908. - Rетт. Neue Beitr. z. Phylog. und Syst. d. Miriden, p. 75 et 81. 1910. - REur. Öfv. af. Finsk. Vetensk.-Soc. Förb. Bd. LIV. 1911-1912. Afd. A. ㅊọ 6, p. 32. 1912.

Corticicolae H.-Sсн. Wanz. Ins., IX, p. 139. 1853.

Aradidea Costa Add. Cim. Neap., p. 6. 1860.

Aradida Stíl Hem. Afr., 3, p. 30. 1865.

Aradina ST.̊̀ Öfv. Vet.-Ak. Förh., p. 671. 1870.

Aradidae subf. Aradina Ståc Enum. Hemipt., p. 135. 1873.

Aractides Put. Cat. Hém., ed. 2, p. 31. 1875.

Діагнозъ. Caput parte postoculari antice ad oculos parte anteocnlari haud latiore, bucculis luretissimis. Oculi fortiter exserti. Rostrum basin prosterni attingens vel hane superaus, rarissime basin capitis hand superans. Antennae articulo primo lurevi, crasso, basi subito in stylum brevissimum oblique coarctate. Trochanteri breviusculi, cum femoribus connati et ab his haud vel aegre discernencli. Tenter incisuris plurimis medio angुulatis. Stigmata a margine laterali ventris longe remota, propre basin sogmentorum posita. Segmentum septimum rentrale maris hemisphaericum, segmentum octarum totum latens.

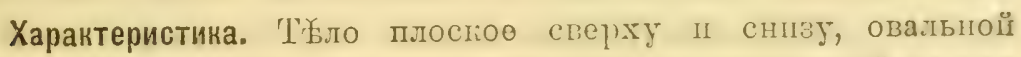
формы. Голова горпзонтальнал, янльетел расцепіениой иа три 
тастп: поретвій отростокь: Мдаюційсл далеко вперетъ п на два

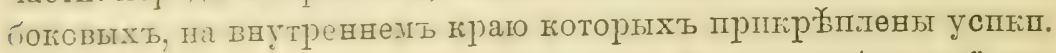

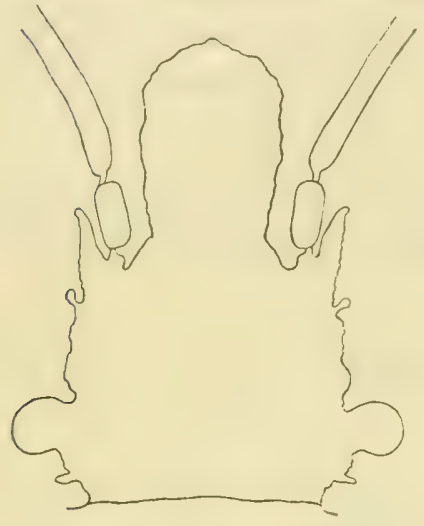

Prс. 18. Голова Aradus Fabr.

Впередш глазь по большеп̈ части находитея острый шипъ,

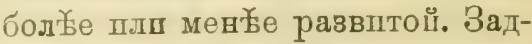
няч часть головы, лөжащая позади глазъ, не шире переднеї, лежацей передъ глазамп, вытянута назадъ ввыдег्) височныхъ отростковъ घлц зубдовъ;

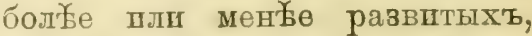
часто отсутствующшхъ. Глаза спльно выдающіеся. Глазкп отсутствують. Скуловые отростки очень короткіе, образующіе хоботковыц желобокъ. Хоботокъ

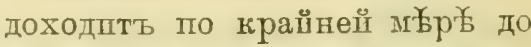
основанія переднегрудп пш өщө дальше, четырехчленпковый,

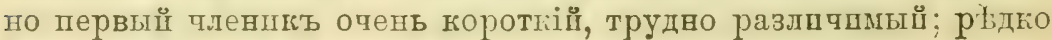
хоботокъ доходпть только до основанія головы.

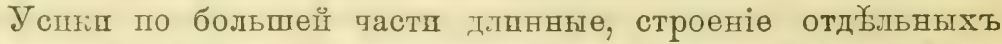
членповъ пхъ очень разнообразно у отдыљльныхъ вшдовъ. Пер-

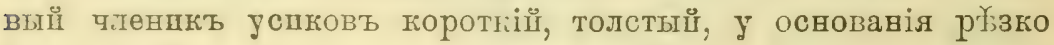
съуженныц въ короткую косую вожку.

Надкрылья состоять пвъ corium'a, clavus'a I membrana. Clavus нпкогда не заходить за вершину щитка, нъ вершшне

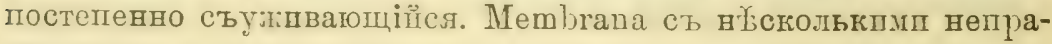
вшльным ц анастомозпрующпмпся эғплкамп. Среднія п заднія плевры простыя. Большннство гранпц сегментовъ посередшн危 ввпдег үгловт. Дыхальца расположены далето оть бокового гірая, возл告 основанія сегментовт. Вертлугп пороткіо, сливmiесs сь бетрамп, мҺсто соедпненія пхъ трудно пли совсџмъ незамбтно; лапғи двучленшіовыл, поготки лшшены прпдатковъ

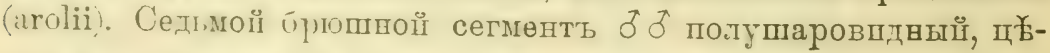
лшкомь скрыватщі亡 восьмої генптальный сегментъ.

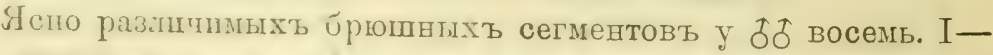

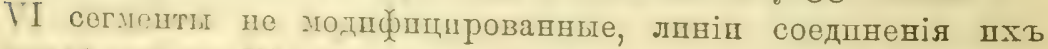

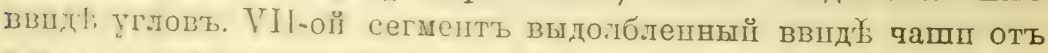
задияг Іірая ліоторої отходять дв

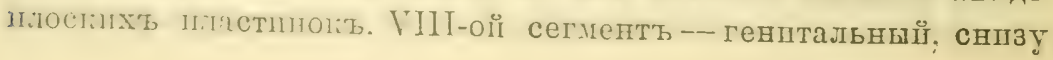


совершенно не вадшъ, цйлакомъ помищаетсл въ чашеобразномъ углубленіп VII-го сегмента, видимь пипь со спнной сторовы, если удалить налкрылья.

$\mathrm{y}$ 우 также восемь ясно различпмыхь б́рюшныхт сегментовъ: песть сходяшпхся по лпніп образующей уголы, VII II VIII- генптальные, молиффшцрованные.

Если провестп гомологію айдолшнальныхъ сегментовъ съ

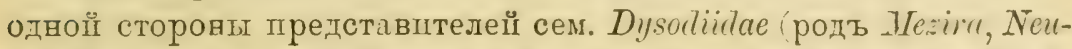
roctenus) ил съ другої стороны cex. Aralidac (родъ Arudus), то мы увидпмъ, что VII-ой сегменть никакшхъ частеіг гөнптальнаго аппарата, у сем. Aradidae представляетсл значптельно вшдопзиненным. VII-ой сегментъ : Dysodivilae является глубопо вдвннутымь въ предығущій сег-

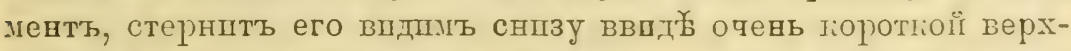
ней часті бугвы $T$, прпчемъ боповые отросткп короткіе, цергооб́разные. VII-ої сегменть у сем. Arudidae пөретерпґваеть стьдующія модибопапіп: онъ являетсл соверпенно не втянутымъ въ предыдущіі сегментъ, стернатъ его ввит. дна глубогой, полушаровшдной чашиш, длинвый, спльно выпуклый; боговые отростки большіе, ввшды् плоскпхъ пластпнъ, смбщенныхъ на вершинныі край сегмента.

VIII-ої сегменть - генитальный, у сем. Dysodiiclae почти на. подовпну выставляетсл наружу п явлетсл концевым сегмен-

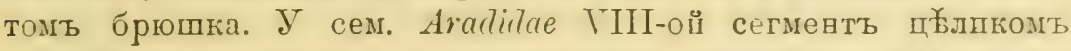
скарытъ въ глубогомъ чапеоб́развомъ углубленіп VII-го сегмента, впдим только сверху и VII-ой сегменть съ свопми спльно развштымп боковымп лопастлмг является ғонцевымъ сегментомъ бргопка.

Эти отлпчія въ строеніп II взапмоотношеніп айдомшнальныхъ сегментовъ являются по моему мн шающимп по вопросу о выд

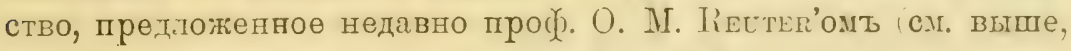

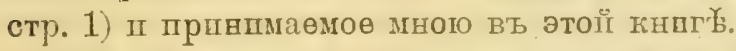

VII-й сегменть 운 - генптальный, у Dysodicilae съ очень сшіьно развитыль тергптоль и редупированныз стернитомт прц разсматриваніп снизу насъкомаго in toto вцдимымь только

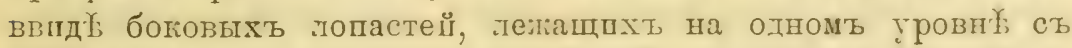

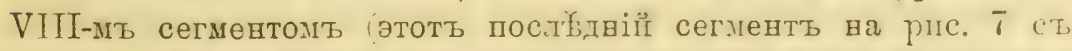
оо̆означеніемъ нумерадіп сегментовъ осталя безь обозналенія

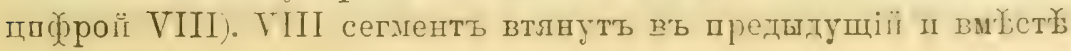




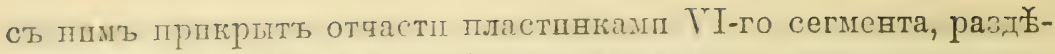
ленпши щелью rima genitalis: наружу выставляетсл довольво гначительно тастьо. -

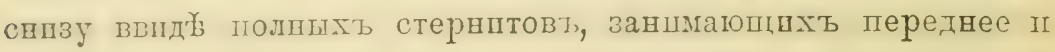
заднев положевіе.

Обзоръ родовъ. Едпнственнлій родъ сөмейства Aracus Faвг. съ многочиследныпп впдамп широко распространенъ въ па-

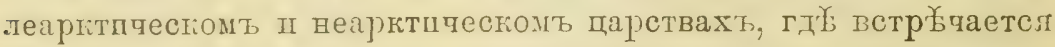
громадное большинство его представителей. Немногочисленные впды прпнадлежать ф人унамь Щентральной п Южної Америкп,

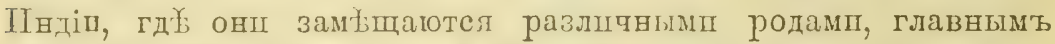
образомъ Mezira Ax. Serv. п Neuroctems Fiев. предыдущаго се-

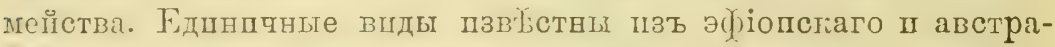
ліїскаго парствт. Въ палеарктпчесгомъ царств виды рода Aradus, связанные біологшчесп съ льсомь, пирото распро-

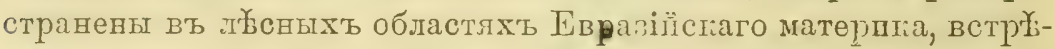

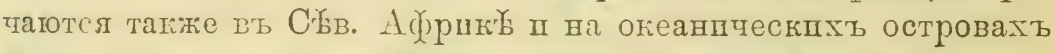

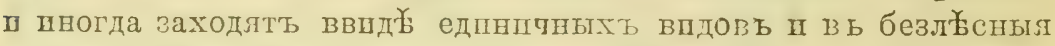

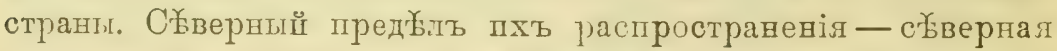

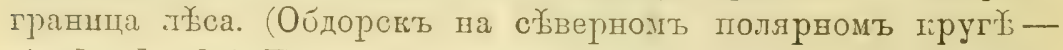
Aradus lugubris Fald., A. angularis J. SAнLв. - на p. Fолымғ у c. Kазачье, 1. pallescens H. S. frigidus Irı. у ifinганска п др.).

\section{Родъ 1. Aradus FАвг. 1803.}

Aradus FABr. Syst. Rhyng., p. 116 (partim). 1803.-FIEB. Eur. Hemipt., p. 34 et 110. 1861. - Flor Rhynch. Livl., 1, p. 377, 1860. - Dovgr. Se. Br. Hem., p. 269. 1865. - Srí Hemipt. Afric., 3, p. 37. 1865.-Sri亡 Enum. Hemipt, 3, p. 135. 1873,-Pur. Synops. de Hém.-Hétér. de Fr., 1, p. 128. 1879. - Drst. Fn. Br. Ind., 2, p. 157. 1904.

Piesostoma L.1p. Essai, p. 53. 1832.

Aneurisoma Cost. Add. Cim, Neap. 1860.

Stenopterus Sig.x. Ann. Soc. Ent. Fr., p. 120. 1865.

Leptopterus Puт. Catal. Hém., 2 éd., p. 32. 187.

Діагнозъ. Corpus ovatum rel oblongo-oratum. Caput prolonEatione antica sulyeylindrica, obtusa, apice integra; lobis lateralilus antenniferis in spinan antrorsum vergentem productis, mareine exteriore interdum tuberculo vel denticulo armatis; ante oculos saeje dente vel tulierculu instructum; caput pone oculos 
inerme, lolis temporalibus retrorsum prominentilus, instructum; his saepe deficientibus. Oculi globosi, ralde prominentes.

Rostrum basin capitis superans, plerumque basin prosterni attingens vel longius.

Pronotum transtersum, longitudine sua latius. lateribus raro rectis plerumque dilatatis; antice interdum sinuatis, dentatis rel crenulatis, interdum fere integris; supra carinis quatuor (duabus lateralibus et duabus intermediis) instructum: carinis rarrissime deficientibus. Scutellum elongatum, triangulare, apicem clari attingens, marginibus plus minusve fortiter elevatis. Hemelytra basi dilatato-ampliata rel recta, abdomine plerumque angustiora et apud $ㅇ$ 오 bretiora. Membrana renis quatuor, apice inter se saepissime conjunctis. Sterno segmentisque rentralibus sulco subtili, in prosterno distinctiore instructis.

Характеристика. Тюло овальное, шлш шпроко-овальное, ухлцненно-овальное, рұдно яйцевпдное. Голова несеть передній от-

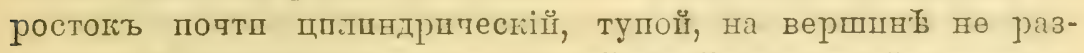

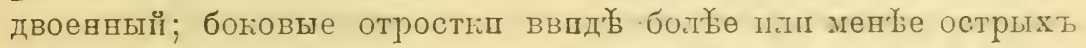
шиповъ, направлены впередъ, пвогда расходящіеся, на внбшнемъ краю очень часто воорүюненные и́ольшшь шлп меньшиь бугорномъ пли зубцомъ; передъ глазамп часто находится

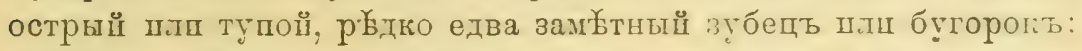
позадш глазъ голова невооруженная, оттянутая пногда назадъ

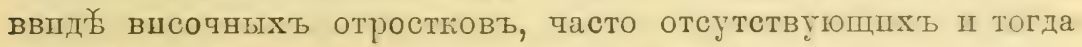
голова кзадш спльно съужшвающаяся. Глаза шаровпдные, спльно выдающіея.

Хоботоль тонкіӵ, длинный доходитъ до основанія передне-

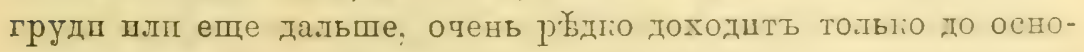
ванія головы.

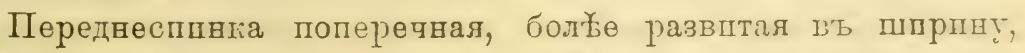

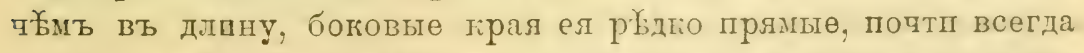
болье или менъе огругленно-расширениые, впереди тасто вы-

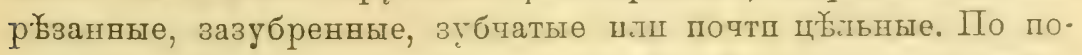
верхности переднеспинки проходятъ два боловыхъ іл два сере-

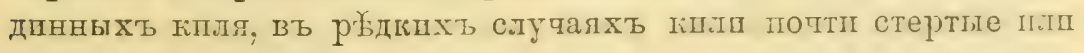
совсьй отсутствуюшіе.

Шитпкъ удланенно-треугольный, съ боловыми краямп

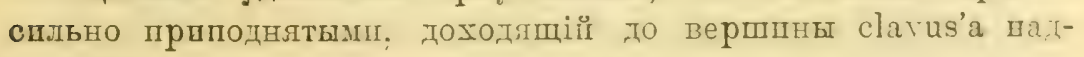
крылій. 


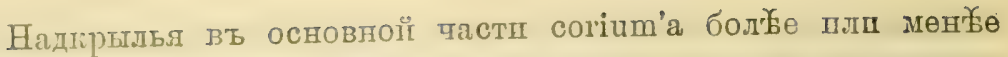

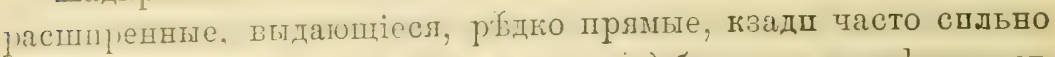

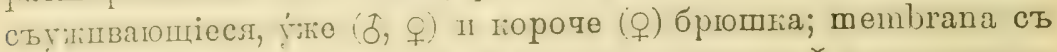

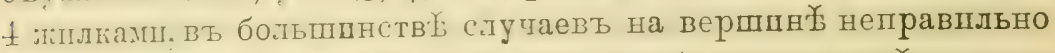
анастомозшруюшихся. Грудь п сегленты брюшка прорђзаны неглубокшмъ, продольнымъ желобкомъ.

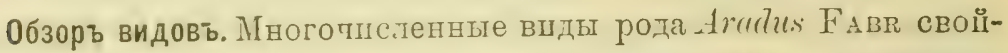
ствены поqтп исклюпительно палеарктпqесіому и неарктцческому палствамъ, где водптея громадное, большннство его видовъ. Въ фүаунахъ неотропическаго, австраліискаго п эббіопскаго царствъ почтп совсъмъ не представ:нено сем. Aractictce.

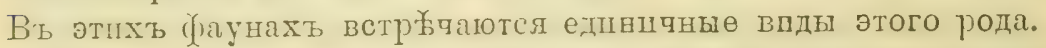

Очень б́дна пмп пा оріентальная фауна, насчштывающая около 10 вцдовъ рода, по больпеі частью блпзихъ къ палеарнтпческимъ вадамъ.

Фауна неарктпческаго царства насчптываетъ но्र́сгілько десятновъ видовъ, пзъ которыхъ, гва вида общпхъ съ палеаргтическимъ царстволь: A. crenatus $\mathrm{S}_{\mathrm{AY}}$., A. lugubris FalL.

Вь палеарптическоль парств встрбчаетея насколько теперь пзв бстно наполольее чпсло вшдовъ- 1 , неравномюेрно распространенныъ по отдылным областямъ и провпндіямъ дарства.

Кромъ 2-хь вшдовт общшхъ съ неарктикой, въ палеаркти-

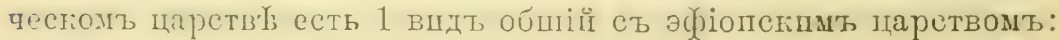
A. flavicornis DaLm.

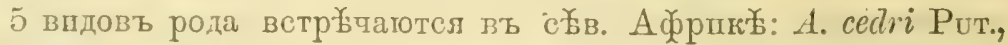
A. stenopterus Bergr., A. subsimilis Horv., A. Trueperi Reut., 1. flavicomis DaLx., прпчемъ порвые 3 пзъ ншхъ для нея әнде-

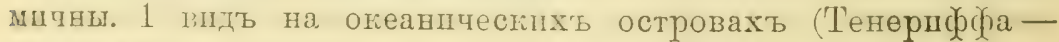

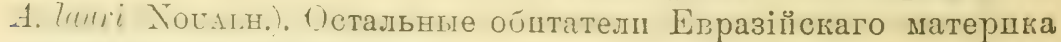
II прилегатихъ острововъ.

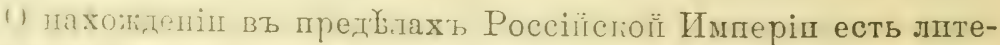

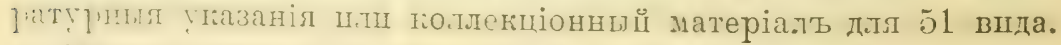

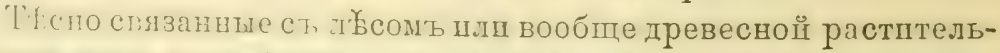

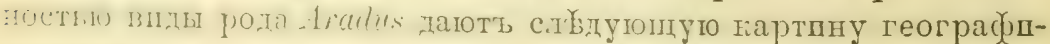

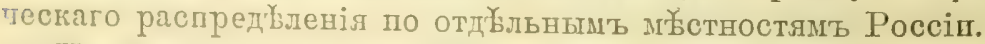

Напбольшее тисло вшдовъ рода Aradus въ предблахь Рос-

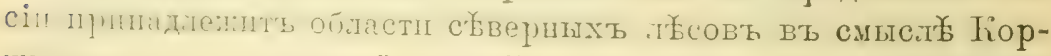
жинскаго, т. е. пирокої полост сплошншхь летсовъ съверной 


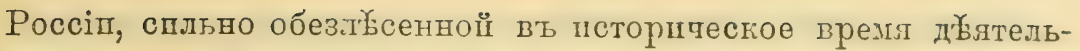

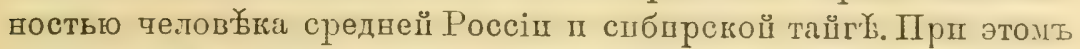
ф人ауна әтой областп по этому семейству представляется довольно однородної для западної половнны ел - Европейско Іо Россіи п восточної - Спбири.

Изъ 25 впдовъ сем. Aractidae своч̆ственныхъ областц сбверныхт, льсовъ 14 впдовъ являютея общпмп для об̆биъ половпнъ ои́ласти, II толыко 3 вшда ветрбчены только въ Европейcroil Poccin (A. truncatus Freb., A. signaticomis. F. SAHLB., A. aterrimus Fiев.) и $S$ видовт и 1 раса тольто въ Сибири (A. pallescens.

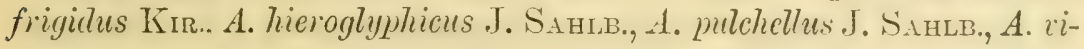
tiosus $\mathrm{J}_{\mathrm{Ar}}$., A. morio $\mathrm{J}_{\mathrm{AK}}$., A. nemtschinovae $\mathrm{J}_{\mathrm{AK} .}$. A. poppiusi $\mathrm{K}_{\mathrm{Ir} .}$, A. (Q.) Lrevirostris Honv, A. corticatis (L.) rar. ammlicomis FABR.). Изъ 25 вц,овъ 11 являютея вполн䄈 әндемцчными для області:

A. brevicollis FALL.

A. pallescens frigidus Kir.

A. hieroglyphicus J. SAHLB.

A. anisotomus $\mathrm{PUT}$.

A. signaticomis F. SAHLB.

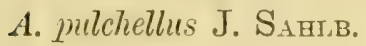

A. angularis J. $\mathrm{S}_{\mathrm{AHI}} \mathrm{B}$.

A. laeviusculus REUT.

A. crenaticollis $\mathrm{F}$. $\mathrm{S}_{\mathrm{AHLB}}$.

A. poppiusi $\mathrm{K} \mathrm{rr}$.

A. (Q.) brevirostris Honv.

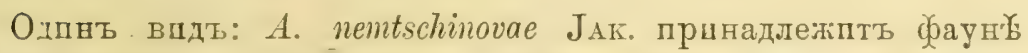
смежной области третпчныхъ лбсовъ, заходя на востогъ Сігбарш, капъ крациніи западный этапь своего географбпескаго

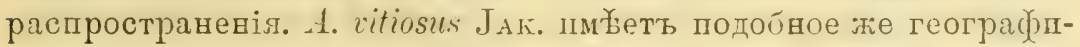
ческое распространеніе. Деслть остальныхъ вшдовъ широго распространены ІІ въ др. областяхъ ${ }^{1}$ ).

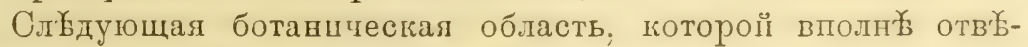
чагтъ данныл геограбическаго распространенія вшдовъ рода

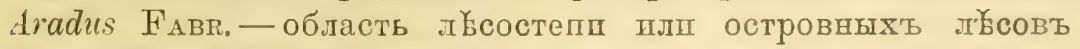
Европейской Россіп. Фауна ея состоптъ пзъ 9 впдовъ п 1 разновшдности, шзъ которыхъ $7--$ обціе ст предыдуней ойластьг,

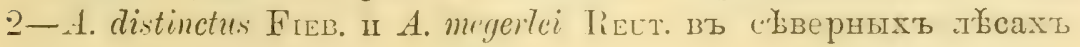
не ветрбेтаттея.

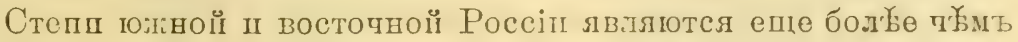
предылуцая область ойбдненная п'ьсамп п слұдовательно щи-

1) Географичеспо распространеніе А. planus FАви. соверпенно невыясненное. Даниля о нахожденіп его вт Волпнспой губ. (ПАуоский), па

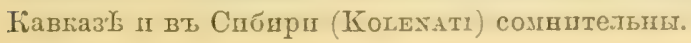




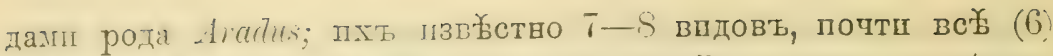

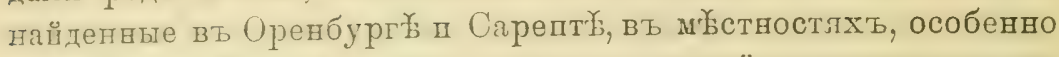
первой, еще богатихъ лйысомт пли древесной растительностью.

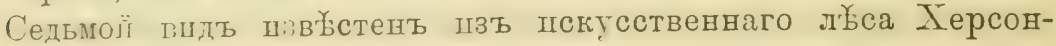
скої губ. Чистая степь повпдшгому совершевно лдшена видовь этого рода.

Изъ этнхъ видовь -2 плш 3 :

A. eversmanni $\mathrm{J}_{\text {AK., }}$ A. sareptanus $\mathrm{J}_{\text {AI., }}$ A. selectus $\mathrm{J}_{\text {AI. }}$

әндемпчны для об́ластш, 4-общіе съ двумя предыдущшмп

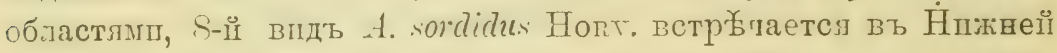
Австріп п Вевгріп.

Область релпктовыхт льсовъ Крыма II Кавказа являетсл также естественной зоогеограбфпеской ойтастью д.я вшдовь рода Aradus, харағтершзуется нахожтеніемь въ, ней 11 вцповь ${ }^{1}$ ), частьг обцихь (Т) для Тірыма п Кіавлаза, пайденныхъ

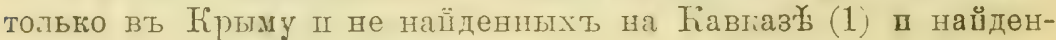
ныхъ только на Ківказ

Четыре вида эндемпчвы для області - $A$. tauricus J $\mathrm{JK}$. I 1. cancasicus Kó. (Крымъ In Kавгіазъ), A. somcheticus Kir. (Bariasгазте) п A. divericomis Horг. (Талышь, Кутапскал губ.). Среди-

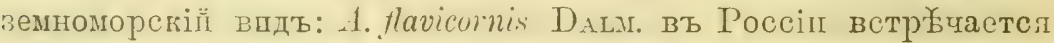

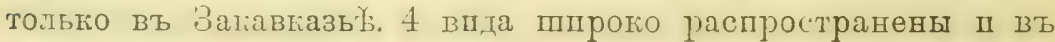
З-хъ предыдущихъ областяхъ. Трп вида являются общшмп съ областью островныхт лғсовь (A. distinctus Freb, A. cinnamomeus

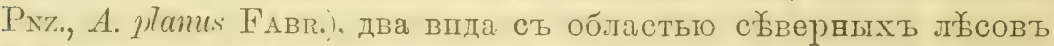
(A. truncatus Freb., A. cinnamomus $\mathrm{P}_{\mathrm{N} z}$.). Впдт A. versicolor H. S.

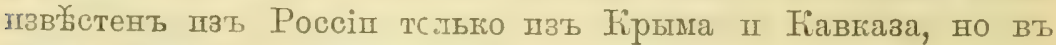

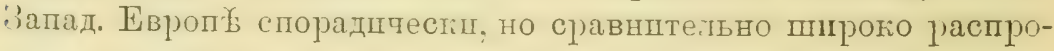
страненный.

Туран('кой провннціп средпземноморскаго поддарства, прпнадленіать о впдовь рода Aradus, пзь которыхь четыре для нея эндемпчны:

Aradus liomarovi J $\mathrm{AK}$. A. turkestanicus $\mathrm{J}_{\mathrm{Ax}}$.
A. setiger Krr.

A. bergrothi JAK.

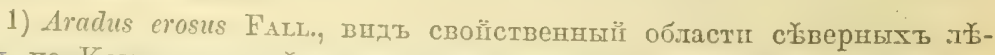

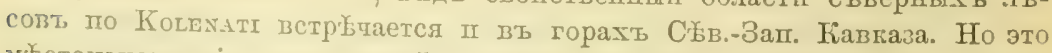

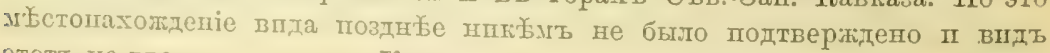
әтоть не введент вт счеть Крымско-Кавказскпхт, впдовъ. 
Плтый впдъ шшрого распространенный пю всей палеартітпе-

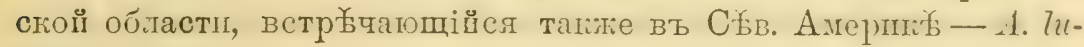
gubris FALL.

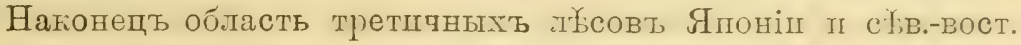
Ћ̈тая, гуда входять І русскія владенія на Дальнемъ Востоко по р. Уссурп п средн. теченію Амур, представллетт, также естественную, рҺзко отгранпченную, зоогеографичестію область распростравенія вшдовь рода Aradus.

Въ полномъ согласіш съ богатствомъ породъ древесной ра-

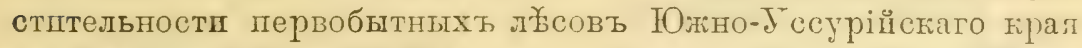
мы находпмь богатую фауауну этого рода состолщую пзъ 24 впдовъ, пзъ которыхъ 10 для нея эндемичны:
A. spinicollis $\mathrm{J}_{\mathrm{AK}}$.
A. bergrothianus KIR.
A. ussuriensis JAK.
A. compar KIr.
A. transiens KIr.
A. dissors $\mathrm{Kr}$.
A. consentaneus HorT.
A. semilacer KIr.
A. melas JAr.
A. unicolor Krr.

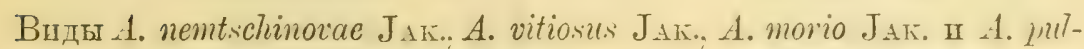
chellus J. S九нцв. ваходять Іі въ части Спбиргі, входящія въ

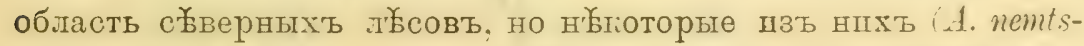

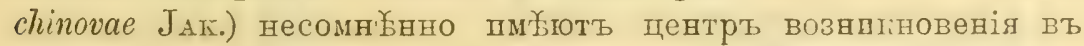
области третпчныхъ люсовъ. Видт, A. anisotome: Рет., спбирскій, доходящій до Фпнляндіп. 3 вшда шпроко распространены по палеаритпческой областп. Два впда 4 . brevicollis F.LL. I

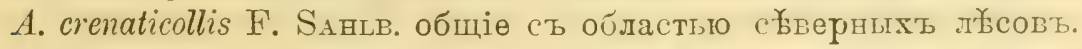
Характерво далг области отсутствіе $A$. depressu. (F.) II A. corticalis (L.), распространенныхъ почтп по всей палеарнтикй, піром'

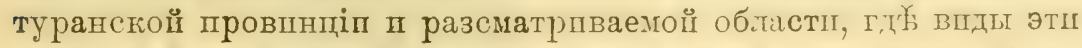
повпдиому замбшены вшарнымш вшдамп 1. consentuneus. Horr. II A. melas J AI.

Біологшчески впды рода Aradu: совершенно нө пзслйдываны. Большпнство пхъ эиветъ подъ корой леревьевъ (лшствен-

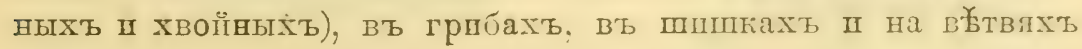
сосны.

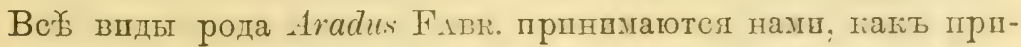
надлежащіе гъ этому рогу, хотя больпое разнообрлзіе II гетерогенность его впдовъ прі большеї детальности шзученія, іри

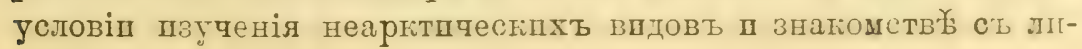




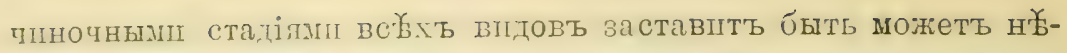
поторпмь группамь рода пршдать генерпческое значеніе.

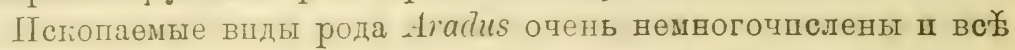
относятея къ түетпчному періоду, главншщъ образомъ изъ олпгопена ( 1 вцда пьзъ балтії̈скаго янтаря); два впда шзъ міодена.

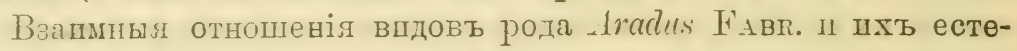
ствевная группиовка по доступному намь матеріалу предста-

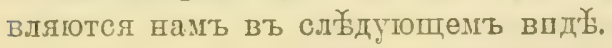

Aradus (s. str.) STrì.

\{\}

versicolor H. S.

diversicomis HorT.

spinicollis $\mathrm{J}_{\mathrm{AK}}$.

ussuriensis $\mathrm{J}_{A \mathrm{~K}}$.

tauricus JAK.

$\left\{\begin{array}{l}\text { cimamomeus Pxz. } \\ \text { stenopterus Bergr. (tumb poza } \\ \text { Stenopterus Sigi). } \\ \text { lauri Noual. }\end{array}\right.$

cimamomeus Pxz.
stenopterus Bercr. (tunt poza
Stenopterus Sigi).
lauri Nouale.

(depressus ( $\mathrm{F}_{\mathrm{ABR} .}$ ) (тшпъ рода

distinctus Freв.

transions Kir.

notutus Rex.

Pisostoma Lar.).

consentaneus. Horr.

dissimilis Cosix.

somcheticus KIR.

pallescens H. S.

var. frigidus $\mathrm{K}_{\mathrm{IR}}$.

erosus FALL.

Tiuthyi Horv.

reuterianus $\mathrm{P}_{\mathrm{UT}}$

truncatus FIEB.

lawsoni SAuxd.

eversmaini $\mathrm{J}_{\mathrm{AK}}$.

fiomarovi JAs.

setigr Krr.

crassicomis BoH.

stricus Hort.

crenatus SAY.

$\left\{\begin{array}{l}\text { brevicollis FALL. } \\ \text { bergrothiamus KIR. } \\ \text { compar KIR. } \\ \text { orientalis BERGR. }\end{array}\right.$

$\left\{\begin{array}{l}\text { unicolor Kir. } \\ \text { pictus BAER. } \\ \text { hieroglyphicus J. SAHLB. } \\ \text { limeprri liEuT. } \\ \text { caucasicus Kol. }\end{array}\right.$ 
anisotomus $\mathrm{PuT}$.

f signaticornis F. SAHLB.

\{pulchellus J. S.1нLi.

(bergrothi $J_{\mathrm{AK}}$.

lugubris $\mathrm{F}_{\mathrm{ALL}}$.

$\checkmark$. nigricornis REUT.

montandoni REUT.

flavicomis DALM. (=macro-

phthatmus $\left.\mathrm{J}_{\mathrm{AK}}\right)$.

angularis J. S $\mathrm{S}_{\mathrm{AHLB}}$.

laeviusculus Revt.

v. simillimus REUT. (bimaculatus REUT.

selectus $\mathrm{J}_{\mathrm{AK}}$ ( $?=$ sareptanus $J_{\text {AK) }}$.

dissors Krr.

sordidus HoRT.

vitiosus $\mathrm{JAK}$.

hahni Rect.

semitacer KIr.

aterrimus Fres.

v. moestus Reut.

$\mathrm{r}$. diversicollis REUT.

morio $\mathrm{J}_{\mathrm{AK}}$.

crenaticollis F. SAHLB.

poppiusi KIR.

inemtschinovae $\mathrm{J}_{\mathrm{AK}}$.

cedri Put.

\section{Aradus (Quilnus) STAL.}

parvicollis STiL. subsimilis Hort.

discedens Horv. minus BERGR.

brevirostris HoRT.

Изъ этнхъ впдовъ: stmopterus Bergr, lami Noualн, dissimilis Costa., Tuthyi Horv.. lawsoni SAUnd., notetus Rer.; planu. Fabr., crassicornis BoH., serbicus HorT., orientatis Bergr., montandoni ReLT., hahni Reut., cedri Puт., parvicollis Sti̊L, subsimilis Honk., breviro-

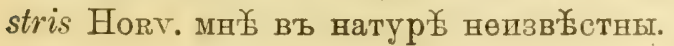

ОПРЕД'ЛИТЕЛЬНАЯ ТАБ.ТНЦА ПОТРОТОВ' РОДА ARADUS' F.ABR.

1 (2). Хоботопт длинный, достигающій основаніл переднегруди пли часто заходящій за него. Боковые края переднеспини боль্ые пли менъе огругленно-расппрениые. . . . . . . . подродъ I Aradus Sт.і.

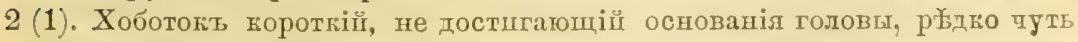
заходяцій за вершину переднегрудш; боковые края переднеспинш прямые . . . . . . . . . подродъ II Quilnus Sтї.

1. Подродт Aradus (s. str.) Sта̊L. 1873.

Aradus (Aradus) STÅL Enum. Hemipt., 3, p. 135. 1873. 
Діагнозъ. Rostrum coxas anticas attingens, saepe multo superans. Pronotum lateribus phis miunste dilatatis.

Характеристика. Впды относящіеся ні этиму погроду шмйють

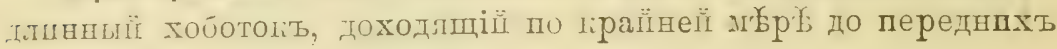
ляшекъ плп гораздо длиннъъе.

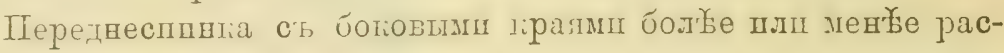
ппреннымш.

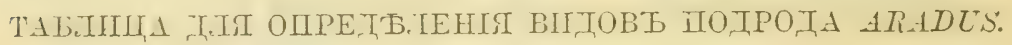

1 (8). Второї членцк успловт тіропе третьло. Бртшно спльно расшпряющеес тзади.

2 (7). Усппп толстые, толще бедерь ногь. II и III-ій членикп къ вер-

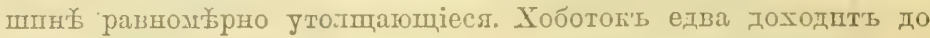
ляшекъ переднихь ногъ.

3 (6). Перегнеспшнга вдвое пшре своей длины. Боқовые крал ея закруг-

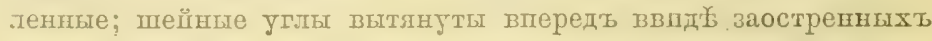
угловт. Второї членпкъ успиовь вдвое тороче третьяго. Вершшнные уллы сеглентов соппехіvит'а запрулленные, нерыдаюпіеся.

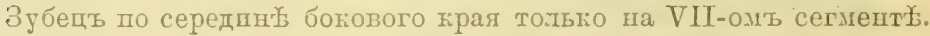

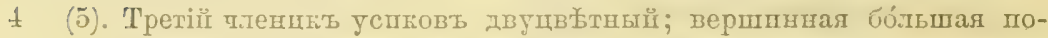
ловпна его бұ.лая. Боговые грая щштпка въ вершпнной своей пастп ліелтоватаго пв б́та. Брішио сверху и снизу рыжеватобурое, свю́тло пі темно-пятнистое. . . . . . 1. A. versicolor H. S.

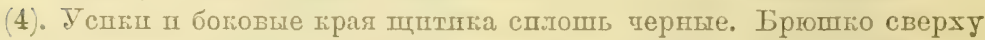
II снизу буровато-qерное, вершшныле углы сегментовъ желтоmithe . . . . . . . . . . A. diversicornis Horr.

6 (3). Второй тленпь јспюов одень незнапптельно тороче III-го. Переднеспшиа очень тороткая, шприна ея въ $2 \frac{1}{2}$ раза больше длины, боговые края ея образують уголь съ загругленной вер-

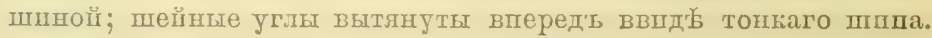

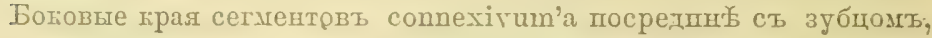
особенно явственнымъ па VI II VII сегментахъ, вершинше углы сегментовь connexivum'a заостренные, выдаюпіеся :. . . . .

\section{. . 3. A. spinicollis $\mathrm{J}_{\mathrm{AK}}$.}

7 (2). Успип довольно длпнные, тонкіе, тоньше бедерь ногъ. II-ої ІІ III-iй тленпи цилшдрпчестіе II только на самой вершинат. головчато-утолщенные. Хоботогь опень длинный, доходящій до середши среднегруди. Боковые грая переднеспнші образугть поттп прямой уголь, вершпна котораго лежить по середши переднеспші; шейые улы вытянуты впередъ, ввпды не пиротаго, тупого угла............. . . ussuriensis Јак.

8 (1). Второї тлепшт успио длшнияе третьяго.

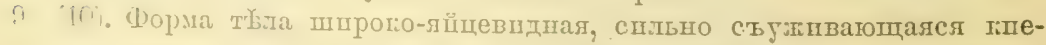
редп; переднеспика одень лороткая, у́же расширеннаго осно-

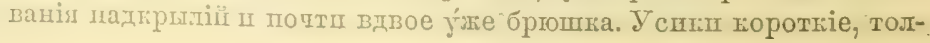


стще, почті одшнаговой толщины съ бедраміз ногт. II-ой членшкь на $1 / 4$ длиние третьяг, толще другпхь плениловь. . . .

10 (9). Форма тео. га овальнал.

11 (26). Второі̆ qленшк успковъ едва.длпнние третьяго; переднеспниа ншкогда не шире основанія надкрылій.

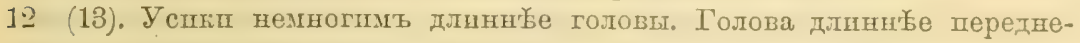

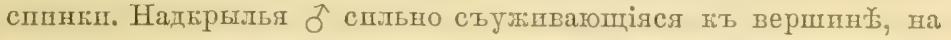
гонц官 снова расшщряющіяся, 우 - пасто укороченныя, немного длиннъе питпка съ редуцированной membran’oй. Кплп переднеспинки мало выдающіеся, стертые . . . . 6. A. cinnamomeus Pхz.

13 (12). Ј спғи значптельно длинияе головы.

14 (19). Передніе углы переднеспнип сь больпиит бълымъ пятномъ; надкрылья у основанія сшльно распшренныя, толе съ.б́блығ пятномъ, шире переднеспинш.

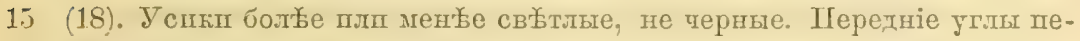
реднеспинш вытянуты впередъ, пріостренные. Connexivum съ боговыми краями отдығыныхъ сегментовт, прямымш. Надгрыпья св'́оллыя, жшлкІ ІІ пятна на нпхь бурыя.

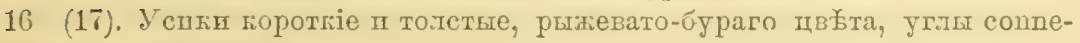
xivum'a прямые.

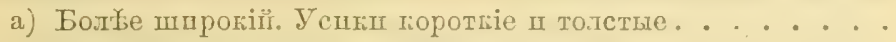
7. A. depressus (FABr.).

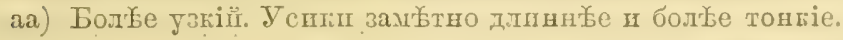
... var. leptocerus Honv.

16. Усипи гораздо болье длшниые Iл тонкіе. Углы connexivum'a острые, опушенные внизъ . . . . . 8. A. consentaneus Horv.

18 15). Јсши терные, толстые. Задняя половина согіum'а перная. Боковые края сегментовъ сопnехіуит'а затругленные. . . . . .

. 9. A. somcheticus n. sp.

19 i1). Переднесппна всл одноцвьттнал. Надкрылья у основанія едва распиренныя, не шире переднеспинкп.

2) (23). Второй членшъ усшковъ однаковой толщпны у оспованія, пакъ

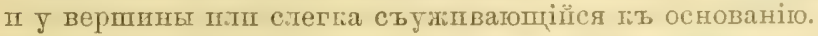

21 (22). Боговые края переднеспниц сшльно зазубренные, загругленные.

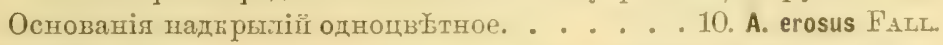

22 (21). Боковые трал переднеспини угловато-зағругленные, слабо зазубренные. Основаніе надкрылій съ бъ̆лым пятномт. . . . . .

23 (20). Второй плениъ јсшовъ у оспованія сильо съуженныи.

24 25. Успи очешь спльно утолщецные, хассивные, чериаго двыта; II-ой членци у вершпни въ два раза толще своего осповапія, III-ій тлениғъ толще II-го. Г'олова совершенно не съужешная позадп гхазъ. Боговые отросткі ея длиныые, острые. Шередпеспина трапецондальная, съ боговыми праямп широго заругленнымп, съ замбтными зубцамп; шейные углы ея острые, выдающiеся . . . . . . . . . . 12. A. reuterianus Puт. 
25 (21). Уснкп пормально толстые. Голова позади глазь очень горотко съуженная, боговые отростки ея короткіе. Переднеспншка мельозазубренная, угловато-зағругленная, съ неболыпо выемиой впередп; шейные углы не выдағщіеся, закругленные.

а) Голова вмғстет сь глазами пире своей длины. Bторой тленшкъ усиковъ у основанія сразу спльно съужпваюійся. Общій цвйтъ тобла же.ттовато-бурый. . 13. A. pallescens H. S.

аа) Голова болье узкая, длшна ея превышаетъ ширину. Второй тленик успковь бол条е тонкій, къ основанію постепенно

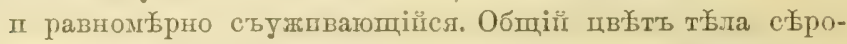
вато-qерный . . . . . . . . var. frigidus nor.

26 (11). Второй пленпкт успковт значптельно длиннйе третьяго; рбдко второй членпьъ очень незначптельно длинне те третьяго, но тогда переднеспинка гораздо шире растиренной тастп надкрылій.

27 (68). Второй членпкь усиковъ на всемъ протяженіп одннаковой толщнны пли самое большее у вершпны немного болье толстый, ч危ъ у основанія.

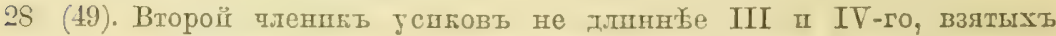

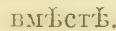

29 (30). Второй членшкъ успюовъ бо.бловато-желтаго цвйта.

30 (31). Надкрылья б гь вершин вершины membran'ы снова расширяюшіяся. ㅇ неизвъстна . . .

31 (30). Надкрылья у вершины membran'ы вторично не расширяющіяся, пногда $(q q)$ сшльно укороченныя, едва заходящія за вершину второго сегмента ......... 15. A. distinctus J A .

32 (29). Второй членшкъ успковъ не бъловато-желтаго цвбта, тапе всего чернаго цвйта.

33 (38). Шереднеспинка замх́ттуо шире основанія надкрылій; второй членпкь усиковъ тоныше третьяго; надкрылья у основанія расширены очень незначительно.

34 (35). Боговые грая первыгъ брғшныхъ сегментовъ огругленные, вершинные углы пхъ закругленные, слегка выдающіеся, V п VI-го сегментовт, спльно выдающіеся. Переднеспнка незначптельно выдается надъ основаніељъ надкрылій ввидағ вершишы тупого угта . . . . . . . . 16. A. brevicollis FALL.

3.) (31). Вершпные углы сегментовь connexivum'a выдаются впередъ ввнда, угловт сь острымп вершвнами, тагъ что боковой край connexivum'a представляется крупно зубчатымъ. Боповые края переднеспинд выдаются наль основаніемь надкрылій ввиды крыльеобразныхт лопастей. У основанія надкрылій бо̆ловато-

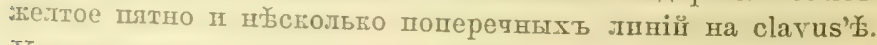

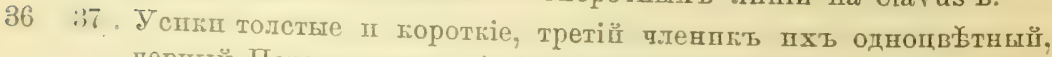
перный. Переднеспнка болые қороткая п широкая, боковые края ея снльо зубчатые сь глубокой вырғзгой впереди . . . . . . . . 17. A. bergrothianus nom. nov. (emarginatus BErgk. nec. SAT). 
37 (36). Успкп болье тонкіе п длинные, третій пленикъ ихъ, исклютая самаго основанія его, бълый переднеспнка боль্бе длинная п узкал съ небольшой вырбзкой впередп, боковые края переднеспннй съ мелкими зубчиками. . . . . . 18. А. compar n. sp.

38 (33). Переднеспинка ј’е основанія надкрылій пли одинакової сь нпмь ширнны.

39 (40). Передніе углы переднеспини продвшнуты знатптельно впередъ ввшдъ пирокпхъ угловъ; боковые крал переднеспини впередп съ бұлымъ пятнохт; боковые прая переднеспннии мелко зазубренные; надкрылья у основанія очень сильно расширенныя. Второй п третій членшкп успковь спльно утолщенные, гораздо толще I п IV-го членпковъ........ 19. A. transiens n. sp.

40 (39). Передніе углы переднеспини не вытянуты впередт вввды выставляюшися лопастей боковые края переднеспинки впередп одноцвытные, на всемъ протяженіи пхъ сильно зубчатые; над-

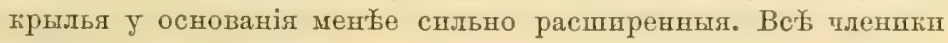
успковъ мало отличающіеся по толщшне́.

41 42). Боковые края переднеспннк тупоугольно закругтенные; успки горпчневаго цвыта, длинные пі сравнительно тонкіе, петвертый пленпьь немногпмь короче третьяг, брюшко сильно кзади распиренное, на верхней поверхности по бокамъ connexivum'a на каждомь сегхенто треугольное п овальное углубленіе . . . . .

42 (41). Боковые края переднеспини правильно, широко закругленные.

13 (46). Щитшъ широкій, по серединб значительно прпподнятый, боковые грая его занругленные; верпина его на самомъ конць желтоватая.

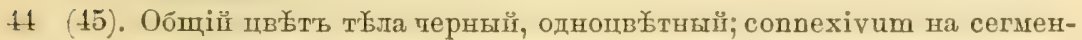
тахъ съ овальными углубленіямп. II-ой членић усиковъ у основанія qерный, вершнна его желтовато-бұлая. . . 21. A. melas JАк.

45 (11). Боковые края переднеспннк, основаніе надкрылій, сахая вершина щитика п вершинные углы сегментовъ connexivum'a желтовато-бурые.

a) Третій члениъ усивовъ черный . 22. A. corticalis (Lins.). аз) Третій тленпкъ успковъ наполовшну бълый . . . . . ... var. annulicornis FABR.

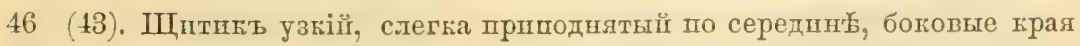
его прямые.

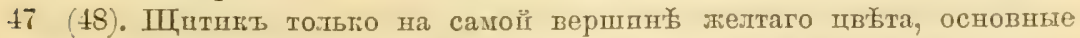
углы переднеспннг, основаніе надтрылій и пногда задніе прая сегментовъ брюшка желтовато-бурые . . . 23. A. planus Faвr.

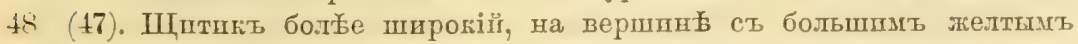
пятномт. Переднесппнга пі наднрылья одноцвоттныл . . . . . . . . 24. A. betulinus FALL.

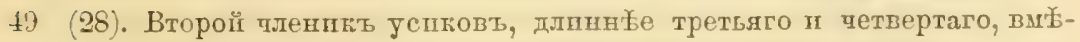
сть взятыхт, тонкій, тоньпе бедеръ ногъ.

50 (53). Второй пленикъ успковъ желтаго цвйта. Боқовые крал переднефауна Россін. Насыпомия подужествокридия. VI. 


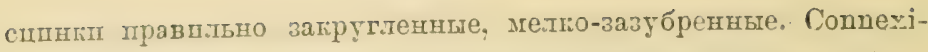
vum по середпнех қаждаго сегмента съ двумя черными крушнымп пятнампг.

51 52\%. Боковые отрости голопы вооруленные на внушнек қраю

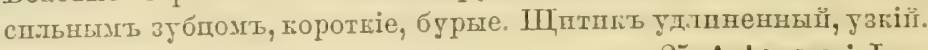
. . 25. A. komarovi JAK.

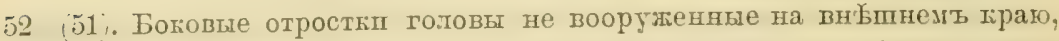
острые, тонгіе, зерхняя половнна пхь въ вершпной части жел-

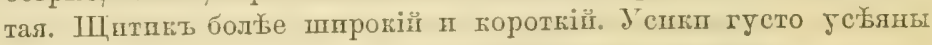
бугоркамп, на верхушкахъ которыхъ сидять волоски . . . . ...26. A. setiger n. sp.

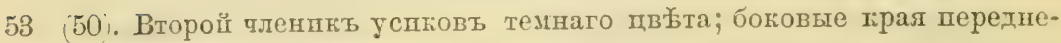
спннки съ сильными зубцамп, слабо загнутые.

54 (57). Боковые прая переднеспнкі расширены ввшды прямого угіа.

55 (56). Зубцы по праямт дереднеспнни болыпіе. IV-щй членшкь јспговъ равент по плинд третьемг пли немного его пороче . . .

- . 27. A. krueperi Reut.

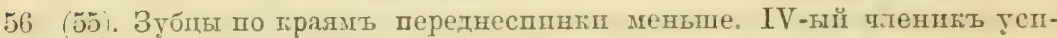
цовъ длишнбе III-го. . . . . . . 28. A. hieroglyphicus J. SAвLB.

57 (5). Боковые грая переднеспнки расширены ввшд тупого угла.

58 (61). Четвертый ч.тенпк успиовъ почти равенъ или туть городе третьяго.

59 (60). Боковые грая переднеспини тупотгольно расширенные, пост⿱⺊口 вершпшы угла иь основанію снльно сходящіеся. Јспки длинные, тонкіе, второй членик шхь одннаковой длшны съ головой. Божовые прая переднеспинки съ круннымп зубцами . . . . . .

\section{- . 29. A. caucasicus Kor.}

60 (59). Ботовые грая перетнеспнш тушоугольо расширение, посль вершшны угла слабо сходящіеся, почти параллельные, запругленные. Јспи лоротхіе п толстые, второй членпь пхт пороче головы. Боковые ғрая переднеспниц ст жебольшиш зубцаяп .

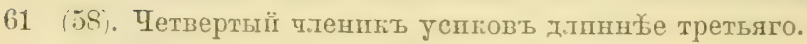

62 (65). Щитпъ по середпно ст возвышеніемъ. Боковой прай надкрылій у основанія зазуборенъ. Второй пленшь успковъ п голенп ногъ въ выдагцихся бугоркахъ, на верппног бұловатыхъ.

63 (61). Второї членшк успковт слегка лороче головы. Вершннные углы абдомпнальныхъ сегментовъ особенно III-V-го замкобтно продви-

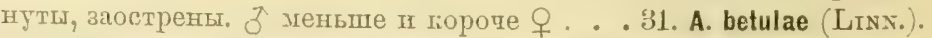

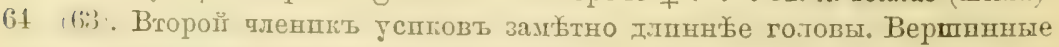
углы абдомпнальыхъ сегментовъ III-V-го опень незначптельно продвпнуты. of іл $q$ одшнағовой ветпчнны . . 32. A. brenskei Reut.

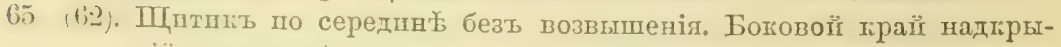

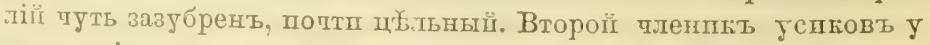
основаніл ш вершины головтато-утолшенный, цакь п голени ногт, Попті гтадкій, съ мелкпи однопв孔тным бугорками.

66 б

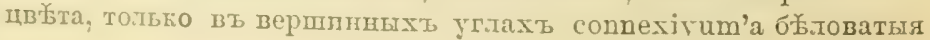




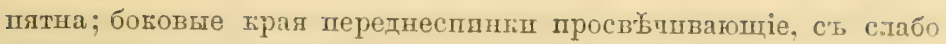
выдагщшыся зубцами . . . . . . . 33. A. unicolor n. sp.

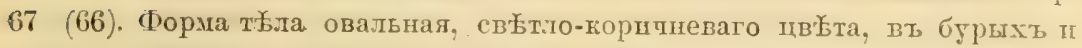
грасновато-рыжшхт пятнахт; боговые грая дереднеспинг съ сильнымп, острымш, зубцами. . . . . . . . 34. A. pictus B̈̈r,

68 (27). Второй членпи усиюоь у основанія гораздо тоньше, т先мъ у вершины, длиннеке, часто опень знатительно III-го членша.

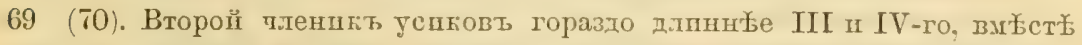
взятыхъ; боковые края съ спльными зубцами; височные отросткіт снльно развиты . . . . . . . . 35. A. anisotomus J'Ut.

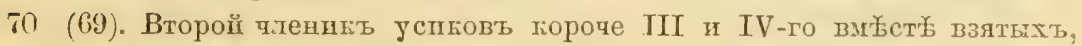

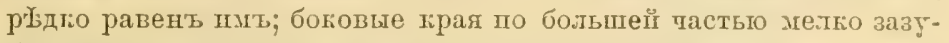
бренные, висоуные отростгі отсутствують шли мало разиите.

71 (74). Третій пленик успиовь весь бълый илш желтоватый.

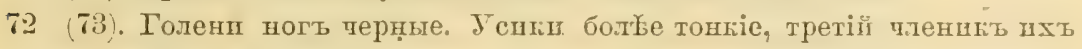
бълый. Оть шейныхъ угловъ переднеспни отходить впередъ небольшой зубецъ . . . . . . 36. A. signaticornis F. S.ндз.

73 (72). Голени ногъ желтые, только на вершинё бурыя. Успгі тораздо болье толстые, третій члениц шхъ қелтоватый. Шейнше углы переднеспинп закругтенные, безъ выдающагося зубца. . . . .

. 37. A. pulchellus J. SAHLB.

$7 t$ (71). Третій членпкъ успювь черный шли черный съ бъ.товатой верпाнної.

75 (76). Усикп толстые, второй членпкъ только у самаго основанія слегка

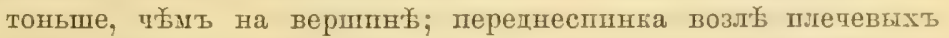
угловъ съ большимъ ілелтымъ пятном'

76 (75). Усикц тонкіе, II-ой членшкъ пхъ иъ основаніг спльно утонтающійся.

76 (79). Второй членикт уситовь у основапія на протяженіп $1 / 4$ своей длины сразу сильно сжать.

77 (78). Боковые края переднеспини расшшренные, иъ шершшио сильно съуживатщіеся, впереди съ явственной выемкой, посл官 середины пь основанію почтп параллельные; шейные углы продвинуты впередъ. Голова позадп глазь постепенно с'ужшваюшаяя. Усики болье длпнные II тонғіе, сплошь . . (var. nigricornis Reut).

пли псклютая вершнны III-го членцка, пногда пі вершины II-то, перные . . . . . . . 39. A. lugubris Fall.

78 (77). Боковые грая переднеспиніп почтп прямые, слабо расширенные; пейные угы закугленные, тупые, впередп прямо обрубленные; голова позаді глазъ сразу съуживающаяся въ очень ћороткую нелвственную шею; усип толстые п коротпіе, первый членит пхт, основаніе II-го II иногда вершнна IV-го черные; II-ої, III-ій п IV-ый qленпки бұловато-лелтые. . . . . . . . . .

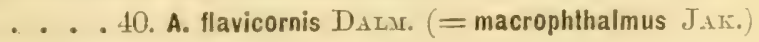

79 (76). Второй пленпк успновъ отъ вершины гъ основаніо постеденио съужпватецій, безь рłзљаго сжатія у своего основанія.

80 (97). Второй членшк успковъ пороче головы. 
-1 (82). Пейнғе угты переднеспинки острые, прямо продвинуты впередъ. Второй членпк успюов одень тоншій

. . 41. A. angularis J. SAHLB.

\&.2 (81). Шейные углы переднеспшн тупые пли на вершины прямо обрубленные.

-3.) (91). Corium надпрыпій съ ббловатымп поперечвымп жилгами. Задніе углы абдоминальшыхъ сегментовъ п задніе ґрая ихь бқловатаго цвъेта.

St (85). Надкрылья безь пятна на расппренной частп согіum'а; средшнные ппли переднеспни впереди спльно сблпженные, позади паралтельные.

а) Переднеспина вдвое пли немногпь меньше шире своей

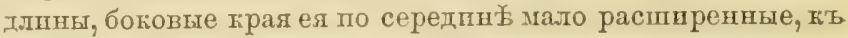
основанію почтп парал.ельные, рҺбдко слегка сходящіеся. Предглазничные шипы на головб тупые, но явственные .

. . 42. A. Iaeviusculus $\mathrm{Reut}$.

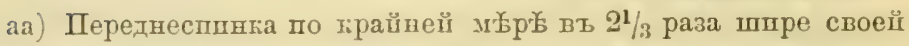
длины, боковые края ея по серединег спльно распиренные, пь основанію сходящіеся, загруглевные. Предглазничные бугоркп очень незначительные, неявственные . . . . . . . var. simillimus REuT.

8.) 84. Посредпно расшпенной тасти corium'a большое пятно бълаго

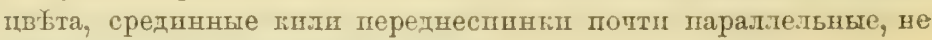
сблпженные на передней половине․

91). II-ой членикъ усиковъ отъ вершшны къ основанію постепенно п равномю्厃ेрво утончающійся.

88). Успии тонгіе, II-ой тленпъ пхъ тоньпе голеней ногъ, толщина его у вершины незначительно превышаеть толщину его у основанія; боговые трая переднеспшкц съ замбобными зубцами. . .

-8 (87). Усик гораздо толще, II-ой тленпкъ пхъ у основанія въ $11 / 2$ раза тоньше, тағыь у вершпны; прая переднеспнии мелко зазубренные. Шейные угли впередп прямо обрубленные или закругленные.

-9 (90). Шейные углы переднеспши впередп прямо обрубленные. Втоpoĭ членикъ успков бол年е пороткій. Передній отростокъ головы длпнныц, бол年е тонкій, мало выпуклый, боковые отросткщ

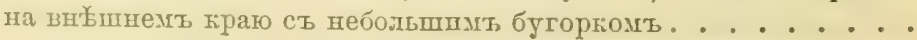

. . 44. A. bimaculatus REUT.

90 (89). ІШейые углы переднеспнни впереди слекка закругленные. Второй членит јспковъ бол实 длиный. Передній отростокъ го-

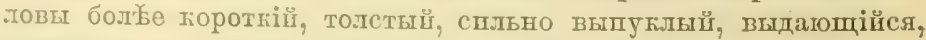
иоговые отростки на внынтекъ траю невооруженные . . . .

.. 45. A. selectus $J_{\mathrm{AK}}$. (=? sareptanus $J_{\mathrm{AK} .}$ ).

91 мі. Шейые углы переднеспни продвинуты впередт, впереди зашругленые. Второй пленшк успковь на $1 / 3$ своей длины оть 
вершины спльно утонтающійс, отъ середины къ основанію на всемъ протяженіп почти одинаћовой толщпны.

92 (93). Боковые грая переднеспнки впереди съ глубогой выемгой, кзади правильно загругленные. Кпли переднеспини въ задней

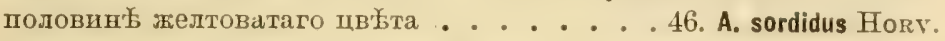

93 (92). Боковые края переднеспинии позади середпны тупоугольно за-

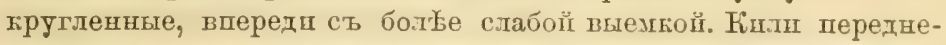
спинки на всемъ протяженіп черные . . . . 47. A. vitiosus JАк.

91 (83). Надкрыль совершенно черныя, безъ св бллыхъ поперепныхь жплоғъ п пятенъ; абдомшнальные сегменты тольто въ вершпныхъ

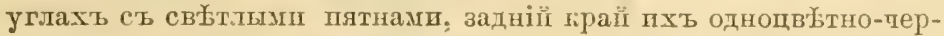
ный.

95 (96). Задніе углы пятаго сегмента брюшка спльно выдающіеся за край передняго угла шестого сегмента; боловой край переднеспинки впередш сь глубокой выемкой; боковые тірая щптика сильно прцподнятые . . . . . . . 48. A. semilacer n. sp.

96 (95). Вершшнный уголь $V$-го сегмента не выдается надъ основнымь угломь VI-го сегмента. Боковой трай переднеспинг впереді съ слабой выемкой. Боковые края пптика гораздо менье прпподнятые ${ }^{1}$ ).

а) Переднеспика вт $2 \frac{2}{5}$ раза шире своей длшны, боковые края ея впередп съ силной выемкой, менбе спльно сходящіеся. Щптикт съ боковыми краями, спльно выгнутымш, першпна его тупая . . . . . . 49. A. aterrimus FIEB.

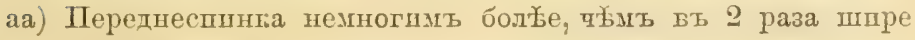
своей длпны.

b) Боковые грая переднеспинт ппереди спльн загнутые, менъе спльн выемчатые. Шитикъ съ боковымп праям, прямыми; вершина его заостренная . . var. moestus REvт.

bb) Боковые гірая переднеспнкп впереди очень слабо загиутые пли попти ровные. Шитпкъ съ боковыми граями, почтіг до середины съ легтої выемкой, дал官е прямые. . . ... var. diversicollis RELT.

97 (80). Второй членць успковъ одшнаковой длины или длинначе головы.

98 (99). Усики и ногп очень тонкіе, второй членикъ успковъ длиннехе головы, къ вершиног очень незначительно, постепенно утолщающійся. Шейные углі переднеспнкп продвпнутые впередъ, на

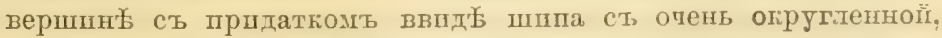
широкой вершиной. Надкрнлья одноцвб̆тно-тершыя, у основанія почтп прямыя, не распшренныя . . . . 50. A. nemtschinovae JAћ.

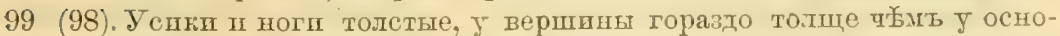
ванія. Шейные углы переднесппни безъ прндатковъ. Надкрылья у основанія спльно расширенныя.

100 (101). Второй тленшт уситовъ болье торотшіи, начниая ст середины сразу спльо съужшватщйся. Переднеспина одннатовой шщ-

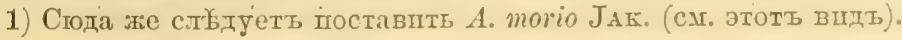




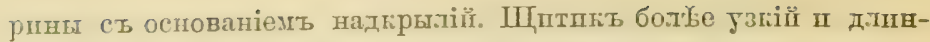

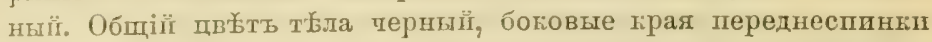
цъ основанію, вершинные углы connexivum’a п отдасти надזррылья - бұлые . . . . . . 51. A. crenaticollis F. Sahlb. 101 (100). Второй. пленпк успков болье дынный, къ основанію посте-

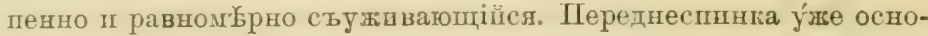

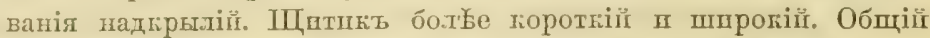
цвъть ты.та грязно желтовато-бурғй . . . . 52. A. poppiusi n. sp.

\section{Aradus versicolor H. S. 1835 .}

Aradus versicolor H. S. Nomencl. ent., p. 59. 1835; Wanz. Ins, 5, p. 93, f. 541. 1839. - Freb. Eur. Hem., p. 110. 1861.-Puт, Synops. Hém.-Hét. de Fr., I, p. 129. 1879. - Reut. Rev. syn. Het. palaearct., II, № 189, p. 231 (ed. sep.). 1888.

Corens spiniger Schellexi. Geschl, d. Land- u. Wass.-Wanz., p. 19, t. 5, f. 2. 1800 (nec Fabir.).

\section{Фаунпстическая литература, касанщаяея Россін.}

Aradus versicolor REut. Berl. Ent. Zeit., XXV, p. 189. 1881 (Tauria). - JAK. Hor. Soc. Ent. Ross., XXXVII, p. 237. 1905 (Tauria: Alma). - JАK. Труд. Русск. Әнтом. Общ., ХII, стр. 111. 1880-1881 (Transcaucasia Akstafa, Karavan-Saraj). - Horv. in Schnerder, Naturwiss. Beitr. z. Kenntn. d. Kaukasusländ., p. 80. 1878 (Transcaucasia: Kutais); Sitzungsb. d. naturw. Geselsch. issis" in Dresden, p. 95. 1879 (Trans(eacasia: Suram).

\section{Экземпляры Зоологическаго Музея.}

A mone (우). Signoret.

Dalmatia ( $($ ).

Tauria: Alma. 24. VI. 1884 (ठ). RETowski.

Tauria: Tavel. 1. VI. 1907 (ㅇ, larva). Kiritshexio.

Tauria: Korbekly. 28. IV. 1907 (q). Christoforov.

Tauria: Kosmodamianovskij monasterium in fl. Alma (q). Kiritshexкo.

Caucasus sept. occ. (). SтARK.

Caucasus occ. Utsh-dere (2 $\left.\sigma^{\top}\right)$. Koenig.

Caucasus occ.: Suchum ( $\left.{ }^{\top}\right)$.

Caucasus occ.: Batum (ㅇ).

Caucasus occ.: Batum. VIII. 1902 (ठ઼).

Transcaucasia: Karavan-Saraj ( $(7$, ,, ). BALAssoGro.

Transcaucasia: Alistafa $(\partial$, o $)$. Balassoglo.

Дiarн03ъ. Corpus Latum, retrorsum paulo iठ) vel fortiter (q) intundato-lilatatum. Caput, antennae, apice articuli tertii excepto, thorax fusco-nigri; dimidio apicali articuli tertii antennarum, maculis lonstumlinalibus ad angulos anticos pronoti, carinis intermeiiis apul basin, hemelytris, in partibus basalibus venarum malculisque fuscis exceptis, nec non margine lato interiore lobo- 
rum segmenti septini rentralis - albidis; articulo primo antenuarum, marcrinibus lateralibus pronoti ante hasin abdomirseque fuscis.

Caput longitudini suae aequilatum; lobis lateralibus crassis, urevibus, apice acutis, albidis, margine exteriore tuberculo parvo armatis; lobis temporalibus latis, prominentibus, parte postoculari capitis parti anteoculari fere aequilonga.

Antennae crassae, sat breves, articulo secundo quam articulus tertius duplo breviore, articulo tertio bicolore, basi et apice crassitie fere aequali.

Rostrum basin prosterni attingens.

Pronotum margine postico sinuato; marginibus lateralibus crenulatis, fortiter rotundato-ampliatis, apice sinuatis; angulis anticis prominentibus; carinis pronoti lateralibus - parallelis, intermediis basin versus divergentibus.

Scutellum angustum, marginibus lateralibus scutelli rectis, elevatis, apicem versus fuscescentibus.

Hemelytra basi rotundato-dilatata, apicem versus valde angustata; corio scutello in $1 / 3$ longiore.

Описаніе. Голова одпваково развштая, кағъ въ длину, такъ II въ пирпу; передній отростокъ ея короткіці, немного заходящій за первую четверть второго тленика усиковъ, съ боговъ сжатыи; боковые отростні заходять немногшиь болье

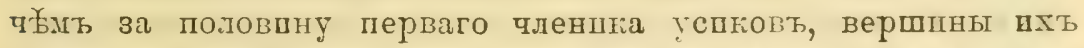
бълыл, внишвіи край вооруженъ небольшимъ зубцомъ; прөлглазнпчные отросткп аебольшіе, направленные вверхъ; заднял часть головы слабо съужшвающаяся къ основанію, несеть впсочные отростки пирокіе и тупые; поверхность головы круднозернистая, заднля половпна ел съ глубокпм подковообразным углубленіемъ, доходящпм до глазє.

Успки қороткіе, толстые, самый толстыі третії тленикъ пхь почти одинаковой толщшны съ б́едрамп ногъ и толщө голеней. Первый плевикъ короткій, овальвый, буроватый, въ два раза

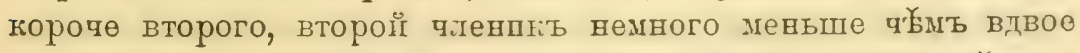
короче третьяго, черныц, у основавія немного товьше, чүмъ у вершины, третій членикъ на ${ }^{1}$;, длинне его би́.тьая половина ú гъ вершин съ слабо и постепенно утолцающій я, тетвертый членшьь черный, пилиндрдqескій; сь закругтенвой вершиной тоньше третьяго членика. 
Хоботокъ доходпть до освованія пөреднегрудш.

Переднесппнка поперечная, пприна ея въ два раза превос-

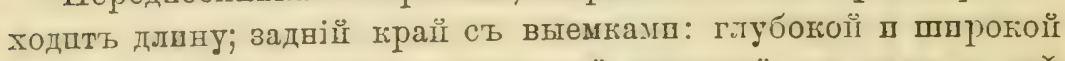
перөдъ щиткомъ и незначительної выемкої на самомъ двь্ первой; боковые храя съ мелкпми зубчпкамп на всемъ протяженіп, загнутые, впереди съ глубокої выемкой, позадп нея правцльно закругленные; плечевые үглы ппрого закругленные,

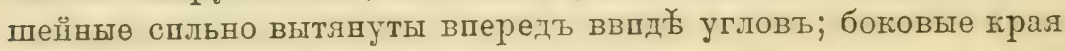
вдередп пироко окаймлевы бђлой полосой, сзади съ узкой полоской такого же двйта; срединные кшлц переднеспннкп къ основанію расходящіеся, на передней половннй болье сблю-

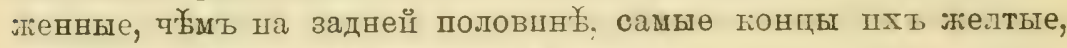
боковыө кили параллельные, на переднюю половпну переднеспинки нө заходящіе.

Щштокъ удлиненно-треугольныц, үзкій, боковые гірая его

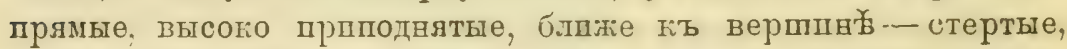
желтоватаго щв Һта, вершшна заостренная; поверхность щитіа крупно-зернистая.

Надтрылья у основанія расширены, гіь вершинег спльно съужпвающіяся, гораздо үже бргока, достигають вершины седьмого (るす) плп шестого ( $q$ ) брюшного сегмента; согіum желтовато-б́благо цвъта за псллюченіемъ черныхъ богового

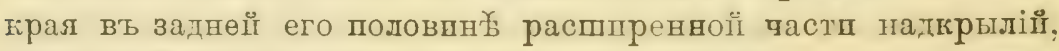
средшнной жшлкп, меморранальнаго шва пг бурыхъ пятенъ межлу

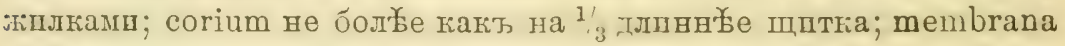
въ бурыхъ плтнахъ. Connехігы гірасновато-бурый, основные тглы отдыльныхъ I- $\mathrm{T}$ сегментов' сверху п снпзу съ широкимп, занпмаюппмп 2' наму, VI сегментъ почти сплошь черновато-бурый, вершпнныө үглы I- $\mathrm{T}$ сегментовъ, внутренніө края боковыхъ отростковъ TІ-го сегмента, п рлдъ, шногда двоїной, пногда совсүмъ отсут-

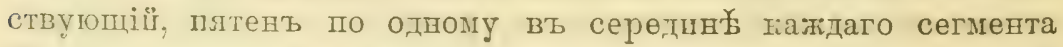

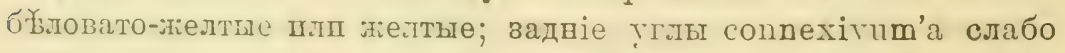
выдаю!ціесл, запругленные; боковые края connехітuп'а округтение; зазуіренные. Снизу голова п грудь; за псключеніемь передняго п задняго тгловь переднегруль, черныя, брюпко рыжевато-бурое съ такими же пятнами, какъ пा сверху.

Поги буровати-желтыя; основанія II вершины бедеръ широко б́.повато-желтыя, середина пхъ бурая, спльно затемненная.

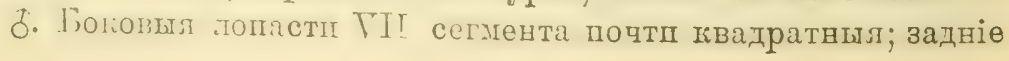


грая пхъ съ зазубренної выемкой по середпно, внутренніе загругленные, оть освованія расходящіеся, на верппна্ закругленвые.

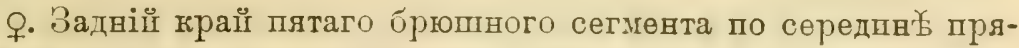
мої, средпнная лшнія шөстого сегмента равна боковымъ краямъ его, срединная ливія седьмого сегмента ва ${ }_{1 / 3}^{\prime}$ пороче шестого сегмента п почти вдвое длинне̌ㅛ восьмого сөгмента.

б. Длина - 6,4 милл., шпрпна - 2,8 мплл.

ㅇ. Длпна -8 мшлл., ширігна $-4,4$ мплл.

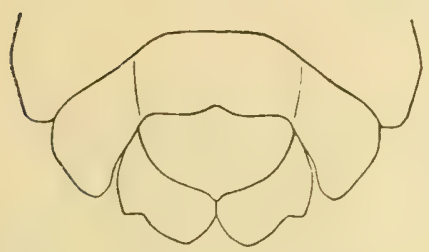

Pнс. 19.-Стерниты брюшка VI-VII.

Aradus versicolor H. S. ठ․

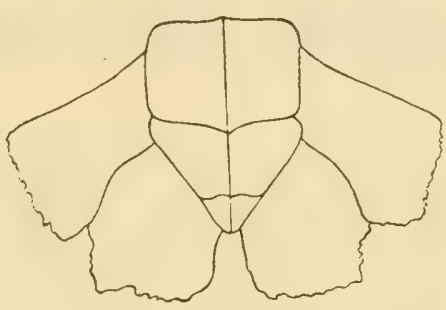

Pнс. 20.-Стерндты брюшта VI-VIII.

Aradus versicolor H. S. ․

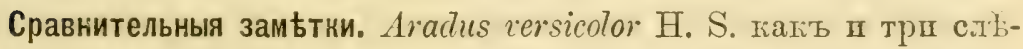

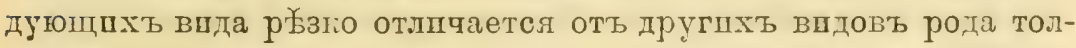
стымп, короткдми успками пі въ особенности коротғшмъ II-ымъ члөникомъ, который короче III-го, такжіе corium'омъ надкрылії. только на $1 / 3$ длиннеㅏе щптка.

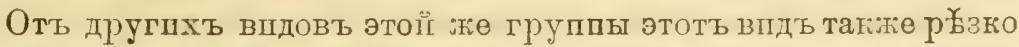
отличается: отъ A. ussuriensis JAк. гороткпмъ хоботкомъ, больъе короткпмъ вторымъ членпкомъ успков'ь, толщиной нхъ ш т. п.,

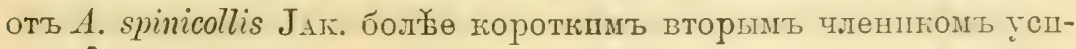
ковъ; формої переднеспинки пі connexivum'а.

Aradus diversicomis Horv. напиолбе и́лпзко стопть гіъ разсматриваемому внду.

Географическое распространеніе. Впдъ распространенъ въ Средвеп̆ и Южной Европ年 (Франція, ШШвейдарія, Гөрмані: Пталія, Далмація, Венгрія, Румннія, Гредія), вт Малой Азіп II въ Крыму п ва Кавгаз

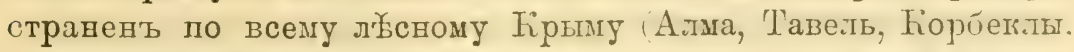
Чатырдагъ, Ғосьмо-Даміановскій монастырь, Старый Тірымт,

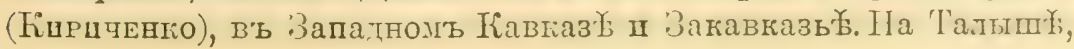




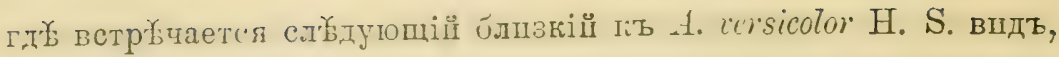
посльдніп् нө нап̈денъ.

Образъ жизни. Въ Ғірыму видъ этоть встрғпаетея подъ корої пней, отъ срублтенныхъ деревьевт небольпдми колоніямш.

\section{Aradus diversicornis Horv. 1878.}

Aradus dirersicornis Horv. in Schnetder Naturwiss, Beitr. z. Kenntn. Kaukasusländ., p. 80.1878.

\section{Фаунистичекая .итература, касающаяея Россіп.}

Aradus diversicornis Horv., loc. lit., p. 80 (Talysh: Leskoran).

Діагнозъ. Corpus Iatum, retrorsum paulo iठ) rel fortiter (q) rotundato-dilatatum, nigricans; maculis longitudinalibus ad angulos anticos pronoti, hemelytris, venis in parte posteriore maculisque exceptis, maculis in angulis apicalibus segmentorum abdominalium maculisque latis loborum segmenti sexti-albidis; articulo primo antennarum, abdomine pedibusque fuscis.

Caput longitudini suae aequilatum; lobis lateralibus crassis, brevibus, apice acuminatis, in margine exteriore denticulo armatis; lobis temporalibus latis, retrorsum vergentibus; capite pone oculos parti anteoculari fere aequilato.

Antennae nigrae, articulo primo fusco; articulo secundo tertio magis quam duplo breviore; articulo tertio crassiore; articulo quarto tertio in $1 / 4$ breviore.

Rostrum coxas anticas attingens.

Pronotum margine postico sinuato, lateribus rotundato-ampliatis, antice sinuatis; angulis anticis angulato-prominentibus.

Scutellum lateribus eleratis, unicoloribus. Hemelytra basi dilatirta, corio scutello in 1/: longiore, lutea, apicem versus fuscoirrorata, venis postice fuscis.

Species A. versicolori H. S. affinis, a qua antennis unicoloribus, nimis, marginibis lateralibus scutelli apicem versus haud Harescentibus, abdomine nigricante differt.

Описаніе. Голова шпрокая, одшналово развптал, какъ въ лличу, талт, п вь шприну, етва съуживагшаяся кзадп, позадш глазт; перетнії отростогь, заготящій за первую треть второго

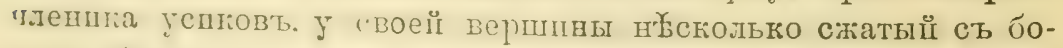

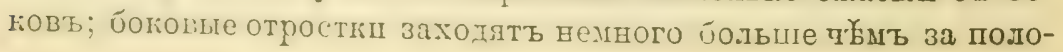


вшну перваго членпка успковъ, внбетвії край пхъ у основаніл вооруженъ спльнымъ зубцомт, більшпмъ, чбмъ предглазнич ный зубецт; впсочные отростка толстые, тупые; заднял часть головы съ глубокшмъ, подковоообразвымъ углублленіемъ.

Ј спип короткіе, толстые, чернаго цв пхь коротко-овальныі, вемного длиннеке половпны второго членпка; второї членпкъ циливдрпческій, ва ${ }^{2}$ корочө третьлго, третій самый толстый, поттп цилшвдрпческій, сьужнваюпюйсл кь своему основанію; четвертыі членикь ва одну четверть короге третьлго, правильн дштивгрпчеслой формы, у самой вершины тупо-заостренный, съ нексколькамп бұ.тым волоскамп.

Хоботокъ доходшгъ до переднихъ ляпекъ ногъ, немного нө достигая основного края переднегрудн.

Переднесппна төрная, боковые края возльғ пейныхъ угловъ єя несуть шпрокое II удлпвенвое по краю пятно желтоватоú Łлаго двйта. Переднеспина поперечвая съ шейными углами вытянутымп въ выдаюшіесл вперегъ п ль внғ углы; передній п задніі края переднесппнки глубоко выемчатые; боловые грая округленные въ передней половпнеъ съ легиой выемкой, загнјтые вверхъ, сь довольно правпльнымп, легкпмп зазубрпнамш; ґшли пөреднеспинкп ясво выражены, одноцв бтно-черные, два средншхъ выше другшхъ, къ основавію замғтно расходящіеся.

Шитокъ удлпненный, боковые края его высоко прпподнятые, одноцв бтные.

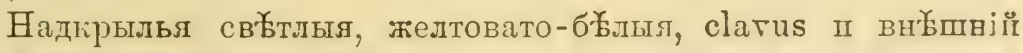

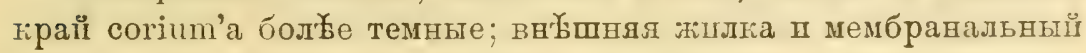
шовъ-об́а спльно утолщенные, въ задней своөі̆ части чер-

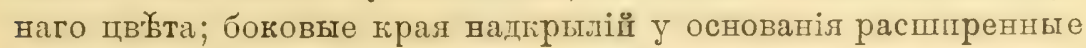
I загнутые вверхъ; membrana бурая съ блестящцм жилкамш, пвогда съ сырымп пятнами; надкрыльл бле брюшка и дости-

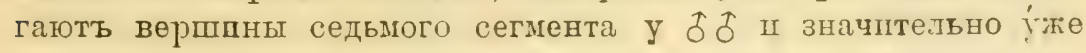
о́ргшка п достпгають лишь основанія седьмого о́рюшного сегмевта у 0 ㅇ․

Боковые краз сегментовъ брюшка зазуо́ренные, въ вершинныхъ углахъ сегментовъ расположены бъ.оовто-желтыя, нелсныя пятва.

Ноги бурыл, бедра по середшн各 широго затемненћ.

§. Седьмої сегментъ сшььо выпуклыі, б́одовыя лопастп его почти горпзонтальвыя, вн条шніе грая ихт запругленние. гъ вершино съ угтоватої выр 


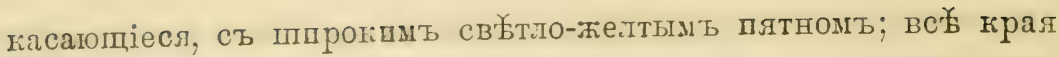
зазубренные.

‥ Задній край пятаго брюшваго сегмента прямой, средняя линія әтого сегмента по длпне равна боковымъ краямъ его.

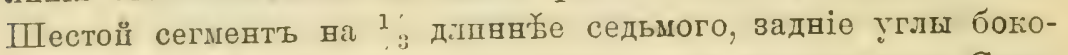
выхъ лопастеї заходятъ за вершину седьмого сегмента. Седьмой сегментъ втвое длиннеке восьмого, боғовыя попастц его горпзонтальныл, вершинный пі внутревніі грая заћругленвые, пзвутрц широко разставленные съ большпмъ свътло-желтымъ

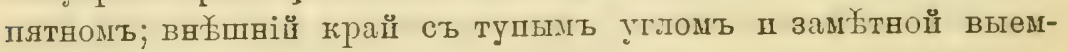
кої; всъ края зазубренные.

ઈ. Дллина 6,6 малл., пприна 3,4 милл.

‥ Дллина $7,5-8$ мплл., пиршва 4 мшлл.

Сравнительныя замьтки. Вщцъ этоть очень блпзокъ кт A. virsicolor H. S.; отличается оть него одноцьбтнымп усшкамд. боковымш ғраямш щитка сплошь червымц, цв бтомь брюшна, которое сверху Іл снизу буровато-черное, только вершпнные углы сегмевтовъ ; елтоватые.

Географическое распространеніе. Aratus diversicornis Horv. водитсл въ Закавказь': въ л宅сної областп Талыша (Тенкорань,

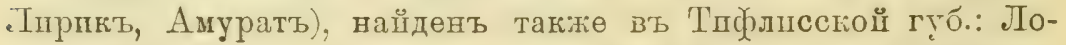
мпсъ-Мта близъ Боржома (25. IX. 1910 Ћенпгъ). По пвсьменному сообщенію проф. О. М. Reстег'а въ Гельсингфорскомъ Мүзе этоть впдь есть шзь Асхабада (эожеть быть Астрабада?).

\section{Aradus spinicollis JAK. 1880.}

(Табл. I, фориг. 9).

Aradus spinicollis JAк. Bull. Soc. Nat. Mosc., 1880, 1, p. 166.

фауниспческая лптература, касающаяся Россіп.

Aradus spinicollis JAK. Ioc. cit., p. 166 (Vladivostok).

Экземпяяры Зоологическаго Музея.

Raddevka in fl. Amur (ठ).

Vladirostok. (2우).

Дiarн03ъ. Corpus late-orale; lateribus fere parallelis (ठ己) vel retrorsm fortiter dilatatis o, griseo-fuscum, maculis ad angulos anticos pronoti parteque dilatata corii sordide albidis. 
Caputlongitudini suae aequilatum; prolongatione antica brevi, crassa, apice truncata; lobis lateralibus crassis, longis, acutis, fortissime divergentibus, margine exteriore muticis; tuberculis anteocularibus distinctis, acuminatis; lobis temporalibus obtusis, retrorsum prominentibus; caput pone oculos parti anteoculari fere aequilatum.

Antennae breves, crassae, nigricantes; articulo primo fusco, brerissimo, latitudine sua vix longiore; articulo secundo quam articulus tertius parum breviore, basi quam apice nonnihil tenuiore, articulo tertio omnibus crassiore et longiore, articulo quarto tertio in $1 / 4$ breviore.

Rostrum medium prosterni attingens.

Pronotum longitudine sua magis quam duplo latius; margine posteriore subrecto; marginibus lateralibus reflexis, dentatis, angulato-ampliatis, apicem et basin versus valde convergentibus, antice sinuatis; anguli antici haud prominentes, pone oculos dente spiniformi, magno instructi; carinis subparallelis, intermediis antice approximatis.

Scutellum elongato-triangulare, apice acuminatum, marginibus elevatis; superficie basi convexa.

Hemelytra basi late dilatata; membrana fusca. Connexivum medio segmentorum punctis duobus seriatim positis ornatum; angulis apicalibus segmentorum valde prominentibus, lateribus segmentorum quinti (ठ) vel quinti et sexti medio denticulo armatis.

§. Segmentum quintum ventrale sexto aequilongum, lobi laterales segmenti sexti posteriores iis approximati, lobi laterales longi et lati, marginibus interioribus fortiter distantibus, leviter rotundatis, marginibus posticis basi denticulo valido, obtuso instructis, dein subrectis.

ㅇ. Segmentum quintum margine apicali subrecto, longitudine lateribus segmentoque sexto longiore; segmentum sextum segmento septimo in $1 / 4$ longiore; lobis lateralibus segmenti sexti fortiter transiersis, apice apicem segmenti octavi attingentibus; segmentum septimum sequente duplo longius, lobis lateralibus marginibus interioribus rotundatis, posticis basi dente valido, acuto armatis.

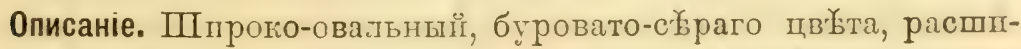
ренная часть надхрылін п нешшрокая полоса у пейнхь угловъ переднеспнки св белыя, бълыя. 
Голова одшнаково развптая какъ въ дливу, таћъ Il въ шприну высты сь глазамп. Перетиї отростокъ ея толстый п короткій, своей вершиноі заходпть едва за самов основаніе второго членшка усшковь, шприна его одпнакова на всемь протяліеніш; боковые отростпш, достигапшіе почти верпшны перваго члевика успковъ, сально развптые, вь вершпнной своей половинб очевт, острые, пзогнутые и направленные гіъ внъ, на пвешнемъ краго своемъ безъ зубца пли бугоріа; предглазнпчные зубцы большіе, направленные вверхъ и къ вв占; впсочные отростш разипты, тупые, такь qто голова позадп глазъ такой же ширины, какь п передъ нимп; на поверхности головы подковообразное углубленіе, задняя часть лотораго не достигаетъ основанія головы.

Ј сшкп коротгіе, толстые, чернаго цв Һта, шхъ первый членпгъ горотко-овальвыц, въ четыре раза короче второго, желто-бураго цвъта; второй членпкъ незначщтельно, но явствевно съушивающійся иь основанію, едва короче третьлго; третій членикъ самый длшнныц п толстый четвертый на 1 короче третьлго съ бъліг вершиной, тоньше второго члениға у его основаніл.

Хоботокъ достагаеть середшны переднегруді.

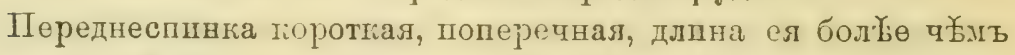
вт два раза короче ширшвы, задніі гіраї ел съ очень незначптельної п пологой выемғой; сшльно загнутые боковыо грая образують уголь съ загругленної вершпной, вершпнная сторона потораго съ глуболой выеміоц̆, на всемъ протяленіп вооружкеные отстоящимш тругь оть труга зубцамп, изъ которыхъ

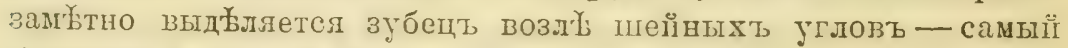

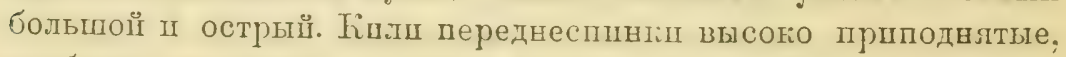
особенно къ задней половиноһ перегнесппик, бугорчатые, средшнные на задней половшн ставленные, qર્屯мъ на переднеї половпн店.

ЦИтцљ треугольвый съ внсого прпподнятымп боловымш гралми; поверхнисть его въ основной трети снабжена поперепнымъ подвятіемъ.

Надгрылья буровато-сђрыя, съ бұлымъ пятномъ у спльно

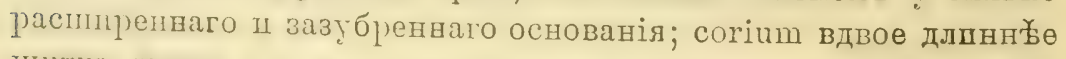
щитан, жилю его желтовато-бурыя, пространство между нимп

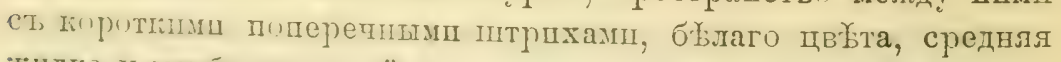

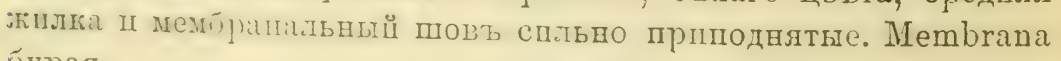
оуррая. 
Боковые края бргоныхь сегментовъ мелко зазубренные,

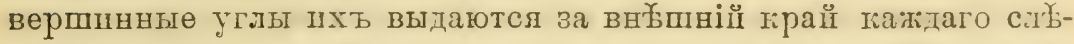
дующаго сегмента; по серединя; шестого сегмента (す) плш пя-

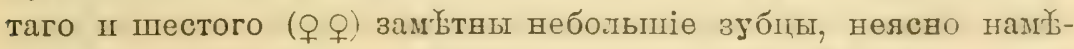
чагщіся II на предыдущпхь сегментахъ. По бокамъ канддагі сегмента по дв尔 чөрныхъ точки п большому углубленію, заншмающихъ почти всю площадь connexiтum'a, на внутреннемьзаднемъ углу котораго находптся на каждом сегменть по богорку.

Ногп бурыл, съ свйтлыми кольдамш на бедрахъ ш голенлхъ.

§. Седьмой бргонной сегменть выпуглый, боковыя лопастп его загнуты вверхъ, внъпнії храй шхъ у освовавія с'ь большимъ угломъ, образованнымъ выръзкої заднеї части этого грая, внутренніе края слегка загругленные, отъ самаго основанія

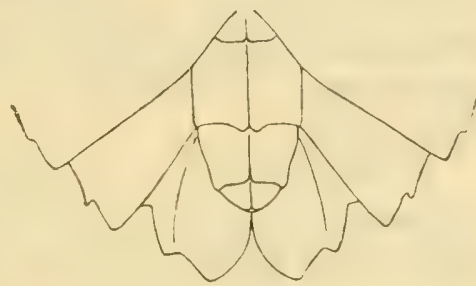

Pric. 21. - Стерниты бріогіа VI-VIII.

Aralus spicotis JAк. $q$ (пз B. BiIIIвостогіа). широко расходящіеся.

ㅇ. Серединвая линія шестого брюпного сегмента длиннҰе боковыхъ его праевъ, длиннъе пятаго сегмента п равна седь-

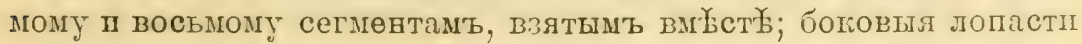
его доходять до вершины восьмого сегмента, боковой край пхъ по середпн尔 съ небольшия зรбцомъ, вериинные угіы пріостренные, отстоящіе оть попастей седьмого сегмента; седьмй сегменть на ${ }_{/ 3}^{1 / 2}$ короче шестого, боковые его лопасти съ вноңпншмп граями прямымп, вооруленвые иольшшм зуйцомъ, внутренвіе края - огругленные, у самаго основанія сопрпкасащіеся, далие спльно расходящіеся, поверхность основной половины лопастей ш вздутые боловые грая пхъ выпуклые, густо

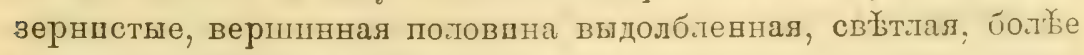
гладкал съ р’дкпмп зервышкамп.

§. Длпна - 5,4 мплл., ширина у основанія надкрылій 2,6 милл.

ㅇ. Длина 6,8 мплл., ппршна брюшка - 3,8 мплл.

Сравнительныя замьтки. Відъ этоть по строенію успіквь; ! ғоторыхъ второї пленигь короче третьяго прамыгеть тольіо 
гъ двумъ предшествуюшим (A. versicolor H. S., A. diversicornis

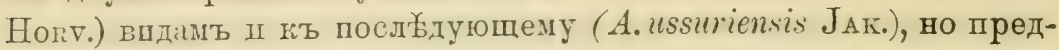
ставляеть совершенно особнякомъ стоящій вшдъ, легко отличнмый по строеніг б́оковыхъ краевъ сегментовъ connexivum'a, Iо середшнб которыхъ находятся зубццы, увелпчпвающіеся въ

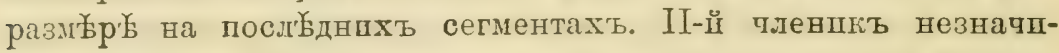
тельно гороче III-го, боковые отростки головы длпнные, острые, сильно расходящіеся, боговые крал переднеспини спльно зубтатые, расширенные ввшд прямого угла съ огругленной вершпной, надтірылл у основанія распиренныл ва большомъ про-

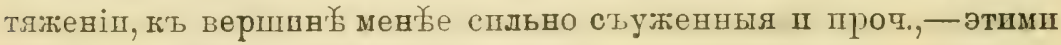
признагами A. spinicollis $J_{\text {Aк. }}$ тегко отличается отъ первыхъ ДВуХт ВІдовъ.

A. uss.ruiensis $\mathrm{J}_{\mathrm{A}}, \mathrm{у}$ котораго также второй членпкъ успковъ незнатптельно короче IlI-го р хзко отличается прпзнаками указаннымп нижө при этомъ посдъднемъ видљ.

Географическое распространеніе. Aractus spinicollis $\mathrm{J}_{\mathrm{AK}}$. пзв стенъ пока только пзъ Южно-У ссурійскаго края (Владивостогъ).

\section{Aradus ussuriensis $\mathrm{J}_{\mathrm{AK}} .18 \mathrm{i} 6$.}

(Таб.і. I, (бпг. 5).

Aradus ussurensis JAK. Bull. Soc. Nat. Mosc., 1876, 3, p. 113.

Фаупиститеская лптература, касающаяся Россіп.

Aradus ussurensis JAK. loc. cit., p. 113 (Ussuri).

\section{Энземпляры Зоологическаго Музея.}

Ussuri (†. f). DrBowskr.

Vladivostok (2q).

Vladivostok (q). Malkina-Panixa.

Korea sept.: T'shan-pen (ㅇ). 10. VI. 1897. Vน. Kousnor.

Діагнозъ. Corpus ovale, fusco-castaneum, marginibus lateralilus pronoti antice ad angulos anticos, corio hemelytrorum, maculis fuscis exceptis, antennis, pedibus maculisque obsoletis in angulis apicalibus connexivi nec non maculis magnis in marginibus interioribus luborum segmenti rentralis septimi sordide albido-flavescentibus.

Caput longitulini suae aequilatum, prolongatione antica sat loncra. crassa, lobis lateralibus longis. haud crassis, apice acu- 
minatis, albidis, margine exteriore denticulo distincto armatis; tuberculis anteocularibus magnis; Jobis temporalibus obtusis, latis, prominentibus; caput pone oculos parti anteoculari aequilatum.

Antennae longae et sat tenues, flavescentes, apice articuli secundi, basi et apice articuli tertii nec non ariculo quarto toto fusco-nigricantibus; articulo primo latitudine sua fere duplo longiore, margine exteriore et interiore fusco notatis, articulo secundo basi et apice quam medio nonnilil crassiore, longitudine quam articulus tertius in $1 / 4$ breviore, articulo tertio apicem summum versus incrassato, longitudine quam articulus quartus in $1 / 4$ longiore.

Rostrum longum et gracile, modium mesosterni attingens, urticulo primo basin capitis attingente.

Pronotum latum, magis quam duplo longitudine sua latius; margine posteriore late, sat profunde sinuato, marginibus lateralibus angulato-ampliatis, basin et apicom versus convergentibus, rectis, marginibus reflexis, vix crenulatis, fere solum undulatis; angulis anticis parum prominulis; carinis lateralibus subparallelis, intermediis antice approximatis, basin versus convergentibus.

Scutellum angustum, elongatum, apice acuminatum; marginibus valde elevatis, medio flavescentibus, apice nigris.

Hemelytra basi dilatata, latitudine quam pronotum angustiora; corio scutello sesqui longiore, flarescenti-albido, fusco-maculato; membrana fuscesconti, fusco maculata; apud 오 saepe forma brachyptera reperitur: hemelytris medium semmenti tertii attingentibus; corio scutello paulo longiore, membrana rudimentaria, haud valvante.

Pedibus pallidis, femoribus tibiisque basi, apice, annulo lato medio fuscis, spatiis latis prope coxas albidis.

Описаніе. Продолговато-овальныц, желтовато-бураго цвъта.

Голова одинаково развштая, какъ въ длину, такъ и въ ппнрину (вмүст各 съ глазами); перөдній отростокь ея толетиї, по длпнर्के равный остальвої части головы; боковые отростки длинные, тонкіе, спльно заостренные, вершины ихь б́.̆ыоватыл, съ

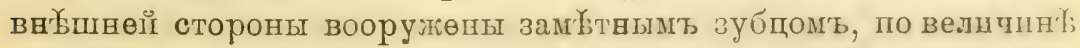
не уступающимь предглазншчнымъ; вщсопные отростки есть; 
на поперхиости головы погтовообразное углубленіе, доходящеө до основанія головы.

d'спки длиние и тонтіе, грязво-;нетоватые, полосы по бокамъ перваго членціа, вернпны второго пи третьяго, основаніе третьяго пі весг, четвертый буроватые; первый членикъ короткоовальный, на половпну пороче второго, толще обопхъ слйдующихь членпковъ; второй членпюь слабо утолщенный у основавіл п у верипиы, почті правильної цшлиндршческой формы, на I/t короче третьяло; третій членик сильво расширенный у своей вершины, на ${ }^{1} / 4$ длиннеге петвертаго.

Хоботокъ длшнный п тонкій, достшгающій середины средне-

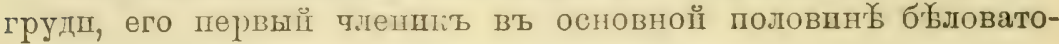
желтаго цв先та достигаеть основанія головы.

Переднеспнга шпрогал, попөречнал, ширшна ел болоํ⿻

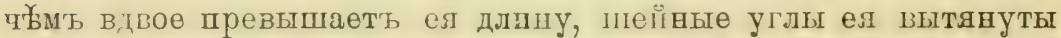
въ небольпіе, выдвинутые впередъ зубцы, переднії край почтп прямой, заднії ппрогіо п довольно глубоко выемчатый, боговыө края загнуты вверхъ п посередшв о्⿱宀 образуютъ прямої

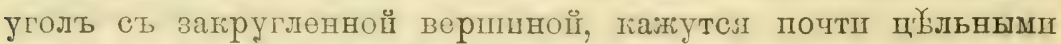
съ слабо замғтної волншстостью, объ стороны угла прямыя. Кили переднеспннки слаб́о приподнятые, параллельные (q), у

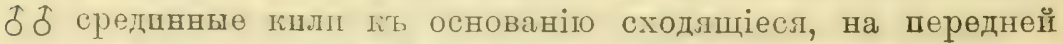

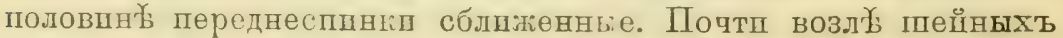
угловъ шежшть, большое желтое плтно, шцущее по боповому краю почти до вершины выдающагося болового крал переднеепингт.

Щитокт, узкій, треугольный, ст, прпподнлтыми боковымп

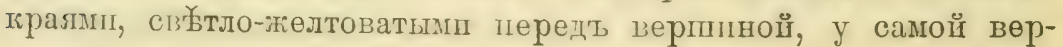

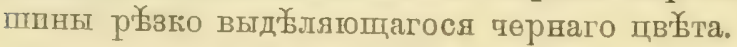

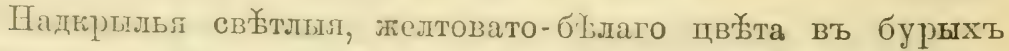

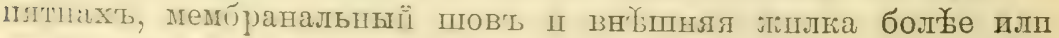
мепl:е тсмиыс, надірыльл у своего оспованія расширеныя, уже переднеспнки и б́рюшка, у обопхъ половъ достпгающія осно-

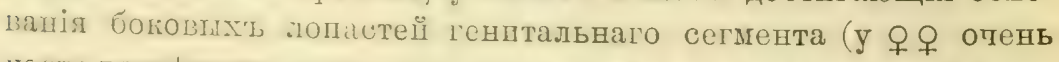

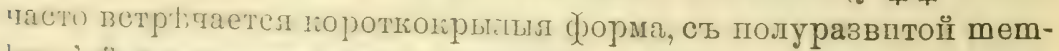

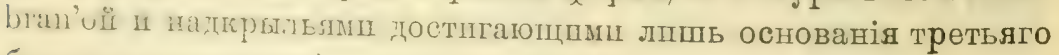
брюшного сегмента); membrana въ бурыхъ пятнахъ.

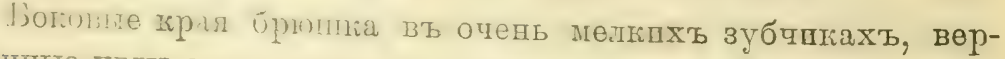
пинные углы слегка выдаются надъ слидующциљ. 


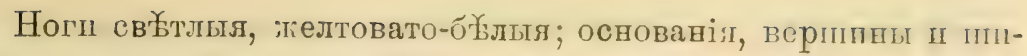
рокія, серөдинныя кольда бөдеръ и голеней бурыл.

§. Седьмої сегментъ выпуклый, боковыз лопасти өго сплино загнутыя вверхъ, въ б блыхъ пятнах по внутренғему пा заднему траю, задній и внутренній грал пхь закругленые, внутревніе оть основанія сразу, шпроко расходящісся.

‥ Срединная линія шестого брюшного сегмента равна дливй седьмого и восьмого сөгментовъ, взятыхъ вмо्ғстет; вершины боковыхъ лопастөй спускаются до уровня вершины восьмого сөгмента, седьмой сегменть вдвое длинн它е восьмого сегмента; восьмої сегментъ съ задвнмъ краемъ правильно округленнымъ, окацмленнымъ желтовато-б官лымь ободкомъ. Боковыя лопасти седь-

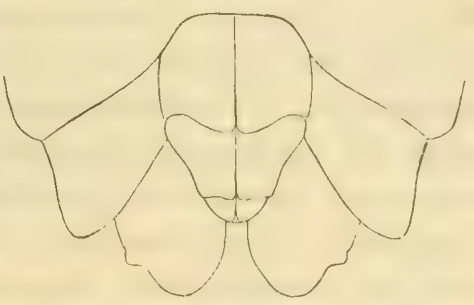

Pнс. 22.- - Стерниты бртониа VI-VIII.

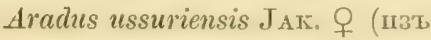
Владпвостога). мого сегмента длинныя, внбшніі край ихъ съ больпимь, яснымт зубцомъ, позади котораго лежпть выемка, внутренніе края ишроко разставлевы, закругленные съ большимт пятномъ бъ:лвато желтаго цвёта.

Ђ. Длива-7 мплл., пирпна брюпка-3,2 милл.

ㅇ. Длина-8 милл., шщрина брюшка-4 милл.

Сравнительныя замьтки. Aractus ussuriensis JAк, каксь пI три

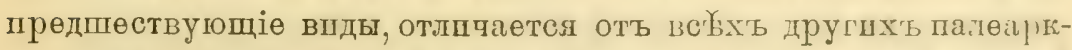
тическихь впдовъ рода вторымъ членшимь уенков', готорыі

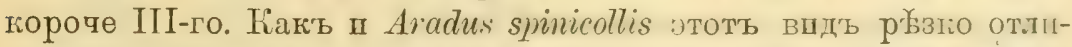
чается отъ двухъ первыхъ впдовъ съ одної стороны ц оть выше названнаго вида съ другой стороны.

Отъ всебхх этихъ видовъ $A$. ussuriensis отлпчается: длин-

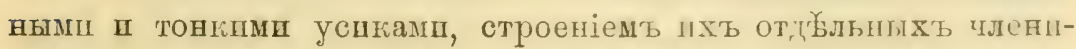
говъ, переднеспнкой, боковие тірая доторой прямоугольно расширенные, но слабо зазуб́ренные, безъ глубокой выемки

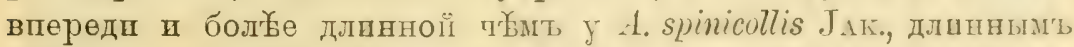
хоботкомъ, достигающия середивы среднегрудш, криловымь диморфицмомъ 웅.

Группа вддовъ съ коротпшм втоцим членшкомь усптовъ,

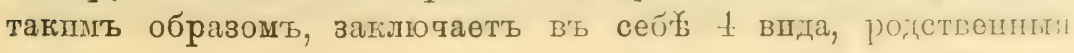




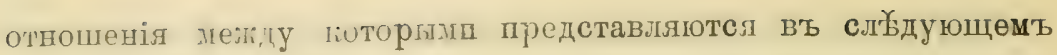
Вшд्मेक्ष:

$$
\left\{\begin{array}{l}
\text { A. versicolor H. S. } \\
\text { A. diversicornis Honv. } \\
\text { A. spinicollis J J } . \\
\text { A. ussuricnsis } \mathrm{J}_{\mathrm{AK}} .
\end{array}\right.
$$

т. ө. группа пзъ 3-хь первыхъ впдовъ довольно естественна и

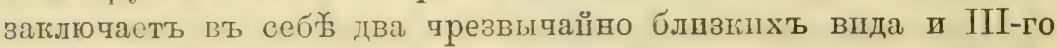
значптельно уклонпвшагося, но сохранпвшаго еще видшууо свлзь съ 2-мл предыдущим. Посльдніи вшдъ повидимому соверпенно не пметь родственныхт отношеній ко всґмъ пре-

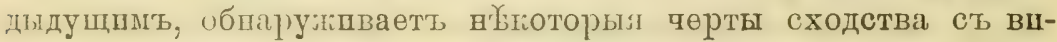
домљ $A$. crenatus SAy. Значевіе спстематпческп важнаго прпзнака, сúıщкающаго его съ этої группой - гороткаго второго qленпи усповь не можетьь быть вылснено ввпду полнаго отсутствія данныхь по до-пмагннальному развитію, не только

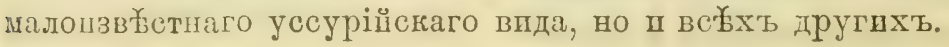

Географическое распространеніе. Lradus ussuriensis JАк. встрł-

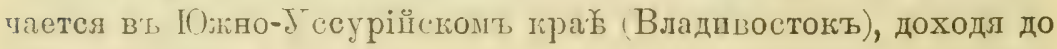
С年верной Кореп (Чанъ-пенъ).

5. A radus tauricus JAK. 1906.

('Табл. I, фог. 7).

Aradus tarricus JAK. Rev. russ. d'Ent., VI, 1906, p. 220.

Фаупетическая литература, гасацщаяся Россін,

Arcudus tauricus JAK loc. cit., p. 220 (Tauria: monasterium Kosmo-Damianovskij).

Экземплары Зоологическаго Музея.

'Thuria: monasterium Kosmo-Damianovslij in initio fl. Alma, distr. Jalta (Q. ). Kiritsinento.

Caucasus sept.-occ. forsitan districtus Sotshi (2 q). Sтагск.

Піагнозъ. Corpus latum, oloratum, brunneo-fuscum. Caput lonwitulini wac werulatmm, prolongatione antica brevi, crassa; lobis latchalibn: cras.iuscnlis, sat longis, apice acuminatis, recurvatis, mallgine caterione derticnlo di-tincto armatis; tuberculis ante- 
ocularibus obtusis; lobis temporalibus obtusis; capite pone oculos leviter et breviter angustato.

Antennae breves, crassissimae, fuscae; articulo secundo reliquis crassiore, quam articulus tertius in $1 / 4$ longiore, articulo tertio quarto in $1 / 4$ longiore.

Rostrum coxas anticas attingens.

Pronotum breve et angustum, quam caput brevius et quan hemelytra basi angustius, antrorsum angustatum; margine posteriore late et profunde sinuato, marginibus lateralibus obtuse rotundatis, basin versus vix, antrorsum fortiter angustatis, marginibus vix reflexis, minute denticulatis; carinis praesertim liturnlibus paullo obliteratis, subparallelis.

Scutellum elongato-triangulare, apice acuminatum, marginilus elevatis.

Hemelytra rudimentaria, apicem segmenti tertii paullo superantia, basi abdominis angustiora, marginibus lateralibus basi clilatatis, denticulatis; corio scutello paulo longiore, membrana haud valvante, pallida, fusco-striata.

Ventre superne obscuro, angulis apicalibus segmentorm fuscis.

ð. Ignotus.

․ Segmentum quintum ventrale sexto paullo brevius, margine apicali sinuato; segmentum sextum septimo in $1 / 3$ longius, lobis lateralibus apice obtuso-rotundatis, apicem segmenti oct:rí superantibus; lobis lateralibus segmenti septimi longis ot latis, marginibus interioribus dirergentibus, rectis, marginilus posterioribus rectis, medio dente magno, ulice rotundato, instructis.

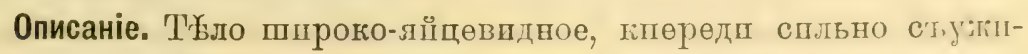
вающееся, төмно-бураго цв Ү̌та.

Голова одшнаково развитая, пакт, въ длину, такь иг гъ Ми-

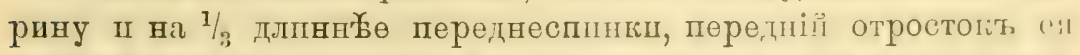
толстыї пг довольно короткій, заходить за вершину перьио тленика успковъ, боковые отростін толетье, направтените прлмо впөредъ, ковцы ихь заостренные и загнуты внутрь, на пияюпемъ краю шхъ довольно зничптельный зубецъ; передъ гла:ами

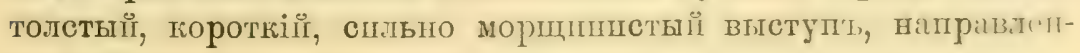
ный впередъ, височвые отростцц өсть.

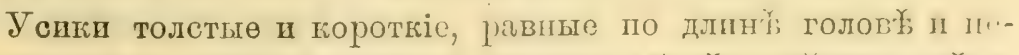

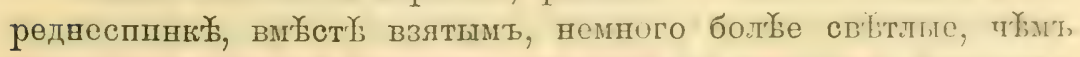

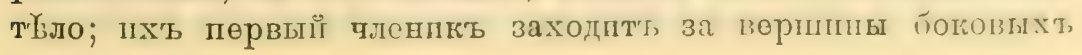


отростковт, па половнну евоей длины, второї членикъ у основанія пи всрпшиы одшнатіової толцшны, самый толстый, на 1/3 плинысе третьяго, треті члениг у основанія съуженъ въ очень короткую ножіу, вершина өго слегка толще его основаніл, на 1/4 длшнве те петвертаго членпка.

Хоботог'ъ доходитъ до ляшекъ пөрөднихъ ногъ.

Перегнеспинка кпереди съуливаюиалея, короткая, болье

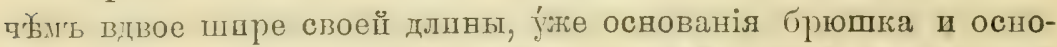
вапія надкриліпі, передній трай ея прммой, задній съ пирокой п глубоюоі выемкой, боковые прая впөрөдп прямые, въ вадней

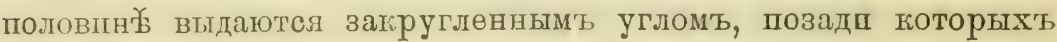
толіе прямые, туть сходящіссл; грая неправильно п слабо зубчатые.

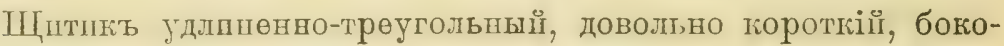
вые грая его приподнятые.

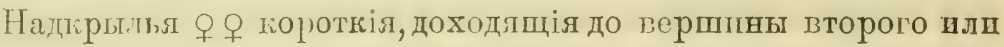
третьяг брюшного сегмента, у основапія расшпренные, слегіа вагнутыл, зубяатыл, согіum пезватптельно длпвнеге пцтпиа; meml,rana узкая, бураго цвйта, внутренпіе края правої и леквий половпны ея сопрпіасаюціеся, нө перетрещиваюпіеся.

Боковые края брюпяыхъ сегментовъ въ основныхъ углахъ черновато-бурые, задніе угы болье свұтлые, желтоватые.

Бедра ногь бурпґ, верпины пхт, вертлуги и голевп св бтлыя, желтоватыя.

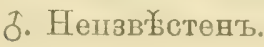

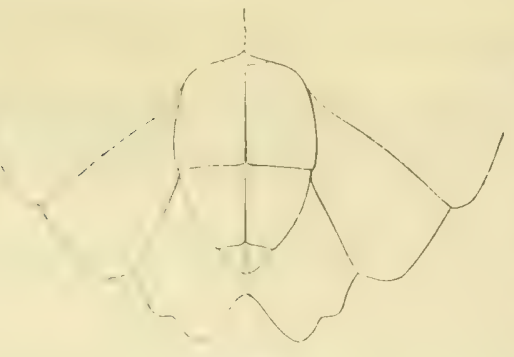

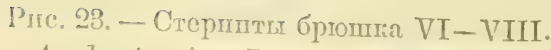
Aradus tanticus Jar. ㅇ. (пзт. Kртала).
ㅇ. Плтыц брюшної сегменть слегка короче шестого, задній край его выемчатый; пестой сегментъ на $1 / 3$ длпннеке седьмого, боговыя лопасти его на вершина্⿸厃㔾 тупоугольнозакругленныя, заходять за уровень вершины восьмого сөгмента; лопасти сөдьмого сегмента спльно развитыя в'б длину ІІ шприну, внутренвіе грая пхт расхолящеся, прямые, задніе - прямые, по

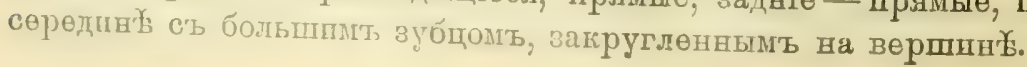


ㅇ. Длпна - 7,8 мплл., ширпна брюгка -4,2 мп.тл., шпрпна пөреднеспивкп -2,3 мплл.

Сравнительныя замьтки. Видъ этотъ пзвґстный только по

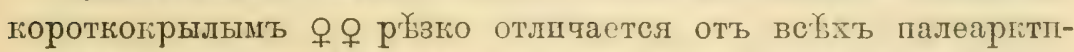

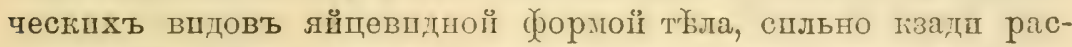
шпреннаго, надкрылгям, расппренная тасть которлхъ уже брюшка у основанія, короткої п узиої переднеспннио̆, готорая у́же надкрылій у ихъ основанія.

По форме головы, толстымъ, коротлшщь јсшкамъ, шпрокому техулу, видъ этотъ походптъ на вшды группы A. versicolor H. S., но рьзко оть нихъ отличается вышеуказанными признагами, вторымъ тлевипомь успковъ длпнн施 третьяго п проч.

Географическое распространеніе. Вшдъ әтоть пока шзв'Встенъ лпшь пзъ Тірыма (верховья р. Алмы въ Алтпнскомь утзды ш зап. побережья Кавказа (Сочинскій округъ).

\section{Aradus cinnamomeus PNz. 1794.}

Aradus cinnamomeus Panz. Faun. Germ., 100, 20. 1794. - Freb. Eur. Hem., p. 111. 1861. - Sign. Ann. Soc. Ent. Fr., p. 119. 1865. - Reut. Öfv. Kongl. Vet-Akad. Förh., 1872, № 5, p. 49; Entom. Tidskr., 1882, p. 76.Puт. Synops. Hémiptér.-Hét. de France, 1, p. 130. 1879. - REüт. Rev. Syn. Heter. palaearct., p. 232, № 190. 1888 (ed. sep.).

Aradus leptopterus Gerar. Faun. Eur., XVII, 8. 1834.-H. S. Wanz. Ins., 5 , p. 91, f. 539. 1839. - Foon Rhynch. Livl., 1, p. 894. 1861) - Sri:N. Anu. Soc. Ent. Fr., 1865, p. 120.

Aradus Perrisi Dur. Ann. Soc. Ent. Fr., 1815, p. 225, t. 3, f. IUI.

Aradus albopunctatus Schourz Arb. i. Veränd. Schles. Ges. f. Vaterl. Kult. 1816, p. 116.

\section{Фаушистиеская литература, касающаяея Россін.}

Aradus cinnumomeus SamLr. Medd. Soc. Faun. F'l. Fenn. Förlu, VII, 1881, 1. 40 (Fennia: Nurmis, gub. Olonetzkaja: Gorki in fl. Swir). - Medd. Soc. Faun. Fl. Fenn. Förh., XXX, p. 31 (Fennia: Mohla).

Aradus leptopterus Fror loc. cit., p. 394 (Livonia: Kremon, Srgewold, laens Stint, Haselau).

Aradus cimnamomeus J Ак. Bull. Soc. Nat. M[ose., 1875, 4, p. 2622 (gul]. Charkov: Tshuguev).

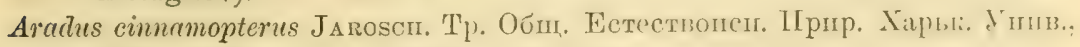
VIII, 1872, стр. 55 (Charkov, Kupjansk).

Aradus cinnamomeus $J_{A K}$. Hor. Soc. Ent. Ross., VI, p. 111, 1870 (gub. Simbirsk: Syzran, gub. Saratov: Chvalynsk). 
Aradus cinnamomeus Osir. Ver\% d. palaearkt. Hem., III, 1910, p. 130 (grub. Petersburg).

\section{Экземпляры Зоологическаго Музея.}

Germania (Q).

Gallia $(2 \sigma, 2$ o $)$. Putox.

Carniolia ( $($ ).

Gub. Ljublin, Gornaja Niva prope Novaja Alexandrija. 1s. III. $1211(\delta$, Q $)$ IL'insli IJ.

St. Petersburg $(12 \pi, 12$ 우).

St. Petersburg (2 $ð, 2$ ㅇ). Konnig.

Gub. St. Petersburg. 10. VI (). Bunchr.

Gub. St. Petersburg: Lelijazhja. distr. Peterugof. 2. VII (ㅇ). 3. VIII (ठ)). 19. VIII (2 万人). 28. VIII (2 q). 1897-1898. Вгахсні.

Gul). St. Petershurn: Serezhino. distr. Iamhur. 20 q), 24 (

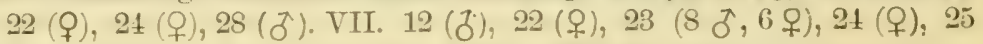

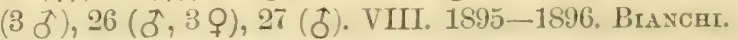

Gub. St. Petersburg: Gorjelovo, distr. Tzarskoe Selo. 8 (2 $\delta, 2$ Q), 11 (q),

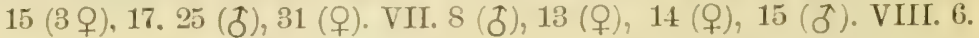
IX (3 J, q). 189S. Novotorzey.

Podolia: Kamenez-Podolskij. 25. II. 1911 (q). JАкuвоwsкт.

Transcaucasia: Borzhom. 12. V. $05(\delta, q)$.

Дiarн03ъ. Corpus parrum, ovale, retrorsum paulo dilatatum, cinnanomeum; caput latitudine sua paulo longius, prolongatione antica crassa, lata, longa: lobis lateralibus latis, brevibus, apice acutis, margine exteriore denticulo acutiusculo armatis; tuberculis anteocularibus destitutis: lobis temporalibus obtusissimis; capite pore oculos parte anteoculiri paulo angustiore, collum nullum formante.

Antennae crassiusculae, breves, capite vix longiores; articulo secundo tertio vix longiore, articulo tertio ovato, articulo quarto nigro-fusco, quam articulus tertius vix longiore.

Rostrum apicem mesosterni paulo superans.

Pronotum longitudine suil luplo et limidio longius, quam cilput lucvius, margine posteriore levissime sinuatum: marginibus lateralibus crenulatis, obtuse angculato-dilatatis; carinis obliteratis.

Scutellum ançustum, eloncratum (ろ) vel sat latum (o), marginibus lateralibus leviter elevatis.

Henclytra mox pone basin subito fortiter angustata, apicem versus iturum ampliata (ठ) vel liemelytra lata (q), saepe rudimentaria (q), quam scutellum paulo longiora, basin segmenti secundi attingentia, membrana nulla. 
Dorsum abdominis utrinque foveolis biseriatis nigricantibus instructum.

Описаніе. Овальвый, кзадш слегта пли спльно расшпряющіĭся (q, f. brachypt.), желтовато-коргчневый, пногда ғрасновато-горпчневыі.

Голова очень большая, длина ел слегка превыпаетъ пшрину и на $1 / 3$ короче переднеспинкп п пцтшка взлтыхт вмбстю́; передній отростокь ел массивнњї, очевь толетый, длинный, доходитъ до половпшы второго тленика успіовъ; боговые отростки довольно широкіе, довольно длинные, заостренные, на внеㅎшнемъ краю по середине съ сплыным зубцомъ; предглазвпчвыхъ бугорковь нҺть; вшсопные отростки тупые, короткіе, закругленные. Поверхвость головы ровная, мелко-зернистая, у основанія передняго отростка съ рґзкой, в'ь гцд冬 угла бороздкой, черноватаго цвЪта, подюовообразное углубленіе у основавія головы слабо вдавленное, за внутревним граемт глазь лежить глуболос, въ вшды гороткой дуги шли прямое,

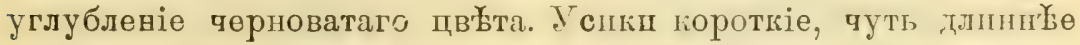
головы, толстые, коричневые, червортый членикт буровато-чернаго цв'ьта, первый членшкъ вдвое короче второго, второйдилпндрнческій, почтп одпнакової толпциы съ третьны и незначительно его длшнне, третій членщк - овальный, тетвертый тоньше третьяго п одинагової съ нимъ длины.

Хоботокъ доходить до основанія переднегруди.

Переднеспика попөретная, в' два ст, половнної раза пире своей длины, передній и заднії грая ея широко п во глубоно выемтатые, боковне трал тупоугольо-затругленные, такъ qто переднеспинка кпереди сплын, лзади слегка съужпвающался, слабо вазубренные; шойне углы слегка продвпнуты впередт, задніе закругленные; поверхностг, переднеспнип довольно ровная, ғилп нелвственные, слабо приподияте, ппереди совеҮмь пстезающі, средпнные почтп параллельвые, боковые къ основанію спльно расходящіөся.

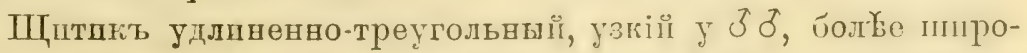

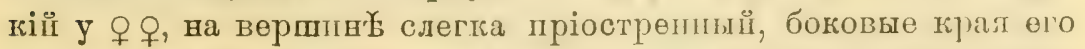
слегка прпдодвятые, поверхность, пцтика у основанія прпподнятая.

Надпрнлья у основаніл слегка расширенпыл, corium у пол-

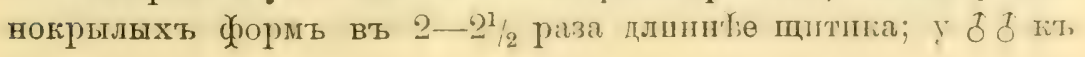




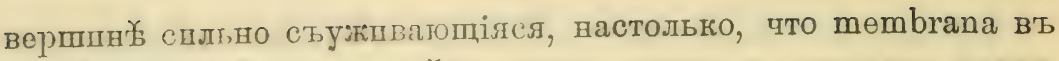
своей переднсй тастп пмејеть вшдъ узкаго ш длиннаго гілина, даль্九е надкрыльл у самої вершшны вновь расширяющіяся, доходящія до основанія седьмого сегмента; mеmbrana перноватая

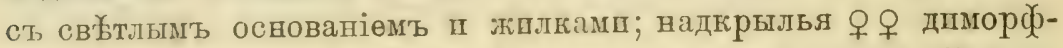
ныл: у полнокрылої бормы (f. macroptera) пљ верпинет нормально съужпванщіясл, доходящія до основанія пестого сөгмента, membrana пормальная, черноватая, основаніе ея п жплки болте евбълыя; у короткогрылой (ормы (f. brachyptera) надкрыльл доходятъ до основанія второго сегмента, верпина пхъ тупоугольно закругленная, membrana недоразвпта.

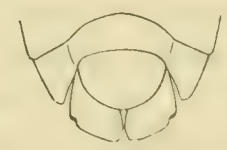

Рпс. 24- Стерпптт

брromica VI-VII.

Aradus cimmamomeus PANz.

ठ̄ (пзт, С.-Петербургскої губ.).

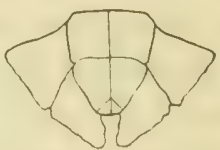

Pис. 25.- Стеритті

брromria VI-VIII.

Aradus cinnamomeus Panz.

우 (пзт Лгоблиской губ.).

Верппные углы сегментовъ сопnехітим'а съ мелкши бы-

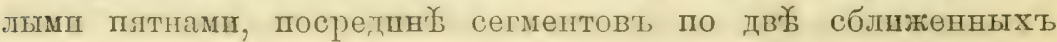
черныхъ пли трасныхт вдавленныхъ точки. Ногш желтоватокоричневыл или корпчневыя.

§. Длина $-3,5-3,8$ милл., шпрпна $-1,7$ милл.

․ Длина - 4,6 - мвлл., ппршна -2 мшлл. (f. macropt.), 2,4 милл. (f. brachypt.).

Сравнительныя замьтки. Впцъ этотт, легіо отлггчаетея оть

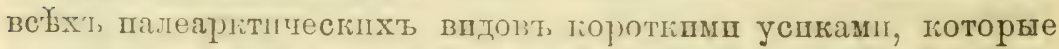

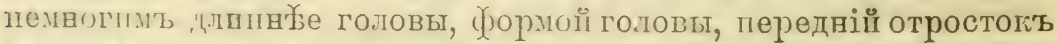

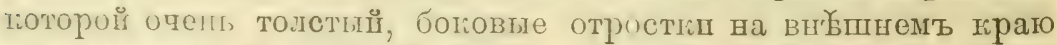
съ снльнымт зуи́домъ, такъ что отросткп кажутся двузубча-

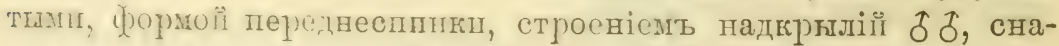

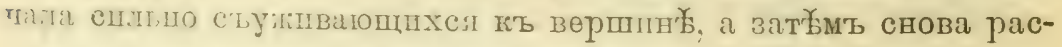
ширлющшея, п другшми признаками.

Гестрафичссие распространеніе. Витъ широко распространен-

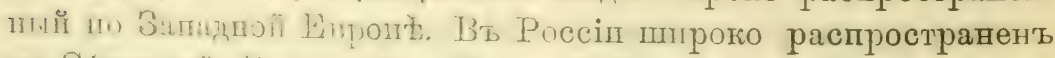

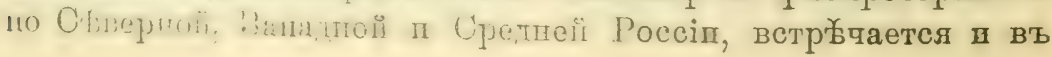




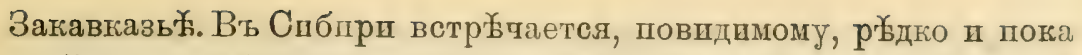

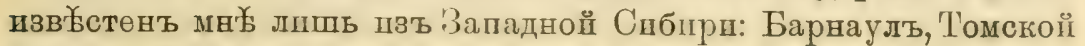
губ. (25. V. 04. Е. Г. Роддъ).

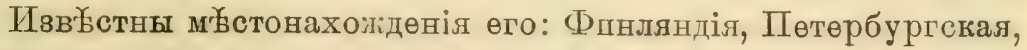
Олонецкая, Люблшнская, Ломжннская, Лшффляндская, Подольская, Харьковская, Спмбирская, Саратовская, 'Т'шерлисская, Томская губернін.

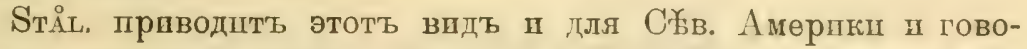
ратъ: "specimen unicum texallum a speciminibus europaeis distinguere nequeo".

Образъ жизни. Видъ этотт, главнымъ образомт, жшветъ на

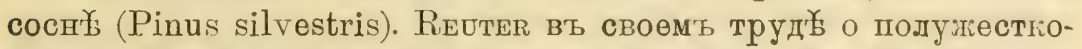
крылыхъ, свойственныхъ палеарктическимъ хвойнымъ деревьямъ, собралъ объ этомъ вшды слйдующія данныя.

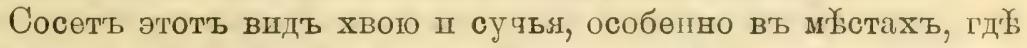
вытелаель смола, иногда большими колоніями, среди ліоторыхъ много личинокъ.

Въ Венгріи причпняетъ вредъ псклюдптельно сосновымъ л'ссамъ ІІ размножается въ ншхъ въ громадныхъ колпчествахъ. Pinus nigra иногда остается совершенно безъ хвоп оть вреда, причиненнаго сосаніемъ $A$. cinnamomeus.

Зпмуеть онъ подъ корої Pinus, Picea excelsa, Salix, Betula,

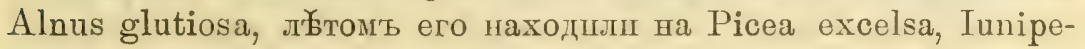
rus и даже на Salix.

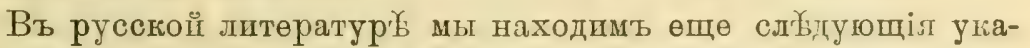
занія. Въ Россіи F'сог указываеть на нахожденіе въ Лшффляидіш его зимой на Picea excelsa; Лковлевъ находшль этоть видъ у корнеіі дөревьевъ на опушк' березовыхъ лґсовъ въ Саратовскої п Спмбирскої губ. Ярошевскй находпль много лџтнокь

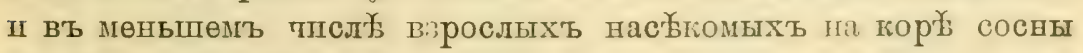

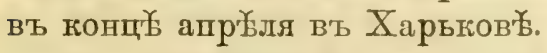

Въ Ломжнекой губ́. вредъ оть $A$. cimnamomeиs ощутителенъ въ віді⿱⺊口 усыханія вершінъ сосенъ, на готорыл нападаетъ этоть видъ въ большомь колцчеств', ютясь подь отстающим плоцадғами норы особенно верхней части ствола.

Въ С.-Петербургскої губ. по нао̆люденіямъ Ј. В. Бтанти Aradus cinnamomens дөржптея в'ь звачптельшомт числер особөї препмуцественно, хотя пе псключптольно, на отқұльно сгояпцхт, здоровыхъ соснахт средней толщшны (дюймовъ $3-5$ вт, 


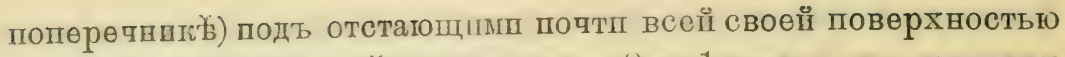
шластинкамп корп, пмғьюцими около $0,3-1,0$ мшлл. въ толщину II прплегающип своей ншжней стороной къ сочнымъ qастямъ

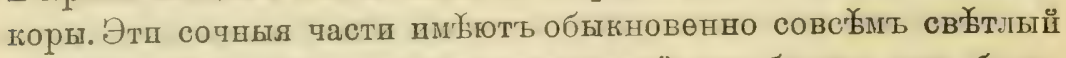

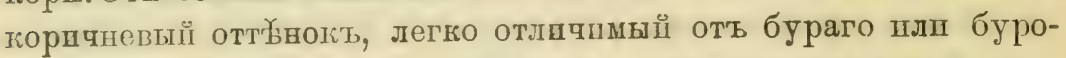
вато-Іірпчневаго оттебнка прпкрывающпх пластиногт.

\section{A radus depressus (Fabr.) 1794.}

Acanthia depressa Fabr. Ent. Syst., IV, p. 22. 1794. - WolfF Icon. Cim., IV, p. 129, taf. XIII, f. 123. 1804.

? Acanthia plana FABR. Ent. Syst., IV, p. 73. 1794.

? Acanthia alata Fabr. Ent. Syst., IV, p. 76. 1794.

Arcudus depressus Fans. Syst. Rhyng., p. 119. 1803.-H. S. Wanz. Ins., V, p. 93, f. 542. 1839.-R. F. Sarli. Mon. Geoc. Fenn, p. 144. 1818.-Kol. Meтет. entom., p. 23, sp. 227. 1857. - Flor Rhynch. Livl., 1, p. 391. 1860. FieB. Eur. Hem., p. 112. 1861. - Dougl. Sc. Br. Hem., p. 271, t. 9, f. 9. 1865. - Reut. Öfv. Kongl. Vet.Akad. Förh., 1872, № 5, p. 50. - SAUnd. Trans. Ent. Soc. Lond., 1875, p. 253. - Puт. Synops. Hém.-Hét. de Fr., 1, p. 130. 1879. - Reut. Ent. Tidskr., 1882, p. 76; Rev. Synon. Het. palaearct., p. 232, № 191. 1888 (ed. sep.). - SAUnd. Hem. Het. Br., p. 139, t. 13, f. 3.1892 .

\section{фаупистическая литература, касающцаяя Россін.}

Aradus depressus J. Saulis. Medd. Soc. Faun. Fl. fenn., VII, 1881, p. 40 (Fennia mer. usque Leppävirta $-62^{\circ} 40^{\prime}$, in sept. Savolaks). - R. F. S AнLв. Mon. Geoc. Fenn., p. 144, 1848 (Fennia: Yläne, Nyslott). - J. SAнLb. Notis. Sällsk. Faun. Fl. fenn. Förh., VI, 1868, p. 182 (gub. Olonetzkaja : Kivinebb). - JAK. Bull. Soc. Nat. Mosc. 1875, IV, p. 262 (St. Petersburg).-Flor Rhynch. Livlo, I, p. 391.1860 (gub. Livland, Kurland).Окц. Изв. Имп. Общ. Лтоб. Естествозн., Аитр. пा Геогр., VI, 1870, p. 24

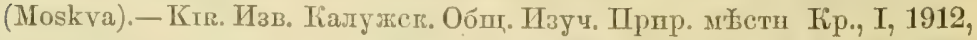
p. 71 (Kaluga). - РАтsсн. Зап. Кіевск。 Общ, Ест., X, 2, p. 417. 1889 (gub. Volyn, Podolia), - JAE. Hor. Soc. Ent. Ross., IV, 1866, p. 148 (Orenburg),-J JAK. Rev. russ. d'Ent., VII, 1907, p. 194 (Krim: T'avel).KoL. Mer. ent., 1856, p. 442 (Caucasus, Transcaucasia). - Horv. in Schneid. Naturwiss. Beitr. z. Kenntn. d. Kaukasusländ., p. 81. 1878 (Transcaucasia: Mamutly).-Horv, in Radde Nuseum Cauc., p. 464. 1899 (Transcaucasia: montes Meskenses). - J. SAHLB. Kongl. Svensk. Vet.$\Lambda$ kad. Handl., XVI, 4, 1879, p. 21 (gub. Tobolsk: Zelenkina in. fl. Irtysh.).

Эвземпари Зоологическаго Музея.

Gallia (O).

Vosges $(30)$.

Helvetia: Siviz. (ठ). Merrer-Dür.

Germania (Q). 
Germania: Finkenkrug bei Berlin (ठ). Buedorn.

Hercynia. SAxesen.

Hamburg (ठ). Koltze.

Rhinback. 18. V. 84 (q).

Hungaria sept.: Kékkö. 26. V III (ठ). Honvג'тн.

Fennia (ठ). Sahlierg.

Fennia: Blagov (ठ઼). Reutek.

Fennia: Nyslott (ㅇ). Oвеrт.

St.-Petersburg (ㅇ).

St.-Petersburg (Q). Koenia.

Gub, et distr. St. Petersburg (ठ). ILJIN.

Gub. St.-Petersburg. 5. VI (ㅇ). Bianch.

Gub. St.-Petersburg: Moskovskoje Shosse. V. 1861 (, 2 , 9 ). Mori.1witz.

Gub. St.-Petersburg: Lebjazbja. 19. V. 1898 (ठ). BranchI.

Gub. St.-Petersburg: Lebjazhja. 5. VI. 1898 (). Вілалснг.

Gub. St.-Petersburg: Lobanovo. 27. V. 1906 (Q). VLAsov.

Gub. St.-Petersburg: Ostrovki in fl. Neva. 14. VI. 1906 (Q)). G. JAconson.

Gub. St.-Petersburg: Ostrovki in fl. Neva. 21. IV. 1906 (). G. JAcobson.

Gub. St.-Petersburg: Ligovo. 9. VI. 1902 (q), G. JAcobson.

Gub. Moskva: Bablovo, distr. Klin. 25. IV. 1906 (3 ठ̋, Q +). Surnxov.

Gub. Moskva: Bablovo, distr. Klin. 28. IV. 1906 (). Smrnov.

Livonia (Q).

Kiev. 20. VIII. 1898 (3 $\delta$ ). G. JACoBson.

Gub. Charkov: Kurjazh. (ठ઼, ㅇ). J AroschevskiJ.

Tauria: Tavel, distr. Simferopol. 6. V. 07 (q). Christororov.

Caucasus occ. (3 5,2 ㅇ). Starck.

Gub. Eniseisk: Torgashino, prope Krasnojarsk. 27. V. 1897 ( J, q). 1. J 1 conson. Gub. Tomsk: Kolyvan. 18. V. 1907 (ठ). TARAsova.

Діагнозъ. Corpus breviter late-ovale; antennae, caput, pronotum, marginibus lateralibus antice exceptis, scutellum, maculis venisque in parte posteriore hemelytrorum fuscis; corium fuscomaculatum.

Caput longitudini suae aequilatum; prolongatione antica brevi, crassa, lobis lateralibus brcribus, crassis, apice acuminatis, margine exteriore muticis; tuberculis anteocularibus acutis, distinctis; lobis temporalibus obtusis, prominulis; capite pone oculos parti anteoculari fere aequilato, dein subito in collum brevissimum attenuato.

Antennae breves, crassae, fuscae; articulo secundo tertio paullo longiore, apicem versus levissime incrassato, tertio secundo crassiore et quam articulus quartus longiore.

Rostrum coxas anticas attingens.

Pronotum longitudine sua magis quam duplo latius, margine posteriore subrecto, marginibus lateralibus rotundatis, valde re- 
flexic, crenulatis, apicem rersus fortiter angustatis, profunde sinuatis, postice hasin versus rotundatis, fere hand convergentibus; angulis anticis antrorsum prominentibus; marginilus lateralibus antice latissime albido-limbatis, hyalinis, disco pronoti dimidio apicali deplanato, postice valde convexo; carinis elevatis, verrucosis, intermediis medio approximatis, retrorsum divergentibus, lateralibus subparallelis.

Scutellum elongato-triangulare, apice acuminatum; marginibus alte elevatis, stylato-verrucosis.

Hemelytra basi late et fortiter lilatata, reflexa, crenulata.

Connexivum marginibus lateralibus segmentorum rectis, infuscatis, angulis apicalibus leviter prominulis.

Pedes ferruginei, femoribus medio et apice fusco-annulatis, tibiis interdum medio et basi fuscescentibus.

Описаніе. Овальный, голова, переднеспинка п цитпюь черные.

Голова гороткая, широгая, одчвагово развітая, капъ в' длину, такь и въ шпрпгу; переднії отростогъ ел короткії, толстый; боговые отростки широгіе, тороттіе, на вершннй сильно заостренные, өдва расходящіесл, внбшпій грай шхъ не вооруженныи; предглазнцчный зубецъ спльяый, острый; вцсочные отросткі тупые, пирокіе.

Успн гороткіе, толстые, чернаго цвљта, пногда слегка буроватые, первы членић желтовато-бурый, второї пленикъ

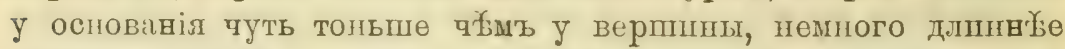
третьлго, третій, спдящій на тонкой ножк告, у оспованія очень

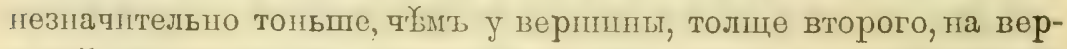

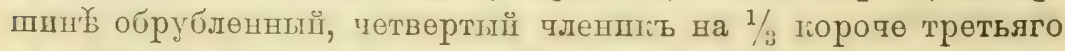

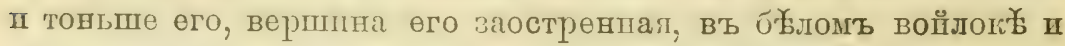
въ длинныхъ волоскахъ.

Хоботопь пороттій, өдва доходящіі до передншхь ляшегъ,

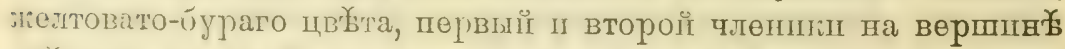

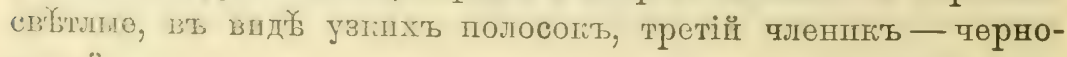
ватый.

Перодисепина гдвос шире своеї дтши, задній край ея

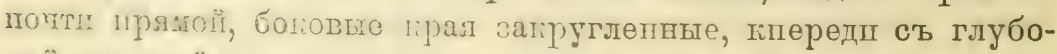

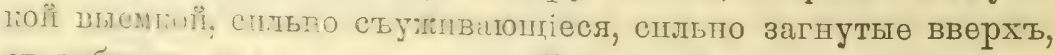

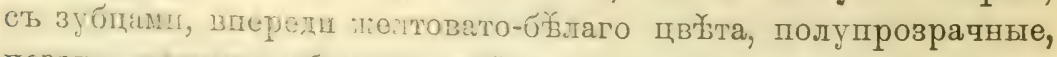

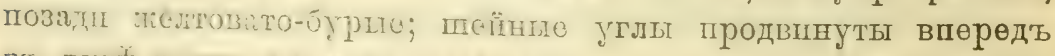

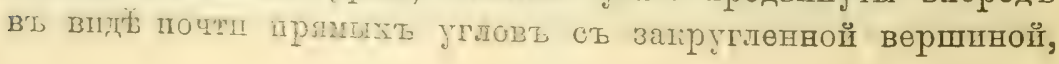


плечевые углы тупоугольно-закругленные; кили переднеспини желтовато-бурые, высоко-прпподиятые, бугорчато-морщинистые, боковые кили почти параллельные, средшнные по серединка сближөнные, къ основанію расходящіеся, пространство между кшлямп почтп все гладное, блестлщее. Переднеспннга немного

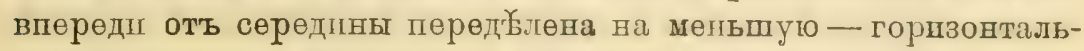
ную половпну п бо́льшую, спльно вышуклую половпгу.

Шптикъ удлиненныі, съ высоко-прцподнлтыми краями, на вершпнъ заостренныі, у основанія поперечно-шрпподнлтый, къ верпинег правпльно поперечно-морщинистые.

Надгрыльл бұлаго цвљтта, съ бурыми пятвамд у основанія II вершины corium'a II по вношнему краго его, жплкн у основанія и вершины corium'a бурыя; corium вдвое длшвноеое пцтпка, боловые края его спльно расширенные, так' что распцренная тасть надкрылії, равная по длпне щитику, пире переднеспнкі, спльно загнутые, зазубренные; membrina б́ълая, съ пятнами бураго пли чернаго цво्रта, плтна вөршинъ двухь гільтогъ, образованныхъ ㄹ, 3, 4 жплкамп, очень больпія.

Connexivum желтовато-бурый, ботовые крал его прлмпе,

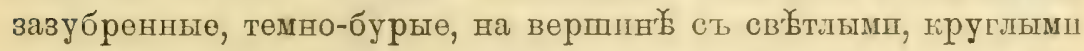
пятнамп; вөршпнные углы сегментовь чуть, выдающіесл, закруглөнныо. Снпзу голова, грудь, боковой край распшренной частп надкрылій у основанія п вершины его, боғовые грал connexivum'a, пскючая пятөн въ основныхъ углахь, генитальныө сегменты п бововыя лопасти седьмого и оттасти пестого сегмента - темно-бурые.

Пространства вокругъ ногъ, груглыя пятна въ оснониыь углахъ сегментовь connexivum'a, задніе края гөнптальыхъ сегментовъ, края генптальної щели 웅, большое пятно на боковыхъ лопастяхъ седьмого сегмента-былые; бргшко поричнөво - или красно-бурое, сь төмно-бурнмп цг свотлымп пятнами, особенно сосредоточеннымп по середшни․․

Ноги бурыя, бөдра п голени съ св бтлып Іольцамп у основанія пा вершины.

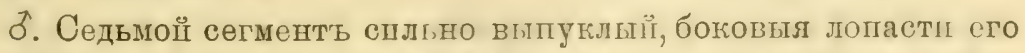

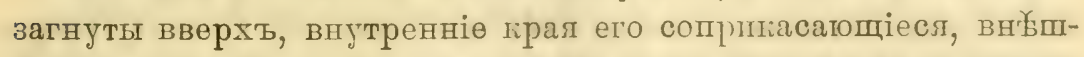
ніе чуть закругленные, залніе ғрал съ тупымъ, мало-выдагщшмся зубдомъ. Боковыя лопастц шестого сөгмента си́лпґөн亡 съь вноํпними краями лопастөй сөдьмого сөгмента. 
ㅇ. Пятыі брюшноі сегменть у основанія сильно вырқзанъ,

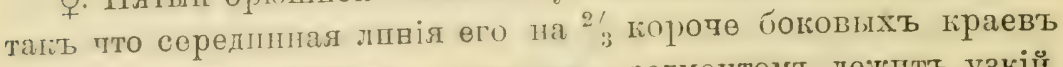
сегмепта; между пятимь и шестымь ссгментомь лөжпть узкій, округленной формы, гакъ бы қобашочный сегментъ; пөстой сөгмеать на половину длиннҮе седьмого, почти квадратной формы; седьмої сегменть ндвос дыннияе восьмого; боковыя

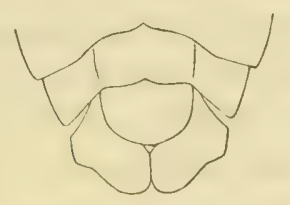

Pнс. 26.- Стеринты бргшка VI-VII. Aradus depressus (Fairr.) ঠे (изь Московской губ.).

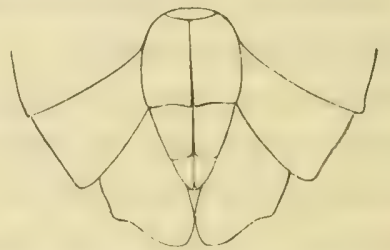

Pнс. 27. - Стерниты брюнка VI-VIII. Aradus depressus (FАвเ.) 우 (нзъ C.-Нетербургспой губ.).

лопастп шестого сегмента доходить на уровне заднихъ угловъ до вершаны восьмого сегмента; боковыя лопасти седьмого сегменті почтп одиналово развитылг въ длвну и ширшну, внутренніе грая ихт, запругтенные, незначительно отстолщіе другъ

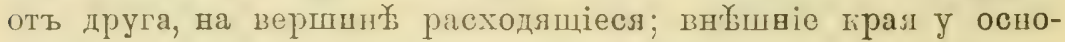
ваніл съ широкимъ, выступаюпшм угломъ.

§. Длина -5 милл., ппирпва - 2,2 мплл.

ㅇ. Длива -5,5-6,4 мплл., пшршна - 2,7 мплл.

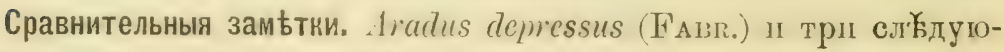
цихъ вида составляють раузгіо отерченную группу, харагтерпзугщуюся рлдомт, рђзкшхт прпзнаговъ. L.ропте для типа этої группы A. depressus предлагаль особый родь Piestosoma.

Сюда относятся вшды;
A. depressus (FABr.)
A. consentaneus Horv.
var. leptocerus Honv.
A. someheticus Krr.
A. dissimilis CosTA.

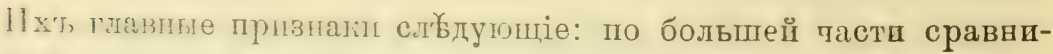
тепьн милів виды, голова позади глазъ сразу не съужшваю-

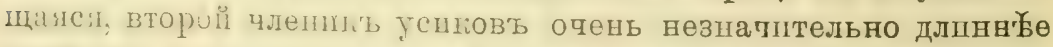

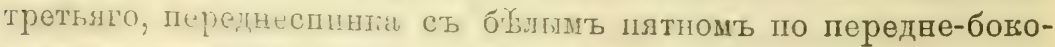

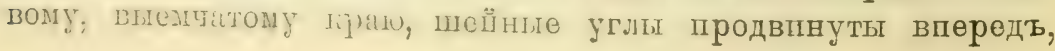


надкрылья у основанія сшльно распвренныл, ппре переднеспинкц, бъловатаго цвотта.

Оть всьхъ вшдовъ группы A. depressus (FAвг.) оглпчается

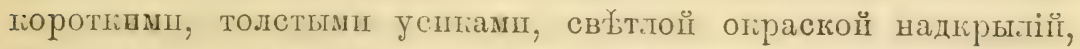
боковымш краямш connexivum'a прямыми, съ стабо выдающцмпся, не заостјеннымш вершинными угтам connexivum'a.

Географическое распространеніе. Видъ этотъ шпроко распространенъ по Зап. Европ年, ветр

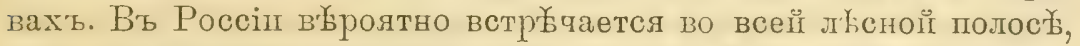

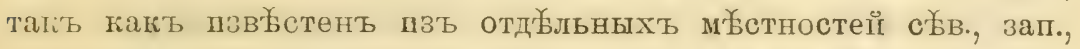

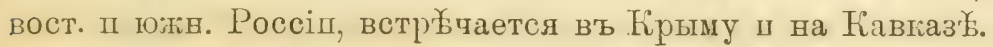

Вь Спбпрп рүдогь (повндимому) ш далего на востогт не пдеть, по крайней мърђ извъстенъ только изъ 'Тобольской,

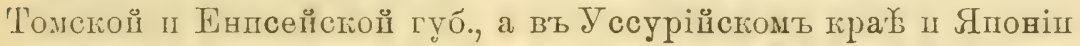
замбщенъ витарнымъ видомъ.

Образъ жизни. Встрбетаетсл, главнымъ образом'ь, подъ гіоpoî березъ (Betula), но указывался в для другихъ деревьевъ (Ulmus, Carpinus, Quercus).

Aradus depressus leptocerus Horv. 1881.

Aradus depréssus var. leptocerus Honv. Tèrmész. Füzet, V, p. 223. 1882.

\section{Фаупиетпеская литература, гасающаяея Россін.}

Aradus depressus var. leptocerus Horv. loc. cit., p. 223 (Lenkoran).

\section{Экземпляры Зоологическаго Музея.}

Persia sept.: Shachrud ():

Дiarн03ъ. Ut typus, sed corpore angustiore, antennis logioribus et gracillioribus, marginibus lateralibus pronoti ante medium fortius sinuatis.

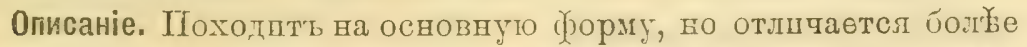

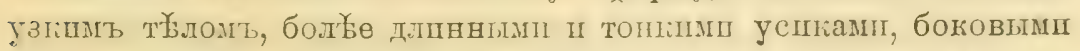
праями переднеспинтіи впередп болье сшльно выемтатыми.

Сравнительнып замьтии. Разнпвпдность әта, повндимому; :

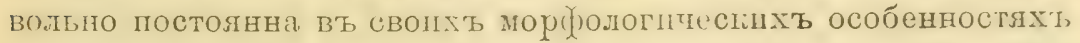
и лвляетел геогра()пчестой расой ю:наго побережья Каспіӥс-

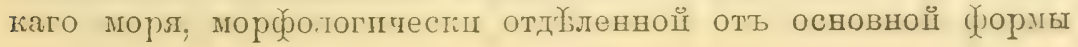

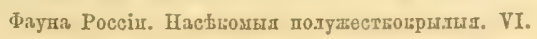




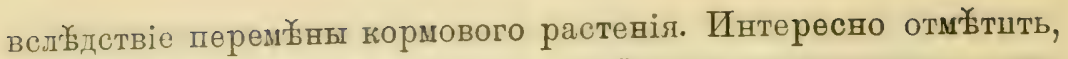
что морифологпчесгал особенность этой расы-знатптельно удлџненные п утонченние по сравненію съ основной форормой успк повторяется у другого вида A. consentaneus Horv., обптателя третичныхъ л冬совъ Уссурійскаго грая.

Географическое распространеніе. Геограбитеская раса эта свой-

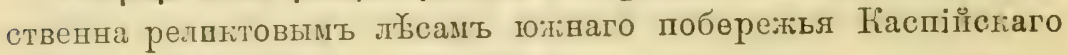
моря: на Талыше и въ СЪ̈. Персік.

0бразъ жизни. Встрбатается подъ торой бука (Fagus).

\section{Aradus dissimilis Costa. 1847 .}

Aradus dissimilis Costa Cimic. Cent., 2, p. 254, t. 3, f. 1. 1847. - Freb. Eur. Hemipt., p. 382. 1861.

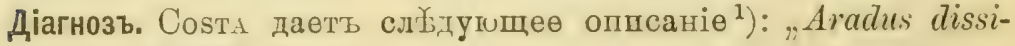
milis, nob. Taf. III. Fig. 1.

A. fusco-griseus, prothoracis angulis anticis elythrorumque basi extus dilatata albidis, membrana alba griseo-maculata; antennarum articulis primis tribus rufo-ferrugineis, supra pallido maculatis, quarto nigro, quinto cinereo, secundo tertio longiore; abdomine ferrugineo saltus nigro punctato; rostrum mesosterni medium attingens $\delta$ ㅇ.

Long. lin. $2-2^{1} / 4$, lat. lin. $5 / 6-1$.

A. depresso maxime affinis et primo intuitu similis; accurato tamen examine dignoscendus.

Statura constanter minor.

Antennarum articulus secundus tertio magis quam in illo longior, magisque conicus. Articuli tres primi fusco-rufescentes, secundus et tertius supra macula rotunda pallida, quartus niger, quintus cinereus.

Rostrum prosterni marginem posticum ultra producitur et mesosterni medium attingit.

Elytriu nervo maximo transverso marginem externum attin-

1) Видъ этоть отсутствуетт въ толтекціяхъ Зоологическаго Музея II оппсаніе его помгено въ очень рб̆домљ пзданіи, отсутствующемь

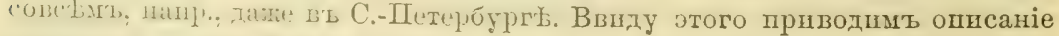
автора этого вида Costa (выпнсіа нзт соч. Costa любезно сообдена намъ

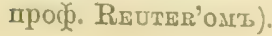


gente, membrana nervis externis milus flexuosis: qua diversa nervorum dispositio ut melius pateat, elytrum hujus speciei (Fig. cit B) atque A. depressi (Fig. 1 his) sinnus exhibuimus.

Abdomen fusco-ferrugineum, subchloroticum, supra segmentis basi fuscis; subtus serie triplici untrinque punctorum nigrorum, punctis seriei interna majoribus.

Pedes rufescentes (femoribus medio obscurioribus; tibiis basi apiceque annulo pallido.

In colle Camaldulensi, supra populorum cortices, vagantia pluria specimina legimus.

Variat: abdominis marginibus supra subtusque late virescentibus. Post mortem tamen saepius et color viridis evanescit, rarius distinctus remanet".

Описаніе. Буровато-съраго цвঝта, вершпнные углы передне-

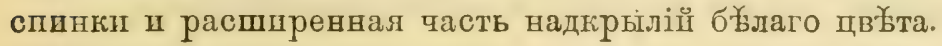

Усики красновато-рыжаго цв'ъта съ св Бәлымп пятнами на первыхъ трехъ членикахъ, четвертый членикъ черный; второй членикъ длиннбе третьяго.

Хоботокъ доходить до середины среднегрудш. По велшчния

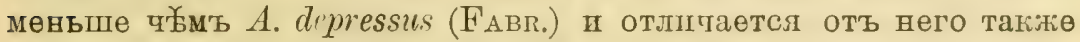
жнлками corium'a п membran'ы надпрылі亡, которыл пначө расположены, а также болье длиннымъ вторымъ членшкомь успковъ.

Сравнительныя замьтки. Reuter (Wien. Ent. Zeit., IV, 1885, p. 151) указываль на возможность пдентпчностп этого вшда съ Aradus depressus FABR. var. leptocerus Horv. $Я$ не впдйль әкземпляровъ A.dissimilis Costa, равно какъ рнсунковъ автора әтого вида.

Географическое распространеніе. Пзв бестенъ пізъ Италіг (Неаполь) п Румыніп (Sinaïa, Ranatapulni на Карпатахъ).

\section{A radus consentaneus Horv, 1905.}

Aradus consentaneus Horv. Ann. Mus. Nat. Hung, 8, 1905, p. 415.

Діагнозъ. Corpus breviter ovale. Caput, pronotum, scutellum fusco-nigra, hemelytra albido-testacea, basi et apicem versus fusco-variegata. 
Caput latitudine sua vix hrevius; prolongatione antica brevi, crassa, apice truncata, lobis lateralibus brevibus, crassis, apice acutis, albidis, margine exteriore muticis; tuberculis anteocularibus acutis, loljis temporalibus obtusis, prominentibus; capite pone oculos parti anteoculari aequilato, dein subito in collum brevissimum attenuato.

Antennae longae, crassiusculae, flavo-testaceae vel fuscae; articulo secundo tertio paullo longiore, basi quam apice leviter tenuiore, articulo tertio secundo $1 / 6$ breviore.

Rostrum coxas anticas attingens, pallicum, articuio primo nigro.

Pronotum longitudine sua duplo latius; margine postico vix sinuato; marginibus lateralibus angulato-rotundatis, reflexis, denticulatis; antice late sinuatis, late allido-limbatis, apicem versus fortiter, basin versus minus fortiter, angustatis; angulis apicalibus prominentibus; carinis intermediis medio approximatis.

Scutellum elongato-triangulare, apice acuminatum; marginilus valde elevatis, rectis; disco basi convexo.

Hemelytris basi late dilatatis; nembrana albida pone medium nigro-maculata.

Connexirum marginibus lateralihus sermentorum rectis, infuscatis, angulis apicalibus prominentibus, acutis.

J. Loli laterales segmenti ventralis septimi fusco-nigri, pone medium macula albida notati.

0писаніе. Овальный, голова, переднеспнка, щитигъ, боговыя лопасти седыного сегмента черние; боковые грая сегментовъ connexivum'a, бокової траї распиренної частц надкрылій, зад-

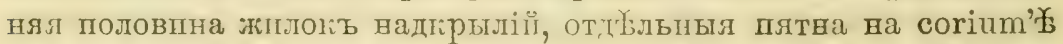

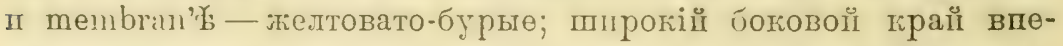
реди пөреднеспшкп, надірилья, пятво по середино̆ боковыхъ лопастеї седьмого сегмента боблые.

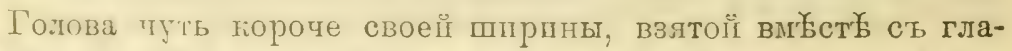
замп; нере,гніи отростокъ ея толстыц̆ пा довольно дллнный, бо-

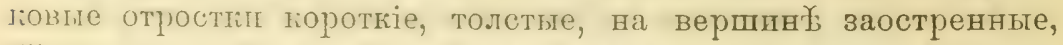

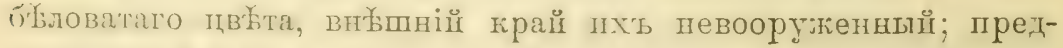

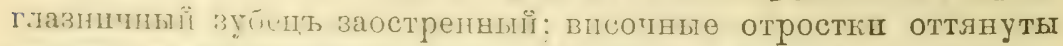

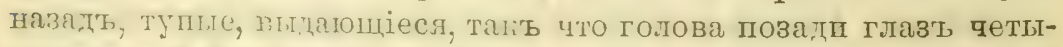

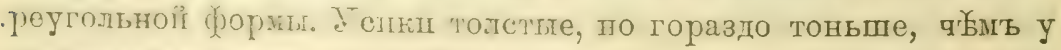

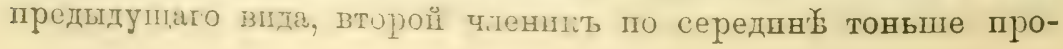


дольнаго діаметра глаза, повольно длинные, почти равные голов шины второго I третьяго члевпіовъ буроватыя, шхъ первыц тленикь короткій, овальный, второй пленшкь немного тоньше

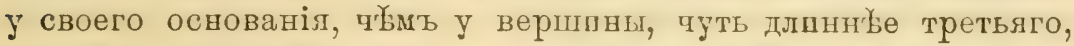
третії одиноковоі толщшны со вторымь, на 1/6 его короче, чет-

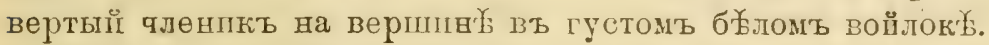

Хоботокь доходпт до ляшегъ передншхь ногт, св'тлый, первыц члөнпкъ өго чөрноватыц.

Пөреднеспинка вдвое пире своей длшы; задній краї ел съ легкої выемкої, боковые крал угловато-расширенные, загнутые, зубчатые, қпереди и кзади съужншающіеся, впереди съ значительноц̆ выемкої, шпроко окайлленної бұлымъ; передніө углы продвинуты впередъ, задніе тупые; средшнные кпл пршподнятые, по середшнб сблпкевные, боговые параллельные.

Щштићь удлиненно-треугольный, на вершине заостренныц; поверхность его у основанія прпподнлтая, боғовые грая высоко пршподнятые, прямые.

Надкрылья у основанія спльно расшшренныя, къ вершпне съуживатдіяся, расширенная часть надкрылій длинняе остальной части согінт'а, боговые края ел зазубренные, сшльн загну-

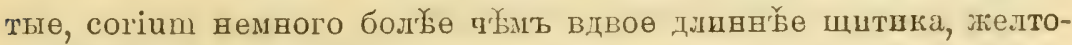
вато-бълаго двыта, съ буроватымі пятнами; membrana бъ.ловатал, съ бурымш пятнамп, особөнно крупнымш на вөрпшне․

Боковые края сөгментовъ connexivum'a оћаймлены по внйнему граю темно-бурымп полосамш; вершцнные углы выдающіеся, острые; опущенныө вншзъ.

Свизу червовато-бурыи, по бокамь брюшка желтовато-

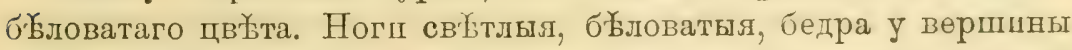

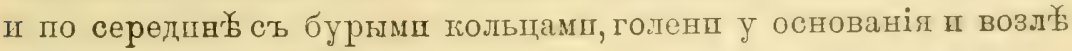
вершины буроватыя.

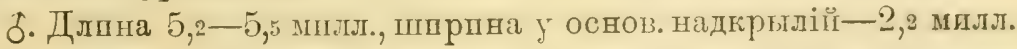

Сравнительныя замьтки. Отъ вотхт вщдовъ группы A. depressus (

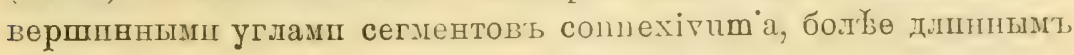
текломъ, тонкшми п длинными успкамш.

Географическое распространеніе. Видъ описант быль нзъ Мпоніп (Саппоро, на остров

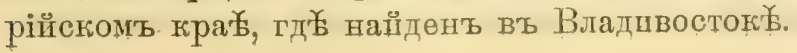




\section{Aradus somcheticus n. sp.}

\section{Экземпляры Зоологическаго Музея.}

Sine datis e coll. KuschaKevitsir (ठ).

дiarнозъ. Corpus late-ovale, fusco-nigrum, macula ovali prope angulos anticos pronoti, fascia latissima in medio corii nec non pedibus, annulis mediis femorum et tibiarum exceptis, sordide flavescenti-albidis, marginibus apicalibus segmentorum abdominalium maculisque loborum lateralium segmenti sexti, in medio sitis, flavo ferrugineis.

Caput longitudini suae aequilatum, prolongatione antica brevi, crassa, leviter compressa, lobis lateralilus brevibus, crassis, apice acuminatis, margine exteriore muticis; tuberculis anteocularibus obtusis; lobis temporalilus ol,tusis, pone eos caput subito in collum brevissimum angustatum.

Antennae sat breves, crassae, fusco-nigrae; articulo primo basi pallido, articulo secundo tertio parum longiore, basi quam apice levissime tenuiore, articulo tertio cylindrico, sat longo, articulo quarto tertio $1 / 3$ breviore.

Rostrum medium prosterni attingens.

Pronotum longitudini capitis aequilongum, longitudine sua duplo latius, margine postico latissime leviter sinuatum, marginibus lateralis crenulatis, valile reflexis, rotundatis, basin versus modice angustatis, antice sinuatis, apicem versus fortiter angustatis; angulis anticis parum prominulis, antice rotundatis; carinis subparallelis, intermediis medio approximat.

Scutellım elongato-triangulare, apice acuminatum, marginibus valde elevatis.

Hemelytris basi ralde dilatatis; parte dilatata margine laterali reflexo, crenulato, quan pronotum latiore, fere $\%$ corii occupante; basi et dimidio apicali corii basique clavi nigris; membrana nigra.

Comexirmm marginibus lateralibus sogmentorum rotundatis, angulis apicalibus rotundatis.

J. Segmentun sextum ventrale quinto paullo longius, linea media lateribu-que loborum aequilongis, lolis lateralibus segmentorum :exti atrque ultimi listantibus: lobi segmenti septimi marginibus interioribus ultra melium contiguis, dein distantibus, 
marginibus exterioribus subrectis, medio sinu levi et angulo obsoleto instructo, margine laterali recto.

Species $A$. depresso (FABr.) affinis, magnitudine majore, colore corporis obscuriore, angulis anticis pronoti antice magis rotundatis, marginibus lateralibus pronoti antice vix sinuatis, macula parva, haud vitta lata ornatis, membrana unicolore, fusco-nigra, connexivo nigro, marginibus apicalibus segmentorum late ochraceo-flavis, lateribus segmentorum rotundatis distinguenda.

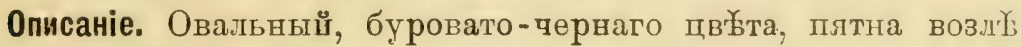
переднихъ угловъ переднеспинкп, надкрылья по середин危 пхъ расширенной частп, шцрогія полосы по вершннному краю сегментовъ connexivum'a - грязно буровато-желтыя.

Голова одинаково развитая въ длину п въ ширпну; перөдніи отростогъ ея толстый, довольно длинный, значштельно заходпть за вершину перваго члевпка успковъ, боковыө отросткш широкіе, короткіе, не спльно заостренные, расходящіеся, на вво̆шнемъ краю невооруженвые; предглазншчныі бугорогъ явственный, но тупой; вцсочные отросткц тупые, выдвинутые назад'ь, такъ ұто голова позадш глазь почтп такої же ширшны, какъ I впереди, у самаго основанія лишь съужпвающаяся в'ъ короткую шею. У сики довольно длинные, толстые, черные, только оспованіө перваго членика буроватое; второї членшкъ чуть боль্ье тонкій у основанія, ч各ъ у верпины, слегка дливв третьяго, третій дшлиндрическій, у основанія съуженныі въ коротгую

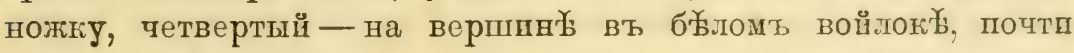
вдвое короче третьяго.

Хоботокъ доходитъ до середины переднегруди.

Переднеспинга вдвое шире своей длины, длпна ея равна голов'́; задній краї ел съ слабой выемкой, почтп прямой, боговые края закругленные, но ппереди спльно съужпваюціеся, съ легкой выемкой, кзади менбе съуживающіся, крал на всемъ протяженіп загнутые, мелко-зуб́чатые; поверхность переднеспинки въ задней половпног, сильно выпуглая, срединные кшл по сөрединегे сближенные.

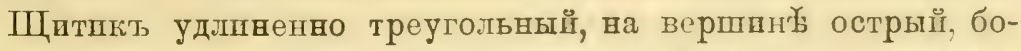
ковые края его сильно приподнятые; поверхность щитика у основанія ровная.

Надкрылья у основанія спльно расширенеыя, стегка зазубренныя, съ боковыми граями приподнятыми, расширенная 


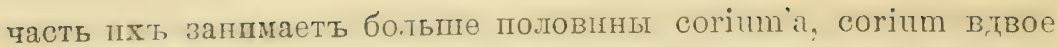

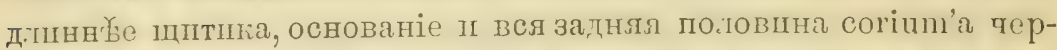

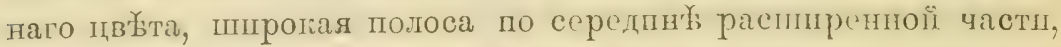

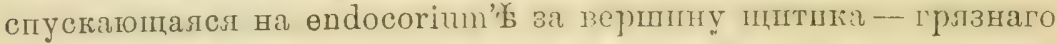

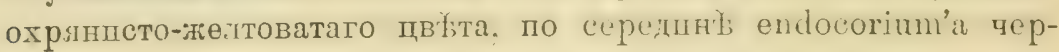
ныя пятва, membrana-буровато-черная, съ 4 простымш, не анастомозпрующимися жилкамш.

Connexivum чернаго цво̆та, по заднпм'ь краям'ь сегментовъ

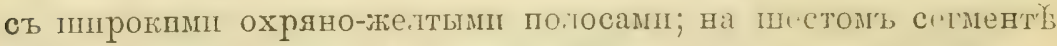
и по середннч боговыхь лопастей седьмого сегмнта - пятна

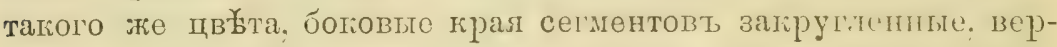
шинные углы мало выдающіеся, закругленные.

Снпзу буровато-терный. Нога жестоватыл, бедра ин голени съ широппмъ чернымъ кольцомъ по середин

§. Шестой бргшной сегмент, немного дишиче илтаго сег-

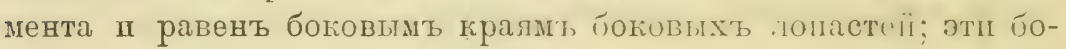
ковыя лопасти отстоять оть лопастеї сл'здующаго сегмента;

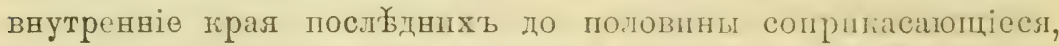

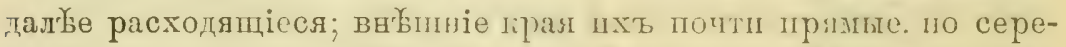

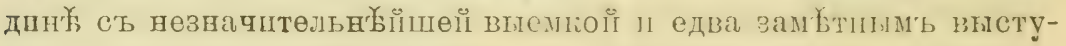
помь, боковой край прямо․․․

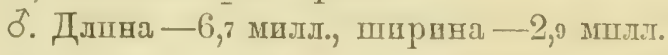

Сравнительныя замьтки. Вадъ этоть очень похогпть уа. 1. dejmessus (FAвr.), отличаетея оть него трупної величиной, болье темной ограспой всего тезла, черными усиками, шейными угіами

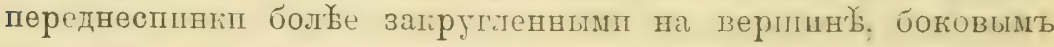
краемъ переднеспнкп впереги опень незначптельно вирłзанної, окайленнымъ не шшрогой полосой, ‘ небольшшмъ пат-

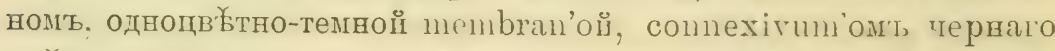

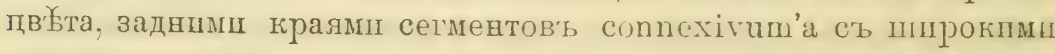
охрянно-ігелтым полосамш, закругіеннымп боговыми граями connexivum'a.

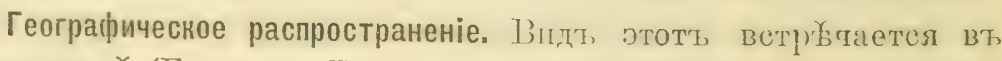
Закавказьъ (Боржомъ, Тибописск. губ.).

11. Aradus erosus FALL. 1807.

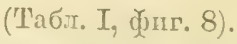

Aradus erosus Falt. Hem. Suec. Cim., p. 137. 1807-R. F: SAHLB. Mon.'Geoc. Fenn., p. 143. 1848. -FIĖ. Eur. Hem., p. 112. 1861.-REúr. Öfv. Kongl. 


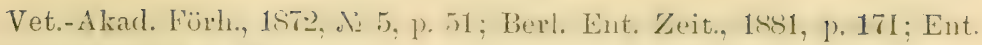

Tidskr., 1882, p. 76 .

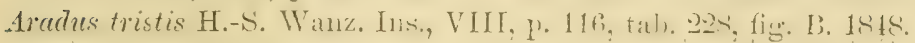

? Aradus armatus Kou. Melet. entom., p. 22, sp. 224. 1857. - Freis. Eur. Hem., p. 112. 1861.

\section{Фаунистеская литература, liacaroщаяся Россіп.}

Aradus erosus R. F. SAHLb. Mouogr. Geoc. Fenn., p. 143 (Eennia: Yläne)。

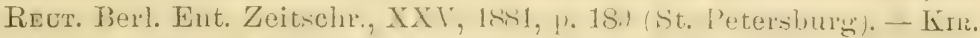

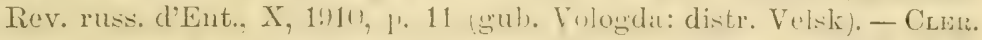
Зап. Уральсг. Общ. Јюоб. Естествозн, ХXV, 1905, стр. 1-6 (gub. Perm: distr. Ekaterinburg).

\section{Экземплары Зоологичеснаго Музея.}

St. Petersburg ( $\left.\sigma^{\pi}\right)$.

Gub. St.-Petersburg: Gatshina (). Soтzis r.

Jtyn-chaja, prov. Jakutsk. 26. VI. 1901 (ठ゚). Pfitzesarejer.

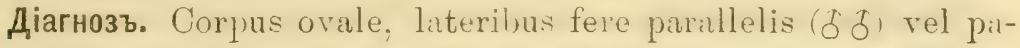
rum dilatatis, nigrricans, angulis apicalibus segmentorum abdominalium utriuque obsolete pallidis.

Caput longitudini suae aequilatum: prolongatione antica crassil, brevi; lobis lateralibus antrorsum vergentibus, lrevibus, latis, apice acutis, margine exteriore lenticulo minutis:imo praeditis; tuberculis anteocularibus deficientibus, capite ponc oculos parti anteoculari fere aequilato.

Antennae crassissimae, lreves, articulo secundo tertio palullo longiore, articulo tertio reliquis crassiore, quan articulus quartus fere duplo longiore.

Rostum basin prosterni attingens:

I'ronotum longitudine suil minus quam duplo latius, marginilus lateralibus apicen versus rat fortiter, lusin relsus levius angustatis, medio rotundato-dilatatis, dilareratu-erosis: angulis anticis sublentato-prominulis: mirrine posteriore profunle sinuato; carinis paulo elevatis, lateralibus retrorsum divorgentibus.

Scutellum elongatum, angustum, aprice acuminatum; marginibus paullo elevatis.

Hemelytris basi paullo dilatiti : pedibns piceis.

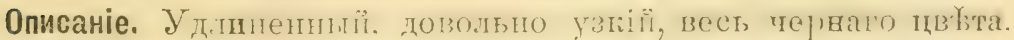

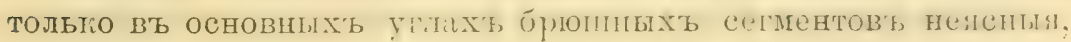
маленькія; бъловатыя пятна. 
Голова одинаково развітая, какъ в’ь дішну. такъ п въ шпрпну, передвій отростогъ ея спльно сжатый. короткій; боковые отростиц острые. съ вн备шней стороны прямые, вооруленные маленыниъ зубцомъ; предглазничиы зубецъ отсутствуетъ. височные отросткп очень тупые. очень мало выдающеся; поверхность головы очень гүубо зернисто-бугорчатая. Успкі чернаго

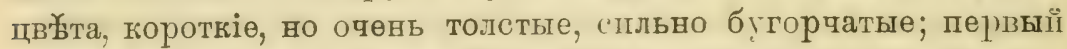
членикъ пхъ очень толстыи. въ $2^{1} / 2$ раза короче второго, второй членикъ незначптельно толще перваго. почти одпнакопої толщины у основанія п верппны, при основавін спдить на

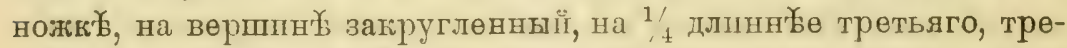
тій слегка утолщающійся гіъ вершшне, толще четвертаго, во у

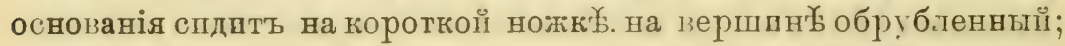

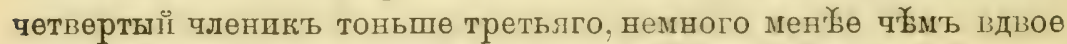
короте третьяго, овальный, на вершин заостренныі.

Хоботокъ доходитъ до ляшекъ пөредншхъ ногъ.

Пөреднесппнка попереqная, вдиое пшре сноей ллпны, задній край өя съ глубокой выемкой, боковые края неправпльно зубqатые, впереде '` спльной выемкой, гзади правшльно за-

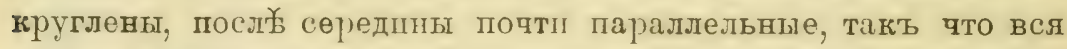
перөднеспнка пм'ьетъ обратно-серддевидную Һорму, съ обрублөнвой вөршиной; передніө үглы вытлнтты вперелъ въ вид бо

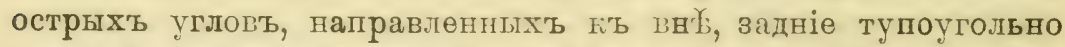
закругтенные; квлп переднеспини очень незначительно приподнятые, серединные - кзади сіегіа расходяпіеся; поверхность переднеспикп ровнал, по середив б передйлена неглубокой бороздкой, зернисто-бугорчатая.

Щитпюь длинны и узій. съ заостренной вершуной, боковые края его слабо прпподнятые; у осноланія слегка поперечно-приподнятыи, къ вершинеㅎ зернисто-бүгорчатый, съ попөречнымп морщинкамп.

Надкрылья у основанія очень слабо распиренныя, къ иер-

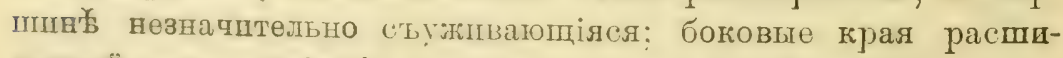
pөнной частп corium'a слегға загнутые, зазубренные; corium въ $1 \frac{1}{2}$ раза длиннеке цитика; membrana черная.

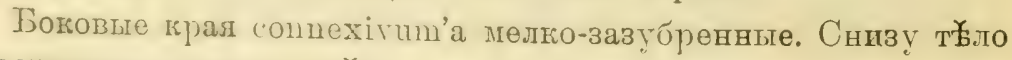
совершенно чернаго цвйта, только ногп бурыя.

ð. Воліове топасти пестого бргшного сегмента доходятъ

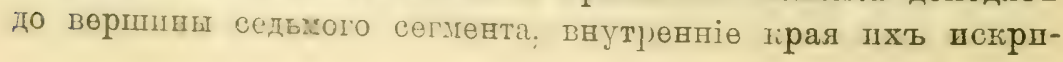


влөнные, глубоко-выр бъзавные, отстоящіе отъ внर्্ेшвяго края лопастей слюдующаго сегмента, внь̆шніе края пхх закругленные; седьмої сөгментъ сильно выпуклый, боковыя лопасти его широкія п довольно длинныя, загнутыя вверхъ, внутрөнніө края

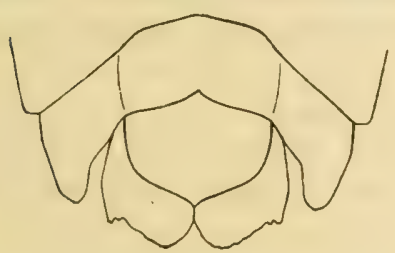

Рис. 28. - Стерниты брюшка VI-VII. Aradus erosus FALL. ðै (изъ С.-Петербургской губ.).

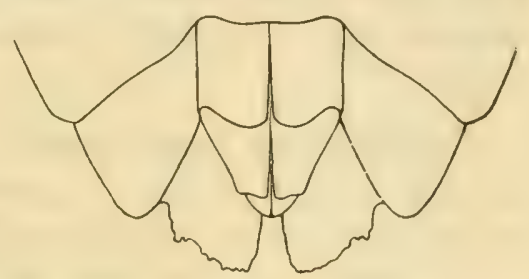

Рнс.29.-Стерниты брюшка VI-VIII. Aradus erosus FALL. 우 (изъ C.-Петербургской губ.).

пхъ зазуоренные, отъ самаго основанія расходящіеся, внейніө края закругленные, у основанія съ большимъ вубцомъ, вадніе края спльво зазубренные, почти прямые, косо направлөнные.

ㅇ. Плтый бргшноі сегментъ равевъ по длив危 шестому, задвій краї его прямої, пестої сегментъ на $1 / 3$ длиннеъе седьмого, боковыя лопасти шестого сегмента доходятьь до вершины восьмого сегмента, восьмой сегменть болье че йы вдвое короче сөдьмого, боковыл лопасті его сильно развитыя въ дливу, внутренніе края ихъ широко разставлөнные, почтп прямые, вно्্ेпніө крал неправшльно и крупно зубчатые, съ тупымъ угломъ у основанія.
๙. Длина - 6,8-7 милл., ширива $-2,7$ милл.
‥ Длина -8,4 милл., пирина -3 милл.

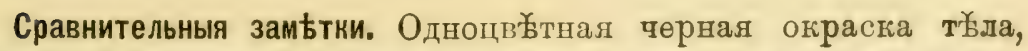
успки съ вторымъ членикомъ незначительно больље длиннымъ,

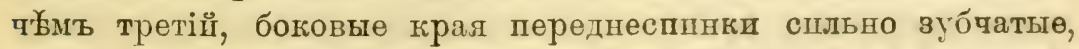
пироко закругленвые, кперөдп спльво съужпвающіеся, пейные углы вытлнутые въ видег зубцовъ, боковыя лопасти шестого брюшного сегмента ठे вырбзанныя, искршвленныл - эти признаки достаточно характеризуютъ әтоть видъ.

Къ этому впду по строенію успковъ блпзко стоптъ Aradus Tuthyi Horv., опвсанный пзъ Венгріп, но отличающійся меньшей величиной, боковымп отростками годовы, невооружевными 


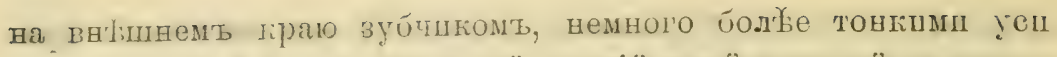
камп, пороткой переднеспиной, задній краї поторой съ нездатительной выемкой, боловымг тралми чүть зазубренными, не

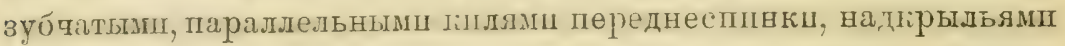
чернопато-бураго пьтта, connexirum’oмъ еъ грязно-б́лыми пятнахп (см. Honrítн, Természetrajzi Füzetek, XXII, 1899, p.: 449).

Географичесное распространеніе. Aradus erosus FALL. въ Зап. Езроп务 пзвђстенъ цзъ Гөерманіп, Скандннавск. полуострова, Тпроля п Молдавіп (на Карпатахъ).

Вь Россін ветрбчаетсл жь Финляндін, С.-Петербургекой, Вологодекой, Пермсгой гу́์. Вь Спи́щри найденъ на крайнемъ себверо-востокег: Якутекої обл.

Оппсанie Kolenati $A$. armatus Kol. тольто пи можно отнести

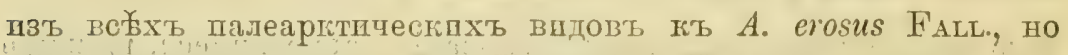

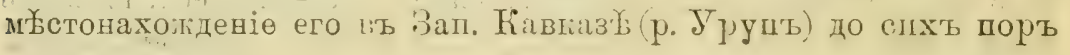
не подтверждено.

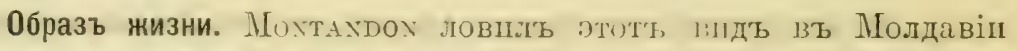

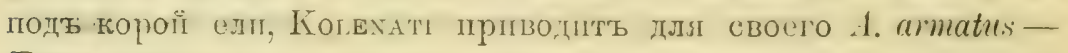
Faynes.

\section{Aradus truncatus Freb. 1861.}

Aradus truneatus Freß. Eur. Hem., p. 112. 1861. - PUt. Synops. Hém.-Hét. de Fr., I, p. 181. 1879

\section{Фаушесическая литература, касающалея Россіп.}

Aradus truncatus J. SAhLB. Medd. Soc. Fn. Fl. Fenn., XIII, 1886, p. 195 (Fennia: Jaakkimvaara).-Kir. Rev. russ. d'Ent., XII, 1912, p. 363 (Tauria, Tauria: Korbekly, forte,

Дiarн03ъ. Nigro-fuscus, opacus: capite latitudine basali cum oculis aequilongo: pone oculos rotundato-constricto, spinis lateralibus marcine externo obtusissime dentatis, dente anteoculari majusculo; rostro tantum bisin coxarum anticarum attingente; antenuis crassic, capite circiter dinidio longioribus, articulis tertio secumlo parum breviore; pronoti lateribus medio subangulatn-rotundatis, angulis anticis productis sed obtusis, margine laterali sultilisime crenulato vel antice subtilissime denticulato, carinis di-coidalifus subpumallelis, lateralibus pone medium abbreviatis; sentello itente riangulari, concaro, marginibus elevatis; 
corio dimidio basali fortiter dilatato, parte hac dilatata margine externo recta, apice subite oblique truncata: rostro, macula magna subbasali corii, angulis apicalibus segmentorum abdominalium, fascia loborum lateralium segmenti primi genitalis feminae pedibusque pallide-flaventibus; macula corii punctis paucis fuscis; femoribus et tibiis annulo medio apiceque femorum superne fuscis. (sec. Reuter).

Long. ㅇ. $7 \frac{1}{2} \mathrm{~mm}$,

Описаніе. Буровато-чернаго пвґта. Голова одинаково развитая въ длину х шпршну; переднії отростокъ ея толстый, довольно длинныи; боковые отросткп толстые, короткіе, не спльно заостренные, внғлніи прай пхъ съ мало-замғтнымъ зубцомь;

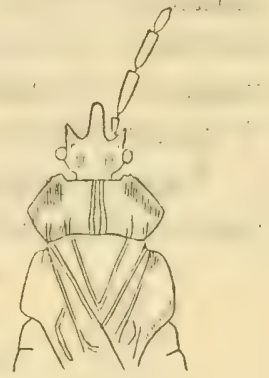

Pirc. 30.-Aradus truncritus Fine. (pric. O. M. Reuter'a). предглазничные зубды довольно больтіе; голова позадп глазь округлевно съужпватщаяея, на поверхности съ ,цвумя глубоктма углубленіямп.

Успкп толстые, довольно длинные, чернаго пв бта; пхь первый членшк почтіг на $\frac{1}{3}$ своей дливы ваходпть за вершпну: боголыхт, отростковъ головы, второї членпць равенъ по дипн

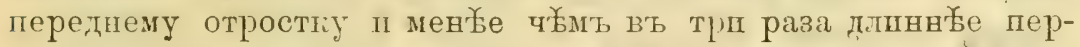

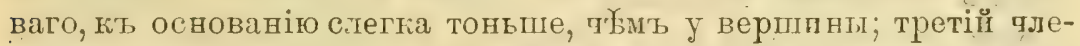
никт немного гороче второго, и одшнаковой толщшны съ его вершиной, петвертыі почти вдвое короче третьято.

Хоботощъ доходить почти до основаніл переднегрудш, жіелтоватаго цвйта.

Переднесппнка короткая, пороче головы, поперечная, ши-

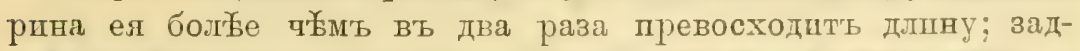
ній край ея шпроко п очень слабо выемчаты г, боговье края угловато-закругленные, кпередп іп пзади сильно съуживающіеся, сильно п пироко загнутие, очень мелконзазубренные. Срединные кпли впереди бол'⿱宀女一е сблшенные, боковые параллельные.

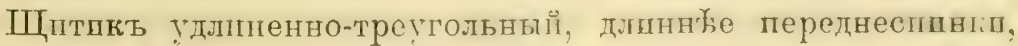

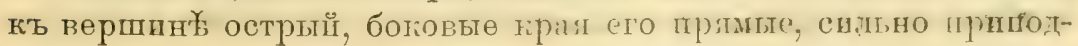
нятые; поверхность его у основанія приподнятая.

Надкрылья у основанія расшпренныя, расшијенная талсть пхъ только у самаго основанія запругленная, почти на пемь 
протяжекіп прямая, у верпшны сразу косо-обрубленная; позади основанія corium'а лежить большое пятно, тапже какъ по-

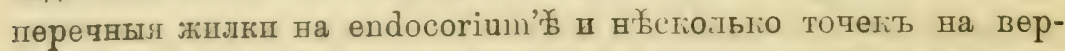

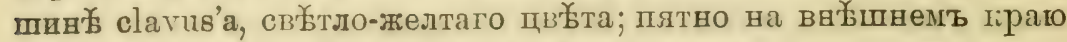

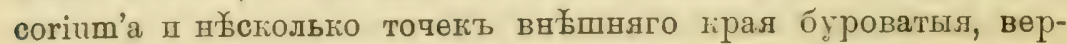
пинная половина corium'a буровато-черная; membrana-бурая, 2 жнлки ввошнято края у оспованія желтоватыя.

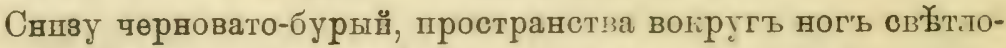
желтыя, брюшко по сөредине буровато-рыжее, вөршннные углы

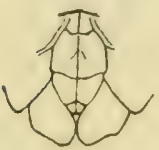

Pис. 31.-Стернитнг брюшка V-VIII. Aradus truncatus FIEB. 오 (pric. O. M.

Recter'a). сегментовъ, точки по обћпмъ сторонамъ брюшка II полоса на ботовнхт отростіахь седьмого сег-

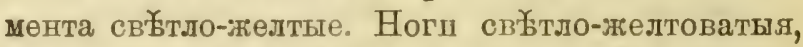
тольцо по сөредпвљ бедеръ и голевей, вөршпна бедерь сверху, самое основаніе толенеі і по по сльднііі членикъ лапокъ на вершпнег бурые.

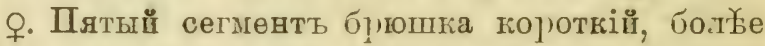
q斿 вдвое короче шестого, заднії край его по середшн安 пүямой, по объимъ сторонамъ съ зыемками, по его поверхностп проходятъ два тупыхъ кпля, косо-направленныхъ; шестой сегментъ у

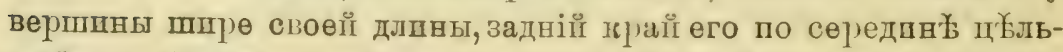

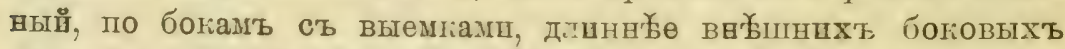
граевъ лопастөй; вершпны боговыхъ лопастеї доходять го уровня вершшны восьмото сегмента; седьмой сегменть на $2 / 5$ короче пөстого сегмента, заднії пірай его широко углопато-выр қзанный боковыл лопасти седьмого сегмевта ширкія, внутренніө края ихъ до сөреднвы сопџнасаюціеся, далью расходящіеся, на вершин各 угловато-запіругтенные. у вершины съ легкой выемкой, восьмой сегментъ на 2/, вороче седьмого.

Сравнительныя замьтни. Araclus truncatus Fiев. легко от:іичаөтся оть большинства вшдовъ рода вторымъ членикомъ усиковъ, которыи очевь незвачптельво длпнн官е третьяго; оть групшы A. depressus (FABr.) пг түуппы A. erosus FalL., имъющихъ подоб-

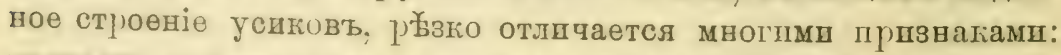
үгтовато-расшпренным боловыми краями переднеспиниц бөзъ

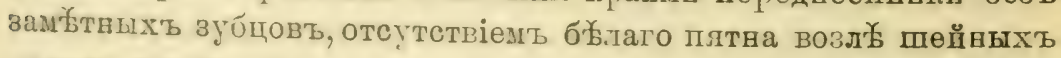
угловт переднөспини (какъ у түтппы $A$. depressus (FАвг), прямымъ, обрубленнымъ вндшнимъ гіраемъ расширенной части

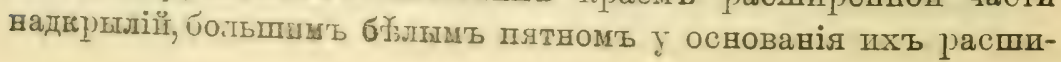


ренной частп, общимъ habitus'омъ. Оппсаніе вида взято изъ рукопиег O. M. Redter'a.

Географическое распространеніе. Средне-европейскій вадъ, встј) мыніи. Въ Россів указанъ для Финляндіи и Крыма.

Крымскія мыстовахожденія приведены по әкземплярамъ очень стајой коллекціи и требують подтгеждевія, хотя ва-

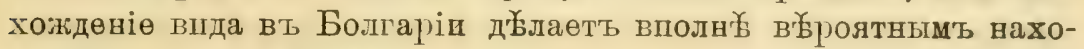
жденіе өго и въ Крыму.

13. A radus reuterianus Put. 1875.

Aradus Reuterianus Put. Petit. nouv. ent., 1875, 스 121; Ann. Soc. Ent. Fr., 1876, p. 279; Synops. Hém.-Eét. de Fr., I, p. 132. 1879.

\section{Энземпляры Зоологическаго Музея.}

Gallia: Drôme (2 J, 6 J). Puton.

Діагнозъ. Nigricans, opacus, ovalis, angulis apicalibus segmentorum connexivi sordide testaceis, macula subhumerali corii sordide albida, saepe tota obsoleta; capite latitudine cum oculis paullo vel vix longiore, spinis lateralibus margine exteriore denticulo armatis, dente anteoculari nullo; rostro coxas anticas vix attingente; antennis valde clavato-incrassatis, articulis secundo et tertio simul capite vix longioribus, secundo apice quam basi saltem duplo latiore, tertio apice secundo distinctissime crassiore et hoc circiter $1 / 4$ breviore, quarto tertio parum breviore, sed angustiore; pronoto trapeziformi margine antico toto recto, angulis anticis extrorsum prominentibus, lateribus ante eos haud sinuatis, haud explanatis, leviter rotundatis, margine fortiter dentatis, angulis posticis late rotundatis, margine basali truncato, carinis discoida-

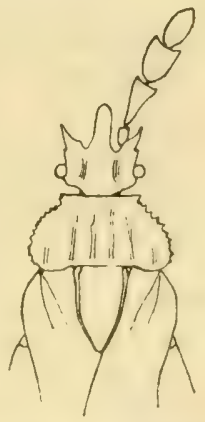

Pric. 32. - Aradus reuteriouns Рот. (pบe. O. M. REUTER'a). libus intermediis parallelis, lateralibus retrorsum levissime divergentibus; corio basi leviter dilatato.

Описаніе. Овальный, чернаго цвъта.

Голова одннапово развштая въ длину п пирину, пөредвіі отростокъ ея дливный, довольно тонкій, боковыө отросткш слөгіа 


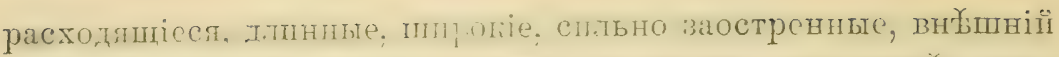

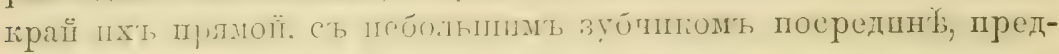
г.лазнщчные бугоркц отсутствуютъ, височные отросткі тупые,

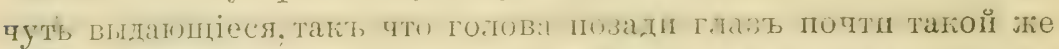

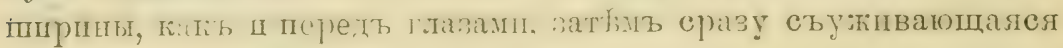
въ очень пороткую шею.

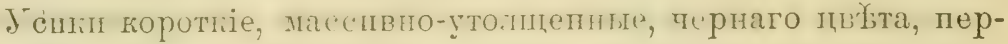

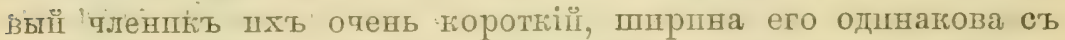
длинної, второї пленшкт, на $1 / 4$ длинне третьяг, оть основа-

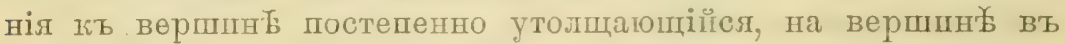

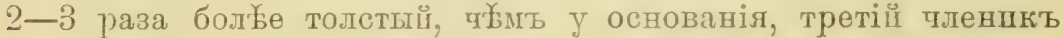

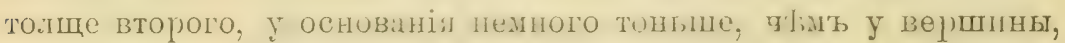
тетвертыц слегка гороче третьлг, овальныи, значптельно тоньте третьяго.

Хоботокь доходить до переднихь ллшекъ.

Переднеспинка короче головы, вдвое пире своей длпны;

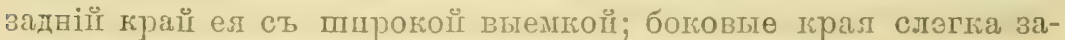

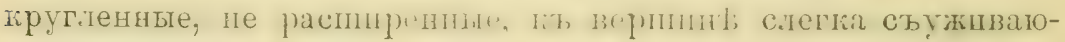

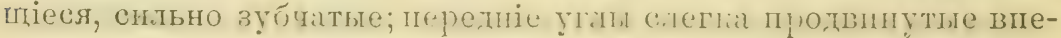

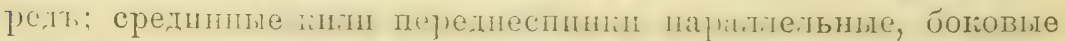
слегка расходлщіеся къ основанію.

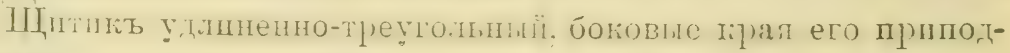
нятые.

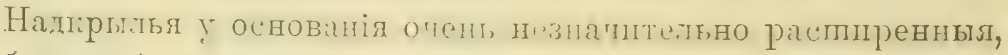
слабо зазубренныл; пногда сь небольшимъ бъловатымъ плтномъ. Connexivum съ вершіннылп угламп сегментовъ желто-

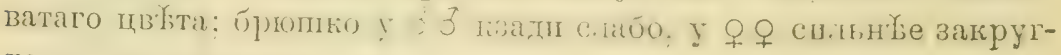
ленно-растиренпое.

Ногц черныл, ляпкп, вершины голенеї ш лапки желтоватобурाя.

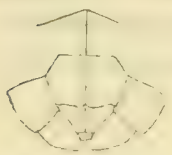

I'nc. 33. - CтерIIITS V-VIII.

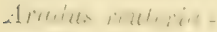

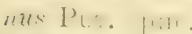
O. M. Reutrin'a).
Ј. Длпна-4 мплл., пиршна брюшка-1,7 милл.

‥ Длшва-5 мплл., шпрпна бргшка-2,3 мшлл.

Сравнительныя замьтки. Вшдъ ръзако отлачаю-

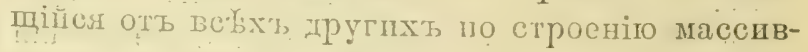
НЫХт, ТОістыхт уенговЪ.

Географичесиое распространеніе. Cүегиземномор-

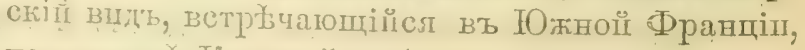
на островђ Корспкљ п вь Далмапіп. 
14. Aradus pallescens H.-S. 1839.

Aradus pallescens H.-S. Wanz. Ins., V, p. 92, tab. 175, f. 510. 1839. - Fieв. Eur. Hem., p. 111. 1861. - Put. Synops. Hém.-Hét. de Fr., I, p. 131. 1879. Aradus cimamomeus H.-S. Nomencl. entom., p. 59. 1835 (nec PAxz.).

\section{Энземпляры Зоологическаго Музея.}

Sine datis (q).

Діагнозъ. Breviter oralis, retrorsum leviter dilatatus, brunneofuscus; angulis apicalibus segmentorum connexivi allidis, marginibus interioribus loborum lateralium segmenti septimi ventralis flaro-limbatis.

Caput latum, longitudine sua latius; prolongatione antica longa et haud crassa, basi sat lata, apicem rersus angustata, parti reliqui capitis aequilonga; lobis lateralibus latis, lorevibus, apice paullo acuminatis, intus leviter recurratis, margine exteriore muticis, rotundatis; tuberculis anteocularibus obsoletis, obtusis; lobis temporalibus parris, haud prominentibus: capite pone oculos in collum latum, brevissimum sensim angustato, postice basin versus linea arcuata, laevi, callosa, flavescenti praedito nec non impressionibus longitudinalibus latis instructo.

Antennae breres, crassae, capite et pronoto simul sumtis aequilongae, nigrae, articulo primo et basi articuli secundi solum fuscis; articulo primo breviter ovali, articulo secundo capite breviore, basin versus fortiter constricto, dein subito incrassato, crasso; articulo tertio secundo $1 / 4$ breriore et paullo crassiore: articulo quarto tertio $1 / 3$ breviore et sat multo tenuiore.

Rostrum apicem mesosterni attingens.

Pronotum longitudine sua duplo latius, quan caput brevius: margine postico late sinuato; marginilus lateralibus subtiliter crenulatis, reflexis, rotundatis, apicem versus fortiter angustatis, basin rersus fere parallelis, late rotundatis; angulis anteriorilus obtusis, rotundatis, haud prominulis; carinis parallelis, basin rersus nec non margine postico marginibusque lateralibus posticis pronoti flavescentibus.

Scutellum elongatum, angustum, apice rotunlatum: marginibus lateralibus parum elevatis, apicem versus flavescentilus: disco basi convexo.

Hemelytra basi dilatata, dein latissime sinuata, pallide-fusca vel fusco-testacea, apice corii obscuriore: apud 오오 liemelytra

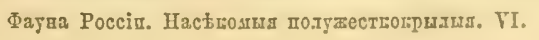


saepe ablureviata, medium segmenti quarti ventralis attingentia; membrana sat lata, haud valvante.

Pedes fusco-testacei.

ㅇ. Segmentum ventrale quintum sexto aequi-

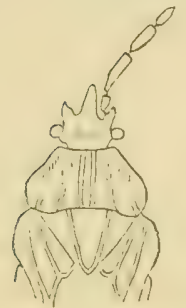

Pric. 31.-Arudus pallescens H.-S. (рис. O. M. ReUTER'a! longum, margine apicali medio leviter et lateribus fortiter sinuato; segmentum sextum septimo fere duplo longius, margine apicali anguste emarginato; lobis lateralibus segmenti septimi marginibus interioribus distantibus, marginibus exterioribus late rotundatis.

Oписаніе. Коротко-овальвыі, ғъздп слегка рас-

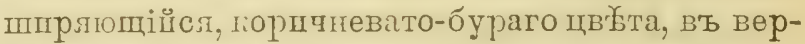

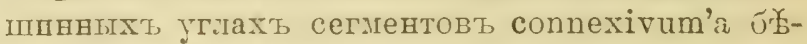
тшя пятна, внутренніо грал боговыхт гопастеї сөдьмого брюшного сегмента окаймлены жіелтымъ.

Голова очень шпроғая, пшре своеї длшны, передвій отро-

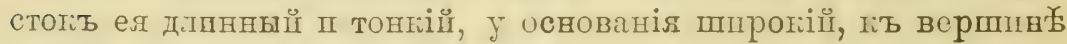

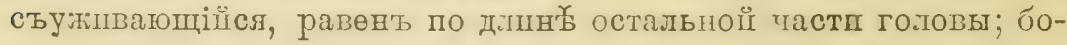
ковые отросткп широкіе, короткіе, па вершшне сл слибо заостренные, загнутые внутрь, внгекшиій гірай пхъ закругленный, негооруженныи; предглазнштные бугоркп мало выдающіеся, тупые; впсодные отросткп незначительные, почтп невыдающісся, такъ что голова позадп глазъ постепенно съужшвающался въ очень короткую, широкую шею; на поверхностп головы у основанія дугообразнал гладкая, блестлщал пшнія, желтоватаго цвегета, лежащая позадп шпрокпхъ вдавленіп.

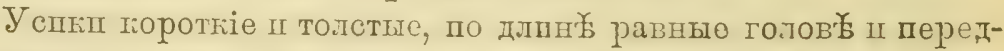

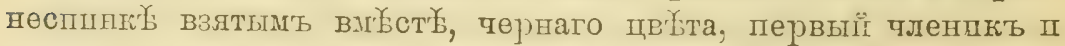
основаніө второго б́рые; первый членшгъ коротко-овальннй, второї членпкъ короче головы, у самаго основаніл спльно

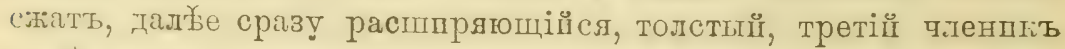
на 1/4 хоропе второго п очень незначптельно его толще, петвертыї членикь на $1 / 3$ гороче третьяго Il гораздо тоньше его.

Хоботокь доходшть до основанія среднегруди.

Переднсспнка вдвое шпре своей длины, короче головы; задпі край ел ппроко выемчатый, боғошые лірая заліругленные,

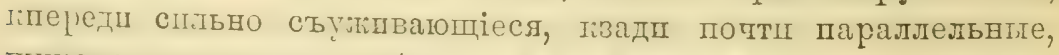
мироло зағругтеннце; боковые края очень лелко-зазубренние, 


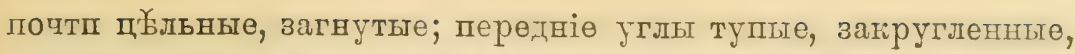
не выдающіеся впередъ; кпл переднеспннп параллельвые,

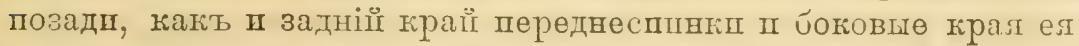
у основанія желтоватаго цво्бта.

Щштикъ удлиненный, узкій, на вершшнґ закругленныг; боковые края слабо пршподнятые, къ вершине желтоватаго цв'ь'та; повөрхность его у основанія пршподнятая.

Надгрылья у основанія расширенныя, дальше съ очень.

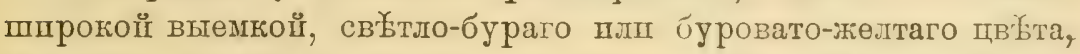

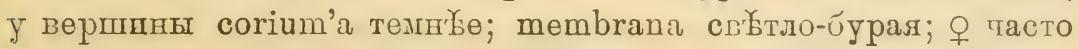
бываетъ II коротколрылая, надкрылья ея доходять до середшны IV-го бргшного сегмента, membrana довольно широгая, но не перекрөщивающаяся.

Ногк буровато-желтыя.

ㅇ. Пятыі брюшної сегменть равенъ по длшнек шестому сегменту; заднії край его по середнне, слегіа п по бокамь
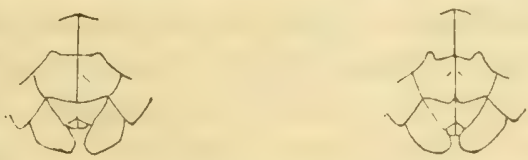

Pшс. 35 и 36. - Стернпты V-VIII. Aradus pallescens $\mathrm{E} .-\mathrm{S}$. . $($ (puc. O.M. Reuter'a).

сцльно выемчатый; шестой сөгменть почти вдвое длинн宅е сөдьмого, дшскопдальная часть его попөречная, затній краї его сь узюої вырхззкой; боковыл лопастц седьмого сегмента съ внутренншмш кралми, пироко разставленнымш, внутревній гірай пхъ пшроко закругленный.

Длшна-6-7 мшлю., ширпна надкрылії у основаніл (р)2,2 милл.

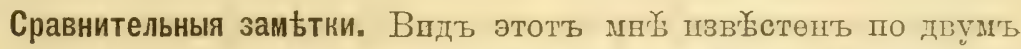
우오 (forma brachyptera): пзъ Гарда п безъ меㅜстонахоженіл.

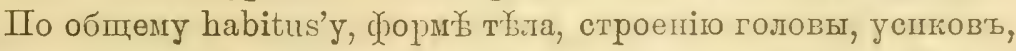

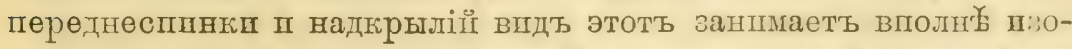
лшрованное положеніе среди всњхъ остальныхь вшдовъ рода, легіо отличаетея по второму члениту јспиовъ, поторыї немного длшннее третьлг, но у оспованія спльно сжать II гораздо тоньше, чеे̆ъъ у вершпны.

Географическое распространеніе. Видт своӥственный IO;ної п् 


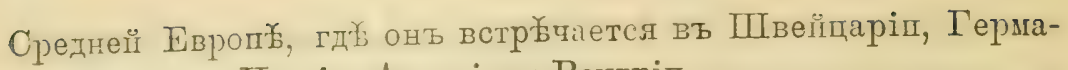
ніп, Франціп, Италіг, Австріп ІІ Венгріп.

Aradus pallescens frigidus nor. (an sp. propria?).

(Табл. II, фпг. 16).

Діагнозъ. Breviter ovalis, retrorsum dilatatus, griseo-nigricans, angulis apicalibus segmentorum connexiri maculis albidis obsoletis praeditis.

Caput latitudini sua a aquilongum; prolongatione antica sat Jreri, parte reliqui capitis distincte breviore, haud crassa; lobis lateralibus brevibus, crassis, apice parum acuminatis, margine exteriore muticis, paullo dirergentibus; tuberculis anteocularibus obsoletis, obtusis; lobis temporalibus haud prominulis; capite pone oculos sensim in collum breve angustato.

Antennae crassae, breves, quam caput et pronotum paullo breviores, nigrae; articulo primo breviter ovali, articulo secundo capite multo breviore, basin rersus valde angustato, sed haud constricto, articulo tertio secundo $1 / 4$ l, reviore, paullo crassiore, cylindrico, articulo quarto tertio ${ }^{1}$ greriore et multo tenuiore.

Rostrum apicem mesosterni attingens.

Pronotum duplo rel interdum minus quam duplo longitudine sua latius, quam caput brevius; margine postico late sinuato, marginibus lateralibus subtilissime crenulatis, reflexis, rotundatis, apicem rersus fortiter angustatis, basin versus fere parallelis, rotundatis; angulis anterioribus obtusis, rotundatis, haud prominulis; margine antico margine postico 2-21/2 angustiore; carinis pronoti intermediis subparallelis, interdum antice fortiter approximatis, carinis lateralibus basin versus leviter convergentibus vel subparallelis.

Scutellum elongatum, angustum, apice rotundatum; marginibus lateralibus parum elevatis; disco basi convexo.

Hemelytra basi dilatata, reflexa, dein latissime sinuata; membrana pallide-fusca; apud 우 suepe hemelytra abbreviata, apicem segmenti quarti rentralis attingentia, məmbrana vix ralvante. Pedes nigro-fusci.

Опнсаніс. Тіоротто-овальны:, тзадл расшпряющійся, съровато-

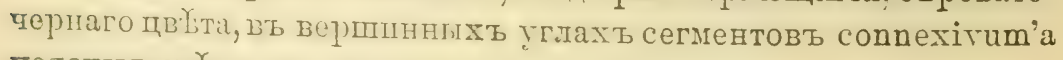
неясныя св оेтлыя пятна. 
Голова одинаково развптал въ длину и ширшну; передніч отростокь ел довольно горстгій, тонкій, корочө остальної пастп головы; боковые отросткп короткіе, толстые, вп条пній жраї пхъ невооруженный, на вершпнеб слабо заостренные, незначптельно расходлщіеся; предглазнпчные бугоркп мало вLдающіеся, тупые; вшсочные отростки не выдающіесл, такъ что голова позадш глазъ постөпенно съужпвающаяся в' короткую mero.

Успкп толстые, короткіе, немного пороче толовы п передне-

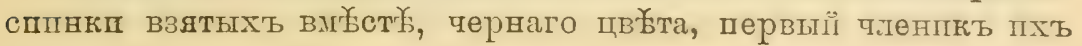
ғоротко-овальныц, второї членшіъ гораздо ғороче головы, гъ основанію значптельно утончающійел, но безь рхзљкаго статіл, третії членпкъ на $1 / \frac{4}{4}$ короче второго, толще его, цилиндрпческої формы, четвертый тленшкь на $1 / 3$ корочө третьлго, значительно его тоньше.

Хоботокъ доходить до верпины среднегрудш.

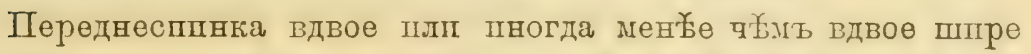
своей длпны, короче головы; заднії граї ея съ ппрогої выемкой; боковые края очень слабо зазубренные, загнутые, закругленные, кпереди спльно съужнвающіеся, кзади почти параллельные, передніе углы тупые, закругленные, не выдающіеся впередъ; передній крапі

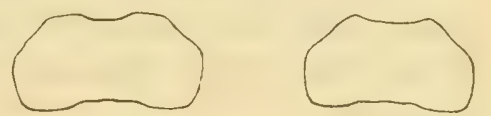

Рис. 37.- Переднесппва 'Avadus pallescens frigidus $\mathrm{K}_{\mathrm{IR} .,}$ шндпвпдуальныя варіацін. въ 2-21/2 раза у́ле задняго; кили переднесппнип: средпнныө почтп параллельные, вногда спльно сблюженные впереди, боговые слабо сходяпіеся къ основанію пли почти паралтельные.

Щштиь удлпненныи, узкій, на вөршипђ закругленшый; боғовые грая слабо приподнятые; поверхность его у основанія прпподнятая.

Надкрылья у основанія расшпревныя, загнутыя, да.тше ст очень пирогої выемпой; memlrana свІтло-бурал; 오 тасто бывають короткокршлыл, съ надкрыльлмп доходлщпми до вершпны чөтвертаго брюшного сегмента, membran'ой чуть пережрещшвающейся.

Ногп черно-бурыя.

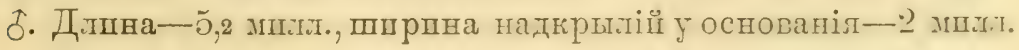

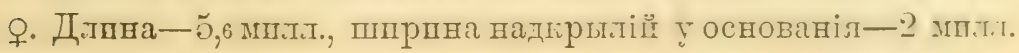


Сравнительныя замьтни. Форма эта очень блпзка кь Aradus pallescens H.-S., отишчается оть него qернымъ двйтомь всего

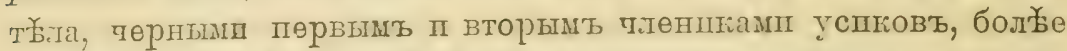

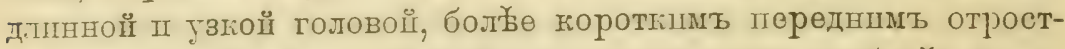
ғомт ея, менъе широкпмп боғовылп отросткамп, болье длшнными ші тонкпмп үспками, второй пленикъ, котораго болье по-

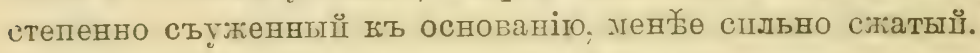

Можеть быть самостоятельный вшдъ; тольо блпзкіпі къ

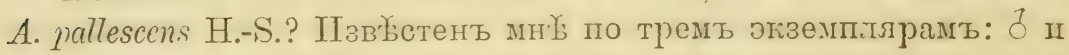
2 우 (f. macropt. II f. brachypt.).

Географическое распространеніе. Форха эта наїдена В. Рор-

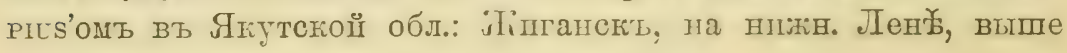
съвернаго полярнаго круга.

Aradus pallescens H.-S. повольно шпрого распространенъ въ Средней п् отчасти Южной Европ'

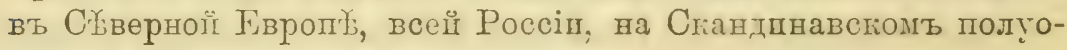
стров

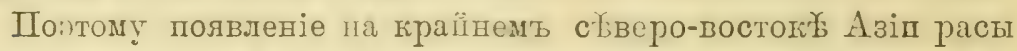

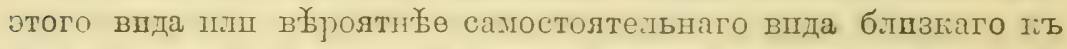
A. pullescens H.-S. представляеть большой зоогеограбодичсекій пнтересъ.

15. Aradus eversmanni $J_{A K}, 1878$.

Aradus Eversmanni JAE. Bull. Soc. Nat. MIosc., 1878, 1, p. 131.

Фауншстітеская лштература, касагощаяся Россія.

Aradus eversmanni $\mathrm{J}_{\mathrm{AK}}$. loc. cit., p. 131 (Orenburg).

\section{Экземпляры Зоологическаго Музея.}

Orenburg ( $\left.\sigma^{7}\right)$. Eversarain.

Дiarн03ъ. Corpus ovale, fuscum, articulis duobus primis antennarun, wacula magna partis dilatatae corii pedibusque flaris.

Caput longitudini suae aequilatum; prolongatione antica longa, hand crassa; lobis lateralibus latis, brevibus, apice acutis, antrorsun vergentibus, margino exteriore muticis; tuberculis anteocularilus ralidis: obtusis; lobis temporalibus parum prominulis; capite pone oculos parte anteoculari parum breviore, basin rersus linoir arcuata, callosa, nitida, albido-flarescenti praedito.

Antennae sat longae: tenues, articulo secundo quam articulus 
tertius dimidio longiore, quam tertius et quartus nonnihil breviore, tertio quarto longiore.

Rostrum basin prosterni attingens.

Pronotum capite longius, longitudine sua magis quam duplo latius; margine posteriore late sinuato, marginibus lateralibus, subintegris, valde reflexis, rotundato-ampliatis, basin rersu. paullo, apicem rersus fortiter angustatis; carinis subparallelis.

Scutellum sat breve, apicem versus acuminatum.

Hemelytra basi dilatata, macula flarescenti in medio partis dilatatae ornata, dein angustata, membrana apicem versus dilatata, fusca.

Pedes flavi.

5. Segmentum rentrale quintum marginibus lateralibus segmentoque sexto sesqui brevius; lobi laterales segmenti sexti all lobos segmenti ultimi approximati, apice rotundati; hi longi, marginibus interioribus approximatis, apice divergentibus, marginibus exterioribus rotundatis, crenulatis.

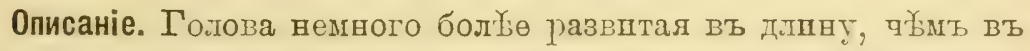
шпрпну; пөредній отростогь ея длинныи, подтп равный остальної частп головы, сравнптельно тонкій; боковые отросткіг тогстые, коротпіе, заостренные, заходять за половпну перваго чле-

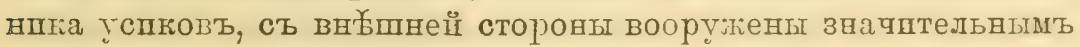
зубцомъ, предглазничные зубцы толстые, спльные, тупыо; впсочвые отросткп тупые, слабо выдающіеся, тагъ что голова позадп глазъ такой жіе шпршны, капъ п передъ глазами; подғовообразная выемка на поверхвостп головы доходпть до ея осповавія. Глаза замю्fтно стебельчатые.

Јспки тонкіе, довольно длинные, пхъ первыө два членпка бъловато-желтые, третій темвыі, почти черный, четвејтыйбуіый; первый членпиъ коротіо-одальный, заголящій немного дальше половпны переднлго отростка головы; второй членшк

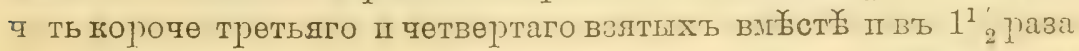

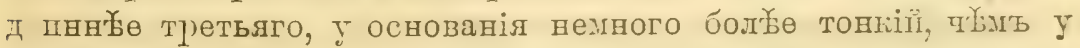
вершины; чевертые короче третьяlо.

Хоботокъ длинный, достигаеть основавія переднегртди, его первый членикљ желтый, осгальные бурые.

Переднеспнка короче головы, поперечшал. пиршна ел болґе

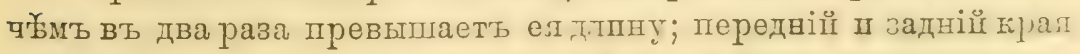

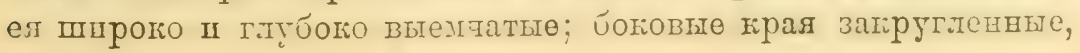




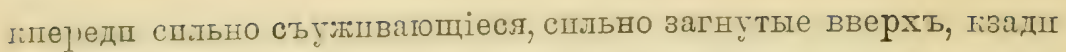
правпльно зағілугленные, на всемъ протяженіп съ правпльныли, очень мелипм зубчпкамп; кпли переднеспшнип прпподнятые, отстоящіе другъ оть друга на равномь разстояніп, параллельные, божовые впереди укороченные.

Щптпкъ треугольныи, довогьно короткіі, боговые гірая его слегка прнподнятые, поверхность зөрнистая.

Надкрылья у основанія растиренныл, зазубренныл, къ основанію спльно съужшвающіяся іп на самой вершине снова рас-

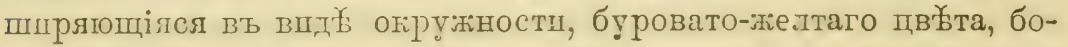

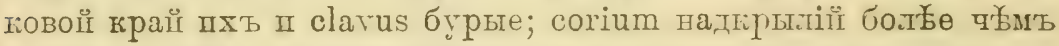
вдвое длшннеке пштнка; membrana у основаніл узкая, къ вер-

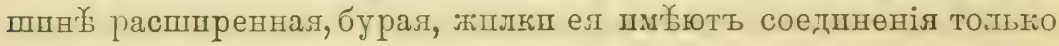
у вершины ея.

ઈ. Плтыї брюпної сегменть в`ь 1/2 раза горочө свопхъ боковыхъ краевъ п средней лшніп шестого сегмента; седьмй сегмент'ь выпуклый, боковыл .топастіг его очевь шпрокія ш длгнныя, съ вноㅁнеці стороны образують тупой уголь съ боко-

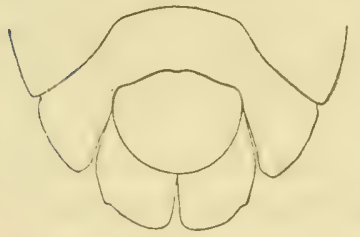

Рпс. 38.-Стерндты брюшта VI-VII. Aradus eversmanni љак. ठ (пзъ Оренбурга). вымъ краемъ; внутренніе края сблшжееные, но ве соприкасающеся, у

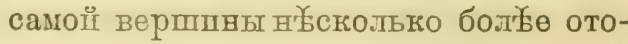
двинутые; задній прай зазубренный, съ мелкшмп незамкотнымп зубчнкамп, закругленныи.

Ноги одноцв үेтныя, бъзовато-желтыя.

Плина-6 мплл., пшрпна брюшка2,4 мијлт.

Сравнительныя замьтки. Вндъ этотъ рҺъко отлшцается товкпмп,

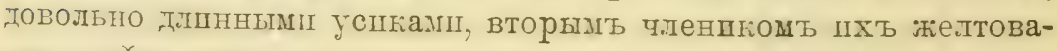

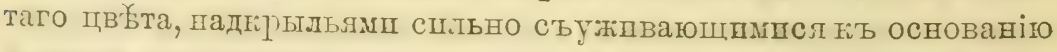
II снова расппряющшися въ областг вершпны membran'ы.

Географическое распространеніе. Вшдъ этоть пзв'стент только

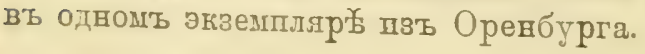

\section{Aradus distinctus Freb. 1861.}

Aradus divinatus Fmo. Eur. Hem.p p. 111. 1861. - Р’'т. Sjnops. de Hém.-Hét. de Fr., I, p. 132. 1879. 


\section{Фаупистическая лптература, касающаяея Россів.}

Aradus distinctus Horr. Bull. Soc. Entom. Ital., XIX, 18S7, p. 212 (Podolia: Olgopol).

Діагнозъ. Nigro-fuscus, opacus, antennarum articulis duobus primis totis vel articulo primo apice secundoque, ima basi excepta, angulis apicalibus segmentorum abdominalium, margine interiore loborum segmenti genitalis maris, spiraculis, coxis apiceque femorum pallide flavis, rostro, articulo primo antennarum, apice excepto, saepe etiam ima basi secundi pedibusque pallide ferrugineis vel fuscescenti-testaceis; capite cum oculis subpedunculatis longitudini latitudine aequali, pone oculos fortiter constricto, dente anteoculari valde obtuso, spinis lateralibus breviusculis, muticis vel denticulo in medio margi-

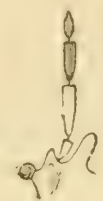

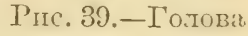
Aredus distinctus Fieb. (рпс. O. M. Recteria! nis lateralis instructis; rostro mesosterni basin attingente; antennis capite circiter dimidio longioribus, crassis, articulo secundo versus basin leviter angustato et tertio circiter dimidio longiore; pronoto fortius subangulato-rotundato, margine subtilissime crenulato vel fere integro, angulis apicalibus obtusis, haud productis; scutelli lateribus ante apicem leviter sinuatis; corio dimidio basali externe ampliato (sec. REUTER).

Описаніе. Широко-овальный, черновато-бураго цвбта, вершинвые углы сөгментовъ соnnехіхим'а съ неяснымп желтоватыми пятнами.

Голова одпнаково развитая въ длину п въ ппршну (вмессто съ глазамп); переднії отростокъ ея толстый, кт верппне․ съуживающійся, довольно длпнный, значптельно заходить за вершпну перваго членпка успковъ; боговые отросткц толстье, короткіе, на вершине в заостренные пा чуть загнутые внутрь, на

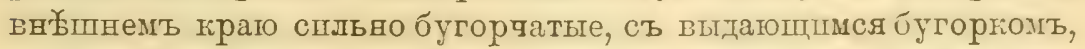
который пногда отсутствуетъ; предглазнпчные бугоргп тупые; впсодные тупые, мало выдающеся, такь что голова позади гтазт сразу спльно съужпвающаяся. Успкіг толстые, довольно короткіе, первый п второй пленшпг пхъ спопь, плш по прайеей

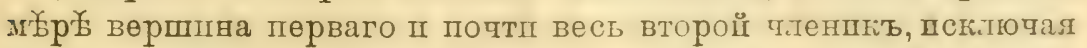
его основаніл, жіелтоватаго цв'бта, третій п четвертый члевциц червые, четвертыи - слегіа буроватыи; первый членпкъ- ротній, овальный, второї - 


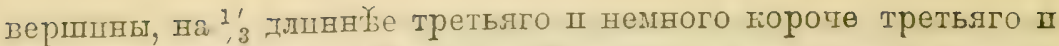

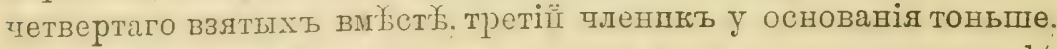
पыль у вершины, ? вершины толще третьяго членпка, на $1 / \frac{1}{x}$ длиннеке четвертаго.

Хоботокъ желтаго цв Һта, доходптъ до основанія переднегрудп.

Переднеспнка широко-поперечнал, въ 21/2 раза ппре своей длпны, короткая, кіроче головы; передвії граї прямой, заднії

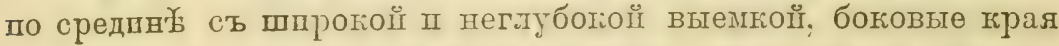
расшпренные, правциьо закругленные, напбольшая шпршна пхъ немного позадп сөредины, піъ вершпнй - шльно, къ основанію - слабо съужшвающіесл, мепю-зазубренные, слегка загнутые; передніе углы тупоугольно-закругленные; боговые кшли переднеспшнки ліъ вөршпне расходящіеся, срединные параллельные.

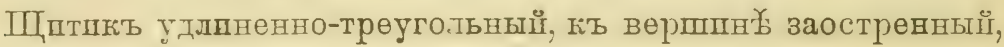
боковые жрая өго приподнятые.

Наткрылья у основанія расппренныл, грязно-желтоватаго

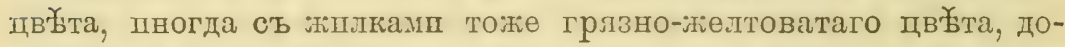
ходлть до основанія седьмого сегмента п немного уюже брюшка

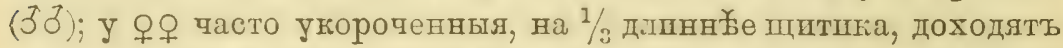
до основавіл третьяго сегмента, mеmbrana-рудшментарная, лежащая вся по внутреннему краю согіum'а.

Бокової граї connexivum'а слабо загругленныі, углы сегментовъ не выдающіеся.

Ногп желтовато-бурыя.

‥ Пятый брюшної сегменть на $1 / 3-2 / 5$ короче шестого, шестої на 1/3 длшннеке седьмого ш равенъ седьмому II восьмому

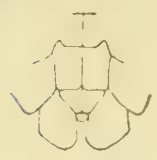

Pirc. 20.-CTep-

inisti úpronnia

V-VIII. Aradus distinctus FrEB. ㅇ․ (pre. O. M. RetTI:Iit). вмегеті взятымъ; боновыя лопасти пестого сегмента вершинами свонми едва доходять до уровня вершины восьмого сегмента; лопастп седьмого сегмента съ внутреннщм краямп шш-

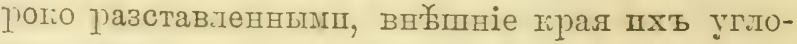
вато-загруглениые, вершшный угопь широко затругленный.

오. Длпна -7 мплл., ппрнна -2,8 мплл.

Сравнительныя замьтки. Вштъ этоть рәзко отлптается оть всґуғь видовъ рода, довольно корот- 
пимп, тонипм успкамп, первыї п второй члөнпкъ которыхъ

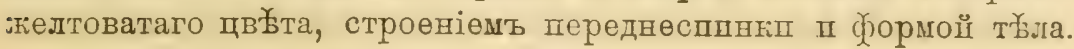

Географичесное распространеніе. Южпо-европейскії вшдъ, встрґпающійся въ Австріп, Венгріп п Румыніп, ІОго-Зап. Россіш

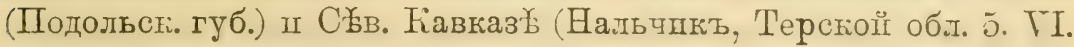
1909. Д. Глазуновъ).

\section{Aradus brevicollis Fatr. 1807.}

Aralus brevicollis Falz. Mon. Cim. Srec., p. 33. 1807; Hem. Suec. Cim., p. 137. 1829. - R. F. SAнLb. Mon. Geoc. Fenn., p. 143. 1848. - Flor Rhynch. Livl., 1, p. 390. 1860.-REut. Öfv. Kongl. Vet.Akad. Förh., 1872, 소 5, p. 52 ; Ent. Tidskr., 1882, p. 77.-Puт. Synops. Hém.-Hét. Fr., I, p. 132. 1879 .

\section{фаупистическая литература, касающаяся Россік.}

Aradus brericollis R. F. SAнLB. Mon. Geoc. Fenn., p. 143. 1818 Fennia: Runsala). - Reut. Öfv. Kongl. Vet.-Akad. Förh., 1872, 고 5, p. 52 (Fennia: Pargas).-J. SA Wasa).-Reutr. Ent. Tidskr., 1882, p. 77 (Hangö, Åbo).一 Hexrs. Ess. Entom., II, 1822, p. 22 (St.-Petersburg).-Fuor Rhynch. Livl., I, p. 390 (gub. Kurland, Livland).-REur. Rev. d'Ent, VII, 1888, p. 200 (Vladirostok).

\section{Энземпляры Зоологическаго Музея.}

Fennia (q). Reuter.

St.-Petersburg $\left(\sigma^{\top}\right)$.

Gub. St.-Petersburg: inter Jukki et Shuvalovo. 17. V. 1891 (q). Gerzensteix. Gub. St.-Petersburg: Serezhino. 4. VI. 1896 (Q). Braschi.

Gub. St.-Petersburg: Serezhino. 22. VI. 1896 (). Branchr.

Gub. St.-Petersburg, distr. Petergof: Lebjazhja. 10. VI. 1901 (q). Brascir. Gub. St.-Petersburg, distr. Petergof: Lebjazhja. 4. VI (Q). BraxcHI.

Kazan. 21. V. (ð). Ebersmany.

Radderka in fl. Amur (O).

Sine datis $(4 \pi)$.

Діагнозъ. Corpus late orale, nigricans, angulis apicalibus se mentorum abdominalium nec non annulis basalibus et apicalibufemorum tibiarumque - albidis.

Caput latitudine sua longius, prolongatione antica crassa, sat longa; lobis lateralibus longis, apice acutis, antrorsum vergentibus, margine exteriore denticulo parrulo instructis, hoc saepe defticienti; tuberculis anteocularibus parrulis, lobis temporalibus prominulis; capite pone oculos parti anteoculari fere aequilato. 
Antennae longae, crassae, nigrae, articulo secundo tertio tenuiore, ${ }^{1 / 4}$ longiore, articulo tertio quarto fere duplo longiore.

Rostrum basin prosterni paullo superans.

Pronotum longitudine sua duplo et dinidio latius; margine postico late et profunde sinuato, marginibus lateralibus angulatorotundatis, quam hemelytra basi latioribus, apicem et basin rersus fortissime angustatis, denticulatis, antice reflexis; carinis intermediis subparallelis, basi obsoletis.

Scutellum elongato-triangulare, apice acuminatum, marginibus eleratis, ante apicem flarescentibus, disco medio convexo.

Hemelytra basi parum dilatata, reflexa; membrana fusca.

Connexivum angulis apicalibus segmentorum leviter, segmenti quinti et sexti sat fortiter prominentibus.

Pedes nigri, coxis, annulis basalibus et apicalibus tibiarum albidis.

Описаніе. Овальныц, большой, чернаго цвъта, снцзу часто рыжевато-бурый, пятна въ верпанныхъ углахъ сегментовъ connexivum'a сверху п снизу, рядъ точекъ на connexivum'ঝ снизу, ляшки пи кольца на голеняхъ ногь бълые.

Голова длшнная, длшна ея превышаетъ пирпну, передній отросток' довольно длинный, чуть заходяпіі ва вершину перваго членшіа успковъ; боковые отростіл острые, длинные, едва расходящіеся, на внобшнемъ крато безъ зубца, но пногда съ одень небольшимъ бугоргомъ; предглазниqные зубцы мало развптые, га вершшне́ прптупленные, внсочные отростип тупые, ппрокіе, такъ тто голова отъ основанія боковыхъ отростковъ до вершпны впсочныхъ представляется почтш правпльно ғвадратноџ̆; позадп гдазъ находштся подковообразное углубленіе, не доходящее до основаніл головы. Успюп длшнные ІІ толстые, чернаго цв'ьта; первыц членпкъ шхъ часто буроватый, торотхіці, овальный, почтп въ четыре раза гіроче второго, второ ї

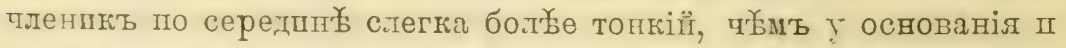
вершины, на ${ }^{1}{ }_{4}$ длуннеке третьяго, короче третьяго п् четвертаго

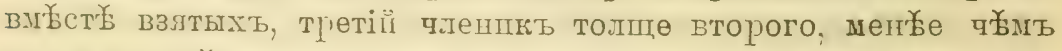

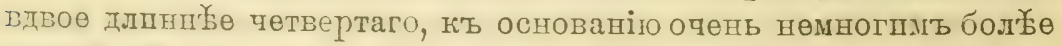

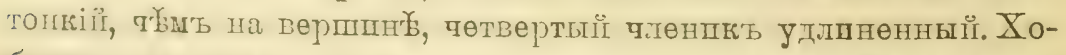
ботокт, путь заходпть за вершину среднегруди, бураго цвйта.

Переднеспнка пирого поперетная, въ $2_{2}^{11}-3$ раза ппре

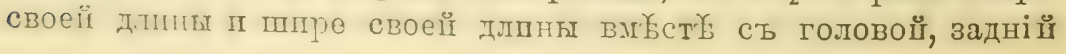


край ея съ тлубокой выемкой, боковые грая мелго зуйчатые, сшльно расшпренные, по сөредпнеб угловато-огругленвые, ппередп п жзадп спльно съужпвающіесл, впередп загнутые; оть шейныхъ угловъ отходятъ впередъ съ нижней стороны отростки; кцлш переднесппни мало возвышенные, почтп параллельные.

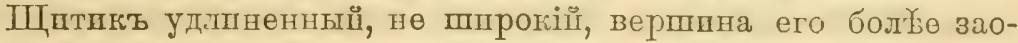
стренная, боковые грая его закругленные, прштоднятые, прш основаніш широкіе, бугорчатые, дальше въ вшдељ узкаго борта по середпн宅 спльно понпжающагося; поверхность щитика зер. ншсто-морщинпстая, у основанія приподнятая.

Надкрылья у основанія не особенно сшльно расширенныл, загнутыя, правпльно зазубренныя, къ вершшнех съулгвающіяся; corium дочти въ $1 \frac{1}{2}$ раза длиннеке щитпка; membrana бурая. Боковой край connexivum'a зазубренный, загнутые вершшнные углы сегментов' тупоугольно-огругленные, выдающіес, I-III сегментовъ незначптельно, IV - замејтно, V-очень спльно; возл乩 бокового края сөгментовъ находптся неясное тглубленіе, занимающее почтп всю длину сегмента, а за ншмъ два сблпженныхъ черныхъ пятна, пзъ которыхъ нпжнеө явственно окружено зернистостью желтаго цвътта ІІ пятно это представллется глазчатымъ.

Ногп бурыл, на голеняхъ передъ основаніемь п вершпно

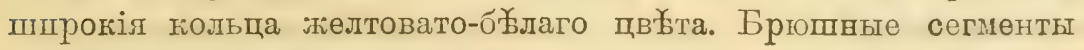
снизу сь крупнымп, темнымп, вдавлөннымп пятнамш п желтымп точками.

§. Боковыя лопасти шестого брюшного сегмента отстоятъ

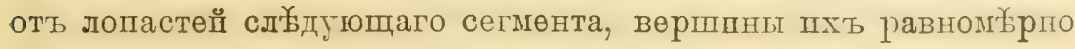

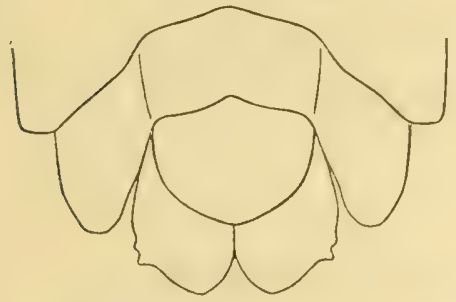

Pнс. 41:- Стернпгы бргшпа VI-VII. Aradus brericollis FALL. 万.

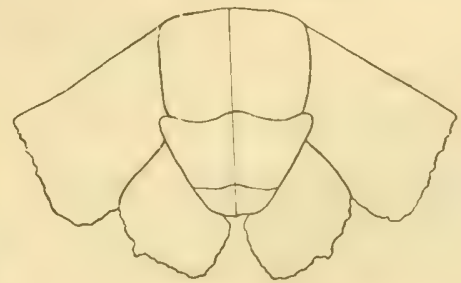

Pirc. 42. - Стериптц бргшпа VI-VIII. Aradus brevicollis FALI. ㅇ..

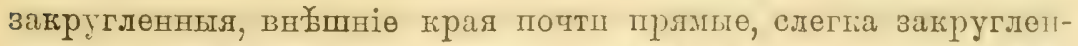
ные; седьмой сегхентъ сдльно выпуклый, боповыя лопастп его спльно вагнуты вверхъ, длпнныя п шпрокія, внутрениіс гірая 
пхъ почтп прямпе, расходящіеся, широко окаймленные желтымь, ботовые крал слегка закругіөнные, у вөрппны съ небольппмь бугоргіомь, задній край прямоі, спльно зазубренный.

ㅇ. Плтый бргшной сегменть очень незначитөльно короче шестого сегхөнта; заднії жрай его выемчатый; шестої сегхентъ на $1 / 3$ длшнниебе седьмого, боковыя лопастп его спльно поперечныл, на вершине закругленныя, доходять до вершины восьмого

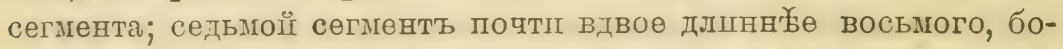
повыя лопастп его почтш одшнаково развптыл въ длпну пा пшршну, внутренніе грая шхъ закругленные, начшная съ самого основанія ппроко разставленные, вн危пніе края по сөредпнй образують слегка выдаюоіися уголь.

Ђ. Длпна $-7,5-S$ мплл., пприна перөднеспннтіп $-2,8$ мплл.

ㅇ. Ппрпна-9-9,5 мплл., ширшна переднесппнкп-3,8 мплл.

Сравнительныя замьтки. Вшдъ этотъ хорошо отлпчается оть другпхъ сильо распиренной переднеспнкой, которая⿱ ппре основанія надкрылій, довольно толстымп, длнннымп усшкамг,

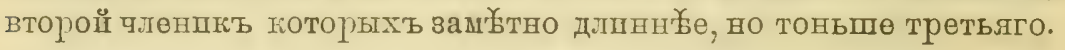

Географическое распространеніе. Araches brevicollis F.LL. псклю-

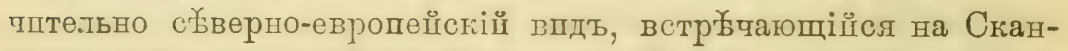

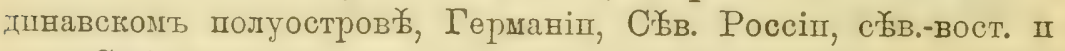
вост. Сибири.

Въ Россіи онъ пзв Һсстенъ пзъ Фшнляндіп, С.-Петербургской губ., Тпфорляндіп, Кіррляндіп, Казанп, Якутска (Dr. B. Poppius),

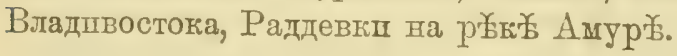

\section{Aradus bergrothianus nom. nov.}

Aradus emarginatus Bergr. Ent. Monthl. Mag., XXII, 1885̄-1886, p. 8 (nom. praeoce., nec $\mathrm{S}_{\Delta \mathrm{Y}} 1831$ ).

Экземпляры Зоологическаго Музея.

Vladivostok. 1911 (ठ઼). Malkina-Panna.

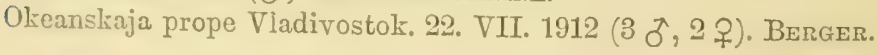

Діагн03ъ. Corpus late ovale, nigrum, pronotum marginibus lateralibus antice ot postice anguste albidis nec non macula basali hemelytrorum, vittis latis endocorii, marginibus scutelli post medium, augulis posticis segmentorum annulisque tibiarum autem allilis. 
Caput latitudini suae aequilongum, prolongatione antica crassa, brevi, apice truncata, lobis lateralibus longis, baud crassis, acutis, divergentibus, margine exteriore tuberculo distincto armatis; dentibus anteocularibus acutis, validis; lobis temporalibus obtusis, prominulis, apice acutis.

Antennae sat crassae, longae, nigrae; articulo secundo tertio vix longiore, basi et apice paullo incrassato; articulo tertio quarto paullo breviore.

Rostrum basin prosterni attingens.

Pronotum transversum, longitudine sua duplo et dimidio latius; margine postico trisinuato, marginibus lateralibus latissime dilatatis, dentatis, apicem versus fortissime angustatis, rotundiltis, antice profundissime emarginatis, basin versus fortiter angustatis, subrectis; carinis elevatis, intermediis medio approximatis, basi albidis.

Scutellum latum, marginibus alte elevatis, post medium fliris, apice sursum alte reflexis.

Hemelytra basi parum dilatata, macula albida ornata, endocorio maculis nonnulis albidis, transversis praedito; membrana fusca.

Connexivum marginibus lateralibus distincte crenulatis, angulis posticis admodum prominentibus, subserrato-emarginatis.

Inferne fusco-nigrum. Pedes fusco-nigri, tibiis prope apicem et basin flavo-annulatis.

Описаніе. Овальный, чернаго цвъта, основаніе надпірылій п поперечныя полоски на еndocorium', небольшіе участип боговыхъ краевъ переднеспинкп впередп п сзадп, боковыө гірая щитпка пөредъ вершпной его, вөршшнные угль сегментовъ connexivum'a и тольца на ногахъ бұлаго цветта.

Голова одинаково развптая въ длпну п шпршну; передпі: отростощь ея толстыи, довольно моротпій, боковые отростип длшные, острые, слегка расходлщіесл, сахал верппна пгъ

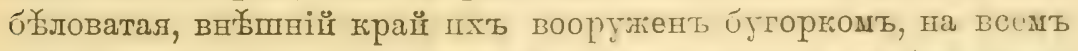

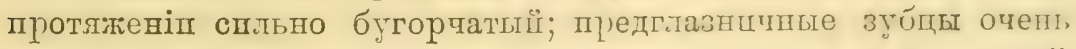

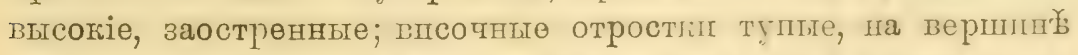
оканчпвающіеся острымъ бугоргомъ; позадш г.лзъ голоша стегка съужпвающаясл; полковообразное үг.ту́леніе ва поверхности головы доходшть до ея основаніл.

Успки терные, толстые, довольно коротгіе, первый члипит 


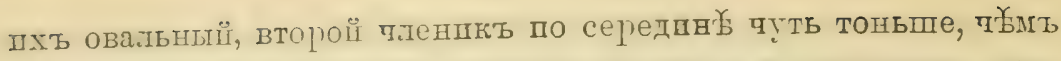
ү остованія п т вејппны, гороче третьяго ш четвертаго взя-

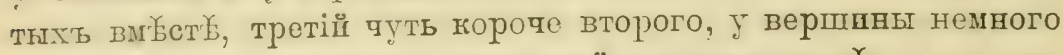

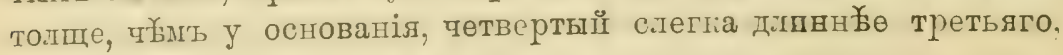

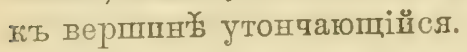

Хоботокь доходить до основаніл переднегруди.

Переднеспинґа шпроко-поперечная, въ $21 / 2$ раза шире своей

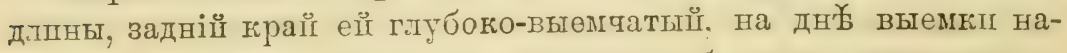
ходптся вторпчная, небольшая выемка; боковые грая спльно трыльеобјазно расшпренные, по середпно огругленные, къ основанію ІІ вершин'ь сп.ьно съуживающіеся; впереді немного

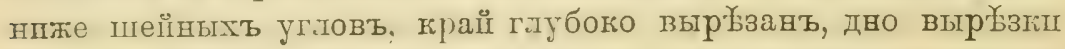
бълтаго цвйта, боғовые грал къ основанію на всемъ протяненіп почтц прямые, возл尔 салаго основанія бълғаго цвйта; боковые прая спльно загнутые вверхь, прпподнятые, съ крупнымп ш мелкпми зубцамп; средшниые тил переднеспиніш по сөредшно्⿱宀 боковые короткіе, чуть расходящіеся.

Щитшкъ удлпненныі, боковые края его высоко прпподнятые, около вершшны на короткій пүомежутоль понпжающіеся,

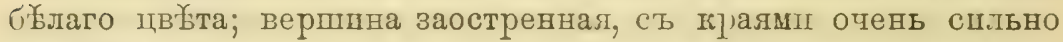
загнутымп кверху.

Надірылья у основанія слегка расшпренныя, съ бłлымь

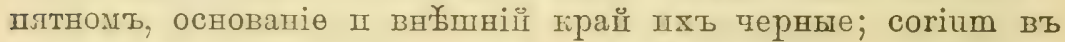

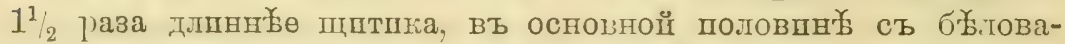
тымп пятнамп, особенно въ ои́ластп еndocorium'a; membrana бтрая, съ густої сътью жилокь; жплкп бурыл, окайменныя блестяпци линіямп.

Connexirum съ очень нелсными бұлымп пятнамп въ верппнныхъ угіагъ сегментовъ; боковые края его спльно зазубренние, задніе углы паждаго шзъ сегментовь отень сдльно шродвпнутые, такъ что трая брюшка крупно-зубчатые.

Ногш бурыл, пространство вокругъ ногъ, вертлугп, кошьа пеједь основаніемъ пи вершиной бедеръ п голеней жәелтовато-

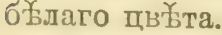

‡. Боковня лопасті пестого брюшного сегмента отстоять оть лопастеї спидугщдаго сөгмента; седьмої сегментъ сп.тьо

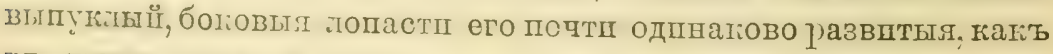

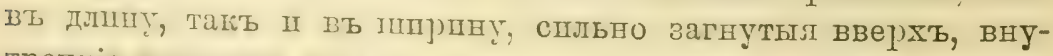
тренпіе прал пхт прлмые, расходящіесл подъ острымт угломь, 
желтоватаго цвъта, продолжающагося, по половшны седьмого сегмента, ботовые жүал слегка закруглннные, задніе - прямые. пю середпн съ глубокой вцемкой п однцњ больпимь зубцомъ.

q. Основної прай пятаго брюпного сегмента спльно выемчатый; плтый сегменть по срединной ппніц равень шестому.

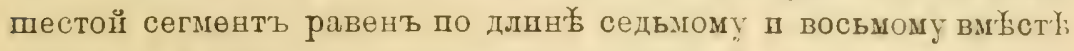
взятымъ, боковыя лопастц его заходятъ за уровөнь вершины восьмого сегмента, соприкасаютея съ лопастям седьмого сег-

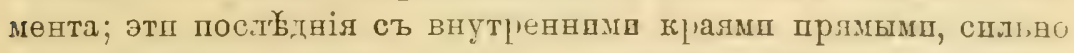
расходящпмися, задній ғрай съ сильної выръзой. больпим, зуб̆домъ впереди и меньпшмп по серединх⿱宀.

§. Длина 7 мплл., ширина перөднеспинки - 3,2 мшлл.

ㅇ․ Длина-9 мшлл., пиршна 4 милл.

Сравнительныя = замьтки. Впдъ этотъ по толстымъ, сравнштельно длиннымъ успкамъ, второї членикъ которыхъ очень незначительно длинн危е п тоньше третьяго, но ґороче третьяго ІІ четвертаго членика вмьсто в вятыхъ, по пирокой пөредне-

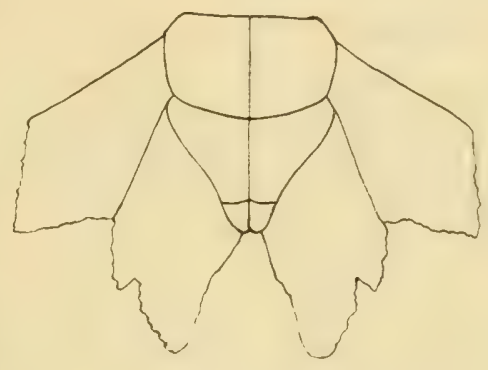

Pнс. 43. - Стернитц VI-VIII. Aradus bergrothianus KIR. ㅇ (nз' Южно-У ссурійспаго края). спинею́, втетупающей за уровень основаніл надғірылій, по въ большей пцп меньшөй степенц. выступающиљ заднимъ угламъ сегментовъ брюшка, ограсгі⿱ ногъ пा другия пгрпзнагамъ образуеть естественную группу съ предыдущимъ вшдомь A.brevicoll is. FALL., а въ групп年 этой представляеть соверпенно особый типъ, повторяюшійся у трехт,

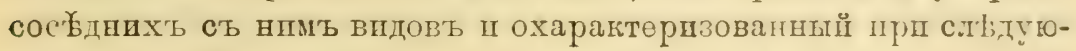

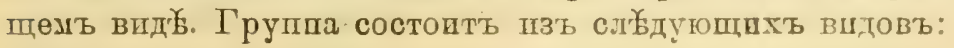

$$
\left\{\begin{array}{l}
\text { A. brevicollis FALL. } \\
\text { A. bergrothianus KIr. } \\
\text { A. orientalis BERGR. } \\
\text { A. compar KIR. } \\
\text { A. mirabilis BERGR. }
\end{array}\right.
$$

Географическое распространеніе. A. bergrothiums описань бил,

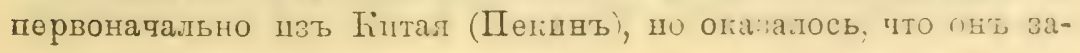




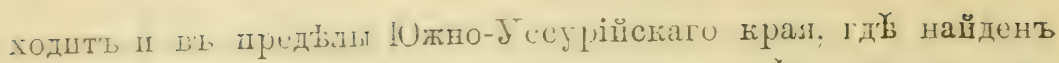

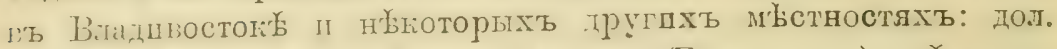

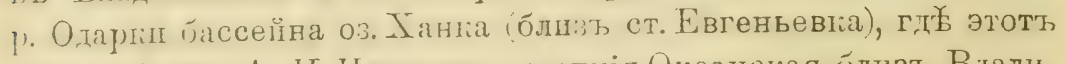

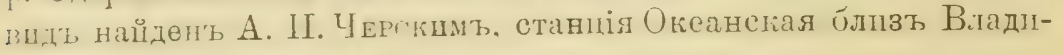
востока (В. Бергер' ).

\section{Aradus compar $10 . \mathrm{sp}$.}

(Табл. I, фип. 6).

\section{Энземпляры Зоологическаго Музея.}

Vladivostok. 1911 (ठ゚). MaLEIXA-PANixa.

Дiarн03ъ. Corpus late orale, nigrum, hemolytris basi ot medio Jate, articulo tertio antennarum. hasi excepto, marginibus lateralibus pronoti antice angustissime, marginibus lateralibus scutelli ante apicem angrulisque apicalibus sorrmentorum abdominalium albis; loli laterales sermenti septimi marrinibus interioribus albiro-limbatis.

Caput latitudini suat a equilıngrum: prolongratione antica crassa, sat hrevi; lohis lateralibus longis, haud crassis, apice acutis, allilis. margine exteriore denticulo armatis: dentibus anteocularibus validis, acutis; lolis temporalihus ol,usissimis, levissime prominulis; capite pone oculos angustato.

Intennae longae, sat tenues; articulo secundo tertio vix longriore, basi et apice quam medio leviter crassiore; articulo tertio in hasali triente nigro, cetero allido, apice distincte crassiore, articulo quarto tertio vix breviore.

Rostrum basin prosterni superans.

Pronotum lireve, longitudini capitis aequilongum, longritudine sua iluplo et dimidio latius; margine posteriore profunde trisimuato; marginibus lateralilus latissime dilatitis, quan hemelỵtra multo litiorilus, ralde sursum reflexis, irregulariter crenulatis, fere integris, apicem et l,asin versus fortiter angustatis: marginilus lateralilus anticis rotundatis. apice imo profunde et breiter sinuatis.

-cutellum angustum, elongrato-triangrulare; mar.rinibus elevatis, post medium spatio brevi humiliore, albido.

Hemelytra bası dilatata, reflexa, crenulata; clavo, corio basi angustissime ot apice sat lato - nigris, hoc medio albido; mem- 
brana nigra. Augnulis posticis segrmentorum admodum prominentibus, ut latera abdominis serrata-incisa evadant.

Til,iae prope apicem et basin, femori apice albo-annulatar.

ठ. Segmentum rentrale sextum quinto vix longius, lobi laterales sıgmeutormu ultimorum paulo distantes, apice rotundati; lobi laterales segmenti septimi lungi et lati, marginibus interioribus rotunditis, divergentibus, marginibus posterioribus sinuatis. basi dente instructis.

Species A. bergrothiano $\amalg .1=$ emarginate BERGr.) affinis, a qua antennis tenuioribus et longioribus, articulo tertio albo, marginibus lateralibus pronoti minus profunde emarginatis, lıaud dentatis; colore hemelytrorum, lobis lateralibus segmenti sexti haud acutis, sed angulato-rotundatis aliisque notis facile cognoscitur.

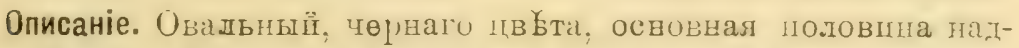
прылій, узгіе и короткіе участи богового күая переднеспнкц

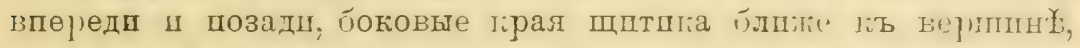

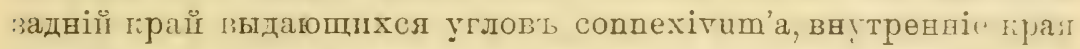
боковыхъ лопастей седьмого сегмента желтовато-бълые.

Голова одинаково развитая, какъ въ длину, такъ ш въ ши-

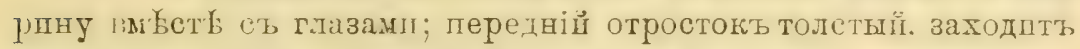

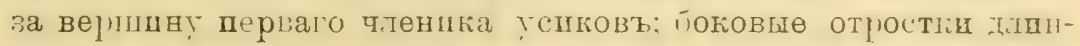

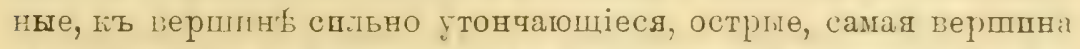
пхъ бблая, на внойнем граю вооруженные явственнымъ бу-

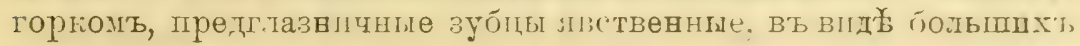
острыхъ пиовъ, направленыхт иверхъ; височные отростгш очень түпые, мало-выдающіеся, тағъ что голова позади глазт, къ основанію съужпвающаяся.

У сики довольно тонкіе, длинные, чернаго цв'ља, третій чле-

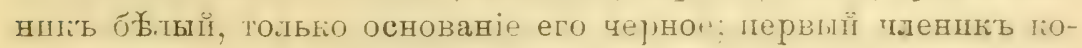
ротіій, овальнй, толще второго членика, вторий тлениіъ едві

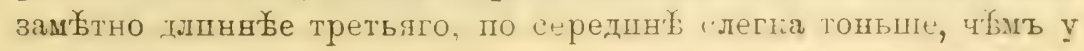
основанія II верпины, короче третгяго п тетвертаго взятыхъ

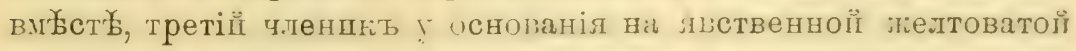

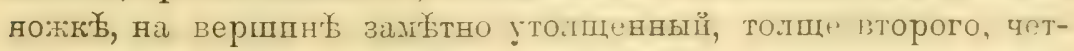
вертый членикъ чуть короче третьяго.

Хоботоль заходить за основаніе переднегууди, осниани. перваго п второго члевика его желтоватаго цво्́̆та.

Переднеспнка короткал, одинаковогі длины съ голової, ппрокая, въ $21 \%$ раза шире своей длины; задній прая ел ст 


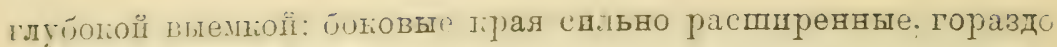
шире нидтрысій у ихь основанія, тгтовато-закругленные, послй

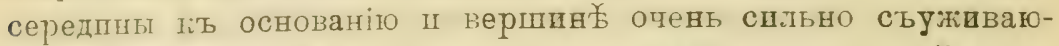

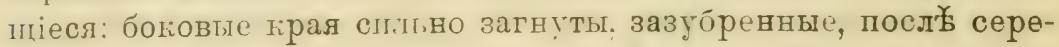
гины ст глубокой. но пчень ғоротпой выемкой впередп п неэначптельнов̆, но широкої по заднему краю, дно цырбзокъ

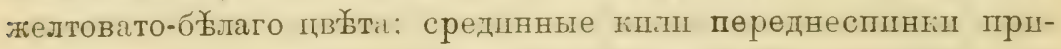

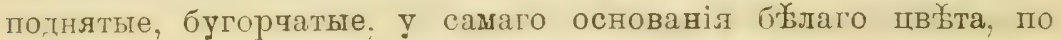
сөрединеㅎ сближенные, боковыя очень короткіе.

Щштпю удпиненный, узкій, вдвое длиннеке своей пирины, на вершиноз заостренныи: боговые ғрая "го сильно прпподня-

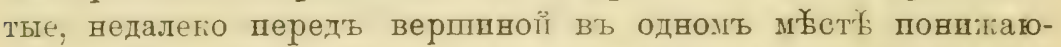

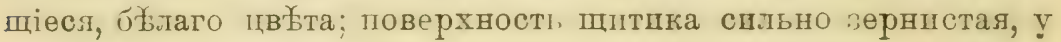
основанія приподнятая.

Надгрыля у основанія сравнптельно не спльно расширөн-

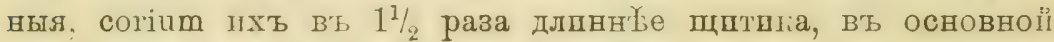
бо́льшөї половнн

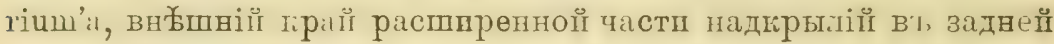
половнды, поперечныя, широгія полосы енdоcorium'а, вся задняя половпна наткрылії черныя; membrana черная.

Боковые края connexirum'a зазубренные; задніе углы от-

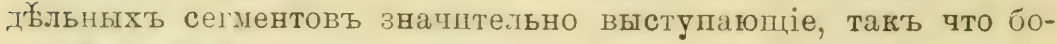
хової край брюпка является лрупно зубчато-вырбзаннымъ. боковые края отдығыьныхт сегментовъ одругленные; пестого сегмента тупоугоьно оюругленный, задніө үглы сегмевтовъ желтовато-бълаго цвътан.

Ногп черныя, бегра и гогенш передъ основаніемъ п у верпины съ бұловатымп кольцами.

ઈ. Боковыя лопасти седьмого сегмента сь внутренншмп граяміг окаймленнымп бұлымь, расходящшмся.

3. Ллпна-S милл., шпрцна переднеспинкп-3,4 милл.

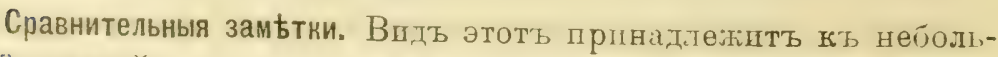

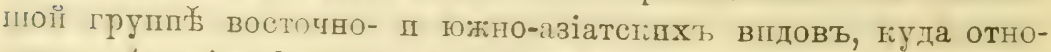
citcis A. orientalis Bersin. A. bergrothianus Krr. iemarginatus Brimin, A. mirabilis Bergr, очень хараптерныхь по строенію

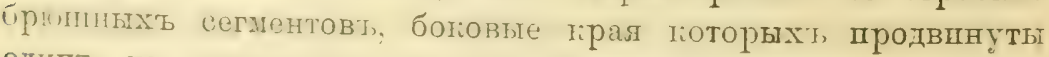
одинъ надъ другпмъ такпиъ образомъ, пто краї является

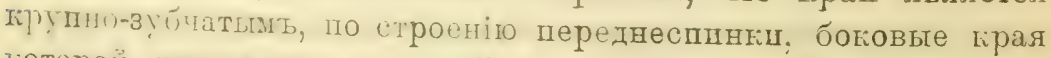

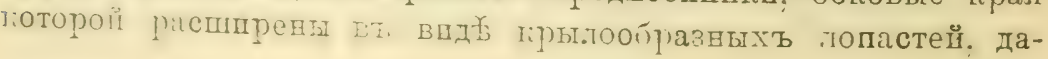


леко заходящпх за освовавіе па,цирылій ш пи другия прцзнакамъ.

Блпяе всего вашъь вшдъ стопть къ 1 . lergrothianus Kin, отъ

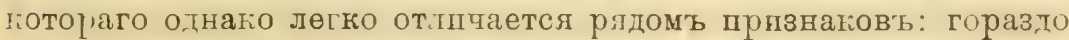

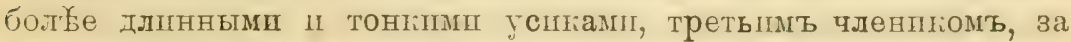
псллюченіемъ его основанія, бълаго цвб̆та, значительно менбе

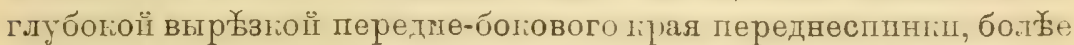
длпннымі, но менбе пирогімп боковыми лопастями передне-

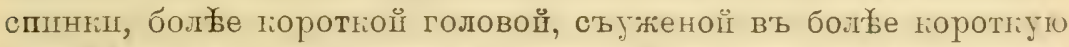

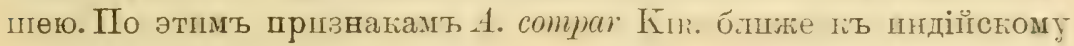

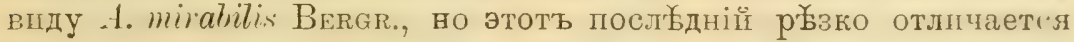
боловыми гіраями сегментовт брюшиа, раздтітенным на три острія, широкшмь щитшіомъ п тругимп признапами ил ие иожетъ быть съ нимъ смо्্ेшанъ.

Географическое распространеніе. Подоб́но свонм сородичамъ видъ этоть пршнадлежить фоун务 Восточной Азіп пा найдент

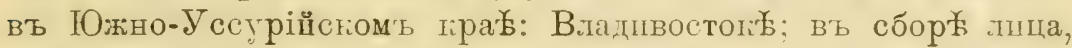
отирывшаго этотъ вщдъ есть татіне и предыдущій відъ, что до-

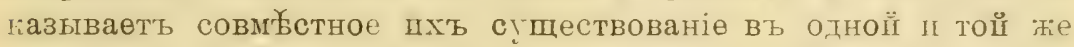

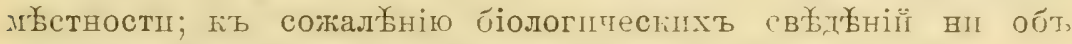
одномъ пзъ нихъ мы не пмкемъ.

\section{Aradus transiens u. sp.}

(Табл. I, (үпг. 10).

Діагнозъ. Corpus late-ovale, nigro-tuscum, maculis ad angulus anticos pronoti, liemelytris claro, venis in parte posteriore corii, corio basi et apice maculisque inter venas corii nigris excepti:angulis apicalibus segmentorum connexivi nec non mar winibus interioribus loborum lateralium segmenti septimi abdominis sordide-fusco-albidis.

Caput longitudini suae aequilatum, prolongatione antica cras:a, longa, lobis literalibus brevibus, crassis, apice acutis et recurratis, margine exteriore muticis; tuberculis anteocularibus mannis, obtusis; lobis temporalibus obtusis, prominulis; capite pone oculos parti anteoculari aequilato, lein subito in collum lrevissimum attenuato.

Antennae sat longae, valula incrassatae, dense veruculosae, articulo primo reliquis tenuiore. latitudine sua inplo longiore: 
articulu secundo crascissino. medio quam basi et apice crassiore. quam articulus tertius $1 / 3$ longiore, articulo tertio secundo vix tenuiore, quam articulus quartus ${ }^{1}$ :; longiore, articulo quarto tertio multo tenuiore, fere laevi, apice albido-tomentoso. lone piloso.

Rostrum coxas anticas haud attingens.

Pronotum longitudine sua duplo latius, margine postico late et profunde sinuato, marginibus lateralibus crenulatis, reflexis. rotundatis. antice profunde sinuatis, apicen versus fortiter angustatis: anculis anticis extrorsum prominentibus, rotundatis. marginibus lateralibus ante melium macula oblonga sordide fuscoalbida ornatis: carinis elevatis. rerrucosis, parallelis: disco pronoti postice transversim rugos".

Scutellum latum. apice acuminatum, flavescens: marginibus alte eleratis apice flaris: disco basi conrexu, postice transversim rugiosu.

Hemelytra basi fortiter dilatata. reflexa, crenulata: pars dilatata $1 / 3$ longitudinis toti corii occupans, dein hemelytra valde angustata; corio scutello minus quam iluplo lougiore, sordide fusco-albido, clavo, basi corii costisque in parte posteriore nec non maculis in parte media et posteriore corii inter costas niwris: membrana fuscente-nigra. basi et prope anculum apicalem corii maculis ferrugineis prierlita; renis simplicibus. solum apice conjunctis, pallide cingulatis.

Cmmexiruni marginibus lateralibus segmentorum abdoninalium rotundatis, crenulatis, angulis apicalibus prominentibus. rotundati-: connexivo flavo-ferrugineo, marrinibus lateralibus late niwris, angulis pallilis: lobis lateralibus sementi septimi nigris. marginibus interioribus late albis.

Pedes fusci, femoribus tibiisque basi et apice pallidis.

o. Segmentum rentrale quintum margine postico fortiter ar"uato-sinuato: segmentum sextum sommento quinto ${ }^{1}:$ breviore. laterihus suis distincte hrovins: pars liscoidalis segmenti sexti thansversa. lobi laterales apice rotundati; segmentum septimum sexto atequilongum ot segmento octavo duplo longius: lobi laterales longici et lati, fere orliculares, marginihus interioribus regulariter rotundatis, parte dinidia contiguis dein diverentibus: marcinilus exterioribus rotundatis.

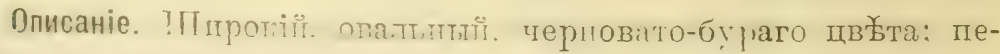
редпеппна въ верппныхъ углахъ; вершина питика, над- 


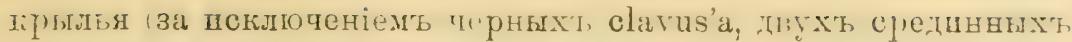

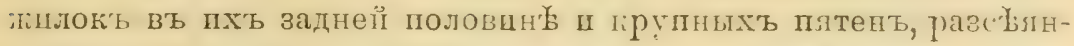
выхь по всему corium'y), вершинные углы сегментов' conneхіvum'a II внутренніе ґрая боковыхъ лоплстеї седьмого сегмевта - грязно буровато-бълаго цв'ьта.

Голова одшнажово развптая въ длину п пирину; пөредніц отростокь ељ толстый. длпницй, значптельно заходяцій за вер-

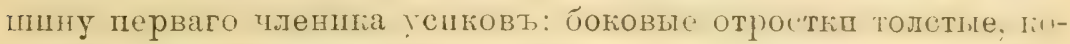
ротғіе, заостренныя вершпни пхь загнуты слегка внутрг. внбатпій край шхъ не вооруженный, но на всемъ протяженіи спльво

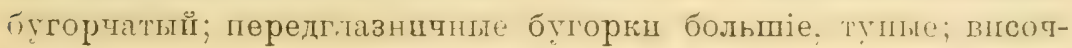
ные отросткі тупые, оттлнутые назадь, тапь что голова позади глазъ почти такой жө ширпны, какъ п перөдъ глазами, затеќьь сразу съуживающаяся въ ғороткую, тонкую шею.

Усшкп длинные, очень толстые, густо покрытле шипикамн; первый членпкъ ихъ тоньпе другихь, ширина его вдвое короче длпны, второї членшкъ самыц̆ толстый, по сөредын占 за-

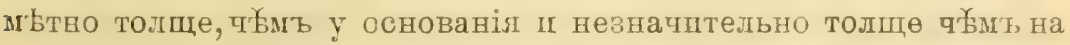

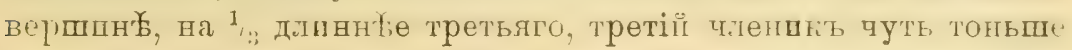
в'торого I гораздо толще кагъ перваго, таєь I четвөртаго, ва 1.; длинняе четвертаго, четвертый тонкій, значптельно тоньпе

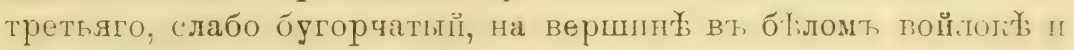
c’ь длинными волоскамн.

Хоботокъ не доходпть до ляпекъ передншхъ ногъ.

Переднеспина вдвое пире своей длпны, задній край ея ст

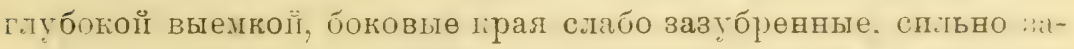
гнутые, округленные, вперөти съ спльної вцелгої. пь верпинт:

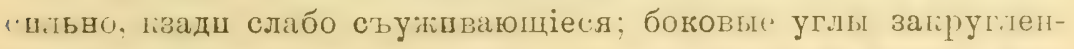

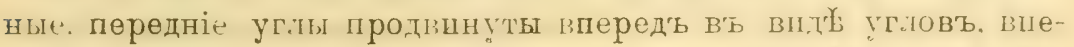
реди закругленныхуь, ст, вершиной нанравленой кт внь: йо-

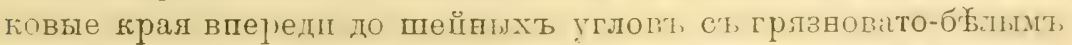

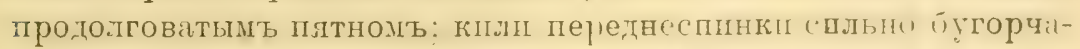
тые. высоло пршподняте. паралтылные; повертист, переднеспинди у основанія почеречно-моршпнистал.

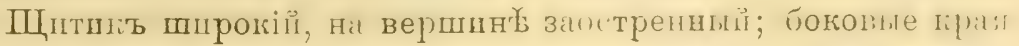
его высоғо прпподнятые, у верипны тілтагы пықа; поверх-

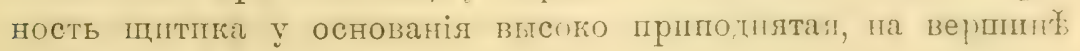
поперечно-морщиншстая.

Надкрылья у освованія сильно расшпренныя, загнутыя, мелко зазубренныя, дальше на остальныхт $2 /$, своей дипвы 


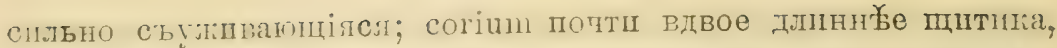

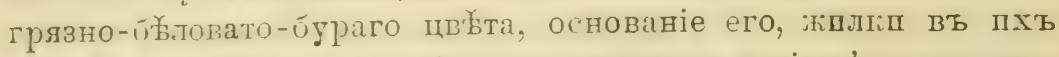
задней пасти п плтна особенно у вершпны согіum'а вдоль жъштоль, талже весь clavus - терные; membrana-буровато-черная, v ея основаніл и возле вершины согінт'а - желтоватыя пятна,

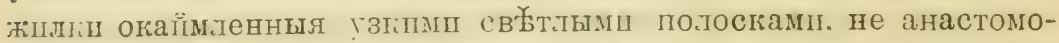
:आ1р)ющіяся.

Гоковые края сегментовъ connexivиm’а закруглевные, мегко зазуборенные: вершшнныө углы сегментовъ выдающіе, закругленные; поверхность connexivum'a ;ғелтовато-и́уроватая, јоковые края сегментовь широко огаймленные чернымъ, верппнные углы сегментовъ ст желтопато-буроватымш пятнамп; внутренніе ґрая боковыхъ попастей седьмого сегмента съ большимъ бълымъ пятномъ.

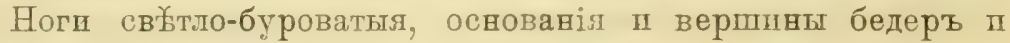
голеней б́ бловатыя.

Снизу голова, грудь, псключал плтна у переднпхт угловъ, I боковые края йрюшка буровато-черние, брюпно красноватобуроe.

○. Нөпвв

q. Задній край пятаго о́рюпного сегмента сшльно дугообразно выгнүтый; серединная тинія пестого сегмента на 1/8 корочо пятаго II тороче свопхь боговыхь гіраевъ; дискоидальная уасть шегтого сегмента сиььн поперечная; боковыя лопасти на вер-

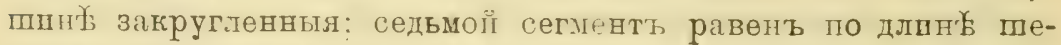
стому п вдвое дливн пирокія, почтп круглпя. внутренніе края пхъ правильно за-

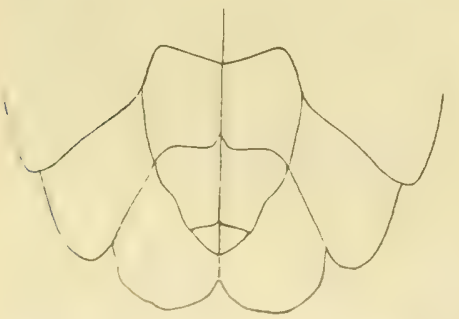

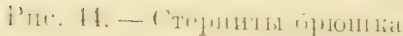
VI-VIII. Aradus transiens $\mathrm{K}_{\mathrm{IR}}$. . кругтенные, до $1 / 2$ своего протяженія сопрпкасаюіеся, далье płзко расходящіеся; задніе края загругленные.

Длива - 7 милл., пгиргва. бртопюка - 3,6 мшлл.

Сравнительныя замьтки. Aractus transiens m. по строенію усшковъ, второй II третії члевпкп поторыхь очень значптельно

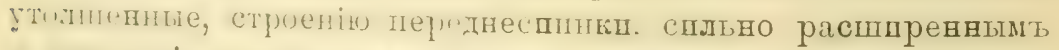

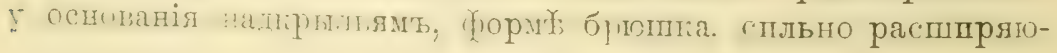


плауос: твади, правильно округленнаго. сь вершинными углам сегментовь закругленнымш; выдапюшмисл п другим прпзнакамъ легко отлічается отъ встхь другшхъ вндовъ.

Оть всьхъ мв务 пзв

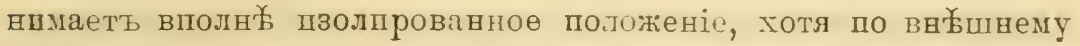

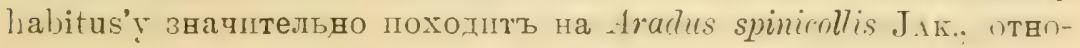
сящагося совершенно къ другої грушпо рода.

Географическое распространеніе. Этоть, Вшдъ найленъ въ Н)ноУссурійскомъ крах⿱宀⿻三丨。

\section{Aradus crenatus SAr. 1831.}

Aradus crenatus SAI New Harmony Indiana, Dec. 1831; Compl. Writ., 1, p. 352. 1859.

Aradus conspicuus H.-S. Nomencl, entom., p. 59. 1835.

Aradus corticalis H.-S. Wanz. Ins., V, p. 90, f. 538. 1839 (nec Lins.). - KoL. Mel. entom., p. 438, sp. 222. 1856.

Aradus dilatatus Duf. Ann. Soc. Ent. Fr., 18t4, p. t5̃ t, to 10, f. 1.-Finb. Eur. Hem., p. 113. 1861. - Reur. Öfv. Kongl. Vet.-Akad. Förh., 1872, oํ 5, p. 53. - Рот. Synops. de Hém.-Hétér. de Fr., I, p. 133. 1879. - Rect. Ent. Tidskr., 1882, p. 77.

Aradus annulipes Вон. Öfv. Vet-Akad. Förb., 1852, p. 25.

\section{Џауинтическая литература, насающаяса Россін.}

Aradus dilatatus JA . Rev. Russ. d'Ent., VII, 1907, p. 194 ('Tauria: Olsuj). Aradus corticatis KoL. Nelet. entom., p. 438.1856 (Transcaucasia: Tillis).

Aradus ditatatus Honv. in Sitzungsb. d. naturw. Gesellsch. "Jsis" in Dresden, 1879, Heft. 1, p. 95 (Transcaucasia: Suram, Ak Bulak).-JAк. Tpyд. Pyсcк. Эит. Общ., XII, p. 112, 1879 (Transcaucasia: Derbent),- Horv. in Radde. Die Fauna und Flora des Südrestlichen Caspi-Gebietes, p. 252. 1886 (Talysh: Lenkoran).

\section{Энземпляры Зоологичеснаго Музея.}

Sine datis (q). Purox.

Italia (q). Puros.

Lugano (q). Putor.

Morea. Hagios Wlassis. (2q). Brexske.

Austria ( $($ ) .

Carniolia (ㅇ).

Hercynia (Q).

Tauria: Olsuj (prope Sevastopol), 25. T. 1907 (9). ZABNIX.

Caucasus (2 o). Kolenati.

Caucasus: Derbent $(2 \bar{\sigma}, \mathbf{1} q)$. Korarov.

Caucasus: Lagodechi. 1896 (ㅇ). MLokosievitsm. 
Caucasus: Lagodechi. 2. T. 1912 (q). Mromosinruscis.

Caucasus: Ljulakeran, distr. Lenkoran. 15. V. 1909 (q). Kreıtshexko. Caucasus: Sym, distr. Lenkoran. 6. V. 1909 (Q). Kiritshenko. Patria ignota $(10,4$, $)$.

Діагнозъ. Corpus late-orale, retrorsun fortiter dilatatum iq!: cinnamomeun, fusco-rariegatum.

Caput latitudine sua paullo longius. prolongatione antica brevi. crassa: lobi. lateralibus loncris. hand crassis, apice acutis. margine externo denticulo armatis: tulerculis anteocularibus sat acutis, distinctis: lobis temporalibus ol,tusis: capite pone oculos parti anteoculari paullo angustiore.

Antennae longae, sat tenues, unicolores; articulo secundo tertio sesqui longiore, basi quam apice vix crassiore, articulo tertin quarto $1 / 5$ longiore.

Rostrum basin prosterni attingens.

Pronotum longitudine sua magis quam duplo latius, medio latitudini hemelytrorum fere aequilatum, margine postico pr.funde sinuato, marginibus lateralibus lentatis, retlexis. obtusanwulariter rotundatis, basin et apicem rersus fortiter angustatis: carinis lateralibus medio vix approximatis.

Scutellum elongatum, sat angustum, apice acuminatum, marrinibus elevatis.

Hemelytra basi dilatata, apicem versus fortissime angustata, membrana dilute fusca, nigro-maculata.

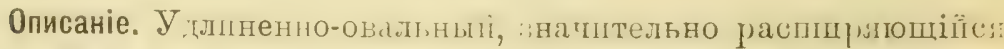

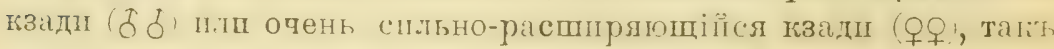
что ппрпна брюшка, едва на 1/5, короче своей длины, корпчневаго две́та.

Голова немного дляннбе своеі亡 ширины, передній отростопт ея сжатыі сь боковъ, спльно возвышающіпіся, заходящіі за вер,пин перваго членићі успковъ: поковые отростки лороткі

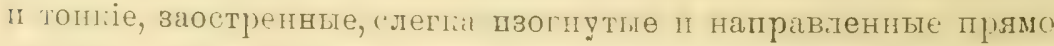

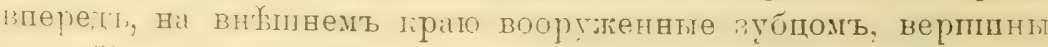
шхъ боловатыя; прөдглазншчные зубцы довольно острые; височные отростип шпрокіе, тупые.

У спки длинвые пі сравнительно тонкіе, одноцво̆тные; пер-

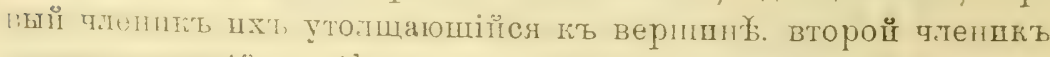

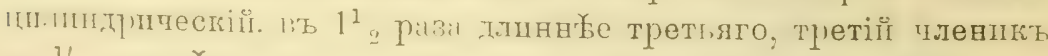

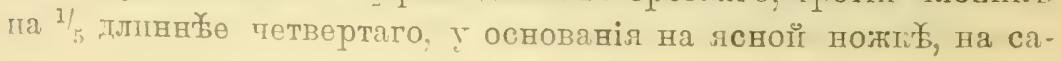




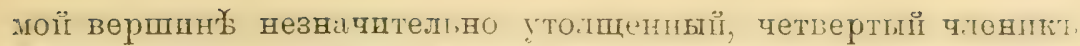
волосшстый, къ вершпны спабо утолщалойся, заостреннии.

Хоботокъ доходпть до основанія переднегрудп.

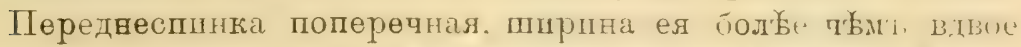
пшре своей длшны, вадній край ея ст, пирокой втемкой, боговые края расширевы въ тупой уголь, загнутые, неправпььи

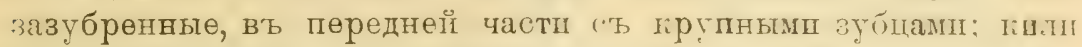
переднеспинп толстие, бугорчатие, боковые кпереди укоро-

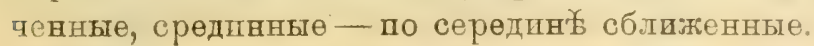

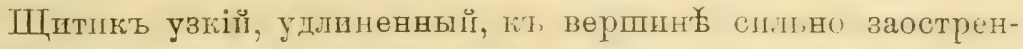
нып, боковые края сильно вздутые, приподнятые.

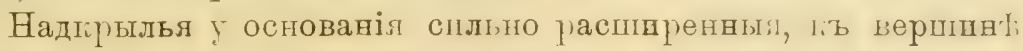
спльно съуживающіяся, въ бурыхъ пятнахъ, доходящія до

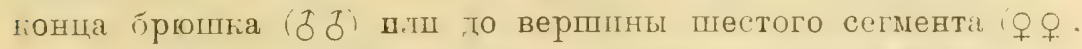
corium вдвое длиннеке пптика, membrana свътло-бурая. Вт. темныхъ пятнахъ.

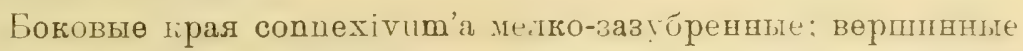
углы сегментовь закругленные, чуть выступающіе: по середшнек сегментов' connexivиm'а находятся неправильно-треуго.ьвыя. күупныя, гладкія вдавлевія, позадп которпхь лежатъ во всю длпну сегмента вытянутыя, голюеобразныл, прдподнятыя во:выпенія.

Снизу темно-коршчневыц въ области головы II груди, брюнко красновато-бурое; сь чернымь пятномь на кандомт

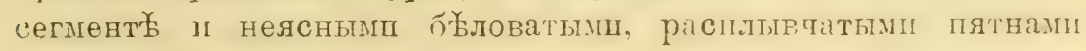
возл年 внйтняно жрая.

Ногц буроватыя, въ области вертлуговь, а также вершинныя кольца бетерь, кольц возлек्, основанія ш верлины голеней — быловато-желтыл.

ઈ. Пестой брюпной сегменть съ боковымш лопастями не

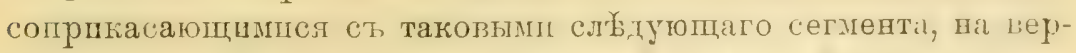

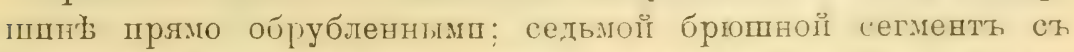
боковыми допастлмп загнутыми нверху, внбпній, край нхю, лосо-направленный, прямой, затній прай ст едва ныдапшим:

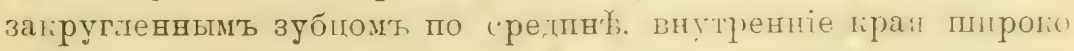

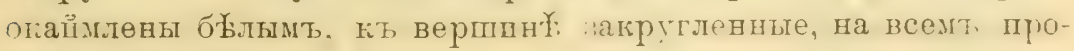
тяженіп расходящіесл.

q. Шестий брюшной сегменть равень, по средниї линіи иятому сөгменту п на $1 / 2$ длиннйе седьмого, боковыл лопасти его не догодять до уровня вершины восьмого сегмента; седьмой 


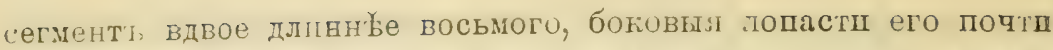
гва,тратныл, внутүениіе края пхт расходящіеся подъ прямымъ угломь, вноㅎв르 края почти прямые, съ чуть выдающимся, тупымъ зубцомъ по середине́.

Ђ. Длшна - 8 мплл., ширшна брюшка - 3,5 мшлл.

‥ Длина - 9,5-9,8 милл., ширіна бргшка -5 милл.

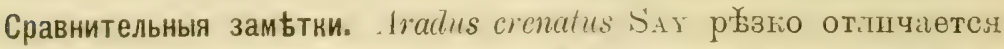

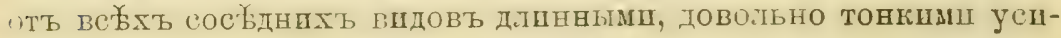
камп корпчневатаго цвбта, длпнным четвертым членпкомъ успковъ, который то.тько на ${ }^{1}$; короче третьяго, сильно јаспирөннымъ брюшкомъ.

Географичесное распространеніе. Этотт, ппть первоначально

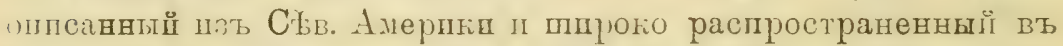
Запатної Европ年, въ предъ.тахь Россіп ветрбчаетсл тольғо вт,

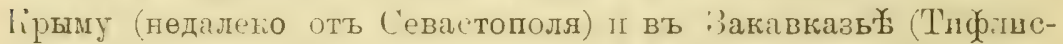
ская губ., Дагестанъ, Талышъ). Встрғыпается таюже въ С‡в. Персіп.

Образъ жизни. Указмваетея різипчнымп авторами діл иногихъ деревьевъ: груши, дуба, бука, ппхты.

\subsection{Aradus betulinús FALI. 1829}

Aradus betulinus Fald. Hem. Suec. Cim., p. 135. 1829. - R. F. S.iнlb, Mon. Geoc. Fenn., p. 142. 1818.-Freb. Eur. Hem., p. 113. 1861.-Reur. Öfv. Kongl. Vet.-Akad. Förh., 1872, ㅊó 5, p. 53. - Pст. Synops. Hém.-Hét. de Fr., I, p. 133. 1879. - Reut. Ent. Tidskr., 1882, p. 78. - Bergr. Rev. d'Ent, 1887, p. 244.

Aradus brevicollis H.-S. Wanz. Ins, V, p. 94, f. 543. 1839 (nec FALt.).

\section{Фаунистическая литература, касающаяея Россіи.}

Aradus betulinus J. SAHLB. Medd. Soc. Faun. Fl. fenn., VII, 1881, p. 41 (Fennia: Yläne, Teisko, Kuusamo). - Reut. Öfr. Vet.-Akad. Förh., 1872, 시 ó, p. 55 (Fennia: Tavastland); Entom. Tidskr., III, 1882, p. 78 (Fennia: Abo). - Krr. Rev. Russ. d'Ent., X, 1910, p. 12 (gub. Vologda, distr. Velsk).-JAK. Bull. Soc. Nat. Mosc, 1875, IV, p. 262 (St.-Petersburg).Ars. Cat. ins. prov. Mohilev., 1902, стр. 67 (Mogilev). -J. SАнцв. Kongl. Svensk, Vet.-Akad. Handl., XVI, ㅅ․ 4, 1878, p. 21 (Enisejsk).

Энземпляры Зоологическаго Музея.

Moldavia: Brosteni in montibus Karpathicis ( $q$ ).

Moldavia: Cruce in montibus Karpathicis ( 3 J, 3 우). IIontandon. 
Fennia: Yälne.(). Reuter.

Fennia: T'erioki. 22. V. 1897 (q). Braxchi.

St.-Petersburg $(\bar{\delta}, \underline{+})$.

St.-Petersburg (ㅇ). Hunmel.

St.-Petersburg (Q). Овект.

Gub. St.-Petersburg: Preobrazhenskoje, distr. Luga. 1t. V. 1898 ( $\bar{\sigma}$ ). Puesk c. Gub. Smolersk: Ruporovo prope Bjelyj. 1-3. VI. 1901 (q). Maxmor.

Gub. Perm, distr. Kamyshlov, Parschina. 14. IX. 186t (ठ). Czenavowski.

Gub. Perm, distr. Kamyshlov, Pylaevo. 18. IX ( $($, $q$ ). Czenanowski.

Gub. Tobolsk, distr. Tjumen: Tugulymskoje. 22. IX. 1864 (1. う, 3 む). Czek৯NOWSKI.

Діагно3ъ. Corpus orale, retrorsum parum dilatatum, nigricans, articulo primo antennarum, scutello apice late, angulis apicalibus segmentorum connexivi, marginibus interioribus loborum lateralium segmenti sexti pedibusque interdum pallide ferrugineis.

Ciput latitudine sua latius, prolongatione antical longa, latrrilus compressa, lobis lateralibus apice acutis, fortitre direrorentilus, margine exteriore muticis; tuberculis antencularibus distinctis; lobis temporalibus obtusis; capite pone oculos parte anteoculari fere aequilato.

Antennae crassae, sat longae, articulo secundo tertio et quarto simul sumtis aequilongo, articulo tertio quarto $1 / 3$ longiore.

Rostrum coxas anticas attingens.

Pronotum longitudine sua magis quam duplo latius, margine posteriore profunde sinuato, marginibus lateralibus rotumbatir. dentatis, apicen versus fortiter hasin versus minus fortiter angustatis, carinis subparallelis.

Scutellum angustum, elongato-triangeulare, marginibus lateralilus eleratis, apice late flavo-ferruginen, obtuse rotundato. HemeJytra basi parum dilata, reflexa; membrana nigra, venis hyalinocingulatis.

Описаніе. Овальный, порпчневато-черноватаго цвъ̆а, больное пятно на вершине щитпа, задніе углы сегментовь сомпехіvим'а и внутренніе жрая боловыхь лопастеї сетьмого орюшного сегмента-бъловато-экелтаго цвљта.

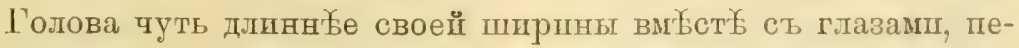

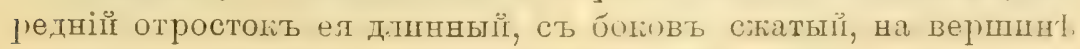
довильно острый боковые отростіл динные, острие, расходи-

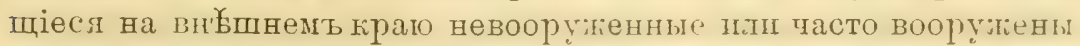
неяснымъ, слабо выраженнымъ б́угорномъ, самая верпина ижн

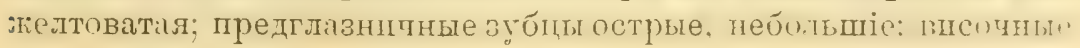


отросткп короткіе, толстые, выдающіеся, такь что голова позади глазъ такой же ширины какъ п передъ глазамп. У сикп толетые, но довольно короткіе, черные, первый членщкь их'ь желтовато-

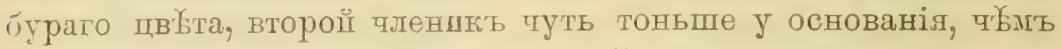

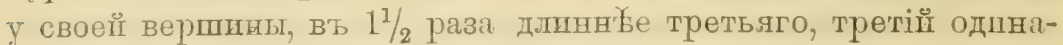
юовой толщины со вторымъ, цитндрпческій, четвертый на 1/3 короче третьяго.

Хоботоћь доходпть до ляшекъ переднпхь ногь.

Переднеспшна поперечнал, вдвое шире своей дпшы; передній и задніці края ея глубоко выемчатые, боковые края по середпн ш шроко закруленные, ппереди сильо съуживаюпіеся, пвади незначштельно съужниваюшіесл, на всемь протяженіп неправпльно зубчатые, не загнутые; пит почти параллельные, спльно пршподнытые, бугорчатые.

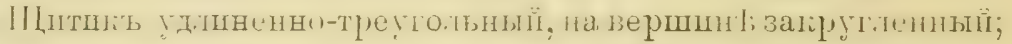
боковые грая его прппотнятые, прямые (ठる) пли поти прямые (qо), поверхность щштпюа у основанія прпподнятая.

Надкрылья у основанія сшьно распиренныл, загнутыя, зизуббенныл; согіши почтп вдвое глиннłе щитпк; membrana терная, жнтки ея свттыля.

Connехіvum съ двумя черными пятнам на каждомь сегмент боловые края его мелко зазубренные, задніе углы отдъльныхь сегментовъ чуть выдающіеся.

Ноги бурыл, вершины бедерь г голеней бұловато-желтыл.

Ј. Седььмой брюшної сегменть сильо выпуклый, боновыл лопастп его загнуты вверхь, внутренніе грая пхт пироко окаи-

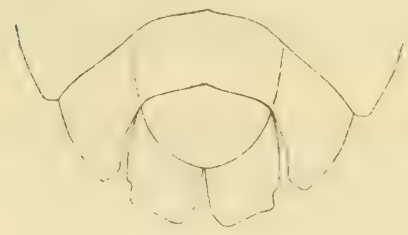

Pric. 45. - Стерниты ортониiа VI-VII. Aradus betulinus F.inx. 3 изт С--Петербургекой губ.).

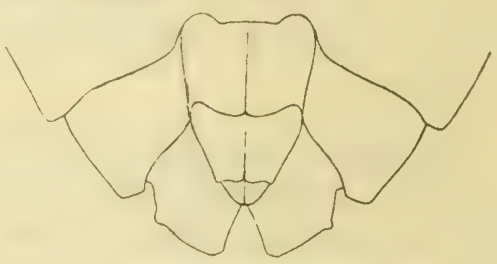

Pнс. 46.-Стерниты бргшка VI-VIII. Arodus betulines FaLl. $Q$ (нат Kapпатт $)_{2}$,

маен желтықъ, слегка закругленные, почти отъ самаго основанія постепенно расходящіеся, задній краї прямой, чуть вогнутиі, зазуоренный, бокової траї прлмой, съ спльной выемкой у 


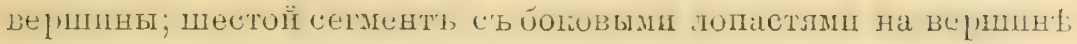
эг.товато-закругленнымш, по́руб́.тенным, отстомщим оть :10шастей слекдующаго сегмевта.

․ Средннная линія пятаго орюшного сегмента равна по

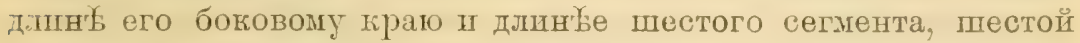
сегменть на $1 / 2$ длинне се седього, боғовыя лопасті его слегка зимдять за уровень вершшны досього сегмента; седьмой сегментъ вдвое длиннеңе восьмого, боковыя лопасти его съ внутревними ғралми, довольно широко јазставленными, прямыми,

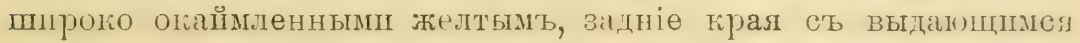
вубцомъ; боковыя лопасти шестого сегманта довольно далеко выдаютея за лопасти седьмого сегмента.

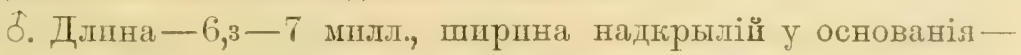
$\stackrel{2}{, 5}$ MIIIII.

‥ Длина- $8,5-9$ мплл., ширина надкрылії у основаніл 3,5 MIJI.

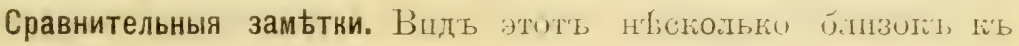
A. corticalis (LinN.), но хорошо отличаетел отъ него боль⿱㇒㠯 толстыми усиками, болье удлиненнымь п узкимь щцтикомъ, вер-

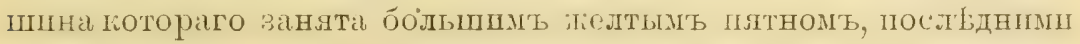
сегментали брюшка и пхь боковыми лопастями, совершенно разіпчнымь образомь уетроенныхъ у обопхь видов'

Географическое распространеніе. Вить этоть пироко jиспри-

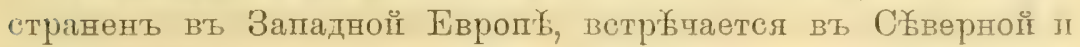
Средней Россіп пи въ Спбирш.

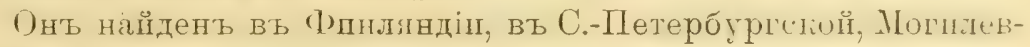

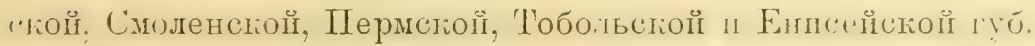

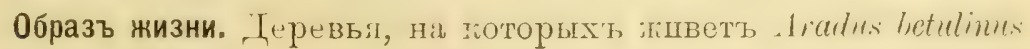

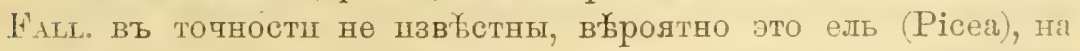
которой находпль этоть вндь въ Румыніи Мохтахрох.

\section{Aradus planus FABR, 1803 .}

Arudus plemus FAir. Syst. Rhyng., p. 120. 1803. - Kol. Melet. entom., p. 439. sp. 223. 1856. - Fieß. Eur. Hem., p. 112. 1861.

Aradus montivagus Krrז. Canad. Entom., XLI, p. 30. $190 \%$.

\section{Фауниспеская литература, касанщаяе Россін.}

РАсzовк з Зап. Кіевет. Общ. Естеств., X, 2, p. 417 (gub. Volyn).

Kol. loc. cit., p. 140 (Transcaucasia: Dagestan; Sibiria: Barnaul). 
Дiarн03ъ. Fusco-niger; abdomine pracsertim inferne ferrugineo, pronoti carinis ad basin limboque basali, apice scutelli, marginibus rel angulis apicalibus segmentorm abtominis ner num hemblytris sordide pallilo-ochraceis, basi et apice clari nigris; corio medio nigro- et ochraceo-reticulato, apice suturaque membranae nigra; capite latitudine basali cum oculis distincte longrore, dente anteoculari obtusissimo rix distinguendo, spinis lattrallibus acutis externe muticis, subsinuatis; rostro prosterni al]icem attingente, articulo primo rostri medium capitis vix attingente; antennis crassis, articulo secumlo subaequaliter incrassato. wapite ab oculis ad apicem frolongationis aequilongo et duobus articulis ultimis simul sumtis etian longitudine aequali; pronoti lateribus arcuato-rotundatis, suhtilius denticulatis, angulis anticis obtusis, hand froductis, margine postico medio fortiter sinuato, sentello anguste triangulare, pronoto fere dimidio longiore, lateribus rectis, reflexis, disco concalve, apice ohtuso-truncato; perlilus fusco-testaceis rel ferrugineis, cuxis trochanteribusque fallidioribus (sec. REUTER).

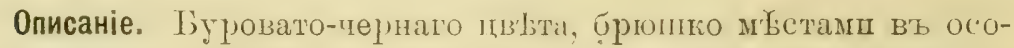
бенности на ниіней поверхности ржавчнннаго цв'ьта; кили переднеспнни въ залней пхъ части, также такъ основной гірай переднеспнкц, вершшна пштпй, задніе прал пи только вершинные углы сегментовъ cmnехігй'а и надкрыля грлзиго

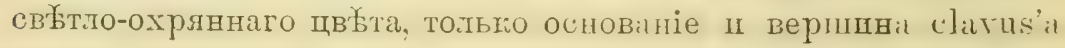
черные, серетпна согіuп'а съ че]ными полосамп, основаніе его II мембранальный шовъ - черные.

Голова длинная, длина ея яветвенно превышаеть ея ширцну; боғовые отростіп острые, на вн.ишнемь грап невооруженные, расхогящіеся; предглазниные отростки едва намбченные, сдва различпмые.

Хиготогь доходпть до основаніл пьереднегруди, его первый членікъ едва доходить до середины головы.

У спки толстые, второї членшкъ почтп равномебрно утол-

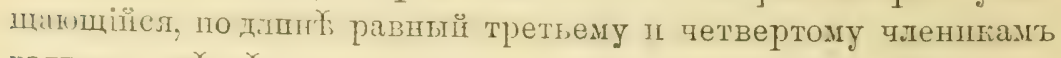

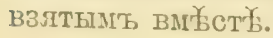

Переднеспина сь задншы траемь выемчатымь; боковые

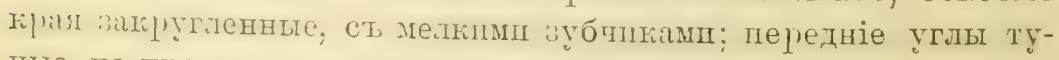
пые, не продвннутые впередъ.

ШЦпткь треугольный, узкій,на вершщне тупо обрублен- 


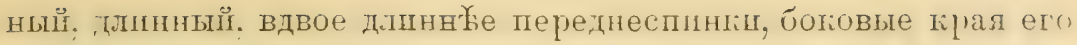
загнутые, прлмые: поверхность щитика у основинія вынуғтая. Ногц желтовато-бурыя шли ржавобурпя; ляшкш ІІ вертлуги болюе светлые.

$$
\text { Ділнна-8,5 мплл. }
$$
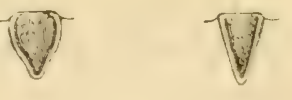

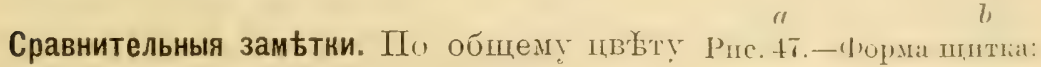

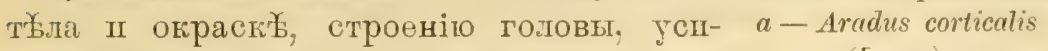
ковъ, хоботка, переднеспинкі, надкрыліі II брюшка видъ әтоть походпть на $A$. corticalis (LiNм.), но отлшчаетсл очень узкимт

(LINx.), b-Aradus planus FaBr. (puc. O. M. Reuter'a).

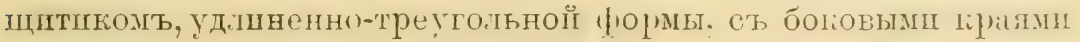
прямыни.

Подь шменемъ plamus у FАвпгсus'a фигурпрують два различныхъ вида. Первый огдсанный вт Entomologia systematici. emendata et aucta. T. IV. Hafniae. 1794 какъ Acanthia plana.

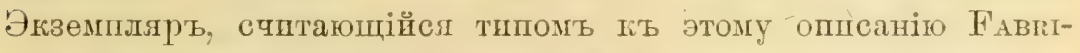

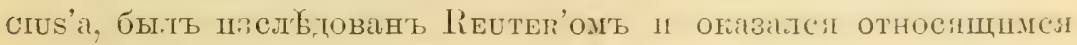

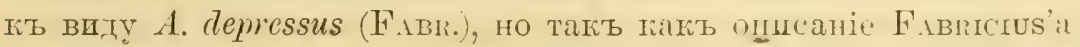
pасходитси сь этпмь әкземплиромь, то назвавіе: Acantlia plana HAвг. 1794 отнесено Línteriom i Revis. Synon. Heter. palacaret.: II, p. 232 отд. отт.) ґъ сшнонцмамъ A. depressus съ сомноңніемъ.

Позднеке въ Systema Rhyngotorum. Brunsvigiae. 1803. FAвигецs подь пменемь Aradus plame, даеть діагнозь тругог

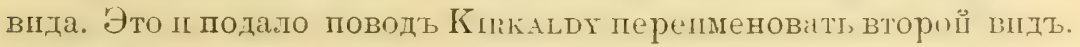
предложивь для него названіе $A$. montivagus.

Видъ этоть очень мало пзвю्стенъ, пороткіе діагнозы его дають Fabricius (1803), Kolesati (1856), Fiebef (1861) a Putun

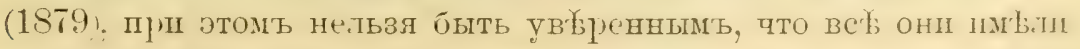
одшвъ ІІ тоть же видъ. Для даннаго выше опшсаніл п діагноза я воспользовался пюбезно предоставленным, мнж описаніемт

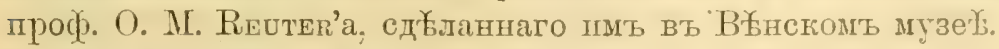

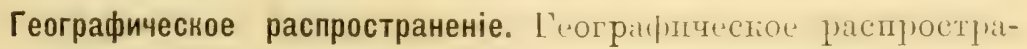

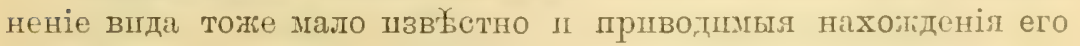

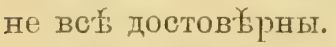

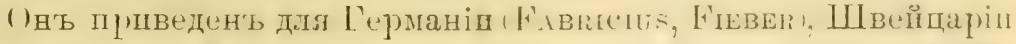

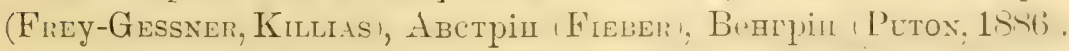

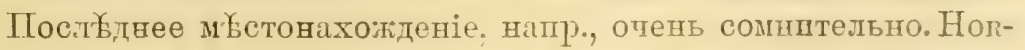

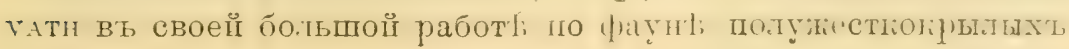

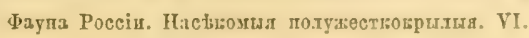




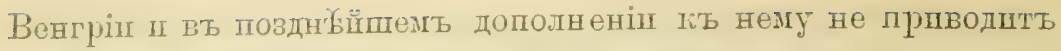
этого внда для мбетної фауны.

Русскія хиестонахожденія A. planus FАвг: Волынекая губ.

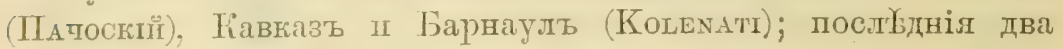
указанія тіажутея мю斿 сомнительными, первое безусловно нев ьрное.

\section{Aradus corticalis (LiNs.) 1758.}

Cimex corticatis Lrvy. Syst. Nat., өd. X, p. 442. 1758; Fauu. Sv., sp. 916. 1761. Acrenthia corticatis WoLfF ABBILD. Wanz., III, p. S7, tab. IX, f. 81. 1802. Aradus complanatus Berar. Handb. Ent, II, p. 256. 1835. - H.-S. Wanz. Ins., V, p. 95, f. 544. 1839 .

Aradus corticalis R. F. SAHLỉ. Mon. Geoc. Fenu., p. 142. 1848.- Flor Rhynch. Livl., 1, p. 388. 1860.-Fieb, Eur. Hem., j). 112. 1861.-Dougr. Sc. Brit. Hemipt., p. 272: 1865. - Reut. Öfr. Kongl. Vet.-Akad. Förh., 1872, № 5, 1. 54.-SAund. Trans. Ent. Soc. Lond., 1875, p. 254.-Put. Synops.

- Hémipt.-Hétér. de Fr., I, p. 133. 1879. - Reut. Ent. Tidskr., 1882, p. 78. - Bercir. Rev. d'Ent., 1887, p. 244. - Reut. Rev. Syn. Het. palaearct., II, p. 238, Jo 192. 1888. - SAund. Hem. Het. Br., p. 138, t. 13, f. 13, 1892.

\section{Фауинтическая литература, касающаяея Россіи.}

Aradus corticulis R. F. SAmLi. Mon. Geoc. Fenu, p. 142. 1818 (Fennia tota). Reut. Öfv. Kongl. Vet.-Akad. Förh., 1872, № 5, p. 54 (Lapponia). J. SAнli. Medd. Soc. Fn. Fl. fenn., VII, 1881, p. 41 (Fennia: Vasa). Reut. Not. Sällsk. Faun. Fl. Fenu. förh., XI, 1870, p. 82 (Fennia: Pargas). - Reut. Entom. Tidskr., 1882, p. 78 (Fennia: Abo, Karelen, Södra, Osterbotten). - Flor Rlyuch. Livl, I, p. 388 (gub. Livland, Kurland).-Cederhelis Taun. Ingr. prodr., 1798, p. 269 (St.-Petersburg).Kir. Изв. Калужск. Обш. Изуч. Шршр. Мґстн. грал, I, 1912, стр. 71 (Kaluga). - Paczosr. Зап. Kieвег. Общ. Ест., X, 2, p. 417 (Kiev, gub. Volyn), - Horr. Bull. Soc. Ent. Ital., XIX, 1887, p. 282 (Podolia: Olgopol). - JARosch. Тр. Oб́m. Ест. Пршр. Харьт. Унив., VIII, 1874, P. 55 (Charkor, Konstantinovka in distr. Zmier).-JAK. Hor. Soc. Ent. Ross., IV, 1870, p. 148 (Gub. Simbirsk: Syzran; gub. Saratov: Chvalynsk, Sarepta; Orenburg).- GeBL. Bem. iib. Ins. Sib. in Ledebour's Reise durch Altai-Geb., 1830, p. 18 (Altaj). - J. SAHLB. Kongl. Sv. Vet.-Akad. Handl., XVI, 수 4, p. 21, 1878 Gub. Enisejsk: Enisejsk, Anziferovo $)_{-}-J_{A K}$. Hor. Soc. Ent. Ross., XXVII, 1893, p. 294 (Gub. Irkutsk: Kultuk). - JAK. Hor. Soc. Ent. Ross, XXXVI, 1903, p. 322 (Gub. Irkutsk: fl. Iret). - Kre. Rev. Russ. d'Ent., X, 1910, p. 81 (gub. Yologda, distr. Velsk et distr. U'stjuzhsk).-Krr. Rev. Russ. d'Ent., X, 1910, p. 179 (Gub. Tomsk: Kaltajskịj Bor, Meret).

Энземплары Зоологическаго Музея.

Berizal ( $\left.\sigma^{-1}\right)$. I'utox.

Simplon (2 $\bar{\delta}, 2$ O i. I'uton. 
Hercynia (Q).

Fennia (Q⿱中) .

St.-Petersburg (2 9$)$.

St.-Petersburg $(\widetilde{\jmath})$. HuMmex.

Gub. St.-Petersburg: Lebjazhje, distr. Petersof. ㄹ. VI. 1898. Norotorzev.

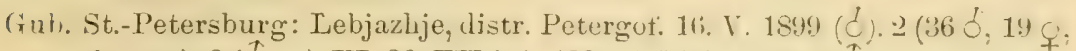

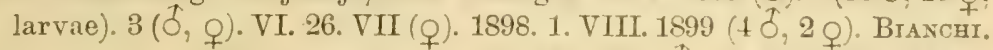

(iub. St.-Petersburg: Tshernaja Lachta. 28. VI. $1898\left(\frac{1}{2}\right.$ ). 21. VII. 1897 q) t. VI. $1899(\bar{\delta}, q)$. BIANChI.

Gub. St.-Petersburg: Preobrazhenskaja. 14. V. 1896 (q). MAzaliakI.

Gub. Novgorod, distr. Krest'zy: Voronja Gora. 11. V. 1898 (o). Sснипрт.

Gub. Novgorod: Bologoe. 19. VIII. 1904 (ठう, larvae). Zartzev.

Estonia (P).

Estonia: Shmezke. 7. IV. 1901 (o). M.AZARAKI.

Gub. Ljublin, Novaja Alexandria. 25. IV. 1911 (q). IL'Tnskis.

Gub. Moskva, distr. Ruzsk, lacus Glubokoe. 4. VI. 1901 (ठ). Kozhevмiкov.

Gub. Moskva, distr. Ruzsk: lacus Glubokoe. 6. VI. 1901 (ठ). Voronкоv.

Lisino (Q). SовоLEy.

Gub. Tambor: Morshansk, Ostrovka. 4. VI. 1868 (ㅇ). P. ChromaJA.

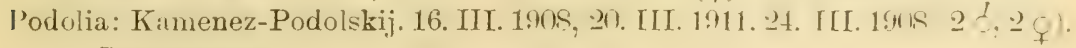
JAKLBOWSK.

Gub. et distr. Ufa. 27. V (ठ). St.ıbeus.

Kazan (ठ).

Charkov (ठ).

Gub. Charkov: Kupjansk (3 o). Ivaxov.

Rossia mer. (Q).

Gub. Tobolsk: Berezov. 19. V. 1909 (P). Zattzev.

Gub. Tobolsk, distr. Berezov, Shorkaly. 17. V. 1909 (Jarva). Zattzev.

Gub. Tomsk, distr. Mariinsk: Elizavetinskij Zavod. 15-30. VI. 1903 (q).

Gub. Tomsk, distr. Kuznezk, fl. Kajzas syst. Abakan. 3. VII. 1897 (१). W AGNER. $_{\text {G }}$

Gub. Tomsk, distr. Barnaul. 18. VI. 1911 (2 ठち). A gentova.

Gub. et distr. Tomsk: Semiluzhnoe. 10. VIII. 1908 (ठ). EmelJaxov.

Enisejsk (ठ゚, ᄋ).

Krasnojarsk (q). Кıвокт.

Gub. Enisejsk: Krasnojarsk ( $($ ).

Basicha, prope Krasnojarsk. 1895 (ð). Uгвтсн.

Gub. Irkutsk: Pashki (Q).

Gub. Irkutsk: Kultuk (2. J).

Gub. Trkutsk: Kultuk 21-23. V. 1898 ().

Gub. Irkutsk: Nikolajerskij Zavod. 25. V. 1899 (Q). Litristzev.

Gub. Irkutsk: fl. Bjelaja (q), Gartung.

Gub. Irkutsk: Padun in fl. Angara (Q). Czeканowskt.

Gub. Irkutsk: fl. Iret (2 $\delta$ ).

(rub. Irkutsk: Witimskoje Viski iq:

Bajkal mer.-orient. 1871 (ठ). Solskr.

Bajkal mer.-oce. 1871 (Q). SoI.skx. 
Sine datis (2 $\delta, 2$ o ). Puton.

Sine datis $(\delta)$. Reuter.

Sine datis $(6 \delta, 5$ Q $)$.

Діагнозъ. Corpus orale, retrorsum parum dilatatum, nigro-fuscum, margine pronoti ad augulos posticos, apice summo scutelli. lumelytıs hasi marulisque in angulis posticis segmentorum abdominalium sordide luteis; antenuarum articulo primo pedibusque ferrugineis.

Caput latitudine sua nonnibil lougius, prolongatione antica longa, crassa, sat lata; lobis lateralibus longis, acutis, valde divergentibus, margine "xteriue nuticis; tuberculis antencularihus parvis, lobis temporalibus parum prominentibus; capite pone oculos parti anteoculari fere aequilato.

Antennae crassae, sat longae; articulosecundo duobus ultimis vix lereviore.

Rostrum apicem prostermi attingens.

Prowotum lougitudine sua plus quam duplo latius; margine posteriore late et profunde sinuato, marginibus lateralibus rotundatis, dentatis, apicem versus fortiter, basin versus minus angustatis; carinis intermediis subparallelis, lateralibus basin versus divergentibus.

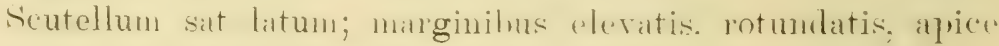
ipso flavo, disco medio convexo.

Hemelytra basi dilatata, reflexa.

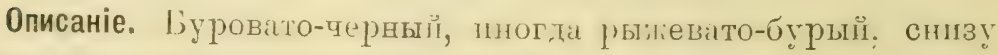

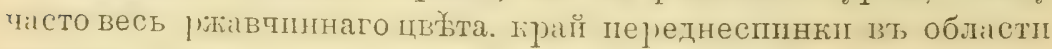

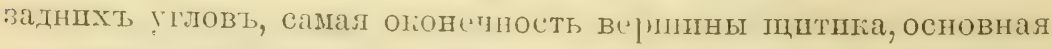
половдна нацкрыліі п пятна в’ заднихъ углахъ сегментов' бргока - грлзно-буровато-желтаго дв ғта.

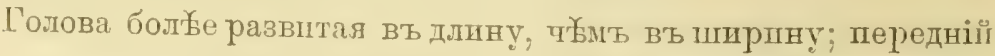
отростокь ея длпнныи, сжатый съ боковъ, далеко заходшть за

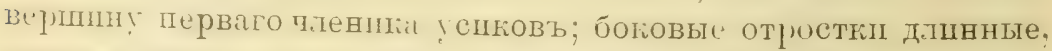
истрые: спльно расходлдіесл, на вн

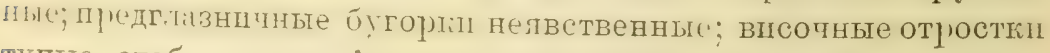
тупые, стабо выдапщеся, тапь что голова сейчасъ же позадп

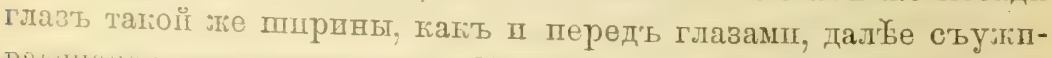

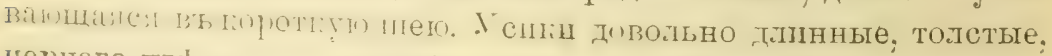
чернаго цвыта, пхь первыпі членикь немногпљ $(1 / 4)$ заходить за верпины боловыхь отростіовъ головы, второї qленштъ у осно- 


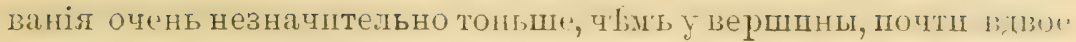

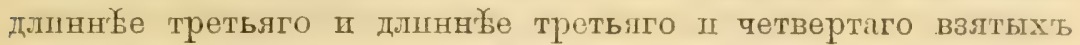

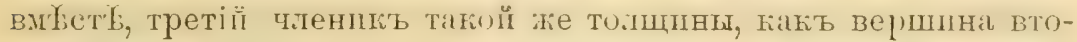

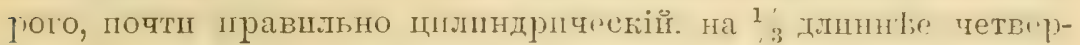

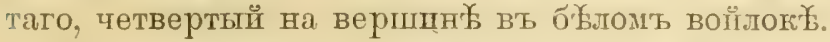

Хоботокъ немного заходить за ляшшп передншхь ногъ, чер-

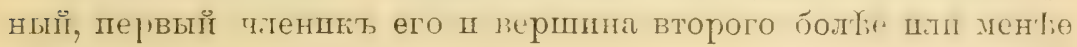
буроватые.

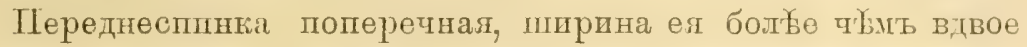
превышаеть тлпну, короче головы; передній край ел съ слабой,

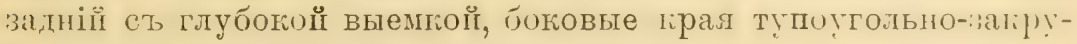
гленные, сшльо зубчатые, впереди чуть загнутые, кшереди спльно, піь основанію слабо съужнваюіесл; шеп̆ные углы ту-

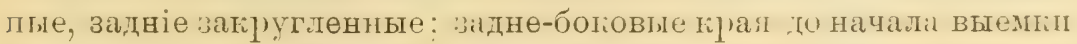
заднлго края, основаніл средшнныхъ жплей II два линейныя вздутія возл'з заднихь угловьь переднеспинки-буровато-жел-

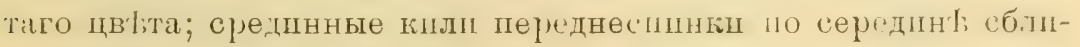
жөнные, боковые кь основанію расходящіесл.

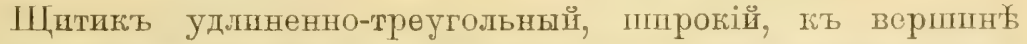
(легка сьужшвающйсл, самая ононечность его буровато-лелтал;

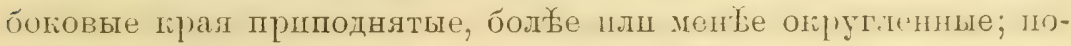
верхность щитшка у основанія приподнлтал.

Надірылья у основаніл довогьно спльно расширенным. Іізади

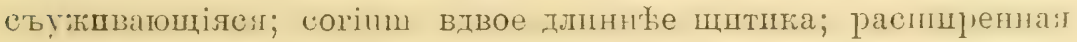

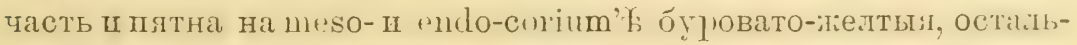
ная часть черная; membrana черная, у основанія, вдоль жилокљ I плтна межлу ними бұловатаго пвыта.

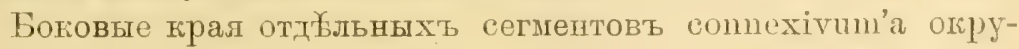
гленные, вершинвые углы чуть выдающіеся, закругленные, сь большими желтымп пятнами.

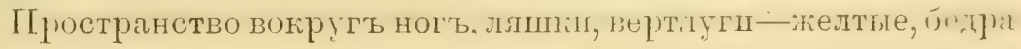
ногъ бурыя, голени болеке светтлыя.

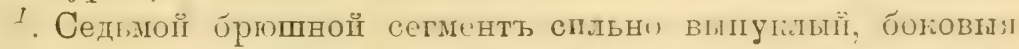

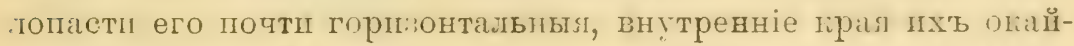
мленвые желтымь, зағругленные, слабоо рисходяшіссл, задніе прая ихт закргтенные, зазубенные, внғшніе края соприкасающеся съ лопастями шестого сегмента.

ұ. Плтый брютной сегментьь по средней пиніш пороче пиестого сегмента; шестой сегменть на ${ }_{2}^{1}$. тынице седьмого, боговыя лопасти его не доходять до уровня вершины восьмого сег- 
мента; седьмой сегменть иочти втүое длипнье восьмого, боковыл лопаети его сь внутреннши краями окаймленнымп желтымъ, пряльмш, расходящимия, задніе гірая гопастей заяубренные, "легта занрут.тение: б́ковыя липасти пестого сегмента очен!, незначительно выдагтся за лопасти сөдыого сегмента.

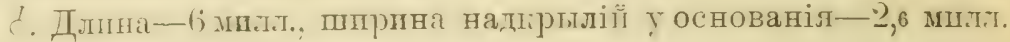

․ Пллина-7,8-8,6 милл.; ширнна надкрылії у основанія2,8 мா.I.

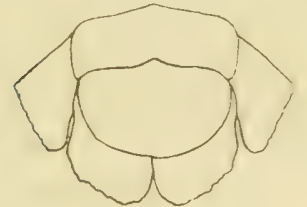

Pпс. 4S. - Стерниты бргешка VI-VII. Aradus corticalis (Lmxx.) के (пзт С.-Петербургекой губ.).

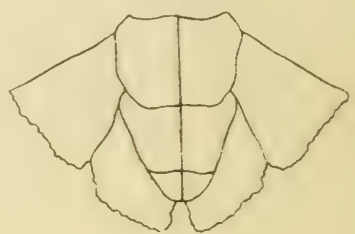

Przc. 49. - Стерншты бртила

VI-VIII. Aradus corticalis (Linx.) 오 (пзт C.-Петерйуримпоӥ губ.).

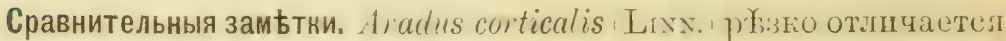

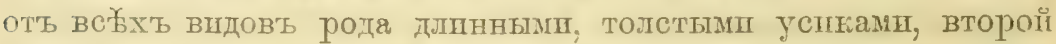

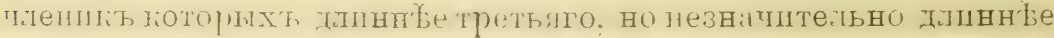
суммы III и IV-го членпновъ, острымш спльно расходяпимисл

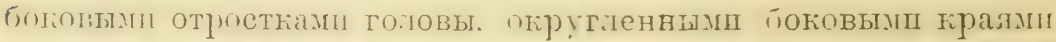
переднеспшнш ш другши прпзнакамп.

Оть блшзкшхь жъ непу вшдовъ: A. betulinus FAll, A. planus IiABr. II A. melas JАk. отличается признакамп, указанными при этихъ вшдахъ.

Географическое распространеніе. ШІпроно рияснрост]аненный по

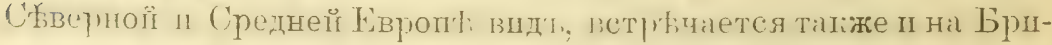
"анскпхь островахь.

Вь Россіп пшроко распространенъ вь Европейской части ел до южныхъ степеї п въ Спбнри до Байкала.

До спхъ порь найдень въ Јаппландіп, Фпнляндіп, Олонец-

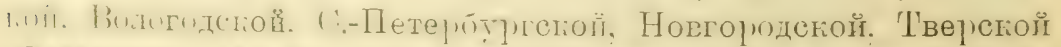

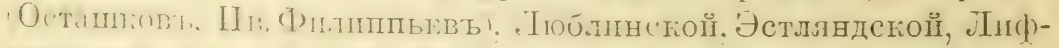

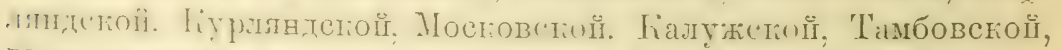

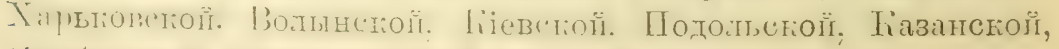

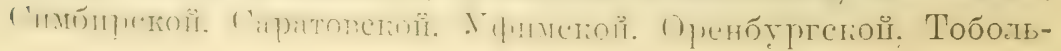




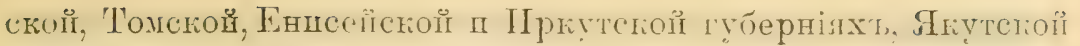
обл. (Якутскъ, Poppius).

0бразъ жизни. SAHLberg указывяеть на нахожденіө его на

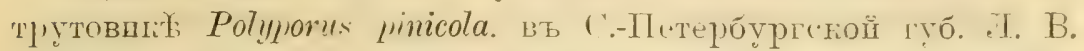

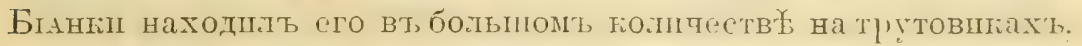
селящихся на пняхъ ерубленныхъ сосенъ. Въ Лнфляндіп п

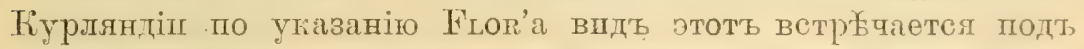
корою отмершпхъ Pinus silvestris.

\section{Aradus corticalis annulicornis FABr. 1808.}

Aradus annulicornis FABr. Syst. Rhyug., p. 118. 1803. - ErEB. Eur. Hem., p. 113. 1861. - Put. Synops. Hém.-Hétér. de Fr., I, p. 134. 1879.Reut. Rev. Synon. Het. palearct, II, p. 234, № 193. 1888 (ed. sep.). Aradus melanchoticus Pux. Synops. Hèm.-Héter. de Fr., I, p. 134. 1879. Aradus corticalis var. annulicornis BERGR. Rev. d'Ent., 1887, p. 245.

\section{Фаушистическая литература, касацщаяся Россіш.}

Aradus unnulicornis Jак. Труд. Русек. Энт. Общ., VIII, 1876, p. 70 (Sarepta). Aradus corticatis Jak. Rev. Russ. d'Ent., VII, 1907, p. 194 ('Tauria: Eni-Sala). Aradus annulicornis Horv. Sitzungsber. d. naturw. Gesellsch. Isis, 1879, p. 96 (Transcaucasia).

Aradus corticalis var. anmelicornis Horv. Rev. d'Ent., 1891, p. 72 (Ordubad).

\section{Энземпляры Зоологичеснаго Музея.}

Simplon (ठ). Putos.

Swiz (b).

Charkor (o).

Podolia: Kamenez-Podolskij 3. IV, 1910 (q). JAkuBowskr.

Gub. Charkov: Kupjansk (Q). Ivasor.

Gub. Saratov: Sarepta (2 3,3 o).

Tauria: Eni-Sala. 20. IV. 1907 (2 q). Christoforov.

Tauria (Q).

Transcaucasia: Nowyj-Aphon. 28. VI. 1900 (q). Voronkov.

Transcaucasia: Sucbum (q).

Transcaucasia: Batum $(20,8$ 우).

Transcaucasia: Borzhom $(23, q)$.

Gub. Irkutsk: Kultuk (q).

Transbaicalia: 'Troizkosaysk. VII. 1903 (q). Mrснхо.

Transbaicalia: Tshita. 16. V. 1912 (q). GArrIuuk.

Діагнозъ. Ut typus, sed articulo tertio antennarum albido, dimidio vel triente basali nigra excepta. 


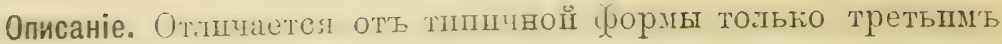

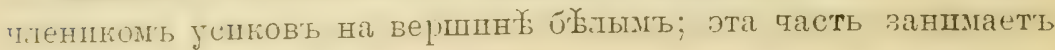
пногда половину успка пли $2 / 3$ его.

Сравнительныя замьтки. Эта форма отъ обыкновеннаго А. cor-

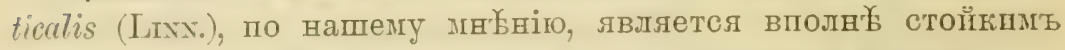
подвитомь, вполну изолшрованнымъ отъ основноі фюрмы.

Подвидъ этоть въ цыломъ не носить характера геограсби-

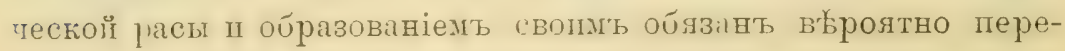

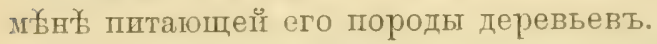

Географичесное распространеніе. Њстрђчаетсл въ Г'ерханіш, Швейциріш, Франціш, Венгріп, гды встр)зается іп основная

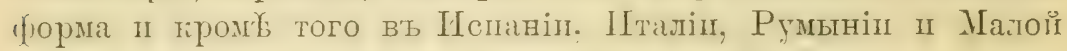

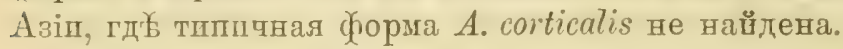

Въ Россіи на сқвер скаго распространенія выступаетъ совмйстно съ основной формой, на юг -являетея едпнственнымъ представителемъ conspecies A. corticalis (Lixn.).

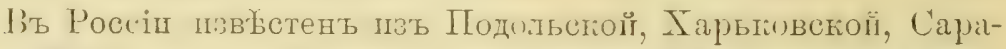
товскої (Cарепта), Крыма, Зап. Зальвғазья (Новый Афонъ,

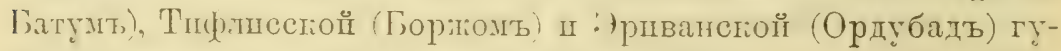

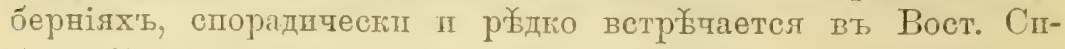

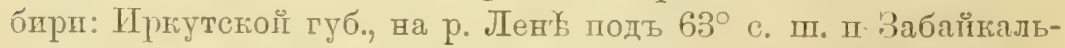
ской областц (Члта, Тропцкосавскъ).

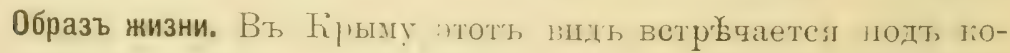
рою бука (Fingus).

\section{Aradus melas $J_{A K} .1880$.}

(Таб... I, фйг, 11).

Arudus melus JAK. Bull. Soc. Nat. Mosc., 1880, I, p. 168.

«ฉаушиетиеская литература, касающаяея Россін.

Arachus melas J $\mathrm{Ak}$. loc. cit., p. 168 (Vladivostok)

Экземпляры Зоологическаго Музея.

haddevka in fl. Amur. (2 o).

fl. Amur. (Q)

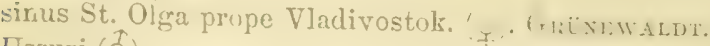

Ussuri (ठ). 
Дiагнозъ. Corpus ovale, unicolor nigricans, articulo tertio antennarum, basi excepto, albo, angulis apicalihs segmentorum abchminalium obsolete albido-flaris, pedilus fuscescentibus.

Caput latitudine sua longius, prolongatione antica crassa, sat longa: lobis lateralibus longis, acutin, livergentibus, margine extrriore muticis, tuberculis anteocularibus obtusis; lobis temporalibus obtusis, parmu prominentibus; "apite pone oculos partianten(ulari aequilato.

Antennae crassae, sat longae, articulo secundo tertio fere duplo longiore, basi quan apice paullo tenuiore, articulo tertio quarto $1 / 3$ longiore.

Rostrum basin prosterni attingens.

Pronotum longitudine sua plus quam duplo latius, margine basali protunde et late sinuato, marginibus lateralihus rotundatis. fortiter lenticulatis, vix reflexis, alpicem rersus valile angustatis, basin versus vix convergentibus; carinis lateralibus paulo diversentibus, internedis subparallelis.

Scutellum sat breve et latum, pone medium angustatum, apice acmminatum; marginibus lateralibus elevatis.

Hemelytra basi modice dilatata, corio et membrana unicolorilus, nigricantilus.

Connexivum ad margines interiores elerationibus longitudinalibus praeditun.

0писаніе. Uвальный, тернаго цвтта, вершшные углы сегментовљ connexivum'a сь неясными буровато-зелтыми плтнамп, третій членшкъ усиковъ, псключая его основанія, бълый, ногш бурыя.

Голова болғе развитая въ длпну, чбмъ въ ширнну; передвій

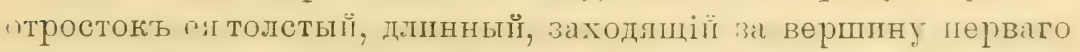

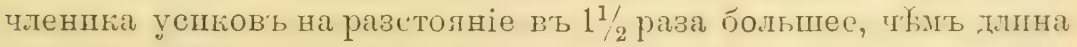
этого послйдняго; боновые отростии длинные, толстые, на верпин ные; прддглазншчный бугорокт туной, маль выдающійсп; височные отростки тупые, выдаюшіеся, такь что голова пюзадш глазт, такой же пиршны, какъ ш передъ глазами.

Успки толстые, довольно длинные, черные, третій членикь пхь двуцвҰтный, желтовато-былый въ верппнной половины,

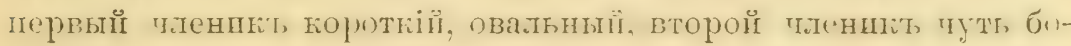

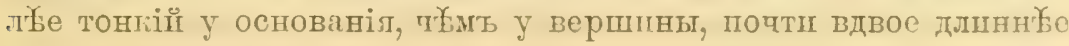




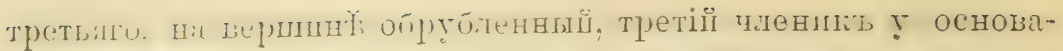

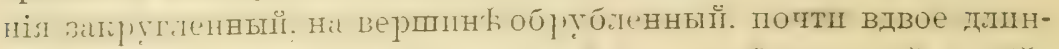

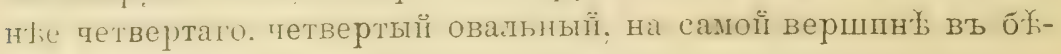
๘омъ войлок'

Хоботокъ буроватый, доходшть до основаніл переднегруди.

Пиреднеспика поперечнил, болье чъмь вдвое пире свосй

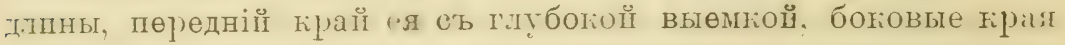

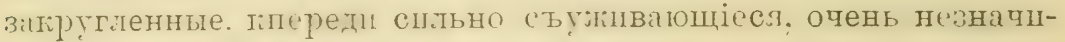

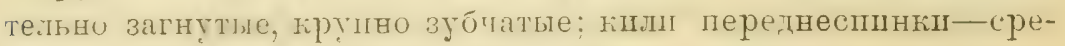

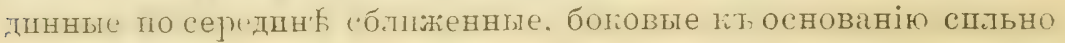
расходящіеся.

ШПтиюь сравнптельно короткій п пшрокій, длина его только

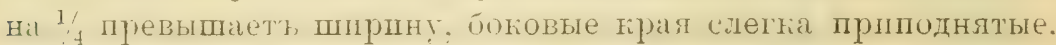

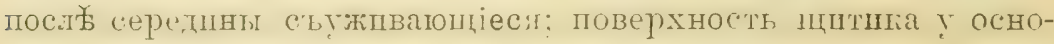
ванія приподнятая.

Надкрылья у основанія расшшренвыя, мелко зазубренныљ,

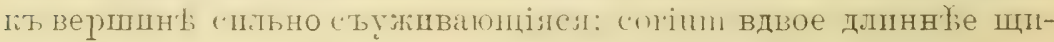
тпка, membrana черная.

Connexivum одноцв б́ғныі, въ верлинныхъ углахъ нелсныл, маленькія желтоватыя плтна; на сегментахъ по середшно्্́ бокового ғрая прохотить возвыпенный. пирокій бугорчатый жцьь, по сторональ лотораго: внфиней-находится углубленіе. занимаюее почти всю длпну сегмента, внутреннеі - дв бо черныя точки.

Ногп бурыл, пространства вокругъ ногъ, ляшки п вертлуги болюе св зитлые.

'Т'́́ло сншзу черное, вершинные углы сегментовь п точкп по одної у основного крал сегментовъ жіелтые.

Ђ. Седымоп брюшной сегменть сдльно выпуклый, боковыя

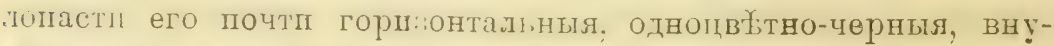

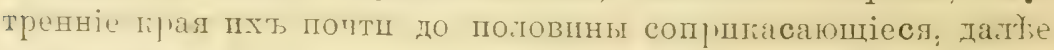
lil:xодынiеc:

․ ПІестоі брюпної сегменть немного короче пятаго и на

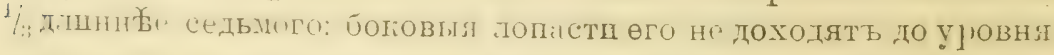

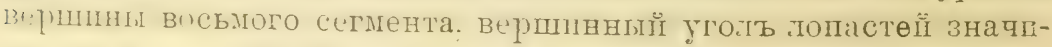

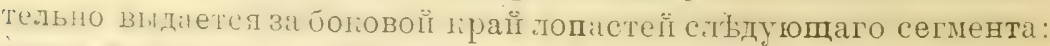

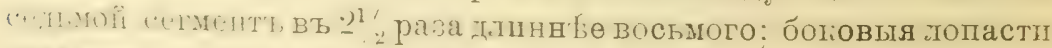

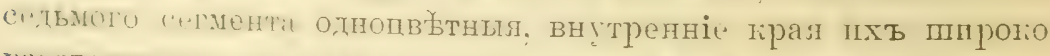

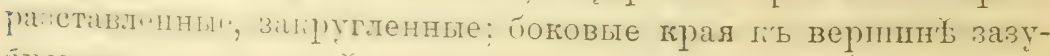

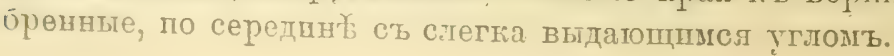


ट. Длина-т милт., пиирина натюрылій у основанія-2.5 митл.

९. Длина-7,3-S,1 милл., ширина надкрыліі у основанія$2,6-3$ милл.

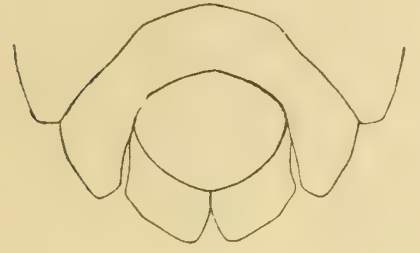

Pнс. 50. - Стерниты бргониа VI-VII. Aradus melas JAK, ס (пзъ Южно-У ссурійскаго крал).

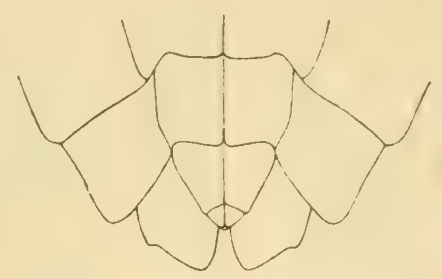

Pвс. 51. - Стернить úргшта́ VI-VIII. Aradus melas JAK. O (изъ Юэно-У ссурійскаго прая).

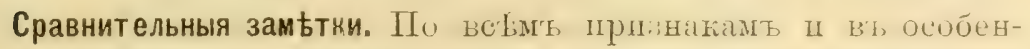

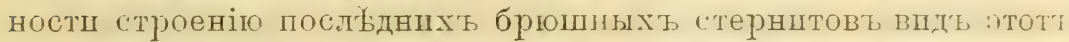
близко подходить къ $A$. corticalis (LINN.) $\nabla$ ax. annuliconis FABR., но отличается оть него черной одноцвътной окраской всего

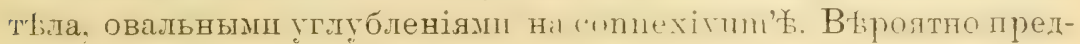
ставляеть лить расу этого вида.

Географическое распространеніе. Вщц' :тоть пскачительни

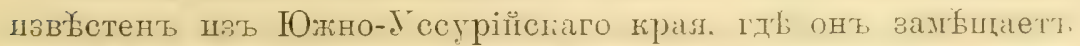

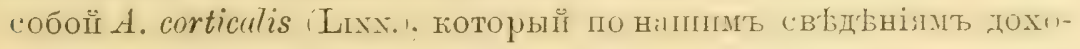

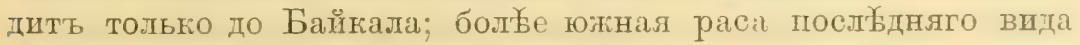

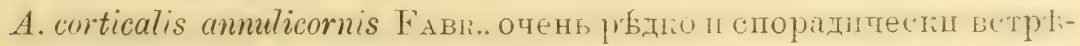

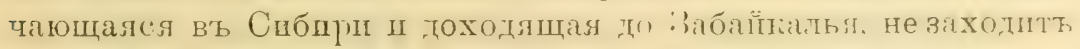
однако въ Южно-Уссурійскій край.

\section{Aradus megerlei Kinut. 1881 .}

Aradus crenaticollis FreB. Eur. Hemipt, p. 113. 1861 (nec F. SAHLB.). Aradus Megerlei Reut. Berl. Ent. Zeit, 1881, p. 172.

\section{Энземпляры Зоологическаго Музея.}

Podolia: Proskurov. ก-6. VIII. 1897 (ठ), ZuвошsкY. Tauria (ơ).

Дiагнозъ. Ferrugineo-fuscus vel t'usco-cinnamomeus, opacus, vena costata interiore corii rufo-ferruginea; rostro et pedibus terrugineis, coxis, trochanteribms ipsogne apice temmomi ot tibiamm

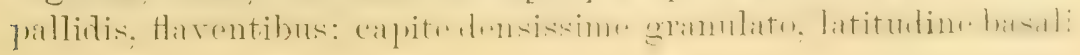


cum oculis sat multo longiore, pone oculos denticulo minuto margrinali, denticuluintenculari uhtusisino. spinis lateralibus longinsculis, acutis, muticis; rostro coxas anticos hand superante; antennis capite vix $2 / 5$ longioribus, crassis, articulo secundo duobus nltimis simul suntis anpuilongu: pronoto lateri-

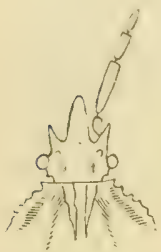

P'11:. 5-3.-1radus megerlei RECT. (puc. O. M. REuTER'a). bus rotundato-dilatatis, antice haud sinuatis, margine ab apice ultra medium irregulariter fere serrato-dentatis, carinis discoidalibus lateralibus versus basin divergentibus, versus apicem in callum granulatum prolongatis, hoc callo obliquo utrinque carinis intermediis exteme subcontigun. his vasus apicen obtuse callosinlilatatis, granulatis et distincte divergentibus, versus basin sensim gracilibus et obsoletis, ante margi ${ }^{2}$ nem basalem abbreviatis; scutello sat lato, lateribus leviter arcuatis, disco versus basin convinisulo: hemelytris hasi minus fortiter ampliatis; angulis apicalibus segmentorum abduminalium anguste pallidioribus (sec. Reuter).

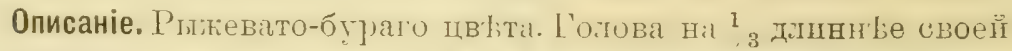
ппрнны еь гтізим: передній ея отростогъ длинный, боговые

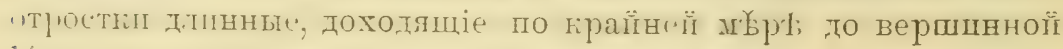
1/4 перваго членика усиковь, острые, боковой край ихь прлмой, невооруженный, предглазнпчные бугорки очень тупые; голова позади глазъ съуженная, съ обћпхь сторонъ отходятъ по маленькому вубипку; поверхность головы очень густо зернпстая, позади еь двуля продольнымп жіелобкамш.

У спкі толстые, почти на $2 / 5$ длпнн施е головы, буровато-рыжіе,

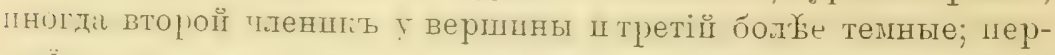
вый членишь доходить до середпны переднлго отростка головы,

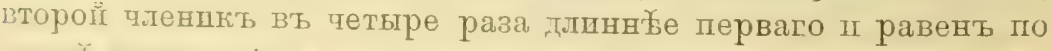

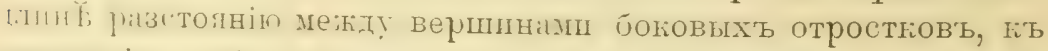

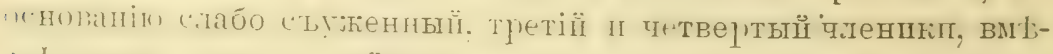
етl' взятые, одшнаковой длшны со вторымь, прпчемъ третій поттц на $3 / 7$ хороче второго; четвертый членикь очень незнаqигетьно короче третьяго.

Гоботокъ не заходить за ляшиш переднихъ ногъ, первыи плениге его едва доходпть до глазт; второй походить до основанія голови. 
Перөднөспнка короткал, короче толовы, ширина ел по сеједин危 вдвое больше длины головы; задній край ст сильниі выемкой, сь, обұпхъ сторонъ съ широкнмг; загругленными. продвинутыми впередт, лопастяи, пюредній жрай прямой, одиниковой шпрны съ длиной переднеспнни, боковые трая огругленные, впереди безъ виемин. неправильно и довольно сильн зуб̆чатые; передніе углы не пјодвинутые впередъ, сь неб́оп, лшим зубчиками; поверхность переднсппини зернистия; богі-

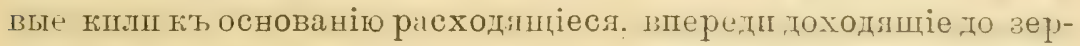
ншстаго вздутія, сопрпкасаюшагося скошеннй стороной ст

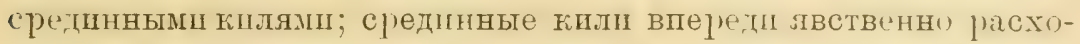
длщіеся, морщцншстые, къ, основанію болье тонғіе и неявстинные, передъ основнымъ краемь укороченные.

Щитик'ь довольно широкіи; боковые края его слегка пзогнутые; поверхность его у основанія приподнятая.

Надкрылья у основаніл слабо распиренчыя. Вершинны. углы connexivum'a съ небольпшии св ботлыми пятнами.

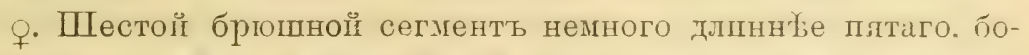
повыл лопасти его доходлть до уровня вөршины восьмого сегмента; седьмой сегменть на $1 / 3$ ғороче пестоги. боговна лопасти

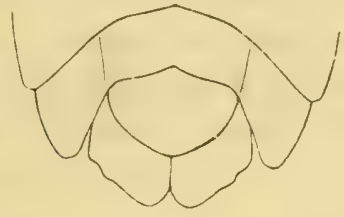

PiІ. 53. - Стерниты брюшка VI-VII. Aradus megerlei Reut. (?) Iै (пзт Кртма).

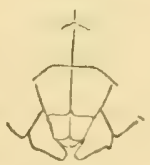

Piic. 54. - Cтернпть бргена VI-VIII. Aradus megerlei REut. $Q$ (pnc. O. M. Recter'a).

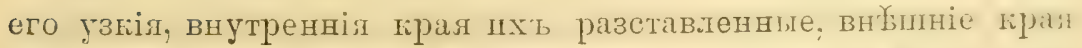

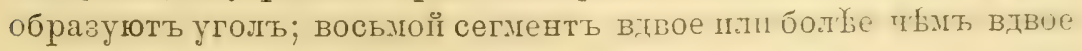
короче сөдьмого.

Длина-7,8 млл.

Сравнительныя замьтки, dradus megerlei lisut. oнноcшт'i liт,

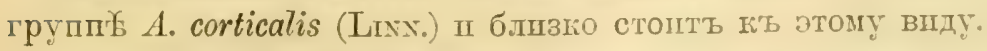

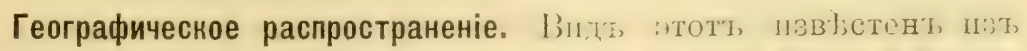

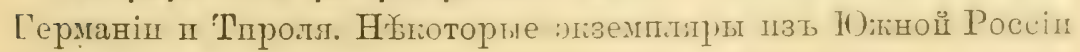

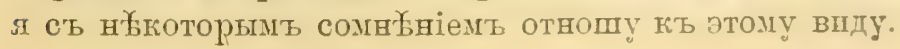




\section{Aradus komarovi $J_{\mathrm{AK}}$. 1885.}

('Таб.т. I, фищг. 13).

Aredus Kómarowit JAE. Hor. Soc. Ent. Ross., XIX, p. 122. 1885.

\section{Џаупиетиеская литература, Һасающаяся Россіи.}

Aradus Komarovii JAk. loc. cit., p. 122 (Transcaspia: Tshulli prope Aschabad).

\section{Экземпляры Зоологическаго Музея.}

Transcaspia: 'l'shulli prope Aschabad. (q). Konarov.

дiarнозъ. Corpus late ovale, cinuamomeo-fuscum, articulis duobus prinis antemarum. matrinibus pusteriore et lateralibus posticis pronoti, angulis appicalibns segmentrum abdominalinm

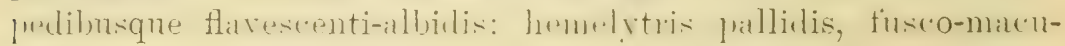
latis.

Caput latituline sua longius, prolongatione antica longa, mediocri, lobis lateralibus crassis, sat breribus, margine exteriore dente valido armatis, dentibus anteocularibus magnis, acutis, Jobis temporalibus brevibus, parum prominentibus; capite basin rersus linea arenata callosa, elevata, albida praedito.

Antennae longae, sat tenues, vermcosae; articulo secundo tertio sesqui longiore nec non articulis tertio quartoque simul

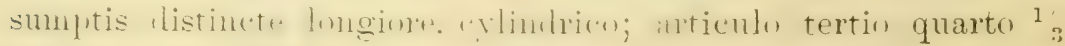

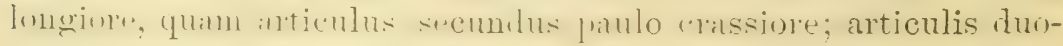
bus ultimis brevissime pilosis.

Rostrum Haricans, apjicem mesosterni attingens.

Pronotum longitudine capitis brevius, longitudine sua plus quam duplo latius; margine postico late sinuato, marginibus lateralibus levissime cremulatis, late rotundatis, antice fortissime reflexis, apicem versus valde angustatis, marginibus lateralibus posticis posterioreque flavo-limbatis; carinis lateralibus basin versus leviter dirergentibus, intermediis medio leviter appropinquantibus, basin rersus vix divergentibus.

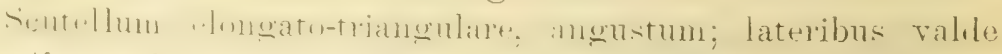
eleratis, rectis.

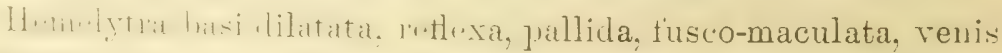

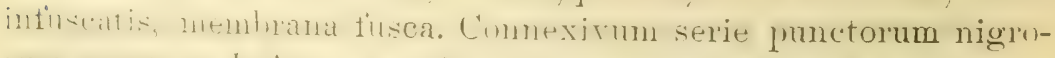

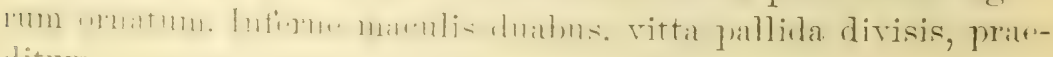
ditum. 
o. Segmentum sextum veutrale segmento quinto aequilongm; lobi laterales segmenti septimi in medio maculis flavis praediti, matrginibus interioribus rotmulatis, late distantihus, marginilus exterioribus rotundatis.

0писаніе. Большой, широго овальный, ліричневито-уураго

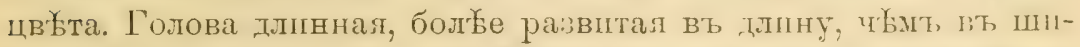

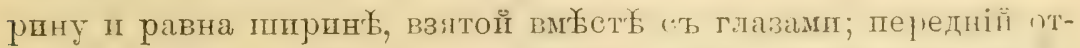
ростогъ ея заходшть за основавіе второго члевпка успговъ на разстолніе равное половин перваго тленшка уснков'т; бокизые отростки короткіе, но шпрокіе, ваостренные, спльно расходящіесл, на внбпғемъ крап вооруженные о́льпим, сшлғнымь зубцомъ; предглазничные зубцы острые, большіе, ваправлеиные вверхх, височные отростки тупые; нодковиобраяное углуббленіе задней поверхности головы не дохидить до основинія головы и

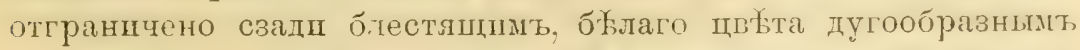

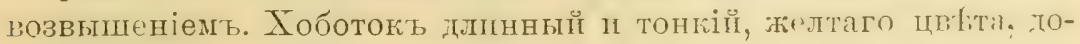
ходить до вершины среднегруди.

Успки длинные п тонкіе, густо усблнные одноцвътными бугоркамп, на вершине қоторыхъ по прайнеї мьрб на тетвертомь II третьемъ членпкахь спдять короткіе волоски; первый членикъ хоротко-овальный, почти одинаково развитый Вт, дену и

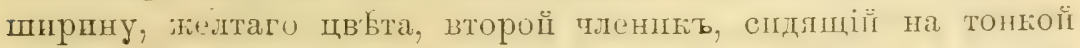

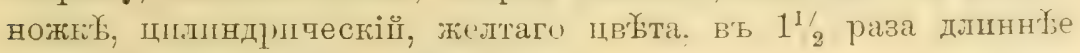

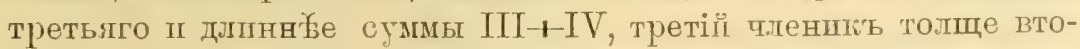

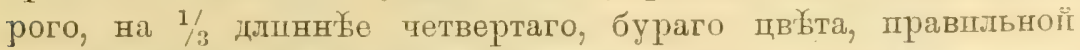
цитпндрпчестой (рорхь, у основанія закругленный, на вер-

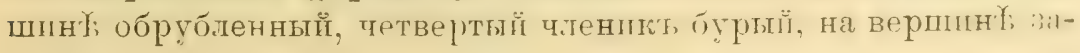
остренныи.

Переднеспнка еильно съуживающаяся ппереди, едва до-

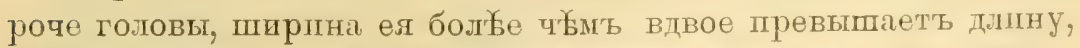

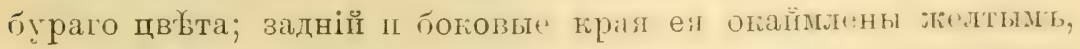

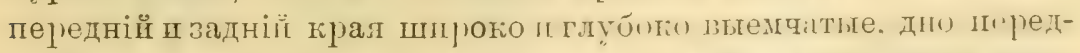

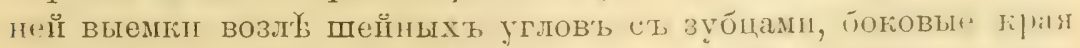
ея зиругленные, мелко зазубренные, окаймлнные желтымь,

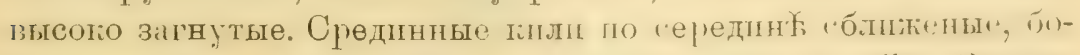

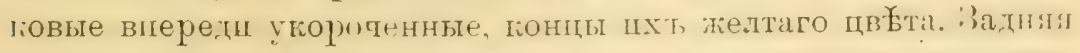
половина поверхностп груби поперетно-морщинистая, ић иерет-

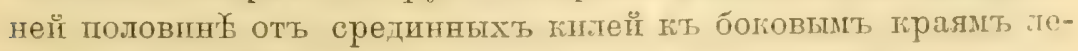
жать черныя, блестлція возвышенія. 


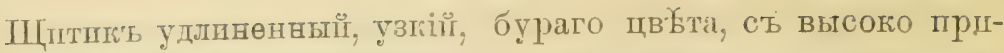
поднятымш, прямыми кіраямш.

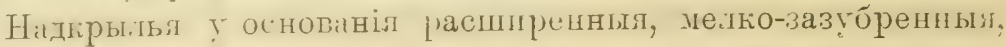

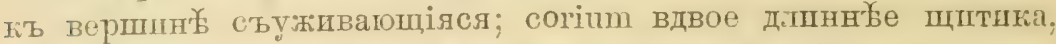

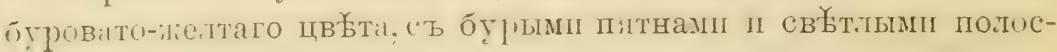
гамп; membrana бурая, безъ поперечныхъ жплокъ.

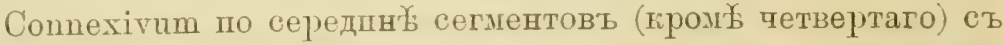

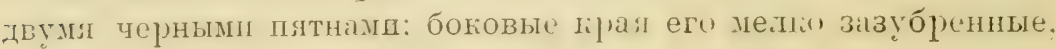
бурые, вершинные углы сегментовъ съ желтыми пятнами, не выдающіеся.

Снизу желтовато-красновато-бурыи, голова іл трудь болье темныя; по середшво бо брюшныхь сегментовъ I - VI пва попе-

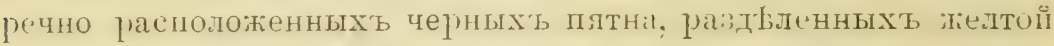

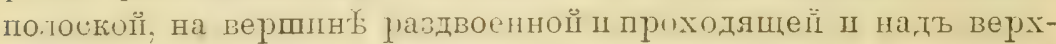

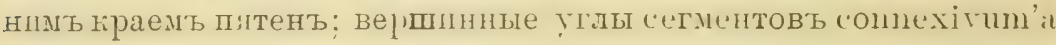
с’ь желтым плтнами; боковыя лопастш седьмого сегмента на

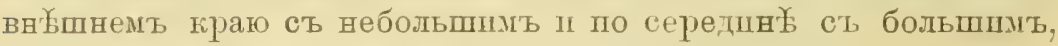
неясным желтым пятнам.

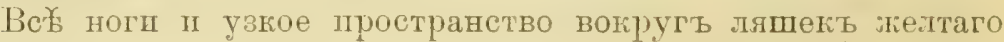
цвйтта.

․ Плтый брюшноц сегменть равенъ боковымъ краммъ І1 c) етиной линіп шестго сегмента, пестой сегменть въ $1^{2} / 2$ раза длтннее седъмого, боковыя лопасти его доходять до уровня

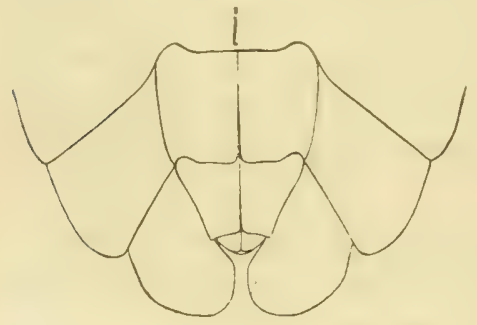

Puс. 55.-Cтеринтти бртшка VI-VIII.

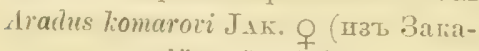
спійскіої об̆:.).

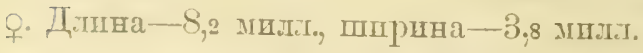

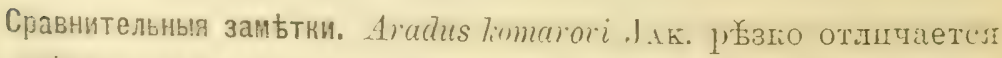

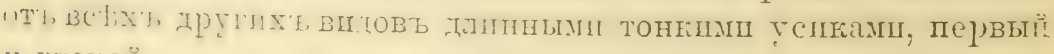

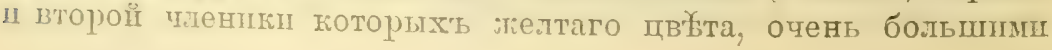




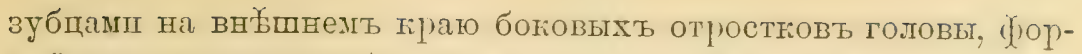
мой переднеспннк, боковые крал тоторой сп.ьно загнуты, пр:-

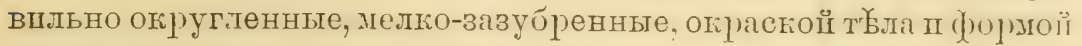
боковыхъ лопастеиі седьмого брюмного сегмента.

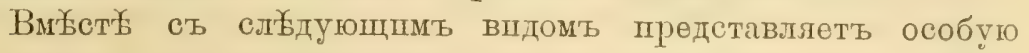
группу, родственныя отношенія которої неясны.

Географическое распространеніе. Едпнственный шзв-бстны ї экземпляр этого вшда найденъ въ Закаспійской области, цъ предгорьяхъ Копеть дага: пшкеть Чүллш.

\section{Aradus setiger n. sp.}

(Табл. I, фопг, 12).

\section{Энземпляры Зоологическаго Музея.}

Turkestan: Perovsk in fl. Syr-Darja. 24. IV. 1905. (q). Oshanin.

Діагнозъ. Corpus late-ovale, sordide fuscescenti-flavum, саpite, dimidio apicali pronoti, marginibus latis lateralibus exceptis, scutello basi nec non marginibus lateralibus segmentorum abdominalium margine exteriore, angulis apicalibus exceptis, fusco-nigris.

Caput latitudine sua longius, prolongatione antica longa, tenui. lobis lateralibus longis, angustis, acutis, apice late albidis, margine exteriore muticis, tuberculis anteocularibus sat acutis, listinctis, lobis temporalibus vix prominulis, tridentatis, capite pone oculos fere sensim angustato, basin versus linea arcuata praedito.

Antennae tenues, longae, flavo-fuscae, articulis II-IV granulis apice setiferis dense tectis; articulo primo breviter ovali, apice pallicliore, articulo secundo tertio sesqui longiore: apicem versus levissime incrassato, articulo tertio quarto in $1 / 3$ longion: apice pallidiore, articulo quarto fusco.

Rostrum flavo-fuscum, coxas anticas attingens.

Pronotum longitudini capitis aequilongum, longitudine sul duplo et dimidio latius, transverso-orale; margine posteriore profunde sinuato, margine antico sinuato et lateribus denticulato, marginibus lateralibus regulariter rotumdat is, valde reflexis, crenulatis; carinis basin versus leviter divergentibus.

Scutellum elongato-triangulare, sat latum et brevo; marginibus lateralibus elevatis, rotundatis; lisco lasi fusco, consexu, dimidio apicali pallido. 
Hemelytra basi fortiter dilatata, crenulata, unicolora sordideHara, basi et apice clari suturaque membranae fuscis; membrana finscescenti-all,ida.

Comexirum marginibus lateralibus segmentorum, angulis apicalibus allido-flaris exceptis, superne et inferne late fusco nigris, medio segmentorum punctis duolus, seriatim jositis, ormatum.

Inferne maculis duabus nigris, transversim positis et vitta prallida divisis, ornatum.

Діагнозъ. Коротко-овальный, грязно-желтоватаго цвйта.

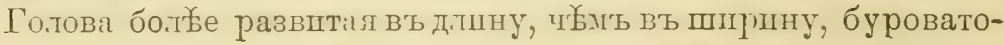
чернаго цво̆та, передній отростокъ ея тонкій, заходить да:теко за основаніе второго ч:гени успковъ; боғовые отросткі длинные, тонкіе, спльно заостренные, расходящіеся, вершина ихъ на

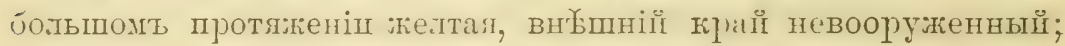
предглазншчный бугорокъ тупой, небольшой; височные отросткі

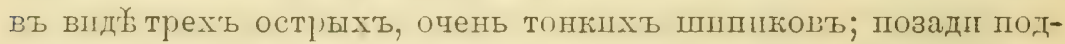
I:овообразнаго угтуб́ленія на поверхности головы находится дугообразный мозолистый возвышенныї панть желтоватаго цвъта; вся поверхность головы сильно бугорчатал.

У сики динные п тониіе, густо усаженные, за пскютеніемъ псрваго qленпка, ғрупным бугоркамп, на вершине' которыхъ (пдятьь волоскі; первый ч:теникь удлненно-овальный, бурыї, вершина его св

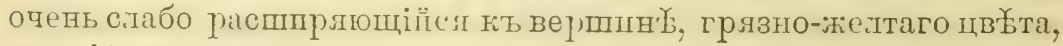

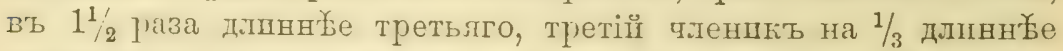

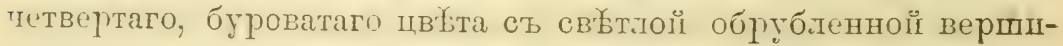
ноў, четвертый членпюъ бурый. Хоб́отокъ доходптъ до лянекъ передншхь ногъ, желтовато-бураго цвк्केта.

Переднеспнка по дішнҢ' равна голов', поперечно-овальная,

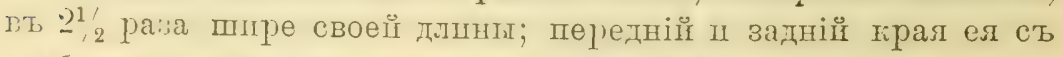

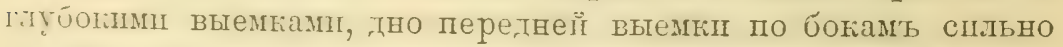
зазуйрено; боғовые трал зағыугленные, сильно загнутые, мелко-

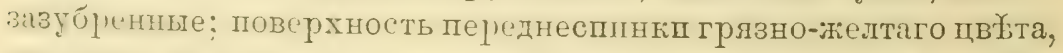
переднял половшна по середин чернал; срединные кили по

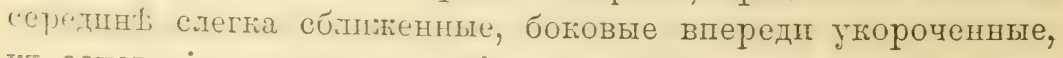
иъь основанію чуть расходящіеся.

Шптпгь довольно широкії ІІ короткії, боковые края его

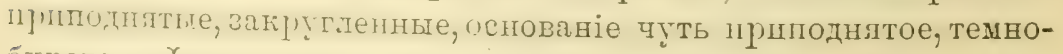
бураго цвотта, вершшнная половшна грязно-желтая. 
Corium надкрылії грязно-желтаго цв'ьта, вдвое длиннҰе

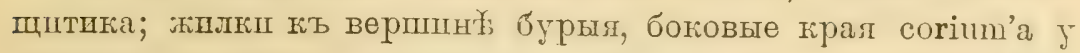
основанія расширенные, мелго-зазубренные; основаніе сlarus'i I отчасти вершина corium'a буроватыл, membrana буроватая,

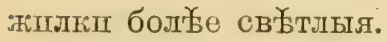

Боковые края сегментовъ сопnехірит'а мелко-зазубренные,

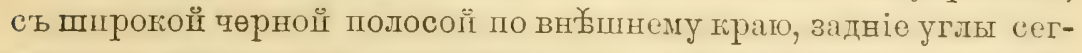
ментовь желтоватые; на внутреннемь граг сегментовь соnnехіvum'a по два черныхъ пятна.

Снизу грязно-желтоватаго пвйта, голова, псключал верхушекъ боковыхъ отростковъ п bucculae, поперечныя полосы переднегрудп, средне-л задие-грудь, пятна на сегментахъ брюшка,

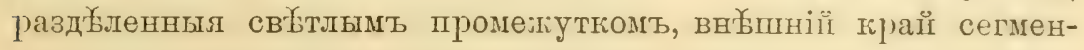
товъ connexivum'a- - чернаго цвљта.

Ногп одноцв'Бтныя, буровато-желтаго пвътта, густо погрытыл бугоркамш, на вершинахъ которыхъ спдять довольно длпнныл волоски.

ㅇ․ Неизв

‡. Плтый брюшной сегменть равенъ пестому, заднії грай его выемчатый шестої сегменть равент седьмому іг восьмому

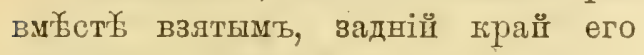
цијльныи; сөдьмой сегменть вдвое длпннеге весьмого, боновня лопастіг его сильно развитыя въ длшну и шпрпну, внутренніе края ихъ закруглөнные, у основанія п् вершпны бо-

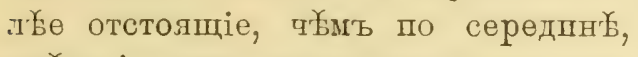
внбшніе края закругленные, у основавія съ тирокой выемкой.

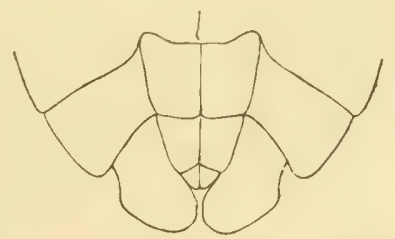

Piic. 56. - Стернітти ирюита VI-VIII. Araclus setiger Kir. 우 (нзъ Сыръ-ПГарьвнстой обл.).

Сравнительныя замьтни. Вшдь этоть близзоль гіб A. liomarovi ЈАк., но отличаетсл оть него острымп, на вершнн боковымц отростками головы, невооруненным на вно̆шнемь краю, болье тонкиь передним отросткомь головы, тоншим

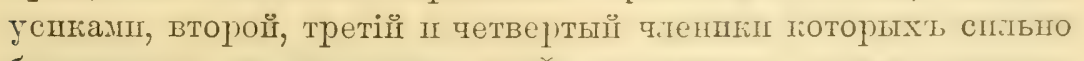

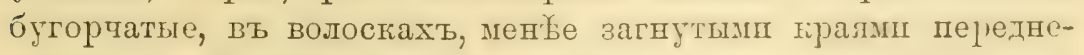

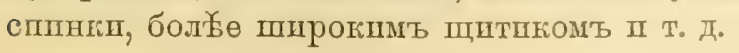

Географическое распространеніе. Новый вндъ этоть найденъ Въ Туркестанх: Перовскь, Сырь-Дарьннской областп. 


\section{Aradus unicolor n. sp.}

(Табл. I, бпг. 14).

Діагнозъ. Сor pus anguste-oroideum, elongatum, unicolor obscure-cinnamomeum, marginibus lateralibus pronoti hemel ytrisque hasi pallidioribus, subdiaphanis, angulis apicalibus segmentorum connexivi obsolete albidis, antennis articulo secundo tertioque apice albo-annulatis nec non apicibus loborum lateralium capitis albidis; connexiro medio segmentorum punctis nigris duobus, scriation positis, ornato.

Caput latitudine sua longius, prolongatione antica longa, crassa, apice rotundata, lobis lateralibus longis, sat tenuibus, nargine exteriore inermibus, solum basi tubereulo obsoleto instructis; tubereulis anteocularibus distinctis, lnbis temporalibus obtusis: parmu prominulis.

Antennae longae, sat tenues, granulis parvis, concoloribus prachitis, quare superficies antemnarum fere laevis videtur; articulo frimo breviter orali, fusco, articulo secmulo capite breviore, quam articuli tetius et quartus simul sump ti paullo longiore, basi levissime capitulato-incrassato, apice distincte sensim incrassato, summo arice allo-annulato, articulo tertio seculo magis quam duplo breviore, fusco, apicem versus incrassato, summo apice albo-annulato, articulo quarto tertio crassiore, longitudine aequali, nigro.

Rostrum medium mesosterni attingens.

Pronotum capite brevius, longitudine sua duplo et dimidio latius; margine postico late et profunde sinuato, marginibus litteralibus reflexis, vix denticulatis (denticulis irregularibus, vix prominulis, apice rotundatis), antrorsum fortiter angustatis, vix sinnatis, postice rotumlatis, levissime convergentibus; carinis mediis subparallelis, lateralibus basin versus divergentibus.

Scutellum sat latum, breve, marginibus elevatis, pone medium sinuatis, apicem versus angustatum, disco medio leviter convexo.

Hemelytra basi parum dilatata, pronoto latiora; membrana pallida, fusco-maculata.

Inferne fuscus, angulis a piculibus segmentorum, trochanteribus, spatio cirea coxas albidis; abdomine lateribus rufo-fusco, segmentis punctis duobus, transversim positis, praedito.

Pule finsci, tibiis basi et apiec albidis.

ð. ignotus. 
o. Segmentum quintum rentrale margine postico bisinuıto, segmento sexto aequilongum; segmentum sextum septimo in ${ }_{3}{ }_{3}$ longius, margine postico integro; segmentum septimum octaro duplo longius; lobis lateralibus segmenti septimi marginibus interioribus rotundatis, late distantibus; marginibus exterioribus apice sinuatis, basi oblique truncatis.

Species ad sectionem $A$. picti BAER. referenda, a qua corpore oroideo, angusto, ad partem posticam abdominis dilatato, unicnlore obscure- cinnamomeo, structura capitis, marginibus lateralilus pronoti haud spinoso-denticulatis structuraque segmentorum ultimorum abdominis distinguenda.

Описаніе. У темно-корпчневаго цвобта, боновые крал переднеспини и надғрылья у основанія чуть свбтлłе, просвичшвающіе; только не ясныл пятна въ вөршінныхъ углах' сегментовъ соnnexivum ‘, вершины второго п третьяго членшковъ успковъ, вершины боковыхъ отростковъ головы бүбловатаго цв'бта; у внутренняго края сегментовъ connexivum'а по два черныхъ пятна.

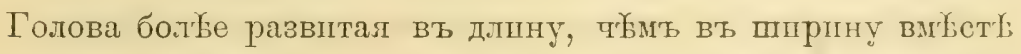

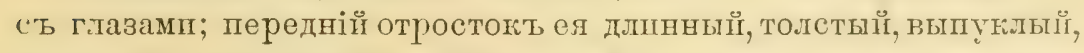
круглый, на вершпнб закруглениый, боғовые отросткі длинные, тонкіе, спльно расходлщіеся, внбшніиі краї пхь не вооруженный, блпже къ основанію сънебольшимъ, неяснымъ бугорюог; предглазничные бугоркп явственные, впсочные отростки туцые, выдающіеся; подковообразное углубленіе у основаніл головы такого же ць'та, какъ п вся поверхность головы, морщпнисто; голова позадш глазъ такой же ширшны, какъ пा передъ глазихи, зат沝 съуживаюшаяся въ довольно длшнную шею.

Јепки дыннные, тонкіе, поверхность пхь покрыта мелюим одноцвътнымп бугоркамп и поэтому кажутея почтш гладким; первый членшкь пх'ь поротко-овальныї, буроватыі, второї членпкъ значительно тороче головы, немного длинные третьяго п четвертаго взятыхт вмегет), у основаніл опень незначительно головчато-утолщенвый, у вершшны вамктно уголщаюицйсл, съ

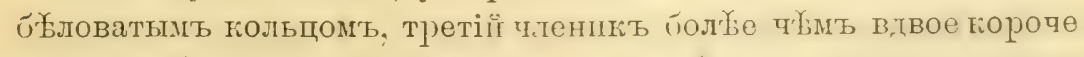
второго, буроватаго цвъта, кь вершины незиачитепьн утолщающійсл, съ бҰлымь кольцомь, четвертый т.тенпк'ь равюнь третьему, толще его, чернаго цвйта.

Хоботокъ доходпть до середины среднегруді. 
Переднеспнга короче головы, ширнна ел почтп въ $21 / 2$ раза ппте ел длпны; задиій ғрай ея съ ппрокой п глубокой выемкой, боговые пірая слегіа загнутые, съ чуть выдающимея, тупымш,

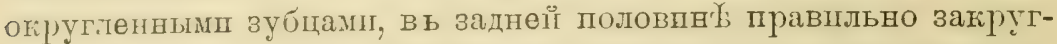
генные, ппередп спльн съуживающіеся. съ туть замйтної выемкой; средннные кплі переднеспннки почтп параллельные, боковые сильно расходящіеся къ основанію.

Щптпьь довольно пшрокій п короткій, къ вершпнек्, съуженныи; боговые ғрая его слабо пршподнятые, посл середшны съ выемкой, поверхность по серетннб слегіа выпуклая, вершива его чуть св ойл年е.

Надкрылья у основанія незначптельно расшпренныл, загнутыл, чуть шире переднеспинг; membrana прозрачнал, бъловатая, съ бурыми плтнамп.

Cнп:зу буроватаго цвъ́та, вершинные углы connexirum'a, пространства вогіруг ляпекъ ногъ и вертлугш бъловатые. брюшко по богамь грасновато-бурое, съ двумя поперечно расположненнымг чернымп точками на каждомъ сегмонтею́.

Ногп бурыя, основанія п вершины голеней бъловатыя.

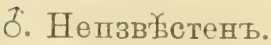

ㅇ. Плтый бргіної сегменть одинаговой длпны съ пестымъ, задніiі гірай его съ выемпамп, шестой сегментъ на $1 / 3$ длиннґе

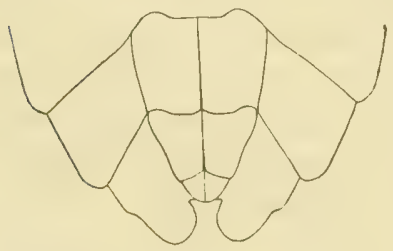

Pнс. 57. - Стернпты брютка VT-TTII. Aradus unicotor KIr. q (пзт Юэно-У ссурійспаго гірая). седьмого, заднії край его цұзльныи, седьмої сегменть вдвое длиннею́е восьмого, внутревніе края боковыхъ лопастей его спльно разставленные, огругленные, вношніе края у верппны съ выемкой, къ основанію косо-србзанные.

о. Длина- 7,5 мплл., пиршна (у основанія надкрыліпі) - 2,2 мплл., (брюшка на уровн全 четвертаго сегмента) 3 мілл.

Сравнительныя замьтии. Этоть видъ по свопмъ главнымъ структурнымт прпвнатамь бливко стопть тіъ $A$. pictus BaEr.

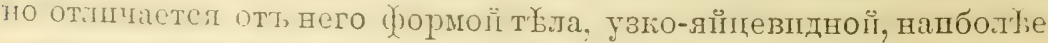

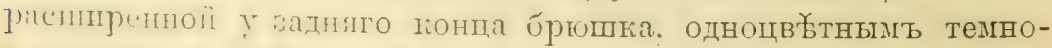

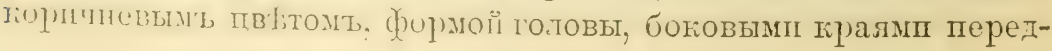


неспннкп съ едва выдаюппмея тупымш зубцамп, бол бе длдннымш надкрыльмш, формой послуднихь стернитовь брюпка.

Географическое распространеніе. ВетрҰчается въ 10жно-Ј ссуpiliскомъ крағ.

Образъ жизни. Най,тенъ подъ ғорой корейскаго кетра.

\section{Aradus pictus BAER. 1850.}

Aradus varius Fald. Mon. Cim. Suec., p. 34. 1818 (nec FABr.). - R. F. SAhlb. Mon. Geoc. Fenn., p. 138. 1848.-Fror Rhynch. Livl., 1, p. 386. 1860.Freb. Eur. Hem., p. 114. 1861. - Reut. Öfv. Kongl. Vet.-Akad. Förh., 1872, Nㅗ 5, p. 57. - Рот. Synops. Hém.-Héter. de Fr., I, p. 137. 1879. REut. Ent. Tidskr., 1882, p. 79.

Aradus pictus Bafr. Berl. Ent. Zeit., 1859, p. 338, t. 6, f. 12.-Rect. Öfr. Fin. Vet.-Soc. Förh., XLIV, p. 151. 1902.

\section{Фаушпстичесіая литература, юасающаяся Россін.}

Aradus varius J. SAHib. Medd. Soc. Faun. Fl. fenn., VII, 1881, p. 13 (Fennia: Yläne, Pargas). - Reur. Ent. Tidskr., 1882, p. 79 (Fennia: Åbo, Satakunta, Nyland). - Reur. Not. Sällsk. Faun. Fl. Fenn. förh., XI, 1870, p. 318 (Fennia: Pargas).

Aradus pictus Popp. Medd. Soc. Faun. Fl. Fenn., h. 35, 1909, p. 93 (guh. Archangelsk, distr. Pinega: Kokornoje). - Krr. Rev. Russ. d'Ent, X, 1910, p. 12 (Gub. Vologda, distr. Velsk).

Aradus varius Fror Rhynch. Livl., 1, p. 386.1860 (gub. Livland).--JAroscu. Труды Общ. Естеств. Прпр. Харьк. Уншв., VIIJ, стр. 55. 1874 (Charkov). - J. SAhlb. Kongl. Sv.-Vet. Akad. Handl. XVI, № 4, 1878, p. 21 (Gub. Enisejsk: inter Turuchansk et ostium fl. Kurejka). - JAK. Hor. Soc. Ent. Ross., XXXVI, 1903, p. 318 (prov. Jakutsk: fl. Zhuja).

\section{Энземпляры Зоологическаго Музея.}

Simplon (Q). Puton.

Karpathes (2 J, 1 o).

Bohemia (ठ)).

Fennia: Yläne (ठ). Reuter.

Prov. Jakutsk: H. Zbuja.

Sinus de Kastri (q).

Sine datis (ठ). Reuter.

Sine datis (q). SIG Xoret.

Діагнозъ, Corpus orale, cinnamomennu, rufo-f'errugineo-et fuscuvariegatum.

Caput latitudiné sua paullo longius, prolongatione antica crassa, longa, lateribus compressal lobis lateralihms longis, lant crassis, fortiter divergentibus, apice acutis; albilis, margine extr- 
riore basi denticulo armatis; tuberculis anteocularibus acutis, albidis; lobis temporalibus obtusis, prominentibus.

Antennae longae, sat tenues, granulis minutis, unicoloribus Iraditae; articulo primo lreviter orali, flaro-ferrugineo, articulo secundo capite fere aequilongo, articulis duobus ultimis longiore, hasi et apice incrassato, flaro-ferrugineo, apice late fusco, summo apice allo-ammlato, articulo tertio quarto paullo longiore, fusco, apice lite albo-annulato, articulo quarto obscure-fusco.

Rostrum fere medium mesosterni attingens.

Pronotum longitudine sua plus quam duplo latius, margine posterine lite et profunde sinuato; marginibus lateralibus fortiter spinoso-dentatis, reflexis, diaphlanis, rotundatis, apicen rersus fortiter angustatis; carinis sulparallelis.

Seutellum breve, sat latum, apice pallido, marginibus eleratis, laevibus, disco medio convexo, basi depresso.

Hemelytra marginibus lateralibus hasi nodice dilatatis, levissime crenulatis, fere integris, costis ferrugineis, interstitiis fuscomaculosis; membrana pallida, fuscu-maculata.

Inferne seriatim rubro-et ferrugineo-maculosus, mesosterno medio nigro notato.

Pedibus, coxis, spatiis prope coxas pallidis.

Описаніе. Св Үтло-коричневый, пиогда ғрасновато-ржавтиннаго цвёта.

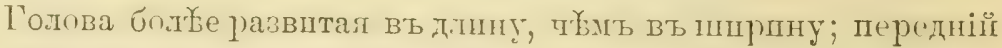
отростокь ея длшнный; боковыв отросткі длпнные, острые,

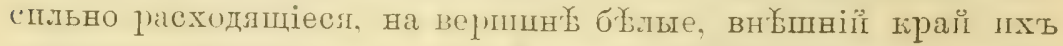
вопруненъ бугортомь съ б́вой вершпной; предглазншчные бугирки болыне, довольно острие, б'.таго цвезта; впсочные отростки тупые, выставляющіеся назадъ.

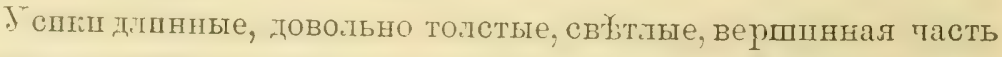
второго членика, шскіючал узкаго польца ва самой вершины, его, третій члениг, псключал его вершпни, п весь тетвертый-буpш": гольц на вершпне второго п третьяго членшка бүловатыл,

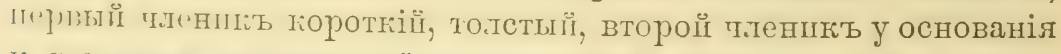

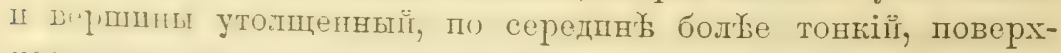

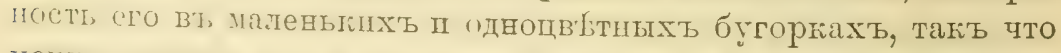

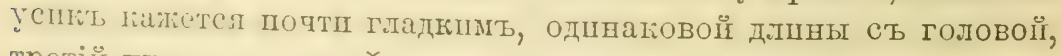

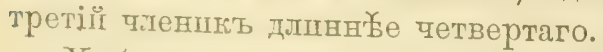

Хоботокь доходшть до середшны среднегрудш. 
Переднеспнка поперечнал, болґе чймь вдвое пире своей

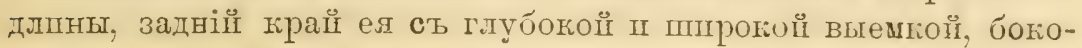
вые края тупоугольно закругленные, кпереди спльно, кады менҰе сильно съужшвающіеся, крупно-зубччатые, слегка прппод-

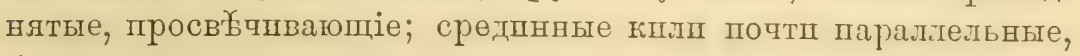
боковые жъ основанію расходящіеся.

Щптикь довольно пороткій, на вершпнеㅎ желттіи, боковые грая его слегка выгнутые, прпподнятые; поверхность его по

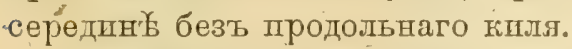

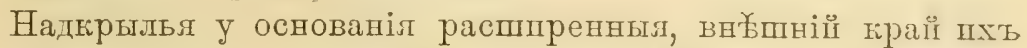

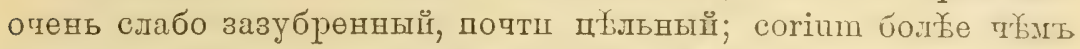

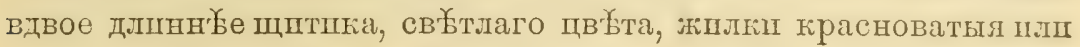
рыжеватыя, membrana свеьтлая, пногда съ буроватьмп пятнамп.

Connexivum грасновато-ржавчннаго шли св 'ътл-корпчневаго цвъта съ черными точками, по 2 на қаждомт сегмента т пятнами краснаго п् бураго цв宅та.

ІІяшіг ногь, пространства вокругъ ншхъ и вершины голеней желтыя, бедра темнете.

§. ШШестої брюшной сегменть равенъ по средней линіп пятому; боловыл лопасп его сблдженныя съ лопастямп седьмого

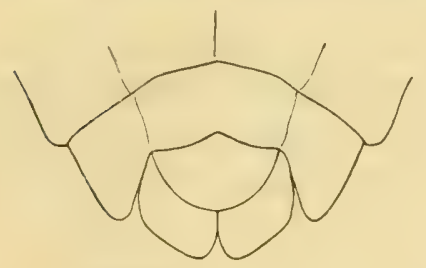

Prс. 58. - Стерниты брюшіа VI-VII. Aradus pictus BAER. o (изъ Финляндіні).

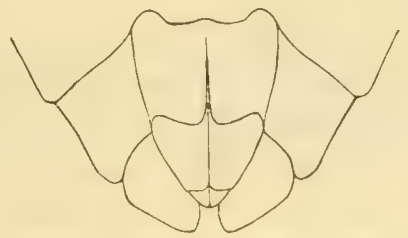

Pлtс. 59. - Стерниты брюшіа VI-VIII. Aradus pictus BAER. 오 (изъ Швейцаріп).

сегмента, боновыл лопасти седьмого сегмента поти горпзотальныл, внутренніе крал ихь ни верпинӗ расходлщіесл, вн各шніе тупоугольно-закругленные, не зазубреннле,

․ Задній прай плтаго сегмента съь двуми выемпамп, срегинная пшнія его чуть длинняе пестого, пестої сегменть въ $1_{1 / 2}^{1 / 2}$ раза длшнияе седьмого, задній край его загругленый, по сере-

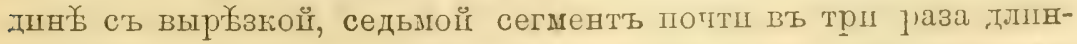
неке восьмого; боповыя лопасти его узгія, внутренніе прая пхт широко разставленные, зағругленые; внъшніе трал угловатозакругленные, ци्бेльные. 
๖. Длпна-6,5-7,6 мшлл., ширшна надкрылій у основанія2,8 мплл.

о. Д.пна-8,2-9,8 милл., шпрпва вадтірылії у основанія 3 мплл.

Сравнительныя замьтки. Aradus pictus Ваег. принадлежпть къ

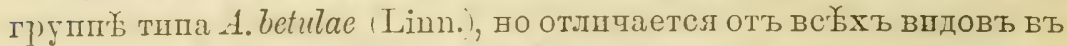
нее входящпхъ вторымъ членшкомъ усшковъ утолцающимся у основанія п у вершины, на самої вершпнет съ узкшм кольпомъ бълаго пв Һта, боковымъ краемь у основанія расшшренной частп

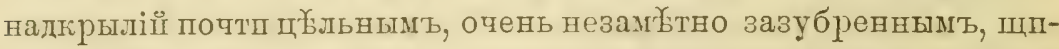
тпком безъ продольнаго возвыпенія, поверхностью успковь и

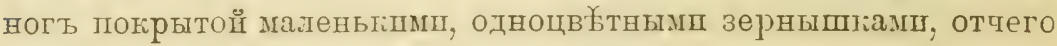
успкп пі ногш кажутея почти гладкпми.

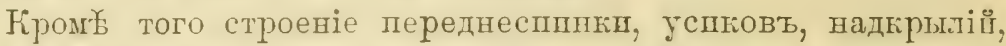

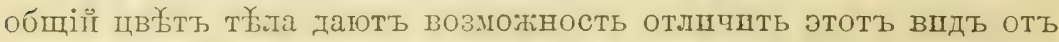
ст祒дугщшхъ.

Географическое распространеніе. Впдъ этотъ свойствененъ большеї частп Европы (Лапландія, Пвеція, Германія, Бельгія, Франція, Швейпарія, Венгрія, Румыніз, Греція), сљљь. п средн. Россіп п Сибпрп.

Въ Россіп пзв年стенъ шзъ (џнляндіш, Архангельской, Вологодской, Лпифляндской, Харьновской губ. въ Европейской Рос-

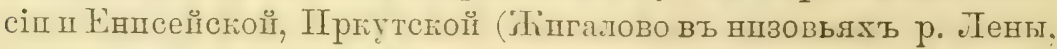
B. Polpus's, Томской (Пнскої боръ: Потерихино 30. VII. 1899 Е. Роддъ) губ., Якутской п Приморской обл.

доходшть на съверх до полярнаго круга (Туруханскь).

Образъ жизни. Въ Фшнляндіп жпветь на Betula alba; на

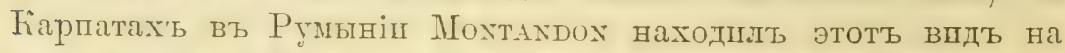
елп, на еліг же (Picea excelsa) нашель этоть впдъ Poppils въ Архангельской губ.

\section{Aradus hieroglyphicus J. SAHLB, 1878.}

(Таб. II, (рпг. 19).

Aradus hierogiyphicus J. SAHLB. Kongl. Sv. Vet.-Akad. Handl., XVI, 4, 1878, p. 22.-Reut. Wien. Ent. Zeit., 1884, p. 131; 1885, p. 150.

Фаушиститеская литература, касагщаяея Россіп.

Aradus hieroglyphicus J. SAнLв. loc. cit., p. 22 (Enisejsk).,REшт. Öfv. Fin. - 
Vet. Soc. Förh., XXXIII, 1891, p. 184 (gub. Enisejsk: Oznatshennoje).-

Krr. Rev. Russ. d'Ent., X, 1910, p. 179 (gub. Tomsk: Inskoj Bor).

\section{Экземпляры Зоологическаго Музея.}

Zhevelevo, ? gub. Enisejsk. (2 J, 2 o).

Gub. Enisejsk: Minusinsk. (q).

Gub. Enisejsk: Krasnojarsk. (3 Q). Krвогт.

Gub. Irkutsk: Moty in fl. Irkut. $(4 \delta, q)$. CzekArowsEr.

Sine datis (q).

Дiагнозъ. Corpus orale (む) rel late oratum (q), nigricans; marginibus lateralibus posticis pronoti, hemelytris basi, interdum obsolete, pallidis, corio albo-signato, connexivo nigro toto, saepius magis minusve fusco-rel rufo-variegato, angulis apicalibus segmentorum pallidis.

Caput latitudine sua paullo longius, prolongatione antica longa, lateribus compressa, sat angusta, lobis lateralibus longis. haud crassis, apice acutis, albidis, margine exteriore denticul, albido vel nigro praeditis, tuberculis anteocularibus acutis, pallidis; lobis temporalibus subacutis, prominentibus; capite pone oculos parti anteoculari aequilato, densissime albido-granulato.

Antennae longae, tenues, articulo primo breviter orali, articulo secundo capite paullo breviore, articulis duobus ultimis simul sumtis multo longiore, articulo tertio dimilio apicali albo, articulo quarto tertio paullo longiore, nigro; antennis praecipue articulo secundo tertioque granulis acutiusculis, pallidis instructis.

Rostrum apicem mesosterni vix superans.

Pronotum longitudine sua duplo et dimidio latius; margine postico late et profunde sinuato; marginibus lateralihus sul) angulo recto fortiter rotundato-ampliatis, fortiter lentati-; carinis: subparallelis, lateralibus antice apicem versus fortiter convergentibus.

Scutellum sat angustum (d) vel latius (o), pronoto longius, marginibus paullo elevatis; disco medio convexo.

Hemelytra basi dilatata, reflexa; membrana nigra, venis sat late hyalino-cingulatis.

Connexivum nigrum vel rufo-Tariegatum, angulis apicalilusegmentorum pallidis.

Pedes nigro-fusci, coxis et tibiis apice flarescentibus.

J. Segmentum sextum rentrale lobis lateralibus apice a lobis segmenti sequentis distantibus; lobis segmenti septimi sat lon- 
gis et latis, marginibus interioribus distantibus, marginibus exteribus leviter rotundatis, basi sub-emarginato truncatis.

q. Abilomen oratum; segmentum quintum rentrale margine pusticu recto, segmentum sextum quinto distincte brevius, distincte transtersum, lateribus lobi discoidalis rotunlatis, versus basin leviter dirergentibus, segmentum septimum sexto fere duplo brevins, marginibus lateralibus segmenti septimi anguste hyalinis; lobis lateralibus segmenti septimi versus apicem angustatis, externe in triente basali in angulum obtusum prominentibus, marginibus interioribus distantibus, divergentibus.

Описаніе. У Улпненно-овальный (ठै) пли шпроко-яйдевшдный (q), темнаго цвҺ́бта, почти черный шли пногда желтовато-бураго

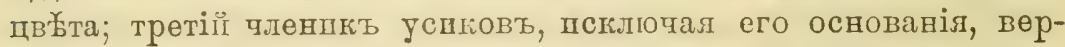
пиеные углы сегментовъ сопиехіүип'а желтовато-б.блые, corium надкрылії покрытъ многочдсленнымп тонквмп полосками бълаго цвйта.

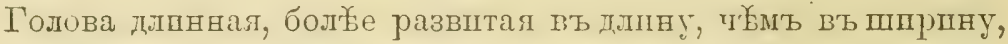
передніи отростокь ея танный, далеко заходить за вершпну перваго членшка усшкошљ, боковые отросткі острые, длшнные,

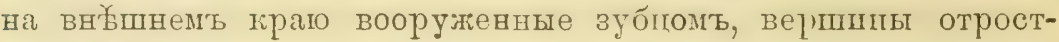

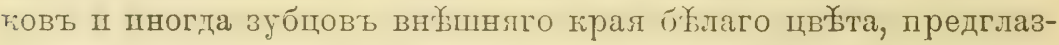
нцчные зубцы большіе, острые, на вершшне․․ бұлые; вшсочные отростки тупые, мало заостренные.

У сикп длинные, тонкіе, второй qленшкь ихъ гораздо ллпнне третьлго и четвертаго виғст взятыхъ, короче головы, темный, у вершины почтц чернаго цво्бта, третій чгенпкъ чуть короче четвертаго, бълаго цвъ̆та, основная половпна его желтовато-бурая, чөтвертый членпшъ черный.

Хоботокь өдва заходить за вершину среднегруді.

Переднеспнка поперечная, въ $2 \frac{1}{2}$ 1'аза шире своей длпны, задній трай ея съ глубокой выемкой, боговые крал прлмоугольпые, распшенные, слегша приподнятые, съ спльнымп зубдамп; пиліг переднеспнип-средшнные почтп параллельные, боловые на вадней дол'; переднеспни параллельные, кпередп сходяпіесл.

Ш,штпюь удлпненно-треугольный, у

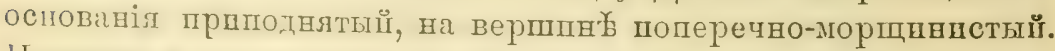
Надкрылья у основаніл распгренныл, вдвое длинние ще щтка,

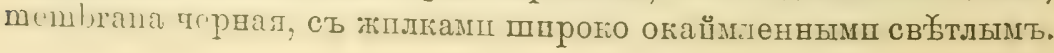


Connexiтum съ вөршиннип угламп сегментовъ нө ситьно продвннутымп, закругленвымп; у внутренняго грал гіалі.даго

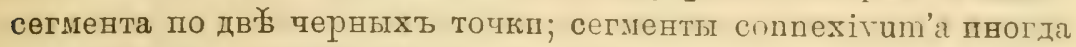
сплошь чернаго цвътта, псгпючая вершпнныхъ угловъ, но чапе

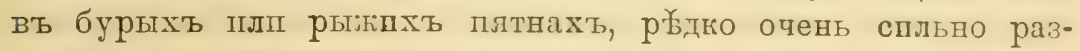
витыхъ.

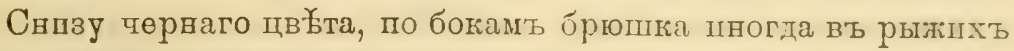
пятнахъ. Ногц бурыл, ляшкп и вершины голеней желтаго двътт.

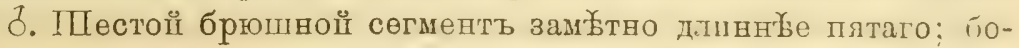
ковыя лопастп его выдаютея надъ топастями слидующаго сег-

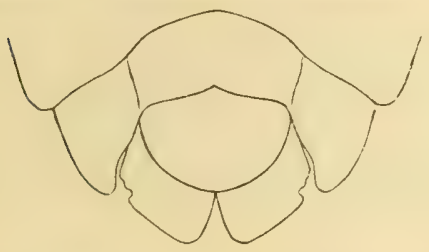

Pнс. 60.-Стернпты бргола VI-VII. Aradus hieroglyphicus

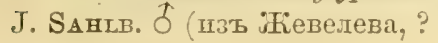
Eнпсейской губ.).

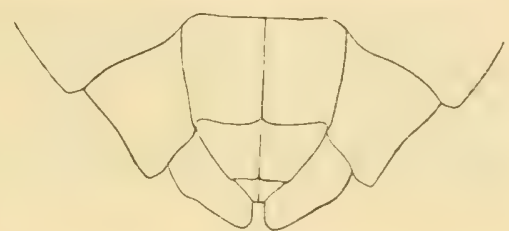

Pпс. 61. - Стернпты бргшга VI-VIII. Aradus hieroglyphicus J. SАнцв. 오 (зъ іћевелева, ? Eнпсейспой губб.).

мента, боковыя лопастц сөдьмого сегмента поперечныл, но спльно развитыл п въ длину, внутренніө крал пхъ оть самаго основанія расходящіесл, слегка закругленные, инейніс края закругленные, у основанія неправшльно вырђзанные.

‥ Брюшко широко-лйцевшдное. Задній грай плтаго б́ргшного сегмента прямой, самъ сегменть значптельно длшнне пшестого; шөстої сегменть въ своей дискошдальної часті попереч-

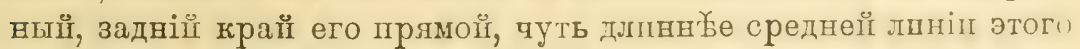
сегмента; седьмої сегменть почтп вдвое короче пестого, сридиннал лшнія его только на ${ }^{1 / 4}$ короте боковыхъ краевт , декопдальвої частп сегмента; этп боковще грал по краг прозратные; боковыя лопастп шестого сегмента догодять до уровня вершпны седьмого сегмента, гі верпшнек съуюпвапшіясл, зна-

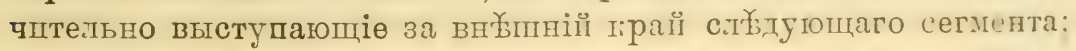
лопасти седьмого сегмента съ внутренвши граям широко рал-

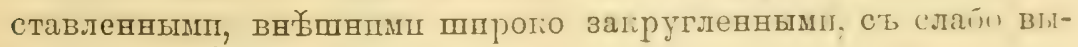
дающимся угломт у основаніл.

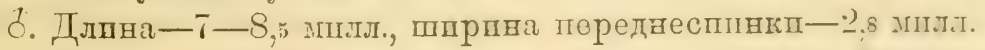

ㅇ. Длпна-8,8-10 мпіл., ппрпна пөреднеспднкт-3 милт. 
Сравнительныя замьтки. Aradus tieroglyphicus пршнадлежшть къ

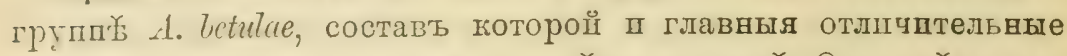

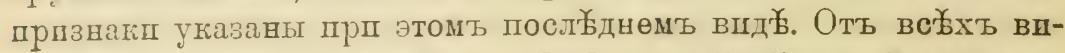

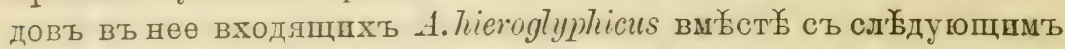
впдом легко отлпчается строеніемъ перөднеспннк, боковые грал которої образуютьь прлмої уголь, шпроко-яйцевшдної

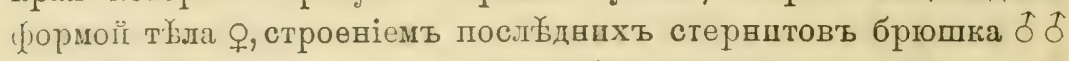
II $q$. Reuter въ свопхъ двухь работахъ, посвлщенныхъ этої групп告, даль вполн字 зағончөнныц й псчерпывающій обзорь пятп видовъ (нзъ общаго числа 7), входящихъ въ нее.

Географическое распространеніе. Это псключительно спбирскій

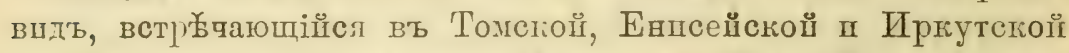

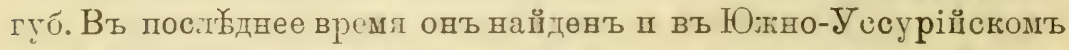
пра близъ ст. Евгеньевка.

0бразъ жизни. Единственно, что пзвђстно о біологіп әтого вида, это то, что J. SAнlberq нашель первые экзелпляры этого вида подъ корой сухого Salix.

\section{Aradus krueperi Revt. 1884.}

Aratus cancasicus Put. Synops. Hém.-Hét. de France, I, p. 138. 1879 (nec Kou.).

Arcedus Krueperi Revт. Wien. Ent. Zeit. 1881, p. 130; 1885, p. 149.

\section{Энземпляры Зоологичеснаго Музея.}

Hungaria occ.: Pápa. IX. 1896 (2 \&).

Діагнозъ. Corpus ovale, retrorsum rotundato-dilatatum, brunneo-fuscum, rufo- et ferrugineo-variegatum.

Caput latitudine sua longius; prolongatione antica longa, sat mediocri; lobis lateralibus longis, haud crassis, apice acuminatis, late albidis, margine exteriore tuberculo albido instructis; tuberculis anteocularibus acutis; lobis temporalibus acutis, prominentibus.

Antennae longae, tenues, articulo secundo capite vix breviore, lense granuloso, articulis duobus ultimis multo longiore, articulo tertio, basi excepto, albido, articulo quarto tertio vix longiore.

Rostrum medium mesosterni haud attingens. 
Pronotum longitudine sua magis quam duplo latius, margine postico late et profunde sinuato, marginibus lateralibus sub angulo recto fortiter dilatato-ampliatis, dentibus lateralibus validissimis praeditis; carinis basin versus leviter divergentibus, lateralibus antice apicem versus convergentibus.

Scutellum elongatum, marginibus elevatis, disco basi convexo. Hemelytra basi sat valde dilatata, crenulata; membrana fusca, venis hyalino-cingulatis.

Connexivum rufo-ferrugineum, fusco-maculatum; angulis apicalibus segmentorum valde prominentibus, segmenti secundi quoque fortiter prominulo.

Pedes fusci, tibiis apice flavescentibus.

J. Segmentum sextum ventrale quinto aequilongum, lobis lateralibus segmenti sexti a lobis lateralibus segmenti septimi latius distantibus, lobis lateralibus segmenti septimi vix transversis, marginibus interioribus distantibus, marginibus exterioribus angulatis, basi leviter sinuatis.

‥ Abdomen ovatum; segmento sexto quinto longitudine aequali, latitudine aequilongo, segmento septimo sexto fere duplo breviore; lobis lateralibus segmenti septimi versus apicem angustatis, marginibus interioribus distantibus, marginibus exterioribus basi dentem obtusum formantibus.

Описаніе. Шшроко-овальвыц̆, гзздп довольно спльно расшщряющійся іг округленный, буроватаго цвъьта, conexivum по середшве красновато-рыжеватаго цв'зта съ бурыми пятнами.

Голова болґе развптая въ длпну, чъмъ въ ппрпну, переднії отростокъ ея длинный, довольво тонкій; боговые отростки длшн-

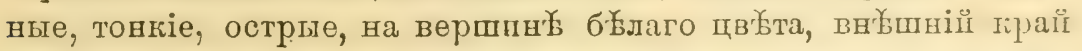
шхъ вооруженъ бугоргомъ бълаго цвътта; предгтазничные бугорки острые; вшсочные отростки острые, выдающіеся.

Успки длинные, тонкіе; второй членши пхъ чуть короче

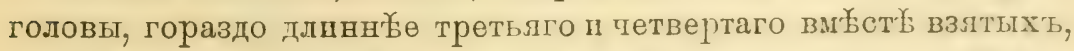
третій члөншкъ бълы:, основаніе его буроватое, четвертый ч.тенпкь отень незначштельно тлдна венъ ему.

Хоботокъ не доходить до сөредшны среднегруді.

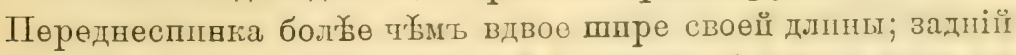
прай ея съ ппрокой п глуйогой выемной, боковые крал с: прямоугольно расширенные, съ спльнымш, групнымш зубцами, 
почті равнтмп по размйрамъ на всемъ протлғеніп переднебоговнхъ краевъ; кплп переднеспнни къ основанію слегка расходлщіеся, боковые впереди кь вершннег переднеспнни сильно сходящіеся.

Щитпґъ удлиненый, боковые трая его пршподнятые, поверхность у основанія прпподнятая.

Надкрылья у основаніл слльно расшпренныл, зазубренныя;

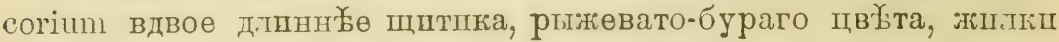
грасноватыл, крупныл плтна вдоль жшлокъ и по вноㅎннему краю corium'i чернаго цв'вта, membrana буроватая, жшлгш свйтоогаймленныя.

Connexivum прасновато-рыжғаго цво̆та въ бурыхъ пятнахъ: вершинные углы всбхх сегментовт, начинал со второго спльно выдающіеся, такъ что края connexivum'a зубчатые.

Ногш бурыл, голөнш на вершшнахъ желтоватыл.

§. Шестої бргшної сегменть одинакової длшны съь пятымъ, боновыя топасти его пирого отстоящія отьь топастей

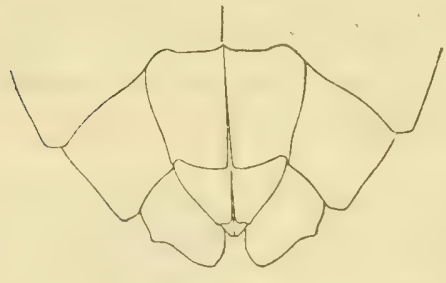

Pис. 62. - Стернпты брюшна VI-VIIT. Arudus Tirueperi REL'T. of (пзъ Венгріш). сльгдуюаго сегыента; боковыл лопасти седьмого сегмента почти одинаково развитыл въ длину іп ширину, едва поперечныя, внутренніе края ихъ расходящіеся, внкетшніе - образують уголъ, у основанія съ легкої выемкої.

ㅇ. Бргшко широко зицевидное, съ, боловымп гралми сшіьно затруглөнными; шестої брюшної сөгменть равенъ по длинет

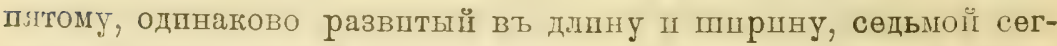
менть почтп вдвоө короче шестого; боковыя :опастп шестого сегмента доходять до уровпі вершины седьмого сегмента; боповыл лопастш сөдымого сегмента гъ верппне съужшвающілся, внутрениіе края пхъ разставленпые, вно̆шніе у основанія съ выдатощшмся тупымъ зубцомъ.

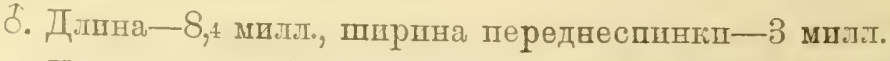

$$
\begin{aligned}
& \text { ㅇ. Длина-9,5 мплл. }
\end{aligned}
$$

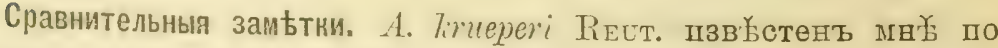
тину этого внда (ई щзъ Мореи), полученном'ь мною на про- 
смотръ, благодаря любезностп проф. О. M. Rештег'а, пзъ Гельсшнгффорскаго Музея.

Впдъ этоть рбзко отлічаетел отъ другпхъ впдов' группш A. betulae п по строенію переднеспнкп, прямоугольно расширенной, спльнымъ зубцамъ боковыхъ краевъ ел, спльно выдаюпшмся вершпнымъ угламъ сегментовъ сопnехіvим'а, расппренвому п закругленному брюшку (す), строенію послйднихъ стернптовъ онъ легіо можеть быть отлпченъ оть остальныхъ вшдовъ.

По строенію переднеспингі онъ блпже всего стопть къ

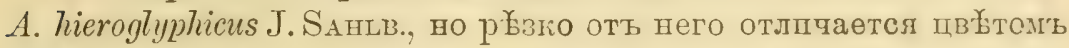

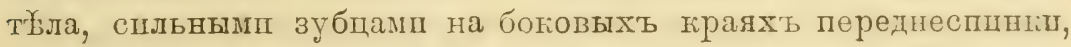
боль্е снльно съужпвающейся ппередш переднеспнной, выдаю-

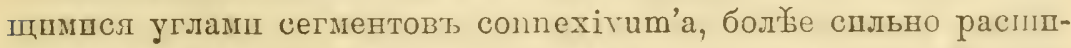
реннымп у основанія надєрыльямш, строеніемъ посль'дншхь стернитовъ брюшка и многпм другшмп пршзнакамш.

Географическое распространеніе. Вघдъ оппсанъ ІіеUтеR'олъ по эґземплярамъ пзъ Гредіп (Морея, Пелодонезъ), Італін, острова Корспіп п Марокко. Позднебе показанъ Ногғатн'омъ для Малої Азіп п Венгріш. Экземпляры этого вшда пзъ Венгріп есть въ

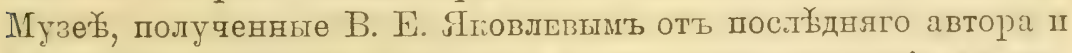
настолько отлпчаютел отъ тппа б, что дають основаніе думать. не есть ли это особый впдъ, отличныї оть A. Rimeperi Reut. I'́

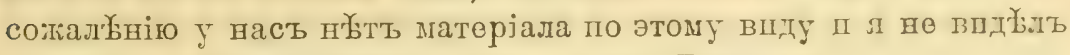
오우 әтого вшда, пропсходящихъ нө пзъ Венгріш.

\section{Aradus caucasicus Kor. 1856.}

(Таб.т. II, (1)г. 18).

Aradus cancasicus Kor. Bull. Soc. Nat. Mosc., XXIX, 1856, p. 438; Melet. ent., VI, p. 20, sp. 221. 1857. - Fieв. Eur. Hem.g p. 11t. 1861.-Reut. Wien. Ent. Zeit., 1884, p. 130; ibid., 1S85, p. 150.

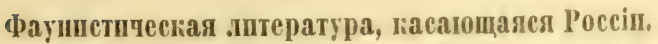

Aradus caucasicus JAK. Rer. Russ. d'Ent, VI, 1906, p. 220 (Tauria: monast. Kosmo-Damianovskij).-KoL. loc. cit., p. 488, sp. 221, 1856 (Caucasus:

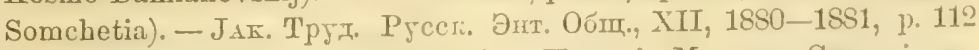
(Lagodechi, Etshmiadzin, Derbent). - Horv. in Museum Caucasicum. Die Sammlungen des Kaukasischen Museum ron Dr. Gustay R.1Ddi, Bd. I. Zoologie, p. $46 \pm 1899$ (Trancaucasia: Tana-Thal). 


\section{Экземпляры Зоологическаго Музея.}

Tauria: Monasterium Kosmo-Damianovskij. (q). Kiritshenko. Transcaucasia: Derbent. (4 $\bar{\delta}, 11$ ㅇ). Korarov.

Transcaucasia: gub. Tiflis. 1901. (Q).). Satunin.

Transcaucasia, gub. Tillis: Lagodechi. 1896. (ठ). MLlorossewicz. Transcaucasia: gub. Tiflis. 19. VII. 1911. (). MLorossewicz. Transcaucasia: Elizavetpol. (2 $\delta, 16$ ㅇ). VinovsKI.

Transcaucasia, gub. Elizavetpol: Evlach. 23. VII. 1896. ()). Transcaucasia, gub. Elizavetpol: Evlach. (3 ơ, 9 o) $)$.

Діагнозъ. Corpus ovale, sorilide flavo-тel-griseo-fuscum, caput latitudine sua longius, prolongatione antica longa, crassa, lobis lateralibus longis, tenuibus, apice acuminatis, pallidis, margine exteriore denticulo instructis; tuberculis anteocularibus validis, acutis, lobis temporalibus acutis, prominentibus. Antennae tenues, longae, articulis duobus primis flaro-fuscis, tertio albo, quarto nigro, articulo secundo capite aequilongo, quam articuli tertius et quartus multo longiore; articulo tertio quarto paullo longiore.

Rostrum apicem mesosterni vix superans.

Pronotum transtersum, longitudine sua duplo et dimidio latius; margine postico profunde sinuato, marginibus lateralibus obtusangulariter rotundato-ampliatis, dentibus validis instructis; carinis basin versus leviter divergentibus. Scutellum breve, sat latum, marginibus lateralibus elevatis, disco basi convexo.

Hemelytra basi parum dilatata; membrana fusca, venis lato hyalino-limbatis. Connexivum angulis apicalibus paullo prominentibus.

Pedes fusci, tibiis flavescentibus.

J. Segmentum sextum rentrale quinto longius, lobis lateralibus a margine loborum lateralium segmenti sexti distantibus; lobis lateralibus segmenti sexti transversis, sed sat longis, marginibus interiorilus apice divergentibus, marginibus exterioribus leviter rotundatis, crenulatis.

‥ 1bdomen obovatum; segmentum quintum ventrale margine apicali recto, segmento sexto medio hoc nonnihil breviore, levissime transterso; segmento septimo quam segmentum sextum duplo longiore, segmento octaro praecedente duplo breviore; lobis lateralilus segmenti septimi marginibus interioribus diverwentibus, marcinibus posterioribus in triente basali in dentem obtusum prominentibus, dein late sinuatis. 


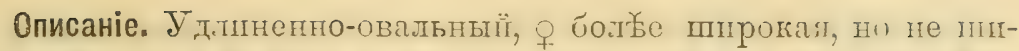
роко лйцевидной қормы, желтовато-рыжаго пи бураго цве́та, въ бурыхъ пгл терныхъ плтнахъ.

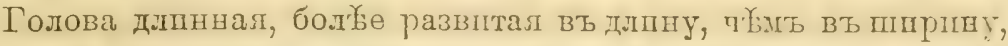
перегтій отростокь ея длнный, ввлутый, захолить за первуг четверть второго членика успковъ, бэговые отростіл динные,

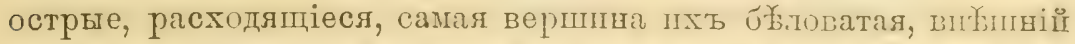

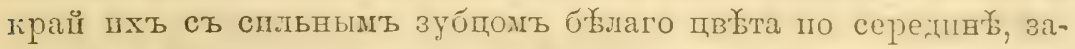
зубрениыи, предглазничные зубцы острые, високіе; впсопные отросткі острые, оттянутые прямо назадъ.

Усцки длинные, тонкіе, поверхность пхь спльно зернпстая;

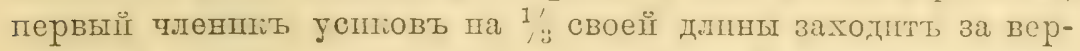
шину боковыхъ отростковъ го.товы, второї членшк гораздо

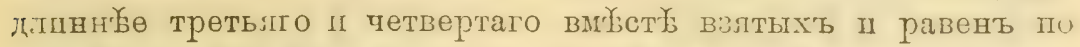

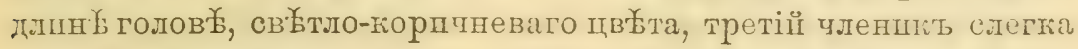

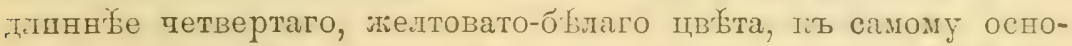

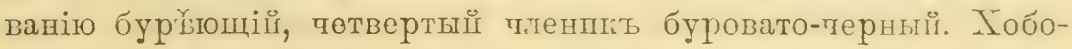
токь чуть заходить ва вершину срөднегрудп.

Переднеспндіа поперетная, В’ $21 / 2$ раза шире своей длпны, сзадп съ глубокой выемкой, боковые ғрал тупоугольно расшшренные, слегка загнуты, съ крупнымп, болыпми зубцахп; тилп переднеспнкп къ основанію слегка расходящіеся, боговте тоходять до половпны передней лоли переднеспнни, пъ вершин сходящіеся.

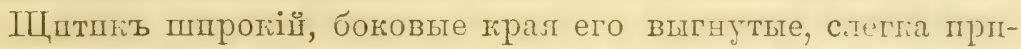
поднлтые, у самой вершшны съ легкой выемкої, съуненный, поверхность у основанія приподвятая.

Нағпрылья у основанія не сшльно расшшренншл, зазубј:ет-

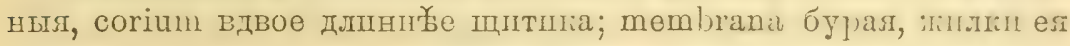

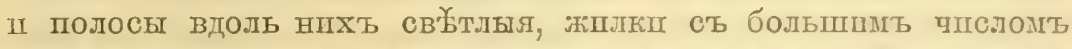
инастомозпрующихь пхь поперепнихь жплокъ. Верппные углы брюшныхъ сегментовь слабо выступающе, зиругтепные. Connexirum съ двуми червыми точками па палғдом семент:

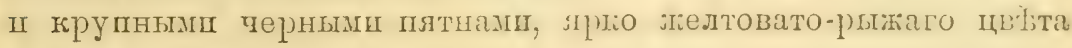
пли часто бураго.

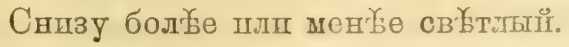

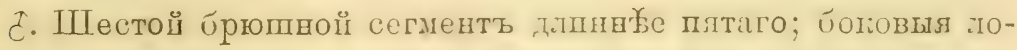
пастп его поперетныл, но спльно развштыл Іі въ дливу, вну-

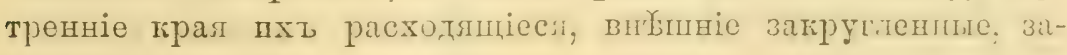
вубренные. 


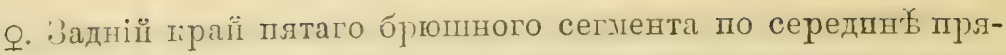
мой, шестої сегментъ немного тороче пятаго, шшршна основного крал его туть больше длшны сегмента, боловые грал его почтп параллельвые, заднії краї шпроко п очень незначптельно закругленвый плш почтш прямой: сөдьмой сегментъ вдвоө ліроче шестого II на $3 / 3$ ћороче свошхъ боговыхъ краевъ; задній

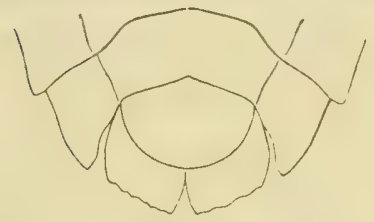

Рнс. 63. - Стерниты брюшіка VI-VII. Aradus caucasicus

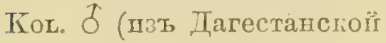
обл. : Мербента).

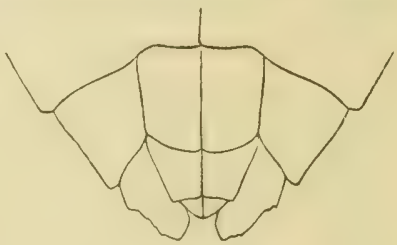

Pшс, 64. - Стерншты брғшта VI-VIII. Aradus caucasicus Kiol. 오 (изь Дагестанстой обл.: Тербента).

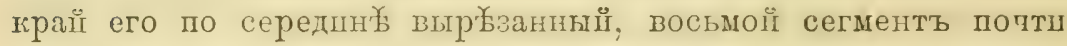
вдвое корочө седьмого; внутренніе гіла боковыхъ лопастей седьлого сегмента расходлщіеся, къ вершшне съужшваюшіесл,

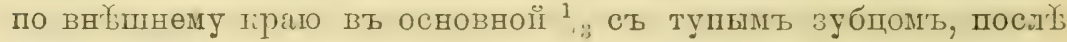
котораго ст пшрокої выемкой.

б. Длпна-7 мшлл., ппрпна переднесппнкп-2,3 мшлт.

ㅇ. Длпна-7,7-8,5 мплл., шприна переднеспннкш-2,22,8 мшлл.

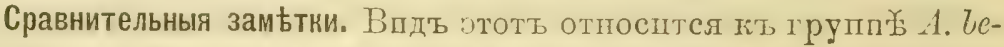

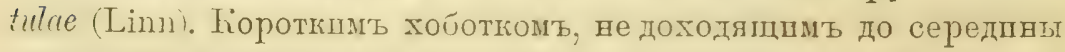
среднегрудп, чөтвертымь тленикомь успіовь равнымъ по длпнћ третьему пли лороче сго, строеніемъ посльдннхъ сегментовъ

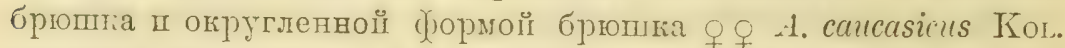
хоропо отлпчается оть $A$. betulae (Lins.) п $A$. brenstiei Reut.

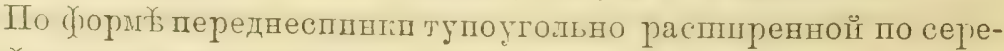

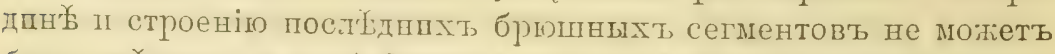

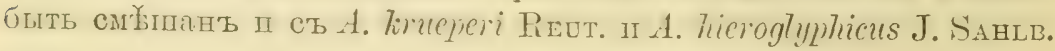

Географичесиое распространеніе. Виль :тоть; главнымт обравомъ, распространень въ Закавказь г, гд⿱⺊口 онъ наїденъ въ

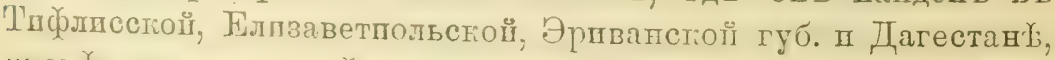

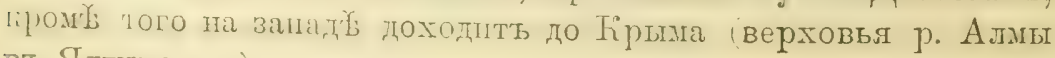
въ Ялтннск. У.). 


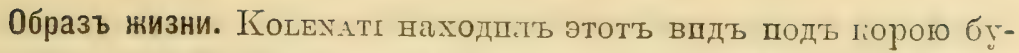

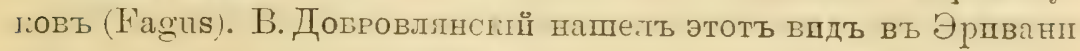
подъ торою сухой пвы (Salix).

\section{Aradus turkestanicus $J_{\text {AK. }} 1894$.}

Areclus turkestanicus JAK. Hor. Soc. Ent. Ross., XXVIII, p. 138. 1894.

\section{Фаунистическая литература, касающаяся Россіп.}

Arcudus turkestanicus JAK. loc. cit., p. 138 (Tashkent).

\section{Эизсмпляры Зоологичеснаго Музея.}

Turkestan: Tashkent. (1 $\delta$, 3 아). Batassogro.

Дiarно3ъ. Corpus ovale, brunneum, flavo-et fusco-rariegatum. Caput latitudine sua longius, prolongatione antica longa, tumidiuscula, lobis lateralibus longis, acutis, apice albidis, margine exteriore tuberculo instructis; tuberculis anteocularibus valilis, acutis; lobis temporalibus prominentibus, acutis.

Antennae tenues, sat longae, sed multo breviores quam in speciebus praecedentibus, flaro-cinnamomea, articulo tertio albo, articulo quarto nigro, apice articuli secundi, ima basi articuli tertii - nigricantibus; articulo prino brevissimo, latitudine sua paullo longiore, articulo secundo capite multo breviore, quam articuli tertius et quartus simul sumpti in $1 / 1$ longiore, articulo tertio quarto vix breviore.

Rostrum apicem prosterni paullo superans, nigricans, articulo nltimo apiceque articuli penultini interdum flarescentibus.

Pronotum logitudine sua luplo latins, margine posteriore late et profunde sinuato, marginibus lateralibus pone medium fere parallelis, rectis, antice apicen versus angustatis; dentibus lateralibus pronoti brevibus, haud validis; angulis posticis late rotundatis; carinis intermelliis basin versus plus minusve divergentibus, lateralibus antice apicem versus fortiter convercentibus.

Scutellum sat breve et latum: narginilus elevatis, rotundatis, apice flavescentibus; disco basi utrinque callis longitulinalibus rufis instructo.

Hemelytra basi modice lilatata, parte clilatata maculit fliva praedita, membrana fusco-nigra, venis hyalino-limbatis.

Connexivum flavo-ferrngineun, marginibus literalihus fuscis, 
nngulis apicalibus parum prominentibus; pallidis, segmentis connexiri medio punctis duobus nec non linea longitudinali praeditis.

Pedes fusci, tibiis basi et apice pallidis.

J. Segmentum sextum rentrale quinto aequilongum; lobis lateralibus segmenti sexti marginilus interioribus profunde emarginatis, a marginibus segmenti sequentis ralde distantibus, lobis lateralibus segmenti septimi transversis, marginibus interioribus apice divergentibus, flavo-limbatis, marginibus exterioribus fere rectis, undulatis.

ㅇ. Abdomen oratum: segmentum quintum ventrale margine apicali recto, segmento sexto medio hoc nonnihil breviore, latitudine sua longiore: segmento septimo sexto duplo breviore: lolis lateralibus segmenti septimi marcinibus interioribus distantibus, marginibus exteriorilıs angulum olstusum formantilus, fere rectis.

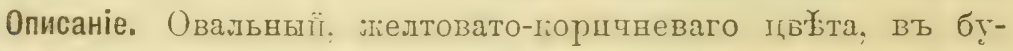
рыхъ п желтыхъ пятнахъ.

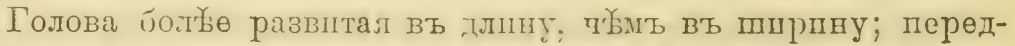

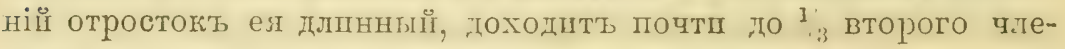
ника успғовт; ботовыо отросткш довольн дининые, заостревпые, самая вершпна пхъ б́бловатая, на внғынемъ краю вооруженние больпиљ бугорномт, расходлщіеся: предглазнпчныө зуо̆ды большіе, острые; впсочные отростки ваостревние, вытлнутые назадт.

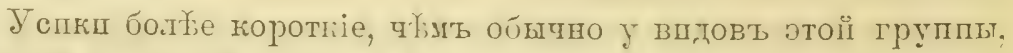
первый п второй членикп пхъ ғєелтовато-торичиевые; первыц членпіъ о чень немного длпнн斿е своей пприи, второї членшкъ на $1 / 3$ гороче головыл п едва на $1 / 4$ длиннесе третьяго п четвертаго взятыхъ вмґсту, довольно слабо бугорчатый, у вершины

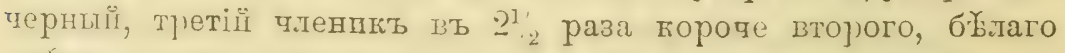
дығта, тольи самое основаніе его буроватое, четвертыи тленшћъ слегка длпннеке третьяго, пернаго цв宅та.

Хйотокь спиа заходит за вејшину среднегруди, не достпгая ел середшны, черныі весь шлп посль্бдніиі члевпкъ его п вөршпа предыдущаго черные.

Переднесппнка вдвое шпре своөї ллины; задвіпі край ел

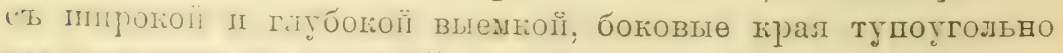

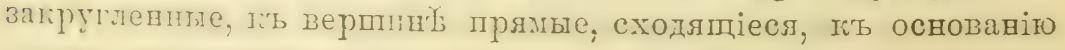

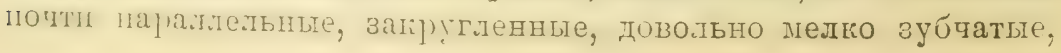


слабо загнутые; гшлш пөреднесппвги слабо прпподнятые, средпнные къ основанію расходящіеся, боковые на переднеї дол;

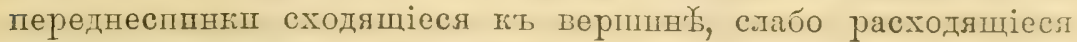
къ основанію на задней дол斿.

Щштикъ короткіו̆, короче переднеспнкі п довольво пшрокій, боковые крал его выгнутые, слабо прпподнятые, красноватаго цвита, на поверхностц его у основанія по объпм сторонамъ вздутія красноватаго пввтта.

Надирылья у освованіл слаи́о, но шпрого распиренныя, почти цијьныя, corium вдвое длшнн施е щптшка, бураго цвйта, жилкп, большое пятно у основанія, многочшсленныя мелтія

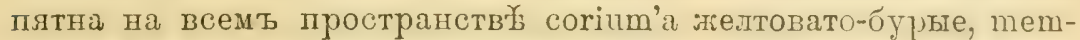

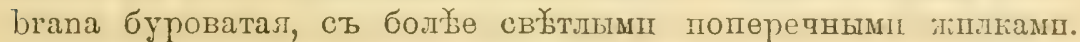
Connexirum св бтлый, съ бурымп полосамп п пятнамп, съ слабо

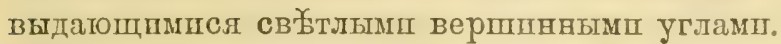

Сншзу переднегрудь по бокамљ п боговыл лопастп бртппныхъ сегментовъ грязно-тіслтаго дво̆бт, въ буршхь продольныхъ п поперечныхъ полосахъ; почтп вся средне- з задне -

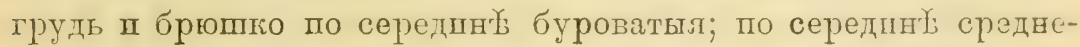
грудп два большпхъ пирокпхъ черныхъ пятна.

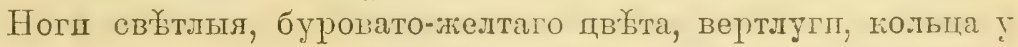
основанія бедерь II вершшны голеней св үิтлые.

3. Боковыя лопасти шестого брюшного сегмента по зағнему граю спльно выр'ззанныл, не сопрпкасающяся ст лопастмп

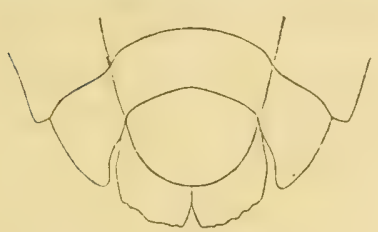

Pпс. 65, -- Стернпты бргшта VI-VII. Aradus turkestanicus ЈАг. Oे (пзъ Сырь-Дарьпнстої об̆.т., тцПт).

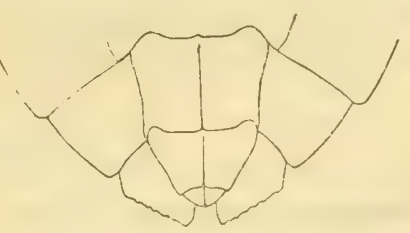

Pric. 66. - Cтеріпты бртопиа VI-VIII. Aradus turkestanicus JАк. ㅇ (пзт, Сырт-Iтарыниской обл., типт).

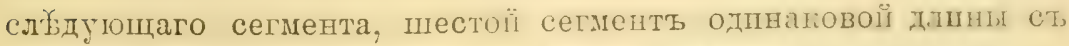

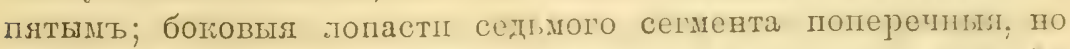

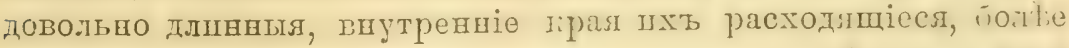

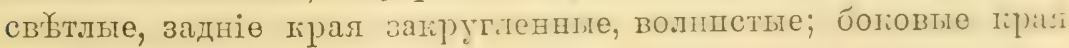
представллоть тупої уголь. 


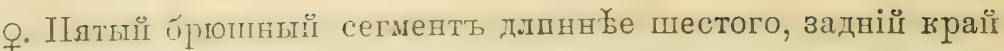
его по ссредпнй прямой; шестой сегменть по срединной линіп равенъ боковымъ гралмт лопастеї его Іі вдвое длшннъе седьмого, почтц одинагіово развптый въ длшну II ширпну, задніiі жрай сго очень слабо закругіенный, боловне края къ основанію слегпа сходящіеся; боковыл лопасти седьмого сегмента поперечны:, внутренніе грая шхъ спьно разстав.деные, слабо рас-

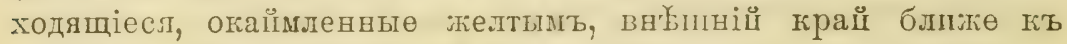
основанію образуетт, тупой угол'下, стороны котораго прямыя; седьмої сегментьь вдвое длпннґе восьмого, боковые іл задніі грая его окаймленные бұлымъ.

๖. Длпна-7 мплл., ппрпна переднеспиниц-2,1 мплл.

‥ Длина-, 4 мглл., ширпна перөднеспшніш-2,5 мплл.

Сравнительныя замьтии. Видъ этоть принадлежпть гъ групп方

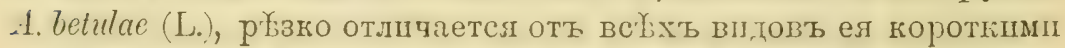
успками, формої переднеспнки, мелкими зубцами боковыхъ краевъ ея, строеніемъ послҰдншхь сегментов' брюшка. По

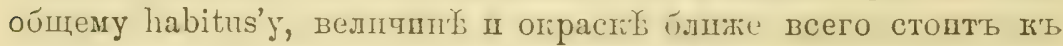
A. cancasicus KoL., но выпеприведенными признаками, также

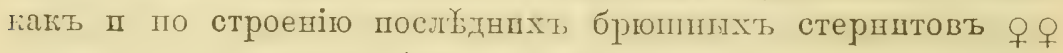
лөгко отъ него можетъ быть отлпчөнъ.

Географическое распространеніе. Видъ әндемпчевт длл Турке-

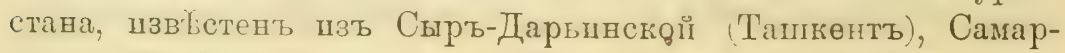

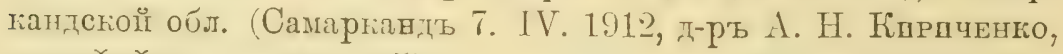

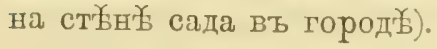

\section{Aradus margianus n. sp.}

\section{Экземпляры Зоологическаго Музея.}

Transcaspia: Turkmenia. (ठ). KoenIG.

Transcaspia: Imam baba, distr. Merv. 26. III. 1912. (ठ). V. Koshantschrkow. Transcaspia: Kusbka. (o).

Діагнозъ. Corpus ovale, feminae late orale, fusco-cinnamomeum, nigro maculatum; articulo tertio antennarum albido, ipsa basi nigricante excepta.

Caput latituline sua longius, prolongatione antica longa, lobis literalibus acutis, tenuibus, apice pallidis, margine exteriore denticulo armatis; denticulis anteocularibus validis, acutis; lobis 1.-nijorililus: acutis, proninentibus. 
Antennae longae, tenues, dense granulosae; articulo secundo capiti aequilongo, quam articuli tertius et quartus simul sumpti multo longiore, apice late nigro, articulo tertio quarto longiore, articulo quarto nigro.

Rostrum apicem mesosterni paullo superans.

Pronotum longitudine sua magis quam duplo latius, margine posteriore profunde sinuato, marginibus lateralibus sub angulo obtuso dilatatis, dentibus ralidis instructis, apicem et basin versus fortiter convergentibus; carinis subparallelis, lateralibus apice apicem versus convergentibus.

Scutellum elougatum, apice flavescens, obtuse rotundatum, marginibus elevatis, disco basi convexo.

Hemelytra basi modice dilatata, reflexa, margine integra; membrana nigra, venis late pallido-cingulatis.

Species structura segmentorum ultimorum ventralium formaque abdominis , articulo tertio antennarum quarto longiore, marginibus lateralibus pronoti sub angulo obtuso dilatatis nee non colore et margnitudine $A$. turliestunico $\mathrm{J}_{\mathrm{Ar}}$, affinis et simillimus, a quir antennis longioribus et tenuioribus, praecipue articulo secundo, pronoto marginibus lateralibus denticulis ralidis instructis, marginibus posticis basin versus fortiter convergentibus, hand subparallelis, hemelytris basi fortius, sed angustius dilatatis distincta.

Описаніе. Удлиненно-овальный, о пппого яйцевпдная, буровато-горшчеваго цв於та, въ бурыхъ пятнахъ; третіі тленикъ

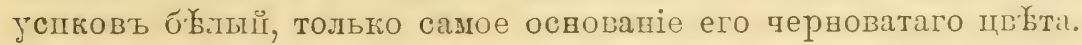

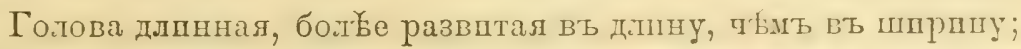
передній отростокъ ея длинный, далего заходящії зи основаніс второго членшға усшғовъ, боғовые отростіп длинные, острле,

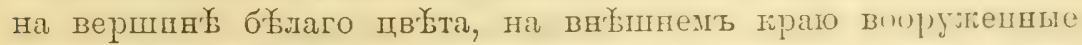
крупнымъ зубцомъ; предглазнптные бугорніг острые, спльно развитые; височные отрости острые, вығағоціесл назатъ.

Ј спкп длинные п товкіе, густо зернистие, первый п второй

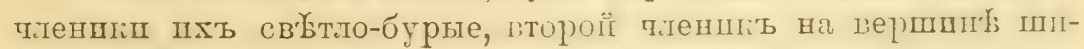
роко зачерненъ, третій члениг, пслтютая самато основанія

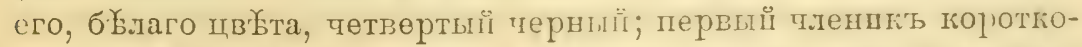

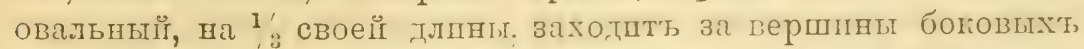

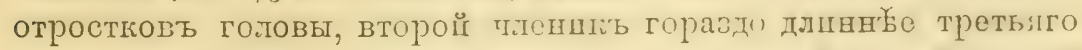

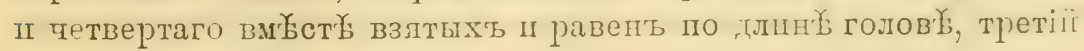
члевикъ длинн施 четвертаго. 
Хоботокь слегка заходшть за вершшну среднегруди.

Переднеспнка почтп въ 21', раза пире своей длшны, затвій

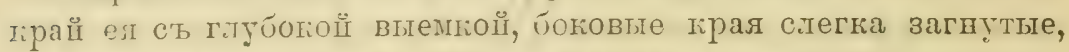
съ большим, сшльнылп зубцамп, тупоугольно расширенные, ть

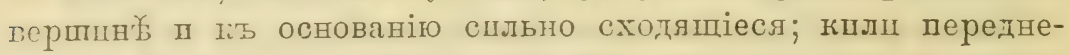
спннкп почтп параллельные, боловыө кпередш спльно сходящшіеся.

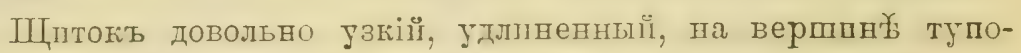
закругленый, желтоватаго цв'Бта; боловые гірая его слабо приподнятые, поверхность у основанія прпподнятая.

Надкрылья у основанія доволын спльно, но не широко расппренныя, бокової тірай распиренной части почтп цҢлғныи; corium вдвое длпнн务е пштика, распшренное основаніе его,

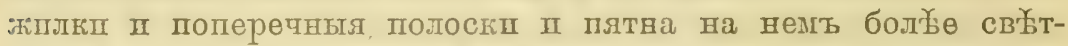
лшл. жлелтовато-гірпчневыл, остальное пространство иуроватаго

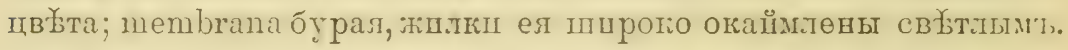

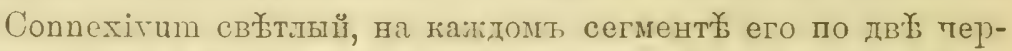

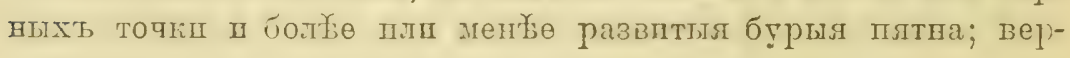
шинные углы сегментовъ слабо выдаюпіеся.

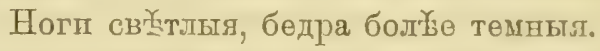

§. Пестой брншної сегмевть одшнакової длпны съ пятымъ, боновыя ловасті его по заднему краю ст, спльной вырґзкой, от-

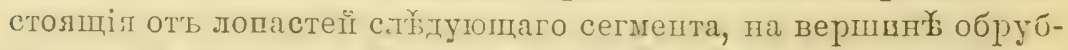
ленныя; лопастіг седьмсго сегмента сильво развптыл въ длпну; шнутренніе края пхь расходящіеся, задніс драя прямые, сшльн зазубренные:

․ Грюпко пшроко лйцевшдное: плтыї сегментьь динн пестого, загніпі прай его прлмой; шестой ссгментт вдвос длпнне седымог; боповыя лопасті седьмого сегмента съ внутрен-

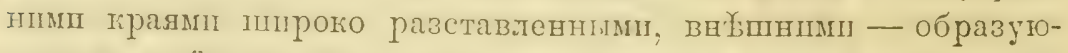
пцмп тупої угогт, съ спіьно зазубренної пщжей стороной.

б. Длшва - 7, м млл., шшрпна переднеспинкщ - 2,4 мплл.

ㅇ. Длпва- 8,9 мшлл., ширшна передвеспинкп - 2,6 мплл.

Сравнительныя замьти. По строенію посл年,нихь сегментовъ

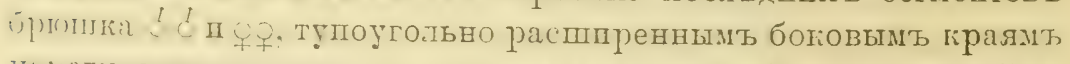

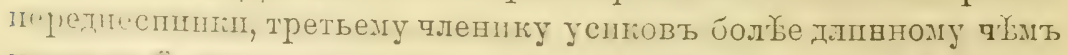
тетвертиї, нашт, впдъ блпзко примыкаеть въ групп年 $A$. betulae,

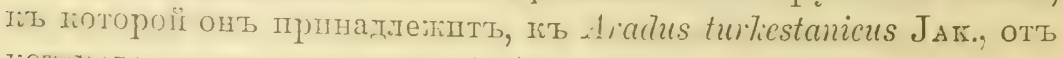

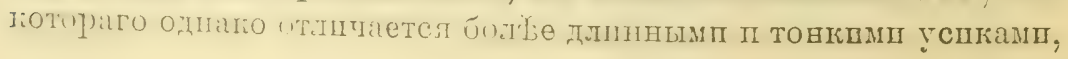


въ особенностп вторым тленикомт пхъ, который одитаговоі длпны съ головой ил зватительно діпннҰе третьяго ш тетвертаг”

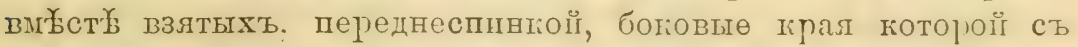

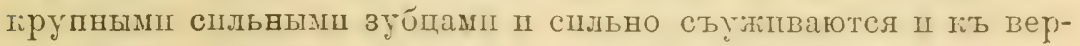
ппн но не такъ пироко, какъ у A. turkestanicus, бол条ө узкпиь II длиннымъ щптикомь, широго яйдевпднымъ бргопгомь

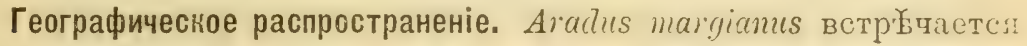

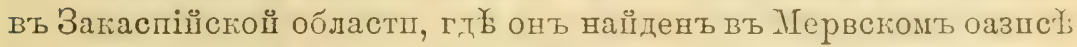
(Кушка п ст. Имамъ-баба по Ћушкпнскої жел бзно-доровіной в вотек).

\section{Aradus betulae (LINN.) 1758.}

Cimex Betulae Lins. Syst. Nat., ed. X, p. 442. 1758; Fauna Sv., sp. 918. 1761. Acanthia betulae FABr. Syst. Ent., p. 695. 1775; Ent. Syst., IV, p. 73.1794.

Acanthia varia FABR. Suppl. Ent. Syst., p. 526. 1798.

Aradus Betulae Fabr. Syst. Rhyng., p. 119. 1803. - R. F. Sarlb. Ion. Geoc.

Fenn., p. 138. 1848. - Flor Rhynch. Livl., 1, p. 384. 1860. - Freb. Eur.

Hem., p. 114. 1861. - Reut. Öfv. Kongl. Vet.-Alad. Förh., 1872, i 5,

p. 56.-Puт. Synops. Hém.-Hétér. de Fr., I, p. 138. 1879.-Reut. Ent.

Tidskr., 1882, p. 79; Wien. Ent. Zeit., 1884, p. 132; ibid., 1885, p. 150:

Rev. S5n. Het. palaearct., II, p. 234, № 194. 1888.

Aradus annulicornis AHrexs Faiun. Ins. Eur., I, p. 22. 1812.

Aradus ellipticus Duf. Ann. Soc. Ent. Fr., 1814, p. 453, t. 10, f. 5, 6. - Kón.

Melet. ent., p. 437, sp. 219. 1856.

Aradus Geneonymus G_re. Bull. Soc. Ent. Ital., 1, p. 276. 1869.

Aradus betulae var. simulans Revт. Wien. Ent. Zeit., 1881, p. 132.

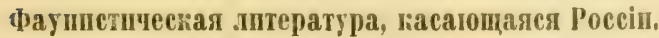

Aradus betulce J. SAHis. Medd. Soc. Faun. Fl. fenn., VII, 1SS1, I) 43 (Fennia: Kuusamo-66 $30^{\prime}$ sept. lat.). - REut. Not. Sällsk. Fn. Fl. Fenn. förh., XI, 1871, p. 318 (Fennia: Pargas). - J. SAHLB. ibid., IX, 1868, p. 1S: (Karelia mer. or.); ibid., XI, 1871, p. 299 (gub. Archangelsk et Olonetzk). - Popp. Nedd. Soc. Faun. Fl. Fenn., XXXV, 1908-1909, p. 93 (gub. Archangelsk, distr. Mezen: Tshublazhskaja). - Cen. Faun. Ingr. prodr., 1798, p. 270 (St.-Petersburg).- L. Віахсні Труд. прұспов. біолог. станш. Илп. СШБ. Оӧш. Ест., II, 1906, стр. 63 (gub. Norgorod: Bologoe). - Fror Rhynch. Livl., I, p. $38 \pm$ (Livland, Kurland). - JAk.

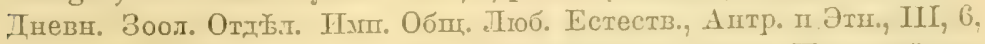

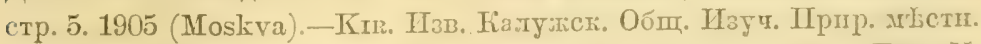
Kp., I, 1912, стр. 71 (Kaluga)- - PAczosк Зап. Kiевст. Оóщ. Ест., X, II, p. 417 (Volyn, gub. Kiev: Radomysl).-Hory. Bull. Soc. Ent. Ital., XIX, 1887, p. 282 (Podolia: Olgopol). - Berke Bull. Soc. Nat. Mosc., 1859, № 1, p. 83 (Kamenetz-Podolsk). - Јаголсн. Тр. Общщ. Ест. Шрир. 
Харьт. Унев., VIII, 1874, p. 55 (gub. Charkov: Kupjansk).-JAк. Hor. Soc. Ent. Ross., IV, 1867, p. 149 (Kazan, Sarepta, Orenburg); Rev. Russ, d'Ent, VI, 1906, p. 220 (Tauria: Staryj Krym). - KoL. Mel. entom., p. 437, sp. 220 et 219. 1856. (Caucasus). - Horv. Sitzungsber. d. naturw. Gesellsch. Isis, 1879, p. 96 (gub. Tiflis: Suram).-ЈAк. Tруд. Pусск. Әнт. Общ., XII, p. 113. 1879 (Dagestan: Derbent).-Horv. Hemiptera in RADDE Museum Caucasicum, 1899, I, p. 464 (Transcaucasia, gub. Tshernomorskaja: Utsh-dere; gub. 'Tiflis: Lomis-mta). Horv. Rev. d'Ent, X, 1891, p. 72 (Transcaucasia: Ordubad). - GebL. Bem. üb. Ins. Sib. in Ledebour's Reise durch Altai-Geb., 1830, p. 18 (Altai).-J. S.ıнцв. Kongl. Sv. Vet.-Akad. Handl., XVI, № 4, p. 21. 1878 (gub. Tobolsk: fl. Sosva, Tobolsk; Enisejsk).-KIr. Rev. Russ. d'Ent., X, 1910, p. 179 (gub. Tomsk: Kaltajskij Bor, Meret, Tudrala).-REut. Öfv. Finsk. Vet. Soc. Förh., XXXII, 1891, p. 184 (gub. Enisejsk, distr. Minusinsk: Oznatshennaja).-JAK. Eor. Soc. Ent. Ross., XXVII, 1893, p. 295 (gub. Irkutsk: Irkutsk, Markovo, Kultuk, initio fl. Irkut); ibid., XXXVI, 1903, p. 322 (gub. Irkutsk: Pashki, Iret).

Aractus betulae var simulans Reur. Wien. Ent. Zeit, 188t, p. 132 (Amuria).

\section{Экземпляры Зоологичеснаго Музея.}

Moldavia: V. Barnar in mont. Karpathicis ( 1 万, 3 q). Morrandon.

Fennia: Terioki. 13. VII. 1899 (q). Novotorzev.

Fennia (q). Sahlberg.

St.-Petersburg. 16. V. 1859 (q). A. KüCHäEWITSCH.

St.-Petersburg. 12. V (ठ). Koenra.

St.-Petersburg. 1869 (3 3 , 5 ㅇ, larvae). SoLskr.

St.-Petersburg (f).

Gub. St.-Petersburg: Krestovskij Ostrov. 4. V. 1862 (larva). Morawirz.

St.-Petersburg: Ljesnoj ( $\bar{\sigma})$.

St.-Petersburg: Ljesnoj. 10. IV. 1908 ( $\sigma, 9$, $)$. Surrexov.

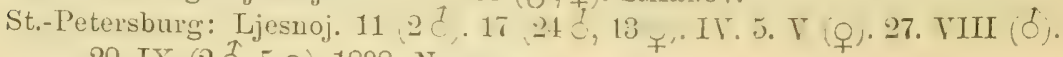
20. IX $(2 \delta, 5$ o ). 1898. Novotonzev.

St.-Petershurg: Ljesnoj (j). Silantjer.

Gub. St.-Petersburg. 5. VI (4 え). BIANcur.

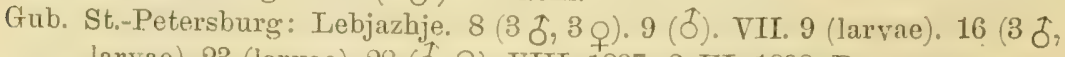
larvae). 23 (larvae). 28 (j, q). VIII. 1897. 2. VI. 1898. Biaxchr.

Gub. St.-Petersburg: Lebjazhje 25. VI. 1898 (ठॅ). Novotorzev.

Gub. St.-Petersburg: Udjelnaja V. 1890. (2 ф). Braxchr.

Gub. St.-Petersburg: Ligovo 23. IV. 1900 (1 万人, 1 o $)$. Novororzev.

Gub. St.-Petersburg: Gatshina. (官). Sотzкiл.

Gub. St,-Petersburg, distr. Gdov: Charlamova Gora. 4. VII. 1896 (ठす).

Bubrimati.

\section{Livonia (Q).}

Guł. Mogilev: Gorki. 5. 1V. 1861 (ठ).

Gub. Tverj: Rzhev. 8. VI. 1891 (larvae). Brancer.

Gub. Moskva, distr. Klin: Bablovo 14. VI. 23. VI. 2. VII. 7. VII. 8. VII. $19 \mathrm{C5}$ (2 5,4 ㅇ). Surriov.

Gub. Moskva. 16. V. 1893 (ठ). Durov. 
Gub. Rjazan, distr. Dankor: Gremjatshka. 3. VII. 2. VIII. 29. VIII. 1902 $(\zeta, 3$ q ). P. Searexoy Tian-SchanskJ.

Gub. Rjazan, distr. Ranenburg: Choper. 5. VII. 1899 (ठ). A. Semexov TraxSch.nNsז.

Gub. Rjazar, distr. Sapozhok: Chutor. 30. V. 1901 (ठ). MLejer.

Gub. Charkov: Kurjach. 10. V. 1890 (Q). Jaroschevseis.

Gub. Saratov: Sarepta (ठ己).

Orenburg $\left(\sigma^{\top}\right)$.

Gub. Orenburg: Irgizla. 21. VI. 1899 ( 5 $ð, 3$ 우). G. JAconsox et R. Schmid.

Gub. Orenburg: Irgizla, Lysaja Gora. 21. VI. 1899 (2 ㅇ). G. JAcobsox et R. Schmidt.

Uralsk (ठ). Uvarov.

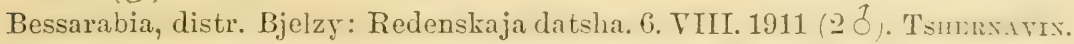
Tauria: Staryj Krym. 12. T. 1906 (3 ð, 3 q). Kiritshexio.

Tauria, distr. Jalta: Korbekly. 24. V. 1907 (larvae). Curistoforor.

Caucasus occ.: Novorossijsk. 14. VI. 1893 ().

Caucasus occ.: Utsh-Dere (7 J, 6 우). Koesig.

Caucasus occ.: Suchum. 1879 (q). T'SchernJATSKI.

Caucasus: Ningrelia ( 5, o $)$.

Caucasus occ.: Batum (2q).

Transcaucasia: Borzhom (o).

Transcaucasia, gub. Tiflis: Lagodechi. 1896 (q). Mroŕossemicz.

Prov. Semipalatinsk: accursus fl. Tshernyj Irtysh et Kaldzhir. 9. VII. 1910

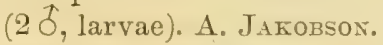

Prov. Samarkand: Melnikovo. 2. VI. 1908 (ф). ZARUdxr.

Sibiria (ठ). MEJNGardt.

Gub. Tomsk: Kolyvan. 18. V. 1911 (q). Tarasova.

Gub. Tomsk: vallis fl. Tshulyshman prope lac. Teletzkoe. 1. VII. 1902 (2 ठ). Jurganova.

Gub. Tomsk: Jajlju, lit. sept. lac. Teletzkoe. 29. VI. 1909 (larvae). Exieljaxor.

Gub. Tomsk: Artybash, lit. sept. lac. Teletzkoe. 17. VI. 1909 (larrae). ExreLJANOV.

Gub. Tomsk: Bajgazan, lit. sept. lac. Teletzkoe. 18. VI. 1909 (larvae). EurEL.JAXYY.

Gub. Tomsk, litus or. lac. Teletzkoe. 23. VI. 1909 (ठ). Emeljanov.

Gub. Tomsk, litus or. lac. Teletzlioe, fl. Tshilish. 25. VI. 1909 (ठ)). Eueluaror.

Gub. Tomsk, litus mer. lac. Teletzkoe, Kirsaj. 4. VII. 1909 (3 す, 2 Q). ExILL-1xoy.

Gub. Tomsk: fl. Bashkaus ad ostium Tshebdara. 8. VII. 1909 (, larvae). Eunidanov.

Gub. Tomsk: Kotan-Karagaj in mont. Altaj. 25. VI. 1909 (larvae). KAzגAкov. Gub. Tomsk, distr. Kuznetzk: fl. Kjzas syst. fl. Abakan. 3. VII. 1897 (larvae). WAGNER.

Gub. Tomsk, distr. Kuznetzk: fl. Kjzas syst. fl. Abakan. 1. 11. VII. 1897 (larvae). A. JAconson.

Gub. Tomsk, distr. Kuznetzk, fl. Ona. 20. VI. 1907 ( 4 İ, 3 ㅇ et larrae). A. Jacoison. 
Gub. Tomsk, distr. Kuznetzk, fl. Ona contra Bolshoj Anzas. 1897 (2 ฮे, 2 ㅇ, larvae). WAGNER.

Enisejsk (o).

Gub. Enisejsk $(\Im$, of).

('ul). Euisejsk, distr. Minusinsk: Uzun-Zhul, syst. 11. Ahakan. 10. VI. 1897 (2 J). A. Jасовsох.

Gub. Enisejsk, distr. Minusinsk: Abakanskij Zarod. 17. VI. 1897 (larva). A. JACOBSON.

Gub. Enisejsk, distr. Minusinsk: Shushenskoje (J, 6 q ).

Gub. Enisejsk, distr. Kansk: Jurty. 7. 8. V. 17. VI. 1911. VerchovsкaJA et MISHin.

Irkutsk. 25. V. 1871 (2 ð, 2 ㅇ). Czemanowsis.

Irkutsk. (6 お, 3 Q ). B. JAKOrLEV.

Gub. Irskutsk. 4. VI 1911 (Q). Tichowrov.

Gub. Irkutsk: Markovo (Q). Kashikarov.

Gub. Irkutsk: Pashki $(\hat{\sigma})$.

Gub. Irkutsk: fl. Tret (20, 2 O).

Gub. Irkutsk: Kultuk ( $\delta$, ?).

Gub. Irkutsk: fl. Bjelaja.

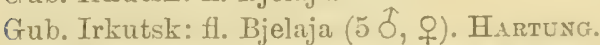

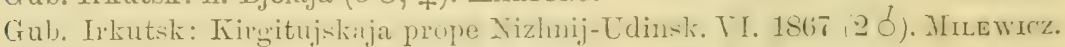
Gub. Irkutsk: Kurzanskaja-Tulunovskaja. VI. 1867 (2 q). Minewicz.

Gub. Irkutsk: fl. Mongol Daban init. fl. Irkut (2j).

Transbaicalia: Tshita. VI-VII. 1866. (o, 우). CzEזANowski.

Gub. Jakutsk: Ityn-chaja. 26. VI. 1901 (2 f, 2 q, larvae). Prizenaejer.

Fl. Amur (J).

A muria: Raddevka (O).

Fl. Amur, ab ost. Bureja ad ost. Ussuri (Kirma) (5, ᄋ.). МLA.AK.

A Chingan usque ad Ussuri. V. 1858 (q). RADDE.

Діагнозъ. Corpus ovale, griseo-fuscum rel ferrugineum, nigrovariegatum. Caput latitudine sua longius: prolongatione antica longa, crassa, tumidiuscula, lobis lateralibus longis, haud crassis, acutis, apice albilis, margine exteriore tuberculo instructis; tulierculis anteocularibus valilis, acutis; lobis temporalibus acuminatis, valde prominentibus.

Inteunae longre, tenues, granulis allidis praeditae, cum corpore concolores, articulo tertio interlum magis minusve albido; articulo secundo longitudine capitis aequali vel vix breviore, quam articuli tertius et quartus sinul sumpti multo longiore, articulo tertio quarto breviore.

Rostrum medium mesosterni superans.

Pronotum transversum, longitudine sua duplo longius; margrine postico prufunde sinuito, marginilus lateralibus ol,tusangulariter rotundatis, fortiter dentatis, pallide diaphanis; carinis dis- 
coidalibus basin versus leviter divergentibus, intermediis autice, laterilibus (interdum et intermediis) postice sacpe pallidis.

Scutellum sat longum, marginibus elevatis, a medio apicem versus fortius angustatis; disco medio longitudinaliter carinato.

Hemelytra basi dilatata, crenulata; membrana fusca, griseovariegata. Connexivum fusco-et nigro-raliegatum; angulis apicalibus segmentorum pallidis, apud $\delta$ s sat prominentilus, anculis basalibus nigris.

Pedes fusci.

Олисаніе. Сłрый плп же.ттовато-бурый, цвогда ржавчинжелтый, въ черныхъ пятнахь, удлиненно-овальноі бормп, б меньше II гораздо тороче ㅇ.

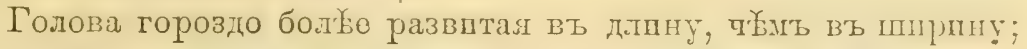
передній отростокь ея толстый, длинный; боковые отростиц лыинные, спльно заостренныс, самал вершпна пхъ бұловаталs,

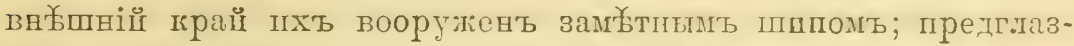

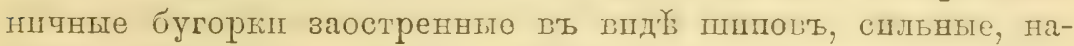
правленные впередъ п вверхъ; височнше отростки ваострениые, направленныө назадъ Іи вверхъ; голова позадш глазъ татой жо шпрнны, какъ п передъ глазамг.

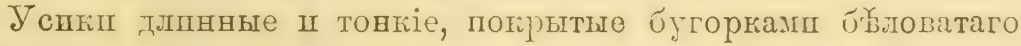
цв Һта, буровато- плш рыжевато-терные, третій члениц, шеогда

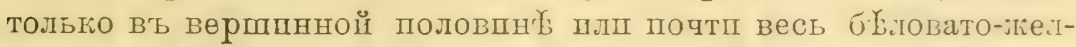

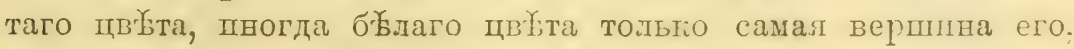
первый членикъ поротко-овальныц, доходить до верпинъ боко-

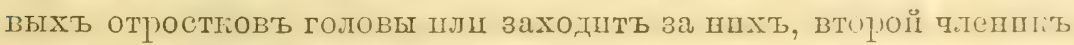

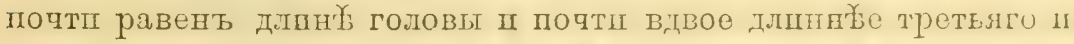

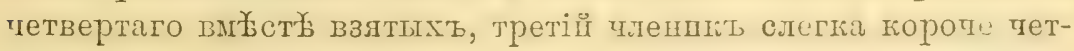
вертаго.

Хоботокь длпнныи, галего заходшть за середину средпегрудш, часто доходя до ел основанія, второй члеппіь его д(и) ходптъ до основаніл переднегрудп шіп шемного его не достигаөтъ.

Передпеспинка вдвое ппре евоеї длшиы; вадній краї ея съ пирогой пп глубокой выеміої, боговне грал “'т сшльвыми зубцами, слегка загнутые, свътые, полупрозрачные, тупо-

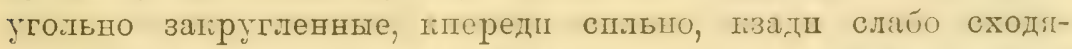
щіеся; пли переднеспнш сшьно прпподнитые, оугорчатые, гъ основанію расходящіеся. 


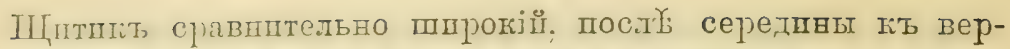
ппнҮ; стулдвающійся; ботовые прал его спльно пршподнятые; поверхность у основанія прпподнлтая, по середине́ съ продольнымъ кшлемъ.

Надкрылья у основанія не спльно растиренныя, зазубренныл; согіи въ желтовато-бурыхъ п черновато-бурыхъ пятнахъ п полосахъ; membrana б́рая, основаніе ея II пространство вокругъ жшлокъ бұловатыя, полупрозрачныя.

Ноги похрытыя бүловатымп бугорками, б́урыя, основанія голеней желтоватыя.

Брюшные сегменты съ чернымп пятнамп въ основныхъ јглахт connexivum'a пи б́.лыми въ вершднныхъ; вершшнные углы мало выдающіеся.

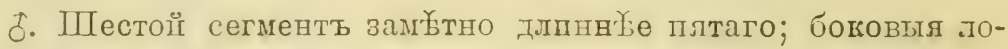
пастіг седьмого сегмента спльно поперечныя.

․ Брюпко къ вершпне спиьно вытянутое: съужшвающееся, съ тпирогої, но замбебної выемкой на боковыхъ граяхъ шестого сегмента. Пятый брюшної сегментъ одпнатовой длпны

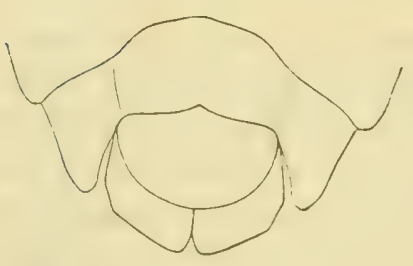

Pнс. 67. - Стернпты бртошіа VI-VII. Aradus betulae (Lixx.) (пзт Әриванской губ.).

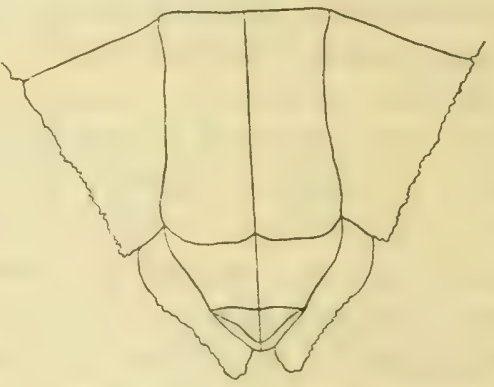

Pис. 68. - Стернпти брюшка VI-VII. Aradus betulue (Lins.) 오 (пзъ С.-Петербургской губ.).

съ ппестым или немного короче его, задній край пятаго сег-

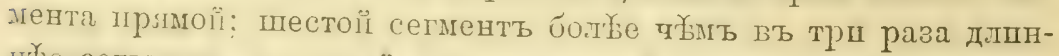

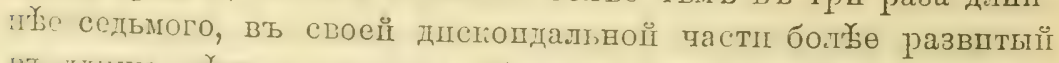

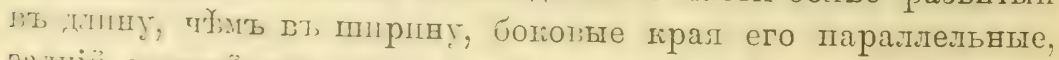

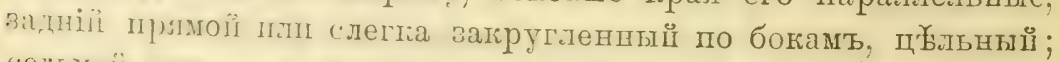

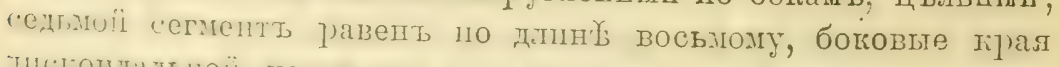

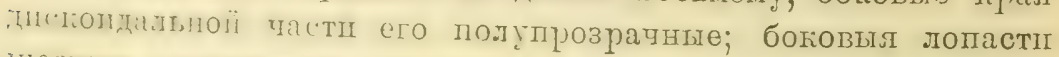

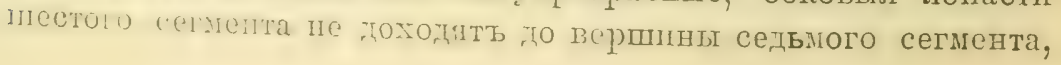


лопасти седьмого сегмента узкія, внхшніе прал пхъ съ пшрокой выемкой, внутренніе широго разставленные.

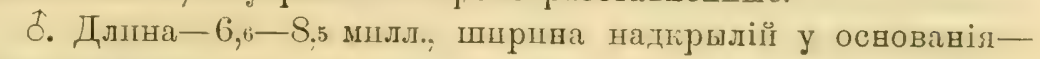
2,2-3,2 милл.

‥ Д.пнва-, $2-11$ мшлл., ширина надкрылії у основанія $2,6-3,2$ милл.

Aralus betulae (Lгм.) представляеть собой conspecies, состоящі пй пзъ нбсколькихъ, обладающихъ суммой устойqпвыхъ морбологпческихъ прнзватовъ, подвидовъ (.subspecies"), вознпгновеніө которыхь, по нашему мн各вію, является результатомь перемұны питаюшихъ шхъ породъ деревьевъ. Въ нбћоторыхт, случаяхъ этп подвыды пзолпрованы тепере п геограбобпески и удовлетворять формальному смыслу төрмпна subspecies, капъ географфпческої единицы. Намъ изв tulae (Lins.), встрботаютіяся въ Россійской Имперіп:

form. ". (Aradus betulae (Lrxx.)). Minor, obscurior, articulo tertio antennarum summo apice angustissime albido; rostrum articulo secundo basin prosterni haud attingente. Больье темно-ограшен-

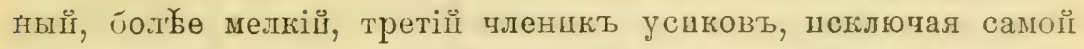
его вершпны, темно-бурый, второй членикъ хобогта но доходитъ до основанія переднегрудш.

эіиветь на берез官 (Betula alba).

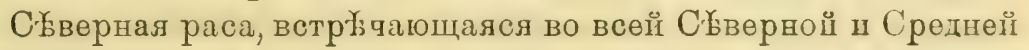
Россіп -и Сибирш.

form. . meridionalis nor. Flavescenti-fuscus, praecedenti major, articulo tertio antennarum dimidio apicali albido; rostrum articulo secundo basin prosterni attingens. жіелтовато-бу ураго пцъта,

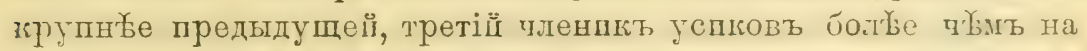
половпну бълый, второй членпюь хоботка доходить до основанія переднегруди.

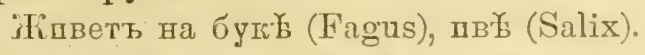

Встрғбqаеся въ южиой и юго-востоqної Россіи (Оренбургь,

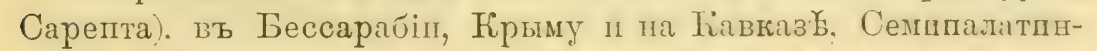
ской ш Самаркандеғой обл. Въ Крыму form. $a$ л тикогда пе находшль.

form. e. ferrugineus nov. (Aradus ellipticus Kou.). Flavo-ferrugineus, articulo secundo antennarum ferrugineo, ubsolete albido signato, articulo tertio albido, basi infuscato; rostrum articulo secundo basin prosterni attingens. Ржапшнно-рыжаго цв бта, вто-

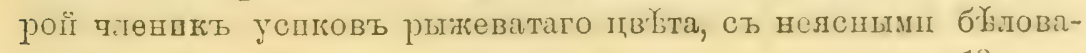

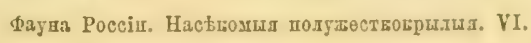


тымп полосам; түетій тленшкь былый, только у самаго осно-

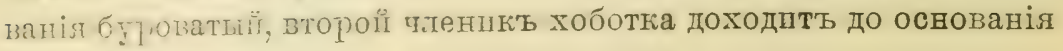
перөднегрудш.

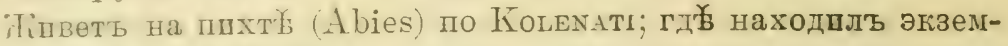
ґ.ізры этой расы Е. Кьнпгъ, я не знаю, но очевь возможно, что

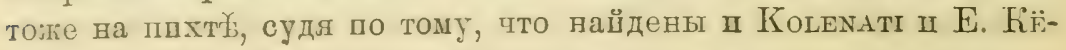
нигом'ь в'ъ одной ІІ той же мекстности.

Встрбчаетсл въ Зап. Закавказь (Caucasus occidentalis, Kot.entt; У У-дере, Сочинск."окр.) и въ Южн. Закавказь' (Јагодехи, Л. Млокоствичъ; 8. Х. 1905. Е. Кёвигъ).

form. d. simulans Revt. Ferrugineus, fusco-variegatus, articulo tertio antennarum albido, basi sat anguste nigricante. Ржавчпннаго цвътта, третіп̆ члениґ почти весь бълый, только у основавія съ узкой чөрноватой полосої.

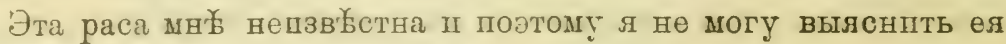
отношеніе къ предыдущей form. $c$.

Дерево непзв Һетно.

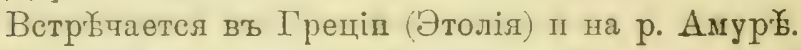

form. e. herculeanus nov. Praecedentibus major et latior, obscurus, hemelytra basi maculis magnis albidis ornata, articulo tertio antennarum toto albo; rostrum articulo secundo basin prosterni

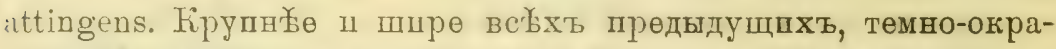
шенный, надкрылья у основанія съ большимъ бблымъ пятвомъ; третій членпи успковъ весь бълыи; боковые края переднеспинкц спльно загнутые. Второї членпкъ хоботка доходпть до основанія переднегрудш.

Дерево неивв Һебетно.

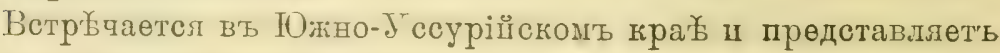
молюеть быть самостолтельный вшдъ.

Сравнительныя замьтни. Aractus betulae (LrNx.) образуетъ особ́ю

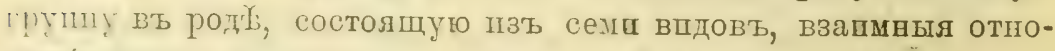

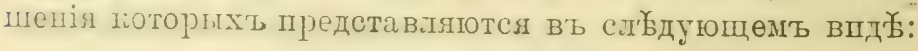

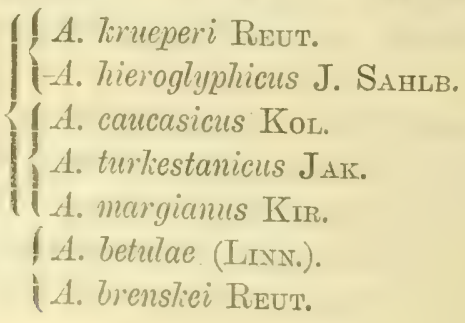


Группа эта характерпзуетсл длпнными пा товкпмп усшкамш,

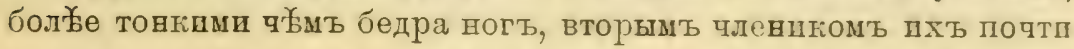
правильно цилиндрцческшмь, только на самой вершінео̆ очень незначительно утолщеннымъ, почти одинагіової длины съ головой; голова вшдовъ группы A. betulae (Lкх.) болье развптая въ длину, чймъ въ ширнну, боговые отростігі ея острые, на вв бшнемъ траю съ острымь зубцомъ; предглазндчные зубды острые, сильные, височные отростки острые, сильно выдающіеся назадє; переднеспинка по бокамь съ о́ольшиш зубцамп, усшк, бетра и голенп ногъ сильно зернпстые; зернистость ихъ состолть пзъ острыхъ, бъловатыхъ бугорковъ.

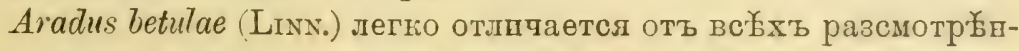
ныхъ выше впдовъ группы длпннымъ хоботкомъ, всегда заходящнмь за серөднну среднегруди, иногда доходящимь до вер-

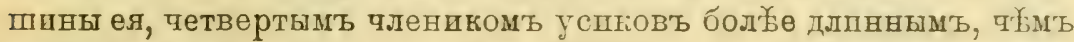

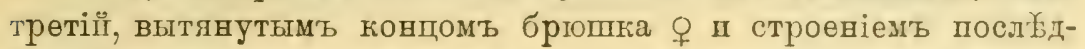
нихъ брюшныхъ стернитовъ.

Географическое распространеніе. Широко распространенны й впдъ, извъстный въ Западної Европ年 пзъ Таппландіп, Шведіп, Гермавіп, Пвейцаріп, Фравціи, Испаніп, Италіп, Австріп, Венгріп, Сербіп п Молдавіп, встрбчqается въ Спріш.

Въ Россіп широжо распространенъ въ Европейской частц ея, въ Крыму, ва Кавказ

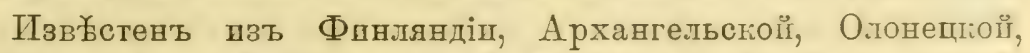
С.-Петербургской, Эстляндской, Лшифляндской, Курляндской,

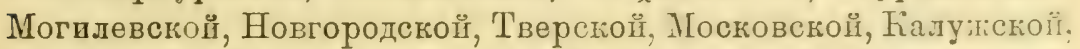
Рязанской, Кіевской, Волынской, Подольстой, Харлтовстой. Казанскої, Самарской, Саратовской, Оренбургской губ., Јральской обл., Херсонской, Бессарабской губ., Кірыма, Зап. Закавказья, Южн. п Вост. Закавказья, Зайсанскаго огіруга Семиталатпнской обл., Самаркандской обл., изъ Томской, Енисейскеоі, Пркутской губ., Забайкальской, Якутсгой обл. п съ р. Амура II Южно-У ссурійскаго края.

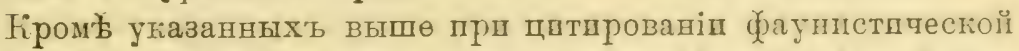

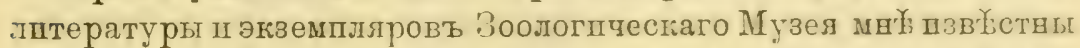
сльдующія мсьонахожденія этого впда: Эстяндская губ.: IIмецке; Новгородская губ.: Померанье 10. VII. 1911. Ф. Мльшнт; Самарская губ. и у. 10. Т. 1909. Бостанжогло; Херсонскал губ.: Черный лйсъ 17. III. 1900. Т. Померандевъ; Кірымъ: Чатыр- 
дагт 18. VI. 1907, Торб́клы ва севв. скл. Чатырдага 24. V. 2. VIIT. 1907. Кшрпченко; Владивостокъ.

0бразъ жизни. Встрбчаетсл, главнымъ образомт, на березъ Lintila alla) п въ особенностп на трутовнкахъ, селящпхся иа

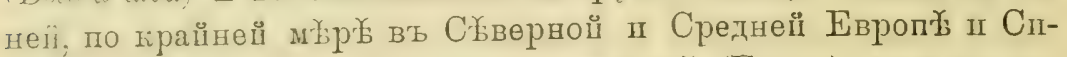
бщрш, вт Лрыму ш на Карпатахь ва бугі (Fagus), хотя въ посльднеї мұстности встрбчаетсл также ін на березъ. На Кавказ

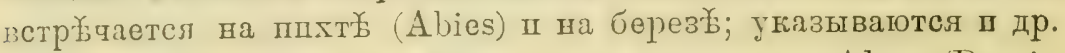
породы, на поторыхъ встрұчевъ былъ этоть впдъ: Alnus (Rossi), Ulinus campestris (Ятовлев'т, въ Казани), Salix (Семппалатпнстая обл.).

\section{A radus brenskei Reut, 1884 .}

Aradus betulae H.-S. Wanz. Ins., $V$, 1839, p. 89, tab. CLXXV, fig. 537. Aradus Brenskiei Revt. Wien. Ent. Zeit., 18s1, p. 131; ibid., 1885̃, p. 150.

\section{Экземпляры Зоологичеснаго Музея.}

Morea: Kumani ( $($ )). Brensire (e coll. Reuter). ? Bohemia ( 2 d, 2 q). coll. anon. BANG-HAdS.

Діагнозъ. Caput prolongatione antica apicem versus tumidiuscula, dentibus anteocularibus maximis, fere spiniformibus.

- Lutenuae articulo secundo, quam caput in $1 / 4$ longiore (d) rel aequilongo (ㅇ), articulo tertio all,o, basi anguste nigro, quam articulus quartus distincte breviore. Rostrum medium mesosterni attingens vel nomibil superans, articulo secundo marginem basalem prosterni superante.

Pronotum literibus oltusangulariter rotundatis, sat fortiter ientatis. Angulis apicalibus segmentorum abdominalium distincto prominulis (ठ) rel laerissine et obsoletissime prominentibus (q), segmenti secundi brevissime prominulis:

c. Sesmentum sextum rentrale quinto distincte longius; lohis lateralilus segmenti septimi distinctissime transversis.

9. I.mgituline muris a qualis. Aldomen subovatum, lateribus rersus apicem vix sinuatum. Segmentum quintum apice truncatum. ynu -..m!nstum sextum lrevius, segmentum sextum lateribus Inmllolic suhrectic, margine apicali integro rersus latera sensim levi-igus:" inuluto, dimidio margine apicali linea media duplo vel moin qum duplo lireviore, lol,is lateralibus apice medium

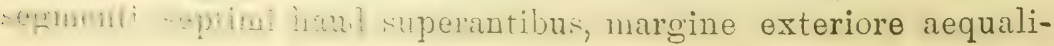


ter rotundatis, interne totis distantilus, segmento septimo lateribus (lobi medii) hyalino-limbatis.

Описаніе. Корпчвевато-бураго цв чнны, удлиненно-овальної формы.

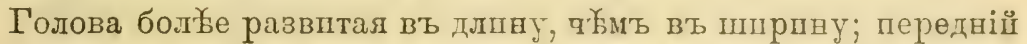
отростогъ ея дливный, толстыи, вздутыц; боговые отростки

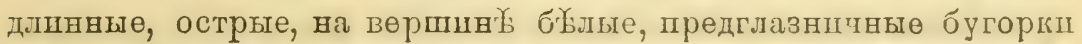
спльные, острые, впсочные отросткщ острые, сшльно выдающіеся назадъ.

Усикп длшнные, тонкіе, второй членпкъ успковъ у $ई$ на $1 / 4$ длпнн施 головы пли одиваковой съ ней длины (q q), третій членпкъ явственно цороче четвертаго, б́қлаго дв'тта, только основаніе его чернаго цвйта.

Хоботокъ доходить до середины переднегрудп пли ещө дальше, второї членикъ его заходить за основаніе переднегрудш.

Переднеспшнка вдвое шире своеї длины, задній краї ел сь глубокої выемкой, боковые грая тупоугольно расширениые съ довольно больтими зубцамп.

Щптпкъ короткій, довольно широкій, боковые края его пршподвятые, поверхность его у основанія прпподнятая.

Надкрылья у основавіл спльно расшпренныл, зазубренныя,

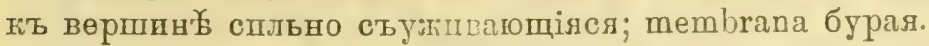

Вершинные углы сегментовъ connexivum'a слаб́ ьыдан-

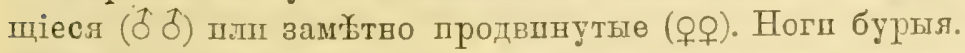

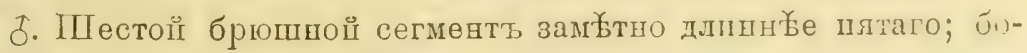
ковыя лопасти седьмого сегмента спльно поперечныя.

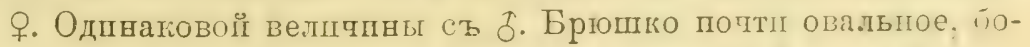

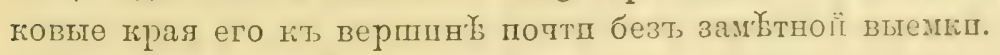

Пятый брюшноі сегменть короче шестого, его задній край прямой; боковые края дискондальної частп пестого сегмента параллельные, почтп прямые, задніи край п务льный, по бокамъ слегка закругленныг, половшна задвяго края вдвое тороче его средней линіп; и́оповыя допасти пестого сегменті доходять до сөредшны седьмого

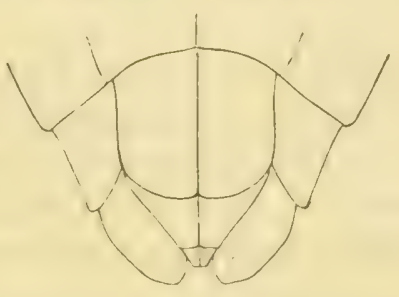

Pнс. 69. - Стеринты брготи: VI-VIII. Aradus brenslici Iiscr. 우 (пзъ Грецін, тппт). 
сегменті, вутүенеіе прая ихь отстоящіе, заднів прая равно-

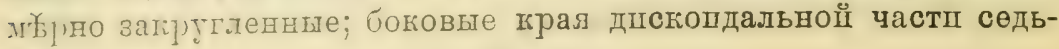
мого сегмента прозрачно окайменные.

§. Дилива-9 милл.

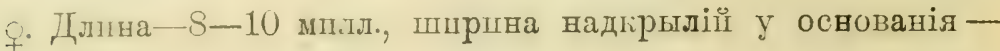
2,8 мпІл.

Сравнительныя замьтки. Aradus lienstiei Reuт. принадлөжшть гъ группо впдъ, отъ остальныхъ вшдовъ группы длиннымъ хоботкомъ, заходящимъ по крайнеї меำ ходящшм до основанія заднегрудш, четвертымъ членшкомъ усш-

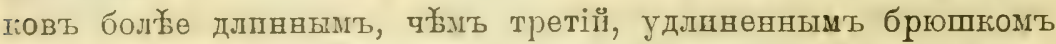

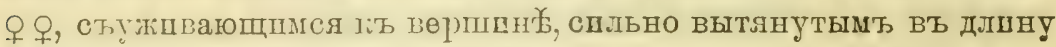
пестымъ брюшнымъ сегментомъ.

Отъ A. betulae (LiNм.) видъ этольь отличается одшнаковой величнной $\precsim$ п् 우, длпвнымъ вторымъ членпкомъ успковъ, кото-

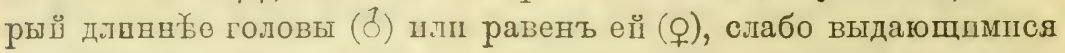
вершшнным угламп сөгментовъ сопnехігurn'a, строеніемъ по-

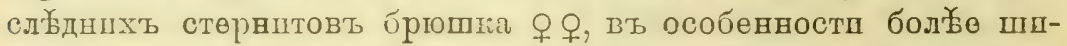
ропши, по внбшнему граю закругленнымп боковыми лопастями седьмого сегмента.

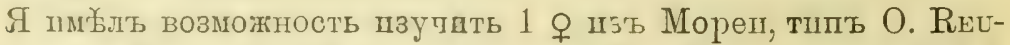

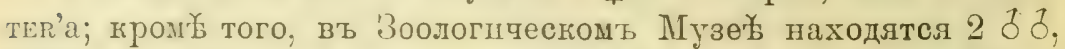
2 우 можетъ б́лт этого же вшда пзъ Богеміп (отъ фошры Bang НАAs), отлцчающеся отъ типа пзъ Греціп больө қрупної велигшної, лркой красновато-рыжей окраской телла, спльно загнутымп боговыма гралмп перөднеспинкп, большимп зубцамш на неї, менҮө закругленной верппной угла боковыхъ краевъ переднеспини, хоботномъ доходящпмъ до основанія заднегрудш II другшмп пршзнакамп.

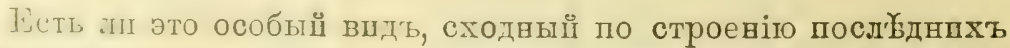
стернитовт пг главным стругітурнымъ првзнакамь съ $A$. brenskei lítт. шли шлентичень с'ь нимъ, представляя значительное уклотеніе отт гретесіаго әкземпяла, я не могу судпть, располагая однимь поломь пI 1 эквемпляромъ этого вида.

Геотрафическое распространеніе. Aradus brensliei Reut. средш-

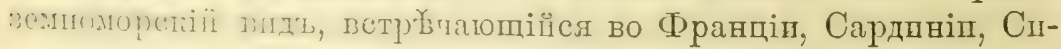
цштіш, Венгріп, Румын, Гредіп п Саріш. 
38. Aradus anisotomus Pưr. 1879.

(Таб.т. II, форпг, 17).

Aradus annulicornis R. F. Sahlb. Mon. Geoc. Fenn., p. 14 (). 1818 (nec Fabr.).Reut. Öfv. Kongl. Vet.-Akad. Förh., 1872, № 5, p. 60.

Arrectus rnisotomus Poт. Pet. nouv. ent., 2, p. 297. 1879; Synops. Hém.-Hét. de

Fr., I, p. 137. 1879.-Reut. Ent. Tidskr., 1882, p. 80. Arcedus amplicollis JAK. Hor. Soc. Ent. Ross., XXIII, p. 78. 1889.

\section{Фаунпстнеская лптература, касающаяся Россіп.}

Aradus annulicornis R. F. SAHLB. Mon, Geoc. Fenn., p. 140, 1848 (Fennia: Yläne).-J. SAHLb. Kongl. Svensk. Vet.-Akad. Handl., XVI, № 4, p. 22 (Tomsk).

Aradus anisotomus Kir. Rev. Russ. d'Ent., X, 1910, p. 179 (dltaj: Jazula, vall. fl. Tshulyshman). - Revt. Öfv. Finsk. Vet.-Soc. Förh., XXXIII, 1891, p. 184 (gub. Enisejsk, distr. Minusinsk: Oznatshennaja).

Arradus rmplicollis Jak. Hor. Soc. Ent. Ross., XXIII, p. 78. 1889 (gub. Enisejsk: Minusinsk).

Aradus anisotomus JAk. Hor. Soc. Ent. Ross.. XXXVI. 1903, p. 32.2 iguh, Irkutsk: Pashki).

\section{Энземплары Зоологичеснаго Музея.}

Gub. Archangelsk: Popova Izba in fl. Tzilma. 13. VI. 1904 (Q). Zhurarskr. Gub. Enisejsk, distr. Kansk: Jurty. 21. V. 1911. VercirovsraJA et Mishr..

Minusinsk (Q).

Gub. Irkutsk: Pashki (Q).

Gub. Irkutsk: Padun in fl. Angara (ठ). Czekanowsri.

Prov. Jakutsk: Monjero, syst. Chatanga, $66^{1} / 2^{\circ}$ lat. sept. (q).

Prov. Amur: curs. med. fl. Zeja, contra Blagovestshensk (q. Nesrscirsorı. Sine datis (Q).

Діагнозъ. Corpus late-ovale, al,domine retrorsum sat fortiter dilatato; fusco-niger, articulo tertio antennarum albo, l,asi ima fuscescente, angulis apicalibus segmentorum connexivi pallidis.

Caput latitudine sua multo longius, prolongatione anticil crassa, longa, lateribus compressa; lobis lateralilus longis, haul crassis, apice acuminatis, allidis, margine exteriore tulerculn distincto praeditis: tuberculis anteocularibus validis, acutis: hhis temporalibus apice acutis, prominentibus; capite pone oculo: parti anteoculari aequilato.

Antennae longae, sat crassae: articulo primo lireriter orali. articulo secundo capite breviore, quam articuli ultini simul sumti distincte longiore, apicem versus sensim incrassato, fucco, articulo tertio quarto aequilongo: articulo quarto nigru. 
Rostrum medium mesosterni attingens.

Prourum longitudine sua magis quam duplo latius, margine postico late et profunde sinuato, marginibus lateralibus reflexis, diaphanis, fortiter denticulatis, rotundatis; carinis subparallelis.

Scutellum sat latum, breve, marginibus elevatis, apicem versus sinuatis; disco medio convexo.

Hemelytra basi sat fortiter dilatata, quam pronotum angustiora, reflexa, diaphana; membrana fusca.

Connexium marginibus interioribus punctis duobus praeditum. Pedes fusco-nigri, tibiis basi et apice pallidis.

3. Segmentum sextum rentrale quinto fere aequilongum; lobis lateralibus segmenti sexti atque ultimi distantibus, margine exteriore leviter rotundatis: lohis lateralibus segmenti septimi horizontalibus, intus apicem versus distantibus, marginibus interioribus rectis, marginibus exterioribus rotundatis.

o. Segmentum quintum rentrale margine postico recto, segmentum sextum quinto brevius, latitudine marginis posterioris aequale, segmentum septimum sexto duplo brevius, lobis lateralilus angustis, marginibus interioribus distantibus, marginilus exterioribus rotundatis.

0писаніе. Овильный, тзади расшпрлюшііїся, черновато-бураго цв'Тта, тольгіо в'ь вершинныхь углахъ сегментовъ connехіvит'а неясныя бұловатыя пятва, третій членпиь успковъ, псплючая самаго его основанія, бълын.

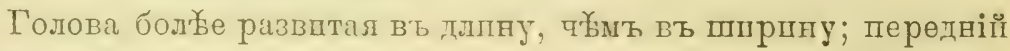
отростокь ел длннвыї, сжатыі съ боковъ; боковые отростғш mирохіе, заостренные; слегц расходящіеся, самая вершдна

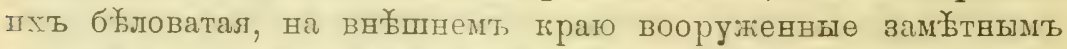
бугоркомь; прегглазнпqные бугоркш больніе, острые; височные отростіп довольно тупые, на вершпнег заостренные, на-

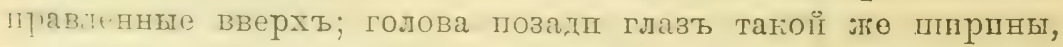
как'ь II передъ глазамп.

Успкп длввные, толстые; первыц членшкъ пхъ бурый, по-

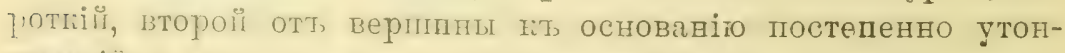

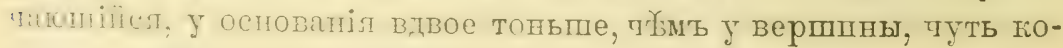

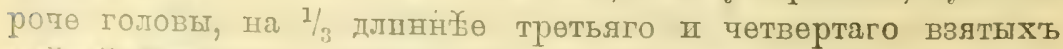

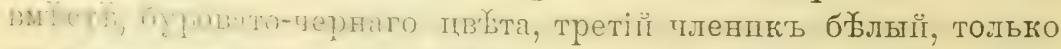

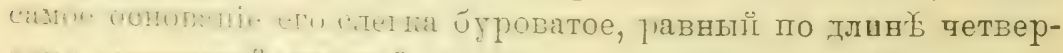

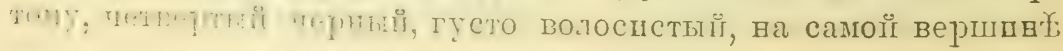


въ б редпны срөднегруди.

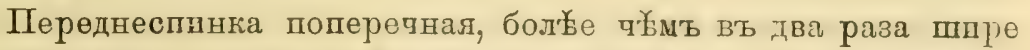
своөй длины, заднің краї ея съ широкой и глубокой выемкой,

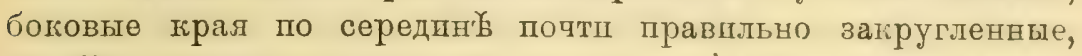

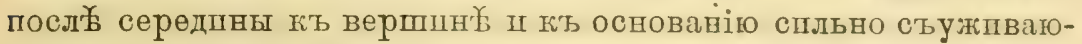
щіеся, слегка загнутые, полупрозрачные, зубчатые; возле шейныхъ угловъ нессіолько особенно большпхъ, острыхъ зубццовъ средшнные кпли переднеспшнкі слабо пршподнятые, почти параллельные, боковые къ основанію расходящіеся.

Щитшь пирокій, боковые грая его приподнятые, у верпины съ спльної выемкой, тапь что вершпва щитка сьуженная, заостренная; поверхность щштика по серединеб приподнятая.

Надкрылья у основанія расппренвыя, зазубренвыя, не много у́ліө переднеспннкп; corium вдвое длпннйе щитка; membran: черновато-бурая, жплкп частью ш простравство вдоль жнлоль бъловатыя; connexivum съ рядомь qерныхъ точекь, расположенныхъ по внутреннему граю по 2 на каждомь сегмент官, вершинвые углы сегментовъ туть выдающіеся.

Ногп бурыя, основанія и вершшвы голеней неясно телтоватыя.

§. Боковыя лопастп пестого брюшного сегмента чуть от-

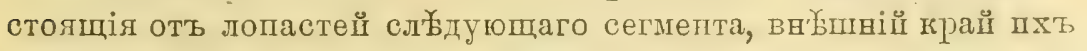

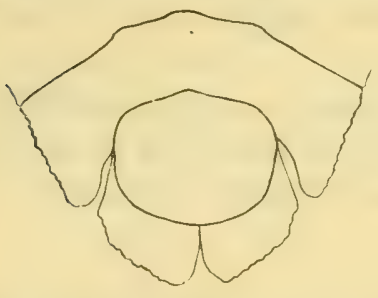

Pпс. 70. - Стерниты брюшта VI-VII. Aradus anisotomus

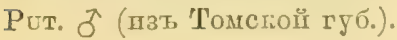

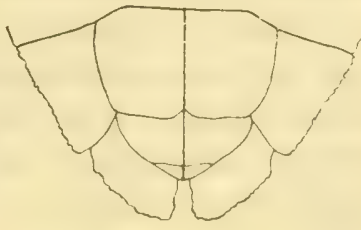

Pпс. 71. - Стерншты бргоша VI-VIII. Aradus anisotomus Put. .

незначтельно закругленный седьмої сегменть спльн вппудлый, боковыя лопасти его горцзонтльвыл, спльо развштіл іг въ длпну, внутренвіө края пхъ слаб́ расхотящіеся, почти пилмые; задніе края ппрого закругленные, у основапіл ст пеи́ольшой выр'єзкої. 
Затві1 тірай пятаго брютного сегмента прямої, шестої сегменты сіегка ґорочө пятаго, средняя линія его чуть длпнно боновлхъ граевь боговыхь лопастеі, боковые края дпскоптальой части сегмента парадлельныо, слегка закругленные,

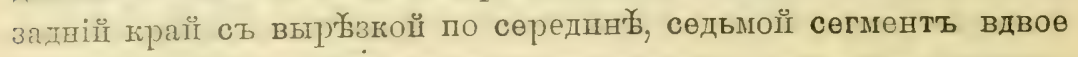
короче шестого; боковыл допастп шестого сегмента немного

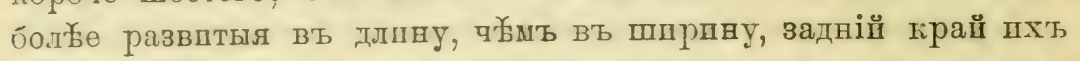
сопрпкасащііся сь попастями седьмого сегмента; лопасти седьмого сегмента очень поротіія, спльно поперечныя, внутренніө трая пхь отстоящіе. прлмые, задніе края закругленные, у основанія слегка срйъзанные.

ઈ. Длвна-8,5 милл, шарпва переднеспннки-3 милл.

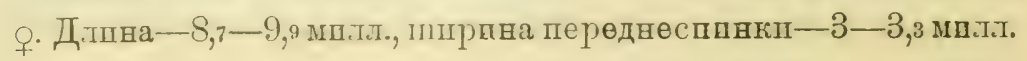

Сравнительныя замьтки. Вшдъ этотъ стопть совершенно особняпомь средш остальныхь, отлшчаясь длиннымы, но довольно толстымш усшкамд, второї членикъ которыхъ отъ вершины къ

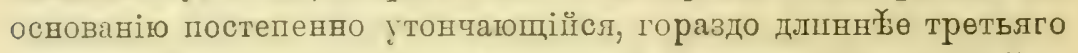

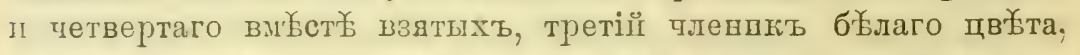
очень длдннымъ передншмь отросткомъ головы, длшннымъ хоботкомъ, доходлщимъ до середины сүеднегруді, широкой перед-

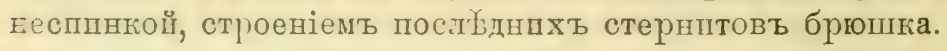

Географическое распространеніе. Видъ это псключительно сшбпрскій, западная граница готораго захватываеть долину р. Пепоры въ Архангельской губ., Фпнляндію п Пвецію на Скандинавскомь полуостров о.

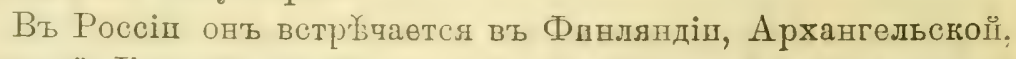
'Јомской, Енисейской, Иркутскоп̆ губ., Ягүтской п Приморской

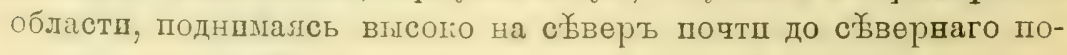
тярнаго круга (Моньөро $66^{1} / 2$ с. II.).

0бразъ жизни. Напдевъ въ Шведіп подъ корої Pinus silvestris.

39. Aradus signaticornis R. F. SAHLB. 1848.

(Табл. II, фопг. 20).

Aradus signaticornis R. F. SAgLB. Mon. Geoc. Fenn., p. 141. 1818. - Flor Rhymch. Livl., 1, p. 390. 1860. - Fies. Eur. Hem., p. 113. 1861.-Reut. Ofy. Kongl. Vet.-Akad. Förh., 1872, № 5. p. 61. - Por. Synops. Hém.Hét. de Fr., I, p. 137. 1879. - REur. Ent. Tidskr., 1882, p. 80. 


\section{Фаунститеская литература, касапщалея Россін.}

Aradus signaticornis R. F. SAHLB, loc. cit., p. 141. 1848 (Fennia: Yläne).J. SAнlb. Medd: Soc. Faun. Fl. Fenn., VII, 1881, p. 42 (Fennia: Yläne, Parikkala).-JAK. Bull. Soc. Nat. Mosc., 1875, IV, p. 262 (Petersburg).Flor loc. cit., p. 390. 1860 (Livonia: Lodenhof).

\section{Энземпляры Зоологическаго Музея.}

St.-Petersburg (ठ). KonnIG.

St.-Petersburg (ㅇ).

Gu7. St.-Petersburg, distr. Peterhof: Leljazhje. 11. V. 1897 (J). 13. VI. 19014 (larv.). Bianchr.

Sine datis (ㅇ).

Діагнозъ. Corpus late orale, breve, nigrum, articulo tertio antennarum cretaceo albo.

Caput latitudine sua longius; prolongatione antica longa, sat tenui, lateribus compressa; lobis lateralibus brevibus, crassis. apice acuminatis et intus recurvatis, margine exteriore muticis: tuberculis anteocularibus obsoletissimis; lobis temporalibus nbtusis, vix prominulis; capite pone oculos sensim breriter angustato.

Antennae crassiusculae, nigrae, articulo tertio toto albo, articulo secundo ima basi subito valde constricto, quam articulus tertius duplo et dimidio longiore, articuio tertio quarto crassiore et in $1 / 4$ longiore.

Rostrum coxas anticas attingens.

Pronotum transversum, longitudine sua duplo et dimidio latius; margine postico late sinuato, marginibus lateralibus minute crenulatis, leviter reflexis, rotundatis, apicem versus fortiter, basin versus leviter angustatis; angulis anterioribus apice denticulo armatis; carinis elevatis, verrucosis, subparallelis; pronoto postice transversim ruguloso, antice inter carinas laterales et intermedias spatiis duobus nitentibus, laevibus praedito.

Scutellum sat latum, apice obtusiusculo, marginibus elevatis: disco basi convexo, apicem versus transversim ruguloso.

Hemelytra basi paullo dilatata, vix crenulata: corio unicolore: membrana nigra, prope venas vix pallidiore.

Connexivum totum nigrum.

Pedes nigro-fusci.

J. Segmentum septimum lobis lateralibus sat longis, marginibus interioribus tangentibus; a pice margine communi vix angulato exciso. 
ㅇ. Sesmostum quintum ventrale margine apicali recto, linea median? marcinibus lateralibus aequilonga et quam segmentum sexiam in I/; lreviore; segmentum sextum leviter transversum, quam sermontum septimum duplo longius, lobis lateralibus apice rotundatis, apicem segmenti septimi attingentibus; segmentum octarum septimo duplo brevius; marginibus interioribus loborum lateralium segmenti septimi divergentibus, rotundatis, marginibus exterioribus rotundatis, basi angulo obtuso, prominulo instructis.

Описаніе. ПГроко-овальвый, червый.

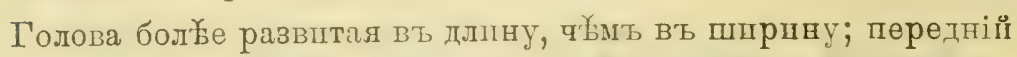
отростогь ел депнныи, довольно тонкії, сжатыї съ боковь, боновые отростки толстые, гороткіе, вперели заостренные и за-

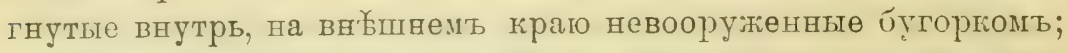
предглазнпчные бугорки нельственные; впсочные отростит очень тулые, едва выдающіесл, тағь что голова позадш глазъ сразу съужпваюпаяся; на поверхвости головы позади глазъ глубокія вдавлөнія, сходящілся подъ угломъ.

Усикг толстые, чөрваго цв'бта, трөтій членпкь пхь весь мраморво-бґлаго цвьта; первый тленпкь короткій, овальный, второї членикь у салаго основаніл сразу сшльно сжатыі, поттп

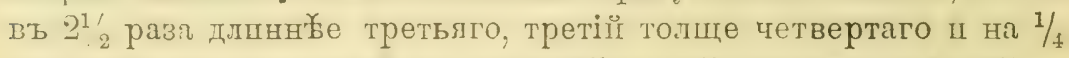

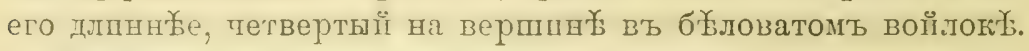

Хоботокъ доходпть до ляшекъ переднпхь ногъ.

Переднеспниі въ 21/2 1)аза шпре своей длпны; задній край ел ст, пшрокой выемпої, боловыо грая мелко зазубренные, слегіа загнутые, заліруллннле, гъ вершпны сильно, къ основанію слабо съужпьащіесл; передніс углы перөднеспнки вы-

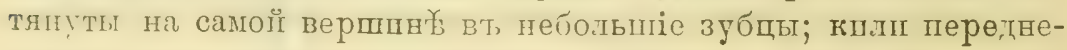
сппніш пүппднятые, бугорчатые, потти параллелпные: задняя погтвнда переднеспнни спльо поперечно-морщиндстая, на

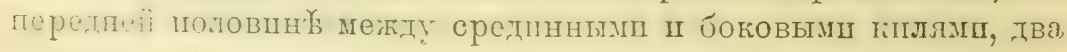
гладепхъ, блестящихъ участка.

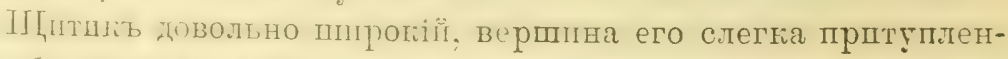

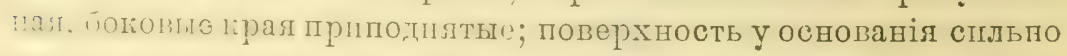

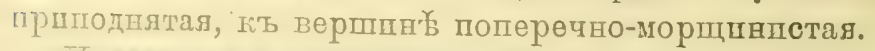

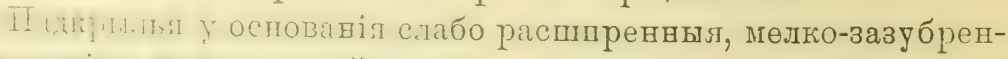

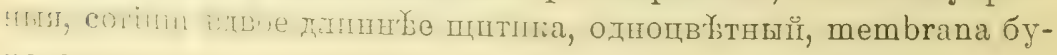

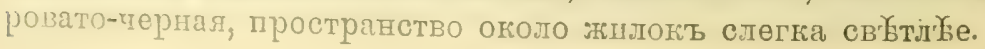


Connexivum одноцв'ътно-черныі, боловые грая его зақругленные, верпинные углы. чуть выдагщіеся.

Ноги буровато-черныя.

§. Боновыя лопастп сөдьмого сегмента спльно развитыя вт, длпну, внутренніе грая пхъ почти на всемъ протяженіп сопрпкасающіеся, только на самої вершпн ъ; общій грай пхь образуеть небольшую, угловатую выр Үззку, боковые грая лопастей закругленные; боковыя лопасти шестого сегмента очень незнаqительно отодвинуты отъ лопастей седьмого сегмента.

о. Задніци краӵ плтаго брюшного сегмента прямой, срединвал линія его равна боковымъ кралмъ сегмента II на $1 / 3$ короче шестого сегмевта; шестой сегментъ слегка поперечвый, вдвое длпнн Үө седьмого, боковыя лопасти его съ закругленнымш вершиннымп угтаму, тежащими на уровн质 вершпны седьмого сегмента; восьмої сегменть вдвое короче сөдьмого, внутренніе

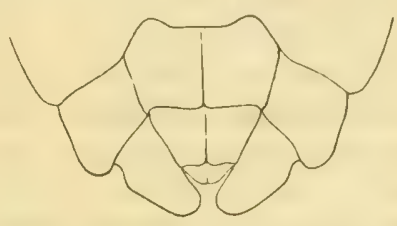

Pпс. 72. - Стерншты бргшка VI-VIII. Aradus signaticomis R. F. Sami в. Q (пзљ С.-Петер) бургекой губ.). края боковыхъ лопастеіг сөдьмого сегмента разставленные, закругленные, боловые края оғругленные, у основанія ст впдающимся тупымъ угломъ.

子. Длпна-5;4 мплл., пиршна вадкрылії у основанія-2,2 мпл.г.

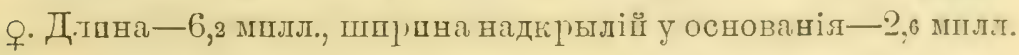

- Сравнительныя замьтки. Aradus signaticomis R. F. SAнLd. pł:зіо

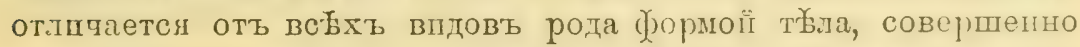

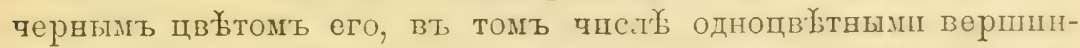
нымш угламп брғшныхъ сегментоль, соверпевно бҢлымт, третьнмъ членикомъ усиковъ.

По строснію второго тленпка уснювъ, мелго-зазубренным боковымъ праямъ перетнеспики, строені обоковыхъ лопастей седьмого брюпного сегмента представллетт никоторое сходстио съ видами группы A. lugubris FAl., во вышепрпведеншпм прпзнаками и многим, другими рьзко отт, нпхъ, отлптается

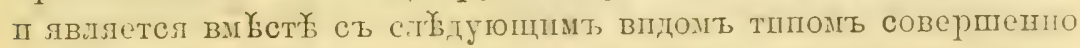
самостоятельноі группы рода.

Географическое распространеніе. Aradis simaticomis псклюті- 


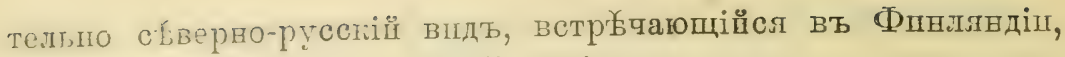
С.-Петербургской губ. п Лпфолядіп.

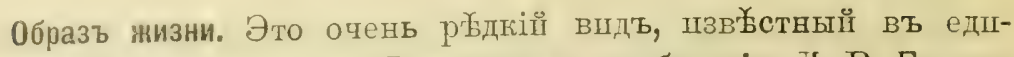
ғпчныхъ экземпярахъ. По јстному сообщенію Ј. В. Банкі

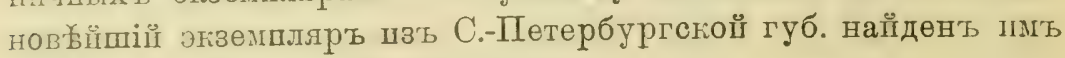
косьбою въ болотистой местностп.

\section{Aradus pulchellus J. SAHLB. 1878.}

Aradus pulchellus J. S.нцгв. Kongl. Sv. Vet.-Akad. Handl., XVI, Nㅡ 4, 1878, p. 23.

\section{фаунпститеская лптература, касающаяея Россін.}

Aradus pulchellus J. SanLB., loc. cit., p. 23. 1878 (gub. Enisejsk: Antziferovo).

\section{Экземпляры Зоологическаго Музея.}

Prov. Littoralis: inter sinum St. Olga et Vladivostok (O). V. GrüNEWALdt.

Діагнозъ. Corpus oblongo-orale, breve, nigrum, articulo tertio intemnarum flavescenti-albido, femoribus apice tibiisque, apicibus nigris exceptis, flavescentibus.

Caput latitudine sua longins; prolongatione antica sat tenui, longa, lateribus compressa; lobis lateralibus brevibus, crassis, apice acuminatis, marginibus exterioribus muticis; tuberculis anteocularibus obsoletis, obtusis; lobis temporalibus obsoletis, haud prominulis; capite pone oculos sensim angustato.

Antennae crassae, nigrae, articulo tertio flarescenti-albido, articulo secundo ima basi subito fortiter constricto, quam caput breviore, articulo tertio secundo duplo breviore.

Rostrum apicem mesosterni attingens.

Pronotum longitudine sua duplo latius; margine postico late sinnito, marginibus lateralibus minute crenulatis, reflexis, rotunhatis; apicem rersus fortiter angustatis, leviter sinuatis; angulis :unterioribus obtusangulariter rotundatis, inermibus; margine ba- ali pronoti "pico duplo latius; carinis valde elevatis, verrucosis, subparallelis; disco basin versus transversim verrucosum.

tontellum elongatum, marginibus lateralibus elevatis; disco apico transversim rugulosum.

Hemelyma hasi dilatita; frate dilatata fusco-nigra; membrana II:-1:3!. 
§. Segmentum septimum ventrale concarum, lobis lateralibus breviusculis, parum explanatis, declivibus; intus apice distantibus, divaricatis ibique margine subrecto; lobis lateralibus segmenti sexti angulis posticis obtusis, paullo productis (sec. J. SАнLB.).

O. Segmentum quintum ventrale margine apicali sinuato; linea mediana quam segmentum sextum breviore; segmentum sextum linea media marginibus lateralibus longiore et quam segmentum septimum paullo longiore; segmentum septimum octavo fere triplo longius; lobis lateralibus segmenti septimi minus transversis, marginibus interioribus late distantibus, fere parallelis, leviter rotundatis, marginibus posterioribus leviter rotundatis, basi distincte emarginatis.

Описаніе. Удлшненно-овальный, чернаго цвйта, третій ч:теншкъ успковъ желто-бълыи, вершины бедеръ п голени, псключая терныхъ вершинъ ихъ, желтыя.

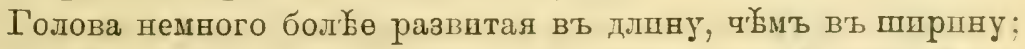
переднії отростокъ ея, довольно тонкій, длшнный, сжатый съ боковъ, боковые отростиг широгіе, короткіе, на вершшнег заостренные, внбетніій край пхъ нөвооруженный; предглазнпчные бугорки мало замбттные, тупые; вцсочнне отросткп неявственные, нөвыдающіеся, такъ что голова позадп глазъ сразу постепенно съуживающаяся.

Усики толстые, черные, третій членикъ пхъ желто-б жылї, первый членпкъ коротко-овальный, второй членикъ пготті : самаго основанія сразу спльно сжать, короче головт, треті亡 членикъ вдвое короче второго.

Хоботокъ доходитъ до вершины переднегрудш.

Переднеспннка вдвое тппе своей длпны; заднії краї ел съ широкой выемкой, боковые крал мелко-зазубренные, загнутые, закругленнше, кпереди сильно съужшвающеся, съ легкой выемкой, кзадп почтп не с'ьужпвающісея, почті параллельные; передніе углы тупоугольно-закүугленные; переднеспинка у основанія вдвое шпре, пүмъ у верпшны; кили переднеспинаш спльно приподнятые, бугортатые, почтп параллельвые; поверхность перөднеспинци позади у оснозанія поперечно-морщинцстал.

Щитикъ удливненный, у вершишы поперечно-морщинисты боковые крал его прпподнятые.

Надкрылья у основанія слібо распшревныя, расширениая 
тасть, псититая самаго освованія ея, буровато-телтая; corium вдвое длпннеге щитика; membrana черная.

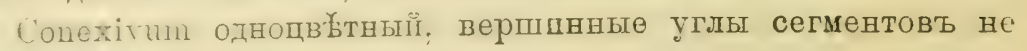
выдаторесл.

Ногш бурыя, ляшки, вершшны бедеръ; голенп, псклюяая пхъ вершинъ, и лапки желтоватыя.

(3. Седьмой сегменть бртогіа снизу выпуклый, боковыя лопастп его ғороткія, мало наклоненныя, внутренніе края шхт расходящіеся, прямые, задніе крал огругленные; задніе угиы боговыхъ лопастей шестого сегмевта тупые, слегка продвпнутые. ПIo J. SAнlberg'y).

․ Задній край пятаго сегмента выемчатыі, средпнная линія сго слегла короче шестого; пестої сегменть по среднеї линіш

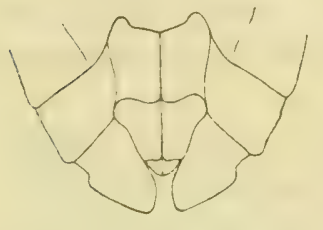

Pис. 73. - Стерниты upumia VI-VIII. Aradus

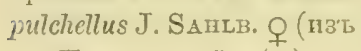

Iршморегіоі обл.). длинн肯е боновыхъ краевъ свопхъ п немвого длиннбе седьмого сегмента, седьмой сегменть почтп втрое длиннею восьмого, боковыя лопасти его мен各е поперечвыя, внутренніе края пхљ широко разставленные на всемъ протяженіп почтц на одпнаковое разстояніе, слабо затіруглеппе, задніе жрая слабо закругленные, у основанія съ сильной выръेзко:

$$
\text { Ј. Длпва }-4 \text { мплл. }
$$

‥ Ллшна-5,5 милл., ширшна переднесппнки-1,8 мшлл.

Сравнительныя заиьтии. Вшть блцзгіiї къ $A$. signaticormis R. F.

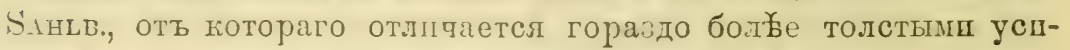

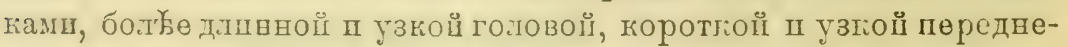
спингоі и особенно ел бормой (переднеспнка впереди вдвое

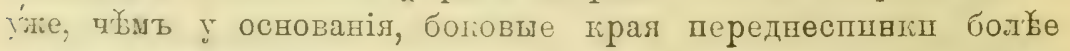
сайо съутпвающеся, плөqевые углы округленные, безъ вы-

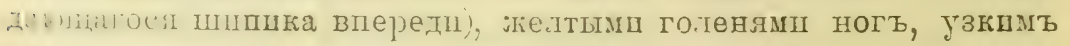
т年ломь пा строеніемъ брюшныхъ стернптовъ о.

Географическое распространеніе. Спйрстій впдъ, шзв Һәстны ї

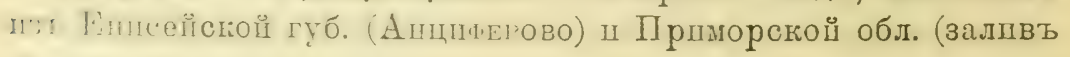

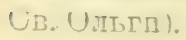

\subsection{Aradus bergrothi $J_{\Delta \mathrm{K}} .1894$.}

(Т'абл. II, Һиг, 22).

Aredus Bergrothi JAK. Eor. Soc. Ent. Ross, XXVIII, p. 136. 1894. 


\section{Фаунпстическая литература, пасающаяся Россін.}

Aradus bergrothi $\mathrm{J}_{\mathrm{AK}}$. loc. cit., p. 136. $189 \pm$ (Tashkent).

\section{Экземпляры Зоологичеснаго Музея.}

Prov. Syr-Darja: Tashkent (ठ̋). Batassogio.

Діагнозъ. Oblongo-ovalis, fusco-nigricans, apice articuli tertii antennarum, macula humerali pronoti, carinis discoidilibus pronoti postice, macula hemelytrorum basi partis dilatatae nec non marginibus posticis segmentorum connexivi flavis.

Caput latitudine sua paullo longius; prolongatione antici longa, crassa, lobis lateralibus longis, acutis, apice flavicantibus, margine exteriore muticis; tuberculis anteocularilus acuminatis, distinctis; lobis temporalibus sensim crassiusculis, obtusis, parum prominulis; capite pone oculos angustato, basi linea V-formi, laevi, callosa flavescenti praedito.

Antennae longae, crassiusculae, articulo secundo basi levissime angustato, dein fere cylindrico, quam caput breviore, fusco, summo apice flavicante; articulo tertio secundo duplo breviore, crassiore, apice late flavo, articulo quarto tertio vix breviore.

Rostrum medium mesosterni attingens.

Pronotum longitudine sua duplo et dimidio latius; margine postico late sinuato, marginibus lateralibus crenulatis, antice fortiter obtusangulariter emarginatis, basin versus angulato-rotundatis; angulis anterioribus obtusangulariter prominulis, apice rotundatis; carinis discoidalibus intermediis basin versus leviter convergentibus, lateralibus subparallelis, postice flarescentibus; tuberculis humeralibus et macula magna prope angulos humerales flavescontibus.

Scutellum elongatum, apice rotundatum, marginibus elevatis, disco basi convexo.

Hemelytra basi paullo dilatata, basi partis dilatatae macula flara ornata, maculis parvis flarescentibus inter rouas praedita; membrana fusca, venis pallidioribus.

J. Segmentum sextum ventrale quinto duplo longius; lobis lateralibus segmenti sexti marginibus lateralibus rectis, posticis ad margines loborum segmenti septimi approxinatis, lato flarulimbatis: lobis apice acuminatis, apicem segmenti septini attingentibus; lobis lateralibus segnenti septimi intus dinidia parte 
tancrentiins, (iejn sub) angulo recto divergentibus, marginibus exterioribus fere rectis.

o. ignöta.

0писаніе. Ј длшненно-овальыщ̆, желтовато буроватаго щеłта, ппронія полосы по затншмъ лраямъ брюшныхъ сегментовъ connexivum'a жептаго цвйта, боковыө крал переднеспннки впе-

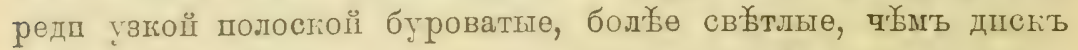
ел, далье къ основанію оцень широко окац̆млены желтымъ, пятво у основанія расшпренної тасти надкрыліі, основанія кшей переднеспинш, вершива третьяго пленшка успковъ, верпшны бедерь, голенп, ппрогія полосы по внутренншм граямъ боковыхь лопастей сетьмого семента таћже желтаго цвєта.

Голова пемного длинне сье своей пирпны, передній отростоғь ея длинный п толстый, заходить за первую четверть длины второго членига успюогь, боговые отростки длинные, заостреннне, салая верпина пхъ желтоватая, внотшній край невооруженный, предглазничные бугоргі заостренные, значительные, впсочные отростки масспвные, тупые, өдва вығающіеся, такъ чтс голова позадш гіазь сразу постөпенно съужпзающаяся; на поверхности ел у основанія гладкая, блестящая дугообразная полоса желтоватаго цвйта.

Јсшкш длинвые, толстые; первый членпюъ пхъ гороткій, овальныи, второї членпиь очень везнапптельно тоньше у самаго основанія, чео̆мъ на всемъ остальномь протяженіп, безь

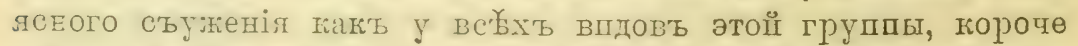
головы и вдвое дішннете третьяг, самая вершина его же.ттватал, третії членшғь слегка длшннће четвертаго, толще второго, ва вершпн

Хоботопь доходшть до сөрөднны срөднегрудп.

Переднеспннга въ 21/2 раза шире своей длины; задній край

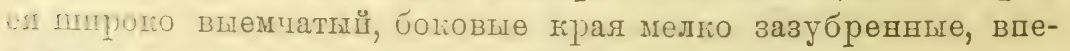

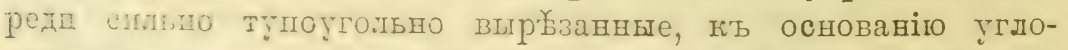

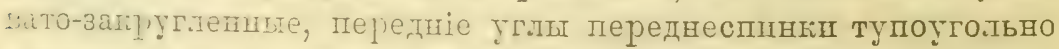

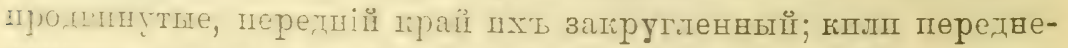

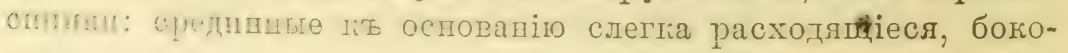
вые - плраллельные, у основанія жғелтоватаго цвитта, плечевыө

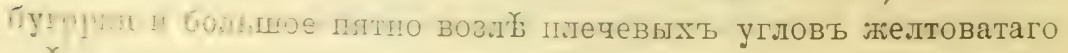

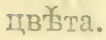

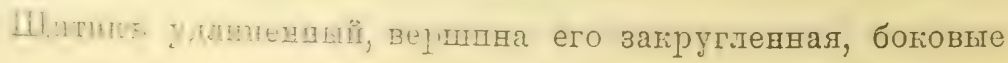


грая прпподнятые; поверхность у основанія слегка припо,нятая.

Налкрылья у основанія слабо растпренныл, у основанія

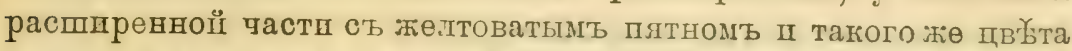
пятнышками между жплћамп corium'a; corium вдвое длшнеке

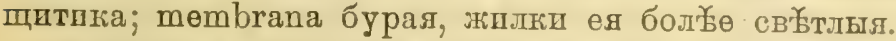

б. Шестої брюпної сегмент'ь вдвое длиннйе плтаго; боговыя лопастц его съ боковымп ғраями прямымш, задндмш краями, соприкасающимися съ лопастями слйдующаго сегмента, пироко окаймленными желтой полоской, вөршины лопасгей заостренныя, доходять до уровня вершины сөдьмого сегмента; боговыя лопасти седьмого сегмента сь внутренними краями на половну сопршіасающіеся, дал官е расходящимися подъ прлмымъ угломъ, вадніе края почти прямые.

๖. Длина -5,з мплл., пирпна надгрылій у основанія - 1,9 мплл.

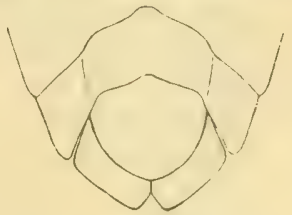

Pнс. 74. - Стерндты úpromsa VI-VII. Araclus bergrathi JAK. $\delta$ ? (1з $\mathrm{T}$ Сарь-дарьнеской об.г, типъ).

Сравнительныя замьтки. Aradus bergrothi JAK. относптея гі

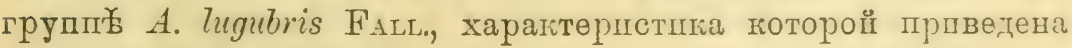

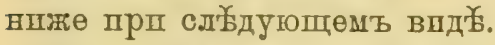

Оть всбххъ вшдовъ әтой группы отличаетея очень толстыми успкамп, второй членикъ которыхъ только у самаго основанія

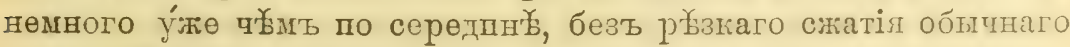
для этой группы, желтоватым пятном у основаніл передиеспинкш, пшрокой переднесппнкой II формої ея.

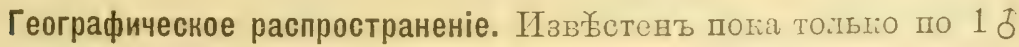
пзъ Туркестана: Ташкентъ.

\section{Aradus lugubris FALL. 1807.}

Aradus Tugubris Fald. Mon. Cimic. Sv., p. 31. 1807; Hem. Sv. Cim., p. 139. 1829.-R. F. SAHLB, Mon. Geoc. Fenn., p. 141. 1818.-H.-S. Wanz. Ins., VIII, p. 114 et 115, tab. 289, f. 888. 1818.-Fuor Rhynch. Livl., 1, p. 382. 1860. - FrË. Eur. Hem., p. 114. 1861. - Reut. Öfv. Kongl. Vet.-Alkad. Förh., 1872, № 5, p. 60.-Puт. Synops. Hém.-Hét. de Frr., I, p. 136. 1879. REur. Ent. Tidskr., 1882, p. 76 et 107; Rev. Syn. Heter. Palaearct., II, p. 285 (ed. sep.), 소 196. 1888; Wien. Ent. Zeit., 1881, p. 136; Medd. Soc. pro Faun. Fl. Fenn., 1. 26, 1900, p. $13 \pm$. 
Aradus affuis KrRBI in Richards Faun. bor.-amer., p. 279. 1837. Aradus Grebleri holisin. ilelet. entom., VI, p. 22, sp. 226. 1857. Aradus rectus SAI Compl. Writ., 1, p. 352. 1857.

\section{Фаунистиеская литература, касающаяся Россіп.}

Árilue lumburis J. Sanub. Medd. Soc. Faun. Fl. fenn., VII, 1881, p. 43 (Fennia tota: Kilpisjürri $\left(69^{\circ}\right)$ in Lapponia, Jokonga in lit. Murmanskij); Not. Saillsk. Faum. Fl. fenu. fürh., IX. 186s, p. 182 (Karelia mer. or.); ibid., p. 230 (Lapponia: Torneå).-Reut, ibid., XI, 1871, p. 318 (Fennia: Pargas).-Lete. Ann. Soc. Ent. Franc., 1892, Bull., p. XXVIII (Ural sept.).JАк. Труд. Русск. Әнт. Общ., VII, 1873, p. $6 t$ (St.-Petersburg). -

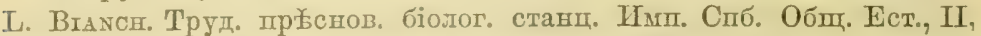
1906, p. 63 (gub. Novgorod: Bologoë). - Krr. Rev. Russ. d'Ent., X, 1910, p. 12 (gub. Vologda, distr. Velsk).-Flor Rhynch. Livl., 1, p. 382. 1860. (Livland: Dorpat; Kurland; Saratov; Sibiria: fl. Birjusa).-PACzоsкг Зап, Кіевск. Обш. Ест., X, 2, p. 417 (Volyn: Kremenetz).-ЈАк. Hor. Soc. Ent. Ross., IV, 1867, p. 149 (Kazan, Sarepta); Bull. Soc. Nat. Mosc., 1874, № 2, p. 268 (gub. Saratov: Sarepta); ibid., 1875, № 4, p. 262 (Orenburg); Rev. Russ. d'Ent., VI, 1906, p. 220 (Krim: Kertsh). Kot. Melet. ent., VI, p. 22 et 23, sp. 225 et 226 (Caucasus sept.; Sibiria: Barnaul.). - Horv. Sitzungsber, d. naturw. Gesellsch. Isis., 1879, p. 96 (gub. Tiflis: Suram). - Reut. Medd. Soc. Faun. Fl. Fenn., h. 26, 1900, p. 138 (Turkestan). - Krr. Rev. Russ. d'Ent., X, 1910, p. 179 (gub. Tomsk: Kaltajskij bor, Meret).-Gebl. Bem. üb. Ins. Sib. in Lederour's Reise durch Altai-Geb., 1830, p. 18 (Altaj).-Horv. Hemipt. in „Dritte asiat. Forschungsr." d. Gr. E. Z гснт, II, p. 251. 1901 (gub. 'Tomsk: Tojanov Gorodok). - J. SAHub. Kongl. Sv. Vet.-Akad. Handl., XVI, № 4, p. 22. 1878 (gub. Tobolsk: Turuchansk; gub. Enisejsk).-JA太. Hor. Soc. Ent. Ross., XXVU, p. 294. 1893 (gub. Irkutsk: Irkutsk, Kultuk, Sajany in initio fl. Irkut); ibid., XXXVI, 1903, p. 322 (gub. Irkutsk: Pashki).-ЈAсовson Tpуд. Тропдтосавско-Кяхт. Отд. Пріам. Отд. Имп. Русск. Геогр. Общ., Х, 1907 (1909), p. 28 (Transbaicalia: Troitzkosarsk). - REut. loc. cit., 1900, p. 13 (Kamtshatka).

\section{Экземпляры Зоологическаго Музея.}

Fennia (J゙,

Fennia: Vyborg (o).

Ciu.. Archangelsk: Kandalaksha. 9. VI. 1911 (ठ). SoLovJer.

Gub. Archangelsk: lac. Imandra, Babinskaja Guba. 12-14. VI. 1911 (q). SoLi, $;$, L :

Gul. Archangelsk, distr. Mezen: Borkovskaja. 1. VI. 1904 (Q). Zhuravser.

Gub. Lrehangelsh, distr. Cholmogory: fl. Emtza, 1. IV-18. T. 1897 (J). Fudel. Ur. Archangelsk, distr. Petshora: Ustj-Tzilma. 6 (ठ). 9 (Q). 15 (ठ)). VI. 1904. ZILRAYSTr.

St.-Petersburg (4 Tे, 6 ㅇ).

St.-Petersburg (ठ). 1861. Moratwitz.

St.-Petersburg (3 o). Konnia.

St.-Petersburg (0). HDMwEL. 
St.-Petersburg. 9. V. 1896. 13. V. 1908 (字, q). G. JAсовsоN.

Gub. St.-Petersburg, distr. Petergof: Lopuchinka. 29. V. 6. VI. 189t. (J, q). Bianchi.

Gub. St.-Petersburg, Novyj Petergof. 15. VII. 1896 (ठ)). Cecchinr.

Gub. St.-Petersburg: Luga. 1869 (Q). SoLsKr.

Gub. St.-Petersburg: Shuvalovo. 20. 24. V. 1897 (2 q). G. JAconson.

Gub. St.-Petersburg: Kamenka. 6. V. 1898 (Q). Prahye.

St.-Petersburg: Petrovskij Park. 7. VI. 1895 (Q). MAZARAKI.

Gub. St.-Petersburg: Gatshina. 10, VII. 1906 (ठ). Barovsk Y.

St.-Petersburg: Uljanka (q).

Gub. St.-Petersburg: Jamburg. 16. VI. 1905 (q). BarovsKr.

Gub. St.-Petersburg: Oranienbaum. 19. V (ㅇ). I. Branchr.

Gub. St.-Petersburg, distr. Peterhof: Lebjazhje. 16. V. 190.5. 23. VI. 1904 (2 ð). L. Branchr.

Gub. Novgorod: Bologoe. 7. VI. 1904 (ㅇ). Z ZatTzeV.

Estonia: Tajla. 10. VI. 1905 (ठ)). Barovskr.

Kazan ( $\overline{0}$ ). Eversmans.

Gub. Perm: Uktus prope Ekaterinburg. 13. VI. 1910 (ठ). G. JACoBson.

Tauria: Kertsh. 6. VI. 1902 (ф). Krritshenko.

Caucasus (ठ). Kolenatr. ("Aradus gebleri KoL。").

Caucasus sept.: Groznaja (o).

Transcaspia: Turkmenia (ㅇ). KoenIG.

Prov. Semiretshje: Kopal. 12. IV (q). Sunitnikov.

Turkestan Chinens. : fl. A tshal. 3. 4. VI. 1889 (5 ð, 3 of). Grum-Grsmimailo.

Tibet septentr.: Montes Russkij, Karusaj. V. 1890 (ф). Psevzov.

Prov. Akmolinsk: Tokushi. 17. V. 1897 (ㅇ). A. JACOBson.

Sibiria (ठ, 2 q). Merngardt.

Sibiria (q). MEINGARDT.

Gub. Tobolsk: lac. Echej in ostio fl. Obj. 17. VI. 1905 (q). Tolmatshev.

Gub. Tobolsk, Ural polaris. 28. VI. 17. VII. 1909 (б, 우). ZAITZEV.

$\operatorname{Altaj}($ Q). MeINGARDT.

Gub. Tomsk, Altaj: Kotan Karagaj. 25. VI. 1899 (ð゙, 2 q). KazNAKov.

Gub. Enisejsk, distr. Kansk: Ilan. 18. VII. 1902 (ठ઼). TArAsov.

Gub. Enisejsk, distr. Krasnojarsk: Norva in fl. Mana. 1. VI (q). RYтsikov.

Gub. Enisejsk: Krasnojarsk. 1. V. 1902 (q). MarsakV.

Enisejsk ( 1 t, 2 o).

Enisejsk. VI. 1856 (2 0,3 우).

Gub. Enisejsk: Torgashino prope Krasnojarsk. 27. V. 1597 \%). A. Jacoßsux.

Gub. Enisejsk, distr. Minusinsk: Shushenskoe $(0, \delta)$.

Gub. Enisejsk: fl. Nizhnjaja Tunguzkit, supra mutes Kagil, cosc:3l' lat. s'lit.

19. VII. 1873 (ठ). CZEKANOWSKI.

Irkutsk $(\delta, 2$ o $)$.

Irkutsk (2 j). JAKovlev.

Gub. et distr. Irkutsk. 3-5. V. 1898 (ठ).

Gub. Irkutsk: Pashki (Q).

Gub. Irkutsk: Kultuk (q).

Gub. Irkutsk: Kultuk. 25. IV. 12. 21. VI. 1878 (3 ơ, 2 q). CzExsorolsir.

Gub. Irkutsk: Wiski (Vitimskoje) (お, 2 o). 
(iuh, Irlutik: Proobrazlutskoje in fl. Nizhujaja Tunguzka. 5. VI. 1873 (q). Czemawomesi i.

Gub. Irkutsk: Padun in $\mathbb{f l}$. Angara (2 ㅇ). Czek ANowser.

Gub. Irkutsk: Nikolaerskij Zavod. 12. V. 1899 (

Gub. Irkutsk: Pivovaricha. 21-27. VII (ठ)). Soldatov.

Gub. Irkutsk: $\mathbb{f l}$. Lena inter Kirensk et Vitim (q). Bunge.

Lim. gub. Trkutsk et prov. Jakutsk: montes Shepetkoj. 10. V. 1873 (q). CzEKANOWSKI.

Jakutsk. 22. VII (q). KIrILLov.

Jakutsk (ठ).

Prov. Jakutsk: Wiluj (ठ).

Prov. Jakutsk: Wiluj. 2. VI. 1889 (Q). Herz.

Prov. Jakutsk: Monjero, syst. fl. Chatanga $-661 / 2^{\circ}$ latit. sept. $(\delta, 2$ o). CzEKANOWSKI.

Prov. Jakutsk: fl. Sachtani prope Bulun in cursus inf. f. Lena. 13. VI. 1908 (Q). Pfizenmejer.

Prov. Jakutsk: a Terchojansk us que ad Choisadach. 19-26. VI.1885(q). Buxge.

Prov. Jakutsl: fl. Endabul syst fl. Duglach et Jana. 6. VII. 1895 (q). Bunge et 'Tou.

Prov. Jakutsk: Kazatshje in ostio fl. Jana. finis VIII (ठ). Bunge.

Transbaicalia: fl. Ingoda. 11. VII. 1898 (2 ㅇ). Suvorov.

Transbaicalia: Tshita, fl. Ingoda. 11. VII. 1912 (Q). M. Gitelman.

Transbaicalia: Tshita, prope fl. Kajdalovka. 24. VI. 1912 (q). Krrchrer.

Transbaicalia: Ustj Kiran in $\mathrm{Al}$. Tshikoj, orient. versus a Kjachta 1. VI. $1903(\$$, ơ). Снозге

$\Delta \operatorname{mur}(2 \delta, 2$ o).

Ussuri (ठ).

Fl. Zeja, syst. th. Amur, contra Blargoyeshtshensk (d, 2 q). Nearshivova.

Prov. Amur: Montes Bureja (Q). RAdDE.

Prov. Littoralis: Vladivostok. 3. V. 1909 (ð). Berger.

Prov. Littoralis: Vladivostok, portus Maj. V. 1861 (d). Vurfius.

Kamtshatka: Kljutshevskoje. 13. VII. 1908 (ठ)). BiAnchr.

Kamtshatka: Kozyrevka. 11. VI. 1909 (Q). Protopopov.

Radackko. 17. XI. 1852 (ф).

Sine datis (o), 3 o).

Діагнозъ. Corpus oblongo-ovale, brunneo-nigrum rel nigrum, cmerulis apicalibus segnentorum abdominalium, articulis secundo tortiuque apice albidis.

Caput latitudine sua longius; prolongatione antica crassa, Jonga; Jolis lateralibus brevibus, sat acminatis, crassis, rectis 7..? Luviter divergentibus, margine exteriore muticis; tuberculis antcocularilus olsuletis, obtusis; lobis temporalibus haud promiinuls: chpith grne coulos subito fortiter angustato, collum brere formantu povtice lasin versus lineis duabus laeribus, callosis, angulariter convergentibus, flavescentibus praedito. 
Antennae longae, sat crassiusculae, articulo secundo capite breviore, ad quartam basalem partem subito fortiter constricto, dein fere cylindrico, articulo tertio secundo duplo breviore, basin versus leviter angustato, articulo quarto tertio breviore.

Pronotum longitudine sua duplo latius; margine postico late et leviter sinuato, margine antico inter angulos profunde sinuato, marginibus lateralibus rotundatis, antice profunde sinuatis, apicem rersus fortiter angustatis, post medium rotundatis, fere parallelis; angulis anterioribus leviter prominulis, obtusis; carinis sul)parallelis, intermediis interdum apicem rersus leviter convergentibus.

Scutellum elongato-triangulare, apicem rersus acıminatum marginibus lateralibus valde eleratis; disco basi conrexo, apice transversim rugosum.

Hemelytra basi recta, haud dilatata; corio nigro, interdum griseo-subhyalino, renulis transversis, nigris praedito; membrana fusca, venis hyalino-limbatis.

Pedes fusci.

Описаніе. Удлшнненво-овальный, буровато-чернаго цв Ұтта, вершпнные углы бргшныхъ сөгментовъ, вершщиы второго п третьяго членшковъ усиковъ бұловатые.

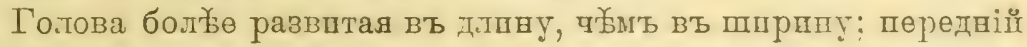
отростокъ ея толстыи, длпнныи, боговыө отростіи тороттіе, довольво заостренвые, толстые, прямые, рәыдко слабо расходящіесл.

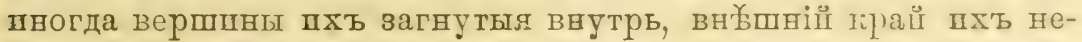
вооруженны , предтлазнпчные бугоркп слабо выраженные, тупые, височные отростки нө выдаюціеся, голова позадп г.аз' сразу быстро съужнвающаяся въ поротіую пето; на поверхносп

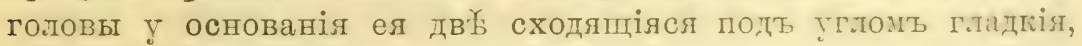
блестящія линіп желтоватаго цвйта.

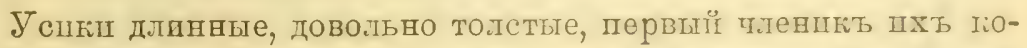

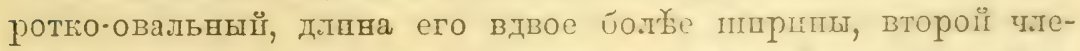
ншкь короче головы, на $1 / 4$ своего протяженія оть оспованія сразу спльно сжатъ, дальше поптп одшпаповой толцинь, третій членпкъ почтп вдвое короче второго, тіъ основанію слаб́ съулпгвающійся, чөтвертый члениґ тороче третьяго.

Хоботокь заходить за вершшну перөднегрудш.

Переднеспниа втвое ппре своей длпны, задній граї ея ппрого п очень слабо выемчатнй; передпі ї трай межту угіами 


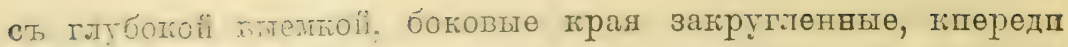
спльто сътплватиіесл, съ гтубокої выемкої, позадп середпны

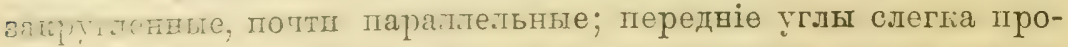
пвшитло ппоредъ, түпые; кптп переднеспннки почтп парал:ельпые, средпнные пногда ппередш слабо сходящіеся.

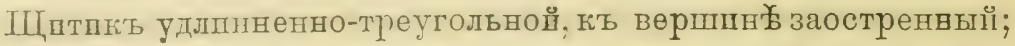
боковые эрая его спльно пүшподнятые; поверхность у основанія

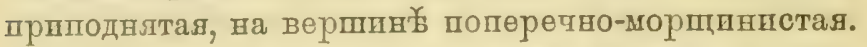

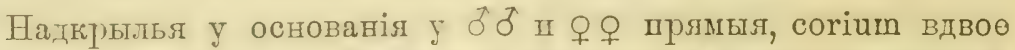

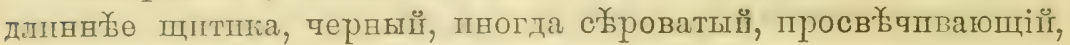
съ многочисленнымш поперечнымш терными жилкамп, membrana буроватая, вдоль жнлокъ свогтлая.

Ногш буроватыя.

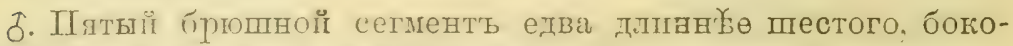
выя попасті седьмого сегмента спльно поперечныл, внутренвіе

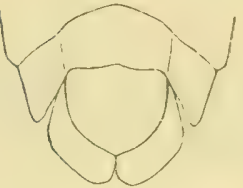

Prс. 75. - Стерниты бргетка VI-VII. Arodus lugulris F $\triangle \mathrm{LL}$. ó (нзт, С.-Петерúypuскої губ.). грая пхъ закругленные, соприкасающіеся, только на самої вершшек्⿱宀㠯 какь бы съ угловатої выр'ъेзкой.

q. Пэтый ópпшиоĭ сегментъ немного короче шестого, задвії край его прямой; пестої сегментъ одннакової ллины съ пятымъ, дискоидальная часть его одинаково развптая въ длину и ширшну, бокоBыл лопастI доходять до уровня вершины восьмого сегмента, задніе углы шхь слегка выдаюшіес за уровень лопастөї сль'дующаго сегмента; сөдьмоі сегменть въ $2 \frac{1}{2}$ 3 раза тороче шестого п вдвое длиннбе восьмого; боковыл лопасті сөдьмого сегмента съ внутренним краям разставленнымп, боковыө края пхъ образують тупої уголь.

お. Плина - 4,8-6 мплл., ппрпна надкрыліп̈ у основанія $1,8-2,1$ MUIग,

ㅇ. Плина - 5,2-6,4 мплл., пшрпна надкрылії у основанія $1,0-2,2$ MнIJ.

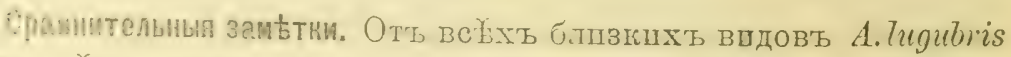

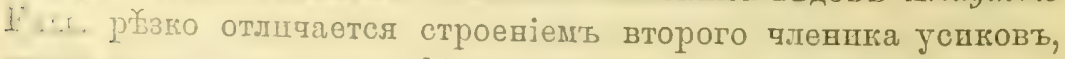

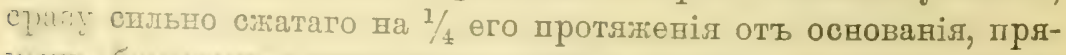

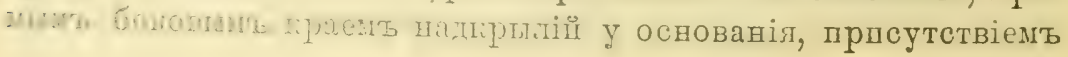


на corium'官 многочпслөнныхъ поперөдныхъ жилочекъ пернаго цв о्वтта.

4. Tugubris FaLL. является типомь обшпрной п трезвычайно тохосной группы, 18 впдовъ которой перечислены выпе на стр. 59.

Вшды въ нее входящіө характернзуются по большей частью маленькой величиной, вторымъ членшкомъ успковъ къ осно-

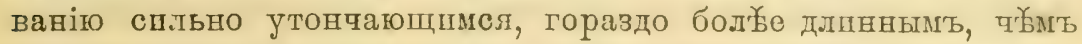

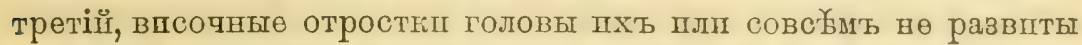

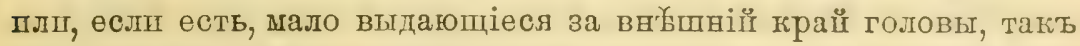
что голова позади глазъ сразу постепенно съуживающался, на поверхностц головы у основанія выступають сходящія подьь угломь плп дугообразно двъ гладеія, блестящія лшнін желтоватаго пвйта, переднеспинга съ боковымп краями, мелко зазубреннымп, рәेдко впереди съ явственнымп но небольшим зубчпкамп, надкрылья у основанія слабо расшпренныя шли прямыл, боғовыя лопастп седьмого брюпного сегмента къ вершив съужпваюшія, спльно поперечныл, госо направленныя.

Взапмныя отношенія между впдами этой группы вылсгены въ двухъ работахъ ReuteR'a ${ }^{1}$ ), въ жоторыхъ даны отлгчія 8 вщдовъ. Отношенія малопзв бстныхъ п педостаточно опшсанныхъ вшдовъ ЯговлевА, двухъ видовъ оппсанныхъ мною въ этой работь оғазалось возможнымъ, пользуясь лшпь возможностьо познаго-

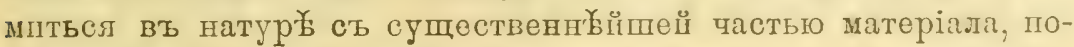
слуншвшаго для опшсанія ReбтеR' любезному отношеніг къ моей работь уважаемаго автора; сльлавшаго напбольпії вкладъ вт напп познанія о сем. Aralidile.

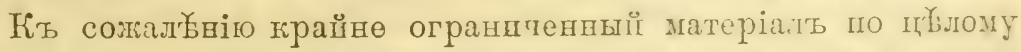

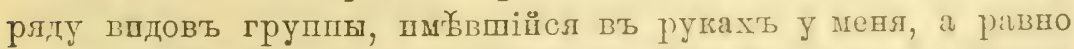

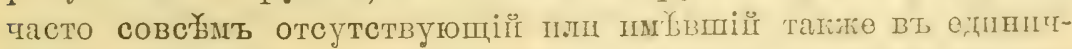
ныхъ экземплярахъ у предыдуцаго автора, не даетт возможности категорпчн神 обрисовать пцды, а оппеаніе многпхт признаковъ не пм Беть статпстики ін не пизволяеть псполєзивать посль'Бдніе ІІ ввестп ихъ въ діагнозы.

1) Redter. Ad cognitionem Aradidarum palaearcticarum (Wiener Entom. Zeit., 1S8t, p. 129-137.), Rovtrk. I) finska arterna af Aradus lumuTris-gruppen (Meddelanden af Societas fro Fauna et Florat Fennica, h. 26, 1900, p. $131-139$. 
Географичеоие распространеніе. ШПроко распространенный въ

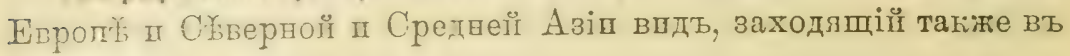
С̆верную Амерпку.

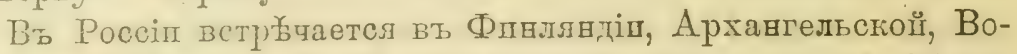
:оготской, Оловөцкой, Петербургской, Новгородской, Пермскої, Эстлядской, Курляндсгой, Волынстої, Казанскої, Саратовской, Оренбургскої, Таврпческой губ., на сеъв. Кавказљ, в'

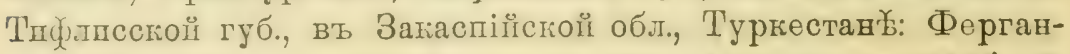
ской обл. (съьв. скл. Алайстаго хребта: Арчш-Башш, S000'. 17.

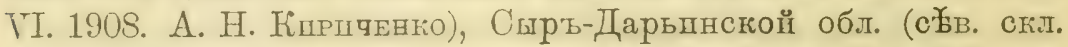
Алегісандровскаго хребта: переваль Маки́алъ, 9870' 12. VI. 1910.

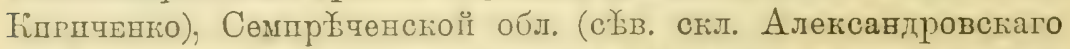
хребта: перев. Аламединъ, 8610'. 4. ТII. 1910. Ћінгпенко). Въ Спбрп: Амиолпесіой об́л, Тобольской, Евпсейской, Томской, ІІргутской губ., Забайгальскої, Япутскоі̆, Амурскої пा Приморской обл., на Камчаткег.

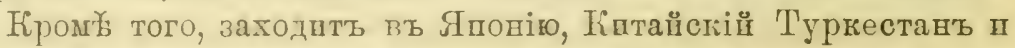
Тпбетъ.

Въ Европ冬 впдъ этоть доходшть до $69^{\urcorner}$с. ш. въ Лапландіп, въ Сибпрп доходить до съвернаго по:ярнаго круга (Обдорскъ Тобольскої губ., Казачье на р. Янаһ въ Якутской обл.) п өще

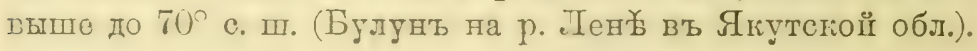

Образъ жизни. Ветрбчаетея подъ корої Pinus silvestris, пногда на хвоҰ (cx. Reuter, зъ Acta Soc. Sc. Fenn., XXXVI, 르 1 , p. 88).

Ведетт очень подвпғной образъ жизнп п поэтому часто по-

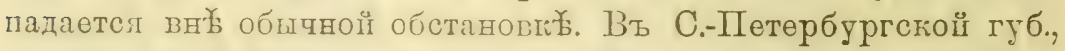

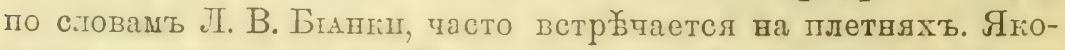

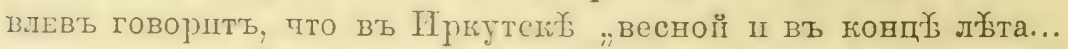

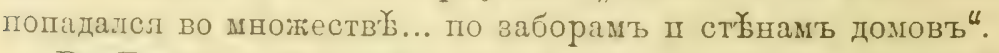

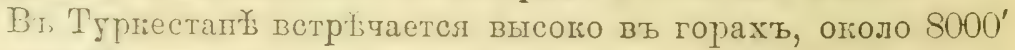

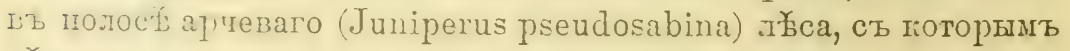
вьвоятно п связанъ біологпческ.

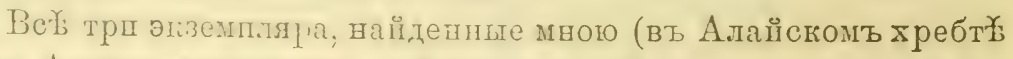

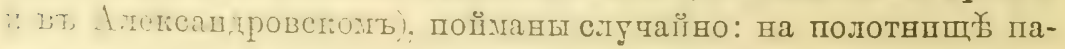
латхи.

Aradus lugubris f. nigricornis Revr. 1900.

Aradus lugubris v. nigricomis Reut. Medd. Soc. Faun. Fl. Fenn., b. 26, 1900, p. 13.1. 


\section{Фаупистическая литература, касающаяся Россіщ.}

Aradus lugubris v. nigricornis Revr., loc. cit., p. 138 (Fennia: Salla).

Діагнозъ. Ut typus, sed antennae totae nigrae.

Описаніе. Отличается оть основної формы сполна чернымш успкамп.

Сравнительныя замбтки. Таксономпческое значеніө этої формы пока ве ясно, какъ какь она пока очень мало пзв'ьстна.

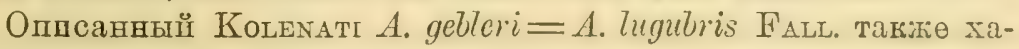
рактеризуется почти черными усшками.

\section{Aradus flavicornis DaLM. 1823.}

Aradus flaricornis Datman Analecta entomologica, p. 88. 1823.-Srít. Hemipt. Afric., II, p. 37. 1865; Enum. Hemipt., 3, p. 136. 1873. - Puт. Synops. Hém.-Hét. de Fr., I, p. 135. 1879.

Piestosoma flavo maculata Luc. Exp\}. scient. Alg.g III, p. 56, t. 1 (Hem.), f. 8. 1849 .

Aneurisoma Lucasi Costa Cim. Cent. Addit. 1860.

Aradus leucotomus Costa Ann. Mus. Zool. Nap., 2, p. 143, t. 2, f. 2.1864.

Aradus flavomaculatus Puт. Ann. Soc. Ent. Fr., 1873, p. 19.

Aradus macrophthalmus JAK. Bull. Soc. Nat. Mosc., 1878, I, p. 130.

\section{Фауниститесая литература, касающаяся Россія.}

Aradus macrophthalmus JAs., loc. cit., p. 130. (Transcaucasia: Derbent).

\section{Энземпляры Зоологическаго Музея.}

Transcaucasia: Derbent. (q). Komarov.

Transeaucasia: Geol-tapa in distr. Aresh, prov. Elizaretpol. (Q). SchllzoyNIKOV.

Дiarно3ъ. Corpus oblongo-ovale, o retrorsum dilataturn, nigrum; antennae, connexivum angulis apicalibus segmentorum albidoflavis, hemelytra inter costas nec non membrana albida, hyalina.

Caput longitudini sune aequilatum; prolongatione antica crassissima, longa, lateribus compressa, lobis lateralibus sat lon acuminatis, margine exteriore muticis; tuberculis anteocularibus distinctis, obtusis; lobis temporalibus obsoletis, haud prominentibus; capite pone oculos subito in collum brevissinum angustatum; oculis magnis marginem anticum pronoti fere tangentibus.

Antennae breviusculae, crassae, albido-flari, articulo primo toto, articulis secundo tertioque hasi nee non articulo quarto 
apice fusmocentiuns; articulo secundo tertio in $1 / 3$ longiore, basin Tereus in triente longitudinis suae ab basi subito fortiter conAtricto, articulo tertio quarto in $1 / 4$ longiore et paullo crassiore.

Rostrum coxas anticas attingens.

Pronotum longitudine sua fere duplo latius, antrorsum angustatum; margine postico recto, marginibus lateralibus reflexis, minutissime crenulatis, fere rectis (ठ) vel post medium levissime rotundatis, fere parallelis, antrorsum angustatis, fere rectis, marginibus interdum totis levissime rotundatis (o); angulis anticis obtusis, rotundatis, apice recte truncatis, angulis posticis obtusis, rotundatis; carinis intermediis subparallelis, lateralibus apicem versus fortiter convergentibus.

Scutellum angustum, elongatum, apicem rersus leviter acuminatum, marginibus lateralibus ralde elevatis, disco basi convexo, apicem versus transversim rugulosum.

Hemelytra basi apud mares parum dilatata, apud 오 울arginibus rectis, apicem rersus angustatis, marginibus lateralibus regulariter crenulatis; margine exteriore, costis et venulis transrersis nigris, iterstitiis inter costas albidis, subhyalinis; membrana alba, hyalina, fusco-maculata.

Pedes fusci.

\$. Inferne lateribus vittis duabus pallidioribus praeditum.

Segmentum sextum ventrale quinto longiore, margine apicali fortiter lisinuato; lobis lateralibus ad lobos segmenti septimi approximatis, sed haud tangentihus; lobis lateralibus segmenti septimi apicem rersus fortiter angustatis; marginibus interioribus imo apice contiguis, narginibus posterioribus rotundatis, marginibus exterioribus rectis.

Описаніе. Удпненно-овальный, 9 гззадп расппряюпалсл,

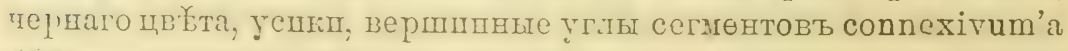

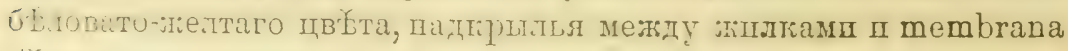
бъ.пя, полупроврачныя.

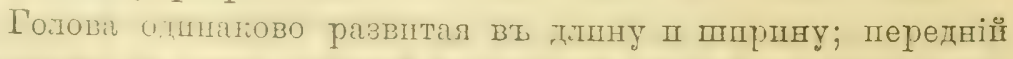

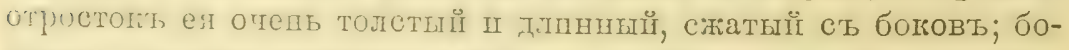

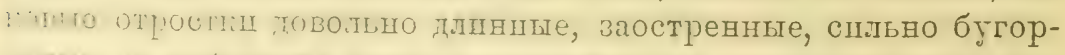

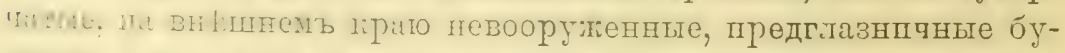

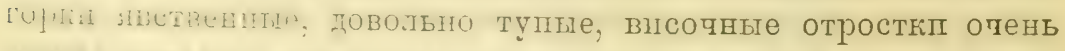

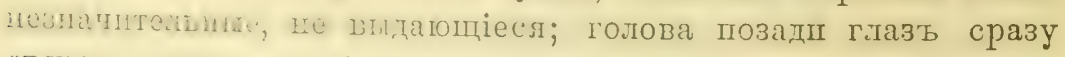
съужпватаяся вь "ччень пороткую шею, такъ тто большіе 
глаза почти соприкасаются съ передндмъ гіраекъ переднеспннкіг.

У спки короткіе, немного длиниће головы, толстые, бЖловатожелтаго цвҺેта, только первый qленић весь, основавіе второго II третьяго II вершцна чөтвертаго буроватые, пөрвый членпюь гуть заходшть за вершину боловыхъ отростковъ головы, второй

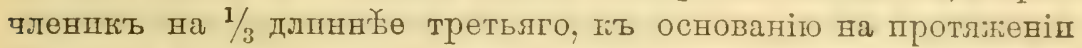
$1 / 3$ своей длпны оть основанія сразу спльно сжатый, третій

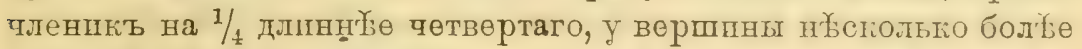
толстыц̆, q安м у основанія, четвертыї членпкъ самый тонкій.

Хоботокь доходпть до передншхь ляшегі, буроватаго пвйта.

Переднеспшнка почти вдвое шире своей лппны, кпереги съужшвающаяся, задніци грай ел прлмой, боковые крал довольно спльно загнутые, слабо зазубренные, посл' середпны къ вер-

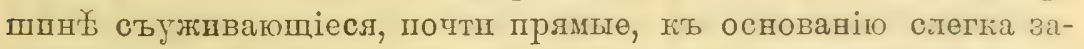
кругленные, пногда на всель протяженіш равном⿰⿱⺊口㇀рно, очень слабо закругленные (q) пли грая почтш прямые (d), пөредніе II задніе углы перөднесппнп тупые, зағругленные, передніе на вөршпне́⿱宀⿻三丨 прямо обрубленныө; срединны кшли переднесппнкп почтп параллельные, боковыө кь верпине спльно сходяціеся.

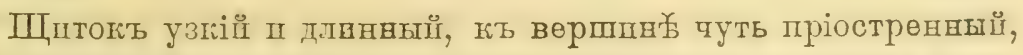
боковые края его спльно прнподнятые, поверхность у освованія вздутая, у вершины поперечно-морщнистая.

Надкрыля (ठ) у основаніл слабо-расшшревныя, у $q-п р я-$

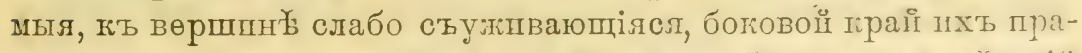
вшльно зазубренъ; corium въ два раза длпннеке питшга, вн

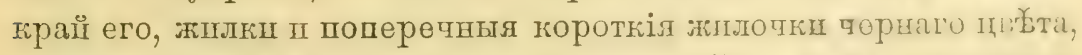

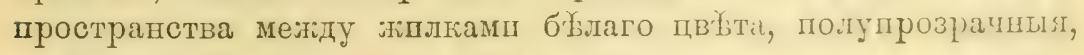
membrana бълая съ буроватымп плтнышкамш.

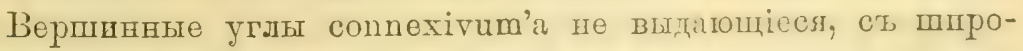
кпли желтымп полосамп по заднему праго сегментовъ.

Ногп буроватыл.

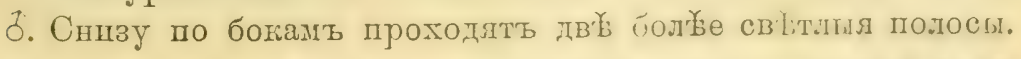

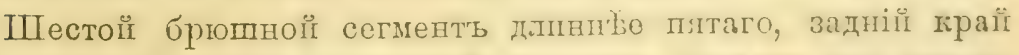
его спльно двояко выемчатый; боловыл лопасти его спльно прпблпленныя, но не сопрптасапоцісл с'т попастями ссдтмого сегмента, внутренніе тіріл пхт, прыные; іопасти ссдьмого сегмента горотьіл, спльно поперетныл, ть вершшны спльно сьь- 


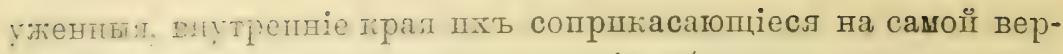
шпнl. по разстаплепные у основанія, боковые края закругленвые.

.. Плтьи брошної сегменть слегка короче пөстого, шөстой cumент вдвое тыпнияе седьмог, боковыя лопастп шестого сегмента доходять до уровня вершшны сөдьмого, задніе углы шхъ закругтенные, сопрпкасаюіеся съ топастям слю्रдующаго сегмента; боковыя лопастп седьмого сөгмента довольно длшнныл,

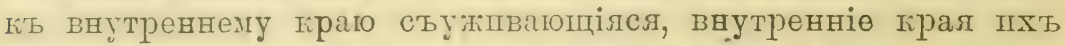
слегка зағругленные, шщрого разставленные, боковые грая сильно закругленные.

5. Длпна-4,4 милл., шпрпна надпрытій у основанія-1,6 пплл.

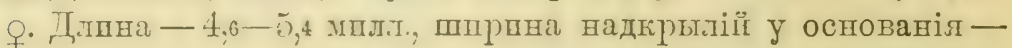
$1,6-1,8$ милл.

Сравнительныя замьтки. Aradus flavicomis DAlм. пршнадлежпть

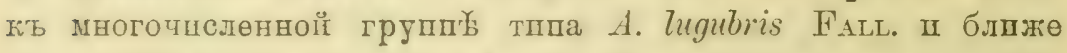

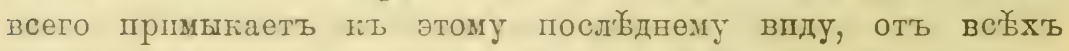

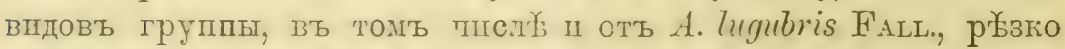
отлпчаетея строеніемь головы, позадп глазъ сразу съужшвающейся в'ь торотіую пею, очень большимъ переднимь отро-

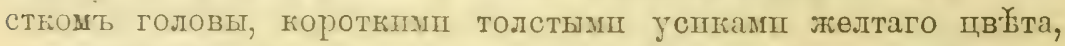
надтрлльям, согіum поторнхъ между жилкамп II membrana б. строеніемъ пөреднеспннип п другни приянаками.

По строевію второго члеппи успковь, сраву спльно сжатаго на протяженіп $1 / 4$ его дішны отт основанія, вщдъ әтоть бапже всего стошть къ $A$. lugubris FALL.

Географическое раслространеніе. Впдъ этоть широко распространенъ по африканскому матерпку въ обопхь фоуншстпчесгихь парствахъ его әфіопскомъ: Сіерра Теона, Кафбрарія и

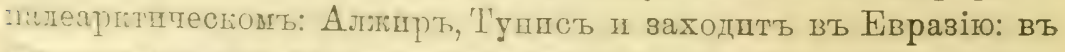

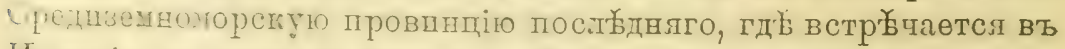

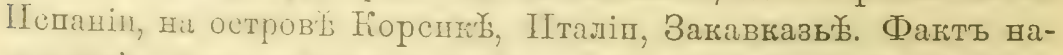

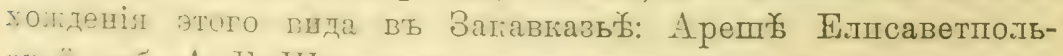

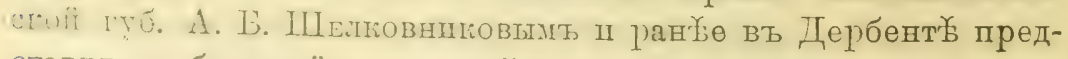
ставляетъ больтої воогеограбоцческій внтөресъ.

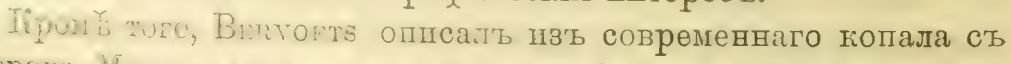
"строва Alaturactapa подт пмепемь .1. madagaskariensis Berv. әтоть жо видъ. 
44. Aradus angularis J. SAHLB. 1886.

(Табт. II, ф્бпг. 21).

Aradus angularis J. SAHLis. Medd. Soc. Faun. Fl. Fenn., III, 1886, p. 153. Reut. Medd. Soc. Fauu. Fl. Fenn., h. 26, 1960, p. 134.

\section{Фаушпспичесая лштература, касающаяея Россіп.}

Aradus angularis J. SAHLB. loc. cit., p. 193 (Gulb. Olonetzkaja: Petrozavodsk). REUT. loc. cit., 1900, p. 138 (Fennia: Nuortijaur, Inari).

\section{Энземпляры Зоологичеснаго Музея.}

Irkutsk. (O). JAKOVLEV.

Prov. Jakutsk: fl. Monjero syst. fl. Chatanga, $66 \frac{1 / 2}{2}$ lat. sept (O). CzEnANoWSEI.

Prov. Jakutsk: Kozatshje apud ostium fl. Jana (ठ). Bunge.

Prov. Jakutsk: Bulun in curs. inf. fl. Lena. 11-16. VI. 1908. (o)). PFIZENMEYER.

Діагнозъ. Oblongo-ovalis, niger, marginibus posticis segmentorum abdominalium Havescenti-albidis.

Caput latitudine sua paullo longius, prolongatione antica sat brevi, apicem articuli primi antenuarum sat multo superante; lobis lateralibus longis, acutis, antrorsum vergentibus, margine exteriore muticis; tuberculis anteocularibus obsoletissimis; lobis temporalibus vix prominentibus; cujite pone oculos sensim angustato, postice basin versus lineis duabus laevibus, callosis, angulariter convergentibus, flavis praedito.

Antennae longae, graciles, nigrae; articulo secundo capito breviore, sat multo longiore quam articulus tertius et quartu: simul sumpti, a basi apicem versus sensim incrussato, granulis magnis sed raro dispositis instructo, articulo tertio quarto vix longiore, apice quam basi duplo crassiore.

Rostrum medium mesosterni attingens.

Pronotum transversum, magris quam duplo longitudino sui latius; margine postico late et leviter sinuato, margine antico fortiter sinuato, marginibus lateralibus minute crenulatis, antico late sinuatis, basin rersus angulato-rotundatis; angulis anticis acutis, antrorsum fortiter proluctis; carinis pronoti subparallelic, intermediis antice leviter approximatis.

Scutellum pronoto longius, sat angustum ( $\delta$ ) rel liutius (pi, marginibus lateralibus elevatis; disco basi convexo, apico tran:versim rugosum. 
Henclinu lani pratlo dilatata (q) vel marginibus lateralibus basi rectis (す); membrana albida.

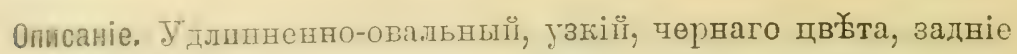
грая сегментовъ connexivum'а желтовато-бълаго цвйта.

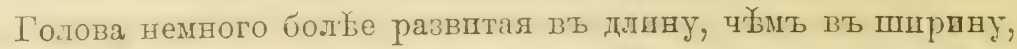
передніи отростокь ея довольно короткій, далеко заходящій за верппну перваго членшка усптовъ, б́оковые отростки длпнные, острые, направленвые прямо впередъ, вноㅎнній край пхъ невооруженныі; предглазнцчные бугорги слабо выраженные; впсочные отросткп чуть выдатщіеся, такъ что голова позадп глазъ постепенно съјнпваюшаясл на поверхности головы ?

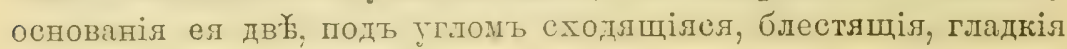
линіп желтоватаго цво̆та.

Јепип длпнные, тонкіе, чернаго дветта; первый членпкъ пхь удлпннедно-овальныи, торотії, второї членикъ слегка короче головы II значительно динннее третьяго II четвертаго

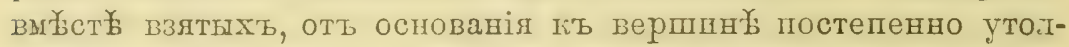
датдійсл, поверхность его въ спльо развнтыхь, но рђдко расположенныхъ бугоркахъ, трөтіі члениць туть длцнни्देе чет-

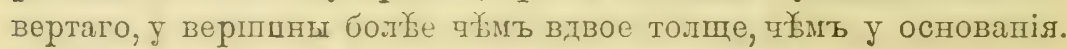

Хоботокъ доходпть до середины среднегрудп.

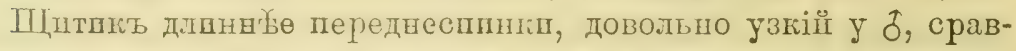
нительно пироліiі у q; боловые лрал еs прпподнлтые, поверх-

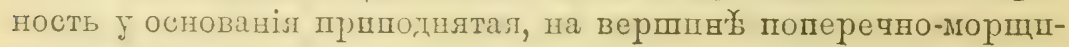
нистая.

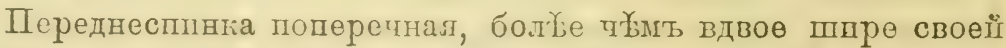
длшны; переднії граї ел сильо вырłзанъ, заднії траї ел съ широкої п легкої зыемкоі, боковые грая мелко-зазубренные, виереди съ шірокої выемгой, кт основанію угловато-закругленнпе; передиіе углы - острые, прямо-направленные впередъ;

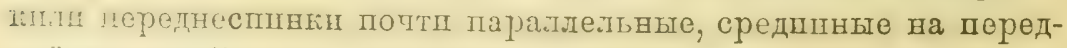
вец половнде혀 слегка сближенные.

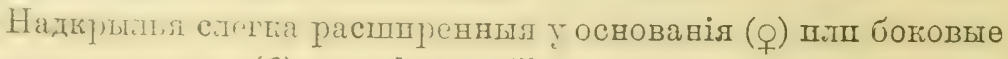
края шхт прямыя (ठ); membrana бъловатал.

Ногп червыя.

б. IIямыі бртопной сегменть слегка коропе пестого, бокозыл лопасті пестого сөгмента сь заднима граямп прямымп, вадніө углы лопастец слепка выдатотся за уровень лопастей седьмого селмента, әти послекднія пь внутреннему краю посте- 


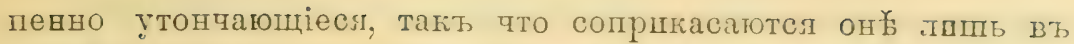
одної точк年, боковые іират образують очень тупой уголь, об́f,

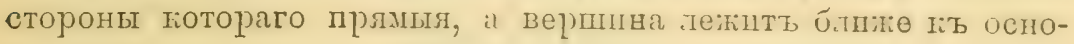
ванію $\left.{ }^{1}\right)$,

‥ Шестої брюшной сегментъ равенъ по дишнхь пятому II вдвое длиннйе седьмого сегмента, дискоцдальная часть его слегка поперөчная, боковыя лопастп доходять до уровня вершины седьмого сегмента, вергпннные уг.ты пхъ вакругленные, слегка выдающіеся за уровень лопастеї слғдууюшаго сегмента; боковыя лопастп седымого сегмента короткія, очень широкіл, внутренніе грла шхь широко разставленные, закругленные, боговые грая образують очень тупощ

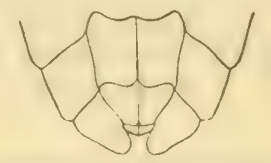

Pис. 76. - Стерниты бргопка VI-VIII. Arartus anmuleris J. SAнLв. 우 (изт Якутской об̆.т.).

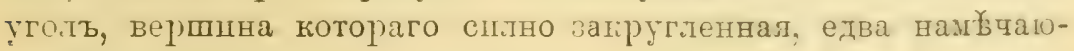
щаяся.

๖. Длпна - 3,6-4,9 мплл., шпрпна надкрылій у основанія 1,6 мплл.

‥ Пцлина - 4,6-5,1 мплл., ширпна надкрылій у основанія 1,7 миллІ.

Сравнительныя замьтии. Aradus angularis J. SAнцв. płzво отлитается оть всыхъ видовъ группы строеніемъ переднеспнки, передніе угшы которої острые, прязо-продвинутые вперегт.

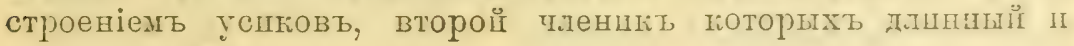
очень тонкій.

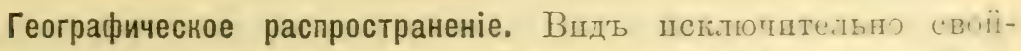

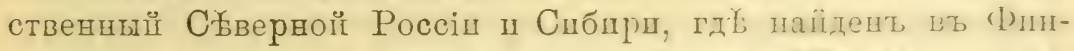

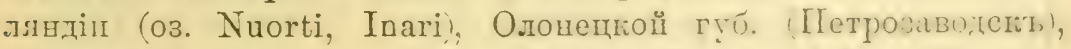

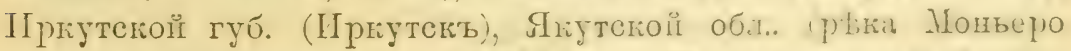

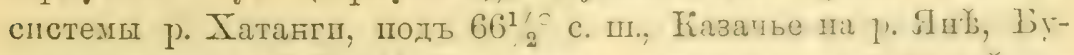

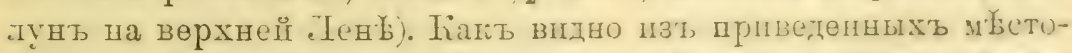

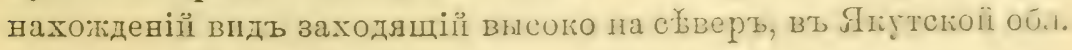
достигагцій сłвернаго полярнаго круга.

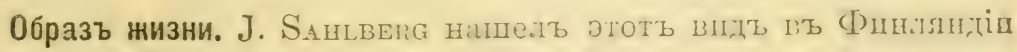
на лцственнпц (Abies excelsa).

1) Такое пменно своеобразное строеніс седыого стернита щметт

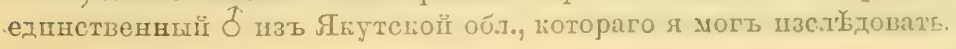


45. Aradus laeviusculus Revt. 1875.

(Табл. II, фопг, 24).

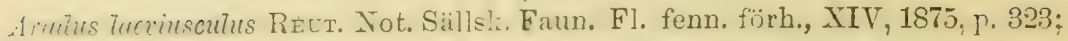
Ent. Tidskr., 1882, p. 76 et 107; Wien. Ent. Zeit., 1884, p. 135; Medd. Soc. Faun. Fl. Fenn., h. 26, 1900, p. 136.

Aradus angusticollis Revt. Medd. Soc. Faun. Fl. fenn., VII, 1881, p. 140; Ent. Tidskr., 1882, p. 75 et 105; Wien. Ent. Zeit., 1881, p. 133.

\section{Фаупистпеская лптература, касапщаяся Россіп.}

Aradus anrfusticollis RECT., loc. cit., 1881 (Muonioniska in Lapponia Torneensi). Avadus treviusculus .T. Sauls. Medd. Soc. Faun. Fl. fenn., VII, 1881, p. 13 (F'ennia: Yläne).-Reur. loc. cit., 1900, p. 138 (Eennia: Orivesi, Samatti, Kiarislojo).

\section{Энземпляры Зоологичеснаго Музея.}

Gub. Irkutsk: Kultuk. (ठ) .

Дiarн03ъ. Corpus oblongo orale, latiusculum, nigrum, angulis apicalibus segmentorum connexivi flavescentibus.

Caput latitudine sua paullo longius; prolongatione antica longa, tenui, loljis lateralilus crassis, sat brevibus, parum dirergentibus, apice acuminatis, margine exteriore muticis; tuberculis anteocularibus obtusis, parvis, lobis temporalibus obtusis, vix prominentilus; caput pone oculos sensim angustatum, postice basin versus lineis duabus laevibus, callosis, angulariter convergentibus, flavescentibus praeditum.

Antennae longae, nigrae; articulo secundo capite breviore, apicem versus sensim et regulariter incrassato, basi ima levissime capitulato-incrassato, articulo tertio secundo fere duplo breviore, articulo quarto tertio in $1 / 4$ breviore.

Rostrum coxas anticas attingens.

J'onotum transversum, longitudine sua magis quam duplo latius, mirne postico late sinuato, marginibus lateralibus subtiliter creuulatis, reflexis, fuscis, subdiaphanis, apicem versus fortiter angustatis, profinde sinuatis, post medium fere parallelis, ima bw: vblique truncatis, angrulis anterioribus obtusis, apice recte irumatis (o) vel rotundatis, panllo antrorsum prominulis (o); carinis li mida!ilus - lateralibus subparallelis, intermedis in limilin antio promoti fortiter approximatis; superficie pronoti po-tice tianererwin musulosia. 
Scutellum elongatum, apice leviter acuminatum, marginibus lateralibus valde elevatis, disco basi conrexo, apice transversim rugulosum.

Hemelytra basi levissime dilatata, marginibus lateralibus fere rectis (ઈす) vel distincte dilatatis ( $(q)$ ), quam pronotum latioribus, parte dilatata medio vix diaphana, macula basali destituta, renulis nonnulis pallidis praedita; membrana fusca, venis hyalino-cingulatis.

Pedes fusci.

Описаніе. Удлпненно-овальныи, шпрокії, буровато-пернаго цв'ъта, задніе углы брюпныхъ сегментовъ желтоватые.

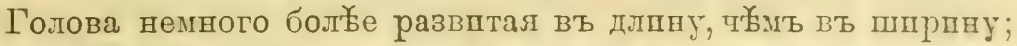
передвій отростокъ ея тонкій, длпнный, боговые отростлш толстые, довольно коротніе, слабо расходящіеся, вершины шхъ заостренныя, вн安шній край нөвооруженный; предглазнпчные бугоркп мало выдающіеся, тупые; впсочные отростип тупые, мало выдающіеся, такъ что голова позади глазъ сразу п постепенно съужпвающаяся; на поверхностп головы у основанія дв сходящілся подъ угломь гладкія, блестящія лпніп жөлтоватаго цвитта.

Успкп длпнные, чөрнаго пв бтта, тонкіе; первый члеппк шхь коротко-овальный, второї пленшкь короче головы, оть вершины къ основанію постепенно и равномұрно утончалопійсг, у самаго основанія слегка головтато-утолпенныі, третій гленшиъ почтп вдвое короче второго, тетверый на $1 / 4$ гороче третьяго.

Хоботокъ доходить до ляшекъ перөднпхъ ногъ.

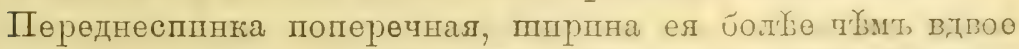
превышаеть длпну; задній краї ея шпрого выемчатий, боловые грая мелко зазубренные, загнутые вцерхъ, буроватые, погупрозрачные, къ верппне

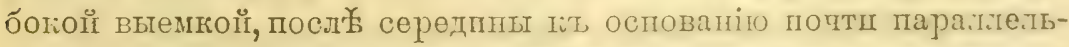

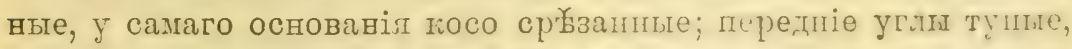

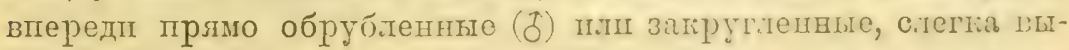
дающіесл впередъ (ㅇ); пплп переднесппки: боловые париі-

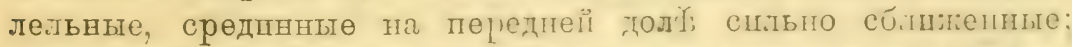
поверхность перетвеспини у освовапія поперетио-морцинистая.

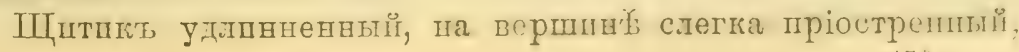


боловте zipusr сго спльно прпподнятые, поверхность у осно-

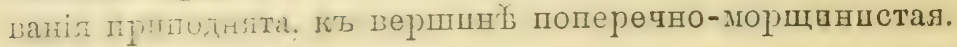

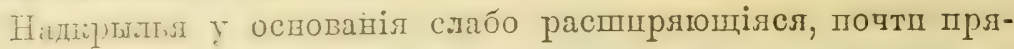

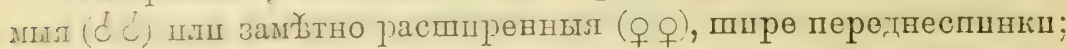

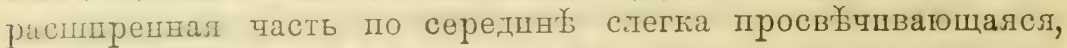

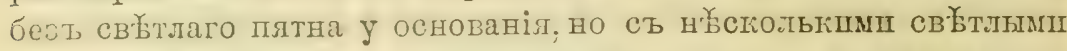
поперечнымп жплгали; membrana бурая, жишп ея окаймлены свҰтлымш, прозрачными полосамг.

Ногп бурыя.

J.

․․ Пестої бргшної сегмент'ь гораздо длшнние пятаго, боговыя лопастд его слегка выдающіяея за уровень боко-

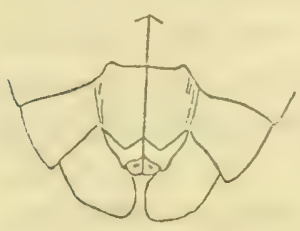

Pne. 77. - Стеріниті бpromia VI-VIII. Aradus laeviresculus Reut. $O$ (p世c.

O. M. Reuter'a). выхъ краевъ лопастей седьмого сег: мента II доходять до уровня вершшны восьмого сегмента; седьмої сегменть

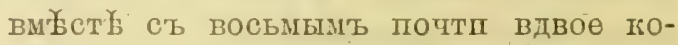
роче шестого сегмента, боковыл лопасті седьмого сегмента съ внутренпнмп кралми пирого разставлевнымш, затругленши, боковые црал пхъ образують очень тупої, мало выдающійся угольь.

ठ. Ллшна - 5,3-5,6 мшлл., шшрпна надкрылій у основанія 2 милл.

ㅇ. Длина - 5,6-6 мплл., шпрпна надкрылії у основанія 2,5 피.

Сравнительныя замьтни. Arachus lacriusculus Revт. хорошо отлпчается оть всбохъ видовъ группы короткшм хоботкомь, не дохотпщи до основаніл перетнегруди, строеніемъ передне-

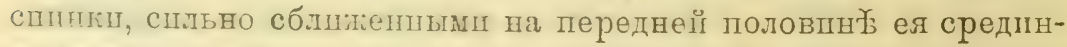

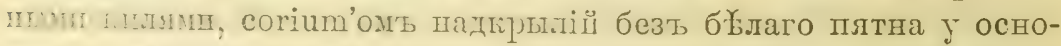

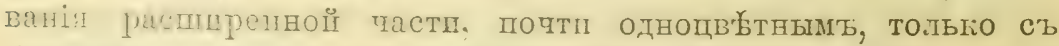
буроватымп попереqнымп жилкамп II др. прнзнакамп.

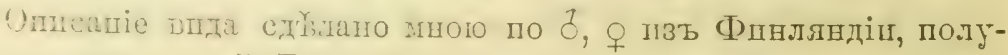

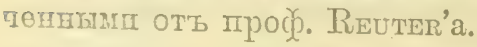

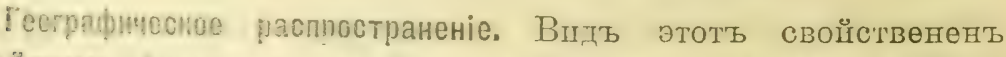

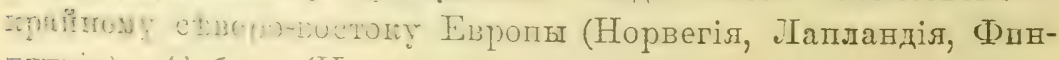

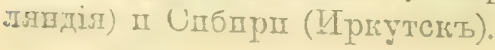


Образъ жизни. J. SAнLberG нашелъ этотъ вшлъ на Abies excelsa.

Aradus laeviusculus f. simillimus REUT. 1875.

Aradus simillimus Reur. Not. Sällsk. Faun. Fl. fenn. fürh., XIV, 1875, p. 329; Ent. Tidskr., 1882, p. 107; Wien. Ent. Zeit., 1884, p. 134.

Aradus lacriusculus v. simillimus Revт. Medd. Soc. pro Faun. Fl. Fenn., h. 206, 1900, p. 136.

\section{Фауппетпеская лптература, касающаяся Россіп.}

Aradus simillimus REUT. loc. cit., 1875, p. 329 (Fennia).

Aradus laevinsculus var. simillimus Rect. loc. cit., 1900, p. 139 (Eennia: Inari).

Діагнозъ. Pronotum longitudine sua saltem $22_{3}^{1 / 3}$ latius, lateribus medio sat fortiter rotundato-ampliatis, basin rersus distincte conrergentibus et rotundatis. Corium feminae margino exteriore sat dilatato. Caput tuberculo anteoculari minutissimo, obsoleto instructum.

Описаніе. Боковые грая переднеспшнгп спьно расшпренные, округленные, жзади схолящіесл, вакругенные; переднеспнка спльно поперечнал, пприна ея почти въ $21 \frac{2}{2}$ раза пире длпны. Бокової краї надкрылій у основанія заме́̆тно расшпревь (). Предглазнпчные бугоргп очень небольшіе, неявственвые.

Сравнителькыя замьтки. Разновп,тность әта отличается оть основної формы

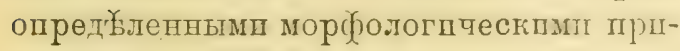
внакамп, дающпмп возможность легко отлпчать объ этщ форормы. Тапсономпческое знаденіе пхь соверненно неясно, тап, макт извтстно

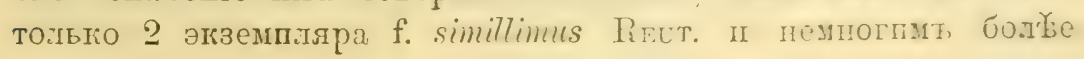
основної формы.

Географическое распространеніе. ВетрҮппется Въ СЪв. Россіи: Фпнляндіп п Вологодск. губ.

\section{Aradus dissors n. sp.}

(Табл. II, (үиг, 23).

Экземпляры Зоологическаго Музея.

Vladivostok. 28. V. 1909 (ð゙, ᄋ). Berger. 
Дiarн03ъ. Oralis, fusco-niger, marginibus posterioribus segmentorum connexivi, macula basali partis dilatatae hemelytrorum pallidis.

Caput latitudine sua vix longius; prolongatione antica sat brevi, crassa, a basi apicen rersus angustata; lobis lateralibus sat breTibus, crassis, dirergentibus, apice acuminatis, margine exteriore muticis; tuberculis anteocularibus obsoletis; lobis temporalibus obtusis, vix prominentıbus; capite pone oculos sensim angustato, postice basin versus linea semicirculari, laevi, callosa, flavicante praedito.

Antennae longae, tenues, dense granulatae, nigrae; articulo secundo capite breviore, quam articuli tertius et quartus simul sumpti longiore, apicem rersus sensim et regulariter incrassato, ima basi rix capitulato incrassato, basi quam apice paullo tenuiore, articulo tertio secundo duplo et dimidio breviore, articulo quarto tertio aequilongo.

Rostrum basin prosterni attingens.

Pronotum capite brevius, magis quam duplo longitudine sua latius; margine postico late et leviter sinuato, margine antico inter angulos sinuato, marginibus lateralibus postice subtiliter crenulatis, rotundatis, l,asin versus parum angustatis, antice distincte subtiliter denticulatis, late et profunde sinuatis, apicem versus fortiter angustatis; angulis anterioribus leviter prominulis, obtusis, apice rotunlatis; carinis deplanatis, obliteratis, subparallelis.

Scutellum elongatum, apice acuminatum; marginibus lateralibus eleratis, post medium leriter sinuatis, disco basi convexo.

Hemelytra basi parum dilatata; macula basali partis dilatatae hemelytrorum et interstitio inter costas corii sordide fusco-albidis; costis carinato-eleratis; membrana nigra, renis hyalino-cingulatis.

Pedes nigri, femoribus apice fuscis.

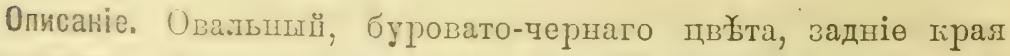
брппндхь сегментовт на connехіvй'љ, плтно у основаніл

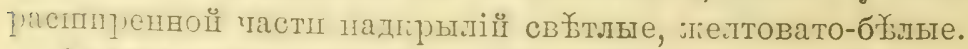

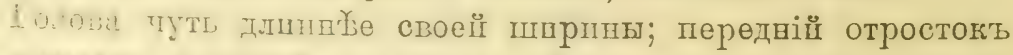

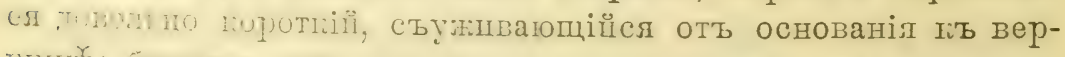

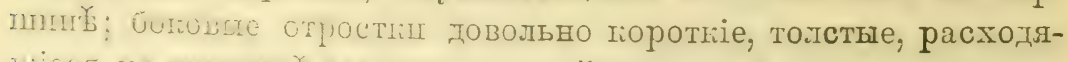

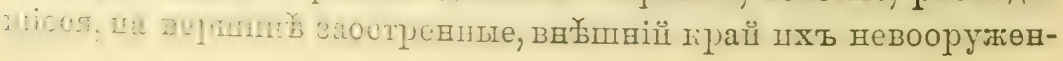


ный, предглазнпчные бугоркп нелвственные; височные отростип тупые, мало выступаюіе, ташь что голова позади глазъ сүазу постепенно съужшвающаяся; на поверхностп головы у основанія полукруглая, блестящая, гладкая лшнія ліелтоватаго цвйта.

У сикц длшные, тонкіе, густо уе孔янные довольно выдаюццмисл бугоркамп чернаго цвйта; первыц qленшкъ пхь короткоовальный, второй членшкъ короче головы, длинн神 третьлго п четвертаго взятыхъ вмбетет, оть вершины къ основанію постепенно I равномҺарно съужнваюційся, у самаго основанія незначительно головчато-утолщенныи, $\mathrm{y}$ основанія немногимъ

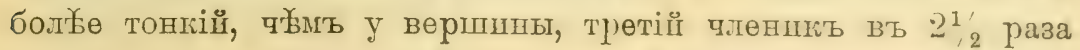
короче второго, четвертыі одинаково і⿱ длпны съ третьшм.

Хоботокъ доходптъ до основанія переднегрудп.

Переднеспнка короче головы, поперечная, болье чйм вдвое шпре своеї длпны; задній край ел ппроко и слабо выемчатыи, пөредній между шейнымп угламп съ выемкой, боковыө грая позадп мөлюо-зазубренные, закругленные, гъ основанію слабо съужпваюшіеся, впередш съ замүтным зубппамп, съ широгой ш глубокой выемкої, спльно съулшвающіеся къ верпинж; передніө углы слегка продвпнутые впеједє, тупые, на вершпнљ, округленные; кили пөреднеспинкп очень плоскіе, стөртые, параллельные.

Щатшкъ удлинненвыи, къ вершшн各 пріостренныи; боковые жрая прпподнятые, у вершпны сь небольшой выемкоі; поверхность пцтика у основанія приподнятая.

Надкрыля у основанія слабо расширенныя, пятно у задняго края расширенвої частп п пространство менду жилками со-

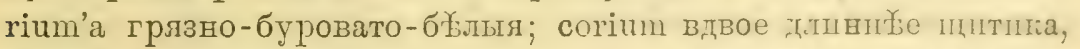
жшлки его спльно выпуклыя; membrina черная, простравства вокругъ жилокъ бұловатыя, полупрозрачныя.

Ноги черныя, вершпны бедеръ бурыя.

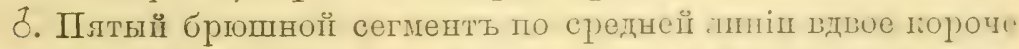

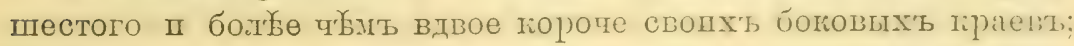
боковыя лопасти пятаго сегмента едва выданціясл за уронен,

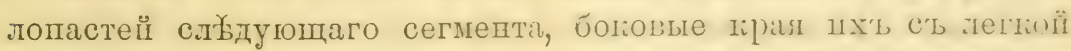
выемкой, боғовыя лопасти шестого сегмента по внутеннему

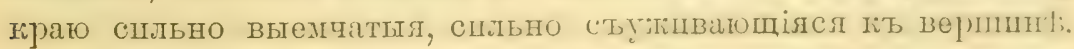

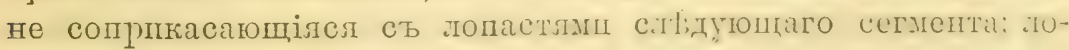

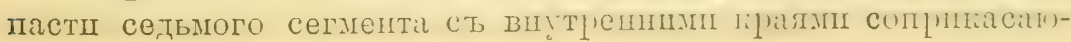




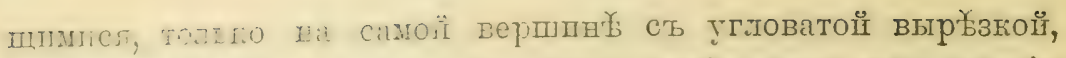

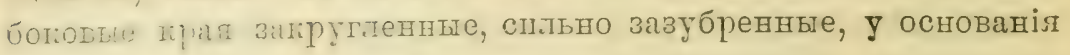
съ выдатоппмя бугоркомъ.

q. Iлтліi úpromiо сегленть по среднеї линіп слегћа дыпнHt: пестого, его заднії дірай выемчатый; шестої сегментъ отинатовой длпны сь седьмым, днскондальная часть его спльно поперетнал, боғовыя лопастп не достигають уровня верппны восьмого сегмента, боковые тірал пхъ съ легкой выемкой, вершинные углы слегка тупые, выдапшіесл за уровень лопастепі слџдующаго сегмента, боковыя попасті седьмого сегмевта съ внутренншмп краямп закругіенным, разставленнымп, боковые грая пхъ съ значптельновыдаюшимя бугоркомъ передъ серединой Іі выемкої пост⿱宀㠯 нея.

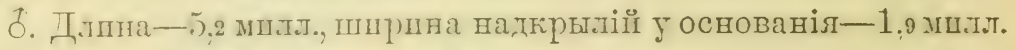

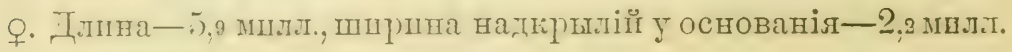

Сравнительныя замьтки. Этотъ новыї вшдъ прпнадле:птъ къ тому подраздоленію группы A. Tugubris FALL, жоторая характе-

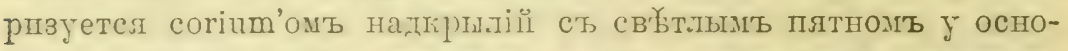
ванія расширенной тасти пхь, вторымъ пленикомь усшковъ оть вершины то самаго основанія равномерно утончаюшагосл; оть твухъ вшдовь стог относлшшхсл: A. limaculatus Reuт. I

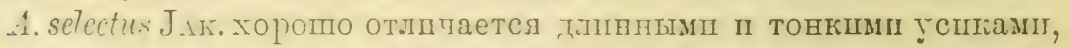

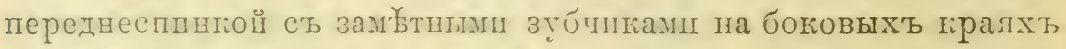

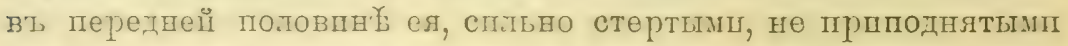
кшлямп переднеспинкл.

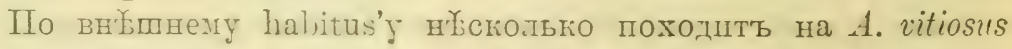

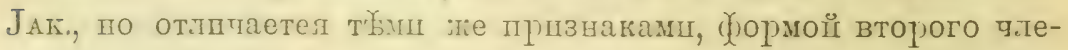
внка успновъ. Ближо всего $A$. dissors стоштъ къ виду $A$. angularis J. SAнLв, въ особенностп по строенію переднеспинит;

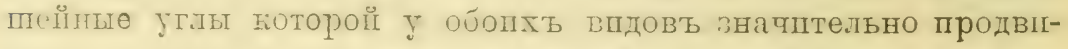
нуты впередъ ц по длпннымъ, тонкпмь успиамъ, но у $A$. ange-

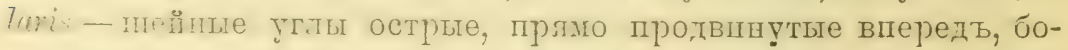

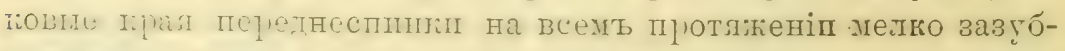

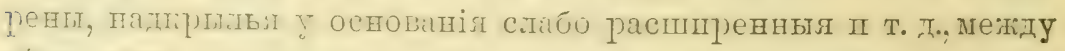

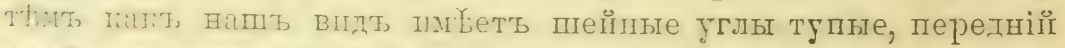

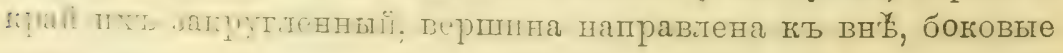
прая переднеспшнш впереди сь явственнымп мелкпмп зубттіамп, надерыльл у основанія довольно спльно расширены II T. I. 
Географическое распространеніе. A. dissors пвв только пвъ Южно-Уссурійскаго грая, гд⿱⺊口了 онъ наїгенъ въ окрестностяхъ Владпвостока.

\section{Aradus bimaculatus Revr. 1872.}

(Табл. II, фориг, 26).

Aradus bimaculatus Reur. Öfr. af Kongl. Vetensk.-Akad. Förhandl., 1872, 치, 5 , p. 58; Entom. Tidskr., 1882, p. 76 et 106; Wien. Ent. Zeit., 1884, p. 135̄; Medd. Soc. Faun. Fl. Fenn., h. 26, 1900, p. 135.

\section{Экземпляры Зоологическаго Музея.}

Gub. Char'kov: Kupjansk (우). Ivswov.

Діагнозъ. Ovalis, sat latiusculus, fusco-niger, marginibus posticis segmentorum connexivi, basi partis dilatatae hemelytrorum, venulis transversis corii sordide flavescenti-albidis, marginibus posticis pronoti prope angulos humerales carinisque postice flavescentibus.

Caput latitudini suae aequilongum; prolongatione antica longa, sat crassa; lobis lateralibus brevibus sat crassis, acuminatis, margine exteriore tuberculo parvulo instructis; tuberculis anteocularibus obsoletis; lobis temporalibus parvis, ultra oculos parum prominentibus; caput pone oculos sensim angustatum, postice basin versus lineis duabus laevibus, callosis, angulariter convergentibus, flavis instructum.

Antennae nigrae, dimidio basali articuli secundi fusco, art:culo secundo quam caput breviore et quam articulus tertius duplo longiore, apicem versus sensim et regulariter incrissato, articulo tertio et quarto simul sumptis socundo aequilongis, articulo tertio quarto fere aequilongo.

Rostrum basin prosterni vix superans.

Pronotum longitudine sua duplo latius, margine postico leviter sinuato, marginibus lateralibus minuto crenulatis, antico profunde sinuatis, apicem versus fortiter ancustatis, postice rotundatis; angulis anterioribus obtusis, apice recte truncatis; carinis intermediis medio approximatis, basin rersus leviter divergentibus, carinis lateralibus subparallelis.

Scutellum elongatum, sat latum, apico rotundatum; marginibus lateralibus rotundatis, elevatis, ferrugineis. 
Hemelytra basi paullo dilitata; membrana albida, fusco-maculata. Peles ferrugineo-fusci, femoribus obscurioribus, apice flavescentibus

Описаніе. ()альныі, буровато-чернаго дв年та, вадніе края сегментовъ connexivum'a бҺловато-жіелтые, основаніе расшшренногі части надкрылій ст больпим бұлым пятном съ калдой стороны, поперечныя інилки согіum'а грязно-лгелтовато-

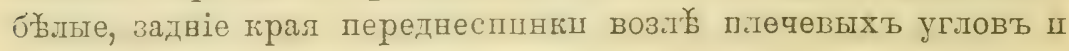
основанія килей ея - желтоватые.

Голова одинаково развитал въ длшну и ширнну, передніи отростокь ел длинный, довольно толстый, боговые отростки поротғіе, довольно пшрокіе, заостренные, на вночшнемь краю вооруженные небольшия бугоркомъ, предглазниные бугоркц незначительные, височные отростиі небольшіе, слегка выдаются ва глазами; голова позади глаз иостепени съужшвающаяся,

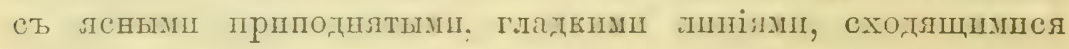
подъ угломъ, жнелтоватаго двътта.

У спкі чернаго цвита, толыо основная половнна второго

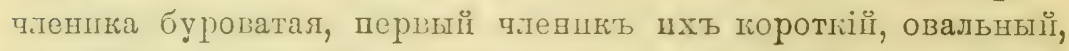
второй членпкь короче голишы, вдвое длиннъе третьяго ІІ равень третьему и четвертому взятымъ гмъст夕, у основанія

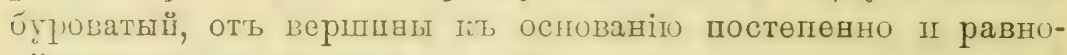

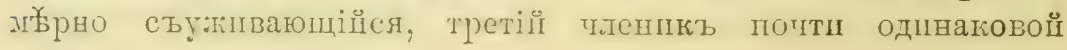
длины съ чөтвертымъ.

Хоботокъ чуть заходитъ за основаніе переднегруди.

ПІереднеспина вт диза раза шире своей длины, задній край ел слегка выемчатый, боговые грал сіабо зазубренные, вперети

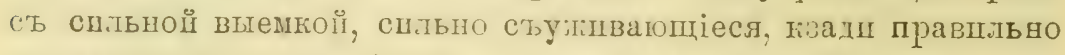

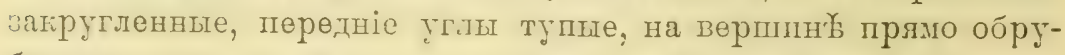

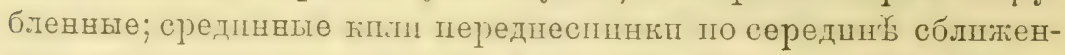
пые. гт основанію слегіа расходящіеся, боговые кшли почти

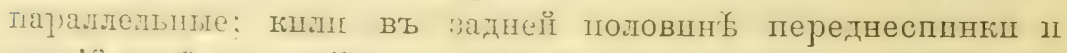

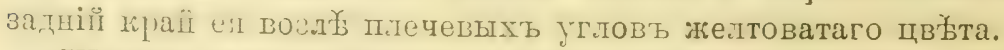

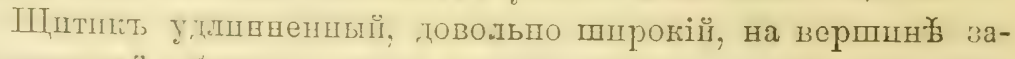

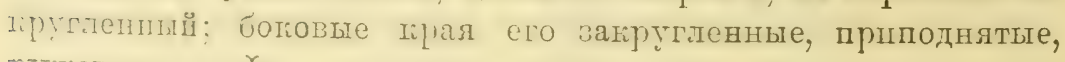

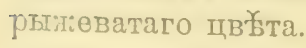

Надкрыля у основанія незначптельно расппренныл, со-

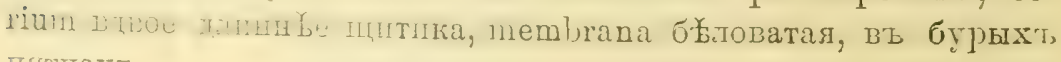
пรгтахъ. 
Ногп рыжевато-бурыя, бедра, псклюгая пхь верпшет, темн安е.

ઈ. Непввъстенъ.

‥ Пятый брюшної сөгменть слегша длинеке пестого, пе-

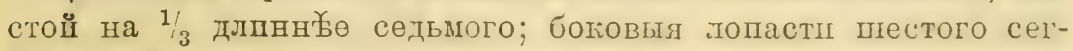
мента доходять до уровня седьмого сегмента, задніе угіы шхъ тупые, не выступаюіе ва краї лопастей слйдующаго сегмента; боговыя лопастп седьмого сегмента съ внутренними краямп широко разставлөнными, закругленнымш, огаймленнымп желтымь, боковые грая вагругленные.

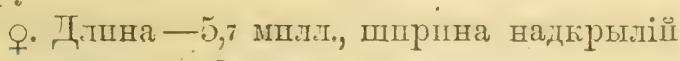
у основанія - 2 милл.

Сравнительныя замьтни, Видъ этотъ относптся къ тому подраздеј ленію группы

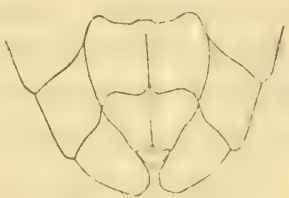

Рцс. 79. - Стернити брюшка VI-VIII. Aradus bimaculatus Reut. 오 (пзъ Харьновской губ.: Кушлиска).

A. lugubris FAlL., corium надгрыліці которыхь у основанія pacширенної части съ бълымъ плтномъ, отъ др. видовъ, пмүющихъ такое же пятно, отлпчается вторнмъ членикомь усшовъ

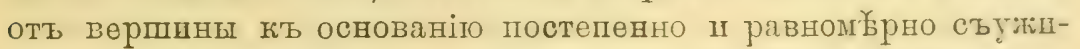
вающпмся, прямо обрубленными впередш шейнымп углами, бо-

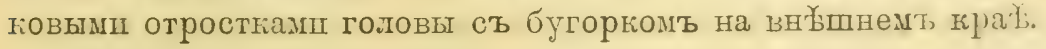

Географическое распространеніе. Вшдъ этоть быль изв Ұстенъ

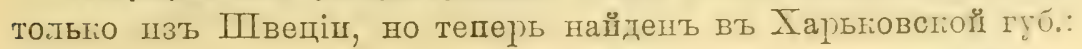
Купянскь.

48. Aradus selectus $J_{A K} .1878$.

Aradus selectus JAK. Bull. Soc. Nat. Mosc., 1878, 1, p. 132.

Фаунистиеская литература, касающаяся Россін,

Aradus selectus $\mathrm{J}_{\mathrm{AK}}$. 1oc. cit., p. 132. 1878. (Sarepta).

\section{Экземпляры Зоологическаго Музея.}

Gub. Saratov: Sarepta. (3 f).

Gub. Saratov: Sarepta. 5. IV. 1865. (Q). ("Aradus sareptanus" JAK. det.).

Gub. Charkov: Kupjansk. (Q). ("dradus sareptanus" JAK, det.).

Sine datis. (ㅇ).

Діагнозъ. Ovalis, fuscus, marginibus posticis segmentorum cunnexiri, macula basali partis dilatatae corii, claro medio, renulis 
transtari: inter costas corii carinisque pronoti in parte posteriore - flarescenti-albidis.

Caput longitudini suae aequilatum; prolongatione antica sat lrevi, tumidiuscula, lobis lateralibus longis, acuminatis, parum divergentibus, margine exteriore muticis; tuberculis anteocularibus distinctis, obtusis.

Antennae longae, sat crassiusculae, nigricantes, articulo secundo capite breviore et quam articulus tertius duplo et dimidio longiore, apicem rersus sensim et regulariter incrassato; articulo tertio quarto vix longiore.

Rostrum basin prosterni vix superans.

Pronotum longitudine sua duplo et dimidio latius, margine postico leviter sinuato, marginibus lateralibus vix crenulatis, antice sat profunde et late sinuatis, apicem versus fortiter angustatis, postice basin versus rotundatis, convergentibus; angulis anticis obtusis, rotundatis, rix prominulis; carinis aequaliter distantibus, subparallelis, carinis postice nec non callis humeralibus et margine pronoti prope his sordide flavescentibus.

Scutellum sat latum, marginibus lateralibus rotundatis, parum eleratis.

Hemelytra basi paullo dilatata; claro basi et medio, corio basi fere nigris, costis maculisque inter costas corii fuscis, macula basali partis dilatatae corii, maculis parvis, venulis transTersis sordile-albidis; membrana albida, n̂sco-maculata.

Oписаніе. Овальныї, б́раго цвъта, задніе жрая брюпныхъ

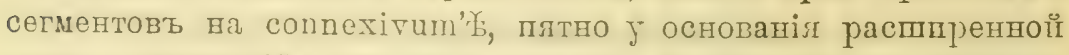
части налтрыній, серетина clavus'a II поперетныл полоски

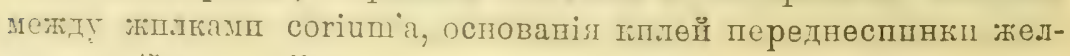
товато-бъдаго цвељта.

Голова одпнағово раздптал въ, динуу п въ ппрпну; передній

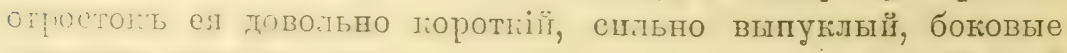
отростки жиннне, острпе, стабо расходяшіеся, внбиній жрай

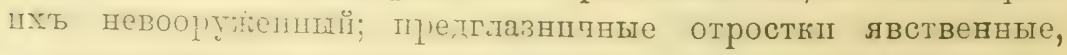
прштупленны $ө$.

у сши длшнные, довольно толстые, буровато-черноватаго

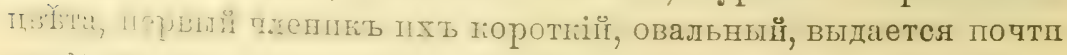
на 1/2 за верпшну боговыхъ отростковъ головы, второй чле-

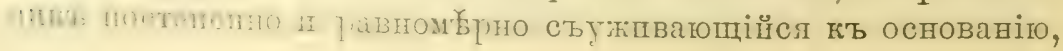


короче головы пा въ $2 \frac{1}{2}$ раза дишнеһе третьяго членшпа, третії членшкъ слегка длиннебе четвертаго.

Хоботокь слегка заходнть за основаніө перөднегруди.

Переднеспнка въ 221/2 раза пире своеї длины, гпереди снльно съултвающаяся; задвіч край ел съ легкой вшемтой, боговые грая слабо зазубренные, впереди съ широгой ц довольно глубокой выемкой, жзаді закругленные, слабо сходящіеся; передніе углы тупоугольно-окруленные, чуть продвинутые впередъ; пшли переднеспнни равно-отстоящіе, почти паралтельные, задняя половпна пхъ, также кань вздутія лөпащіл

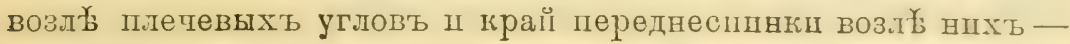
грявно-желтоватаго цво्бта.

Щштикъ довольво шпрогіiі, боговые грал его выгнутые, елабо пршподнятые, вершпна его закругленная.

Надкрылья у основанія слабо расширенныя, corium вдвое

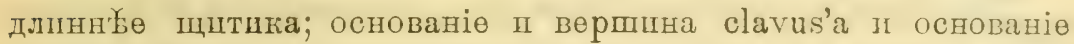

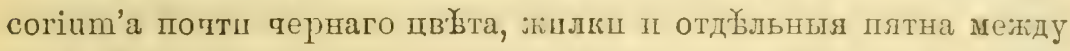
нимп бурыя, пятно у основанія распшренной части согіum'a

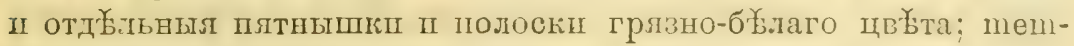
brana бұлая, съ бурымш пятнамш.

๖. Невзвъютенъ.

‥ Плтый бргшної сегменть едва дллннҮе шестого, шестоі сегментт одшнаковой длшны съ сегьмымъ; боковыя лопасти седьоого сегмента почтп продольно поставленныя, боновые края пхъ закругленные, съ едва выдаюцимся угломъ у основанія, внутренніе крал закругленные, разставленные, огайленные жегтымъ.

ㅇ. ПЛлнна $-4,8-6$ мшлл., ширдна надкрыліці у основанія - $1,6-2,4$ мшлл.

Сравнительныя замьтки. Вицъ этотъ бо-

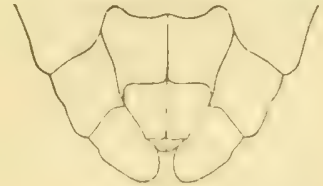

Pirc. 80. - Стернить бртопка VI-VIII. Aratus

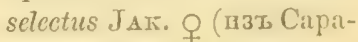

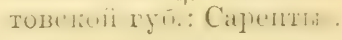
ль্ье всего походшть на Aradus bimacu-

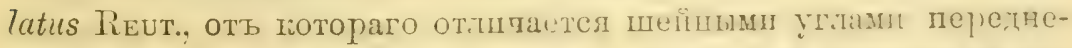
спинка впереди затругленным (q), йловыми отростками го-

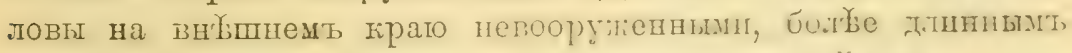

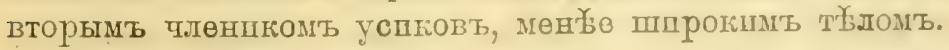

Оть A. sordidus Horv., на жотораго нөмного походить ио

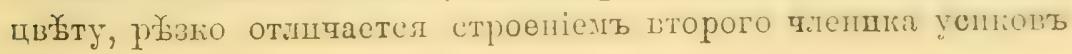




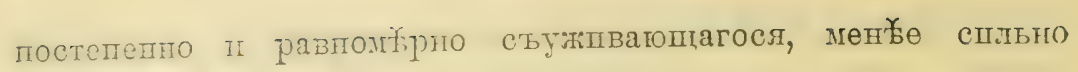
бугортатаго.

географическое распространеніе. Оппсанъ В. Е. Ятовлевымь пзъ Вост. Россіп: Сарепты.

49. Aradus sareptanus $\mathrm{J}_{\mathrm{AK}}$. 1874.

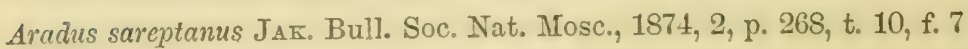

Фаупнстическая литература, гасающаяея Россін.

Aradus sareptanus $\mathrm{J}_{\triangle \mathrm{AK}}$ loc. cit., p. 268. 1874. (Sarepta).

\section{Экземпляры Зоологичеснаго музея.}

Sarepta. $\left(\sigma^{\top}\right)$.

Въроятно $=A$. selectus $\mathrm{J}_{\text {Aк. }}$.

Экіземптярь Aradus sureptanus JAк., послуіпввпіи B. E. Ino-

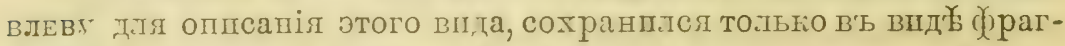
мента, лишеннаго успюове, бргока, половпны надпрылії ш нө

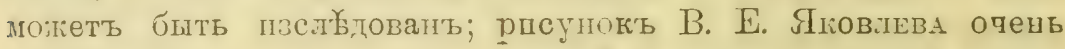

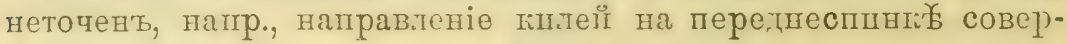
пенно нев брно.

Въ сохранившемся ойломю官 л не могу наїті какихъ апо́о

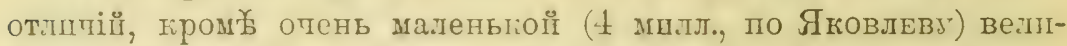

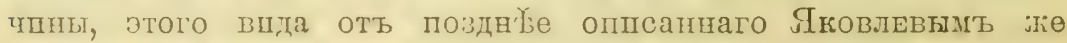
Aradus selectus $J_{A K}$.

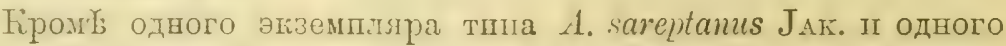

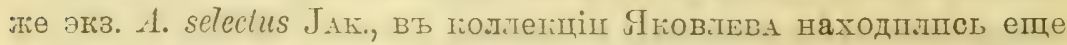
2 зкз. перваго вшда ил 3 экз. второго. Эти два экземпляра "A. sareptamus $J_{\text {Aг. }}$ " соверпенно пе отличпмы отъ типа $A$. se-

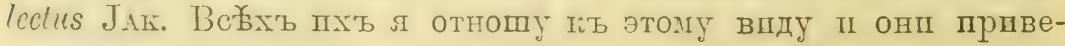
дены выпе.

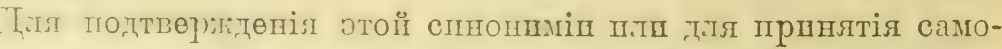

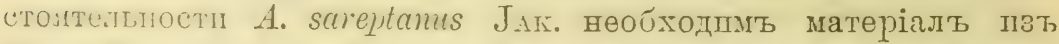

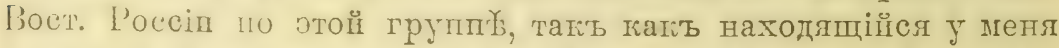
матеріаль недостаточен'ь ш, жром⿱宀㠯夕㔾 того, прайнө плохой сохранности.

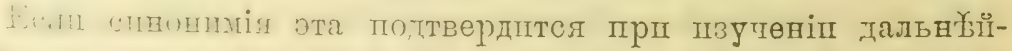

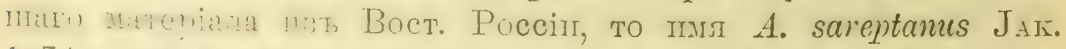

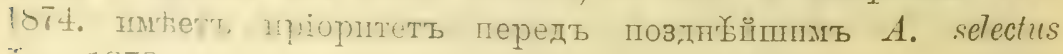
JAR. 1878. 


\section{Aradus sordidus Horv. 1874.}

Aradus sordidus Honv. Berl. Ent. Zeit., 1871, p. 335.-Rect. Wien. Ent. Zeit., 1881, p. 135.

Дiагнозъ. Oblongo-ovalis, nigricanti-fuscus, marginibus posterioribus segmentorum connexivi, macula basali partis dilatatae corii sordide flavescenti-albidis, costis et venulis transversis ferrugineis.

Caput latitudini suae aequilongum, prolongatione antica brevi, lobis lateralibus longis, acutis, fortiter divergentibus, margino exteriore muticis; tuberculis anteocularibus validis, obtusis; lobis temporalibus obtusis, haud prominentibus, capite pone oculos sensim angustato, postice basin versus lineis duabus laevibus, callosis, angulariter convergentibus, flarescentibus praedito.

Antennae sat tenues, longae, dense granulatae, nigrae; articulo secundo capite breviore, quam articulus tertius duplo et dimidio longiore, ab apice in parte $1 / \frac{1}{4}$ longitudinis suae fortiter sensim gracilescente, dein paullo angustato, in dimidio basali fere cylindrico, basi ima capitulato incrassato; articulo tertio apice quam articulus secundus crassiore, articulo quarto tertio vix breviore.

Rostrum medium mesosterni attingens.

Pronotum transversum, longitudine sua duplo et dimidio latius; margine postico late et leviter sinuato, marginibus lateralibus crenulatis, postice late rotundatis, antice profunde sinuatis; angulis anticis obtusangulariter rotundatis, vix prominulis; carinis discoidalibus intermediis antice vix convergentibus, lateralibus parallelis, carinis omnibus basin versus marginibusque circa angulos posticos flavescentibus.

Scutellum angustum, longum; marginibus lateralibus oleratis, medio humilioribus; disco basi convexo, apice transcersim ruculosum.

Hemelytra basi paullo dilatata, apicom versus angustatu, sordide flavescenti-albida; clavo, macula mediana excepta, corio basi et apice nigris, costis et venulis transversis ferrugineis; membrana albida, maculis nonnullis magnis fuscis pracdita.

Inferne nigro-fuscus, marginihus posticis segmentorum connexivi flavo-albidis, lateribus linca albida nitida praelitus.

Pedes fusci, femoribus olscurioribus, apico pallide flarescentibus. 
C. Lolis latcralus segmenti rentralis sexti ad lobos segmenti nitini wice approximati; marginibus interioribus approximatis, flato-limbatis.

o. Segmentum rentrale quintun margine apicali lateribus bisinuato; segmentum sextum quinto fere in $1 / 3$ brevius, lobis lateralibus apicem segmenti attingentibus; segmentum septimum sexto in $1 / 3$ brevius, margine postico medio emarginato; lobis lateralibus segmenti septimi marginibus interioribus flaro-limbatis, basi contiguis, dimidio apicali leviter divergentibus, marginibus exterioribus late rotundatis.

Описаніе. Ј длпнненно овальныц̆, qерновато-бураго цв孔та, зағніе грал сегментовъ на сопnехімим'ю съ бъловатымп полосамш,

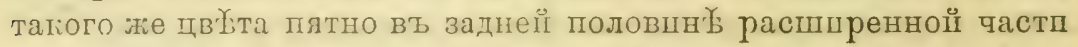
падкрылій, узкія полости п участки между жілкамш согіuт'а.

Голова одинагіово развитая въ длпну пा ширину; передні. отростокь ел довольно діроткії, боговые отростки длинные, острые, спььн расходящіесл, вн条шній край шхь невооруженныц; предглазндтые зуйцы зшаqштельные, притупленые; височные отростки тупые, не выдающіеся, такъ что голова позади

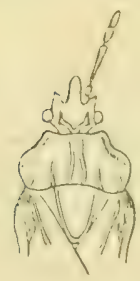

Pinc. 81.-Aradus

sordidus Horv. (IIIC, O. M. RE: $\left.T E R^{2} a\right)$. глазъ постепенно съужшвающаяся; на поверхності головы въ задней половинй подковообразное неглубокое вдавленіе, позадп котораго дв'5 косо-направленныя гладкія, блестящія ли-

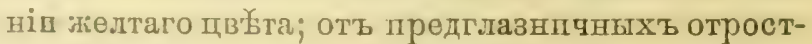
ковъ жъ височнымъ проходятъ продольныя возвыпенія, касающіяся внутренняго края глаз'ь.

У сики длинеые, довольно тонкіе, чернаго двљтта, бугортатые, сь бугоркамп спльно выдающимися; нервыи тленшкъ усиковъ-овальный, короткі. второй членикъ короче головы, въ $21 \%$ раза длцнн冬ө третьяго, оть вершпны на

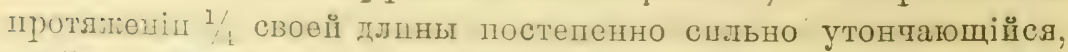

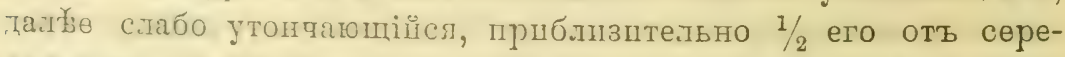

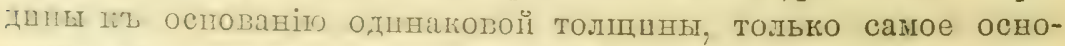

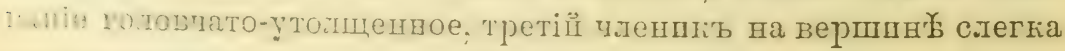
толще второго, слегіа длинн实е четвертаго.

Хоботокъ доходшть до середины среднегрудш.

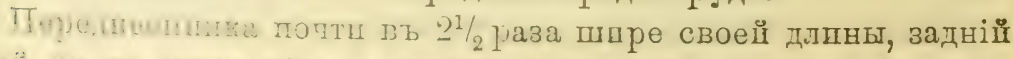

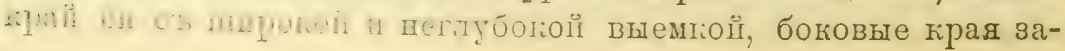


зуб́ревные, въ задней половине. широко закругление, вперөдп съ гіубокой выемкоп; передніе углы чуть продвпнтты, тупоугольно закругленные; килі перөднесппнки: средпиные впереді слегка сблпженные, боловые-параллельные, всћ кпли въ заднеї половпн реднеспшнки возль্ заднихъ угловъ ея.

Щитпь узкій, длинныц̆, боковые грая его пршподпятые, по середпв го понпленные; поверхность его у основанія притоднятая, къ вершинео्, поперечно-морщинистая.

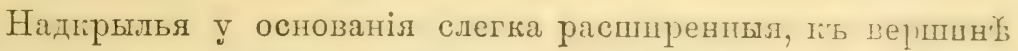

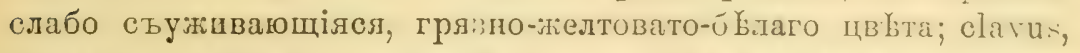
псклютая пятна по серединб, основаніе и вершнна согіица -

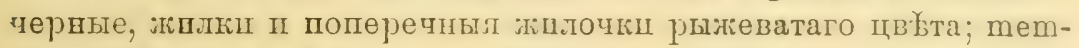
brana бълая съ нйскольншмш крупными бурымш пятнамш.

Снпзу чөрновато-бурый, верпинно прая сегментовъ ц углы ихъ свътло желтые; по ботамъ проходить бұлая и́. стящая линія.

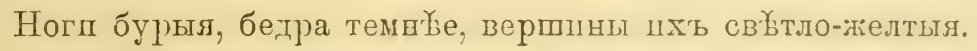

§. Боковыя лопасти шестого бргшного сегмента сильно пршблшжен къ лопастям сльдуюшаго сегмента; внутренніс прал лопастей седьмого сегмента сближениые, оғаилениые желтымъ.

ㅇ. Задвій храй пятато брюшного сегмента съ двумя выемкамп по б́окамъ; пестой сегменть почтп на $1 / 3$ іороче плтаго и слегка короте свопхъ боғовыхъ краевъ; боковыя лопасті доходятъ до вершинц сөдьмого сегмента; сепьмої сөгментъ на 1/3 короче шестого,

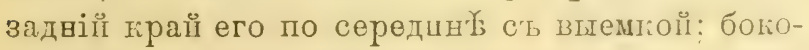
выя логасти седьмого сегмента съ внутреннимп краями окаймленвыми желтымь, у основанія соприкасающимися, ст сөредины слта́о растолящшмися, боговые грая шпроко вакругленшые; восьмой сегменть вдвое короте седьмого.
ð. Длина-5 мплл., шпрпна-2 мплл.
ㅇ. Длпна-5,3 милл.

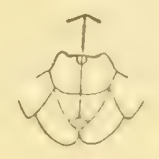

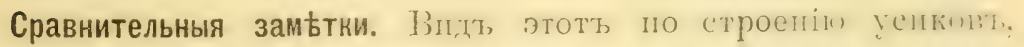

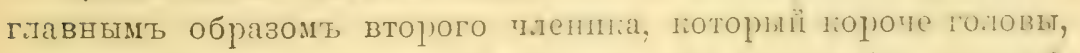

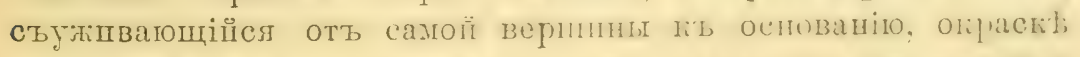

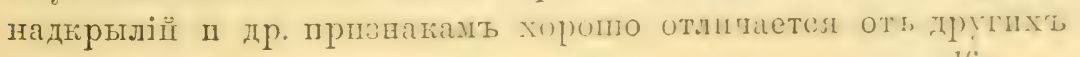

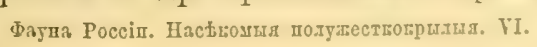

Pirc. 82.-Cтерnumb йрHonlial VI-VIII. - liadu: sordidus Honv. $\subsetneq$ (pric. O. M. ReuTER'a). 
вшдовт группд тппа 1. Tugubris. Блпле всего онъ стопть тіъ востопно-спйлспому A. vitinsus J.к., во строеніе переднеспнни

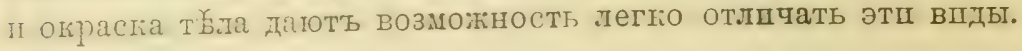

Географическое распространеніе. Видъ А. sordidus Hors.- во-

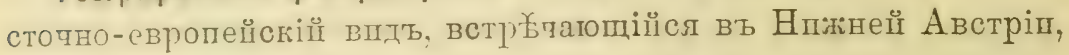
Венгріп ІІ Южной Россіш.

Въ Южнот Россіп онъ найденъ въ Херсонской губ.: Черный І官съ. 10. V. 1900. Д. Померанцевъ.

\section{Aradus vitiosus $\mathrm{J}_{\mathrm{AE}}$. 1889.}

Aradus ritiosus JAK. Hor. Soc. Ent. Ross., XXIII, p. 77. 1889.

\section{Фаушистическая литература, касающаяея Россіп.}

Aradus vitiosus JAE. loc. cit., p. 77 (Transbaicalia: fl. Shilka; fl. Amur.)。

\section{Энземпляры Зоологичеснаго Музея.}

Transbaicalia: fl. Shilka syst. fl. Amur. (O).

Prov. Amur: Raddevka in fl. Amur. (q).

Дiагнозъ. Oblongo-oralis, fusco-niger, marginibus posticis segmentorum connexiri, macula basili prartis dilatatae hemelytrorum flarescenti-albidis.

Caput latitudine sua panllo longiu:; prolongatione antica sat longa, crassa, lobis lateralibus sat crassis, brevibus, antrorsum rergentihus, apice acuninatis, margine exteriore muticis; tuberculis anteocularibus distinctis, obtusis: lobis temporalibus validis, obtusis, paullo prominentibus: capite pone oculos sensim angu*tato, postice basin rersus linea arcuata callosa, laevi praedito.

Antennae longae, sat dense granulatae, nigrae, solum articulo sccumlo medio infuscato; articulo secunclo capite breviore et quam articuli tertius et quartus simul sumti vix longiore, ab apice panllo minus quam in dimidio longitudinis suae sensim ingustato, lein fere cylindrico, basi ima vix incrassato, articulo tertio secundo fere duplo breviore, articulo quarto tertio vix breviore.

Rostrum apicem mesosterni paullo superans.

P'mutum longituline sua magis quam duplo longius; margim postico late et leriter sinuato, margine antico inter angulos profund sinuato, marcinibus lateralibus subtiliter crenulatis, portioe augulato-roundatis, basin rersus fortiter convergentibus, 
antice fortius convergentibus, profunde angulariter sinuatis: angulis apicalibus obtusis, apice rotundatis, prominulis; carinis discoidalibus elevatis, verrucosis, subparallelis.

Scutellum elongatum, sat latum (o), apice obtuso; marginibus lateralibus elevatis, disco basi convexo.

Hemelytra basi dilatata; costis corii carinato-eleratis: membrana albida, fusco maculata.

Pedes fusci, tibiis ad apicem pallidioribus.

I ignotus.

ㅇ. Segmentum ventrale quintum margine apicali recto. linea media segmenti lateribus aequilongum et quam segmentum sextum longius; segmentum sextum septimo in $1 / 4$ longius, linea mediana hujus lateribus aequilonga; segmentum septimum octaro magis quam triplo longius, lobis lateralibus segmenti septimi marginibus interioribus rotundatis, late distantibus, marginibus posticis rotundatis, medio vix angulatis,

Описаніе. Удлшнненно-овальный, буровато-черноватаго пвита,

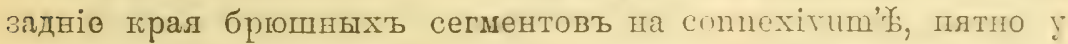

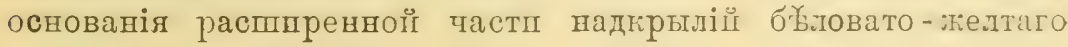
двг्क̆та.

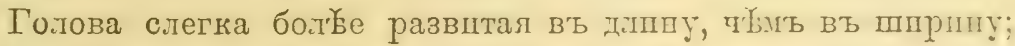
передніи отростогь ея толстыі, длиный, боловые отростіш довольно ппрокіе, лороткіе, прлмо напралленные впередт; иа

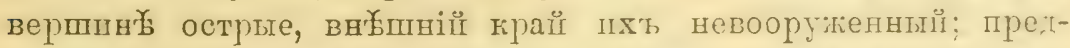
глазвпчные бүгоргіл льственные, тупые; впсочные отростіи довольно массивные, түпые, но слабо выдающіеся нарупу, таш: что голова позадп глазъ постепенио съуншвающался; иа иоверхности головы у основанія түгообразнал возвыпения, блестящая, гладкая линія.

Успки длинные, поверхность пхъ густо покршта бугор-

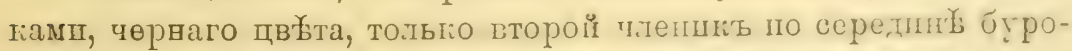

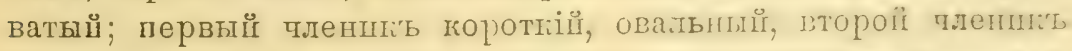

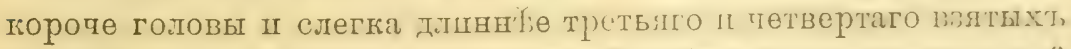

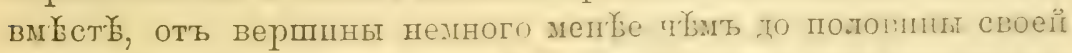

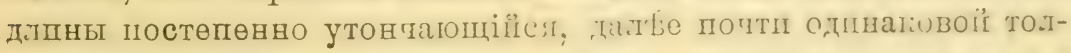
mцны на всемъ протлженіп, у самаго оспованія слегка утол-

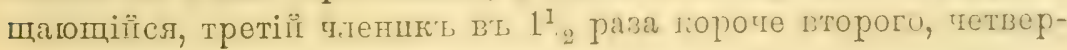
гый членикъ чуть короче третьяго.

Хоботокь немного заходпть за вершину среднегрудш. 


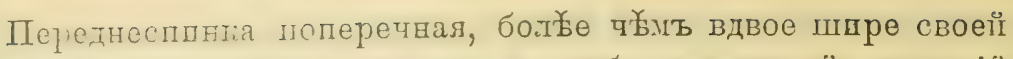

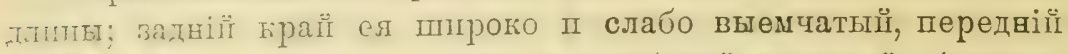
пірай мепт: шейнымп утлам сь тпубокой выемкой; боковые грая мелтіо зазуоренные, тзадп угловато-закруглонные, къ оспованіг спиьно сходящіеся, впередш болье спльно съужпвающесл, съ глубопіой үгловатой выемкой, передніе углы түпые, па вершин закругленные, продвпнутые вперөдъ; кил переднесппип прпподнятые, бугорчатые, параллельные.

Щптшкъ уллшнвенный, довольно широкії (q), на вершпн) притупленныи; боговые грал сго пршподнятые; поверхность ! основанія прпподнятая.

Надірылья у основанія расшпренныя; согіum вдвое длпннЊө щптпа, жплип на немь спльо выдающіясл, membrana бъловатая, съ бурымп пятнамп.

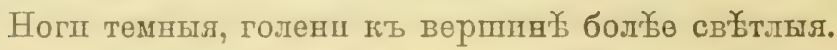

ㅇ. Задній грай пятаго б́рюпного сегмента прлмої, срединпал тинія сегмента равна и́оловымъ тіралмь его и длиннұе

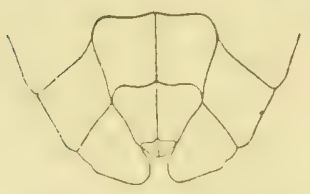

Piгc. 83. - Стернпты 5p vitiosus JAז. ㅇ (пзт Забайкальской общ.: р. Пплга, тппт). шестого сегмента, шестой сегментъ на $1{ }_{4}$ длшннъе седьмого сегмента, средняя линія его равна боковымъ граямъ; седьмой сегментъ, болье чехомъ втрое длиннеке восьмого, по середив бо боковыхъ граевь его дпскондальной части два бильихъ жіелтыхъ пятна внутренніе края боговыхъ лопастей сөдьмого сегмента затругленные, широко разставленные, задніе грая закругленные, по-

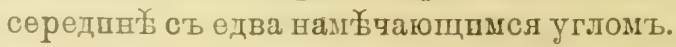

ㅇ. Плина-5,8-6,1 мплл, ширпна надкрылій у основанія2,2 мшлл.

Сравнительныя замьтии. Aradus vitiosus Jак. относится хіъ түғмь впдамт, группы A. Tugutris Fal.., у которыхъ у основанія расmщренноі части натірылій находится бұлое пятно, такь что corium ве одноцв бтто-черныи.

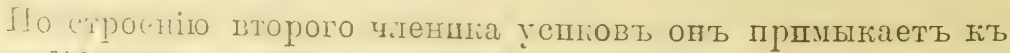

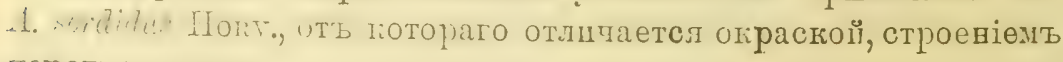
переднеспинки.

Peorpaфnчеспе распространеніе. Вшдь этоть описанъ пзъ 
Заюапюалья п Амурскої обл; найденъ онъ быль ва р. Шплиь п въ Раддевкег (на р. Амурб).

Кром того, гъ этому же виду отнопу экземп.ярт изъ Забайкальской об.л.: Шиванда, Ср’ Бтенск. окр. (3. VII. 1909. А. КіЕл-

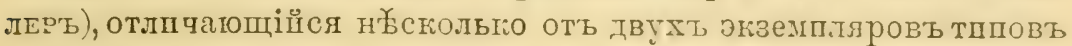
B. Е. ЯковлевА.

\section{Aradus semilacer n. sp.}

(Табл. I, фогг. 15).

\section{Экземпляры Зоологическаго Музея.}

Prov. Littoralis: Nikolsk in fl. Ussuri. 2. V. 1899 (ठる).

Дiarно3ъ. Oblongo-ovalis, angustus, niger, tibiis apiceque femorum fuscis.

Caput longitudini suas aequilatum, prolongatione antica longa, tenui, basi sat lata, apicem versus angustata, lobis lateralibus sit longis, crassiusculis, fortiter divergentibus, apice acuminatis. margine exteriore muticis; tuberculis anteocularibus validis, acntis; lobis temporalibus obtusis, distincte prominentibus: capite pone oculos sensim angustato, basi lineis durbus, callosis, lilevibus, angulatim convergentibus, pallidis praedito. Oculi valde exserti.

Antennae longae, graciles, nigrae; articulo secundo al) apice basin versus in $1 / 3$ longitudinis sua sensim angustato, dein cylindrico, ina basi capitulato incrassato, quam calut lrevine et quam articuli tertius et quartus sinul sumti paull, lungiore. articulo tertio secundo in $1 / 3$ breviore, hoc crassiore, articulo quarto tertio in $1 / 3$ breviore.

Rostrum medium prosterni attingens.

Pronotum longitudine sua duplo latius: quam hemelytra quoque latius, margine postico late sinuato, margine antico inter angulos profunde sinuatu, marginibus lateralibus crenulatis, lintiter angulato-rotundatis, ampliatis, antice late et profunde sinuatis, fortiter angustatis; post menlinm mulice angu-tatic: anghlis anterioribus prominentibus, obtusis. alpice rotunditis: callinisralde eleratis, verrucosis, sublarallelis, intermentio alpice matgis alproximatis.

Scutellum elongatum, ancustum; marginilus altissime eloratis. 
Hemurta lasi late dilatata, coriu unicolore, costis carinatoeleratis; membrana nigra.

Connexisun totum nigrum; angulis apicalibus segmentorum rentralium secundi tertique haud prominentibus, segmenti quarti fillum prominenti, segmente quinti valde prominente, angulum fere rectum formante.

ð. Segmentum quintum ventrale sexto vix brevius, segmentum sextum marginilus lateralibus suis brevius: lobi laterales segmenti sexti apice rotuntati, marginibus interioribus a lobis segmenti septimi value distantilus; lobis lateralibus segmenti septimi longis, vix transrersis, marginibus interioribus divergentibus, pilum rotundatis, marginibu- lateralibus subrotundatis.

o ignota.

Описаніе. Ј длинненный, совершенно чернаго цвъта, только вершины бөдеръ п голени бурыя.

Голюва одинаково развптая в’ь ллпну п тприну; переднії отростокь ея длиный, товольно тонкіи, у основанія расширенный, боговые отростіл довольно длпнные, спльно расходяпіесл, самая вершина пхъ :аостреннал, вно̛̆тній трай невоорүженыи; претглазичние бугорти большіе, слегка заостренные, вшсочные отростғи мало выдающіеся, такъ что голова позадп глазь сразу постепенно стужпваюпяся, на поверхності головт у основанія двЖ сходящіяся подт угломъ, глағкія, блестящія линіп желтоватаго цвътта.

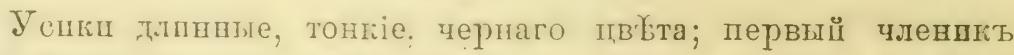
пхт поротто-оватьний, второй членшћ оть вершины на про-

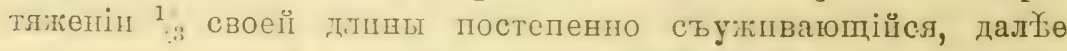
поттп о,тинанової толпшны въ остальной своей части, псключая самаго основанія - головчато утолщеннаго, короче головы п немного дыцннъе третьяго І четвертаго взятыхъ вмбеть, третіи

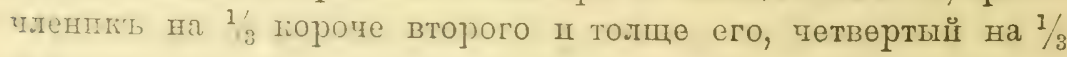
короче третьяго.

Хоботокь доходить до середшны переднегрудп.

Перлдеспина вдвое шире своей длины п пире надкрылій

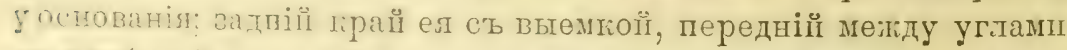

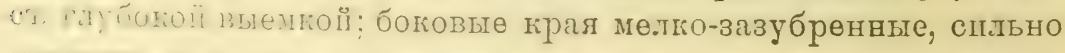

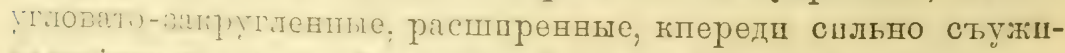

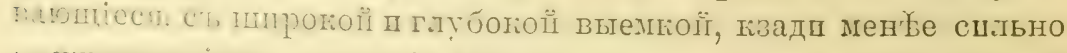

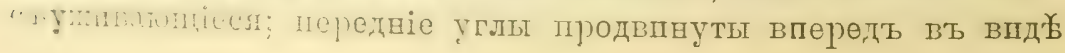




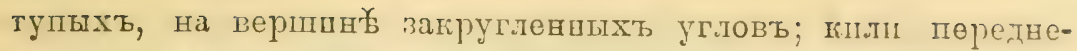
спинп спльо прпподнятые, бугорчатые, параллелыне. сре-

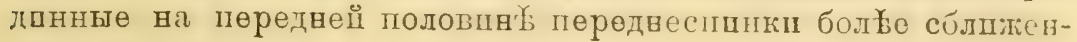
अ

Щитакъ узкій, удлинненныи; боковне грат его спльныйпимъ образомъ прнподнятые.

Надкрылья у основанія широго расширенныя; corium вдвое

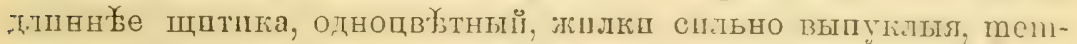
brana чернал.

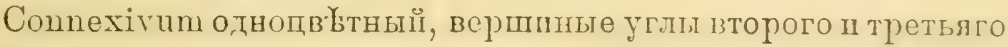
брипныхь сегментивъ соверпенно невыдающіеся, четвертаго едва выдапщіеся, углы пятаго - спльно вцдающісся, въ впде почти прлмыхъ угловъ съ скошенной вершцной.

Ногп черныл, голени и вершины бедеръ бурыл.

‡. Плтый бргшной сегменй слегка короче шестого, шсстой короче свопхъ боковыхъ краевъ, боковыя лопасті шестого сегмента на вершане혀 запругленныя, внутренніе грал ихъ отстоящіе отъ лопастеї слқдугщаго сегмента; седыой сегменть сильно выпуклыі, боковыя лопастш его длшнныл, слабо поперечныя, внутренніе края шхъ расхолящіеся, слегка закругленные, боковые края пхт закругленные.

‥ Нешзв кстна.

б. โлина-5,6 мш.л., ширпна передве-

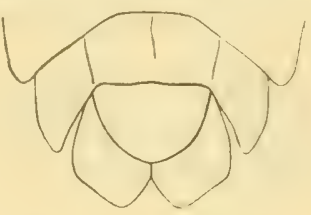

Pнс. 8t. - Стерниты бргшгіa VI-VII. Aractus semilacer $\mathrm{KrR}$, oे (นзт, Прпморекої обл.: HIIтольстіа). сппнкщ-2,2 милл.

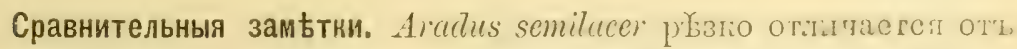
всџхъ одноцвътно-черныхъ впдовъ группы A. lugubris FALL,

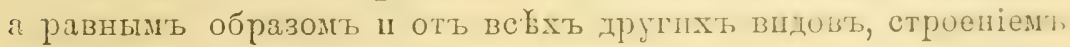
посл务днихъ брюшныхъ сегментовъ.

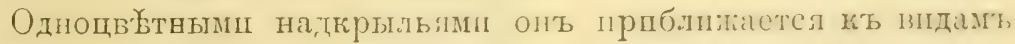

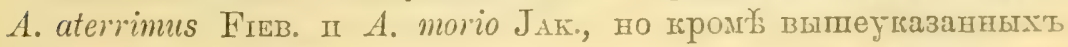
признажовь, легко отличается строеніөль головы п передне-

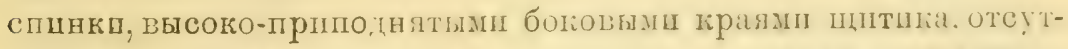

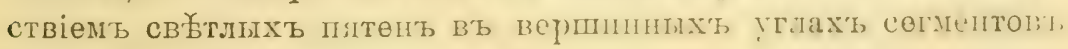
connexivum'a II др. прдзнакамш.

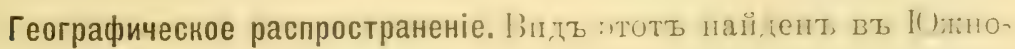

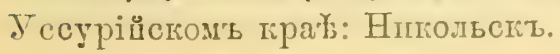




\section{Aradus morio JAK. 1889.}

(Табл. II, фиг. 27).

Arudus morio JA太. Hor. Soc. Ent. Ross., XXIV, p. 336. 1889-1890.

\section{Џауппспиеская лптература, касающаяся Россіп.}

Aralus morio JAk. loc. cit., p. 336 (Ovsjanka in fl. Zeja); Hor. Soc. Ent. Ross., XXVII, p. 294. 1893 (cursus med. fl. Lena infra Kirensk); Hor. Soc. Ent. Ross., XXXVI, p. 322. 1903. (gub. Irkutsk: Pashki).

\section{Экземпляры Зоологическаго Музея.}

Gub. Tomsk, distr. Kuznetzk: fl. Ona contra Bolshoj Anzas. 1897 ( (). $^{\circ}$ TAGNER.

Guh. Irkutsk: Vitimskoje (Viski). ( 5 Q).

Gub. Irkutsk: in cur. fl. Lena inter Kirensk et Witim (q).

Prov. Amur: Ovsjanka in fl. Zeja (O). Nestshrova.

Prov. Littoralis: lacus Chanka septentr. versus ab pag. Spaskoe. 14. 1721 V. 1910 ( 4 广์, 5 q). IKonnikov.

Prov. Littoralis: Vladivostok. 28. V. 1909 (के). BERGER.

Діагн0зъ. Corpus oblongo-orale; latiusculum (ठ) vel late orale (q), nigrum, solum angulis a picalibus segmentorum connexiri Harescenti-allililis.

Cajut latitudine sua juallo longius; prolongatione antica longa, lateribus fortiter compressa, lobis lateralibus breribus, sat crassis, upice acuminatis, margine exteriore muticis, rerrucosis; tuberculis anteocularibus validis, obtusis; lobis temporalibus parun prominentibus, callite pume oculos sensim angustato; 1ostice basin relsus linea arcuata, laeri, callusa, flarescenti praedito.

Antennae sit, lireves, nigrae, articulo secundo capite sat multo breriore, quam articulus tertius et secundus simul sumpti breviore, ab apice in primo triente suae longitudinis sensim fortiter angustato, dein leviter angustato, ima basi capitulato incrassato, articulo tertio secundo in $1 / 4$ breviore et hoc crassiore, apicem rersus censim incrassatr, articulo quarto secundo duplo breviore.

Rostrum sat crassum, coxas anticas fere attingens.

Pronotum transtersum, longitudine sua duplo latius, quam calut luresus; margine posteriore late, sel leviter sinuato, mar: $!_{1}:$ litrulibus subtiler crenulatis, reflexis, rotundatis, basin versus modice, apicem versus fortius convergentibus, leviter immati-; mulis anticis olutusis, haud rel rix antrorsum promi-

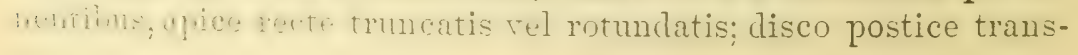


versim-rugulosum, antice callis duobus nigris, nitidis, deplanatis praedito; carinis discoidalibus elevatis, verrucosis, intermellis antice approximatis, postice medio quam basi et apice magis distantibus, lateralibus subparallelis.

Scutellum elongatum, angustum, apice obtuso; marginibus lateralibus valde elevatis, disco basi convexo, apice transversinrugulosum.

Hemelytra basi fortiter dilatata; corio unicolore, costis caninato-elevatis; membrana nigra.

Pedes nigri, coxis tibiisque fuscis.

§. Segmentum ventrale sextum quinto aequilongum; lobis lateralibus a lobis segmenti sequentis distantibus, apice rotundatis; lobis lateralibus segmenti septimi longis, marginibus interioribus divergentibus, rotundatis, marginibus lateralibus rotundatis.

o. Segmentum rentrale quintum margine antico sinuato, segmento sexto quinto aequilongo et quam segmentun septimum duplo longiore, parte discoidali transversa; segmento octiro septimo duplo breviore; lobis lateralibus longis et latis, marginibus interioribus divergentibus, leviter rotundatis, marginilus lateralibus obtusangulariter rotundatis.

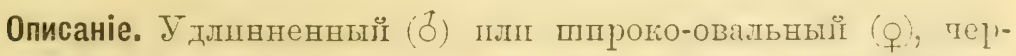
наго цвъта, только вершинные углы брюшныхъ сегментовт ст, желтовато-б’ылымп пятнами.

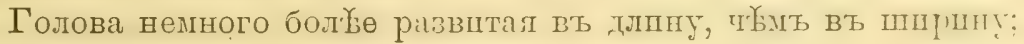
передній отростокъ ея длинныи, спльно сжатыи съ боковъ, боковые отростки короткіе, товольно толстые, веріпины ихт заостренные, внойыній край пхт невооруженный, спиьи иу-

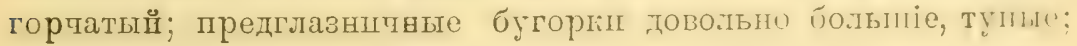
вщсочные отростки мало выдающіся, такь что голова позади глазъ постепенно съунпвающаясл; на поверхностщ головы у

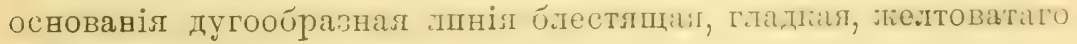
цвйта.

Успкп довольно короткіе, тернаго пвљта; первый члевипь

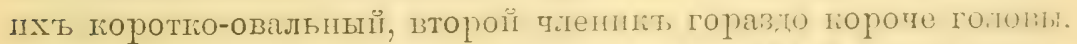

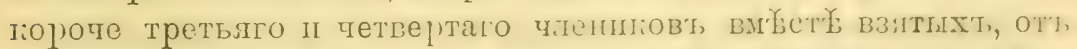

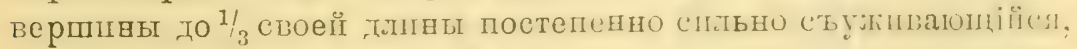

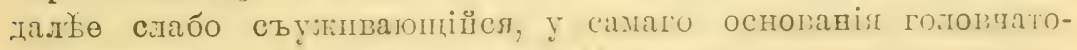

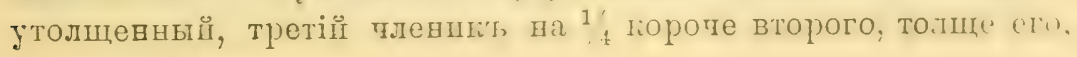




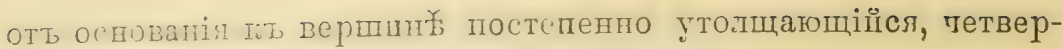
тьй членцкъ почтп въ $2 \frac{1}{2}$ раза корочө второго.

Хоботокь довольно толстый, почтп доходпть до ляшекъ переднпхъ ногъ.

Перидиеспниа поперечнал, слегка короче головы, шприна ел вдвоо больше тлины; затиій трай широко, но слабо выемчатый, болівые прал правпльно мелғо-зазубренные, загнутые, слегіа буроватыс, правпльно закругевные, къ основанію слабо

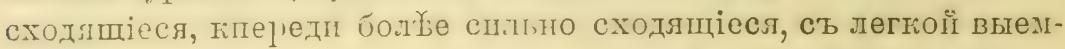
жой: передніе углы түпле, не впдағщіесл шлп стабо выдающіесл впередъ, влереди прлмо обруб́ленные цлп закругтенные; поверхность переднеспини позади поперечно-морциншстал, впе-

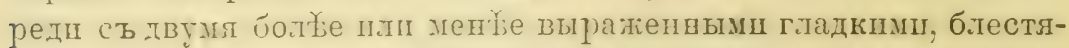

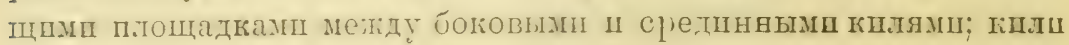
приполнятые; буторчатые; боговые параллельные; срединные

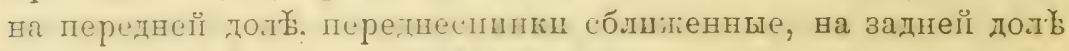

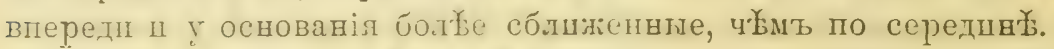

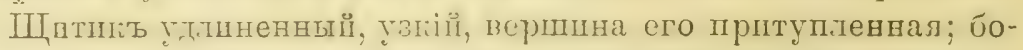
товыс врая сильно прппотнтые, поверхность у основанія прпподнятал, къ вершино поперечно-моршиннстая.

Надкрыня у основанія сшіьо расширенныя, corium одно-

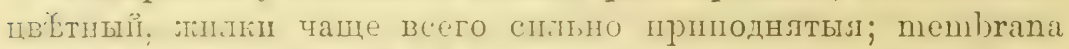
тернал. Снизу терный. Ногш терныл, тяшиш ш голени слегка буроватыя.

б. Шестої бргшнып сегменть равенъ по длшн) плтому;

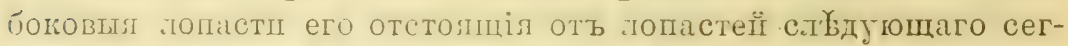

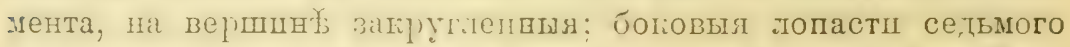

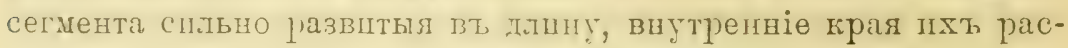
ходящіеся, закругленные, боковые ғрая закругленные.

q.3адніĭ тірай плтаго брнпного сегмента выгнутый, шестої

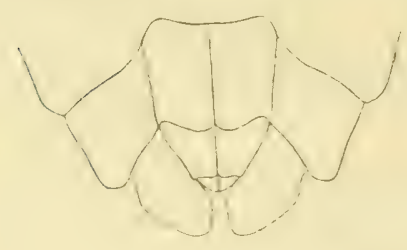

Prс, 85. - Стерниты бргопlа VI-VIII. Aradus morio JА⿱一𫝀口.

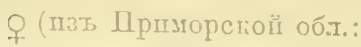
orp?. c. Chackoe). сегментъ немного длинн路 пятаго II вдвое длинн号е седьмого, дтскопдальная часть его одннаково развптая Въ дливу ш ширнну, восьмої сегменть вдвое горочө седьмого: бопновыя топасті седьмого сегмента длшнныя II шпрокія, внутренніе жрая пхъ расходящіеся, слабо закругленные, боковые края тупоугольно-закругленные. 


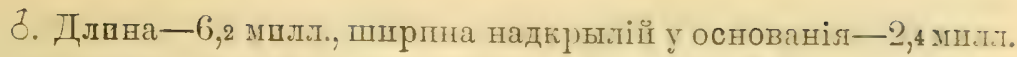

‥ Плина - $6,3-7,1$ мшіль, ширпна надкрылії у основанія $2,4-2,8$ милл.

Сравнительныя замьтки. A. morio J.к. тегко отлцчается отт

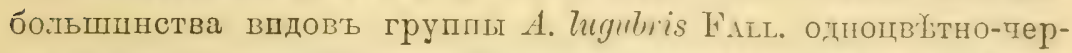
нымп надкрыльямп, одноцвътнымь соmехіким'омь, только вт, вершінныхъ углахъ сегментовт котораго нахо, пятсл желтоватын

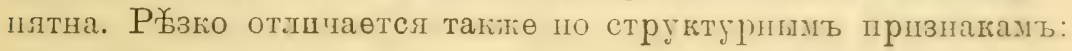
форм.' тьла, строенію усшковъ, головы ІІ т. п.

Оть двухъ другпхь одноцвытно-qерныхъ видовъ групны

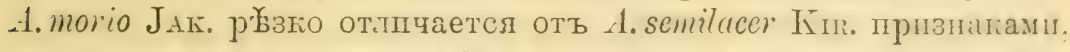

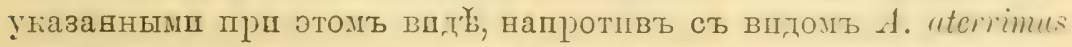
Fiев. имъеть много общаго и быть можеле претставіяетт, его синонимь нли разновшдность.

Географическое распространеніе. Распространент по Средней и Восточнов Спбпри: Томскал, Иркутекая губ., Амурекая, Прпморская об̆л., Южно-У ссурійскій краї.

\section{Aradus aterrimus Fins. 1864.}

Aradus aterrimus FiEB. Wien. Ent. Monatschr., VIII, 1864, p. 210. - Dougl. Sc. Brit. Hemipt., p. 274. 1865. - SACND: Trans, Entom. Soc. Lond, 1875, p. 251. - Put. Synops. Hém.-Hét. de France, I, p. 136. 1879. Reut. Wien. Ent. Zeit., 188t, p. 183. - SAUxd. Hem. Het. Br., p. 140. 1892. - Reut. Med. Soc. Faun. Fl. fenn., h. 26, 1900, p. 137.

\section{Фауџиетпческая литература, касающаяея Россін.}

Aradus aterrimus J. SandB. Medd. Soc. Faun. Fl. fenn. T LI, 1881, I'. 13 (Femini, .

\section{Экземпляры Зоологическаго Музея.}

Livonia: Dorpat. (o). A. Moratwitz.

Aiarнo3ъ. Ladns morio Jak. al specie Lieberiana vix distinguendus et forsitan symunmon hujus speciei est. In quo cisusu

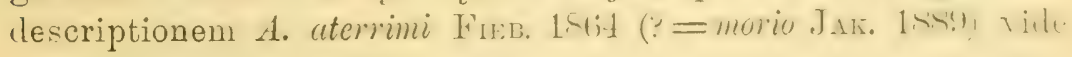
supra.

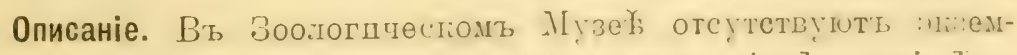
пляры этого вида, но серія толл. Пузея вшда Aradus morio ЈА下.

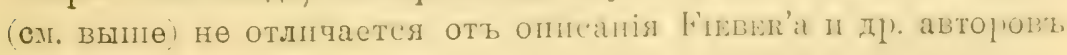
A. aterrimus. 


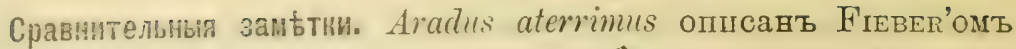

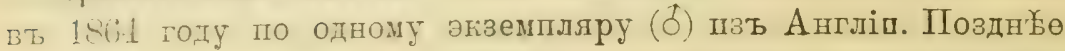
онт, быль ойнаруженъ во Франціш, но Рuтon зваль его тожө

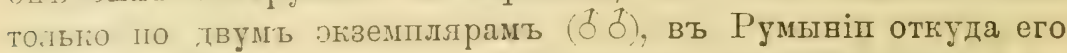
прнводить Мохталдох, но б́езъ ислинть комментаріевъ, ц въ IГспанін. Приведенныі первовачально J. SAнLBerg'омъ пзъ

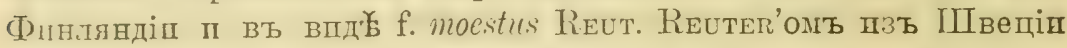

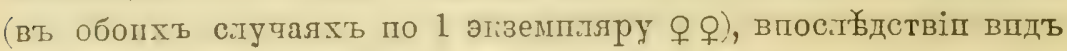

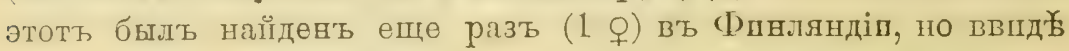
особой f. diversicollis ReUt.

'Таппмъ образопь это чөрелвычайно рбдкії въ Европ尔 впдъ Iт, несмотря на свое широгое распространеніе, не представленъ въ коллекціш Зоологытескаго Мгзея тппчної формої пзъ Европейской частп палеарнтин. Поэтому л не могу сравневіемт, европейсгить экземпияјив съ большой серіей спбир-

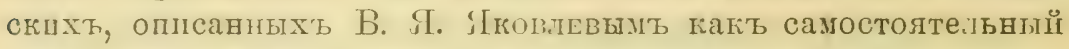
впдъ Lradus morio, ғатегорпчесін установить шдентпчность этпхь видовь, хотя съ своей стороны въ ней не сомн ъваюсь

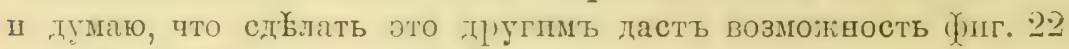

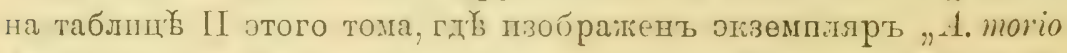
Jак.", со-Туре авторі, совөршенно сходный сь типомь В. Е. ЯКовлева.

Географическое распространеніе. Видь спорадпческп и рӑдко

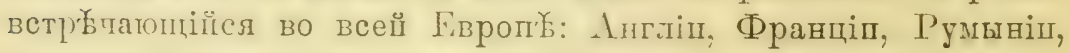

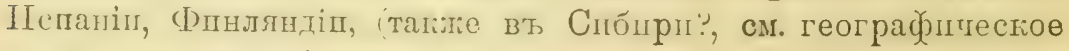
распространеніе A. morio $\mathrm{J}_{\mathrm{AK}}$.).

\section{Aradus aterrimus f, moestus ReUT, 1872.}

Aradus moestus Reut. Öfv. af Kongl. Vetensk.-Akad. Förh., 1872, 소 5, p. 59; Entom. Tidskr., 1882, p. 81; Wien. Entom. Zeit., 1884, p. 133. Aradus aterrimus var. moestus REur. Medd. Faun. Fl. faun., h. 26, 1900, p. 137.

Экземпляры Зоологическаго Музея.

Kazanj. 6. V. (ठ). Eversuraxx. ("Arcidus luctuosus m." Eversas. det.).

Aiarno36. Pronotum longitudine paullo magis quam duplo

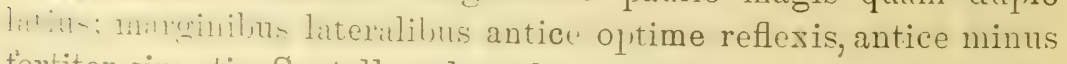
fortiter sinuatis. Scutellum lateribus rectis, apice acuto.

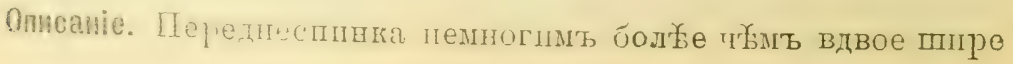


своеї длпны, боковыс грал ел спіьно загиутые, виередп сь стабої выемкой. ІЦитикъ на верпин бз заостренный, боковые края его прямые.

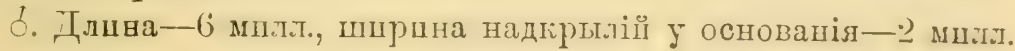

ㅇ. Пилина-6,3 мшлл.

Сравнительныя замьтки. Форма эта отлі-

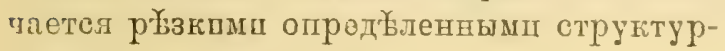
нымш призвакамц.

Географичесное распространеніе. Lradus aterrimus f. moestus опшсана пзъ Швеціп, встрүчаөтся также въ Среднеї (Брянскъ Орговской губ., 3. V. 1907 (ठ). Виноградовъ-Нпквтинъ) п Восточной (Казань) Россіп.

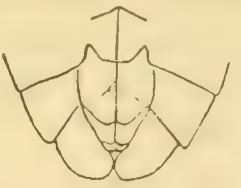

Pric. Siti. - Ctripниты бртош:а VI-VIII. Aradus aterrimus f. mostus Rett. (HII: O. M.

Reuten'a).

Aradus aterrimus f. diversicollis REUT. 1900.

Aradus aterrimus var. diversicollis REut. Medd. Faun. Fl. fenn., h. 26, 1900, p. 137.

Фауниетическая литература, касающаяся Россін.

Arudus aterrimus var, diversicollis Reut, loc. cit., p. 139 (Fennia: Kontiolaks).

Дiагнозъ. Pronotum longitudine paullo magis quam duplo littins, marginibus lateralibus antice levissime reflexis vel subplanis, sul,rectis. Scutellum lateribus usque ad melium leriter arcuittis, dein rectis.

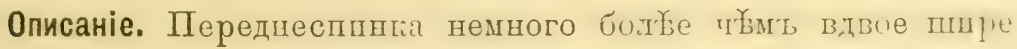
своей длины, боковые края ея впередп почти прямые, очень мало загнутые, шногда почтш ровные, боковые крал щштпіа до середины слегіа загругленные, потомъ прямые.

ㅇ. Длпна-6,5 мплл.

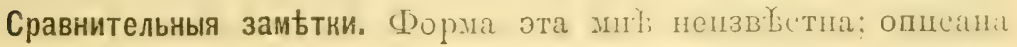
по 1 экз. (ㅇ).

Географическое распространеніе. Hайдена Въ Финциндін.

55. A radus nemtschinovae JAK. (nom. em.). 1889.

(Табл. II, (2иг, 25).

Aradus nemtschinovi JAE. Horae" Soc. Ent. Ross. XXIV, p. 331. 1889-1890. 


\section{Фаушиспческая литература, Һасающаяся Россіп.}

Aradus nemtschinovi JAK. loc. cit., p. 334 (prov. Amur: Ovsjanka in fl. Zeja); Horae Soc. Ent. Ross., XXVII, p. 294. 1893 (Gub. Irkutsk: Sajany in initio fl. Jrkut).

\section{Экземпляры Зоологичеснаго Музея.}

Gub. Irkutsk: Mongol Daban in initio fl. Irkut (ठ).

Prov. Amur: Ovsjanka in fl. Zeja. (q). Nextschrvora.

Japonia (2 Q).

Дiагнозъ. Elongato-oralis, anģustus, niger, angulis apicalibus segmentorum abdominalium flavescenti-albidis.

Caput latitudine sua longius: prolongatione antica longa, sat tenui, post mellium constricta, hasi dilatata; lobis lateralibus longis, sat tenuibus, acutis, fortitr llivergentilus, margine exteriore tuberculis distinctis amutis; tulereulis anteocularibus valiulis, acutis: lobis temporalibus hand prominentibus; capite pone oculos sensim angustato, postice hasin versus lineis luabus laevibus, callosis, angulariter convergentibus, flavis praedito.

Antennae longissimat, gratcillimate, nigrae, articulo secundo fucescente: articulo secundo cap)ite lougiore et quam articulus: tertius duplo longinre; ilicem rexsus sensim sed leviter incrassirto, basi ina calutulato-incrassato, nigro, tertio quarto magis quam in $1 / 3$ longiore, bisi quan apice nonnihil temuiore, gramulis setigeris praedito, articulo quarto dense piloso.

Rostrum basin mesosterni attingens.

Pronotum longitudine sua duplo latius; margine postico ante scutellum sat late et loviter sinuato. marginibus lateralibus late et regulariter rotumbatis: batsin rersus levissime convergentibus, apicem rersus fortiter angustutis, sinuatis, marginibus subtiliter cremulatis, antice apud angulos anteriores denticulo magno, aprice rotundato, haud acuto, instructis; carinis pronoti valde eleratis, antrusum humiliuribus, reprucosis, subparallelis, intermedis andive magris ilpropinguntibus: promoto parte posteriore fortiter Trill:TCl-i11-2ug(1s).

Sentullum lumsitmm, ipso apice acuto, marginibus lateralibus alte elevatis, liscu lusi convro, apice ralde trausversim-rugoso.

Item.1rara lasi fanllu ditatata, lateribus subrecta, unicolora, nima, molio interdun wsolete fusca; mentrana fusco-nigra.

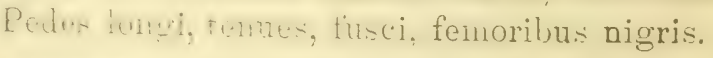

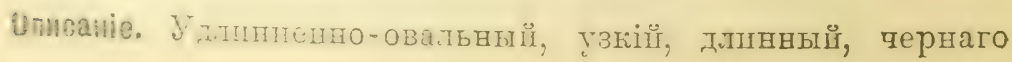




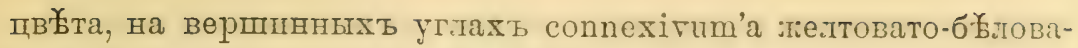
тыя пятна.

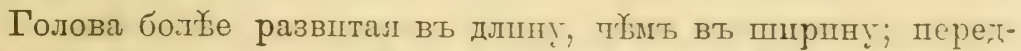
нії отростою ея длпнныї, сравнптельно тониіі, позадш середины съ перетяжкой, у осиованія распиренныи; боловые отросткп длинные, тонкіе, спльно заостренные, спльно расходл щіеся, по внйшнему краю вооруженные вамұтпыљ бугоркомъ; предглазншчные бугорғи лвственные, высогіе, заостренные; впсотные отросткц нө выдающеся, такъ тто голова позади г.тазт, постепенно съужшвапщаяся; поверхность головы у основаніл

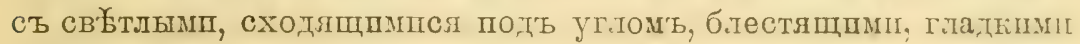
линіямп.

Јспкп длинные, очень тонкіе, черние, пскючал второго члевика, который буроватый: первый членпкъ удлпвенвоовальныц̆, второї членпкь длпннъе головы, ІІ вдвое длинные третьяго, оть вершины къ основанію постепенно, но очень слабо утончапщійся, у самаго основанія головчато-утолщенныці, и́уроватаго цвита, псключая терныхь основанія п верпины, въ

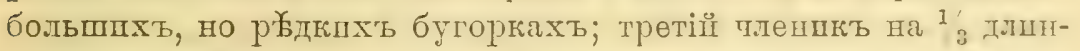

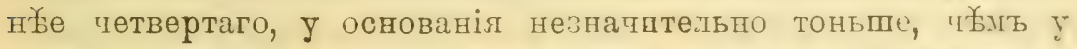
своеї вөршпны, покрытый бугоркамл, на вершпне которыхь

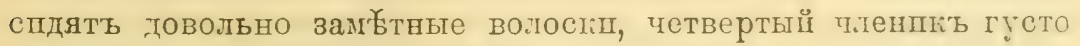
волоспетыц, на вершшв въ бъломь воїлоки.

Хоботокъ доходить до основанія среднегрудш.

Переднеспиніа вдвое шпре своей діпны; задній грай ея надъ щитикомь сь довольно ппрокой II не г.туболіої выемкої, боковые края ея шпроко закругленные, кзады едва сходящісея,

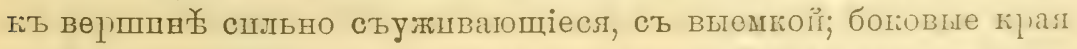
слабо зазубренные, впереди у самыхъ деїншхь угов и иемного дальпе за нщмп ваходятея по большому зубпу съ оіругленной, не острой вершшной; плли переднеспини сильио прпподнятые, кпередц поншкаюиіесл, спиво бугицатие, потт

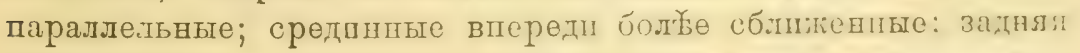
поверхность переднеспини спіьно поперетно-морицнистая.

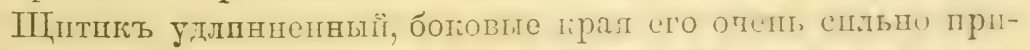
поднятые, вершина заостиенная; поверхность его у основанія приподнятая, къ вершпне혀 поперечно-морщинпстащ.

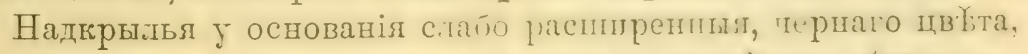

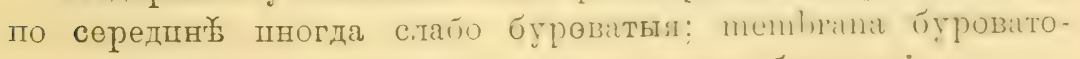
черная; пространства вдоль жплокљ спльно блестящіл. 
Ноге буроватыя, длпнвыя п тонкія, бедра чөрныл.

2. Боповтл попасти седьмого сегмента сильно поперечныя,

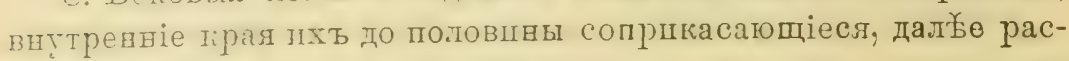
ходящіеся, боковые края закругленные.

․ Плтый брюшвой сегменть тлиннt: шестого, задній жраї

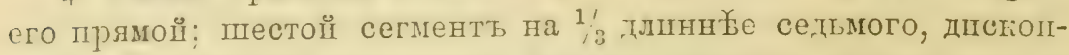
дальная тасть его поперечная, боковыя лопасти выдающіяся за

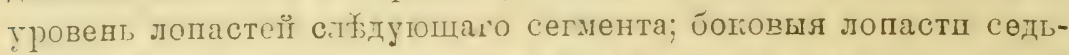
мого сегмента сь внутреннші гіраями слегта закругленным, пе пироко разстівленнымг, боговые гірая обризують передь середной тупой уголь, задняя сторона котораго слегха выемтатал.

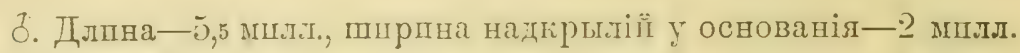

ㅇ. Далпна-6 мплл., ппршна вадырылій у основанія-2 мшлл.

Сравнительныя замьтки. Это очень своеобразный видъ, рбзко

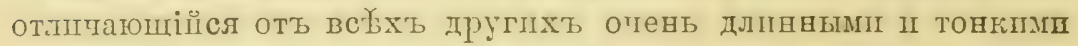
успіами пі ногамп, формой переднеспннки, въ особенностп своеобразными выстүпами на боловыхъ граяхъ ея, общей формоі тела, боговыми отростками голови ш многими другимп прпзнаками.

Географическое распространеніе. Впдъ свойствененъ, главнымъ

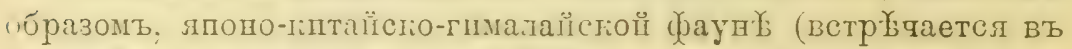

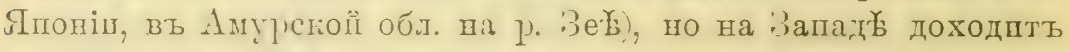
қо Европейско-Спбирсгаго подцарства, такъ какъ найденъ въ

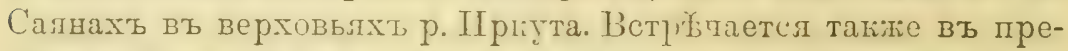

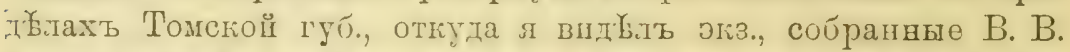

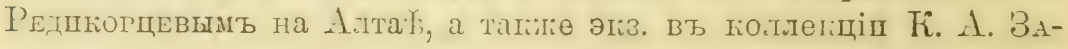
ПасНИКА Пъъ огр. г. Томска.

\section{Aradus erenaticollis R. F. SAILB, 1818.}

(Табл. II, (1иг. 29).

Aradus crenaticollis R. F. SAHLib. Mon. Geoc. Fenn., p. 139. 1818. - Floo Rhynch. Livl., I, p. 381. 1860. - Reut. Öfv. af. Kongl. Vetensk.Akad. Förh., 1872, גi 5, p. 58. - Puт. Synops. des Hémipt.-Hetér. de Fr, I, p. 137. 1879. - Reur. Ent. Tidskr., 1882, p. 75 et 106; Wien. Ent. Zeit., 1881, p. 134; Medd. Soc. Faun. Fl. fenn., h. 26, 1900, p. 137.-KIR. Rev. Russ. d'Ent., XI, 1911, p. 93.

Aradus wagneri JАБ. Зап. Кіаз. Унпв., I, p. 113. $186 \pm$. 


\section{Фаунистпческая литература, каспощаяся Россін.}

Aradus crenaticollis R. F. Sarilb, Mon. (ieoc. Fenn, p. 139. 1818 (Fennia: Uleaborg, Yläne). - J. SAHLi. Medd. Soc. Faun. Fl. fenn., VII, 1881, p. 42 (Fennia: Jokkis, Laukkas in parte sept. Tavastland); Not. Sällsk. Faun. Fl. Fenn. förh., XI, 1871, p. 299 (gub. Olonetzk: Petrozarodsk).F'Lor Rhynch. Livl., 1, p. 381. 1860 (Livonia).-Osн. Verz. d. palaearkt. Hem., III, 1910, p. 129 (gub. St.-Petersburg). - REur. Rev. d'Ent., IX, 1890, p. 241 (Kazan).-ЈАк. Зап。. Каз. Унив., I, 1864, p. 113 (Kazan).Kir. Rev. Russ. d'Ent., X, 1910, p. 12 (gub. Vologda: Glinnitza). J. SAнli. Kongl. Sv. Vetensk.-Akad. Handl., XII, № 4, 1878, p. 21 (prov. Enisejsk: Inserovo). - JAK. Hor. Soc. Ent. Ross., XXVII, 1893, p. 294 (gub. Irkutsk: Kultuk).

\section{Энземплары Зоологичеснаго Музея.}

St.-Petersburg (2 $\delta, 4$ Q).

St.-Petersburg (Q). OвеRт.

St.-Petersburg (2 J). F.AUST.

St.-Petersburg (Q). HUMmé.

St.-Petersburg. 1885 (ठ). Mazaraki.

Gub. St.-Petersburg (ㅇ).

Gub. St.-Petersburg: Levashovo (). Koenig.

Gub. St.-Petersburg: Levashovo. 4. V. 1897 (Q). Mazaraki.

Rossia or:: Kazanj. 4. V (ㅇ). Eversmann.

Enisejsk (2 0,5 o).

Gub. et distr. Irkutsk (Tajga). 9. VI. 1898 (ㅇ).

Gub. Irkutsk: Kultuk (ठ).

Gul.. Irkutsk: Vitimskoje (Viski) $(1 \%, 5$ q).

Gub. Irkutsk: Hadji (Q).

Gub. Irkutsk: fl. Bjelaja syst. Angara (Q). Hartusa.

Ojok, prope Irkutsk. 1871 (q). CzekANowsi.

Діагнозъ. Corpus magnum, ovale, retrorsum dilatatum, nigrmm. marginibus posticis segmentorum connexivi flavescentibus, hemelytris basi partis dilatatae, maculis corrii sordide flarescentibus, articulo secundo antenuarum medio, apicibus fomorum tibiisque fuscis.

Caput latitudine sua longius: prolongatione antica longra, tonui, apicem versus angustati, lateribus compressil, lobis laterilibus crassis, brevibus, apice acuminatis, leviter liverencentibus, margine exteriore nuticis: tuberculis antcocularibus parvis, acutiusculis; lobis temporalibus obtusis, hatul pruminulis: citpitu pone oculos sensin angustato, mostice basin versus lineis duabus laeribus, callosis, angulariter conrergentibus, flurescentibus praedito.

Antennae longae, nigrae; articulo secundo cilpite aequilungo.

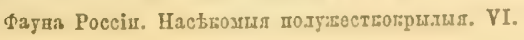


quam articuli tertius et quartus simul sumpti longiore, ab apice in dinidio longitudinis sua sensim fortiter angustato, dein fere crlindrico, tenui, basi ima capitulato-incrassato, articulo tertio secundo minus quam duplo breviore, articulo quarto tertio in $1 / 4$ breviore.

Rostrum apicem prosterni vix superans.

Pronotum longitudine sua magis quam duplo latius; margine postico sat profunde sinuato, marginibus lateralibus subtiliter crenulatis, leviter reflexis, late rotundatis, basin versus modice, apicem versus fortiter angustatis, antice leviter sinuatis, angulis anterioribus obtusis, haud prominulis, apice leviter rotundatis vel recte truncatis; carinis lateralibus pronoti parallelis, intermediis in dimidio antico approximatis.

Scutellum elongatum, angustum, marginibus lateralibus valde eleratis; disco basi conrexo, apice transversim rugulosum.

Hemelytra basi sat fortiter dilatata, reflexa, basi partis dilatatce macula sordide-albida ornata, inter costas corii maculis et venulis transversis praedita; membrana fusco-nigra, basi albila, venis hyalino-cingulatis.

Pedes fusci, tibiis medio pallidioribus.

J. Segmentum ventrale quintum sexto brevius; lobis lateralibus segmenti sexti ad lobos segmenti sequentis approximatis; lobis segmenti septimi longis, marginibus interioribus flaro-limbatis, divergentibus, marginibus exterioribus leviter rotundatis.

o. Segmentum ventrale quintum margine apicali sinuato, quam segmentum sextum brerius; segmentum sextum parte discoidali fere longum ac latum, quam segmentum septimum duplo longius, lobis lateralibus apice rotundatis, apicem segmenti octari attingentibus; lobis segmenti septimi fere longitudinaliter positis, marginibus interioribus rotundatis, haud divergentibus, late distantibus, marginibus posticis rotundatis, ima basi rectis.

Описаніе. Овальный, чернаго цвъта, залніе края брюшныхъ сегментовъ на connexivum'‡ желтоватаго цвъта, основаніе рас-

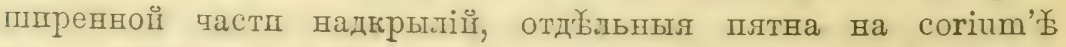

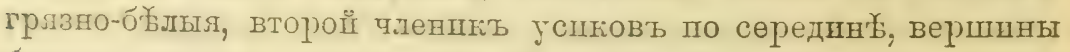
бедерь п голенц буровато-желтоватаго цвйта.

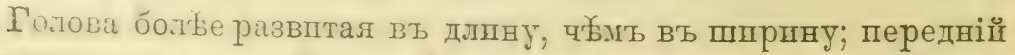

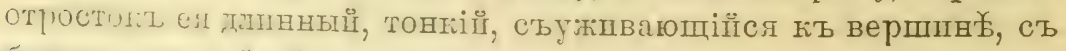

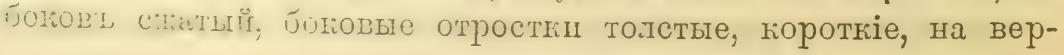




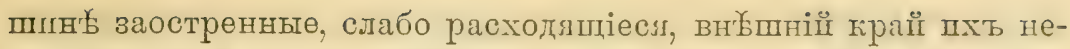
вооруженныи; предглазнпчные бугоркц мало-выдагоіесл, заостренные; височные отросткп тупые, ве выдающіесл, тацљ что голова позадп глазъ постөпенно съужпвающаяся, на поверхностп головы у основанія дв сходящіяся подъ угломъ гладхія, блестящія лпвіп желтоватаго цвю̌⿰та.

Усикп длинные, чернаго цвегेта, второй членикъ, исключая основанія п вершины егобуроватый; первый членикъ коротко-овальный, второй членикъ равенъ по длинег голов各 п

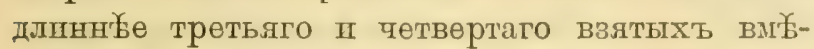
ст危, отъ вөрпины гъ основанію до $1_{1 / 2}$ своей длины спльно, постепенно п равномерно утонтаюційся, далю্ье почти одпнакової толщины на всемъ остальномъ протяженіц, только самое

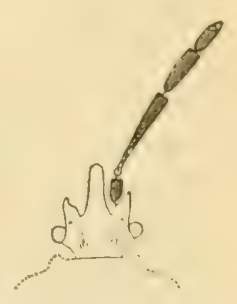
основаніе его головчато-утолщенное, третій членпюь менЊе

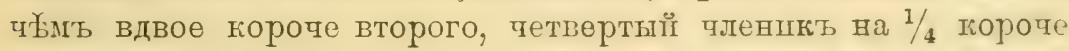
третьяго.

Хоботокъ слегка заходить за вершину среднегруди.

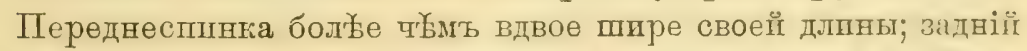
край ея довольно глубоко выемчатыи; боковые ғрал мелго зазуб́ренные, слегка загнутые, ппроко округленные, кзади менеке сильно, кпереді очень спльно сходлщіеся, съ легћоі выемкой; передніе углы тупые, не продвпнутые впередт, впереді слегка закругленные плп прлмо обрубленные; боковые гілі переднеспнип параллельшые, средпниые на передиеї долт: сближенвые.

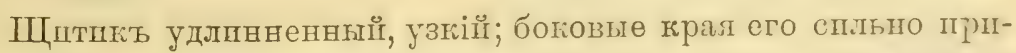
поднятые, поверхность у основанія прпподнятал, у верпини . поперечно-морщинистая.

Надкрылья у основанія замхттно расшпреныя, загнутыл.

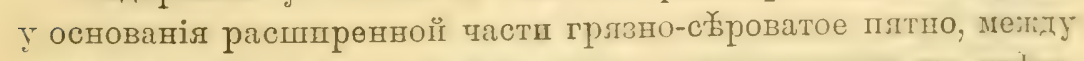
жшлкамп corium' п пятна п поперечныл жилкп татіого піе пвlта, часто отсутствующія; membrini буровато-черная, у осповані:

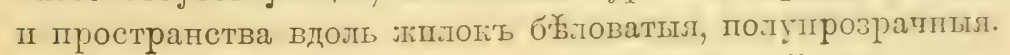

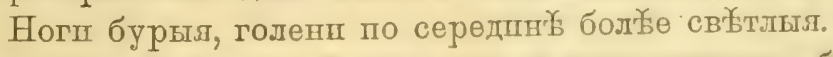

§. Пятый брюшной сегмепт, тороче пестого; болопия липасти шестого сегмента сблптены се лопистями седымого сег-

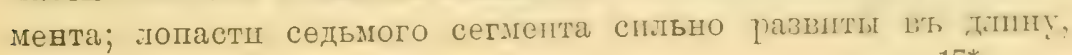




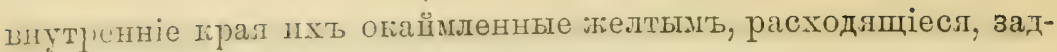
ніе II вне́пі грая слабо закругленные.

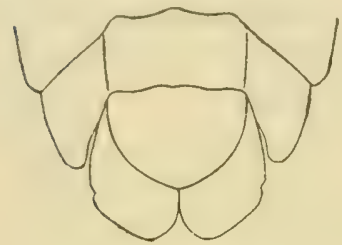

Рнс. 88. - Стерниты úpromria VI-VII. Aradus (renaticollis R. F. SAнцв. O (пзт C.-Петербургской губ.),

ㅇ. Задній жраї пятаго брюпного сегмента выемчатый, срединная линія өго пороче шестого сегмента; шестой сегменть почтц одинаково развнтъ въ длину п штрину, вдвое длиннйе седьмого сегмента, боковыя лопасти его на вершинеѓ⿱⺊口灬 вакругленныя, доходящія до уровня верпины восьмого сегмента; боковыя лопасти седьмого сегмента поставлены почтц продольно, внутренніө края ихъ широко разставленнье, не расходящіеся, закругленные, задніе крал закругленные, у самаго основанія прямые, лосо срызанные.

す. Длпна-6,4-6,5 милл., ширина надкрылій у основанія 2,3 мшлJ.

ㅇ. Длина-7-7,8 мплл., ширина надкрылії у основанія 2,6 мдлл.

Сравнительныя замбтки. Оть всъхъ видовъ группы Aradus lugul,is FALL. этотъ впдъ рбъзко отличается прупной велпчпноц̆, длиннымп успкамш, въ особенностп длшннымъ вторымъ членпком' пхъ, который одпнакової длины съ очень длинної голо-

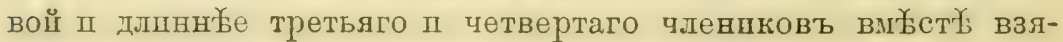
тыхъ, фороооі этого членшка ш другимп признаками.

Географическое распространеніе. С危верно-европейскій видъ:

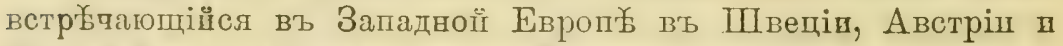

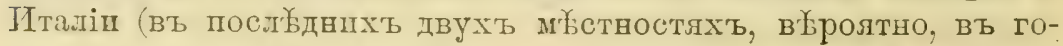
рахъ) и черезъ СҰв. пг С‡в.-Вост. Россію, доходящій до Вост. Спбири.

Въ Россіп пзв бетенъ пзъ Фннляндіп, Вологодскоп̆, Олонецкой, С.-Петербургской, Лпфобллдсской, Казанской, Енисей-

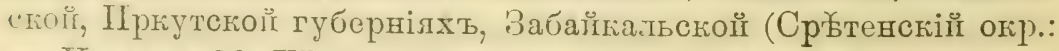
("r. Уруіпіа 26. VI. (99, Пиванда 4. VII. 1909. А. ПI. Келлерь)

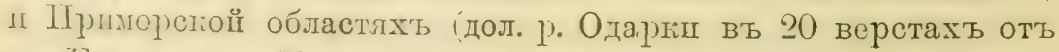

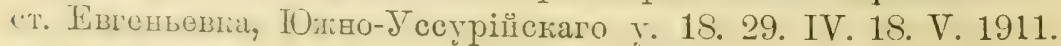
A. Черскиі). 
Образъ жизни. Въ С.-Петербурге́ Е. КЕнигъ находить этотъ видъ подъ корою сосны.

\section{Aradus poppiusi n. sp.}

(Табл. II, борпг, 28).

Діагнозъ. Corpus late ovale, retrorsum dilatatum, sordile brunneo-fuscum, caput, pronotum medio et scutellum fusca, pronoto marginibus latis lateralibus, hemelytris marginibusque pusticis segmentorum connexivi sordide albido flavescentibus.

Caput latitudine sua longius, prolongatione antica crassil, sat longa, apice recte truncata, lobis lateralibus brevibus, crassis, upice denticulum parvulum, acutum formantibus, margine exteriore muticis; tuberculis anteocularibus validis, acutiusculis; lobis temporalibus obtusis, prominentibus; capite pone oculos prurti anteoculari fere aequilato, dein subito in collum breve angustato, postice basin versus linea brevi, laevi, callosa, arcuata, flavescenti praedito.

Antennae longae, tenues, fusco-nigrae, articulo secundo triente apicali fusco-nigra excepta, flavo-fusco; articulo primo ovali, articulo secundo capite longiore, basi ima capitulato-incrassato, apicem versus sensim et aequaliter incrassato, in triente apicili lungitudinis suae sat multo crassiore, dein fere cylindrico, articulo tertio secundo duplo et dimidio longiore, apicem versus sensim incrassato, articulo quarto tertio breviore.

Rostrum basin prosterni attingens.

Pronotum longitudine sua fere duplo et dimidio latius; margine postico late et levissime sinuato, marginibus lateralibus: subtilissime crenulatis, f'ere integris, valde reflexis, diaphanis, rotundatis, antice apicem versus fortiter angustatis, leviter sinuatis, postice basin versus modice angustatis: angulis anterioribus olitusis, haud prominulis, apice recte truncatis, denticulis nomullis, aequalibus instructis; carinis vilde elevatis, lateralibus subparallelis, intermediis antice magis approximatis, tmmidiusculis.

Scutellum breve, sat latum, apicem versus magis angustitum; marginibus lateralibus elevatis, disco basi convexo, apice transversim rugulosum.

Hemelytra basi valde dilatatil, subtiliter crenulata, subliilphana, reflexa; corio albido-cinnamomeo, venis pallide-fuscis; membrana pallida, apice medium segmenti ventralis sexti attingente. 
Connexirun rufo-fuscum, marginibus posticis segmentorum fallidis, angulis apicalibus albidis, segmentis medio punctis duobus nigris praeditis.

Pedes fusci.

§. Ignotus.

Q. Segmentun sextum ventrale quinto longius, parte discoidali segmenti subquadrata; segmentum septimum sexto duplo et dimidio brevius, lobis lateralibus longis et latis, late rotundatis; marginibus interioribus unicoloribus, late distantibus, marginibus lateralibus rotundatis.

Species Arado crenaticolli R. F. SAнг.B. similis, a quo colore, antennis longioribus et gracilioribus, articulo secundo capite longiore, apicem versus sensim et aequaliter incrassato, apice multo tenuiore quam in 4 . crenaticolli, prolongatione antica capitis breviore et crassiore, apice truncata, lobis lateralibus capitis brevioribus et crassioribus, magis divergentibus, apice in denticulos parros, acutos subito angustatis, lobis temporalibus distincte prominentibus. capite pone oculos parte anteoculari fere aequilato, dein subito in collum brevius angustato aliisque notis distinguenda.

Описаніе. Шцрого-овальный, гзади расширяющіїся, довольно лірунной велпчнны, грязного корпчневато-бураго цвйта; голова,

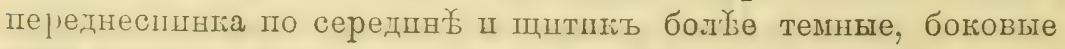
ір)ая переднеспинг, надірылья, задніе тірая сегментовъ сомnехіvит'а грязновато свҺ્бто-коричневые.

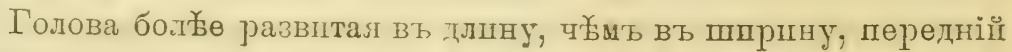
отростокь ея толстый, довольно длпнныи, впереди прямо обрубленныи, боновые отростки пороткіе п толстые, на самой вер-

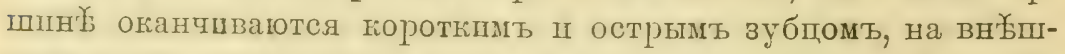
немь граю невооруженные; предглазвпчные бугорпп больпіе, застренные, височные отростюа тупые, спльно выдающіеся назадъ, таґъ что голова позади глазъ почтщ тағой же ширшны.

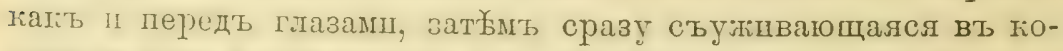
ротіую шег, у основаніл головы дугообразвая гладкая, блестяㅍя лпнія желтоватаго цвъь'та.

У спіп длшнные ІІ тонкіе, второї членикъ пхъ, псключая

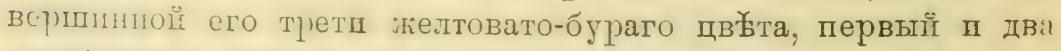
nocidjдихт гітенпіа іл вершинная треть второго буровато-

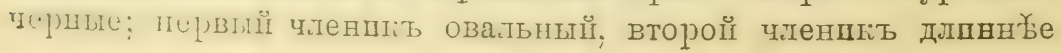


головы, у самаго основанія головчато-утолшценный, кь вер-

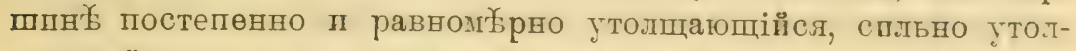

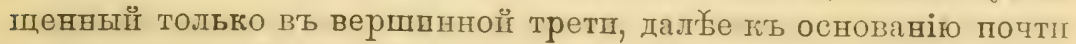
дылшнтрпческій, третій членпкт вь $2 \frac{1}{2}$ раза ґороче второго. ћъ вершинек постөпенно утолщаюпійся, четвертый членшкь пороче третьяго.

Хоботокъ доходить до основанія переднегруди.

Переднеспинка почти въ 21/2 раза шшре своей тлины, задній край ея съ широкої, туть замттної выемкої, боговые гірая очень мелко зазубренные, почтп цијльные, сшьн загнутые, полупрозрачныє, закругленные, впередп очень спльно съулавиюціесл, съ легкой выемюой, позади къ основанію мен神 спльво съужпваюіесл; передніе углы түшые, не выдающіеся впередт,

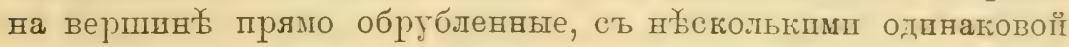
велпчшвы зубчпкамш; жши переднеспнни спльо прпподнлтые, боғовые почти параллельные, срединные впередп боль্ье сблпженные, спльно вздутые.

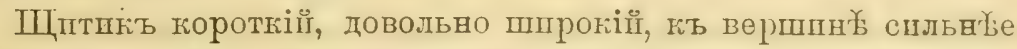
заостривающійся; боковые крал приподнятые; поверхность у основанія приподнятая, у вершины поперечно-морццншстая.

Надкрылья у основанія сильно расшшенныл; загнутыя, полупрозратныя, мелко зазубренныл; согіит бъловато-корцчне-

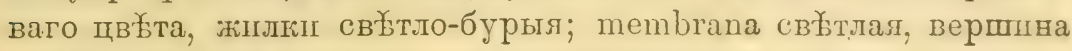
ея доходнть до середины шөстого брюшного сегмент.

Connexivum красновато жорпчневыі, задніс тірая сегментов'ь св 'әтллыя, вершинные углы съ бблымш пятнамп; по серөдиню сегментовъ по два черныхъ пятна.

Ноги бурыл.

Ђ. Неиввъстенъ.

오. Шестой брюшной сегментъ длиннек्.̌ пятаго, дискоидальная часть его одшнаково развптая' въ длпну п

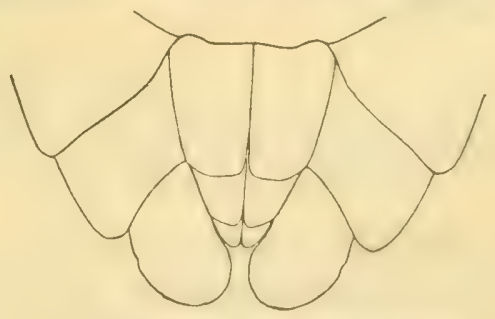

Рис. 89. - Стеришты брюшка VI-VIII. Aradus poppiusi Krr. q (изъ Ягутспой обг., Батылиза). ширину; боковыя лопасти шестого сегмента сь задними углами затругіннным, сплин

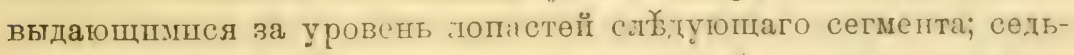
мой сегменть въ $21 / 2$ pißи короче шестого; боловыл лопісти его 


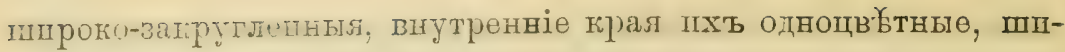
роко разставленные, боковые края вакругленные.

‥ Д.лшна- 7,6 мплл., ширина надкрылій у основанія-3 мплл.

Сравнительныя замьтки. Aladus poppizsi по структурнымъ пршзнакамъ очевь бдпзко стопть к'ь A. crenaticollis R. F. Saнlв. п

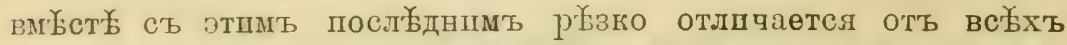
остальвыхъ видовъ группы A. lugubris Fall. длинвымъ вторымъ qленикомь усиковъ, которыї длиннъе головы, крупной велппाной.

Оть A. crenaticollis F. R. S.Aнц. отлпчаегсл желтовато-ӧурымъ

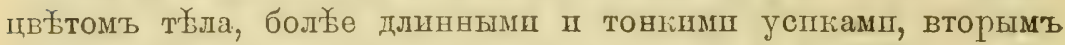

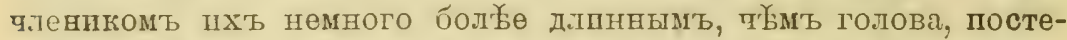
пенно съужнвающпмся къ основавію, гораздо менбе уе утолщеннымъ на вершннб; голова $A$. poppiusi съ болье нороткпмъ и толстымь переднпмъ отросткомъ, на вершшне прлмо обрубленнымъ, боковые отростіп короче и толще, чеямъ у A. crenaticollis

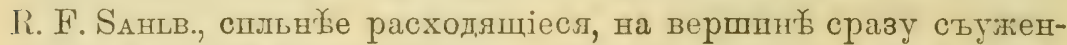
ные вт короткія острія; голова позаді глазъ съ болҮ् выдающпмпсл впсочнымп отросткамш, такъ что почти одннаковой пи рнны, какъ ш передъ глазамш, а заттмъ сразу съуживающаяся въ гораздо бол施 короткую шею.

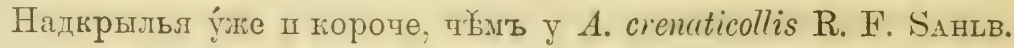

Географическое распространеніе. I)-г Рорргеs напель әтоть

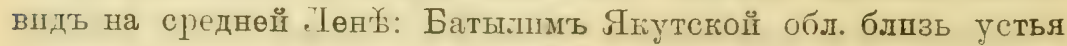
Алдана.

\section{2. Подродъ Quilnus SтÅL. 1873.}

Aradus (Quilnus) Sti̊l. Enum. Hemipt., 3, p. 137. 1873. - Horv. Ann. Mus. Nat. Hung., IX, p. 586. 1911.

Дiarнозъ. Rostrum breve, basin capitis haud vel vix attingens; pronntum fartulum, angustum, trapezoidale, marginibus lateralibus pronoti totis rectis.

Харантеристина. Хоботокьь короткій, доходящій до основанія головщ плш едва заходлщій за вершину переднегрудш. Передне('пннга мальпьгал, узко-трапедовдальная, съ боковымп краями

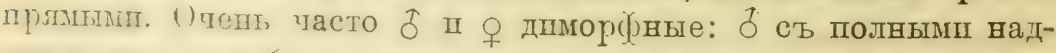

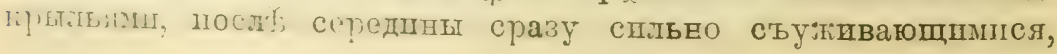


надірылья 오 рудшментарныя, очевь пороткія, въ вшді; чешуй, не заходящія за вөршину щитпка.

0бзоръ видовъ. SтАㄴ, установиль этотъ подродъ для описан-

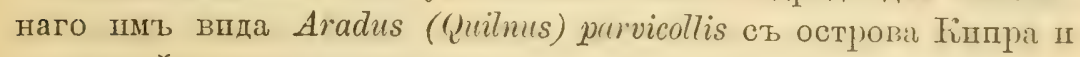

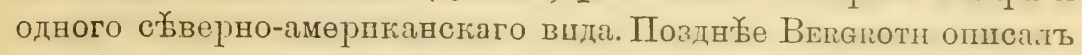
пвъ Австріп впдъ Aradus mirus и Ногт-ітн-Aradus brevirostris пзъ Спбпрш. Прш описавіп послґдняго вшда авторь указываеть на прпнадлежвость его къ разсматриваемому подроду: принаглежность къ нему вида - Aradus minus Bergr. установлена пистьдним авторомъ позднғе (Canad. Entomol., 1906, p. 201); тогда же пмъ описань еще одить неарнтпческій видъ этого подрода.

Наконець вт самое послтлиее времл Ногта́тн'омъ же описано два вида подрода Quilmus Sтr.: Aradus (Quilnus) discedens пзъ Босніп п $A$. (Quilnus) subsimilis пзъ Алжира.

Такпмь образомь, вт, настолщее времл пзв Ұстно плть палеарктическпхь вшдовъ; относящпхея иъ погроду Qиilnu:

Aradus (Quilnus) parvicollis STÅ. Enum. Hemipt., 3, p. 137. 1873. Изъ Герцеговшны, Грецін (Парнась) п острова Кіпра.

A. (Q.) discedens Horr. Ann. Mus. Nat. Hung., IX, p. 5S5. 1911. Изъ Босніш.

A. (Q.) subsimilis HorT. ibid., p. 586 .

Изъ Алжпра.

A. (Q.) Urevirostris Honv. in Dritte asiatische Forschungsieise les Grafen E. Zichx, II, p. 266. 1901.

Изъ Спбири (Тулунъ, Иркутск. губ.).

A. (Q.) mirus Bergr. Wien. Entom. Zeit., XIIT, p. 1S\%. 1S!)4. Изъ Австрін.

Единственный впдъ русской фауны-A. (只) brevirastris

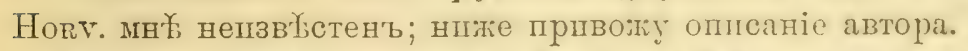

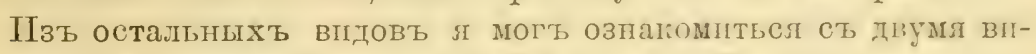

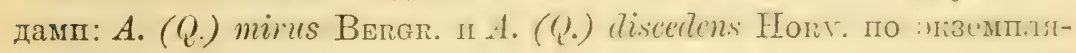
рамъ Гельсингофорскаго Музея.

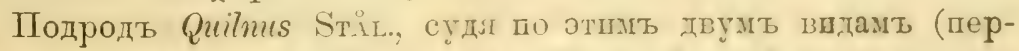

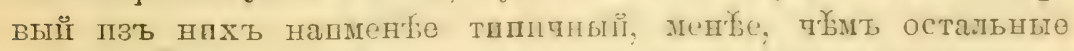
вшды, отгравпченныз отт, подрода Aiaches (s. str.) 11 зиатителтво

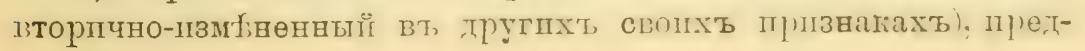




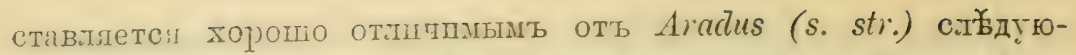
щшми тлавнымп признакамш: 1) очень короткпмь хоботкомь не доходлщим до основаніл головы, рәддко (A. mirus Bergr.) догодицимъ до середины переднегрудп, 2) переднеспинкої, очевь маленькой, съуженной кпередп, съ боковыми краямп-прямымп.

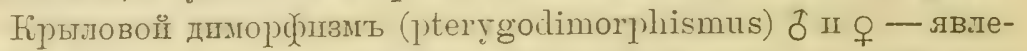
ніө вторштое, довогьно распространенное п вь подроды $A$ ra-

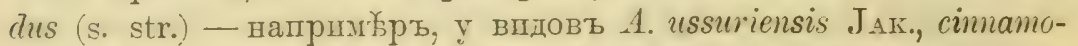
mens PAxz., tauricus JaK., pallescens H.-S., distinctus Fieb.

Мы прпведемъ лишь опшсаніе трехъ видовъ:

A. (Q.) mirus Bergr., A. (Q.) brevirostris Horr., A. (Q.) discedens, Horv.

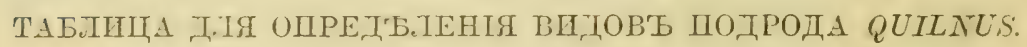

1 (2). Хоботокт заходит за основане головы. Второй иі третій члении успковъ масспвно-утолщенные ...... 1. A. (Q.) mirus Bergr.

2 (1). Хоботопь не доходпть до основанія головы.

3 (4). Шереднеспнка опень незнаппельно гороче головы; задиіі драй ея

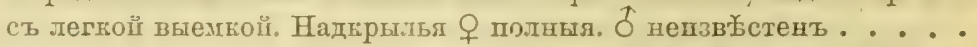

. . 2. A. (Q.) brevirostris Hory.

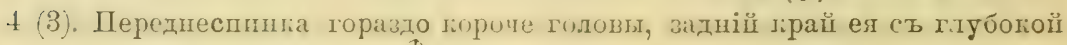
выемғоі̆. Надгрылья почти линейная, въ 4-5 разт јже согіum'a; надғрылья о․ укороченныя, едва заходящія за вершину щштика . . 3. A. (Q.) discedens Horv.

\section{Aradus mirus BERgr. 1894.}

(Табл. II, фииг. 30).

Aradus mirus Bergr. Wien. Ent. Zeit., 1894, p. 189 et 248.

Aradus (Quilnus) mirus Bęrgr. Canad. Ent., 1906, p. 201.

Діагнозъ. Corpus obovatum, retrorsum dilatatum, nigrum; angulis apicalibus connexivi obsolete albido-flavis.

Caput aequilatum ac longum, pronoto longius; prolongatione antica sat crassa, lateribus compressa, apice angustata, lobis lateralibus validis, crassis, apice acuminatis, antrorsum vergentihus; margine exteriore inemibus; tuberculi anteoculares desunt; calnt june oculos subito et fortiter angustatum, lineis duabus pallidis, angulatim convergentibus praeditum.

Antemate crassissimae, capite duplo longiores, nigrae, arti"ulv frino lorevisimn, religuis tenuiore, articulo secundo apicem 
rersus valde incrassato, leviter sulscurrato, quam articulus tertius longiore, articulo tertio apud basin quam apice paulo angustiore, crassissimo, quan articulus quartus in ${ }_{3}^{1}$ longiore, articulo quarto fusiformi, tentiore.

Rostrum apicem prosterni superans.

Pronotum parrum, trapeziforme, antrorsum fortiter angust:1tum; margine anteriore capite cum oculis angustiore, margine posteriore late et leviter sinuato, marginibus lateralibus rectis. crenulatis; angulis anticis pronoti paulo antrorsum et extrorsum prominulis, angulis posticis rotundatis; superficie pronoti plana, carinis destituta, sed ruga media subtili transversa praedita.

Scutellum apice angustum, capite longius, marginibus laterilibus eleratis.

Hemelytra apicen versus parum (すす) vel magis (q q) angustata, basi vix rotundata, leviter crenulata; corium scutello duplo longius; membrana nigra vel leviter fuscescens.

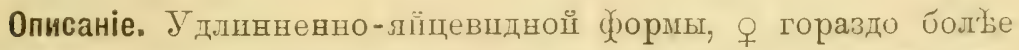
шпрокая, чернаго цвґта, задніе углы сегментовь сопехіvит'а нелсно желтовато-ббловатые.

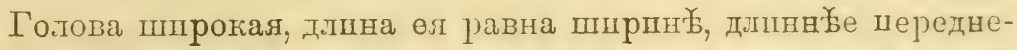
сппнкп; передвій отростогь длиныі, но довольно толстый, сжатый съ боговъ, на вершинег слегіа съуженныи; боговые отростиг спльные, толстые, на вершшне혀 заостренные, прлмо

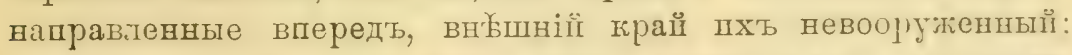

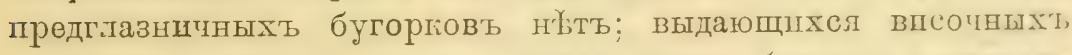

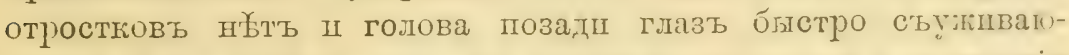
щаяся безт рқзной шеп; на поверхности головы у основаніл сходящіясл подъ угломъ св Ұтлыл, лшнейнл возвытенія

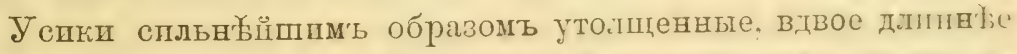
головы, густо-чернаго цвъта; первыц членпюь пхъ очен, ияроткій, значительно тоньше другшхь, второї ч:леншіъ сшино

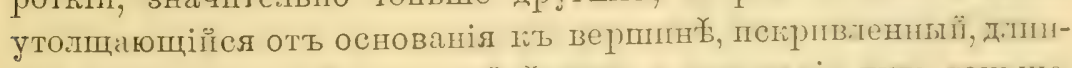

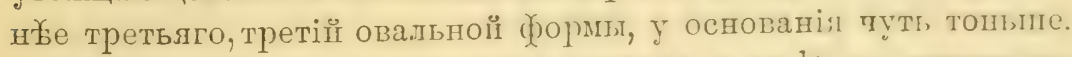

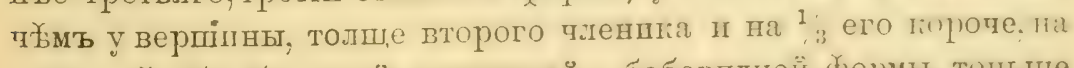

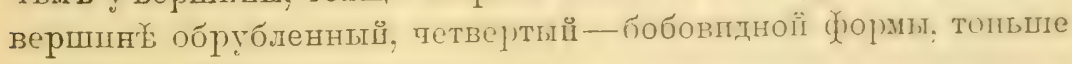
II немного нороче третьяго.

Хоботокъ заходшть за вершпну переднегруди.

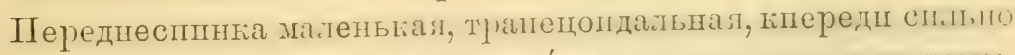

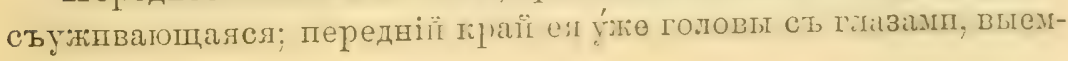


татый, задғій трай съ широгой, слабой выемкой, боковые ғрая прлмпе, мелко зазубренные, передніс углы слегка продвинутые впередь пі пь инж, задніе загруглөнные; поверхность передне-

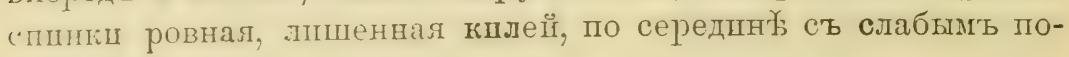
перечнымъ возвыпеніемъ.

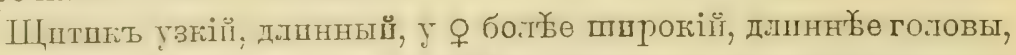
у самой вершины съуғшвающійся, боковые ғрая его прпподнятые.

Надкрылья постепенно съужшващіяся отъ основанія къ верппнт, боковой трай у основанія слегка закругленный, слабо

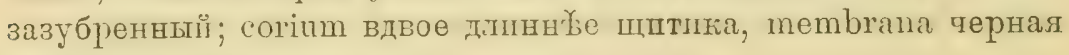
ІлІІ слегка буроватая.

Ногп буровато-черныя.

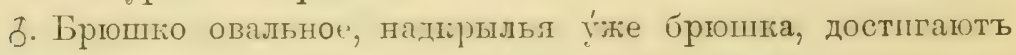
почті его вершины.

‥ Брюшпо ппроко овальное, нағцірылья гораздо у́ліе брюшка, достигають до основанія седьмого сегмента, шестой сегменть

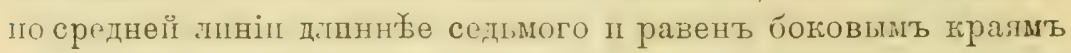

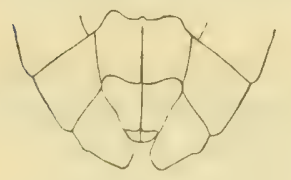

Рпс. 90. - Стерниты ipromrat VI-VIII. Aradus (Quitnus) minus BerGR. of (изъ Австріп: В出а, тиї). свонмъ, боковыя лопасти его доходлть до уровня вершшны седьмого сегмента; сөдьмої сегментъ вдвоө длиннеке восьмого, боковыл лопасти его спльно съуживающіяся къ внутреннему краю, боковые края блпже къ основавію съ выдающимст зубцомь, далье прямой, зазубренный; внутренніе грал зазубренные, широко разставленные.

§. Длпна-4 мплл., пшрнна брюшка-

2 мшлл, надкрылій у основанія 1,4 милл.

ㅇ. Длпна-б мпглл, шпрпна брюшка-2,4 милл., надкрылії у основаніл-1,6 милл.

Сравнительныя замьтки. Оть другпхъ впдовъ подрода Quilmus STAL-Aradus mirus Bergr. отлшчаетсл длинныль хоботіомъ, заходищит за верппну переднегруди. Въ этомъ отношеніп онъ представлеть переходную форху къ подроду Aradus (s. str.), но (троспіе перөднеспнниц совершенно такое же, пакь у подрода Quiluus.

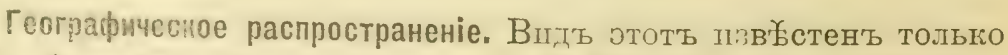

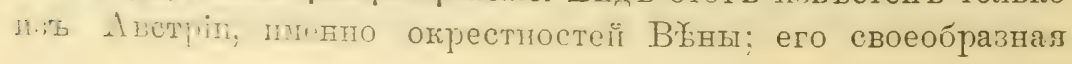


біологія (см. ншже), необпчнал срөди впдовъ рода, можеть бытл,

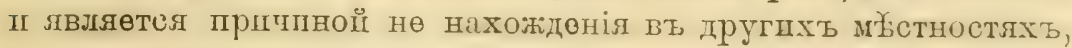
въ томъ чнсл年 и Россіп.

Образъ жизни. Aradus mirus Berqr. описанъ по экемплярамь въ большомъ колпчеств сбитыхъ съ сухнхъ вътвей сосны

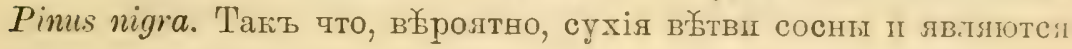
обычнымъ мъेстообитаніемъ впда.

\section{Aradus brevirostris Horv. 1901.}

Aradus brevirostris Horv. Hemiptera in Dritte asiatische Forschungsreise de: Grafen Eugex Zichy, Band II. Zoologische Ergebnisse. Redigirt von Horv. Budapest. 1901, p. 266.

\section{Фаупистичская литература, касаєщаяся Россін.}

Horv. loc. cit, p. 266 (gub. Irkutsk: Tulun).

Діагнозъ. "Ovalis, niger, opacus, sultilissime granulosus; capit» latitudine sua cum oculis vix breviore et pronoto. vix longiore, ante oculos versus apicem tuberculorum antenniferorum obsoletissime ampliato, tuberculis his apice acuminatis, parte laterali extus mutica; rostro brevissimo, basin capitis haud attingente: pronoto antrorsum sensim angustato, basi quam apice duplo latiore, apice capite cum oculis nonnihil angustiore, leriter sinuato. marginibus lateralibus subtilissime crenulatis, subrectis, postice leviter rotundatis, margine postico anto scutellum leviter sinuato. rugis longitudinalibus fere nullis, tantum duabus intermedii: brevissimis, tuberculiformibus, prope marginem apicalem distinguendis; scutello oblongo-triangulari marginibus fortiter elevati:disco basin versus leviter convexo; hemelytris completis, alulumine brevioribus (q), extus basin rersus leviter ampliatis et pronoto latioribus, margine costali subtilissine crenulato. membrana nigra, venis hyalino-marginatis: angulis posticis segmentorum connexivi griseo-albidis, haud prominulis: pedibus surdide tlavotestaceis. ㅇ.

Long. $6^{1 / 4} \mathrm{~mm}$.

o. Lobis genitalibus lateralibus intus late distantibus, lustic." obliquis et emarginatis.

Sibiria: Tulun.

Species haec rostro brerissimn instructa ad sulgenus (p)ilme Stà pertinet. Al, A. nigro Strice ex Amrica Septentrionali. 
cui ville affinis tidetur, capite breviore, lateribus pronoti et hemelytrorum haud denticulatis, sed tantum subtilissime crenulatis, uronoto apice capite cum oculis nonnihil angustiore, rugis longitudinalibus fere omnino destituto marginibusque scutelli fortiter elevatis differt.

Antennae exempli descripti mutilatae" (sec. Horvíth).

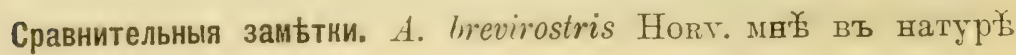
непзв Һстенъ. Описанъ по 1 ․

Географическое распространеніе. Найденъ въ Нрнутскої губ.: Тулунъ.

60. Aradus discedens Horv. 1911.

(Табл. II, ффиг. 31).

Arcedus (Quitmus) discedens Horv. Am. Mus. Nat. Hung., LX, 1911, p. 585.

Діагнозъ. Corpus oblongo-ovile, retrorsum fortiter dilatatum, fusco-nigrum.

Caput latitudini suae cum oculis subaequilongum; prolongatione antica crassa, brevi, lobis lateralibus tenuibus, apice acuminatis, margine exteriore muticis; tubereulis anteocularibus validis, ol,tusis; lobis temporalibus obtusis, parum prominulis; capite pone oculos parti anteoculari aequilato, dein sensim fere regulariter angustato, postice basin versus lineis duabus obsoletis, callosis, laevibus, angulariter convergentibus, flarescentibus praedito.

Antennie breves, crassae, niqrae; articulo primo fusco, breviter ovali, articulo secundo tertio in $1 / 4$ breviore, ambobus crassitie aequalibus, ubique aeque crassis, articulo tertio quarto in $1 / 3$ longiore.

Rostrum brevissimum, basin capitis haud attingens.

Pronotum breve, quam caput multo brevius, trapezoidale; margine anteriore capite cum oculis paullo angustiore, leviter sinuato, margine posteriore hemelytris angustiore, late et profuncle sinuato, marginibus lateralibus rectis, fortiter crenulatis; c:rrinis pronoti intermediis leviter elevatis, brevibus, lateralibusdestitutis.

Seutellum angustum, elongatum, apice obtuso; marginibus lateralibus latis, leviter elevatis; disco plano.

Fenelytra basi dilatata, crenulata, quam segmentum ventrale primum angustiora. 
Hemelytra ơ completa, basin versus fortiter angustata, corio scutello sesqui longiore, membrana angustissima, fere lineari, apice dilatata.

Hemelytra of abbreviata, scutello vix longiora, apicem segmenti primi ventralis haud attingentia, clavo et membrana destituta.

Connexivum marginibus lateralibus crenulatis, angulis apicalibus maculis obsoletis albidis praeditis.

Pedes flavo-fusci.

§. Segmentum ventrale sextum quinto paullo longius, lobis: lateralibus apice recte truncatis, marginibus interioribus a lobis segmenti sequentis valde distantibus, fortiter emarginatis; lobis segmenti septimi fortiter reflexis, marginibus interioribus rectis, divergentibus, marginibus lateralibus leviter rotundatis, medin denticulo valido instructis.

ㅇ. Segmentum ventrale quintum sexto brevius, margine apicali arcuato; segmentum sextum septimo in $1 / 3$ longius, longius latitudine sua, lobis lateralibus apicem segmenti octavi attingentibus, marginibus interioribus late distantibus, marginibus lateralibus ante medium denticulo instructis.

Олисаніе. Удлшнненно-овальный, сшльно расшщяящійся кзадп, буровато-чернаго цвътта.

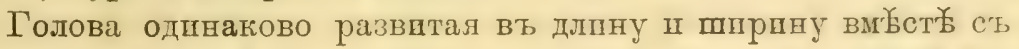
глазамп, передвіп̆ отростокъ ея толстый и очень короткій, боковые отростки довольно тонкіе, на вершине́ заостренные, вн安швій край ихъ невооруженныи; предглазничные бугорки тупые, значптельные; впсочные отростки тупше, выдающіся, такъ ұто голова позадп глазь тапой те шшршны, пакь передъ

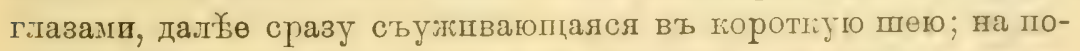

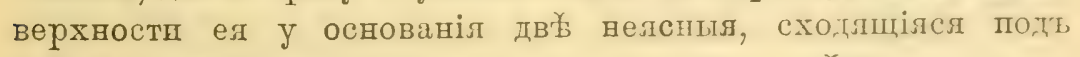
угдомъ блестящія, гладкія лшніп желтоватаго цво̆та.

Успкп пороткіо и толстне, терние; первый чиеншіъ пхх буроватаго цв年та, коротко-овальны роче третьяг, оба онш веюду олинаковой толпин, третій чле-

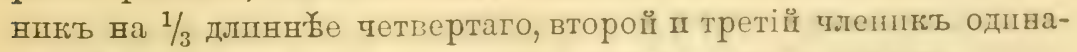
ковой төлщины, остальные очень незначительно төнье.

Хоботокь не доходить до основанія головы.

Переднеспина короттая, гораздо короче головы, трапецоп-

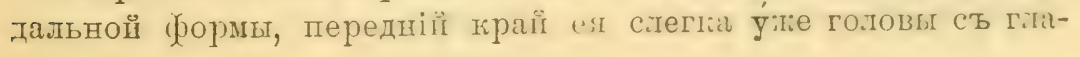


замп, задній прапі втеикой, боғовые грая прлмые, спльно зазубренные, пөредній

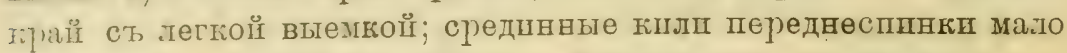
прпшоднятые, слабо выраженные, боковые отсутствуютъ.

Щитпъ узкій, длпнныи, на вершинет притупленный; боковые края слабо приподнятые, шпрогіе: поверхность щитига ровная.

Надкрылья у основаніл расширенныя, зазубренныя, у’же перваго бргшного сегмента; у ఏईे очень сильно съуживающіяся, съ очень узкой, почти линейной membran'ой, вершина которой снова слегка расширяется, закругленная; corium въ $1 \frac{1}{1 / 2}$ раза

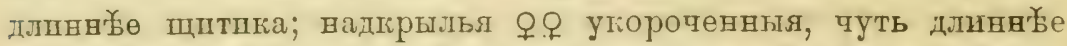
гцитика, не доходящія по вершпны перваго брюшного сегмента; membrana и clavus совершевно отсутствуютъ.

Kрая connexirum'a спльно зазубренные, вершинные углы съ неясными бълыми пятнами.

Ноги желтовато-бурыя.

す. Шестой брюшной сегменть слегка длиннъе пятаго; боковыл попасти его на верпине́ прямо обрубленныя, внутренніе края ихь далело отстоящіе оть лопастей сльһһдугщаго сегмента, спльо вырұ:занные; лопасти седьмого сегмента сильно загнутыя, внутренніе края пхъ расхолящіеся, прямые, задніе

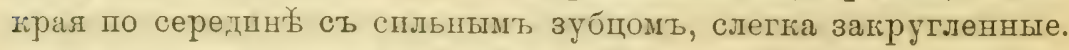

오. Плтый брюшної сегменть слегка пороче шестого, заднії

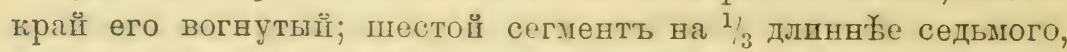
боковыл лопасти его доходять қо вершины восьмого сегмента; боковня лопасти седьмого сегмента с'ь внутренншми краями широко разставленнымп, задніе края съ зубцомъ передъ середаной.

す. Длина - 6-6,6 мплл., пприна переднеспинки - 1,61,8 милл., брюшка $-2,8-3$ мшлл.

ㅇ. โлпна $-7,8-8,2$ мплл., ширпна переднесппнгіп -2 мплл., брюпка $-3,6-4$ милл.

Сравнительныя замьтки. A. discedens Horv. ръзко отльчается

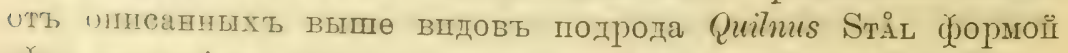

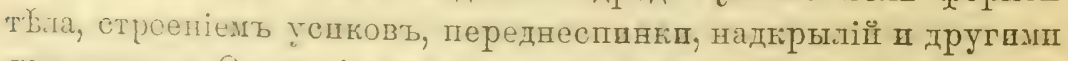

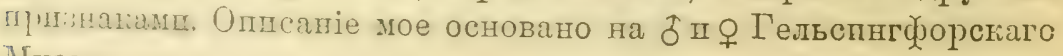
Mузея. 


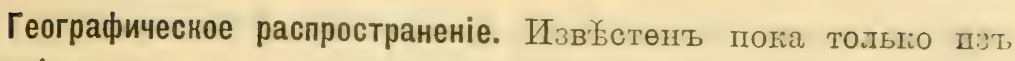
Босніп, откуда описанъ только въ 1911 году.

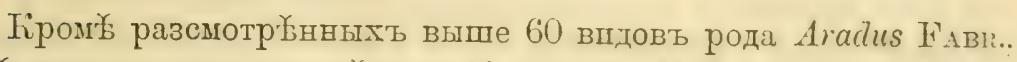

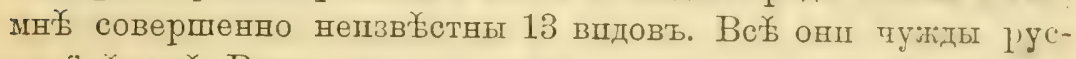

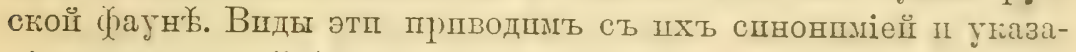
ніемъ на географическое распространеніе.

\section{Aradus (s. str.).}

61. Aradus lawsoni SAUnd. 1877.

Aradus Lausoni Saund. Ent. Monthl. Mag., XIV, p. 5̃2. 18ī; Hem. Het. Br.. p. 139 , t. 13, f. 5. 1892.
Англія.

62. Aradus kuthyi Horv. 1899.

Aradus Kuthyi Horv. Térmesz. Füzet., XXII, p. 449. 1899.

Венгрія.

Впдь блпзкій къ $A$. erosus Fald., но отлпчается велцчпной, отсутствіемъ бугорковъ на вно̆тшнемъ граю боковыхъ отростковъ головы, бол'Бе тонкимп успкамш, строеніемь переднеспнгі II окраской надкрылій и connexivum'a.

63. Aradus notatus Rer. 1888.

Aradus notatus REx. Rev. d'Ent., 1888, p. 192.

$$
\text { Франція. }
$$

По оппеанію автора по окраске походить ва A. depressus ( $\mathrm{F}_{\text {Aвг. }}$ ), къ колорому прпмынаеть и по многнмь стругтурнымь

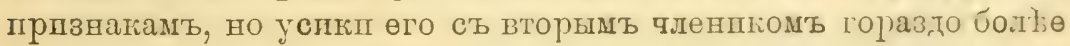
длиннымъ, чею̆мъ третіи.

64. Aradus cedri Рuт. 1873.

Aradus cedri Pur. Ann. Soc. Ent. Er., 1873, p. 20.

Алжиръ.

Второй тленши усиковь этого впда незнаптельно длинџе третьяго.

65. Aradus stenopterus Berar. 1897.

Stenopterus Perrisii Sign. Ann. Soc. Ent. Fr., 1865, p. 120 (nec DUr.).

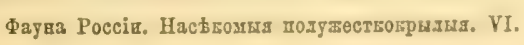


Leptopicnus Pcrvisii Put. ibid. 1876, p. 281; Cat. Hém., 1899, p. 43. Aradus stenopterus Bergr. Rev. d'Ent., 1887, p. 147.

Алжпръ.

Спстематпческое положеніе этого вида мне нешзвъстно; строеніе надкрыліні $\delta$, membrana которыхъ очень узка, а на

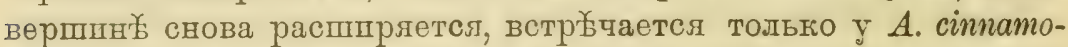
meus PAnz., A. eversmanni JAK., A. discedens Horv., прннадлежащцхъ къ различнымъ группамъ этого рода; 우 съ рудпментарныпи надкрыльями.

66. Aradus lauxi NoualH. 1893.

Aradus lauri Noualir. Ann. Soc. Ent. Fr., LXII, 1893, p. 13.

Тенөрдфо.

Авторь внда Novalnier счптаетъ его блпзкимъ къ предыдущему виду.

67. Aradus crassicornis Bон. 1852.

Aradus crassicornis Boн. Öfv. Vet.-Akad. Förh., 1852, p. 26. - Freb. Eur. Hem., p. 113. 1861 - Reur. Öfv. Kongl. Vet.Akad. Förh., 1872, № 5, p. 55 ; Ent. Tidskr., 1882 , p. 78.

Шівеція, Гөрманія.

Видъ этоть бливокъ къ групп'⿱⺊口灬 $A$. corticalis (LrNм.).

68. Aradus serbicus Horv. 1888.

Aradus serbicus Horv. Rev. d'Ent., 1888, p. 177; Ann. Mus. Nat. Hung., I, p. 12. 1903.

$$
\text { Сербія, Болгарія. }
$$

Horváth счптпеть свої вІдъ б.пинпмъ къ $A$. crassicomis Вон.

69. Aradus orientalis BerGr. 1885.

Aradus orientalis Bergr. Ent. Monthl. Mag., XXII, 1885-1886, p. T.

Японія.

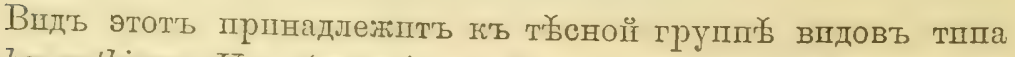
A. bergrothiams Kir. (emarginatus Bergr.) по строөнію брюшка, но хорошо отппчется оть всгехъ впдовъ въ нее входящихъ.

70. Aradus montandoni Revт. 1885.

Aradus Montandoni Reut. Wien. Ent. Zeit., 1885, p. 147.

Румыніл (Бростени на Карпатахъ). 
Видъ этотьь прнвадлежшть къ групп各 A. Tugubris FAL.. II ближе всего стопть къ этому внду, отлштаясь оть него гораздо болье длиннымп п тонкпли успками и строеніемь переднеспинки.

71. Aradus hahni Reut. 1884. Aradus Bahni Revt. Wien. Ent. Zeit., 1884, p. 135.

Германія (Бреславль).

Видъ этоть также относится къ групп年 A. lugubris Fall. ㅍ по н䄈оторымъ прнзнакамъ приблшжается къ $A$. aterrimus Fiєв.

\section{Aradus (Quilnus).}

72. Aradus (Quilnus) parvicollis STÅ. 1873.

Aradus (Quilnus) parvicollis STÅL. Enum. Hemipt., 3, p. 137. 1873.

Кипръ, Грөція, Гердеговина.

73. Aradus (Quilnus) subsimilis Horv. 1911.

Arcedus (Quitnus) subsimitis Horv. Ann. Mus. Nat. Hung., IX, 1911, p. 586.

Алжшрь.

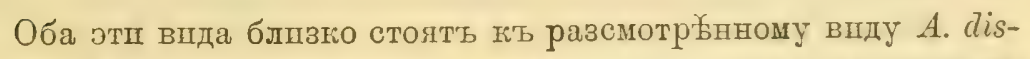
cedens Horv., оть ғіотораго от:пчаются строеніемь успговъ п другими признаками. 


\section{Дополненія и исправленія къ систематической части.}

За время, пропедшее посль; представленія этой работы къ петатп (февраль) до понца печатанія, въ Зоологпческій Музей Академіп Наукъ поступншп еше нбкоторые новые матеріалы по сем. Dysodiidae пі Araclidae, вклютшть тоторые въь наше обозрғніе этпхъ семействъ представляетсл желательнымъ, хотл бы

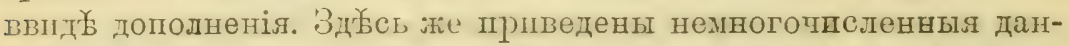
ныя шзъ литературы, пасающейся впдовъ әтихъ семействъ и опуоликованной за указаный промежутоль временш.

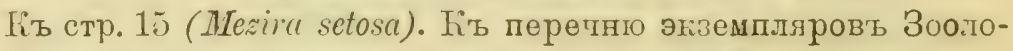
гдческаго Музея добавить:

Prov. Littoralis: Sjedanka prope Vladivostok. 9. VI. 1912. 23. VIII-5. IX. 1913 (4 ठ). BERGER。

Ћъ стр. 41 (Aneurus tuberculatus). Гіь перечню эгзөмпляровъ Зоологпческаго Музея добавить:

Gub. Ljublin: Novaja Alexandrija. 4. VI. 1913 (Q). ILjIsskI. Transcaucasia: distr. Tuapse. 1912 (2 $\delta, 3$ o). Sochnovsis. Transcaucasia: distr. Sotshi. (南). STARCK.

Относштельно географическаго распространенія слҮัздеть добавить сітдующее: Gulde (см. Deutsch. Ent. Zeitschr., 1913, p. 320) нашелт әтоть видъ въ Западной Германін. Одинъ изъ

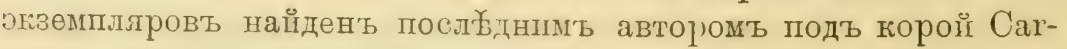
pinus betulus, выпепрпведенный экземпляр' цвъъ Јюблпнской губ. наїденъ подъ корої дуба (Quercus).

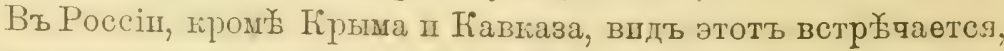

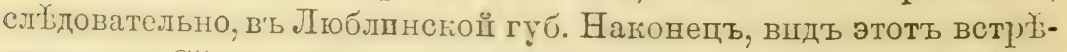
частеі въ СҰверноц̆ Персіп, откуда благодаря любезностп A.L.

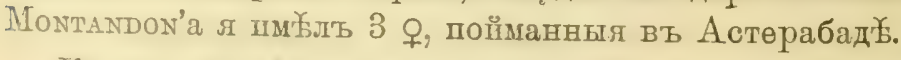

Къ стр. 13 (Aneums mucrotylus). Къ пөречню әкзөмпляровъ Зоологическаго Музея добавнть:

Pruy, Littorali-: Sjedanka Irrope Vladivostok. 9. VIII. 1913 (ठ). BERGEr. 
Къ стр. 56. По түмъ даннымъ, которымп я располагаль, когда писалть о видахъ рода Aradus, ветричающхеяг въ туранской провпнціп средиземноморскаго подцарства я могъ привестп для нея 5 впдовь, шзъ которыхъ 4 для нел эндемпчны. Недавно Мувеемъ получено еще два впд рода Aractus пзъ Туркестана, это: Aradus margianus n. sp. (описанъ на стр. 182 этого тома) ш Aradus betulae (Linn.). Таппмъ образопь ()ауну Tyџreстана по сем. Aradidae составляють б эндемштыхъ для нея вшдовъ ш два вида пшрото-распространенныхъ по всему пагеарктическому царству.

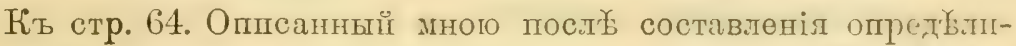
тельной таблпцы впдовь рода Aradus FAвR., на стр. 182--Aradus margiamus Kıр. долженъ быть введенъ въ нее въ ствдуюшпх словахъ:

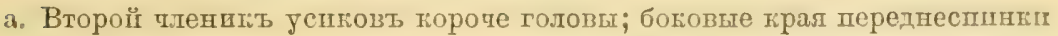
послй середины почтп не съуживающіеся, почтп параллельные, божовые края впередп съ небольшпи, тупымп зубцами

A. turkestanicus $\mathrm{J}_{\mathrm{AK}}$.

аa. Второї ч.теникъ успковъ длинныи, одпнаковой длины иліг длпннбе

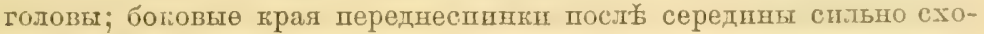
дящіеся, впередш съ сшльными, большими, острыми зубцамп.

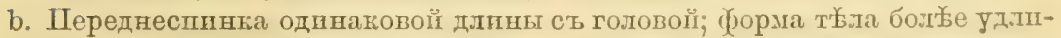
ненная и болбе широкая.

우. Боковыя лопасти шестого брюшного сегхента съ боговычи краямт, образующими уголь (см. рие. 66, гакъ у A. turkestanicus).

A. margianus KIn.

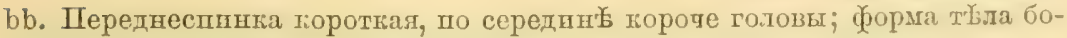
лье укоротенная ип болье узвая.

오. Боковыя лопасти шестого бргшного сегмента съ богозыми пранмп, потти правильно округленнымш, лишь съ выдагощшмея зубцомъ у основанія (cхr. pпc, 64) . . . . . . . . . . caucasicus KoL.

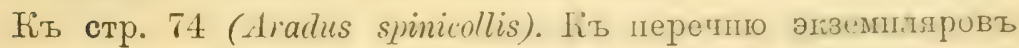
Воологнческаго Музея добавпть:

Prov. Littoralis: Sjedanka frope Vladirostol. ?. VI. 1912 (b, of). Ba:min.

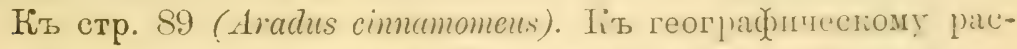

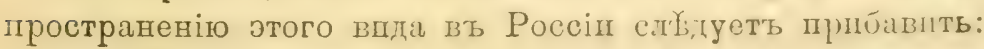

Новгородская губ́. (въ больпомь, гілпчеств); весної этого

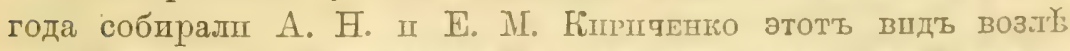

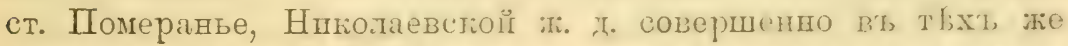

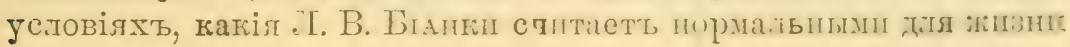




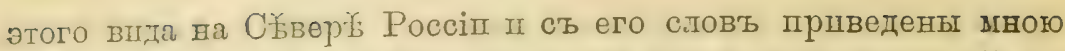
ға стр. 99 этого тома), Рязанская губ́. (въ большомъ чшслй собрапы лпчинкі этого впда ІІ. В. Блангі S. VII. 1913 въ Гремячевگे, Зараїскаго у.).

Ћъ стр. 90 (Aradus depressus). Къ перечню эквемпляровъ Воологическаго Музея добавить:

Gub. Vjatka: Nolinsk. 6. VI. 1899 (ㅇ). PorJetzkis. Caucasus sept.: prov. Kubanj, Psebaj. 22. V. 1911 (む). Volwuchis.

$\mathrm{K}_{\text {ъ }}$ стр. 144 (Aradus corticalis). $\mathrm{K}_{\text {ъ }}$ перечню экземпляровъ Зоологическаго Музея добавить:

Gub. Ljublin: Novaja Alexandrija. 6. VI. 1913 (o). G. JACoBson.

Gub. Kursk: Zacharkovo distr. Ljgov. 17. IV. 1899 (q). Murtens.

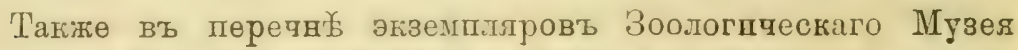
псправить ${ }^{1}$ ): вмгесто Gub. Irkutsk: Vitimskoe (Viski) (q) должно быть Prov. Iakutsk: fl. Viski (q).

Къ географическому распространенію әтого вида прибавить:

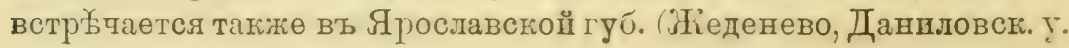
ПЕСТАКов').

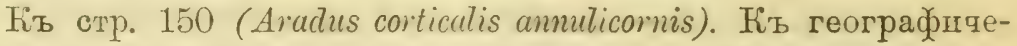
скому јаспространенію этого вида нужно прнбавить нахожде-

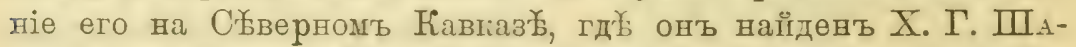

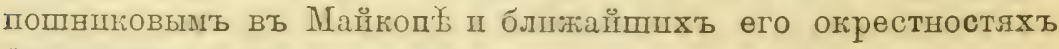
(Махопевскіні л安съ).

Ћъ перөчню әкземпляровъ Зоологпческаго Музея добавить: Transbaicalia: distr. Verchnij Udinsk. 16. VI. 1910 (\$). Pargatsherseaja. Prov. Amur: Ulunga. 16. V. 1910 (o). Mishin et Verchovskaja.

Къ стр. 185 (Aradus betula'). Къ перечню экземпляровъ Зоологическаго Мувея добавить:

T'ranscaucasia: Lagodechi, 23. IV. 1910 (o). MLok ossrewicz.

Gub. Tomsk: vallis fl. Buchtarma. VII. 1899 (ठ). KaZNAKov.

Provi Amur: Ulunga. 5. 12. 18. VI. 1910 (q et larvae). Mishix et VerchorSKAJA.

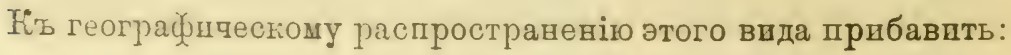

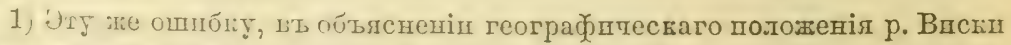

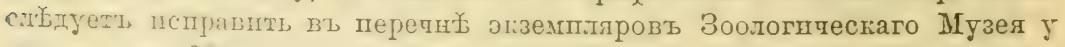

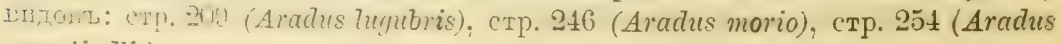
crenaticollis). 


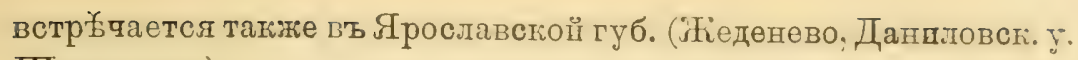
ПЕСТАКов' $)$.

Къ стр.179 (Aradus turliestanicus). Кіъ перечнг әгземпляров Зоологическаго Музея добавить:

Prov. Syr-Darja: Tashkent. 16. III. 1910 (o, larva). ZARUDNY.

Къ стр. 209 (Aradus lugubris). Къ перечню әгземпляров'ь Зоологическаго Музөя добавить:

Fennia. 22-23. VI. 1888 (お). KоEPPEN.

Gub. Enisejsk: Ermakovskoje distr. Minusinsk. 20. V. 1902 (ð). Sтаrск.

Prov. Amur: Ulunga. 11. VI. 1910 (o). Mishin et VerchovskaJA,

Къ стр. 246 (Aradus morio). Къ перөчню әкзезпляровъ Зоологическаго Музея добавшть:

Gub. Enisejsk: Ermakorskoje distr. Minusinsk. 20. V. 1902 (ð). Srarck. 


\section{Географическое распространөніе серіи PHLOEOBIO- TICA Reut. (Cem. DYSODIIDAE I ARADIDAE).}

Главн危йтія данныл геограб̆дескаго распространеніл сем. Dysodiidae п Aradidae уже указаны ва стр. 4 п 54 этого тома при обзорб родовъ этпхъ семействъ. Здъ̆сь мы попытаемсл дать лшшь общую лартшну геограбппескаго распространевіл

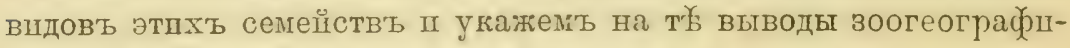
ческаго характөра, которые можно сд⿱人⿻⿰丿亅八兀ать пзъ нея.

Оба семейства имъють совершенво отличный характеръ своего географическаго распространенія, совершенно непохожії у того п другого. Сем. Dy.sodiidae въ палеарктпческой

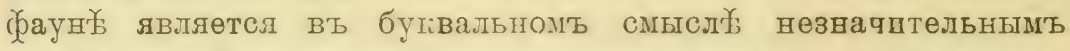
опломкомъ обширнаго ц'ъзаго, въ современную геологпческую эпоху продв'לтающаго въ троппческх'ь странахъ Стараго п Новаго Свътта. Едшничніле представитеди его, оставшіеся въ палеарктической фауни, носять явный релпктовый характерь -

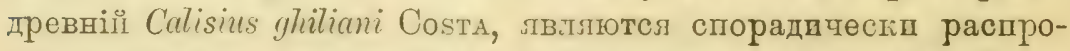
страненными, вымпрающпмп ш находящшмпя въ явної депрессіп новымш для ншхъ условілми жизні (Mezira tremulae (Gerм.), MI.basalis (Fгев.)) пли процвътають въ тбхъ вемногихъ мйбстностлхъ палеарнтчческаго (-1-палеанарктпческаго) дарства, въ которыхъ растительность, климать п т. д. сохранплісь почтп

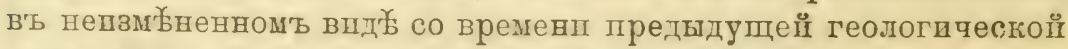
эпохи (Южно-У ссуріїскіе MI. atra JAк., MI. castanea JAк., M. verrucigera (Bergr.), MI. setosa Jax., MI. brevicomis Reut., Aneurus macrotylus J.к., японская MI. scabrosa Sсотт., жптайскій Aneurus sinensis $\mathrm{KIr}$.).

Въ одном' случағ (пменно впды Aneurus lacvis (FABR.) и A. tul.erculutu. МІлӥв.) представптелп сем. Dysodiidae польвуются

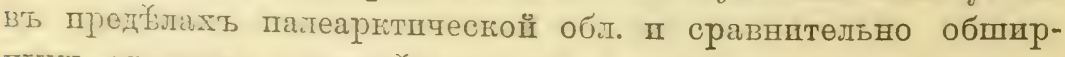
пым иреаломь геограб̆пческаго распространенія п, повшди- 
мому, совершенно не находлтсл въ упадке родъ этотъ какъ разъ лвляется напболье подвергшплся вто-

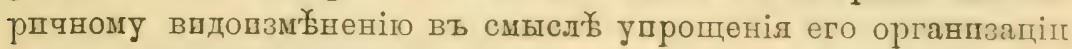
(редукдія жплкованіл).

Сем. Dysodiidae въ ц्रेломь распространено въ веотроппческомъ, оріентальномъ, австралійсломъ, эбіопскомь, веарптпескомъ II палөарктпческомъ царствахъ, причемъ совремонньм центромъ пхъ распространеніл, а, выेроятно, п возникновенія надо счнтать Южную Амерпку, гд⿱⺊口灬 въ настояшее время встрұqается представители свыше чłқы 25 родовъ семейства шзъ общаго писла 30, прцчемъ большнство изъ нпхъ для неп эндемпчны.

Прегставптелп семец̈ства въ палеарктическомь царств относятся къ родамъ Catisius Stil. Weziv" Aм. Serv. In Ancums

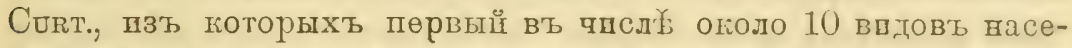
ляеть псключительно центральную п южную Алерпіу іл Австралію, а остальные два космополатпчны.

Родъ Calisiıs тапшмь образонт, поспольгу намъ пзебстно

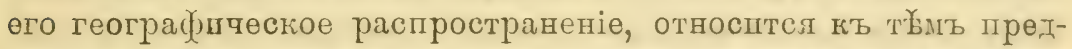
ставптелямъ животнаго міра, которыө связвають бауны неотроппческую п австралійсую, отражал, быть можеть, супествовавшую дрөвнюю связь обошхъ матерпковъ. Елпнственвый

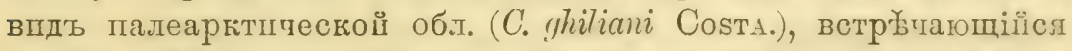

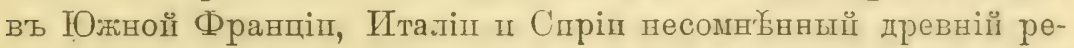
ликть, область распространеніл котораго совершенно оторвана оть обошхъ центровъ (австралійслаго п центрально-амершіансіаго) современваго распространенія вшдовъ этого рода.

Родъ Mezira Ам. Serv., песть впдовъ потораго встр.чаютегі

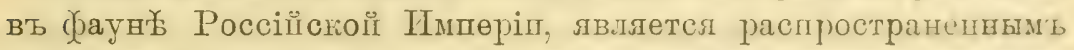

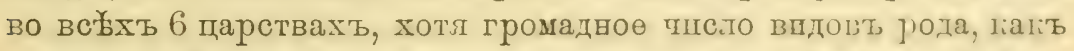

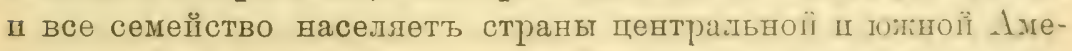
рикп (здтсь встрбчается болғе 30 вщдовъ изъ общаго чпсла 68 впдовъ рода), но әфіопско цајство и иъ осойенности оріен-

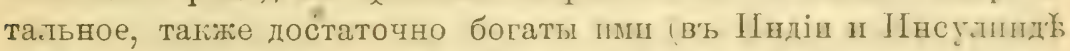

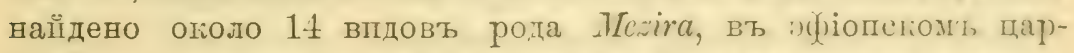
ств

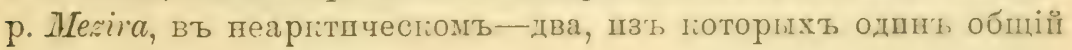
съ неотроппчесгшмь царствомь.

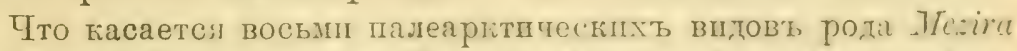
An. Sert. (Mewira tremulae (Gers.), M. setosa Jak., M. "tru Tak.,

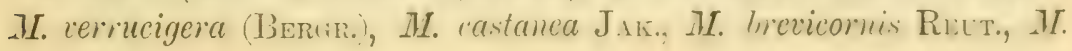




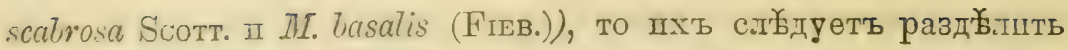
ва двй категоріш.
MI. atra $\mathrm{J}_{\mathrm{AK}}$.
M. brevicomis ReUT.
MI. verrucigera (BERGR.).
MI. scabrosa Sсотт.
M. castanea $\mathrm{JAK}_{\mathrm{A}}$.

представляютъ группу вндовъ свойственныхъ псключительно третцчнымъ лйсамъ средн. төч. Амура, Южно-Уссурійскаго края п Японіп, напедпихъ въ нихъ свое убжжшще-refugium

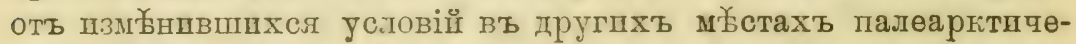
ской области. При этомъ одннъ изъ этихъ видовъ, именно

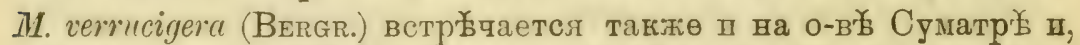
такшмъ образомъ, фауна южно-уссурійскихъ лю्रсовъ этшмъ впдомъ связывается съ талової оріентальнаго царства. Страннымъ образомъ, повидшмому отъ недостаточностпп пзслйдованія, въ Японіп найденъ лпшь однвъ впдъ (M. scabrosa Sсотт.), между түмъъ какъ богатство растительности ея и обшліө въ ней дрөвншхъ хвойныхъ заставляеть ожшдать особенно богатую и своеобразную форауну сем. Dysodiidae и, главнымъ образомъ, конечно, вшды рода Меzira Ам. Serv. Четыре южно-уссуріп̆скшхъ вида

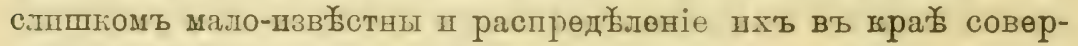
пенно нешзв бетно.

Остальвые два палеарктпческіе виды рода MLеzira: M. tremilae (Germ.) п $M$. basalis (Fiев.) являются ужө чисто палөарітпческим впдамп, прпчемъ ареаль распространенія послобдняго пзъ нихъ огранитивается средиземноморской областью (Андалузія и Греція), а первый пмћеть чрезвычайно перерывчатое, островное распространеніө на евразійскомъ материкґ, встрбчаясь въ Швеціп, Германіп, Италіп, Венгріп, Прибалтійскомъ

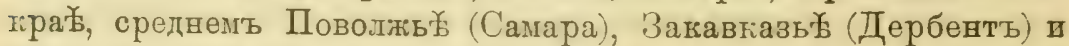
Южно-Уссурійскомъ краґ.

Родъ Aneurus Cuntis заключаетъ в'ъ себб около 25 вщдовъ,

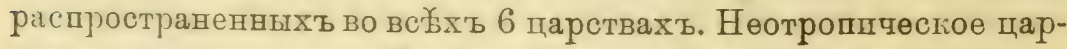
ство заключаеть вт, сөбъ около 9 ввдовъ, в'ь неарктическомъого:то 5 вцдовъ, въ австралійскомъ - 3 , въ оріентальномъ-2 и vxhiоп стомъ-1.

Четнре палеарнтпдескихь впда (Aneurus laevis (FABr.), An. tubernlatus Млӧв., An. macrotylus Jак. п An. sinensis KІr.) вліг

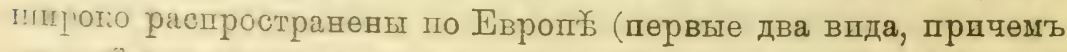

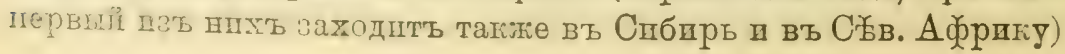


пли свойствены псшючительно Восточної Азін (Aneиms macrotylus Южно-У ссуріискому краю, Aneurus sinensis-провшвпін Сычуань въ девтральномъ Кітаб).

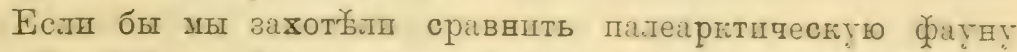
cex. Dysodiidae съ фораунами тругихъ дарствъ, то полную ағалогію предстивляеть форуна неаргтвчесіаго цирства, въ діоторомт,

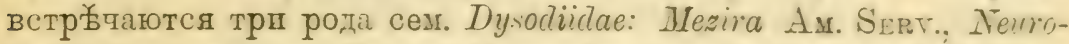
ctenus Fieв., Aneиru.s Cunтіs. Первый п посдабдвій роды общіе съ палеарнтичесгшм царствощъ घ относптельнов зваченіе пгъ въ

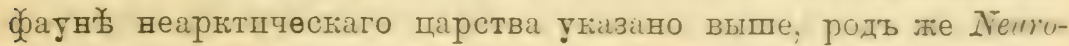

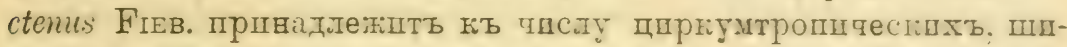
роко распространенныхъ въ неотроппческомъ, оріентальномь.

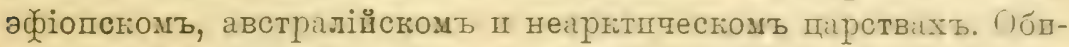
ліе впдовъ этого рода въ оріентальноъ парств б. даеть полное основаніе думать, что ве́роятно онъ заходить п въ фауану палеарктпческаго царства п открытіе одного пзъ восточныхъ видовъ пли спеціальнаго въ Японіп шлп даже можетъ быть въ Южно-У ссурійсскомъ пра пирокое распространеніе рода по всбиз зоогеограбциескиз

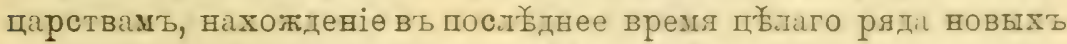
видовъ әтого рода въ СЪ̈верной Америкб.

Оріентальное парство, помнмо общихъ съ палеарғтическимъ

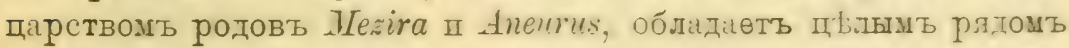
родовъ, ве встрбчающпхся въ палеарғтпескозъ и неарпіпче-

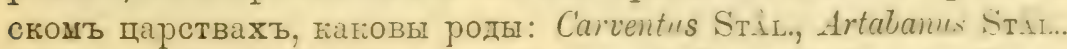
Pictinus Stil., Odonia Bergr., Barcinu. Strit., Acantharadus Bask.

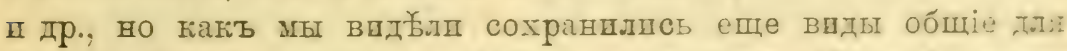

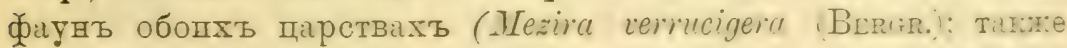

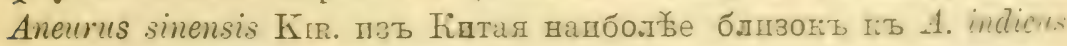
Bergr. пзъ Индіп).

Второе сенейство серіп Phloeobioticn-Aralinae пвляетсп виобороть свойственнымъ, главнымь обризомь, пмевно палеаритп-

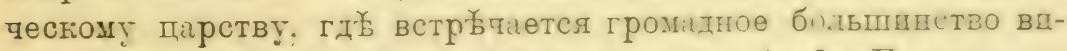
довъ едивственнаго роді этого семейства - Lialu. F.n.

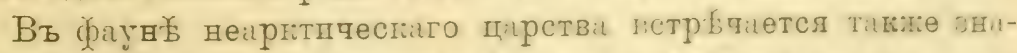

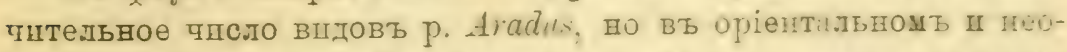
тропическомъ парствахъ пхь очень немного и еднничние пиды

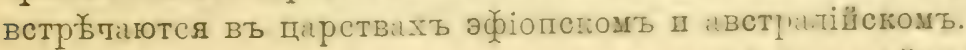

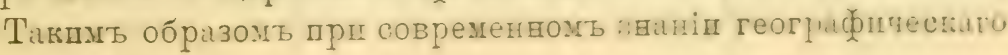




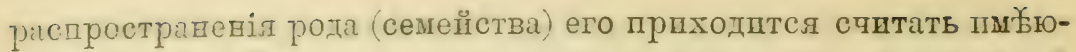

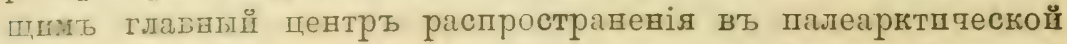
области, хотя внтенспвное пзученіе гемиптеро бауны С Амерциц за посльднее время значптельно увелпчпло чпсло сьверно-амершканскшхь вшдовъ п можно думать, что прп даль-

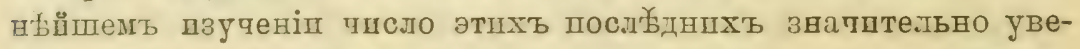

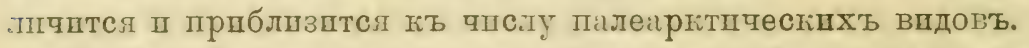

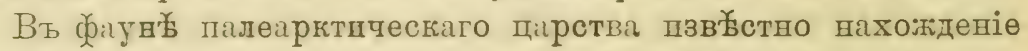
73 вшдовъ, шзъ которыхь трш вшда (Avadus crenatus $\mathrm{S}\lrcorner$ r., A. cinna-

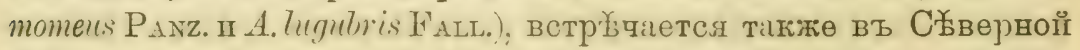
Амерпкеюे, т. е. являются общпмп для палеарптпчеспаго п неарктпческаго дарствъ, а одпнъ впдъ (A. flavicomis D.лм.) пшрого распространенъ по гсему А(ррпканскому матерпку, т. е. является общимъ для царствъ палеарктпческаго у эфіопскаго.

Большинство вндовт роді шшроко ріспространены по всему европейско-спбпрсгому подцарству пілеарктпін, некоторые

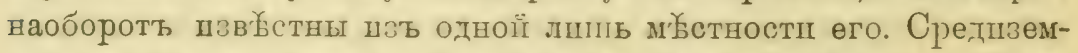
номорскому подцарству не въ узіомъ смыслот Гризебеха псключштельно своциствены слюдующіе вшды: Aradus diversicomis Horv., A. tanricus J.1., A. somclieticus Krr. A.lauri Noualm., A. stenopterus Bergro, A. flavicomis Darm., A. reuteriams Put., A. cedri Put., A. cancasicus Kor.., A. Tirueperi Rect., A. lergrothi Jan., A. liomarovi

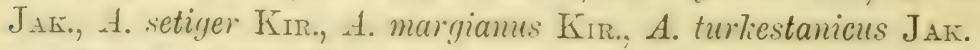

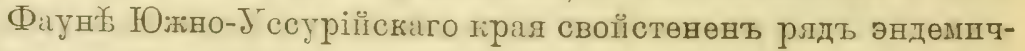
ныхъ для нөя видовъ.

Какъ я угазываль выше на стр. $54-57$ этого тома геогра(ұпческое распространеніе сем. Aracticue, главнымъ образомъ, обустовлпвается тревесної растптельностью, съ ғоторой не-

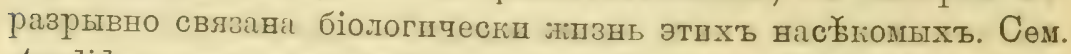
Aradidae - это тлг (Aphidac) средіг Hemiptera-Heteroptera, та্ьсно

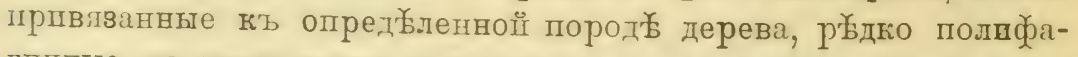
ппчвые, но очень тасто, переходя на другую породу дерева по

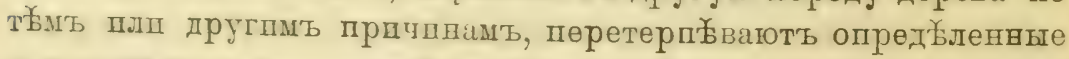

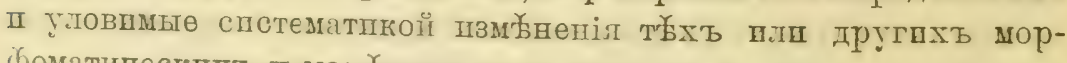
фоматических п морфологпдескихъ прпзваковъ.

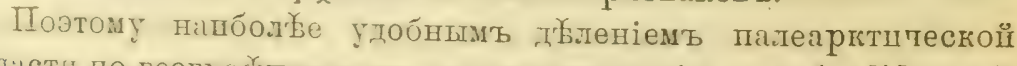

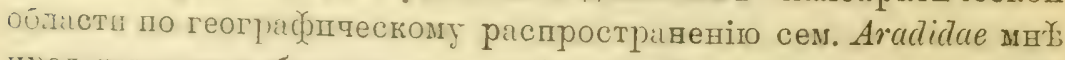

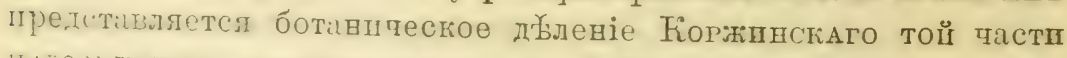

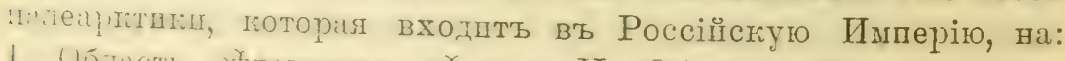

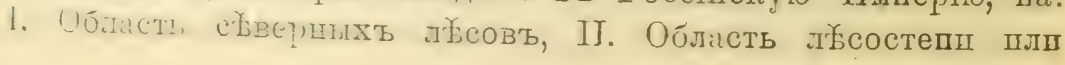




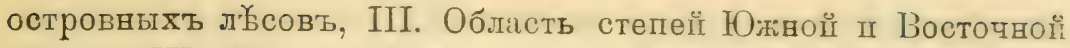

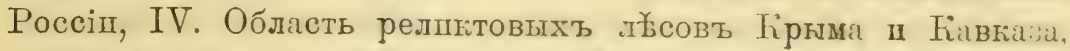

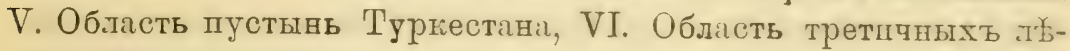
совъ Южно-У ссурійскаго края.

\section{I. Область съверныхъ льсовъ.}

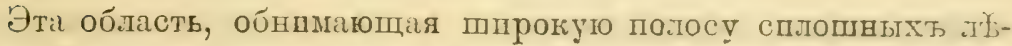
совъ Съверно-Европейской Россіи, спльно обезлъсенную въ исторпческое время Среднюю Россію и Спо̆рспуг тайгу, хирактеризуется вахотдевіем въ неї стьдующшхъ 25 впдовъ cen. Aractidae:

A. cimamomeus $\mathrm{P}_{\mathrm{Axz}}$.

A. depressus (FАBR.).

* A. erosus Falt.

A. truncatus Fieb.

*A. pallescens frigidus $\mathrm{K} I \mathrm{r}$.

*A. brevicollis Faldo ${ }^{1}$ ).

*A. betulinus FaLL.

A. corticalis (Lins.).

A. corticulis annulicornis $\mathrm{F}_{\mathrm{ABR}}$.

A. pictus $\mathrm{BAER}$.

*A. hieroglyphicus J. $\mathrm{S}_{\text {AнLB. }}{ }^{1}$ ).

A. betulae (Linn.)

*A. anisotomus Put. ${ }^{1}$ ).

*A. signaticornis R. F. SAHLB.

*A. pulchellus J. Sa Árb. $^{1}$ ).
A. lugubris FAI.t.

$* A$. angellaris J. SAHLB.

*A. laeviusculus ReUt.

*A. Taeviusculus f. simillimus REUT.

A. bimaculatus Reut. ${ }^{2}$ ).

A. vitiosus $\mathrm{J}_{\mathrm{AK}}$.

A. morio JAr.

*A. aterrimus Fieb.

*A. aterrimus f. moestus ReEt.

$* A$. aterrimus $\mathrm{f}$. diversicollis Reut.

A. nemtshinovae $\mathrm{J}_{\mathrm{AK}}$.

*A. crenaticollis R. F. S $\mathrm{S}_{\text {AHLB. }}{ }^{1}$ ).

*A. poppiusi Krr.

*A. (Qu.) brevirostris Horv.

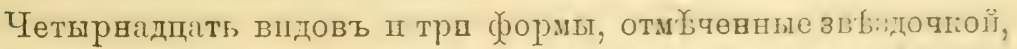
лвляются эндемпчнымп для области, висем, впдовъ (Avalus Urevicollis, A. anisotomus, 1 crenaticollis, A. hioroglyphlicus, A. pulted-

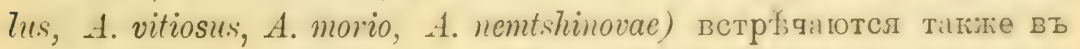

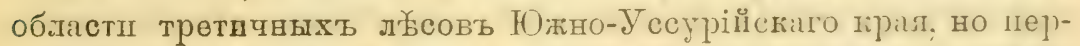
вые пять пзъ нихъ явияются несомтьнно европеїсло-сибпр-

1) Заходить также въ Прпморскуто область, но современвый центрь распространенія этого вида, повшдызому, вь области сыверныхт лысовы.

2) Въ Россіп видт этоть шавозстент тольто пзъ области степей, но

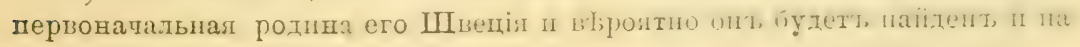
crisep Poccir. 
скпмп видамп, заходящимп также въ Южно-Уссурійскії край, наобороть наховідевіө въ Спбшрп A. nemtshinovae, A. morio (на запады до Томска) и $A$. vitiosus (до Забайкалья) сльддуетъ разсматривать, какь расширеніе пөрвоначальної области распространенія п на этп виды смотретть, какъ на типшчныхъ амуроуссурійскшхь. Остальные впды широго распространены по всему простравству Россіп (A. betulae, A. lugubris), плі почтп также шпроко распространены, но отсутствують въ Турке-

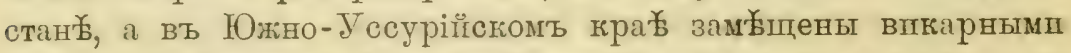
вшдамп (A. depresuss, A. corticalis anmilicornis), два вшда (A. cimna-

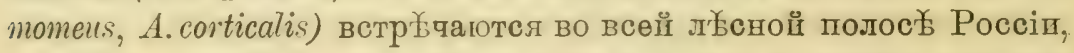
а также заходять первыи - Вь Закавказье, второй въ степи Вост. Россіи (Сарепта).

Распростравөніе трехъ впдовь (A. truncatus, A. bimuculatus, A. pictus) въ Россіп очень мало пзв бетно.

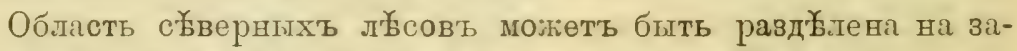
падную Европейскую тасть и на восточную - Спбцрь.

Въ Европейскої части нйдено 17 вшдовъ, пзъ которыхъ трі1 (A. truncatus Freв., A. signaticomis R. F. SAHLB., A. aterrimus Fгев.) до спхъ порь не найдены въ Сибпрп. Сибирская фауна обладаетъ 21 видомъ, взъ которыхъ 8 въ Европ官 не встрғчаготся (A. pallescens frigidus, A. hieroglyphicus, A. pulchellus, A. poppiusi, A. (Qu.) brevirostris, A. vitiosus, A. morio, A. nemtshinovae.

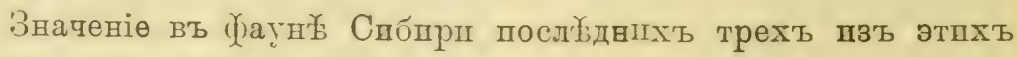
впдовъ разълснено выше, четыре впда прп совремөнномъ зняніш шхъ геограбопескаго распространенія являются эндемпескпмп видами Сибирп, ареаль геограбическаго распространенія которыхъ ограншчнается только той ея частыо, которая входшть въ Европеїско-Спбпрскую область (A.poppiusi, $A$. (Qu.). brevirostris) плп захватываеть и Вост. Азію въ предк्блахъ ЮжноЈссурійскаго края (A. 7ieroglyphicus, A. pul.hellus). Географ̆пческоө распространөніе перваго впда - A. pallescens frigidus представляеть удшвтельный пршмьрь прерывqатаго распростраве-

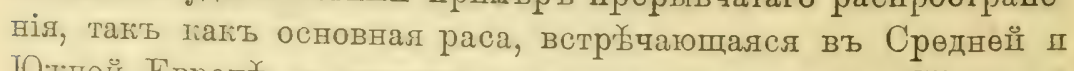

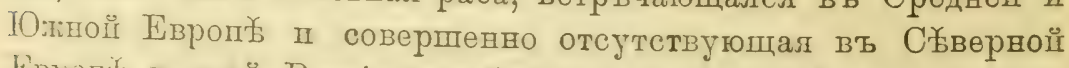

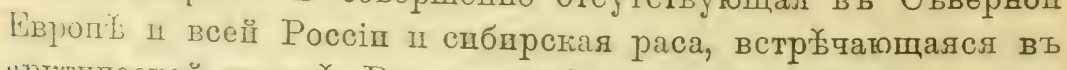
«ргтпрестой полосе Восточной Сибпрп въ настоящее время совөршенно пзолшрованы.

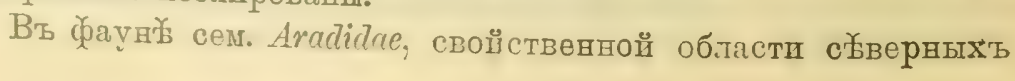


льсовъ, необохдимо өще отмүтпть существовавіе дйлаго рлди скандинавско-спбирскихъ впдовъ, т. е. область географическаго распространенія которыхъ огранпчена въ Европ年 тольто Спандинавскнмп странамп, а на восток', повндимому, проходящнми черезъ всю Сибирь. Виды эти слехвдующіе:

A. anisotomus, $A$. angularis, A. laeviusculus.

Такимъ образомъ всю эту область-область сұвернжхъ л务совъ можно характеризовать необычайнымъ богатствомъ вц-

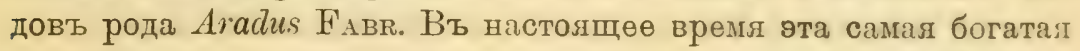
пми область, количественно превосходящая даже первобытныл

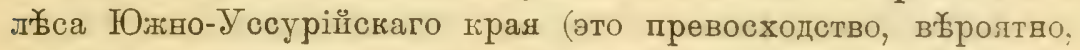
зависить только оть малої степени изученности полужесткокрылыхъ Дальняго Востока Россіп). Больпинство видовъ въ нее входящіе - эндемпчны п составляють положптельнуг характеристику өя. Отсутствіе многихъ средне-европейскихъ видовъ (A. versicolor, A. crenatus), пшироко распростравенныхъ въ Западной Европю, также чрезвычайно хараґтерно для нея и составляеть ея отрицательную зоогеографбпческую характершстику.

\section{II. Область льсостепи или островныхъ льсовъ.}

Этой области свойствены 9 видовъ сем. Aradidae:

A. cinnamomeus PANz.

A. megerlei Reut.

A. depressus $\mathrm{F}_{\mathrm{ABR}}$.

A. pictus BAER.

$A$. distinctus FieB.

A. betulae (Lins.)

A. corticalis (Lins.).

A. Tugubris FALL.

A. corticalis annulicornis (FABR.).

Среди этихъ видовъ н安т ни одного эндемичнаго для области, два впда (A. distinctus, A. megerlei) общіө съ областьо

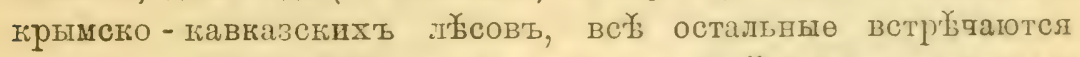

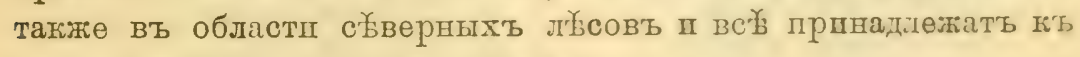
числу пирого-распространенныхъ.

Тажпмъ образомъ әта область хараптерпзуетея 1) џрезвычайнымь объдненіемъ видамп сем. Aruclidae, представленнаго почтп псключптельно очевь ппроко распростріненными видами, 2) присутствіемъ нъғоторыхъ болье юлныхт элементовъ:

A. distinctus, A. megerlei. 


\section{III. Область степей Южной и Восточной Россіи.}

Собственно говоря, эта область совершенно дшпена впдовъ ceм. Aradidae п, вай,енныхъ въ сбоверныхъ окраннахъ ел, пограндчныхъ съ л’бсостепью (Оренбургъ, Сарепүа); правпльне̌е отнести къ предыдущей области.

До спхъ поръ найдено здех্ьь 9 вшдовъ:

A. depressus ( $\mathrm{F}_{\mathrm{ABR}}$ ).

*A. eversmanni $J_{A \mathrm{~K}}$.

A. corticalis (Lins.).

A. corticalis anmulicomis FABR.

A. betulae (Lins.).
A. Tugubris (FALL.).

A. bimaculatus REUT.

$*$ A. selectus $\mathrm{J}_{\mathrm{AK}}$.

A. sareptanus $\mathrm{J}_{\mathrm{AK}}$ ?

A. sordidus Horv.

Пзъ этпхъ вштовъ 2 пли 3 эндемпчны для облісти (A. eversmanni, A selectus, ? A. sareptanus), остальные всъ, встрбчающіеся въ объихъ предыдущшхь областлхъ, тром посльдняго впда (A. sordidus), ветрбьчапцагося вт Венгріп, Нижней Австріп п Херсовской губ.

\section{IV. Область реликтовыхъ льсовъ крыма и Кавказа.}

Эта область тапже хорошо, кащь и область сүзвершыхъ л年совъ, можеть быть охараптергзована опред) төльнымп даннымп географфческаго распространенія сем. Ara-

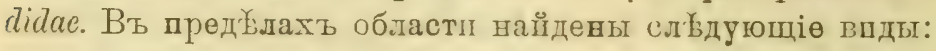

$* A$. versicolor H. $\mathrm{H}$-S.

*A. diversicomis Honv.

$* A$. tauricus $\mathrm{J}_{\mathrm{AK}}$.

A. cinnaniomeus $\mathrm{P}_{\mathrm{AxZ}}$.

A. depressus (FABr.).

*A. depressus leptocerus Horv.

*A. somcheticus KIr.

A. truncatus Fieb.
A. distinctus FreB.

*A. crenatus $\mathrm{S}_{\mathrm{Ay}}$.

A. corticalis annulicornis $\mathrm{FABR}$.

A. megerlei $\mathrm{R}$ EUT.

*A. caucasicus $J_{\mathrm{AK}}$.

A. betulae (Linn.).

A. Tugubris FALL.

*A. Alavicornis Dalir.

Восемь вндовъ шеъ общаго пшсла 15 эндемпчны для областп,

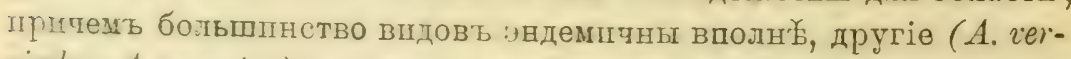
sicolor, A. crenatus) въ предҰлахъ Россійской Имперіп встрюьчаю-

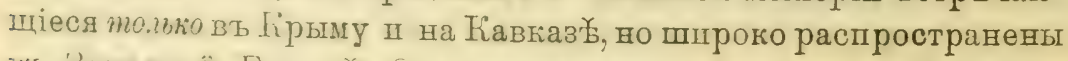

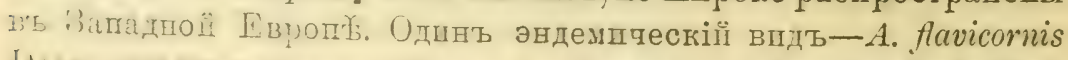

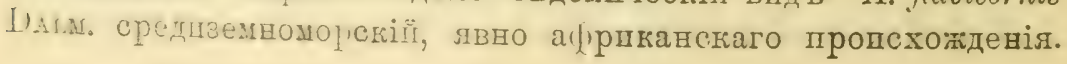




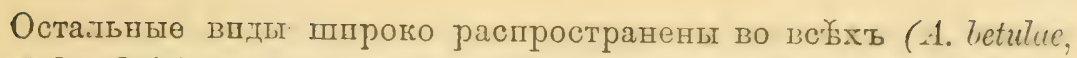
A. lugubris) плш почтп вебхь (A. cimamomeus, A. depressus, A. cor-

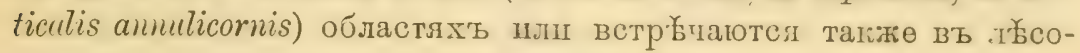
степной области ( $A$. distinctus, A.megerlei).

Въ Крыму пзъ этпхъ видовъ найдено 10, пзъ которыхт два (A. truncatus, A. megerlei) на Кавказ до спхъ порь не найдевы, на Кізиаз ба найдено 13 вндовъ, причемъ впды A. diversicornis, A. cinnamomeus, A. depressus Teptocerns, A. somcheticus, A. distinctus, A. flavicornis не найдены въ Крыму.

Эндемпчные вцды, гапь вцдимъ, почти всь пріурочены ліь

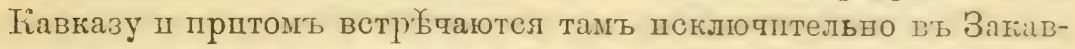

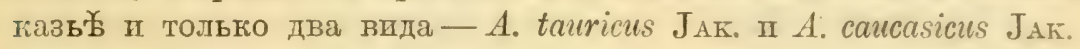
являютея әндемиками Крыма и Закавказья.

Такшмъ образомъ фауна области релштовыхь льсовъ Крыма II Гавказа характернзуетсл прпсутствіемь значительнаго количества эндемпчныхъ для нея впговъ сем. Aradiclae, проншкновеніемъ въ нее западныхт вцдовъ с бвернъе Крыма п Кавгаза на востоць не заходящихъ, отсутствіемъ сеґвверныхъ видовъ, нахожденіемъ средиземноморспихъ элементовъ, но что осойенно пнтересно въ трезвычайно невначительномъ колпчеств Т- 1 вшдъ; т. е. около $7 \%$ обцаго числа.

\section{จ. Ооласть пустынь Туркестана.}

Эта ойласть, совпадающая съ Туравскої провпнціей средшвемноморскаго подцарства, ръвко отличается оть встхт другихъ областеї ш характеризуется немногочислевної фауної по

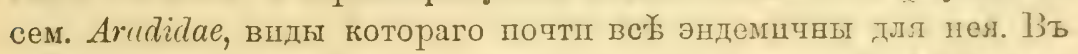
настолщее время пзвъстно шесть впдовь семейства, найденншхъ въ Туркестан䄈:

*A. Tomarovi JAK.

*A. setiger KIr.

*A. turkestanicus JAk.

*A. margianus $\mathrm{Kr}$.
A. betulae (Lins.).

*A. bergrothi $\mathrm{J}_{\mathrm{AK}}$.

A. lugubris FALL.

Четыре вида дія нея юндемшчы, ;ва шпрого распространены

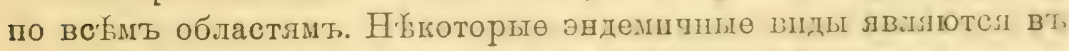

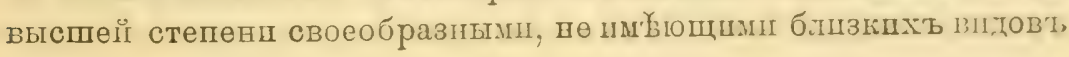
среди остального семейства. 


\section{VT. Область третичныхъ льсовъ Южно-Усеурійскаго} края.

Флунег этой областп свойствено большое чпсло видовъ

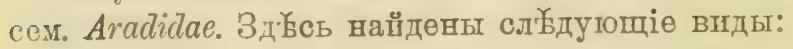
*A. spinicollis J $J_{\text {ATs. }}$
A. betulae (Linn.).
*A. ussuriensis $J_{\text {AT. }}$
A. anisotomus Put.
*A. consentaneus Horv.
A. putchellus J. Saнlв.
A. brevicollis FALL.
A. Tugubris FaLL.
*A. bergrothianus Krr.
*A. dissors KIr.
*A. compar Kir.
*A. transiens KIr.
$*$ A. vitiosus $\mathrm{J}_{\mathrm{AK}}$.
*A. melas J $\mathrm{J}_{\mathrm{AK}}$.
*A. semilacer Kir.
*A. unicolor KIr.
*A. morio $\mathrm{J}_{\mathrm{AK}}$.
A. pictus Baer.
*A. nemtschinovae JAK.
A. crenaticollis $\mathrm{R} . \mathrm{F}$. S $\mathrm{AHLB}$.
A. hieroglyphicus J. SAHLB.

Изъ чшсла 21-го вшда десять вполне для нея эндемдчнш, триг вдда (A. nemtshinovae, A.morio, A. vitiosus) заходять въ Европейско-Спбпрсхую оиласть, но главный центръ шхъ распространенія, несомнґнно, разсматрнваемал область. Остальные 8 видовт почті всб. (5) эндемпческіо европейско-спбпрскіө

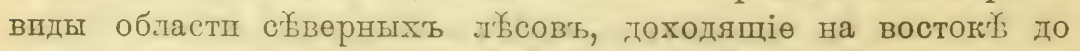

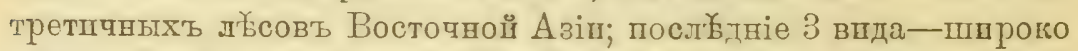
распространенные A. betulae, A. Tugubris II A. pictus BaEr., встрб-

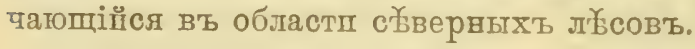




\section{Энологическія условія жизни серіи PHLOEOBIOTICA Reut.}

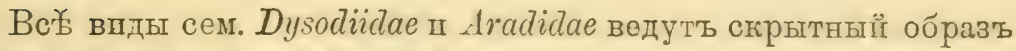
жизнп, прячась подъ корої деревьевъ пли въ трутовпкахъ п, псключая короткаго періода брачныхъ полетовъ у небкоторыхъ видовъ (Aradus depressus, A.lugubris), рбодпо попадаются на глаза даже энтомологу не спедіалшсту. Поэтому какпхъ либо наблюденій надъ образомъ жпзни әтшхъ плостихъ полулестгокртлыхъ, въ соверпенств 务 прпспособивппхся къ условіямт своей

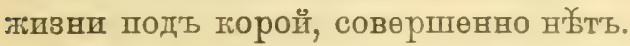

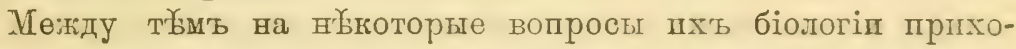
дштея натолкнуться даже прп пзученіп систематпки этпхъ сөмействъ и неим ъेніе данныхъ заставляетъ во многихъ случаяхъ воздержатьея отъ категорическаго сужденія о түххъ или другпхъ морффологцческихъ особенностлхъ нъкоторыхъ таксономпческихъ единицъ ІІ о значеніп этихъ особенностей длл систематики.

Такимъ вогросомъ, межлду прочпмъ, лвляетсл вогросъ о гормовыхъ растеніяхъ (деревьлхъ) видовъ сем. Dysodididae II - Ira-

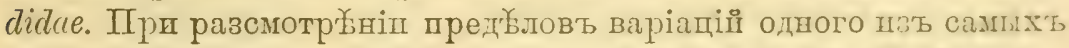
распространенныхъ вшдовъ рода Arudus: A. Zetulae (LIN⿴).) я

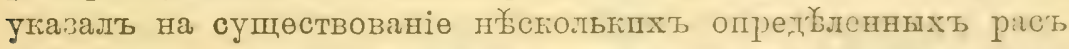

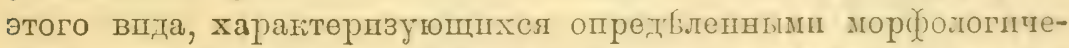

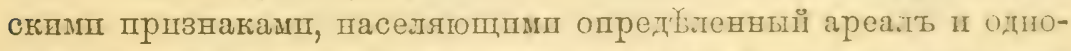

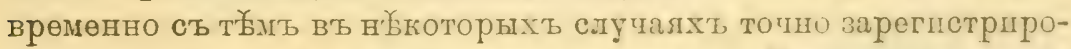
ванныхъ на друпих гормовыхъ деревьлхъ, ттеъъ основная раса

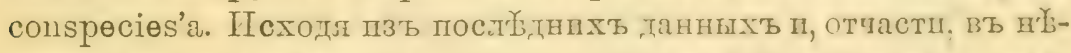
ғоторыхъ случаяхъ частпчнаго совпатеніз ареаловт геограбоческаго распространеніл, я приписываю вознпновепіе мир-

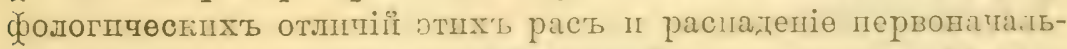

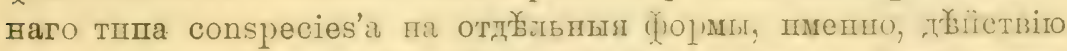

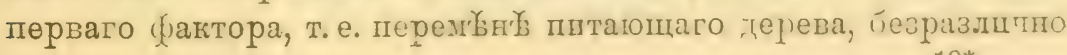


предшествовала-ли :та перемина географфпеской шзолядіп и обравованію самостоятельнаго арелла обнтаніл пли наобороть расппреніе пөрвоначальнаго ареала распространевія вызвало

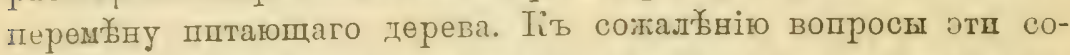
вершенно нө затронуты іл такіе виды водятся на томъ пли

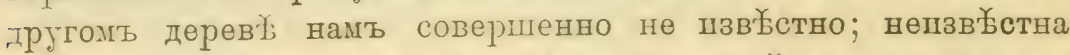
намь полпфагпчность піи монофагпчность түхх шлы другихь

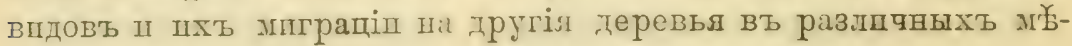
стностяхъ.

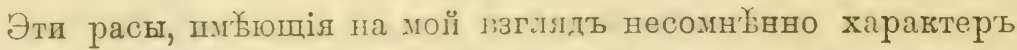

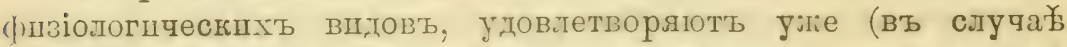

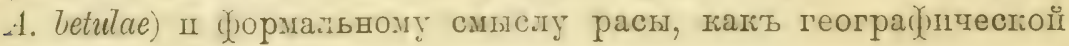
единшцы.

Нвже мы даемъ список, пормовыхъ растеніі п витовъ на

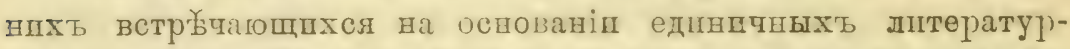
ныхт данныхт. Кіь сожалынію :тотт, сппсогъ является какъ бы сводкой аштературныхь цитатт и совершенно не освыщаеть

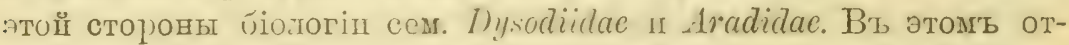
ношеніш громадную пользу могии бы прниести своцм наб́лю-

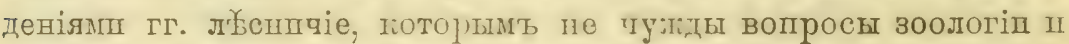
хорошо швв представителеї ливотнаго міра. Надлежащим образомь поставлепншї пу углубленный вопросъ этоть могъ дать не мало матеріалі для сүжденія о мвогихт теоретичесішхь вопросахъ воологін.

Списокъ кормовыхт деревьевъ серіи РНLOЕОВIOTICA Reut. съ указаніемъ вндовъ на ннхъ ветрбчающнхея.

Cerr. Tiliaceae.

Tilia. Aneurus macrotylus JAr.

Ces. Rosaceae.

Rosa. Aneurus tuberculatus MröB.

Pyruscommunis. Aradus crenatus $\mathrm{S}_{\mathrm{A}}$.

Cем. Urticaceae.

Dlmus.

Aradus depressus (FABr.). Aradus betulae (Lins.). 


\section{Ces. Cupuliferae.}

Quercus.

Aneurus laevis (FABr.). Aneurus tuberculatus Мјӧв.

Aradus depressus (FABR.).

Aradus crenaius $\mathrm{S}_{\text {A. }}$.

Aradus corticalis anmuliconis $\mathrm{FABr}$.

Fagus.

Aneurus tuberculatus Млöв.

Aradus depressus (FABr.).

Aradus depressus leptocerus HoRv.

Aradus crenatus $\mathrm{S}_{\mathrm{A} y}$.

Aradus caucasicus Kot.

Aradus betulae (Lrsw.) f. meridionnalis Krr.

Carpinus. Aradus depressus (FABR.).

Aneurus' tuberculatus Млӧв.

\section{Cem. Betulaceae.}

Alnus glutinosa. Aradus cimamomeus PAxz.

Aradus betulae (Linn.).

Betula alba. Aneurus laevis ( $\mathrm{H}_{\mathrm{ABr}}$ ).

Aradus cimamomeus PAxz.

Aradus depressus (FABR.).

Aradus crenatus SAy.

Aradus pictus BAER.

Aradus betulae (Тпхх.).

\section{Cem. Salicineae.}

Salix.

Aradus cimnamomeus PANz.

Aradus hieroglypticus J. SAнLB.

Aradus caucasicus KoL.

Aradus betulae (Lins.).

Aradus flavicomis DArM.

Populus.

Meziva tremulae (Gers.).

Aradus dissimilis Cosr.1.

Aradus pallescons H.-S.

\section{Cem. Laurineae.}

Lamrus. 


\section{Cем. Coniferae.}

Pinus silvestris. Aradus cimamomeus Paxz. Aradus corticalis (Lins.). Aradus anisotomus Рणт. Aradus lugubris FALL. Aradus crenaticollis R. F. S $\mathrm{AHLB}$.

Pinus nigra. Aradus (Quilnus) mirus Bergr. Aradus cimamomeus Panz.

Pinus koraien- irudus unicutor Kir. sis.

Picea excelsa. Aradus cimamomeus Panz. Aradus erosus Fall. Aradus betulinus FALL. Aradus corticalis (Lins.). Aradus pictus BaEr. Aradus Tugubris FALL. Aradus montandoni Revt.

Abies pectinata. Aradus crenatus SAy. Aradus betulae (Lisn.) f. ferruginens Kir. Aradus angularis J. SAHLB. Aradus Taeviusculus Reut.

Juniperus Aractus Tugubris FisL. Aradus cinnamomeus PANz.

Этоть спшсокт хасаетел слппюов немногшхъ впдов'ь ш, за

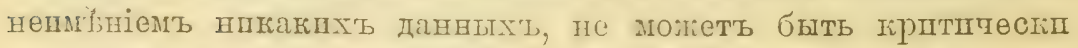

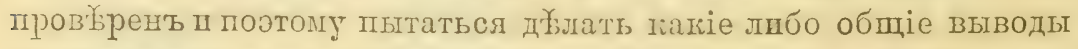

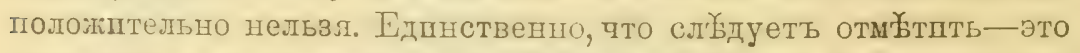
бросающеся вт глаза отлпчіе фаувы хвойныхь деревьевь оть фауны лшственныхъ п особенное богатство пөрвыхъ.

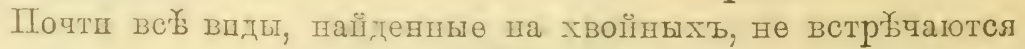

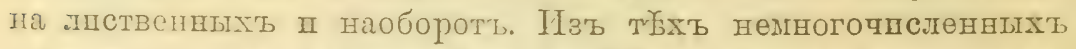

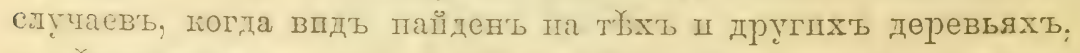
у шікоторыхт вндов' (A. cimamomeиs) этоть переходь можно поставить вт связь с’ь массовимь размно:іевіемь впда, нао́лю-

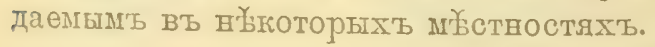




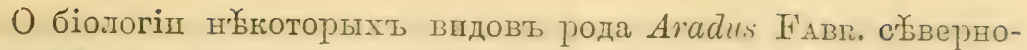
русской фүауны (окрестностей С.-Петөрбурга) пмҺются набли-

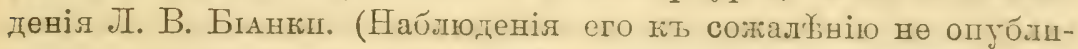

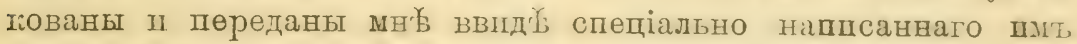

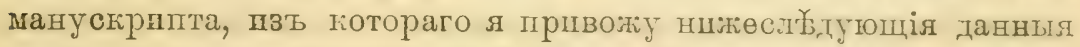

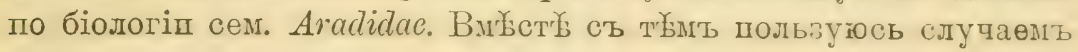
прпнестш мою г.убокою благодарность автору әтого манускрипта за его непзмвнную готовность слукить мн сиоми познаніями сеґверно-русской гемптероф(ауны).

Такь оказывается, что нбкоторые виды рога Avadus, шапр,,

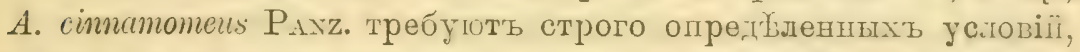

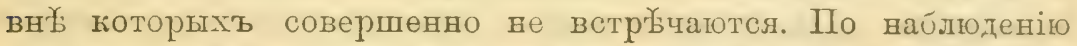

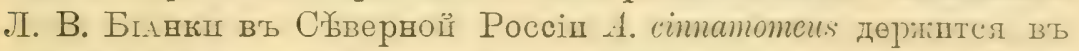
значштельнопь числ' особеї прешущественно, хотл и не шскпочптельно, на отдыльно стоящихь здоровыхь соснахь сред-

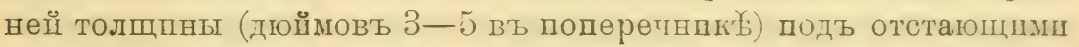
почти всеї своеї поверхностьо п.ластинами горы, ши'ьющим около $0,3-1,0$ милл. въ толщину пи прилегающими своеіи нджней стороної къ сочнымъ частямь коры.

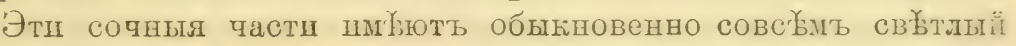

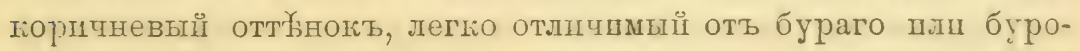
вато-гірпчневаго оттүнка прпкрывающихь пластннокъ. Мри собираніп Ar. cimnamomeиs нопь почти всегда нзлшенэ: подъ тьми пластингамп хоры, поторыя нө удается легко отколупнуть ногтемљ, Ar. cimnamomeиs не попадаетея почтп шнкогда. Подъ тонкимп, напоминаюцими папиросную бумажку, листками самаго верхняго слоя коры стволовь молодыхъ сосенокь пли торой

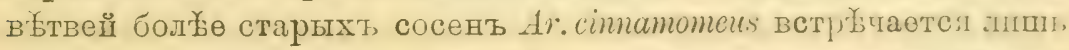

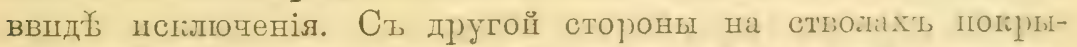
тыхь очень толстыми пластинамш горы, а такіө на соснахь,

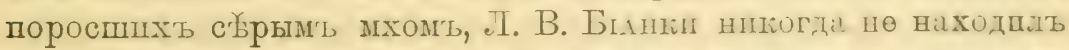
этого клопа, хотя до посльъдияо времеши не о́росалт, попітокт,

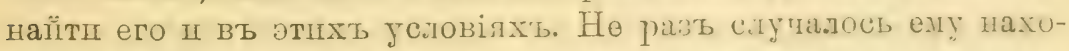
дить Ar. cinnamomeus рлдомь со етарыми, мпиетьми стьлдами,

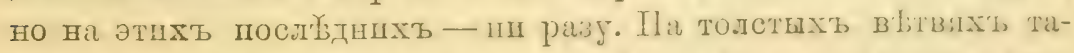

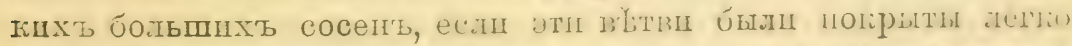

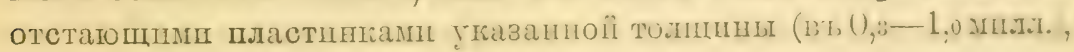

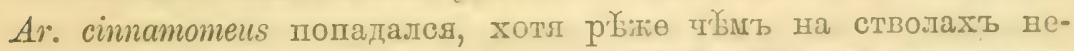

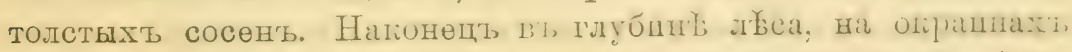

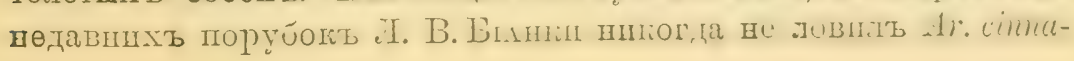




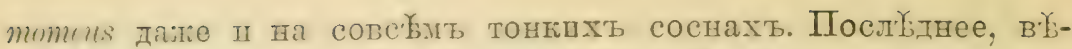

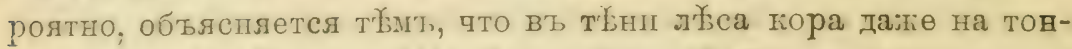

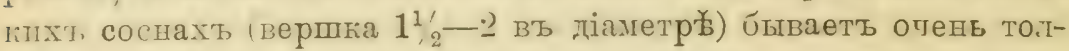
чта іл нлопт, ве можеть добраться до сочвыхт частей деревьевъ.

Такшмь образомь главнымь үсловіемт, тоторому толжна удовлетворлть сосна, чтобы на ней могли суцествовать и хо-

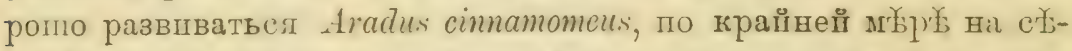

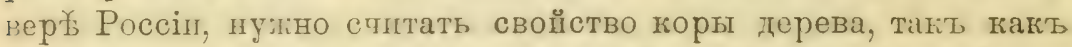
сочныл части коры сосны доставлпотъ ему пшщу. $\mathrm{O}$ этої по-

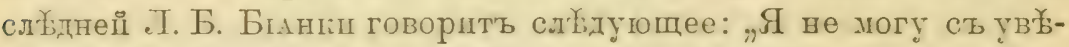

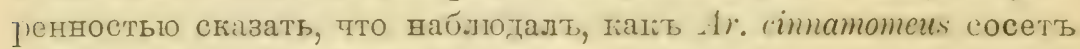

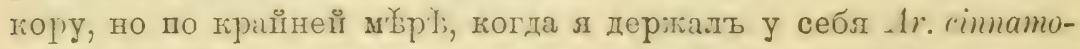

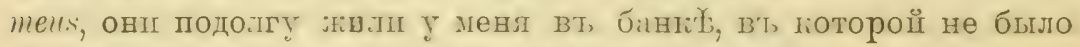
ничего, ғромг; кусковъ соснової коры (времл оть временіг за-

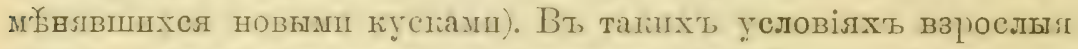

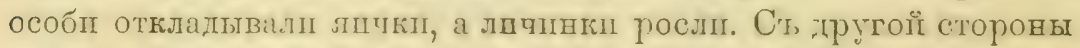

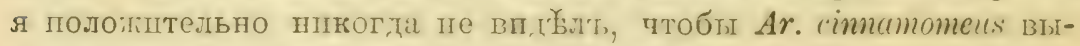

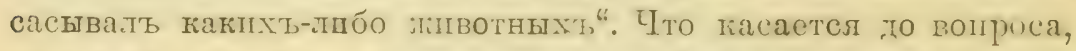

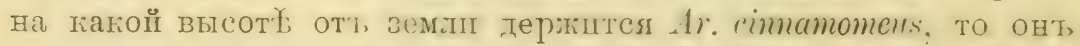
встүитался почтп отъ самої земли то высоты о, дой сажөни, но нуть освованій думать, тто онт, не забпраетел пи очень высоло.

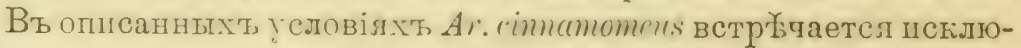

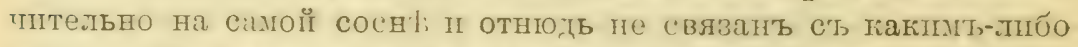

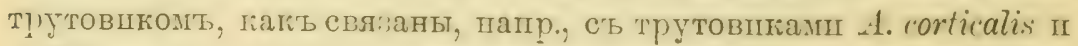
A. betulae.

Arailus cinnomomeus въ С.-Петербургстой губерніп встр‡пается исплючительно на соснат (Pinus silvestris), прпчемъ $q$ ㅇ f. brachyltera ветрбчаютея несравненно уаще f'. macroptera, a

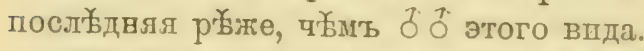

Об́ь f. macroptera әтого вида :I. В. Бннки, между прочнмъ,

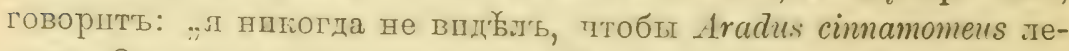

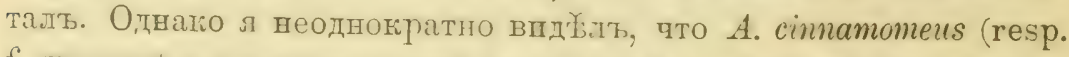
f. macropteral раскрываеть своп крылья, точно готовлсь улетуть, тимь харағтерным двиғеніемъ, которое свойственно многимъ клопамь передъ умираніемь".

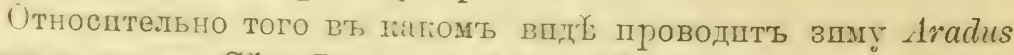

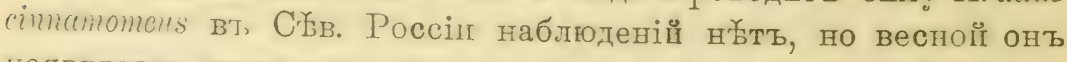
полвляетсл опешь рано, такъ напр, есть дата появленія его въ

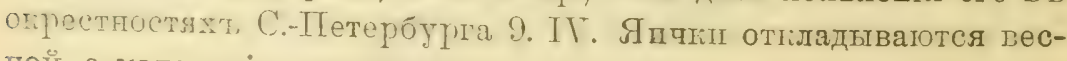
ної, а малешқія лпчнни попадаются съ начала іюня. 
Тюобопытую біологпческую особенность подиятить у этого вида Л. В. Бданки, состоящую въ спосойностц әтого вида вІсёть на корұ прп помощи какой то ншточкп. Очень часто слтqается, qто прп отколупывавіп пластпнци коры та плш пная особь $A$. cinnamomeиs но спдить, пршжившсь къ сочному слою коры, какъ это бываеть чаще всего, но подбшраеть полт сейя ногп, складываөть вытянутые впередъ успк п повпелеть безь двшженія. Еслп дуетъ вь́теръ, хотя бы цдовольно спльный, он шевелпть повпсппмъ плопомъ, но не въ состолніц си́росить

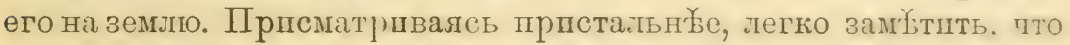

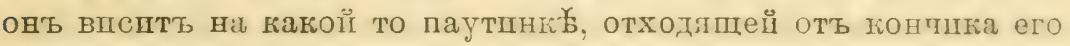
сложенныхъ усиковъ.

Представляеть ли эта паутнниа продукть выд бленія самого клопа или она ничто пное, какъ тягучая смола сосны, нешзвегестно.

Біологію другого обыкновеннаго внда Сłверной РоссіпAradus depressus (F.вк.) Л. В. Банки совершенио не удағось выясвпть. Онь находиль его толыо весной „когда A. depres.sus

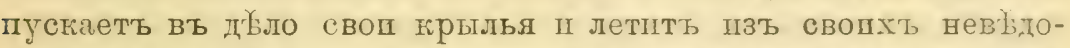

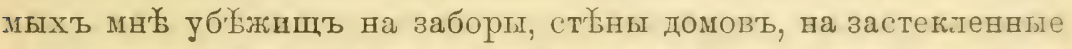
балконы, садптся на дөревья, нө отдавая предпотенія, повиде-

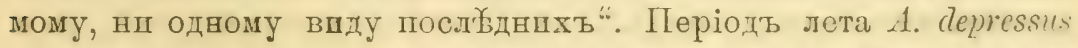
приходится въ среднель на вторую половину десятыхъ пшсель мая. Можетъ быть, благодаря этшмъ полетамъ, веролтно брачнымъ, онъ приводится для самыхъ ризлптныхъ породъ

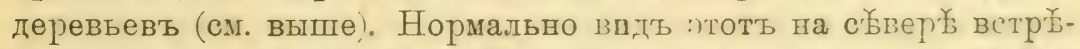

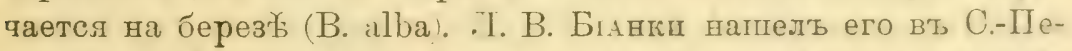
төрбургекой губерніп на сломанныхъ бурею березать на мъстахъ перелома.

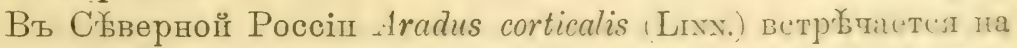
большихь еловыхъ пняхь, поросшихь трутовитомь Polyporus pinicola п покрытыхь толстой корой, по,т ноторув ему

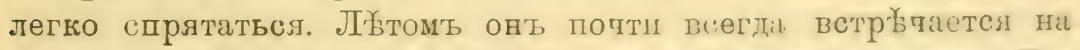
самомъ трутовпке

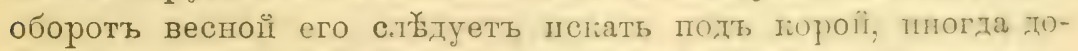
вольно далеко оть трутовпк, но также веег, қа па такихь пияхт.

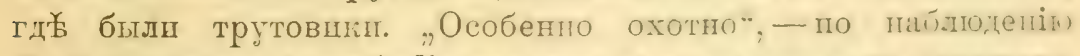

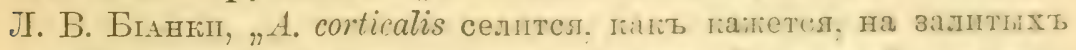

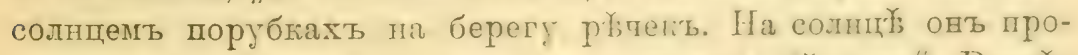

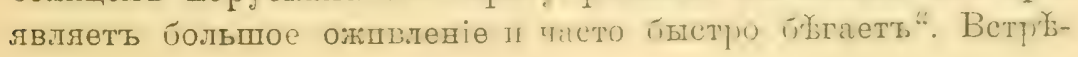


पаөтся, какъ сказано, A. corticalis въ нашеї метстностп толью на елі п ншкогда не быль находши нп на здоровыхъ, ни на поврелгденныхт деревьяхь, а только ва пняхь. Далюе Ј. В.

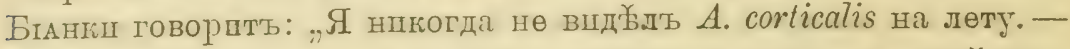
Въ невол年 онъ очень тегғо откадываеть лпчки на коре́ елп; ұзъ которыхъ выходять маленькія, красныя личшнкш. Јпчцнкп

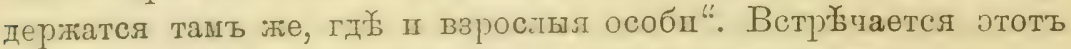
вшдъ обыкновенно очень многочпсленнымш колоніямш.

Aradus betulae (Lixх.) самый распространенныи вид рода почтп по всей палөарктической областп. Вь Сłверной Россіп везд⿱⺊口灬 гд⿱⺊口灬 есть береза (Betula alba) сь не очень молодымп трутовикамп-Polyporus sp., всюду можно разсчптывать наіты A. betulae, вачпнал съ ранней весны п лончая позднеї осөнью.

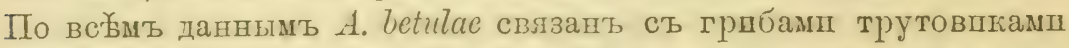

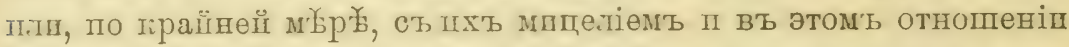
соверпенно сходен'ь съ 1. corticalis. Но въ то зремя какь тоть живеть пснлючительно ни пияхь (еловыхь), A. betulue держптся не только па большихъ березовнхъ пняхъ II на сухостођ, но такле и на соверпенно здоровыхь березахъ. Вірочемъ на здо-

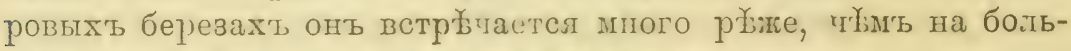
ныхъ, да и то почти всегда не пнач, какт около повренден-

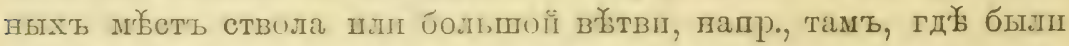

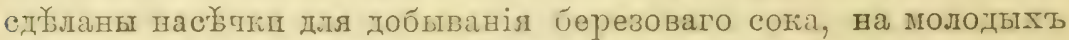
б́ерезкахъ, пзгрызенныхъ :аӥцамп ил т. п. „A. betulae" говорить

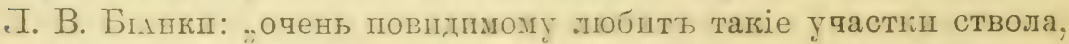
на которыхь вокругь трутовика ростуть лишайнип, а кора неровная, задерпстая, дапщая клопу шозможность спрлтаться въ трещшны ш подъ ея, тапт, сказать, поспутьям. Снявъ сь

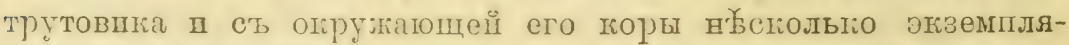
ровъ 1 . letulae, обыкновенно черезъ ногеколыо днеї снова на-

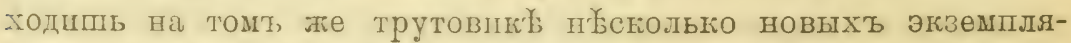
ровъ. Особенно быстро возстанавливается уо̆ыль весної:".

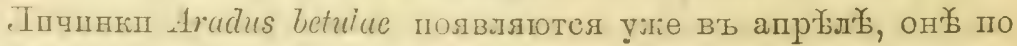

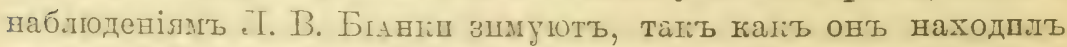
очень метпікъ, толью пто вылупдвшихся лпчшнокъ въ по-

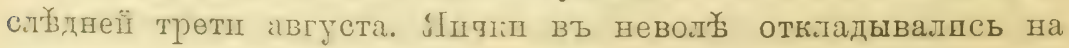
жору беревы въ концर्भे мая.

Aractus trevicollis Fal. найдень однвъ разъ Ј. В. Блннкп на

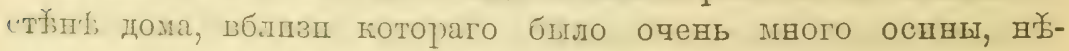

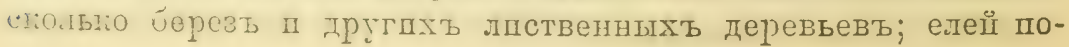


близости не было, по үстному жіе сообщенію О. М. Тестер'а

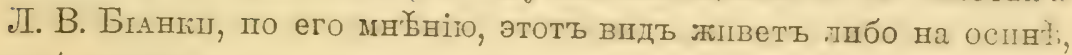
лшбо на ели.

Одной пзъ чрезвычайно важныхъ задачъ пзученія б́іологіп серіш Phloeoliotica гажется намь пзученіс пхт метамор-

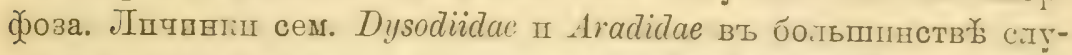

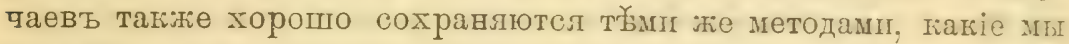
пршманяемь къ imagines, a спстематпческо пзуеніе іп описаніе пхь даөть возможность выяснить зпаченіе тихь прлзва-

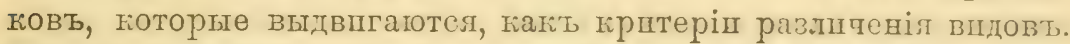
Изъ того небольшого матеріала по личннгамъ сем. Aradidae. поторый пмйетея въ коллегціяхь Зоологпческаго Музея молно

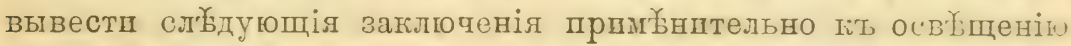
тьхт прпзнатовъ, поторпмп я особевно пользовалея прп составленіц опредеㅎлительной таблпцы впдовъ әтого семеїства (resp. рода Aradus FАвR.).

Тағъ строеніе успковъ, являлсь понсервативнымь вшдовымь

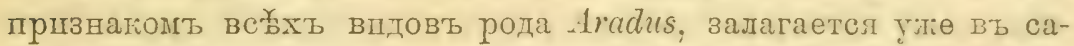
мыхъ ранншхъ стадіяхь постэмбріональнаго развитія въ түјъ существенныхъ чертахь, которыл впосльгдствіц будуть суцествовать э взрослыхъ насґпомыхъ. Напр., личпвка i. versicolu.

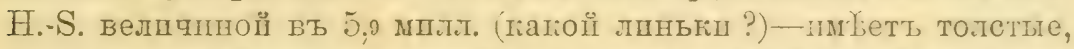

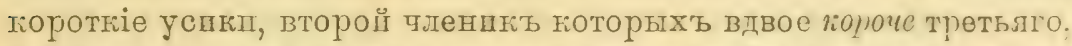
а третій членшкъ, псключая его основанія, бълаго цвъта, тоесть уже обладаетъ всбмп специфопческиш особөнностям въ строе-

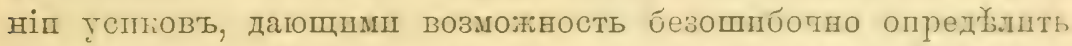

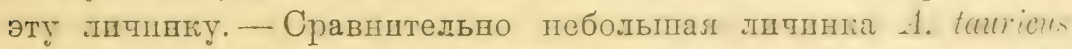

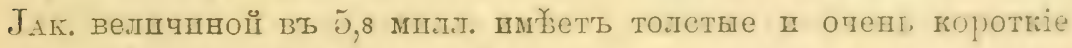

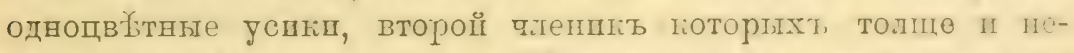

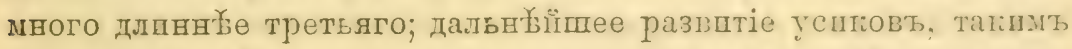

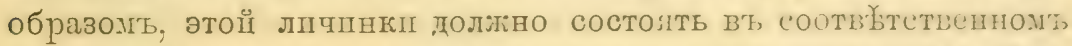

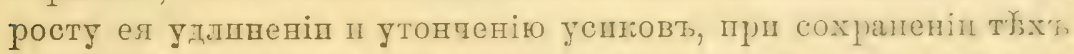

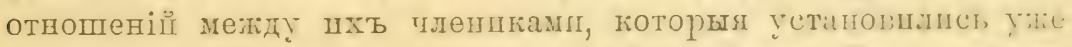

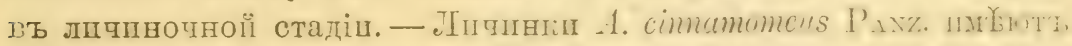

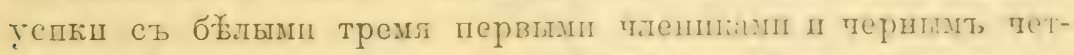

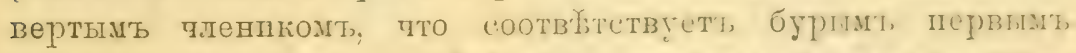

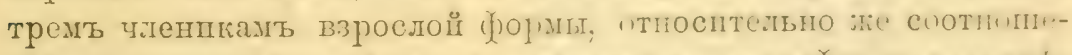

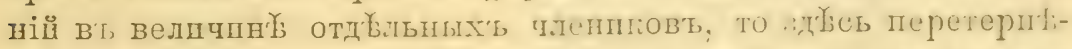

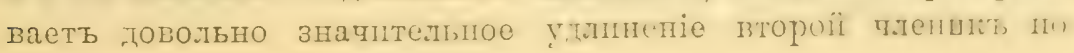




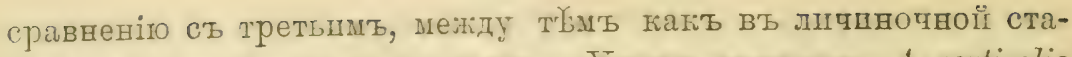
діп онш почтп что равновелпи. - Јешкп лпчпног'ь A. corticalis (Lмх.) па разньхъ стадіяхь развитія (моп эғземпляры оть

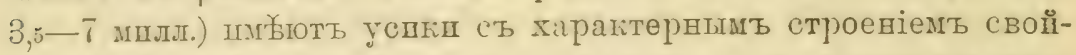
(твенной этой групп'з, т. е. вторымт членикомъ подтп цилин-

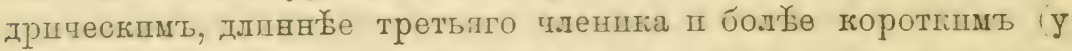
пејвоіг стадіш), равнымъ плш болте длиннымъ, но очень немного

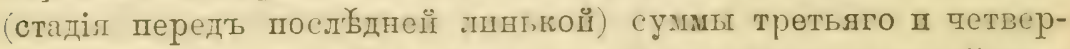

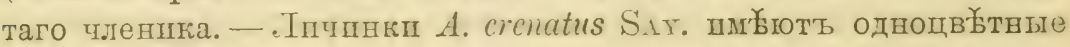

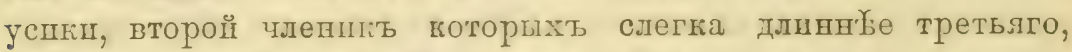

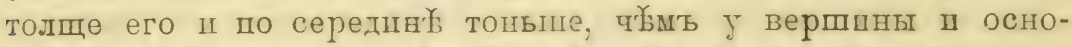

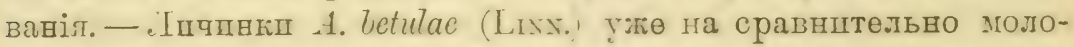
дыхь стаділхь развптія пмејють характерное строеніе второго шленика успковъ, готорый сильо удлинненъ п гораздо длинв

Точно тағже уже вт ранних стадіях развитія затагаетея все характерное воорулене голоп, такъ, чапр., боковые от-

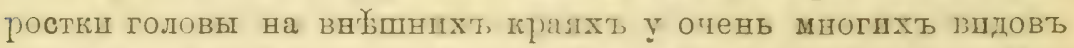
рода, жакъ извбетно, несуть особые зубцы шли бугоргіл. Эти зубды ушіе существуоть' у ппшнокт (въ этомъ отнопевін $\Omega$

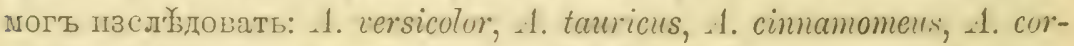
ticalis, A.crenutus, 1. turlicstanicus, 1. betulac, 1. anisotomus, A. simaticornis).

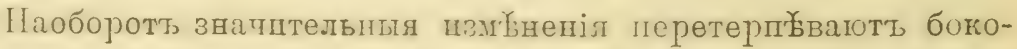

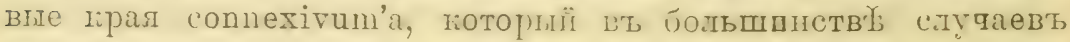
яшллетсл спльно отличымъ ! взрослыхъ осойей по сравненію

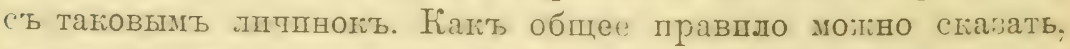
тто задніе углы connexivum'а у шпчннокъ всегда несравненно

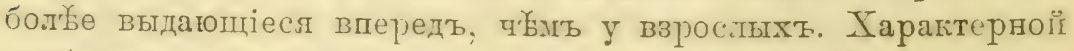

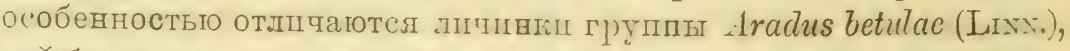

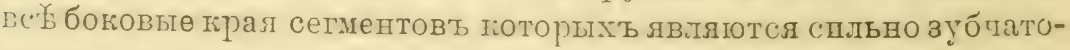

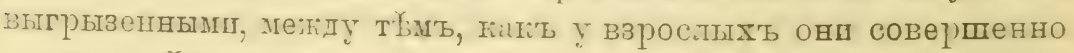
прямые, ц'обльные. 


\section{Алфавитный указатель.}

affinis (Aradus) 210.

alata (Acanthia) 90.

albopunctatus (Aradus) 85.

amplicollis (Aradus) 197.

Aneuridae 3, 6.

Aneurisoma 52.

Aneurus 5, 33.

angularis (Aradus) 66, 221.

angusticollis (Aradus) 224.

anisotomus (Aradus) 65, 197.

annulicornis (Aradus corticalis subsp.) $63,149$.

annulicornis (Aradus) 149.

annulicornis (Aradus) 185.

annulicornis (Aradus) 197.

annulipes (Aradus) 135.

radacanthia 5 .

Aractida 49.

Aradidae 3, 49 .

Aradidea 49.

Aradides 49.

Aradina (Aradidae subf.) 49.

Aradini 49.

Araditae 49.

Aradoidea 49.

Aradosyrtis 6 .

Aradus 52.

Aradus (Aradus subg.) 59.

Arictus 7.

Arictus (Brachyrhynchus subg.) 7.

armatus (Aradus) 103.

aterrimus (Aradus) 67, 249.

atra (Nezira) 10, 18.

arenius (Arachus) 37. basalis (Brachyriynchus) 33.

basalis (Mezira) 33.

bergrothianus (Aradus) 62, 124.

bergrothi (Aradus) 65, 206.

betulae (Acanthia) 185.

betulae (Aradus) 64, 185.

betulae (Aradus) 194.

Betulae (Cimex) 185.

betulinus (Aradus) 63, 138.

bimaculatus (Aradus) 66, 231.

Brachyrhynchidac 3.

Brachyrhynchidae (Aradidae subf.) 3.

Brachyrhynchinae (Aradidae subf.) 3.

Brachyrhynchus 7.

Brachyrhynchus (Brachyrthynchus subir.)

7 .

brenskei (Aradus) 64, 194.

brevicollis (Aradus) 62, 121.

brevicollis (Aradus) 138.

brevicornis (Mezira) 10, 30.

brevirostris (Aradus (Quilnus)) 26t, 267.

Calisiopsis 5.

Calisius 5, 6 .

carpini (Acanthia) 37.

castanea (Mezira) 10, 26.

caucasicus (Aradus) 6t, 175.

caucasicus (Aradus) 172.

cedri (Aradus) 271.

cinnamomeus (Aradus) 61, 85.

cinnamomeus (Aradus) 111.

compar (Aradus) 63, 128.

complanatus (Aradus) 141. 
consentaneus (Aradus) 61, 97.

conspicuus (Aradus) 135.

corticrlis (Acrnthia) 111 .

corticalis (Aradus) 63, 144.

corticalis (Aradus) 135.

corticatis (Cimex) 144.

Corticolae 49.

crassicornis (Aradus) 272.

crenaticollis (Aradus) 68, 254.

crenaticollis (Aradus) 153.

crenatus (Aradus) 63, 135.

deqressa (Acanthia) 90.

depressus (Aradus) 61, 90.

dilatatus (Aradus) 135.

dilatatus (Brachyrhynchus) 12.

discedens (Aradus (Quilnus)) 264, 268.

dissimilis (A radus) 96.

dissors (Aradus) 66, 227.

distinctus (A radus) 62, 118.

diversicollis (Aradus aterrimus f.) 67 , 251.

diversicornis (Aradus) 60, 72.

Ductirostri (Corticolae trib.) 49.

Dusius 7.

Dysodiidae 2, 3.

ellipticus (Aradus) 185.

emarginatus (Aradus) 62, 124.

erosus (Aradus) 61, 102.

eversmanni (Aradus) 62, 116.

ferrugineus (Aradus betulae f.) 191. flavicornis (Aradus) 65, 217.

flavo maculata (Piesostoma) 217.

Haromaculatus (Aradus) 217.

frigidus (Aradus pallescens subsp.) 62,114 .

g'elteri (Aradus) 210.

genconymus (Aradus) 185.

ghiliani (Aradosyrtis) 6.

ghiliani (Calisius) 6.

hahni (Aradus) 273.

herculeanus (Aradus betulae f.) 192.

hieroglyphicus (Aradus) 64, 168.

indicus (Aneurus) 48.

Isoderminae (Dysodiidae subf.) 2. komarovi (Aradus). 64, 156.

Komarowii (Aradus) 156.

krueperi (Aradus) 64, 172.

kuthyi (Aradus) 105, 271.

laevis (Acanthia) 37.

laevis (Aneurus) 36, 37.

laevis (Aradus) 37.

laeviusculus (Aradus) 66, 224.

lauri (Aradus) 272.

lawsoni (Aradus) 271.

leptocerus (Aradus depressus subsp.) $61,95$.

Leptopterus 52.

leptopterus (Aradus) 85.

leucotomus (Aradus) 217.

levis (Aneurus) 37.

Lucasi (Aneurisoma) 217.

lugubris (Aradus) 65, 209.

macrophthatmus (Avadus) 65, 217.

macrotylus (Aneurus) 37, 43.

margianus (Aradus) 182.

megerlei (Aradus) 153.

melancholicus (Aradus) 149.

melas (Aradus) 63, 150.

meridionalis (Aradus betulae f.) 191 .

Mezira 5, 7.

Mezirina (Aradidae subf.) 3.

mirabilis (Aradus) 127.

mirus (Aradus (Quilnus)) 264.

moestus (Aradus aterrimus f.) 67, 250. moestus (Aradus) 250.

montandoni (Aradus) 272.

montivagus (Aradus) 141.

morio (Aradus) 67, 246.

nemtschinovae (Aradus) 67, 251.

nemtschinovi (Aradus) 251.

Neuroctenus 4.

nigricornis (Aradus lugubris f.) 65, 216.

notatus (Aradus) 271.

Orientalis (Aradus) 127, 272.

ovirentris (Mezira) 26.

parvicollis (Aradus (Quilnus)) 273.

pallescens (Aradus) 62, 111. 
Perrisi (Aradus) 85.

Perrisii (Leptopterus) 271

Perrisii (Stenopterus) 271.

Phloeobiotica 1.

pictus (Aradus) 65, 165.

Piesostoma 52, 94.

plana (Acanthia) 90, 143.

planus (Aradus) 63, 141.

poppiusi (Aradus) 68, 259.

pulchellus (Aradus) 65, 204.

pygmaeus (Aradus) 7.

rectus (Aradus) 210.

reuterianus (A radus) 61, 109.

Quilnus (Aradus subg.) 59, 262.

Sareptanus (Aradus) 66, 236.

scabrosa (Mezira) 32.

selectus (Aradus) 66, 233.

semilacer (Aradus) 67, 243.

serbicus (Aradus) 272.

setiger (Aradus) 64, 159.

setosa (Mezira) 10, 15.

signaticornis (A radus) 65, 200.

simillimus (Aradus laeviusculus f.) 66, 227.

simillimus (Aradus) 227.

simulans (Aradus betulae f.) 185, 192.

sinensis (Aneurus) 37, 46.

somcheticus (Aradus) 61, 100. sordidus (A radus) 67, 237.

spinicollis (Aradus) 60, 74 .

spiniger (Coreus) 68.

Stenopterus 52.

stenopterus (Aradus) 271.

subsimilis (Aradus (Quilnus)) 273.

tauricus (Aradus) 61, 82.

tenericornis (Mezira) 26.

transiens (A radus) 63, 131.

tremulae (Aradus) 11.

tremulae (Dysodius) 11.

tremulae (Mezira) 10, 11.

tristis (Aradus) 103.

truncatus (Aradus) 61, 106.

tuberculatus (Aneurus) 36,40 .

turkestanicus (Aradus) 64, 179.

unicolor (Aradus) 65, 162.

ussuriensis (Aradus) 60, 78.

Varia (Acanthia) 185.

varius (Avadus) 165.

verruciger (Brachyrhynchus) 21.

verrucigera (Mezira) 10, 21.

versicolor (Aradus) 60, 68.

vitiosus (Aradus) 67, 240.

Wagneri (Aradus) 20 4. 


\section{Объясненіе таблицъ рисунковъ.}

\section{Таблица I.}

1. Mezira tremulae (Geru.) ‥ (Дагестанская обл.: Дербенть).

2. Mezira atra $\mathrm{J}_{\mathrm{AK}}$. 오. (Южно-У Ссурійскій жрай).

3. Mezira castanea JАК. О. (Южно-У ссурійскій край, типъ).

4. Aneurus sinensis n. sp. 万. (пров. Съ-чуань: Таціен-лу).

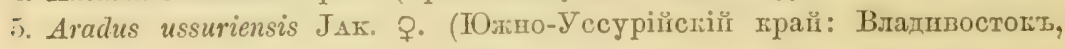
тामъ).

6. Aradus compar n. sp. Ј. (Южно-Јесурійстій край: Владпвостогъ).

7. Aradus tauricus ЈАк. ㅇ․ (Іірымь: Косьмо-Даміановскій монастыру, тппь).

$\therefore$ Aradus erosus FalL. Ј. (Ятутспал туб́.: Ытыпъ-хая).

1. Aradus spinicollis JАЕ. ㅇ. (Южно-У ссурійсгій трай: Владивостогъ).

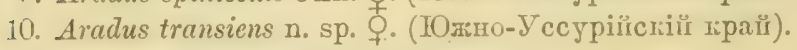

11. Aradus melas $J_{\mathrm{AK}}$. $\mathrm{Q}$. (p. Амурт).

1.). Aradus setiger n. sp. ‥ (Свръ-Дарьнискал обл. : Перовскт).

13. Aradus komarovi JАK. ‥ (Запаспійская обл.: Чулли, тппт).

14. Aradus unicolor n. sp. 우 (10жно-У ссурійскій прай).

1;. Aradus semilacer n. sp. O. (Тано-Уссурійскій трай: Нпгольскт).

\section{Таблица II.}

16. Aradus pallescens frigidus nov.. . (Ягутская обл.: ЖЖиганспъ).

17. Aradus anisotomus Рuт. ‥ (Архангетьсая губ.: Нопова пзба).

1ऽ. Aradus caucasicus Kог. ‥ (Дагестансгая обл.: Дербенть).

19. Aradus hieroglyphicus J. SАнцв. Оे. (Еншсейская губ.: ЖЖевлево).

201. Aradus signaticornis R. F. S

21. Aradus angularis J. S

22. Aradus bergrothi JАК. б. (Сћрь-Дарьинская обл.: Тапкентъ, типъ).

23. Aradus dissors n. sp. ㅇ. (Южно-У ссурійскій грай: Владивостокъ).

21. Aradus laeviusculus Revт. 오. (Фпнляндія: Sammatti).

ע. Aradus nemtshinovae JАк.

2t. Aradus bimaculatus Reut. ‥ (Шиедія, типъ).

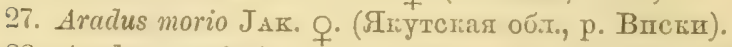

28. Aradus poppiusi n. sp. ㅇ. (Якутекая обл.: Батылицъ).

29. Aradus crenaticollis R. F. SАнцв. O. (С.-Петербургь).

:0. Aradus (Quitnus) mirus Bergr. о: (Австрія: Вбна, типъ).

31. Aradus (Quinus) discedens Horv. Oे. (Боснія). 


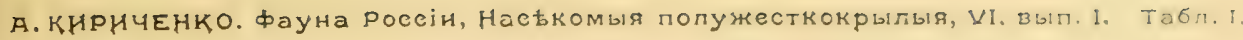
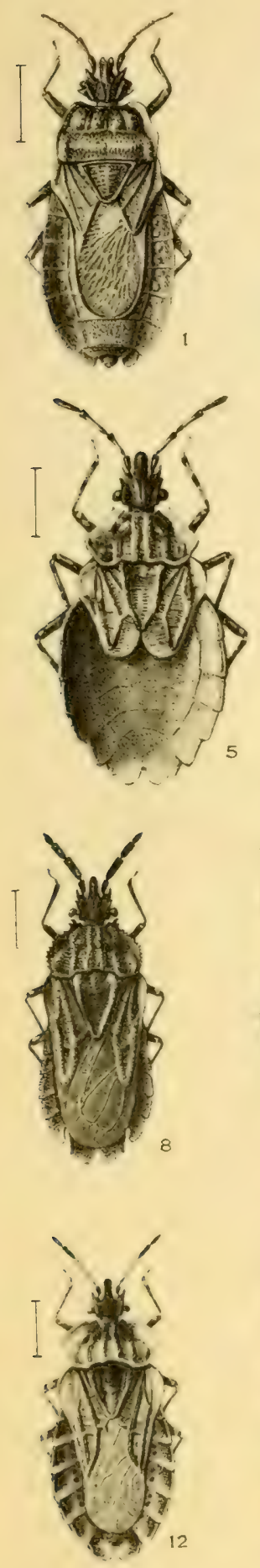
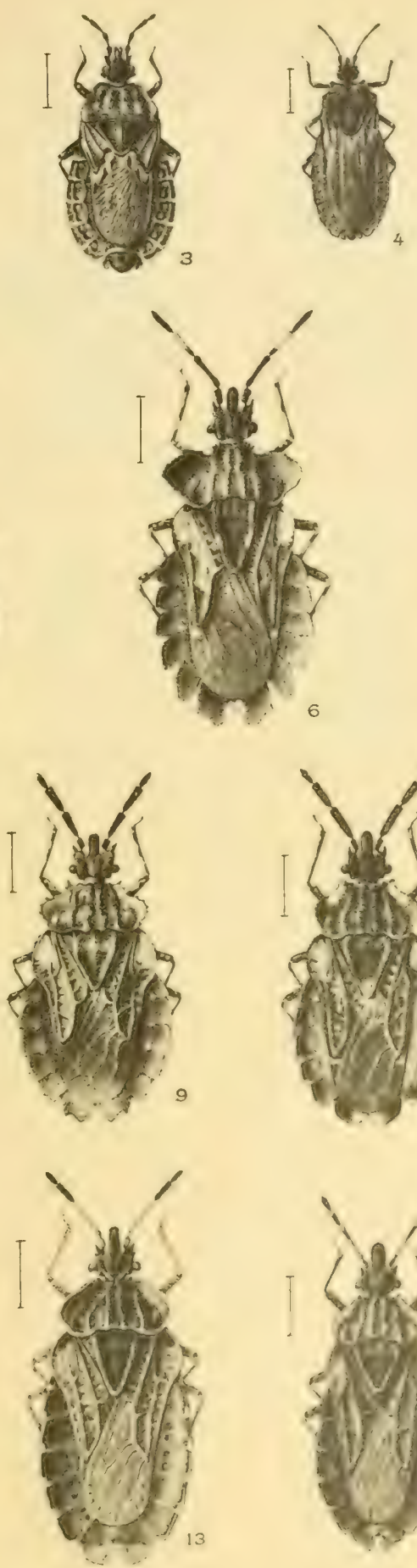
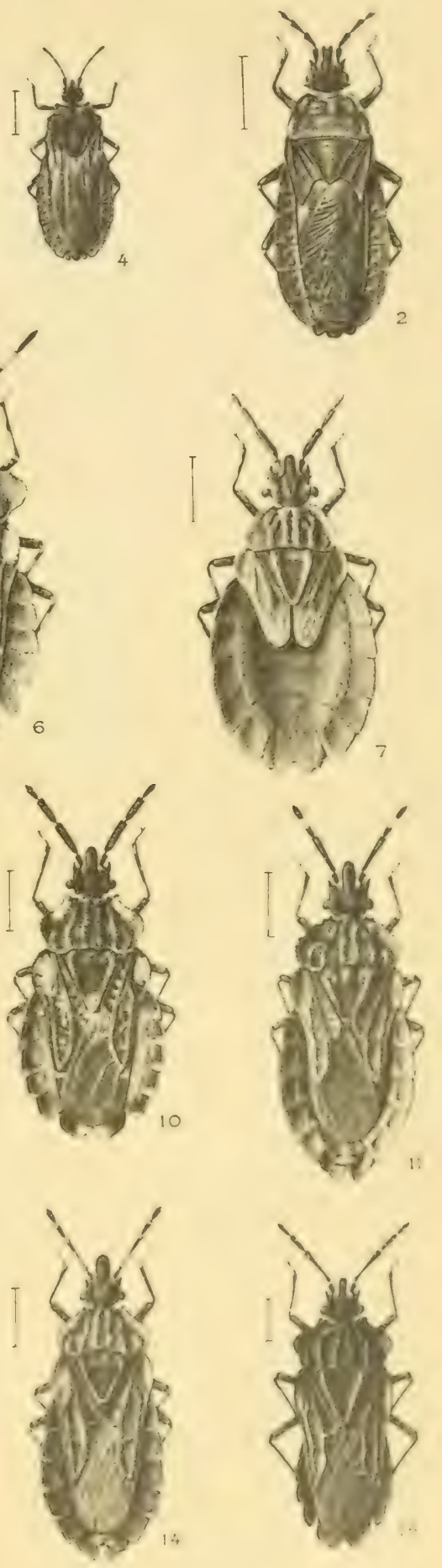

А. КНРКЧЕНКО. фауна россін, Наеькомыя попужесткокрылыя, VI. Bып. I. Tабл. Il.
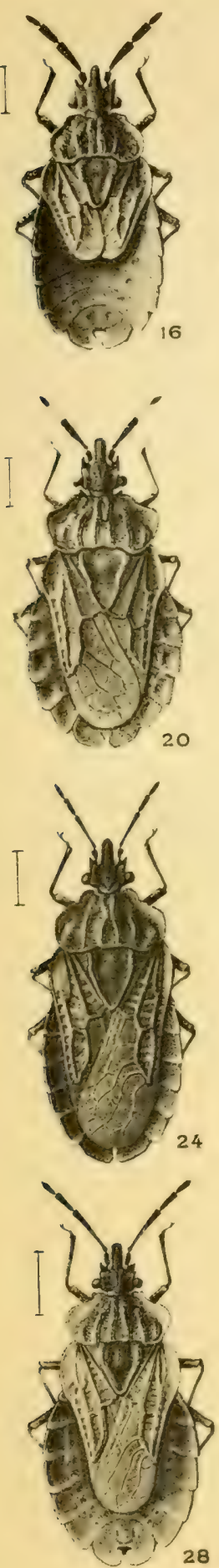
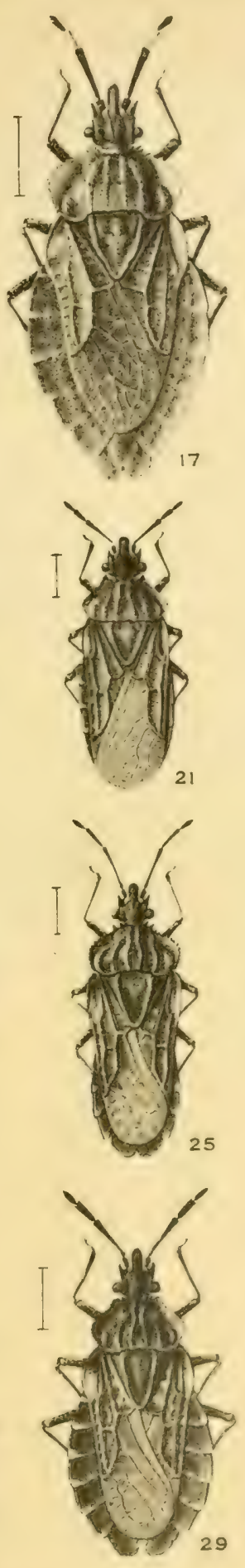
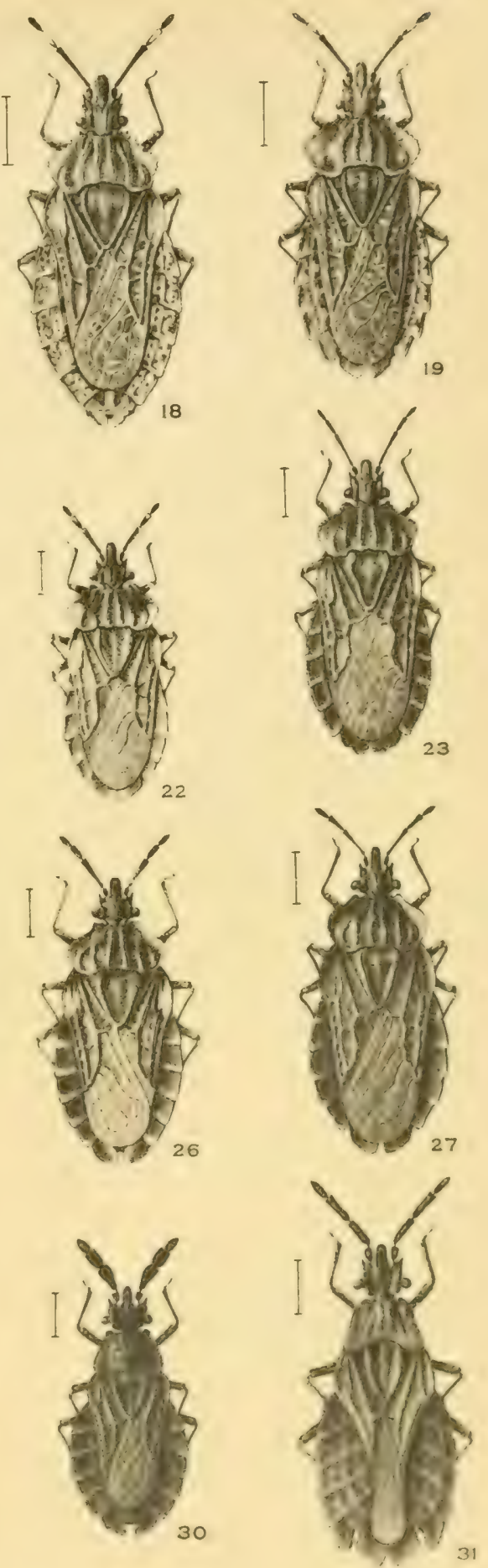



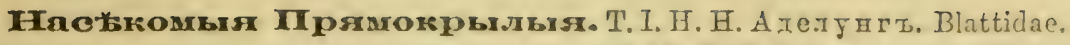

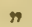

"

s

9

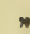

n

$\because$

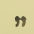

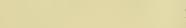

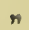

$n$

$n$

n

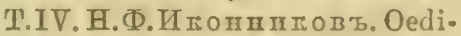
podinae.

Ложнос жтqатокрыльг. T. I. А. H. Бартенегт. Libellulidae $\pi$ Corduliidae. Вып. 1.

ЖКесткокрылыя. Т. I. Г. Г. Лвобсонъ. Chryso. melidae.

"

T. II. Ф. $\Delta .3$ ай певъ. Dytiscidae, Haliplidae, Gyrinidae, Dryopidae II Hydrophilidae.

T. III. E. В. Ядентиовсіи. Staphylinidae.

Cocyuis. IO. H. В агнерь. Aphaniptera.

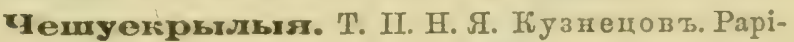
lionidae.

T. III. В. Э. Петөрсенъ. Неsperidge.

T. IV. II. II. 'С бшп вн в. Vanessinae.

T. V. А.Н. А в н нов Ђ. Satyridae.

T. VII, О. И. Іонъ. Lasiocampidae.

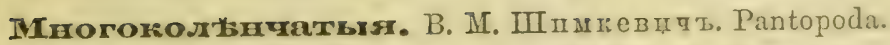

Моллкоски руссктхт морей. Т. I. К. О. Милатевичт. Моль люски Чернаго хоря.

T. II. H. M. Кнпповпчъ. Моллюски СФверншхъ, морей.

T. III. H. А. Смирновъ. Mоллюскп Востопншхт морей.

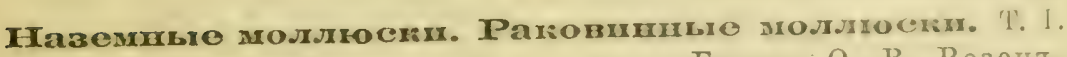
Баронт О. В. Розегі. Testacellidae, Vitrinidae II Glandividae. Вып. 1.

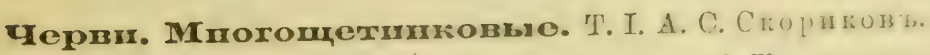

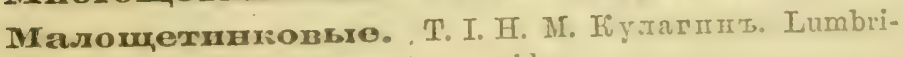
cidae.

Muarm русскихъ nореї. T. I. T. A. I луге.

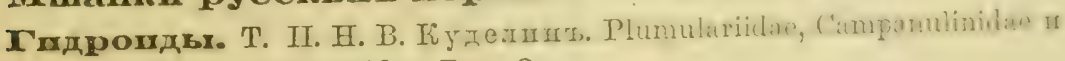
Sertulariidae. Вып. 2.

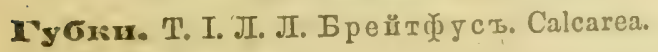




\section{IDAYHA POCCIII}

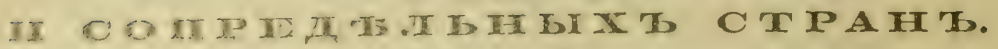

Подт ред. акад. Н. В. Насопова.

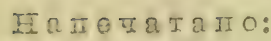

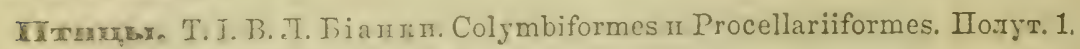
1911. Полут. 2. 1912.

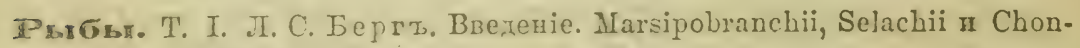
drostei. 1911.

T. III. JI. С. Бергъ. Ostariophysi. Bыm. 1. 1912.

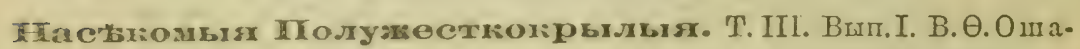
н ни нъ. Orgeriaria.

n

T. VI. Вып. I. А. H. K пp 프 ченцо. Dysodiidae II Aradidae.

Гмдроххды. T. I. А. К. II ипо. Haleciidae, Lafoëidae, Bonneviellidae I Campanulariidae. 1911.

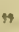

T. II. А. К. II в в во. Plumulariidae, Campanulinidae п Sertulariidae. Bшп. 1. 1912.

프

Птхиқы. T. VI. M. А. Мензбшрт. Falconiformes.

Рыбъ. T. III. J. С. Бергъ. Ostariophysi. Вып. 2 II 3.

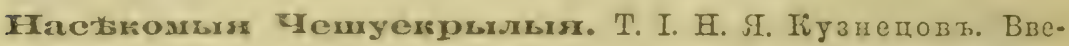
деніе. Danaidae (Pierididae + Leptalidae auct.).

,

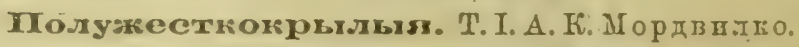

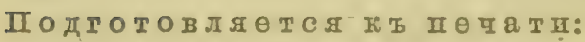
Aphidodea.

Млекопитакоиія. T. I. С. И. Огневъ. Insectivora.

'I. II. А. А. Бялыницій-Бируля. Carnivora,

T.III. Вып. 1. Н. В.Н асововъ. Ovinae и Bovinae.

T. V. K. А. Сатунинъ. Rodentia.

T. VI. H. Ө. Кащенко. Chiroptera.

Птхицу. T. II. B. J.: Біанкт. Pelecaniformes.

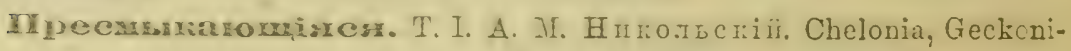
dae, Eublepharidae II Agamidae."

Pвбъ. T. II. J. С. Бергт. Malacopterygii.

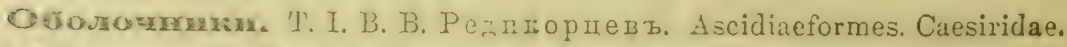

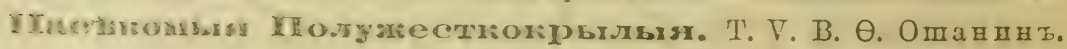
Pentatomidae.

T. VI. Bsim. 2. A.H. Kin-

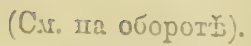
риченго. Coreidae. 




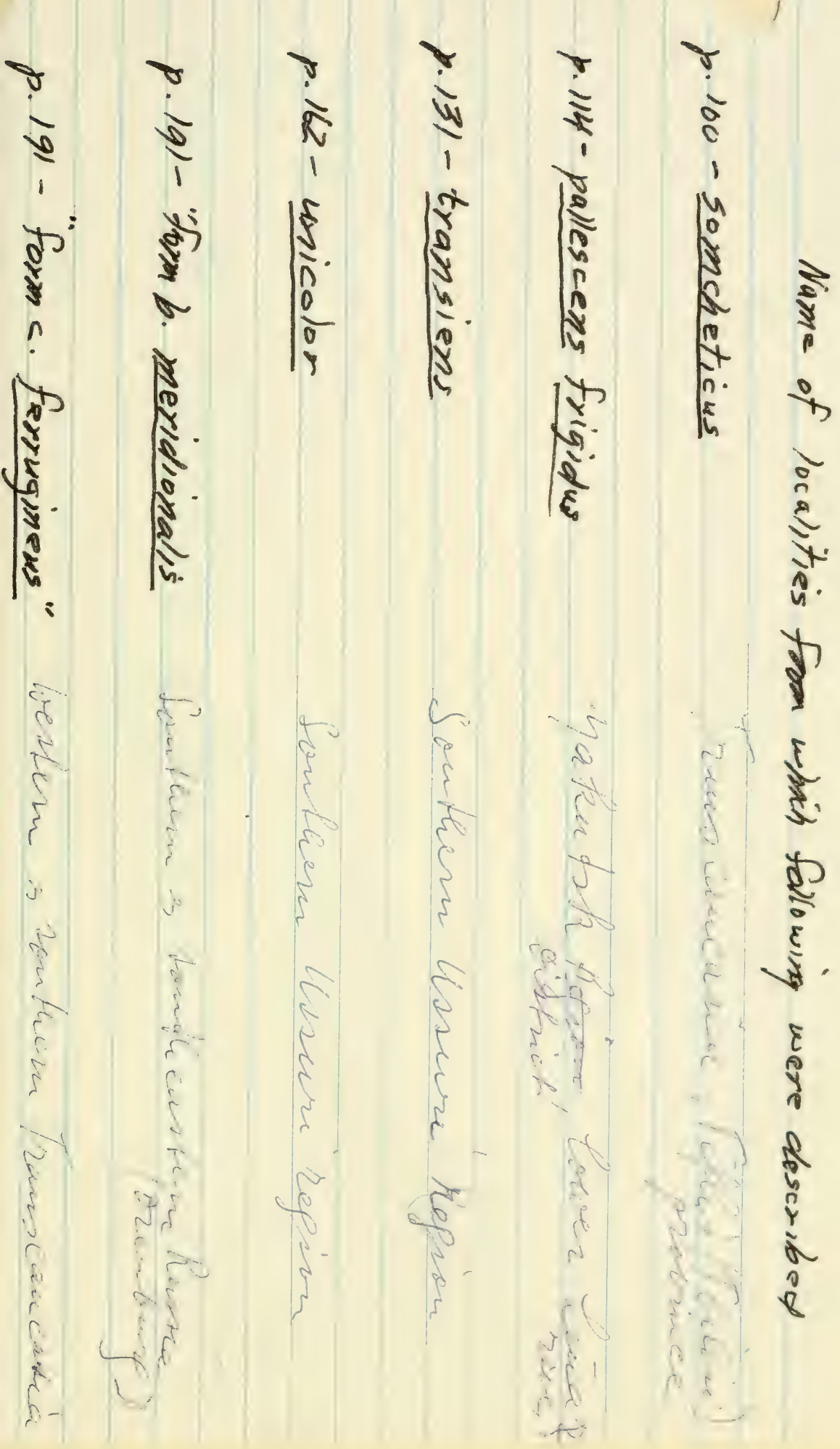



Name of Iocalities fram whih following were daserabed

100 - someretions

114 - pallescens frigidw

$131-$ transiens

122- micalor

Lincien

p.191- Tom b. mexidionalys

p. 191 - "form c. ferruginew"

p.192 - "fornd. simulans

p. pqz - "form e. hercutranus"

p. 259 - poppinsi 

